Fernando Dias Andrade

$N^{\circ}$ USP 1032936

\title{
Pax spinozana
}

Direito natural e direito justo em Espinosa

Tese apresentada ao Departamento de Filosofia da Faculdade de Filosofia, Letras e Ciências Humanas da Universidade de São Paulo para obter o titulo de Doutor em Filosofia

ORIENTADORA:

PrOF ${ }^{a}$ DR $^{a}$ MARILENA DE SOUZA CHAUí

São Paulo

2001 
Para Marlene e Crispim, é claro.

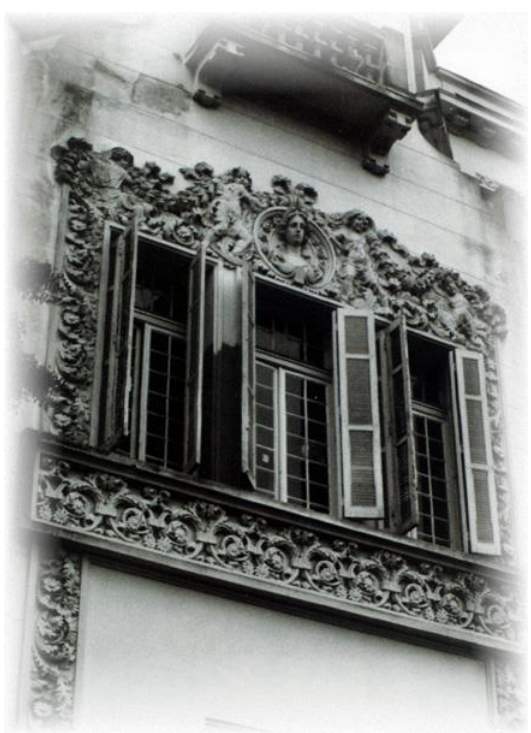


Ordinariamente, como resume um comentador sem parecer inquietar-se quanto ao sentido do que escreve: "Cada existente tem o direito natural de existir como ele é determinado a fazê-lo" [L. MugnierPollet, La philosopbie politique de Spinoza, Vrin, 1976, p. 112]. Se aceitarmos que "Um direito é manifestamente alguma coisa de que se pode se servir ou não" [Fichte, Fondement $d u$ droit naturel, trad. A. Renaut, PUF, 1985, p. 28], que significação conserva a noção mesma de direito em um contexto filosófico em que ela se encontra assim afastada, por princípio, da idéia de uma escolha entre possíveis? Por princípio, já que em Espinosa a distinção entre o ral e o possível não existe: tudo o que é possível é real, e se alguma coisa não se realiza, é que se trata de um impossível. A definição espinosista do possível como uma tendência a existir implica com efeito, como se sabe, que, sendo Deus supremamente potente, não há razão alguma para que essa tendência não se realize - e já que todo possível está em Deus, se Deus é tendência a existir, como Deus é infinito em potência, cada possível existe e a idéia mesma de um possível não realizado perde toda importância (ela obrigaria a conceber uma limitação em Deus). Em conseqüência, perde também toda importância a distinção entre ser e dever-ser (tudo o que deve ser é): ainda é legítimo, nestas condições, falar de um direito, suscetível de ser distinguido do fato e de lhe ser oposto? Logo, um exame da contribuição espinosana à filosofia do direito teria sobretudo o interesse de ressaltar negativamente as condições de possibilidade teóricas de um verdadeiro pensamento do direito: toda filosofia não pode ser filosofia do direito, e certamente não é o vitalismo espinosano que é o melhor posicionado para cumprir tais condições.

A. Renaut \& L. Sosoe, Philosophie du droit, p. 77. 
Especularmente, a operação das "defesas" [do espinosismo] é similar à dos "ataques" porque, em ambas, o pressuposto é o mesmo, qual seja, desfazer o sentimento de que a obra é desconcertante garantindo de antemão sua familiaridade ao fazê-la determinar-se no recinto do que já fora pensado antes dela (os antecessores) e como antecipação do que será pensado depois dela (o precursor). Com raras exceções, três atitudes parecem comandar as interpretações da obra: para os adversários, Espinosa perverte a tradição filosófica; para seus defensores, ele a radicaliza; para os historiadores científicos, ele a sistematiza, seja corrigindo e clarificando o que fora pensado antes dele, no caso dos filósofos, seja oferecendo um quadro metafísico rigoroso ao que seus contemporâneos não filósofos tentavam pensar $\mathrm{e}$ exprimir. Nos dois primeiros casos surge a figura perfeitamente determinada do "espinosismo"; no terceiro, a representação clara e distinta da "doutrina espinosista". Julgamos, porém, que é preciso aceitar a estranheza do pensamento espinosano. Não porque a obra seja um hieroglifo à espera de deciframento que a salvará de incoerências, inconsistências, segredos e mistérios, e sim porque, avessa ao que supomos já saber, fracassaremos se quisermos lê-la segundo o que nos é familiar, pois é então que ela se transforma em texto hieroglífico. Espinosa inova porque subverte, expondo suas idéias num duplo registro simultâneo: no do discurso que diz o novo, ao mesmo tempo que se realiza como contradiscurso que vai demolindo o herdado. A poderosa rede demonstrativa dos textos espinosanos é também um tecido argumentativo e por isso a obra se efetua como exposição especulativa do novo e desmantelamento dos preconceitos antigos que referenciam o presente, subvertendo, nos dois registros, o instituído.

Marilena Chauí, A nervura do real, vol. 1, p. 37. 


\section{SUMÁRIO}

Resumos 5

Agradecimentos 8

Introdução: Direito natural, direito justo: conceitos para o pensamento espinosano

14

Parte I: Do jusnaturalismo ao racionalismo jurídico: o antijusnaturalismo espinosano

Seção 1: Um filósofo voltado para o direito 33

Capítulo 1: Espinosa, filósofo do direito? 34

1.I Reliqua desiderantur: qual é o restante que falta? 34

1.II Lugar da filosofia do direito no pensamento espinosano $\mathbf{6 4}$

Capítulo 2: Espinosa, jusnaturalista? 87

2.I A imagem do Espinosa jusnaturalista $\mathbf{8 7}$

2.II $O$ direito natural em Espinosa: um anticonceito

2.III Jus sive potentia: lex sive potestas 139

Seção 2: Um jurista voltado para a democracia 171

Capítulo 3: Espinosa, hobbesiano? 172

3.I A imagem da reductio ad Hobbesium 172

3.II Espinosa, para além de Hobbes e contra Hobbes

Capítulo 4: Espinosa, jurista? 195

4.I O direito positivo, um instrumento para a razão 195

4.II Democracia, uma necessidade da política e do direito

Parte II: Do direito natural ao direito justo: o racionalismo jurídico espinosano

Seção 3: Em quê Espinosa é nosso contemporâneo? 236

Capítulo 5: Do direito natural aos direitos naturais $\quad 237$

5.I Espinosa e o sujeito de direitos 237

5.II Direitos naturais sem jusnaturalismo? 249

Capítulo 6: Da justiça ao direito justo 262

6.I Justiça desmistificada e necessidade da justiça 262

6.II Direito justo em Espinosa? 270

Bibliografia 279 


\section{RESUMO}

Esta pesquisa defende especialmente quatro teses: primeiro, a idéia de que a filosofia política de Espinosa exprime uma filosofia do direito, e que é necessário considerar o Espinosa filósofo da política não apenas um pensador do direito e da lei, como um autêntico jurista que dialoga com as teorias jurídicas do seu tempo e mesmo anteriores à tradição jusnaturalista moderna (e que também, no que isto é relevante, torna-se um precursor da teoria jurídica contemporânea); segundo, a idéia de que Espinosa elabora uma teoria do direito natural e do direito civil que esvazia por completo a legitimidade dos termos centrais do jusnaturalismo e produz, com isto, uma aniquilação do jusnaturalismo em seu pleno auge (basta lembrar que é o momento em que Pufendorf está elaborando os seus primeiros textos sobre o direito natural e das gentes), o que exige uma linguagem jurídica e política que extingue a conceitografia jusnaturalista, e que também torna Espinosa um antijusnaturalista antes de Hegel; terceiro, a idéia de que a sua teoria político-jurídica antijusnaturalista é uma teoria da política enquanto democracia e da legitimidade enquanto justiça ou justeza na democracia, o que também o torna uma referência antipositivista antes, por exemplo, de John Rawls, e um jurista do direito justo antes, por exemplo, de Stammler; finalmente, a idéia de que a teoria espinosana da democracia exprime um pacifismo teórico em termos seiscentistas (não na perspectiva de uma "ciência política" acerca da guerra e da paz, na perspectiva ética e ontológica da experiência política: uma ética jurídica ou uma teoria da justiça, em termos espinosanos). Realizado, este projeto permite não apenas a sistematização da filosofia jurídica de Espinosa, como permite também uma análise inspirada em Espinosa dos fundamentos da ordem jurídica, assim como de todo o pensamento atrelado a essa prática. Tal análise, a propósito, não é uma excentricidade filosófica por dois motivos: primeiro, porque é exatamente o que o próprio Espinosa havia reservado para os últimos capítulos de seu Tratado político; segundo, porque em não poucos aspectos a prática jurídica contemporânea está equivocadamente distante da idéia espinosana do direito enquanto direito democrático, concepção produzida por um racionalismo jurídico que deseja dar acesso simultaneamente ao verdadeiro e ao pacífico. 


\section{RESUME}

Cette thèse défend surtout quatre idées: d'abord, l' idée que la philosophie politique de Spinoza exprime une philosophie du droit, et qu'il faut considérer Spinoza un philosophe de la politique, non seulement comme un penseur du droit et de la loi, mais comme un juriste authentique qui dialogue avec les théories juridiques de son époque et même les antérieures à la tradition jusnaturaliste moderne (et qui aussi, il est important de le signaler, devient un precurseur de la théorie juridique contemporaine); puis, l' idée qui Spinoza élabore une théorie du droit naturel et du droit civil qui vide complètement la légitimité des termes essentiels du jusnaturalisme et produit, aussi, un anéantissement du jusnaturalisme dans son apogée (il suffit de se rappeler que c'est le moment où Pufendorf élabore ses premiers textes sur le droit naturel et des gens), ce qui exige un langage juridique et politique qui supprime le concept jusnaturaliste, et qui fait devenir aussi Spinoza un antijusnaturaliste avant Hegel; ensuite, l'idée que sa théorie politico-juridique antijusnaturaliste est une théorie de la politique en tant que démocratie et de la légitimité en tant que justice ou justesse dans la démocratie, ce qui le fait devenir aussi référence antipositiviste avant, par exemple, John Rawls et un juriste du droit juste avant, par exemple, Stammler; finalement, l’ idée que la théorie de Spinoza de la démocratie exprime un pacifisme théorique en termes sixcentièmes (non pas dans une pespective d' une « science politique » concernant la guerre et la paix, mais dans une perspective éthique et ontologique de l' expérience politique, une éthique juridique ou une théorie de la justice, en termes spinoziens). Ce projet réalisé, permet non seulement la sistematisation de la philosophie juridique de Spinoza, mais aussi une analyse inspirée sur Spinoza des fondements de l' ordre juridique, bien comme de toute la pensée qui fait partir de cette pratique. Une telle analyse, n'est pas une excentricité philosophique pour deux raisons: d'abord, parce que c'est exactement ce que le propre Spinoza avait réservé aux derniers chapitres de son Traité politique; ensuite, parce qu'en plusieurs aspects la pratique juridique contemporaine est par erreur distante de l' idée de Spinoza du droit en tant que droit démocratique, conception produite par un racionalisme juridique qui souhaite donner un accès simultané au vrai et au pacifique. 


\begin{abstract}
There are four main ideas in this thesis: first, the idea that Spinoza's political philosophy expresses a philosophy of law, and that it is necessary to consider Spinoza as a political philosopher not only as a thinker about right and law but also as an authentic jurist who has a dialogue with the legal theories of his time and even with those who came before the modern jusnaturalist tradition (and who also in what is relevant, becomes a pioneer of contemporary legal theory); second, the idea that Spinoza formulates a theory of natural right and civil right that totally discredits the legitimacy of the core terms of jusnaturalism in its prime (this is the time when Pufendorf is preparing his first writings about natural right and people's right), which demands a juridical and political language that abolishes the jusnaturalist concepts, and which also makes Spinoza an anti-jusnaturalist before Hegel; third, the idea that his anti-jusnaturalist political-legal theory is a theory of politics as democracy and of legitimacy as justice or fairness in democracy, which also makes him an anti-positivist reference before, for example, John Rawls, and a jurist of the fair right before, for example, Stammler; and finally, the idea that the Spinozian theory of democracy expresses a theoretical pacifism in sixteenth century terms (not in the perspective of a "political science" abut war and peace, but in the ethical and ontological perspective of political experience: a juridical ethics or a theory of justice, in Spinozian terms). Implemented, this project allows not only the systematization of the Spinozian legal philosophy, but also an analysis (inspired in Spinoza) of the foundations of the juridical order, as well as an analysis of all the thinking related to this practice. This analysis is not a philosophical eccentricity for two reasons: first, because it is exactly what Spinoza himself had left to the last chapters of his Political treatise; second, because in no few aspects the contemporary juridical practice is wrongly far from the Spinozian idea of right as democratical right concept produced by a juridical rationalism that wants to lead simultaneously to the truth ful and the peaceful.
\end{abstract}




\title{
AGRADECIMENTOS
}

\author{
A verdadeira justiça é a que apazigua o mundo e preserva a \\ familiência da Natureza no bumano. \\ A verdadeira razão é a que dirige as intenções na direção de \\ uma concórdia virtuosa e plena de amores.
}

Exórdio, 18.9.91

Este texto, que certamente não atingiu o objetivo que planejei para ele de uma primeira vez- - uma exposição sistemática da teoria política e jurídica de Espinosa depois de ter esclarecido o sen lugar dentro do jusnaturalismo... nada como passar por esta experiência para descobrir que ainda serão precisos muitos anos para conseguir ao menos chegar perto —, é resultado não apenas de alguns anos de estudos em volta da bistória do jusnaturalismo e a relação de Espinosa com ele, como é resultado, principalmente, de anos ou horas incontáveis de reflexão a respeito da natureza da própria filosofia do direito. O que me permite dizer isso, a essa altura, já não é uma experiência somente minha, mas sim o privilégio de ter partilhado com muitas pessoas, nas trilhas que acompanharam a elaboração deste texto, uma paixão desmedida por esse tema que havia me levado à filosofia e se estabeleceu como o meu alvo principal: a injustica.

Porque a busca dessa pax spinozana era na verdade muito anterior ao tempo em que eu travei contato com Espinosa pela primeira vez - da forma mais privilegiada possivel: por um curso de Marilena Chaui sobre a Parte III da Ética; eu ainda precisaria de alguns anos para melhor perceber o significado desse encontro —, $e$ acredito agora que muito anterior mesmo à minha chegada ao Departamento de Filosofia da USP há exatos dez anos, ela se confunde mesmo com toda a minha vida, quando eu ainda me aproximava da reflexão acerca da injustiça por vias mais tortas, mas já verdadeiras enquanto uma busca. Ter, a certa altura, deparado com esse democrata seiscentista que deu a esse problema — que já chegou a representar, para mim, o indecifrável — uma solução sem exceções, foi o final da minha desconfiança com relação à filosofia. Eu gostaria de descrever essa experiência aqui, mas não é mesmo o caso de farế-lo, especialmente porque não me sinto tendo esse direito depois que percebo que este percurso está, ainda, longe de ser concluído. Falta-lhe ainda um grande restante, mas uns poucos certamente podem, junto comigo, saber o quanto já me significa visualizar esse caminho sem o peso bar- 
dentrópico da angústia originária, a de nunca ter a devida certeza quanto a ser possivel, enfim, trilhar o caminho.

Pensando naquelas pessoas que no perído de elaboração deste texto foram um incentivo constante à minha insistência nele, devo certamente meus agradecimentos a pessoas muito especiais, graças às quais eu tenho descoberto a minha maior alegria nesta vida: meus alunos nos cursos de direito em que tenho lecionado desde o início da pesquisa, e que não apenas me ouvem falar intensamente de Espinosa e outros autores da filosofia moderna como, também, acompanharam corajosamente essa minha experiência inicial como professor universitário. A todos eles, sem exceşão, sinto que devo meu esforço por insistir na filosofia e, também, neste texto: se eu não vivesse essa satisfação indescritivel de partilhar com eles a alegria coletiva do conbecimento, provavelmente cairia na idéia insana de que essa partilha de conhecimento é uma utopia. Não é; definitivamente, não é. E dessa alegria causada pelas nossas intensas conversas — quase que clandestinas em meio ao peso da dogmática jurídica a nos cercar por todos os lados - são testemunhas aqueles que foram meus alunos na Faculdade de Direito de Franca, na Universidade de Uberaba, na Faculdade de Direito de São Bernardo do Campo; e eu não só me sinto grato a eles todos por essa felicidade de ter iniciado, com eles, o percurso docente dessa reação ética à injustiça, como especialmente me sinto infinitamente fortalecido pela satisfação de ser mais e mais humanizado pelo contato com cada um deles. Definitivamente, só o pensamento firme nessa alegria descoberta no convívio com todos eles seria capaz de dividir, nas minhas incontáveis horas de viagens entre Uberaba, Franca, Ribeirão Preto e São Paulo, a atenção da minha reflexão sempre fixada no racionalismo jurídico espinosano.

Mas quero dedicar um agradecimento especial a alguns dos meus alunos, colegas e amigos na Faculdade de Direito de São Bernardo do Campo, porque fui realmente presenteado por eles, em meio a uma turbulenta situação de intolerância intelectual e acadêmica, com seu manifesto de apoio e reconbecimento ao trabalho da filosofia e contra o irracionalismo jurídico que por vezes ocupa ainda o berço da formação jurídica, conquistou para sempre a minha conviçãa na solidariedade acadêmica: isso en devo a Adauto Lopes da Silva, Adriana Giacomassi, Adriana Locchet, Adriane Harue de Souza Carvalho, Agostinho Sidônio Gonçalves, Aguinaldo Balon, Alexandre Alves de Oliveira, Ana Clara S. Garcia, Andréa Mara Martins da Silva, Antonio Prestes de Matos Júnior, Aroldo de Souza Neto, Beatriz Binelho Valerio, Carla Piatto, Carlos Eduardo Novelli, Clándia Pituvak Magdalena, Claudia Sousa Mendes, Cleide Maria Demarchi, Daniel Gonçalves de Lima, Daniela Reis Cerqueira, Denise Ranieri, Donata Padula, Eduardo Finelon Pereira, Eduardo Spinussi, Elder Takayama, Emilene Marilia Duarte, Fernanda Fernandes Santos Diniz, Fernando Gazaffi, Flávio Tadeu dal Fabbro, 
Florisvaldo Chacon, Heloísa Bonora, James Demarchi, Jander Luiz de Souza, Karen N. Ribeiro, Karla Calegari di Martino, Kátia Kimiko Tacoshi, Kelly Cristina Bulgarelli, Leila M. L. Macedo, Lenivaldo S. Campos, Luciana L. Garcia, Luciana Yuki Fugishita, Luciano Alves Henriques, Marcelo Cesar dos Santos, Márcia Aparecida de Souza, Marcos Antonio Pereli, Maria Medeiros, Mario Augusto Bertęini, Mário Barbosa Serra, Maurício Konji Arashiro, Nádia Périgo Serrano Nunes, Natalia Pasquini Moretti, Paulo Roberto Megiaro Andreu, Raquel Moretti, Reinaldo Cova de Britto, Renata C. Carrieri, Renata Fiusa de Paula Freitas, Rogério O. Possedente, Rosana Maria Canal Nimia, Selmo Roberto Pozzi Malheiros, Sheila Pratiz dos Satons, Sidney Moschen, Silvio Marques Costa, Sônia Maria Oliveira, Tatiana Martini, Thiago Sorrentino, Vagner Luis Guarda, Vaneli Cristina da Silva, Vanessa A. dos Santos Machado, Veridiana Bertogna, Vladimir Sidnei Ramos, Wendel de Q. Ondiciati e, para minha alegria por estar também entre eles, men amigo dos tempos em que lecionávamos no ensino secundarista, Francisco Santaella Galvão. Não bastasse todo esse time, a fundação da minha experiência bernardense teve o especial privilégio de contar com o convívio com duas alunas — Alessandra Carbonero Lima e Mariângela Daiuto — que, de minhas primeiras orientandas de monografia a correligionárias no estudo jurídico da filosofia espinosana, tornaram-se minhas protetoras, companheiras e irmãs; foi por expor a última versão deste texto à atenção e à confiança delas, assim como de Renata Rodrigues Rossit e de meu grande amigo também dos tempos de graduação (além de meu professor de hebraico), Edson Faria Francisco, que encontrei alguma segurança para conduzir o meu texto para uma temerária reta final. Ao Edson, especialmente, reconheço a importância de uma amizade pessoal e intelectual de anos cuja identidade maior vai certamente muito além da nossa tara por Frank Zappa e Bob Dylan.

Como não poderia deixar de ser, ainda, este texto deve muito a todos os meus colegas de academia, seja os que lecionaram comigo nas escolas secundaristas do Estado há uns oito ou sete anos, seja os que dividem comigo há três anos essa experiência universitária, seja especialmente os que há anos dividem comigo essa quase clandestina entrega à filosofia... da minha turbulenta chegada tanto à faculdade de filosofia quanto à faculdade de direito (que tive a sabedoria de interromper no meio do curso), impulsionada em especial por Márcio José Crippa de Camargo, Jocimar Souza Carvalho, Cynthia Silva dos Santos, Sérgio Jacomino, Jane Lichtenthaeler, José Ruben de Alcântara Bonfim e João Miguel Valencise, aos meus amigos e almas gêmeas no primeiro encontro com essa vida acadêmica, Elizio Luiz Perez, Douglas Donizete Paganini, Eduardo Toaldo, Sandro Kobol Fornazari, Wilson Frezzatti Jr., Marcos Sidnei Euzebio, Ivone de Moura e muito, muito especialmente Ana Maria Bernadeli e Adriana Gomes da Silva. É a eles que eu devo as melhores lembranças dos piores anos da minha vida. 
Que estão muito, muito pra trás:

Não existe alegria maior do que receber agora, da parte de uma família que foi sempre obrigada a se adaptar às minhas idiossincrasias, confiança e serenidade. Por tudo o que andei passando pelos últimos tempos, é mais do que evidente que eu não teria sido capaz, nem de me entregar a esta tese, nem de continuar minhas pesquisas, nem de continuar meu trabalho, sem o apoio incondicional de todos eles, de meus pais, Marlene e Crispim, a meus irmãos Paulo, Simone e Solange, além de meus tios, meus primos e meus sobrinhos... Junto desse círculo familiar e do meu time de protetoras constantes, a presença eterna de Iêda Maria Roberto, Danielle Fortes Kubnen, Cibelle dos Anjos Marcondes e Cristiene Pereira Silva revela-se sempre a minha maior alegria nesta vida de entrega à filosofia.

Com respeito ao processo de elaboração desta pesquisa, o convívio com meus colegas do Grupo de Estudos Espinosanos da USP forneceu-me não apenas a oportunidade de desenvolver meus primeiros esboços de pesquisa na filosofia de Espinosa, como principalmente me deu o privilégio de ter por perto verdadeiros exemplos de rigor e disciplina intelectual (dos quais um dia espero ao menos me aproximar...), que espero ter sempre por perto e por quem guardo uma admiração sem limites: Cristiano Novaes de Rezende, Eneias Júnior Forlin, Ericka Marie Itokazu, Homero Silveira Santiago, José Eduardo Baioni, Luciana Zaterka, Luís Cesar Guimarães Oliva, Marta Vitória de Alencar, Moysés Floriano Machado Filho e Tessa Moura Lacerda. E na origem entusiasmada e militante desse ingresso no Grupo de Estudos Espinosanos, minha amiga Luciana Rugene do Carmo, com quem dividi a tensão de apresentar pela primeira vez̧, em 1997, meu primeiro trabalho referente à pesquisa que deu nesta tese.

Na tensa fase final, pude contar com toda a atenção dos Profs. Milton Meira do Nascimento e Sérgio Cardoso no exame de qualificação, da mesma forma que tenho contado, desde então, com a paciência não só deles como de outros professores e colegas que se envolveram na finalização do projeto, a saber, a Profa Maria das Graças de Souza e os Profs. José Eduardo Faria e Mauricio de Carvalho Ramos. Especialmente aos professores que aceitaram receber este trabalho para avaliação num prazo realmente muito curto, nem tenho como agradecer devidamente. Não fosse sua disponibilidade e impressionante tolerância, este trabalho não teria ousado aparecer agora. 
E acima de todos e de tudo, devo minha gratidão infinita à minha orientadora, Marilena Chauí. Este trabalho, que só existe porque ela existe, é inspirado especialmente em dois de seus cursos: o curso do primeiro semestre de 1995, em que ela apresentou a teoria espinosana dos afetos, dando como objeto de seminários o Tratado político, experiência que nos obrigou (a mim e meus colegas de seminário: Sandro Kobol Fornazari, Wilson Frezzatti Jr., Lygia Rivero Pupo e Nigge Marianne Piovesan Loddi) a estudar todos os escritos de Espinosa e, a mim particularmente, a oportunidade de pesquisar sistematicamente a bistória do direito natural antes de Espinosa (o que deu num seminário — sobre "O direito natural antes de Espinosa" — que pretendo retomar logo para reformulação, já que agora numa perspectiva muito mais ambiciosa: o direito natural a partir de Espinosa, entendendo-se "a partir" por "numa perspectiva inspirada em"), assim como preparar um texto que seria não só o meu primeiro artigo publicado sobre Espinosa, como principalmente foi o meu primeiro artigo publicado ("Desejo, alegria, tristera: o conatus como potência de existir e agir", in Cadernos espinosanos, $n^{\circ} 1$, t. I). E logo em seguida, no segundo semestre de 1995, o curso (de pós-graduação; ao qual assisti como ouvinte - pois ainda estava na graduação - e o primeiro que ousei gravar) sobre o Tratado teológicopolítico, principalmente a inesquecivel aula de 18 de setembro, onde conbeci pela primeira vez a sua análise integral do capitulo XVI ("Dos fundamentos do Estado, do direito natural e civil de cada um e do direito das potestades soberanas"), sem dúvida a aula por que eu mais esperei em toda a minha passagem pela faculdade de filosofia, e as três horas de gravação que eu mais ouvi nestes anos, a ponto de decorar cada palavra e cada tom. Certamente, se a história da minha chegada à faculdade de filosofia foi marcada por algumas dificuldades, nada se compara ao que ainda viria depois, como uma avalanche de constantes convites a desistir do curso, da filosofia, da reflexão. Desde que tive esse privilégio de tornar-me seu aluno, compreendi o que todos queriam dizer a respeito desse entusiasmo legendário que ela transmite a todos que estejam por perto e na mesma busca. Não é que eu não estaria chegando ao fim desta tese sem toda a inspiração e orientação de Marilena: mais do que isto, eu sequer estaria no "bom caminho".

São Bernardo do Campo, janeiro de 2001 


\title{
INTRODUÇÃO \\ DIREITO NATURAL, DIREITO JUSTO: CONCEITOS PARA O PENSAMENTO ESPINOSANO
}

\begin{abstract}
Longe de nós a idéia, para mostrar como uma fenomenologia jurídica é incompatível com a teoria do Direito natural, de antes de tudo propor, dessa majestosa teoria, secular inclusive, uma exposição exaustiva que depois a "teoria" fenomenológica refutaria, ponto por ponto. [A primeira razão para isso] reside no fulgor com que a filosofia do direito presta-se à "perpétua ressurreição de um cadáver que não cansamos de reenterrar" (Batiffol). Tudo sobre o Direito natural, pois, já foi dito, e não temos a insolente pretensão de acrescentar aí o que quer que seja.
\end{abstract}

Simone Goyard-Fabre, Essai de critique phénoménologique du droit, p. 168.

Existe uma espécie de tabu na filosofia contemporânea do direito: é a questão da justiça.

Esta afirmação parece equivocada, na medida em que essa mesma filosofia contemporânea, por um lado, no bloco anglo-saxão, ainda hoje repercute o impacto da Teoria da justiça de John Rawls, ${ }^{1}$ trinta anos após a publicação dessa obra que — junto com outros grandes textos publicados pela mesma época, mas por muitas razões certamente o mais ousado e impactante de to$\operatorname{dos}^{2}$ - trouxe, a esse cenário político-jurídico tão dominado pelas concepções do utilitarismo,

\footnotetext{
${ }^{1}$ John Rawls, $A$ theory of justice, Harvard University Press, 1971. Edição brasileira (tradução de Almiro Pisetta e Lenita M.R. Esteves): Uma teoria da justiça, São Paulo, Martins Fontes, 1997.

${ }^{2}$ Norberto Bobbio (Teoria geral da política, p. 82), diante da necessidade de reconhecer a importância da Teoria da justiça de Rawls, lembra ainda a publicação de outras obras do mesmo período - como Anarquia, Estado e utopia, de Robert Nozick e Esferas de justiça, de Michael Walzer; a esta lista devem ser acrescidos, pelo menos, Levando os direitos a sério de Ronald Dworkin, e Poliarquia, de Robert A. Dahl — que, como o texto de Rawls, também propõem uma revisão nas bases da política e do direito das décadas anteriores. Entretanto, nenhuma delas causou tanto impacto quanto a de Rawls, exatamente porque elas apenas apresentam um novo caminho de pensamento político, ao passo que a Teoria da justiça não apenas faz isso como, primeiro, demole a possibilidade de se continuar pensando a democracia contemporânea segundo as bases tradicionais do utilitarismo e, segundo, traz à tona um "fulgor teórico" (veja-se a expressão de Simone Goyard-Fabre à epígrafe desta introdução) assentado necessariamente não no pensamento político contemporâneo, mas sim no pensamento político moderno, que para os leitores contemporâneos e em função dos temas levantados (teria Batiffol dito "ressuscitados", como sugerem os "alguns" a que alude o bobbiano Michelangelo Bovero? Cf. op. cit., p. 11) por Rawls é um pensamento
} 
um novo impulso para a discussão das condições em que um sistema jurídico deve operar numa sociedade que se pretenda, hoje, democrática. A afirmação parece também equivocada, por outro lado, na medida em que ainda essa mesma filosofia contemporânea, especialmente no bloco europeu continental, há muito discute o estatuto que o direito deve ter à frente das transformações políticas ocorridas, nas últimas décadas, em países que por todo o "breve século $\mathrm{XX}^{\prime \prime} 3$ foram regidos por regimes autocráticos, sendo ao que parece suplantados por novos ares do espírito democrático (devidos a quê, porém?), o que ao menos tem incentivado, ainda segundo esse discurso contemporâneo, um reconhecimento dos indivíduos na condição fundamental de "sujeitos de direito", assim como do reconhecimento mais ostensivo dos "direitos humanos" que a todos cabem na democracia; mais do que isso, essa reconsideração das bases teóricas e ideológicas da prática política no mundo ocidental tem merecido, especialmente no horizonte teórico cuja tradição é positivista e legalista, uma reflexão quanto à adequação dos aparelhos judiciários a uma prática política mais claramente compromissada com a realidade social das comunidades sob sua jurisdição.

De fato, é mais do que claro que o pensamento político-jurídico da segunda metade do século Xx é em geral marcado por um movimento de revisão dos seus métodos e postulados adotados nas décadas anteriores. Depois que o século havia se iniciado num ambiente de plena confiança na ordem do Estado constitucional, na força das instituições jurídicas, na consistência dos ordenamentos jurídicos, na segurança e desenvolvimento trazidos pela industrialização e pela concepção economicista da política, quem poderia temer catástrofes no horizonte do positivismo jurídico assim como no do utilitarismo? Quem, há um século, poderia negar a tese, universalmente aceita no mundo jurídico, de que uma nação organizada sob o signo da democracia constitucional e do Estado de direito era verdadeiramente autônoma e soberana? Foi sobre essa convicção que se constituíram, sob formas diferentes mas com tantos pontos em comum no que respeita à determinação do legal e do legítimo, positivismo jurídico e utilitarismo jurídico. Foi sobre essa noção corrente que a maior parte das teorias jurídicas da primeira metade do século XX investiu na doutrina da cientificidade do direito, na tese da autonomia técnica do direito em relação às outras formas de discurso e prática política, e principalmente na con-

basicamente jusnaturalista. Sobre o próprio Rawls, como sobre outros autores que, como ele, trouxeram temas do pensamento político moderno para a análise da prática política contemporânea, recaiu a pecha de "jusnaturalista" ou mesmo (graças à crítica da tradição kantiana contra o jusnaturalismo) de "metafísico" - o que o levaria, a propósito, a passar os anos seguintes revisando temas da Teoria da justiça de modo a tentar (na maioria das vezes, inutilmente) reconquistar a confiança teórica dos leitores de tradição kantiana ou kelseniana, assim como dos leitores da própria tradição utilitarista ou economicista por ele criticada originalmente.

3 A expressão, é claro, pertence a Eric Hobsbawm, em Era dos extremos. O breve século XX (1914-1991). Tradução de Marcos Santarrita. São Paulo, Companhia das Letras, 1999. 
vicção de que a determinação de qualquer validade ou legitimidade das ações humanas em sociedade é uma propriedade exclusiva das instituições jurídicas: de um lado, a tradição jurídica fundada especialmente no utilitarismo anglo-saxão considerava que a organização social significava especialmente garantia e preservação da propriedade privada e estabelecimento de uma sociedade de controle institucional da vida moral de seus próprios cidadãos, e de outro lado, a tradição jurídica fundada no historicismo alemão de inícios do século XIX e impulsionada acima de tudo pelo positivismo jurídico de Austin e, já no século Xx, pelo jovem Kelsen, desenvolveu a idéia de que mais nenhuma relação pode ser concebida entre a prática jurídica ou a razão do Estado e as noções da metafísica, os preceitos da moral e as orientações da ética.

Em ambos os campos, constituiu-se enfim a idéia geral de que assim como o direito em qualquer sistema jurídico é, em suma, o conjunto de instituições utilizadas pelo Estado para controlar ou administrar a vida social, ele deve basear os seus conteúdos exclusivamente na existência histórica e concreta da própria sociedade a que se refere, assim como assumir a si mesmo como uma instituição operada fundamentalmente para a ordenação da vida em sociedade e da resolução de litígios. Ao direito, de forma alguma, caberia a preocupação de estabelecer princípios morais ou éticos — como o de justiça — para a sociedade ou os indivíduos: essa determinação dos valores morais ou dos princípios éticos é irrelevante para o direito, se a ele basta ter o poder de resolver litígios ou garantir a preservação das propriedades segundo a obrigatoriedade já das suas normas, não precisa se preocupar em receber a avaliação de uma prática injusta: sua justificação normativa é suficiente para sua eficácia institucional. ${ }^{4}$ Ao direito,

\footnotetext{
${ }^{4}$ H. Kelsen, O problema da justiça, pp. 8-10: "Se a estatuição da norma do direito positivo corresponde à norma de justiça, então o valor jurídico constituído por aquela coincide com o valor de justiça constituído por esta. Diz-se, neste caso, que a norma do direito positivo é justa. Se a estatuição da norma do direito positivo contraria a norma de justiça, valor de justiça e valor jurídico não coincidem; diz-se então que a norma do direito positivo é injusta. No entanto, a justiça e a injustiça, que são afirmadas como qualidades de uma norma jurídica positiva cuja validade é independente desta sua justiça ou injustiça, não são - ou não são imediatamente, pelo menos — qualidades desta norma, mas qualidades do ato pelo qual ela é posta, do ato de que ela é o sentido. Se, por exemplo, uma norma de justiça pressuposta como válida preceitua que todos os homens devem ser tratados igualmente, então um ato legislativo pelo qual sejam postas normas que prescrevam um tratamento desigual dos indivíduos, estatuindo que os tribunais apenas devem punir aqueles que cometeram um delito e não os outros e que devem punir os ladrões com a privação da liberdade ao passo que os assassinos devem ser castigados com a privação da vida, e os atos dos tribunais que aplicam a lei são injustos. Diz-se, nesse caso, que a norma geral da lei e as normas individuais das decisões judiciais que aplicam as leis são injustas. A sua injustiça reside no fato de os atos que as estabelecem contradizerem uma norma de justiça, quer dizer, no fato de, segundo esta norma, não deverem ser postas. De acordo com o direito positivo, porém, elas devem ser postas. Ora, não é possível que algo deva ser e não deva ser ao mesmo tempo. Portanto, do ponto de vista de uma norma de justiça considerada como válida, não pode ser considerada válida uma norma do direito positivo que a contradiga, assim como, do ponto de vista de uma norma do direito positivo tida como válida, não pode ser considerada válida uma norma de justiça que a contrarie. Quando está em questão a validade de uma norma do direito positivo, temos de abstrair da validade de uma norma de justiça que a contradiga; quando está em questão a validade de uma norma de justiça, temos de abstrair da validade de
} 
conseqüentemente, seria inútil preocupar-se com a prática da justiça moral ou ética, já que segundo o positivismo jurídico a prática jurídica não apenas pode se abrigar na mera aplicação do direito positivo, como é exatamente isso que garante a sua eficácia para resolver os casos concretos. ${ }^{5}$ Ao direito, de forma alguma, interessaria para a orientação da resolução desses casos a adaptação de suas normas aos princípios estabelecidos pelas análises das ciências humanas e da filosofia: essa adaptação é irrelevante, se ao direito basta ter o poder de elaborar a sua própria doutrina e justificar sua própria prática institucional sem depender da confirmação das instituições da razão. ${ }^{6}$ Ao direito, finalmente, jamais haveria sentido em adaptar suas formas argumentativas e seus critérios de validação segundo os métodos e critérios da ciência, da metafísica, da lógica, já que à prática jurídica basta utilizar-se de formas de interpretação e decisão que não pedem exatamente uma solução verdadeira, mas uma solução prática, independente da avaliação que sua interpretação estritamente jurídica possa receber de qualquer ciência ou reflexão filosófica. ${ }^{7}$

uma norma do direito positivo que se oponha a ela. Não podemos considerá-las simultaneamente válidas. Portanto, não pode existir nenhuma norma do direito positivo considerada como válida que possa ser julgada como injusta do ponto de vista de uma norma de justiça tida simultaneamente como válida. Por isso, nem de um ponto e vista nem de outro pode valer uma norma injusta do direito positivo. Uma norma jurídica positiva não pode, por conseguinte, ser injusta, nem a partir de um dos pontos de vista nem a partir do outro."

${ }^{5}$ M. Villey, Le droit et les droits de l'homme, p. 8: "Normalmente toda a ordem jurídica procede do Estado e se encontra encerrada em suas leis. É o positivismo jurídico, filosofia das fontes do direito que a maior parte dos jurista aceita e que os dispensa, por submetê-los à vontade arbitrária dos poderes públicos, da busca da justiça."

${ }^{6}$ T.S. Ferraz Jr., Introdução ao estudo do Direito: téenica, decisão, dominação, pp. 48-49: "[...] é preciso reconhecer que, nos dias atuais, quando se fala de Ciência do Direito, no sentido do estudo que se processa nas Faculdades de Direito, há uma tendência em identificá-la com um tipo de produção técnica, destinada apenas a atender às necessidades do profissional (o juiz, o advogado, o promotor) no desempenho imediato de suas funções. Na verdade, nos últimos cem anos, o jurista teórico, pela sua formação universitária, foi sendo conduzido a esse tipo de especialização, fechada e formalista. Esta especialização, embora indesejável porque demasiado restritiva, tem sua explicação. Afinal, não podemos esquecer que o estudo dogmático do direito está ligado a uma dupla abstração. Ou seja, como não existe sociedade sem dogmas, pois, sem pontos fixos de referência, a comunicação social (interação humana) é impossível (por exemplo, sem a fixação básica do sentido das palavras é-nos impossível falar um com o outro, daí a idéia da língua como um código), toda comunidade elabora suas normas. Mas as normas só não bastam. Sua ambigüidade e vagueza (afinal elas se expressam por palavras) exigem também regras de interpretação. É preciso saber dizer não só qual é a norma, mas também o que ela significa. Ora, as normas (ou dogmas de ação) são, elas próprias, um produto abstrato e as regras sociais de interpretação (dogmas que dizem como devem ser entendidas as normas) são também um produto abstrato. Temos, pois, um produto abstrato, as regras, que tem por objeto um outro produto abstrato, as normas. Daí a simples abstração (no sentido de isolar normas e regras dos seus condicionamentos zetéticos). Pois bem, o objeto do conhecimento jurídico-dogmático é esta dupla abstração, que o jurista elabora num grau de abstração ainda maior (regras sobre as regras de interpretação das normas). Com isso, o seu estudo paga um preço: o risco de distanciamento progressivo da própria realidade social."

${ }^{7}$ H. Kelsen, Teoria pura do direito, pp. 370-371: "A interpretação científica é pura determinação cognoscitiva do sentido das normas jurídicas. Diferentemente da interpretação feitas pelos órgãos jurídicos, ela não é criação jurídica. [...] A interpretação jurídico-científica não pode fazer outra coisa senão estabelecer as possíveis significações de uma norma jurídica. Como conhecimento do seu objeto, ela não pode to- 
Em suma: há um século, todas as concepções jurídicas da prática jurídica, apesar de todas as suas diferenças teóricas, mantinham uma mesma convicção universal: o direito, instituição suprema do Estado senão mesmo o próprio Estado, ${ }^{8}$ estava acima de todas as outras instituições da vida social, fosse enquanto prática institucional ou técnica (nenhuma outra instituição social poderia, no lugar do direito, colocar-se como instrumento da resolução de litígios ou da preservação da propriedade), fosse enquanto prática intelectual ou teórica (nenhuma operação técnica do direito tinha necessidade de ser legitimada pelas formas não jurídicas de discurso e de pensamento, e as tradições teóricas jurídicas não sentiam nenhuma necessidade de adequar-se aos métodos e concepções das práticas teóricas não jurídicas). E não haveria, enfim, nenhum problema nisso, já que era exatamente esse conjunto de convicções que garantia, para a sociedade e o Estado, a sua paz e segurança: no Estado que se reconhece como totalmente fundamentado no ordenamento jurídico e nas razões jurídicas — no Estado de direito, pois —, ninguém deveria temer um retorno à autocracia dos regimes políticos sem garantia de direitos, sem preservação da propriedade e da imagem, sem administração soberana dos destinos dos cidadãos: só no Estado de direito, preferencialmente no Estado democrático constitucional, a liberdade e o progresso poderiam ser garantidas plenamente, e justamente porque na prática são tidas, pelas instituições jurídicas, como respectivamente idênticas ao direito à propriedade privada e à ordenação econômica de toda a sociedade.

mar qualquer decisão entre as possibilidades por si mesma reveladas, mas tem de deixar tal decisão ao órgão que, segundo a ordem jurídica, é competente para aplicar o Direito. [...] A interpretação jurídicocientífica tem de evitar, com o máximo cuidado, a ficção de que uma norma jurídica apenas permite, sempre e em todos os casos, uma única interpretação: a interpretação 'correta'. Isto é uma ficção de que se serve a jurisprudência tradicional para consolidar o ideal da segurança jurídica. Em vista da plurissignificação da maioria das normas jurídicas, esse ideal somente é realizável aproximativamente. Não se pretende negar que esta ficção da univocidade das normas jurídicas, vista de uma certa posição política, pode ter grandes vantagens. Mas nenhuma vantagem política pode justificar que se faça uso desta ficção numa exposição científica do Direito positivo, proclamando como única correta, de um ponto de vista científico objetivo, uma interpretação que, de um ponto de vista político subjetivo, é mais desejável do que uma outra, igualmente possível do ponto de vista lógico. Neste caso, com efeito, apresenta-se falsamente como uma verdade científica aquilo que é tão-somente um juízo de valor político."

${ }^{8}$ É a tese de Kelsen, que considera que o sentido verdadeiramente objetivo e unívoco de Estado é o seu sentido jurídico: "A situação insatisfatória da teoria política — que, essencialmente, é uma teoria do Estado - deve-se, em boa parte, ao fato de diferentes autores tratarem de problemas bastante diferentes usando o mesmo termo e, até, de um mesmo autor usar inconscientemente a mesma palavra com vários significados. A situação revela-se mais simples quando o Estado é discutido a partir de um ponto de vista puramente jurídico. O Estado, então, é tomado em consideração apenas como um fenômeno jurídico, como uma pessoa jurídica, ou seja, como uma corporação. [...] O Estado é a comunidade criada por uma ordem jurídica nacional (em contraposição a uma internacional). O Estado como pessoa jurídica é uma personificação dessa comunidade ou a ordem jurídica nacional que constitui essa comunidade. De um ponto de vista jurídico, o problema do Estado, portanto, surge como o problema da ordem jurídica nacional" (H. Kelsen, Teoria geral do Direito e do Estado, p. 183). Entendido o Estado como ordem jurídica, os significados políticos que possam ser relacionados a ele só farão sentido, também, enquanto fenômenos ou atos de relevância jurídica. Para o positivismo jurídico, o que não é visível pelo direito não existe na realidade. 
Ora, é uma verdade racional o fato de que não existe Estado de direito sem a garantia da propriedade privada nem a viabilização do desenvolvimento econômico; todavia, é também uma verdade racional que não é democrático um Estado de direito no qual a garantia da propriedade privada ou a viabilização do desenvolvimento econômico são mais valiosos do que a preservação da vida, e não só da vida humana. É por isso, justamente, que não faz sentido racional identificar Estado democrático a Estado de direito, se por Estado de direito se entende um Estado cuja prática é fundada e justificada exclusivamente pela sua própria estrutura jurídica. É essa, estou certo, a concepção de Estado de direito desenvolvida pelo positivismo jurídico em toda a sua existência: ao colocar que não cabe ao Estado guiar-se por valores subjetivos de justiça mas unicamente pelos preceitos jurídicos explicitados em lei ou pelas autoridades jurídicas, o positivismo jurídico - especialmente o de matriz kelseniana - torna impossível validar a resolução de casos concretos contra o ordenamento jurídico quando isso for por algum juízo racional considerado pertinente; tal prática em contrário ao ordenamento, a propósito, só faria sentido se o conteúdo do direito positivo, da opinião dos juristas ou do juízo dos magistrados não fosse necessariamente adequado a cada caso concreto. Quem, porém, determina essa necessidade de justiça e esse conteúdo do direito diante de cada caso particular? Na prática, as próprias instituições de cuja autoridade depende a determinação de uma solução coercitiva, mas já também a elaboração das próprias normas jurídicas; de maneira alguma, a solução de questões jurídicas depende da vontade externa à das autoridades ou da razão estranha à dos dogmas. A razão das instituições jurídicas, sempre, não carece (para ter sua eficácia concreta, o que segundo o positivismo jurídico é sempre a sua finalidade) ser válida segundo a razão, mas basta-lhe unicamente ser válida segundo o ordenamento jurídico. É essa suficiência fundada na resolução coercitiva de cada caso, independente de quaisquer considerandos de ordem ética e racional ou de ordem moral, que dá às instituições do direito e do Estado o poder de se considerarem legitimadas em cada operação compatível com o ordenamento jurídico; o resto seria "a ilusão da justiça".

Seria mesmo? A profunda mudança provocada nas convicções e métodos do pensamento político e, com menos intensidade, do pensamento jurídico mostram que aquela convicção não resistiu intacta ao peso da história, especialmente a história dos excessos inimagináveis trazidos pela prática política de tantos Estados constitucionais e de direito em todo o mundo, mas especialmente na Europa, autodenominada (em especial pela ideologia alemã) berço da civilização contemporânea, mas berço, certamente, das piores atrocidades políticas e militares da primeira metade do século Xx, na forma institucional do nazismo e do fascismo. Bem ali, em nações marcadas por tradições e cultura seculares, regimes políticos baseados na representação da vontade dos cidadãos e na preservação dos direitos civis, multiplicidade de crenças e povos, eclodi- 
ram nazismo e fascismo - a maior prova, para todo o sempre, de que a consistência institucional de um ordenamento jurídico e de um Estado não pode carecer de uma orientação ética de todas as suas operações. O que tornou possível tanto o nazismo como o fascismo não foram simplesmente a vil virtù e a insanidade de algum gênio político-militar como Hitler, Mussolini, Franco, Stálin; foi, principalmente, a prática sistemática e voluntária, tanto por autoridades como por cidadãos, da violência e da exclusão. ${ }^{9}$ Ora, é claro que no ordenamento jurídico de um Estado não se acha necessariamente a ideologia para a instauração de uma autocracia do estilo do nazismo ou do fascismo especialmente em ordenamentos de Estados constitucionais que se denominam democráticos ou populares, ao menos oficialmente; ${ }^{10}$ o que era o caso dos Estados alemão, italiano e espanhol; mas talvez já não do Estado soviético ${ }^{11}$ —, mas uma autocracia só é implantável ali onde o ordenamento jurídico e a prática política deixam brechas para isso. Jamais o nazismo e o fascismo seriam concretizáveis numa prática política na qual a exclusão social e o desrespeito a direitos civis, ou a ofensiva armada a outras soberanias, fossem de impossível legitimação. A partir do momento em que a violência é legitimada por uma instituição político-jurídica, estamos num estado de coisas tão perigoso quanto o estado de natureza do "modelo jusnaturalista hobbesiano": estamos num estado civil onde a ordem é poder destruir, violar, matar o outro — sem que para isso haja qualquer necessidade racional. ${ }^{12}$

\footnotetext{
${ }^{9}$ Para o caso específico do nazismo, cf. a impressionante estudo de Daniel Jonah Goldhagen, Os carrascos voluntários de Hittler, São Paulo, Companhia das Letras, 2000, onde o autor demonstra detalhadamente como a eficácia da prática sistemática e institucional da exclusão dos judeus dependeu a todo momento da participação da própria população alemã, o que ilustra que a eficácia de qualquer prática governamental violenta depende da submissão ou mesmo da cooptação dos seus próprios cidadãos, seja porque movidos pelo medo do Estado, seja porque movidos pelo ódio àqueles que consideram seus inimigos: jamais a razão é fundamento para a prática da violência.

${ }^{10}$ Em quê pode já ser considerada popular, ainda hoje, a República Popular da China?

${ }^{11}$ A estrutura jurídica do Estado soviético stalinista (que é o que está em questão aqui: é o regime soviético que inaugurou ostensivamente o sistema de expurgo político e exclusão de direitos) era claramente marcada por uma estrutura autocrática; entretanto, como não fazia parte dos planos de Stálin conquistar o mundo (como fazia parte dos planos de Hitler desde a fundação do nazismo), nem a autogestão nacional da União Soviética prejudicava a balança comercial internacional, Stálin nunca foi incomodado enquanto não pensasse em estender o comunismo a outros países; pôde, até mesmo, fazer parte do "time dos Aliados" contra o nazismo e o fascismo. Entretanto, se o stalinismo não impediu a União Soviética de combater o nazismo junto mesmo a aliados ideológica e economicamente adversários, verdade é que impedia, ao mesmo tempo, que a própria União Soviética se tornasse um Estado democrático - não por causa do seu sistema econômico (porque a prática democrática não depende da adoção de um determinado sistema econômico, como pretendem os defensores da democracia liberalista), mas por causa do seu sistema de exclusão de direitos (porque a prática democrática não só depende da criação e preservação de direitos, como ela é criação e preservação de direitos). O que torna a Rússia atual um país mais democrático do que a Rússia soviética stalinista não é a desastradamente iniciada abertura econômica da era Gorbachev, mas unicamente a adoção de um sistema jurídico-político no qual os direitos civis são mais reconhecidos como invioláveis até mesmo pelo Estado.

12 O que Thomas Hobbes diz no capítulo XIII do seu Leviatã (1651), é a descrição perfeita da condição em que se encontra cada um numa condição de violência legitimada pelo Estado: "[...] tudo aquilo que é válido para um tempo de guerra, em que todo homem é inimigo de todo homem, o mesmo é válido
} 
É esse estado de coisas absurdo - absurdo porque de impossível justificação, porque sem razão alguma, sempre - que fez tremerem as bases das teorias político-jurídicas que concluíam pela identidade entre Estado de direito e Estado democrático, entre Estado constitucional e sociedade livre e soberana, ainda que seus teóricos fundamentais fossem na maioria dos casos autênticos e sinceros campeões da democracia e da liberdade, "do direito e da ordem", e que aos que tiveram ainda o desprazer de assistir às anomalias do nazismo e do fascismo, tenha sido necessário por vezes revisar a própria teoria para que ela não mais se permitisse servir de justificativa para a própria prática da violência - uma providência que, em casos estratégicos, não foi suficiente ou deixou muitas aporias. Foram os absurdos das autocracias contemporâneas, ainda, que exigiram do pensamento político-jurídico e da organização institucional dos Estados uma reflexão em busca de novas práticas, que não mais permitissem o retorno aos mesmos erros, que não mais possibilitassem o surgimento dessa contradição histórica que é o Estado democrático de direito ser a causa da sua transformação em seu próprio avesso: que contradição maior pode haver, em termos históricos, do que uma prática política que deveria ser produção de paz e segurança democráticas mas que, instaurada e efetivada, mostra-se produção de exclusão e violência autocráticas? De todas as explicações apresentadas ou esboçadas pelos continuadores no pós-II Guerra do historicismo jurídico, do positivismo jurídico e do utilitarismo jurídico, nenhum conseguiu apresentar uma explicação que deixasse intacta, diante do problema dessa contradição histórico-política, a doutrina original dos seus mestres fundadores. A razão para isso não está numa estreiteza de visão desses papas do pensamento jurídico contemporâneo, mas sim na própria natureza de cada uma dessas correntes, quando transformadas efetivamente em doutrina: quando uma teoria jurídica contemporânea transforma-se em dogmática jurídica, lá se foi o compromisso com a razão mesmo na teoria; e enquanto não se recuperar a idéia de que a reflexão crítica é imprescindível à certeza teórica até mesmo no discurso e no pensamento jurídicos, haverá nesse discurso e nesse pensamento uma abertura total para a instauração de formas novas de exclusão e de violência sistemáticas por parte do Estado e das instituições político-jurídicas. Não à toa, a ciência política do século Xx tendeu sempre a considerar que a democracia sem exclusão é uma impossibilidade.

também para o tempo durante o qual os homens vivem sem outra segurança senão a que lhes pode ser oferecida pela sua própria força e sua própria invenção. Numa tal situação não há lugar para a indústria, pois seu fruto é incerto; conseqüentemente não há cultivo da terra, nem navegação, nem uso das mercadorias que podem ser importadas pelo mar; não há construções confortáveis, nem instrumentos para mover e remover as coisas que precisam de grande força; não há conhecimento da face da Terra, nem cômputo do tempo, nem artes, nem letras; não há sociedade; e o que é pior de tudo, um constante temor e perigo de morte violenta. E a vida do homem é solitária, pobre, sórdida, embrutecida e curta". 
Ora, se houve uma ampla discussão a respeito da revisão da prática contemporânea da democracia, o que essa revisão revelou, além do perigo da legitimação de práticas autocráticas como o nazismo e o fascismo, é que até mesmo numa prática política que se pretenda democrática e não autocrática — porque nela há a garantia institucional de direitos, solução jurídica e pública de conflitos e a organização autônoma e jurídica do próprio Estado; ou seja: todo Estado que atualmente se diz democrático - é possível estar, ainda, longe da democracia: basta não conceber a democracia como banalização da exclusão de minorias em função do benefício de uma maioria; em outras palavras, se todos os elementos que são reconhecidos ainda atualmente como fundamentais numa sociedade democrática — liberdade política, garantia de direitos civis, participação no processo eletivo dos representantes, manifestação pública do próprio pensamento etc - são concebidos apenas como de realização possível e não de realização imprescindível, estamos certamente fora de um Estado democrático de direito, pois que se concebe, na prática, que numa democracia bastaria garantir a existência de direitos, mas não a sua concretização. Ora, direitos que não podem ser exercidos são direitos que não existem. Como diz Norberto Bobbio a respeito da discussão atual sobre os direitos humanos, é mais importante discutir meios de concretizar esses direitos do que discutir quais são eles. Por quê? Justamente porque independente da qualidade do elenco de direitos a que venha chegar a discussão sobre os direitos humanos, a impossibilidade do seu exercício significará sempre a inutilidade da sua existência desde já no papel. Essa observação, porém, vale não apenas para os direitos humanos, mas vale para qualquer tipo de direitos. Se ela é colocada, por Bobbio, diante de uma árdua discussão impulsionada exatamente pela condição não jurídica dos direitos humanos (que só se tornam jurídicos — isto é, só recebem proteção jurídica — quando integram um ordenamento, de preferência já na Constituição), o caso do não exercício de direitos reconhecidos como válidos ou relevantes é muito mais grave quando estamos tratando já de direitos definidos no ordenamento jurídico: pois o que temos, nesse caso, é a constatação de ineficácia do próprio Estado. Voltamos, aí, ao que Thomas Hobbes chama de estado de natureza: uma condição na qual o indivíduo não conta ainda (ou não conta mais) com a proteção do soberano.

O que causava indignação no caso das autocracias de molde nazista e fascista era a constatação de que de um Estado formalmente democrático de direito é possível descambar para uma prática sistemática da violência e da exclusão; o que causa, agora, constrangimento desde essa última metade do século Xx é a constatação, na verdade anunciada desde muito antes, de que até num Estado de direito oficialmente não autocrático a democracia pode estar distante, se não se perceber que a medida da democracia não é a forma de governo, mas a ilegitimidade em qualquer nível da exclusão social. Não se trata, aqui, de identificação entre sociedade democrá- 
tica e sociedade socialista, ${ }^{13}$ até porque a ilegalidade do livre comércio ou a ilegalidade da propriedade privada são, também, formas de exclusão social; a experiência histórica é que mostra que a exclusão social é uma obra fundamentalmente operada pelas instituições, e não pelos particulares, por mais sem caráter que sejam estes. Não por acaso, os primeiros que modernamente mostraram os fundamentos da soberania e autonomia de um Estado apontaram, também, que essa soberania e autonomia depende diretamente da força (ou da fraqueza) das instituições do próprio Estado. O que é possível, o que é legítimo, o que é necessário, o que é válido no horizonte da sociedade e do Estado, tudo isso depende fundamentalmente da qualidade das instituições sociais, que devem ser instrumento e não empecilho para a constituição da paz pública; e, como diz Espinosa, se os homens são levados a obedecer às instituições civis seja por medo de represálias, seja por amor à segurança, é sempre porque ao zelarem pela segurança e realização dos interesses do Estado sentem que seguem um impulso da sua própria índole; ${ }^{14}$ e, como só na democracia as instituições são criadas ou operadas com alguma participação direta de cada cidadão, só nela os homens conhecem que os interesses e a segurança do Estado são o seu próprio interesse e segurança, e será por isso que, em Espinosa, o reconhecimento racional da democracia será a realização de uma paixão alegre coletiva. ${ }^{15}$

É para esse horizonte do pensamento político-jurídico contemporâneo acerca da democracia que esta tese se dirige. Mais do que uma pesquisa de história da filosofia moderna, mais do que uma análise da articulação dos conceitos jurídicos de Espinosa em seu pensamento jurídico, político, físico, ontológico — ético, enfim —, este texto tem a pretensão de mostrar a relevância do pensamento espinosano para o pensamento jurídico acerca da democracia.

Em que medida, porém, é legítimo trazer para a discussão de questões contemporâneas de prática e teoria político-jurídica, um autor moderno? Ou em que medida é legítimo levar a esse autor moderno problemas que lhe são à primeira vista anacrônicos? A chave, sempre, está naquilo que essa aparência tem de irrelevante: naquilo em que esse anacronismo ou essa incompatibilidade escondem, em verdade, uma relação necessária entre pensamento e objeto. Porque não é um pensamento voltado para o fugidio, o pensamento de Espinosa está presente para nós naquilo em que nos esclarece sobre a nossa própria experiência e razão. Porque todo o pensamento espinosano é voltado para a experiência e razão que está presente em cada ser hu-

\footnotetext{
13 Esta é, entretanto, uma questão importante entre os comentadores polítios de Espinosa; a propósito, os trabalhos de André Tosel e Antonio Negri são uma contribuição fundamental.

14 Tratado político, cap. III, $₫ 3$.

15 Ver a propósito deste ponto o capítulo 4.II ("Democracia, uma necessidade da política e do direito"), que entre outras coisas trata da "paixão alegre da democracia" em Espinosa.
} 
mano, ele não está ausente nunca nem guarda anacronismo com nenhum problema: para Espinosa, todos os problemas podem ser colocados. Mas talvez não em quaisquer condições. De fato, em que sentido é válido confrontar toda essa discussão a respeito do horizonte políticojurídico das teorias e práticas contemporâneas da democracia com o vocabulário seiscentista e o pensamento absolutamente racionalista de Espinosa?

Desde logo, antes mesmo de se iniciar um percurso pela obra desse que foi o primeiro teórico moderno da democracia, vale anunciar que o interesse da obra espinosana para a reflexão a respeito da relação entre direito e democracia é duplo: primeiro, porque Espinosa, como autor da primeira teoria moderna da democracia, imprime nessa teoria da necessidade natural da democracia uma filosofia jurídica cujo fundamento também é uma identificação entre direito e democracia; segundo, porque o pensamento espinosano, além de ser um pensamento a favor da democracia, só o é graças a uma concepção completamente racional da política e do direito (ou seja: baseada na experiência política e voltada para o conhecimento verdadeiro da natureza da política e do direito), e não em função de qualquer forma de fanatismo político. Se é verdade que o pensamento político contemporâneo volta-se o mais das vezes para uma reflexão acerca de como alcançar ou manter a democracia, é também verdade que esse mesmo pensamento político deve conquistar a ousadia de dizer o verdadeiro sobre a natureza da política, por mais que essa ousadia - presente fundamentalmente no pensamento moderno de Espinosa — pareça constrangedora ao olhar contemporâneo e ao olhar pós-moderno. Se, como diz Ch. Delacampagne, 16 "filosofia e democracia só podem avançar juntas", a filosofia de Espinosa, ao exigir o realismo racional (ou seja, a filosofia) como observação válida da política e ao deduzir a democracia como forma mais natural da política (porque a mais adequada às necessidades naturais das pessoas em sociedade), é o primeiro, senão em muitos sentidos o único, a identificar filosofia e democracia como uma mesma prática racionalista. No panorama contemporâneo do pensamento jurídico, uma das questões centrais é a definição do que é a democracia, num horizonte de indefinição e dissenso gerais entre teóricos e práticos. Entretanto, apesar desse ambiente natural de contrariedades e multiplicidade de concepções (que Espinosa, a propósito, mostra ser o ambiente mais propício à democracia, porque o mais indicativo da liberdade de pensamento numa república livre), o pensamento jurídico contemporâneo se permite uma convicção: a autocracia, apesar de ser uma ameaça constante e infelizmente um desvio recorrente nos momentos de suspensão dos direitos e nos regimes de exceção, é uma solução injustificável; a democracia (o que quer que possa ser ela), sua alternativa natural, e talvez até uma busca da humanidade. Em Espinosa, justamente, essa convicção de que a democracia deve ser

\footnotetext{
${ }^{16}$ Christian Delacampagne, La philosophie politique aujourd'bui, p. 13.
} 
buscada porque é sempre atualmente necessária, está plenamente fundada e demonstrada, ainda que por vezes se ache recoberta pelas lentes da retórica (essa estratégia tão preciosa no campo da argumentação política, e que se revela mesmo uma necessidade prática para a exposição do verdadeiro acerca da política).

Isso, apenas, para marcar mui superficialmente a atualidade de Espinosa no campo do pensamento político-jurídico. ${ }^{17}$ Porque em termos de história da filosofia moderna, o reconhecimento das justas dimensões do pensamento jurídico espinosano me parece ter sido, até hoje, injustificadamente tímido, especialmente se considerarmos que Espinosa tem sido reconhecido, ao menos, como um dos fundadores do conceito moderno de democracia, e um dos maiores defensores da liberdade na política e na ética. Por que se omite, aí, um reconhecimento do papel da filosofia jurídica de Espinosa dentro da sua concepção da democracia enquanto necessidade natural da vida política? Por que se omite, aí, a desconstrução sem precedentes que Espinosa realiza no pensamento jusnaturalista, a ponto de toda concepção jusnaturalista anterior ou posterior não poder se sustentar diante da teoria jurídica espinosana, se confrontada com ela? Por que a historiografia jurídica contemporânea, ao passar por Espinosa, silencia ou dissimula? As razões para isso não dizem respeito apenas ao cultivo de uma certa maneira de se ler a filosofia espinosana ou a filosofia moderna; essa omissão ou dissimulação — que a seu tempo apresentaremos - guarda especialmente um compromisso com a impossibilidade de resolver muitas aporias do próprio pensamento político-jurídico contemporâneo, especialmente no que respeita à definição da democracia e do direito democrático. Todavia não será, aqui, o caso de contrapor Espinosa a essas teorias contemporâneas, porque o problema contemporâneo é ilustrado no momento como um objeto para o pensamento espinosano - que o alcança e, tanto quanto faz diante das teorias jusnaturalistas, não passa sem incomodar profundamente o olhar contemporâneo; uma tal contraposição só seria legítima depois que se completasse o reconhecimento do pensamento jurídico espinosano tal como ele merece ser reconhecido, uma tarefa a meu ver ainda incompleta, e para a qual com este texto busco apenas apontar e tentar contribuir de alguma forma. Pois justamente, para que seja ampliado esse reconhecimento do pensamento jurídico espinosano tal como ele é (e não segundo o filtro dos seus adversários no "século jusnaturalista" ou dos seus detratores nos séculos seguintes, especialmente no tão antijusnaturalista, antimetafísico e anti-racionalista pensamento jurídico contemporâneo), é preciso ler

\footnotetext{
$17 \mathrm{O}$ peso dessa atualidade será muito mais evidenciado nos capítulos 4 (sobre teoria jurídica e democracia) e 5 (sobre teoria dos direitos subjetivos), se se quiser medir a atualidade de uma filosofia em função dos problemas políticos prementes a que ela oferece uma pronta resposta; mas como também estamos diante de um autor no qual tempo, atualidade e eternidade se entendem de uma maneira muito diferente da comum, talvez só ao final do nosso percurso e no interior da Conclusão possamos entender em que sentido se deve entender que Espinosa é, especialmente em filosofia política, "nosso contemporâneo".
} 
Espinosa por ele mesmo. Se é o caso de compreender nele uma crítica feita à tradição jurídica, é preciso manter a compreensão do pensamento espinosano à luz dele mesmo e não à luz da tradição a que se quiser contrapô-lo. Se é o caso, finalmente, de propor uma leitura espinosana das questões da filosofia contemporânea do direito, não será aqui o lugar — embora seja aqui, enfim, o momento oportuno de se esclarecer o que é essa filosofia jurídica espinosana que depois nos pedirá, sempre, uma ação política no tempo presente, porque o impulso político que a filosofia espinosana vê e exige não é uma concepção atrelada a uma época, mas é uma necessidade imanente à própria natureza humana. Espinosa mostra que estão na natureza humana os elementos naturais que exigem uma vida política em democracia e em liberdade, e fora da violência e da exclusão. Por ser uma tese deduzida do conhecimento adequado da política, essa tese desafia o ceticismo contemporâneo que teme viver de convicções, justamente porque a imagem que tem da sua própria razão é uma imagem de impotência.

Tendo os desafios do pensamento democrático como horizonte e o pensamento políticojurídico de Espinosa como percurso, é preciso saber quais são os grandes instrumentos teóricos para essa análise. Porque de fato, mais do que propor o pensamento espinosano como uma maneira de se pensar, no direito, a democracia — não há nisso, em verdade, nada de surpreendente: o pensamento espinosano é um pensamento que propõe, naturalmente e necessariamente, por sua história e por seu conteúdo, a democracia —, o que esta reflexão propõe é um reconhecimento da potência do pensamento jurídico espinosano enquanto, de um lado, crítica filosófica ao irracionalismo jurídico e, de outro, enquanto atividade política na história do pensamento.

No que respeita ao primeiro aspecto — o pensamento jurídico espinosano, uma crítica filosófica ao irracionalismo jurídico —, temos em Espinosa uma teoria da Estado e do direito que, se por um lado concebe a vida política como realizando-se plenamente na democracia, por outro concebe o direito de uma maneira contrária a duas formas inadequadas de pensá-lo: de um lado, na filosofia, o jusnaturalismo, cujos conceitos são utilizados e subvertidos por Espinosa de forma a mostrar sua falta de sentido numa perspectiva racional da natureza do homem e do Estado; de outro lado, na teologia, o dogmatismo político, cujos preceitos tentam valer como normas para a vida política, sendo que, numa perspectiva racional, revelam-se separados por natureza da natureza da política e da liberdade. Espinosa, ao teorizar a respeito do direito, faz uma crítica simultânea aos erros teóricos dos jusnaturalistas e às pretensões institucionais dos doutores que se pretendem autoridades num campo que não lhes é próprio: a política. O resul- 
tado dessa crítica, que opera especialmente com o vocabulário jusnaturalista alcançando de um mesmo golpe seja as tradições jusnaturalistas, seja as correntes da teologia política, produz como resultado uma inovadora desconstrução do jusnaturalismo (o que exige a elaboração de uma nova forma de se conceituar o direito, o que Espinosa faz) e, ao lado disso, ilegitima por completo a influência das instituições e autoridades não políticas nos campos da política, aí incluído o direito; e, como essa crítica à teologia política é uma crítica não à liberdade para a fé ou para a religião, mas sim uma crítica à usurpação por instituição de um campo que a ela não cabe, temos de ponta a ponta uma crítica que cabe a toda autoridade ou instituição que se pretende válida ali onde não é seu campo natural; ou seja: temos os elementos de uma crítica à operação ilegítima de qualquer instituição que seja; se as próprias instituições jurídicas atuarem contrariamente à sua necessidade natural, ainda que estejam no campo da política não operam enquanto instituições políticas, mas como anomalias despóticas, contrárias à própria política. A crítica espinosana à teologia política é, em todos os momentos, uma crítica válida contra o despotismo na política e a corrupção no direito, porque é uma crítica a toda autoridade fora de seu lugar necessário, uma crítica a todo poder que se pretenda válido independente das necessidades da coisa pública. A teoria espinosana do conatus mostra que isso é uma violência não apenas à democracia, como é uma violência à própria política e à própria natureza humana.

O corolário dessa crítica espinosana ao jusnaturalismo e à teologia política é a necessária perspectiva espinosana da prática da justiça numa sociedade historicamente dada. Embora em Espinosa o conceito clássico de justiça também passe pela mesma crítica desmistificatória traçada sobre as concepções jusnaturalistas, o que a concepção espinosana da natureza da política e da natureza humana mostra é que essas duas expressões de uma natureza que em verdade é a mesma exige um determinado estado de coisas: a natureza humana, desejosa de preservação da potência e persistência na existência, e a natureza da política, cuja potência só se preserva e sua existência só persevera enquanto fundada na potência de todos os indivíduos que juntos compõem o corpo político, exigem a liberdade democrática, isto é, exigem a criação e o cultivo de direitos sem exclusão, seja de direitos, seja de participantes nessa comunidade democrática. A natureza do homem e das sociedades humanas, pois, tem como necessária a construção dessa condição na qual sua potência é exercida plenamente. Ora, como Espinosa deduz a importância das instituições na organização da sociedade e do Estado, é deduzida também a maior potência que as instituições alcançam na medida em que são instituições democráticas: a natureza e o conatus do Estado pedem instituições adequadas à democracia; não se tratará, porém, de mode- 
los, ${ }^{18}$ mas antes de princípios a respeito da necessidade de qualquer instituição política: basicamente, as instituições devem ser instrumento de fortalecimento da vida política e dos direitos dos cidadãos, e não o contrário disto. Por isso, as instituições do Estado não podem ser operadas como instrumentos de exclusão; não podem, portanto, ser instrumento de autoritarismo nem de violência. Para usar um termo mais do que pertinente do pensamento jurídico contemporâneo, as instituições políticas devem ser instrumento para a prática de um direito justo. Essa expressão de Stammler, ${ }^{19}$ concebida como uma crítica a um irracionalismo tipicamente contemporâneo - o positivismo jurídico oitocentista, ao menos aquele que defende sua validade porque se reconhece como autoridade nos processos de legitimação das ações do Estado ainda que tipicamente contemporânea, representa, por um lado, uma concepção jurídica tão fundamental para o discurso contemporâneo quanto o próprio positivismo jurídico (o que não nos interessa aqui por fugir do nosso campo de estudo) e, por outro (o que aqui nos é relevante), representa também um desvio diante do imediatismo do pensamento contemporâneo, pois que opera, ainda que provavelmente contra as intenções teóricas de seu autor, como base ontológica da prática jurídica - e isto porque, ao propor uma recuperação da ética como orientação para a prática institucional do direito, recupera um campo considerado já pelo positivismo jurídico de então uma "metafísica" a ser esquecida. Stammler, nesse raro momento em que o pensamento contemporâneo faz uma crítica de si mesmo naquilo que tem de fundamental a ponto de exigir uma inversão de valores, dá-nos acesso a uma concepção contemporânea dos equívocos do próprio pensamento contemporâneo, e com isso nos confirma que a concepção ética do direito não apenas não é incompatível com a contemporaneidade jurídica, mas é mesmo uma sua necessidade. Ora, embora o direito justo — que, sob outras formas, reaparece nas teorias da justiças das últimas décadas e acompanha o fulgor do que Batiffol, enfim, acusa como ressusci-

${ }^{18}$ Por mais que isso seja polêmico: muitos comentadores consideram que Espinosa oferece modelos de instituições de acordo com os diferentes regimes políticos. Considero essa tese inaceitável e empobrecedora, como busco demonstrar especialmente nos capítulos 4.I ("O direito positivo, um instrumento para a razão") e 4.II ("Democracia, uma necessidade da política e do direito").

${ }^{19}$ Jurista neokantiano do início do século Xx, Stammler é o primeiro autor contemporâneo a fazer uma crítica jurídica à falta de compromisso do positivismo jurídico com a questão da justiça, por meio de uma teoria que torna-se conhecida como doutrina do "direito justo". O significado estratégico dessa teoria, antes mesmo das experiências do nazismo e do fascismo, é interessante para marcar a atualidade a qualquer tempo da crítica aos perigos da prática jurídica despreocupada de qualquer orientação ética, e em termos contemporâneos vale como uma teoria jurídica que consegue denunciar as aporias éticas do positivismo jurídico para além de qualquer manifestação de cunho político (no sentido pejorativo do termo, utilizado freqüentemente por Kelsen quando ataca as pretensões de avaliar o grau de justiça ética de uma prática jurídica). Voltaremos a Stammler no capítulo 6.II, quando for o caso de considerar a existência de uma idéia espinosana de direito justo — não nos termos de Stammler, mas de forma tão valiosa quanto. Diante desse perigo constante que é a idéia de que o justo é a vontade do mais forte, parece-me legítimo propor, para o pensamento de Espinosa, um conceito de direito justo cujo sentido é completamente espinosano e, como em Stammler (ainda que isso seja irrelevante; e também porque num e noutro caso as razões teóricas são extremamente diferentes), é uma necessidade crítica da própria teoria. 
tação constante do jusnaturalismo - não seja um conceito espinosano, é contemporaneamente um conceito para o pensamento espinosano, isto é, é uma idéia compatível com o pensamento de Espinosa e, sob outra forma — a concepção espinosana da expressão paz e segurança —, já presente nele. De modo que a sua relevância numa análise do pensamento jurídico espinosano no horizonte da democracia não se deve a um suposto caráter precursor do pensamento de Stammler, ${ }^{20}$ mas é o pensamento stammleriano que não deixa dúvidas quanto à pertinência e atualidade da concepção espinosana da prática jurídica mais adequada à democracia.

Assim, além do reconhecimento da crítica espinosana ao jusnaturalismo e ao autoritarismo, é completamente pertinente (e no momento propício argumentarei que é mesmo necessário) reconhecer a concepção de um direito justo em Espinosa, porque nele o direito, entendido como instituição, só alcança legitimidade se é capaz de produzir eficácia jurídica sem o preço da exclusão. Se a justiça é definida por Espinosa como uma concepção definida pela própria autoridade soberana (que é a autora das leis civis), ${ }^{21}$ que outra justiça pode ser concebida senão essa cuja eficácia se mede pela liberdade democrática (a única liberdade adequada à verdadeira soberania)? Diante desse quadro básico, e tendo em vista os problemas teóricos e políticos mencionados no início desta Introdução, busco sugerir neste trabalho especialmente quatro teses:

Primeiro, a idéia de que a filosofia política de Espinosa exprime uma filosofia do direito, e que é necessário considerar o Espinosa filósofo da política não apenas um pensador do direito e da lei, como um autêntico jurista que dialoga com as teorias jurídicas do seu tempo e mesmo anteriores à tradição jusnaturalista moderna (e que também, no que isto é relevante, torna-se um precursor da teoria jurídica contemporânea);

Segundo, a idéia de que Espinosa elabora uma teoria do direito natural e do direito civil que esvazia por completo a legitimidade dos termos centrais do jusnaturalismo e produz, com isto, uma aniquilação do jusnaturalismo em seu pleno auge (basta lembrar que é o momento em que Pufendorf está elaborando os seus primeiros textos sobre o direito natural e das gentes), o que exige uma linguagem jurídica e política que extingue a conceitografia jusnaturalista, e que também torna Espinosa um antijusnaturalista antes de Hegel;

Terceiro, a idéia de que a sua teoria político-jurídica antijusnaturalista é uma teoria da política enquanto democracia e da legitimidade enquanto justiça ou justeza na democracia, o que também o torna uma referência antipositivista antes, por exemplo, de John Rawls, e um jurista do direito justo antes, por exemplo, de Stammler;

\footnotetext{
${ }^{20}$ Não acredito mesmo que haja qualquer sentido numa tal idéia; ambos os pensamentos são profundamente valiosos considerados em si mesmos e sem qualquer necessidade de comparação.

${ }^{21}$ Tratado teológico-político, cap. XVI: "A justiça é a disponibilidade constante para atribuir a cada um aquilo que, de acordo com o direito civil, lhe é devido; a injustiça, pelo contrário, consiste em tirar a alguém, sob uma falsa aparência de direito, o que lhe pertence segundo a verdadeira interpretação das leis."
} 
Finalmente, a idéia de que a teoria espinosana da democracia exprime um pacifismo teórico em termos seiscentistas (não na perspectiva de uma "ciência política" acerca da guerra e da paz, na perspectiva ética e ontológica da experiência política: uma ética jurídica ou uma teoria da justiça, em termos espinosanos).

Realizado, este projeto permite não apenas a sistematização da filosofia jurídica de Espinosa, como permite também uma análise inspirada em Espinosa dos fundamentos da ordem jurídica, assim como de todo o pensamento atrelado a essa prática. Tal análise, a propósito, não é uma excentricidade filosófica por dois motivos: primeiro, porque é exatamente o que o próprio Espinosa havia reservado para os últimos capítulos de seu Tratado político;22 segundo, porque em não poucos aspectos a prática jurídica contemporânea está equivocadamente distante da idéia espinosana do direito enquanto direito democrático, concepção produzida por um racionalismo jurídico que deseja dar acesso simultaneamente ao verdadeiro e ao pacífico.

Essa análise, válida tanto do ponto de vista da historiografia da filosofia espinosana, quanto do ponto de vista da reflexão jurídica em geral (a partir da filosofia moderna, mas também a partir de questões tipicamente contemporâneas), é em especial uma tentativa de recuperar para Espinosa o devido lugar que lhe cabe tanto diante do jusnaturalismo quanto diante da filosofia do direito — de maneira que, juntando-me a Simone Goyard-Fabre em sua convicção antijusnaturalista, mas discordando francamente com sua tese de que "tudo já foi dito a respeito do direito natural", proponho, nesta reflexão acerca do papel da filosofia jurídica na prática da democracia, tanto o reconhecimento da antiteoria espinosana do direito natural (a primeira teoria, em verdade, a tornar filosoficamente ilegítimo o projeto do jusnaturalismo), assim como o reconhecimento, através do antijusnaturalismo espinos ano, da necessidade racionalista de se pensar o direito enquanto direito democrático e direito justo. Uma necessidade já indicada em diferentes momentos e sob diferentes perspectivas por Stammler, d'Entrèves, Rawls... mas que não significa, de forma alguma, um ressuscitamento do jusnaturalismo, por mais majestoso (para aproveitar ainda a expressão de G oyard-Fabre) que ele tenha realmente sido. Para apontar a prática jurídica comprometida com a democracia absoluta, ao mesmo tempo que erguer uma crítica ao irracionalismo das

\footnotetext{
${ }^{22} \mathrm{Na}$ Carta 84 (colocada na edição póstuma como prefácio ao seu Tratado politico, obra cuja redação foi interrompida pela morte do filósofo), Espinosa comenta ao amigo destinatário que já escreveu alguns capítulos da obra e restam os finais em que ainda tratará, entre outras coisas, da democracia e "das leis e outras questões particulares que dizem respeito à política". Esse capítulo final sobre as leis, Espinosa nunca escreveu; seria, em sua obra, o único texto em que trata exclusivamente do direito positivo, numa posição privilegiada: depois da demonstração, naquele pequeno tratado político-jurídico, da necessidade democrática das instituições.
} 
instituições político-jurídicas, não é necessário apelar ao cemitério desse mesmo irracionalismo jurídico - principalmente numa perspectiva espinosana, que também enquanto filosofia jurídica é uma reflexão de vida, e não de morte, impotência, exclusão, desistência diante das injustiças que marcam a história da relação entre os cidadãos e as instituições. 


\section{PARTE I}

\section{DO JUSNATURALISMO AO RACIONALISMO JURÍDICO: O ANTIJUSNATURALISMO ESPINOSANO}

Nam lex humanae naturae universalis est, ut nemo aliquid, quod bonum esse judicat, negligat, nisi spe majoris bonis, vel ex metu majoris damni; nec aliquod malum perferat, nisi ad majus evitandum, vel spe majoris boni: Hoc est, unusquisque de duobus bonis, quod ipse majus esse judicat, \& de duobus malis, quod minus sibi videtur, eliget. Dico expresse, quod sibi eligenti majus aut minus videtur, non quod res necessario ita se habeat, ut ipse judicat. Atque haec lex adeo firmiter naturae humanae inscripta est, ut inter aeternas veritates sit ponenda, quas nemo ignorare potest. At ex ea necessario sequitur neminem absque dolo promissurum, se jure, quod in omnia habet, cessurum, \& absolute neminem promissis staturum, nisi ex metu majoris mali vel ipse majoris boni.

Manda a lei universal da natureza humana que ninguém despreze o que julga ser bom, a não ser na esperança de um maior bem ou por receio de um maior dano, nem aceite um mal a não ser para evitar outro ainda pior ou na esperança de um maior bem. Entre dois bens, escolhe-se aquele que se julga ser o maior, e entre dois males, o que pareça menor. Sublinho que é aquele bem ou mal que parece ser o maior ou o menor, respectivamente, para quem escolhe, já que as coisas podem não ser necessariamente assim como ele julga. Esta lei está tão firmemente inscrita na natureza humana que temos de a colocar entre aquelas verdades eternas que ninguém pode ignorar. Dela resulta necessariamente que só por malícia alguém prometerá renunciar ao direito que tem sobre todas as coisas, e que só por medo de um mal maior ou na esperança de um maior bem alguém cumprirá tais promessas. 
SEÇÃO 1

UM FILÓSOFO VOLTADO PARA O DIREITO 


\title{
CAPÍTUlO 1 \\ ESPINOSA, FILÓSOFO DO DIREITO?
}

\begin{abstract}
A filosofia do direito [dos jusnaturalistas] integra-se às visões cósmicas e antropológicas que, em diferentes épocas, as diversas filosofias propuseram. Nesse momento, a filosofia do direito de Espinosa, de Wolff ou de Hobbes... não é senão uma parte de um todo, e, como tal, é evidente que ela participa do espírito metafísico: ela oferece hipóteses, ideais, bem mais que se fixa na realidade objetiva do jurídico para descrevê-la e elucidá-la. E pode-se dizer que, até o séc. XIX, a filosofia do direito - em autores como Pufendorf, Burlamaqui e mesmo J. Domat, todavia mais juristas que filósofos permaneceu essencialmente especulativa. Por essa razão, essa metafísica do direito não pode nos ajudar a conhecer a realidade mesma do jurídico.
\end{abstract}

Simone Goyard-Fabre, Essai de critique phénoménologique du droit, p. 16.

\section{I RELIQUA DESIDERANTUR: QUAL É O RESTANTE QUE FALTA?}

\section{Como classificar um filósofo?}

Espinosa não se dedicou exclusivamente a um só campo da filosofia; ao contrário, parece que não há campo da filosofia pelo qual ele não tenha passado, inclusive a filosofia política e a filosofia do direito. Por isso mesmo, ele não é exclusivamente um pensador da política, e proporcionalmente talvez seja muito menos um pensador do direito. Esteve longe, certamente, de ser um jurista profissional. Qual é, porém, a importância da política e do direito no seu sistema, e qual a sua disposição dentro dele?

No que diz respeito ao Espinosa político, a leitura corrente mostra-nos o autor de uma teoria jurídica que identifica direito natural e potência, de uma teoria política que nega aos teólogos influência no Estado, o autor de um pensamento político e especialmente de uma teoria da democracia que ele não teve tempo de concluir, talvez justamente por ter deixado a política de segundo plano, decidindo tratá-la só depois que o principal estivesse concluído, nos campos da ontologia, da epistemologia, da ética... Esta, talvez, a visão corrente, e ainda a que busca saciar o quanto puder sua curiosidade acerca do filósofo. À historiografia da filosofia política, Espi- 
nosa aparece estranhamente como um autor menos intrigante do que o autor da Ética, do Tratado da emenda do intelecto, dos Princípios da filosofia de Descartes. Para eles, em geral, o autor do Tratado teológico-político e do Tratado político é algo como um analista dos fatos políticos do seu tempo, mas também o elaborador de modelos políticos de um irrealismo impressionante, especialmente no que diz respeito ao projeto da democracia. Quanto ao Espinosa filósofo do direito, para eles ainda, e em geral, talvez ele seja a radicalização daquela falta de consciência do real manifestada diante das coisas da política: seria, assim, autor de uma curiosa teoria contratualista na qual o direito natural absurdamente continuaria presente no estado civil, de uma teoria do direito positivo onde a lei em certos momentos é a fonte maior do direito e em outros pode ser desobedecida arbitrariamente... seria o autor, principalmente, de uma teoria jurídica que identifica o direito subjetivo à potência do indivíduo, negando com isso a realidade do próprio direito, como teria dito Fichte, e impossibilitando a elaboração de uma teoria jurídica efetiva, como já dissera o grande Pufendorf...

Do olhar vulgar sobre a obra e o homem, cultivou-se constantemente a imagem do filósofo solitário e misantrópico, adverso às regras e costumes da vida em comum talvez já desde antes mesmo de sua excomunhão da comunidade judaica de Amsterdã, e partidário de idéias políticas republicanas incompatíveis com os verdadeiros costumes de seus concidadãos e às vezes incompreensíveis até aos seus próximos na filosofia e na política. Em quase todas essas leituras — de seu tempo ou de depois, dos leigos ou dos eruditos, dos práticos ou dos teóricos —, uma dose de excentricidade sobre a figura do filósofo ou de desconfiança quanto à sua plena validade parece sempre estar presente, como se Espinosa, apesar de todo o cuidado conceitual e demonstrativo, estivesse fora de lugar. ${ }^{23}$ Justamente, se é comum que quanto mais difundida a imagem unívoca de um filósofo, mais problemática ela seja por talvez significar que ninguém o leu de perto o bastante, em Espinosa parece que temos, enfim, a pior imagem que se poderia atribuir a um pensador da política e do direito: metafísico, herético, utópico, contraditório, obscuro... Nem mesmo hoje, quando certamente já há uma considerável tradição centenária de estudos políticos a respeito de Espinosa, sua estatura parece ser devidamente conhecida no que diz respeito à filosofia do direito. Mesmo no estudioso mais dedicado ao pensamento político de Espinosa, parece haver quanto a algum aspecto um momento de desconfiança: afinal, esse autor que defendeu a democracia não teria também, de certa forma, legitimado os outros regimes políticos? Esse autor que, na verdade, negou a existência do contrato social não teria, po-

23 Assim, por exemplo, a excentricidade espinosana estaria manifesta especialmente na função de pensador da política: ainda que autor de uma "doutrina" realista, seria como um "psicólogo" que Espinosa teorizaria sobre o Estado, diz Paul Vernière a respeito desse filósofo que segundo ele ao menos não deixou de ser um precursor do grande "jurista e sociólogo" Montesquieu (P. Vernière, Spinoza et la pensée française avant la Révolution, p. 457). 
rém, criado uma nova teoria da relação entre estado civil e estado de natureza? Esse autor, enfim, cujas teses sobre o direito natural são realmente distintas de muitas teses dos seus contemporâneos não teria, porém, feito nada mais do que uma outra teoria do direito natural? Pior: se é verdade que ele nega a validade do contratualismo, não teria Espinosa regredido ao jusnaturalismo dos antigos?

De uma primeira vista, apenas aspectos de filosofia do direito parecem estar presentes em suas obras que chegaram até nós e que de alguma forma tratam da política — a Ética, o Tratado teológico-político e o Tratado político —, além de alguns momentos da sua breve correspondência. Esse conjunto de textos, que permitem a Espinosa chegar diretamente à política, todavia parecem a uma primeira vista mostrar que ele de fato a considerava um aspecto totalmente secundário dentro da obra toda. Afinal, na sua obra principal, a Ética, a política aparece apenas em raríssimos momentos e, ao leitor que pela primeira vez tenha contato com estas teses, a política estaria lá de uma forma que marcaria mesmo sua pouca relevância: como comentários adicionais às teses geométricas e principais da obra; no Tratado teológico-político, pois, o tema central talvez pareça, a esse mesmo leitor, a crítica à religião e à teologia, e não a própria política, já que esta parece mesmo relegada a capítulos finais que, ainda que tenham sido anunciados pelo autor como uma outra questão a ser abordada além da teologia, talvez queiram mesmo significar que a teoria do Estado, numa obra cuja função primordial parece mesmo ser a crítica à relação entre a teologia e o poder, considerada em si mesma seja apenas um estudo protocolar, complementar mas não imprescindível ao tema autêntico do Teológico-político; e finalmente, ao leitor que se depara pela primeira vez com o inacabado Tratado político, a leitura agora é tomada de estupor pelas contradições dessa obra lacônica e dogmática, que começa por uma crítica às utopias e às teorias políticas dos filósofos para propor o desvario utópico mais impensável que se poderia imaginar num filósofo pretensamente realista da política... mais do que isto, o inacabamento do brevíssimo Tratado político (essa obra que talvez pudesse ser concluída de uma assentada, numa boa tarde de concentração) bem ali no início da explicação da democracia, talvez seja ainda a melhor indicação de que o próprio autor, finalmente, deu-se conta da difícil aporia teórica que nem pelas falácias mais absurdas seria capaz de resolver... Enfim, para essa primeira leitura de Espinosa, a política talvez apareça mesmo como prova do estágio terminal do seu projeto racionalista: este, no plano da prática, não teria conseguido manter-se de pé.

Não bastasse isso, a obra política espinosana, por sua brevidade e excentricidade, parece pífia e injustificável diante do peso das teorias dos grandes autores políticos da época: Grotius, Hobbes, Selden, Velthuysen, de la Court... Se Espinosa parece ter dedicado à política e ao direito passagens tão lacônicas ou textos tão densamente carregados de teses dogmáticas e alucina- 
das, aqueles autores, em contrapartida, teriam construído por décadas a fio uma explicação aprofundada e detalhadíssima sobre os fundamentos do Estado e das instituições, e parece que só neles (especialmente em Hobbes), há de fato uma equivalência apropriada entre as teses sobre a política e as teses sobre as outras áreas do pensamento como a física, a análise da religião, a teoria dos afetos... em Espinosa, ao contrário, política e direito seriam um acréscimo sem relação compreensível com as bases ontológicas ou metafísicas do principal da obra, por mais que, como fazem questão de notar tantas leituras, se trate de "uma parte num todo".

Apesar dessa imagem de contradição e desvario teórico, há todavia outra coisa que certamente incomoda esse leitor dos textos políticos de Espinosa, seja o da sua época, seja o que virá depois, na maioria das vezes (especialmente depois do Idealismo Alemão e do surgimento das teorias contemporâneas do direito e do Estado) tomado por uma leitura orientada, já, por uma nova forma de conceber tanto a teoria quanto a prática da política: sente-se, aí, que esses textos ou essas passagens da obra espinosana dizem algo de um radicalismo impressionante até mesmo para uma leitura que considera já radical a forma seiscentista de abordar a política: para seus contemporâneos, Espinosa de um lado radicalizaria as ousadias da crítica à teologia política, e de outro radicalizaria a concepção da política como jogo de forças; para os seus pósteros nossos contemporâneos ou nós mesmos —, Espinosa radicalizaria a ousadia da concepção metafísica da política, e radicalizaria em especial a concepção da liberdade como necessária, ao identificá-la absurdamente com o seu contrário, a própria necessidade. Ou seja: mesmo quando consideradas um momento posterior à obra principal e talvez mesmo incompatível com ela, as teses espinosanas sobre a política e o direito de maneira alguma passam despercebidas pelos seus interlocutores e leitores, convidados por si mesmos a serem prontamente seus críticos e adversários teóricos.

O conjunto dessas leituras, cuja perplexidade em verdade não é sem motivos, produziu o mais das vezes mais uma imagem de intransponibilidade do pensamento político-jurídico espinosano do que uma sua interpretação razoável. Espinosa, antes de tornar-se compreensível, é já um autor cujo acesso depende da superação de uma série de preconceitos ou tabus — um preço alto demais, talvez, para a historiografia contemporânea do direito e da política; mas um preço que, se não enfrentado, deixa por trás dessa imagem pejorativa uma série angustiante de dúvidas quanto às origens das teses políticas de Espinosa, que, por alguma razão a princípio indecifrável, tanto parecem nos dizer: todo indivíduo deseja a liberdade na ética e na política, todo Estado deseja ser soberano e duradouro, todas as instituições merecem ser a base da segurança do Estado e do direito, a democracia é o mais natural dos regimes políticos... não são estas, afinal, as teses defendidas pelas teorias contemporâneas contrárias ao autoritarismo e defensoras da liberdade? 
Apesar da estranheza do pensamento espinosano, que de uma certa maneira se revela ainda mais incômoda quando ousa tratar do mundo da prática e especialmente do mundo da política e do poder, há algo nele que se identifica profundamente com o desejo comum de cada um, independente das suas opiniões sobre filosofia e sobre política. Há algo, nas curiosas teses espinosanas sobre a política, que parece atingir-nos diretamente nas nossas convicções mais íntimas sobre a nossa condição natural e social, convidando o leitor contemporâneo a verificar a validade daquilo que parece ser seu desejo inconsciente de autonomia e liberdade, diante das instituições políticas e dentro da vida política como um todo. Ao mesmo tempo, essas teses produzem ao leitor contemporâneo um incômodo temor: se a idéia de que são fundadas de alguma forma na metafísica parece depor por antecipação contra a sua validade, revelam ao mesmo tempo nessa leitura mesma um vazio conceitual que a sua formação contemporânea deixou pelo meio do caminho, um vazio cujas razões o leitor contemporâneo, em verdade, parece não conseguir fundamentar até o fim, se para isso perceber-se provocado. Mais ainda, as teses espinosanas sobre a política, quando identificam o poder e o direito à potência das instituições e dos indivíduos, parecem pôr em xeque as concepções contemporâneas sobre as fontes do direito e do legítimo, que tinham recuperado, afinal, ao Estado e à sociedade o direito de justificar suas ações por meio de valores morais cuja racionalidade parecia garantida pela própria autoridade das instituições, mas que diante da antítese espinosana são constrangidas agora a justificar sua legitimidade e racionalidade — cuja fonte será qual, afinal, logo agora que todos ainda imaginávamos, por exemplo, que religião e moral não têm influência no poder do Estado? Ao leitor contemporâneo, enfim, o encontro com Espinosa, quando não é sentido como uma experiência de conhecimento dessa outra forma de pensar a política e o direito, talvez seja sentido então como confronto, como uma necessidade de refutação desse outro a fim de confirmar com segurança a validade das próprias convicções. Num caso como no outro, porém, Espinosa é préconcebido como diferença, e não como também nosso contemporâneo; num caso como no outro, ainda que se complete uma leitura do filósofo, ela não o terá compreendido até o fim; enquanto não se perceber a contemporaneidade de Espinosa — sua atualidade; sua imanência — , ele continuará causando, ainda que sob outra forma porque agora sob uma outra imagem desse outro, espanto e indignação. 
Ora, de Espinosa, cuja obra de fato percorre praticamente todas as áreas da filosofia, nunca se duvidou, desde já a formação do espinosismo, ${ }^{24}$ de que se trata entre outras coisas de um pensador autêntico da política. Com efeito, se é verdade que de início - com os Princípios da filosofia de Descartes - o pensamento espinosano se tornou conhecido na qualidade de análise e crítica do pensamento cartesiano, e se logo em seguida - com a publicação, sem nome do autor, do Tratado teológico-político em 1670 - foi difundido como filosofia herética e ateísta, já aí aparece o Espinosa teórico da sociedade e do Estado; já antes, portanto, que a Ética fosse, depois de doze anos, concluída e o Tratado político iniciado (1675).

Ora, como a Ética e o Tratado político só apareceram postumamente em dezembro de 1677, e como em seus sete últimos anos de vida Espinosa teve a leitura de sua obra marcada pela perseguição contra as teses do Teológico-politico, 25 a breve exposição que é feita ali nos cinco capítulos finais a respeito da política e do direito acabou sendo envolvida nas mesmas acusações de ateísmo e impiedade que, de maneira geral, eram voltadas à sua análise da teologia — a qual, de fato, toma a maior parte da obra e deixara os críticos de Espinosa obcecados pela missão de refutá-lo. Assim, toda essa crítica originária que recai sobre as teses do Teológico-político, embora seja atiçada em especial pela análise espinosana da Bíblia e da teologia, acaba por entender que todas as concepções de relevância aparentemente secundária diante do tema central da religião — o poder político secular, por exemplo — são, na verdade, parte imprescindível das concep-

\footnotetext{
${ }^{24}$ O que é o espinosismo? Em lugar da concepção mais comum que tende a designar por "espinosismo" ao pensamento de Espinosa, adota-se aqui o sentido especificado por Marilena Chauí (A nervura do real, vol. 1, p. 21), segundo o qual "espinosismo e espinosista significam: 1) as críticas e as imagens pejorativas relativas à obra de Espinosa; 2) as referências, também pejorativas, que autores fazem a outros para indicar sua suposta filiação ao pensamento de Espinosa, seja do ponto de vista teórico, seja do prático; 3) a caracterização da obra de Espinosa como doutrina". Ou seja, o espinosismo não se confunde com o pensamento espinosano, mas em vez disso constitui uma imagem sempre pejorativa deste, distorção que uma vez deflagrada só faria aumentar com o passar das décadas e dos séculos. O início do espinosismo assim concebido, a propósito, é localizado por Marilena Chauí (op. cit., pp. 114-126) já na primeira interpretação claramente ideológica das idéias de Espinosa - por Willem van Blijenbergh, em breve correspondência com Espinosa (Cartas 18 a 24, e 27) travada de dezembro de 1664 a junho de 1665 —, no caso, acerca da noção espinosana de não positividade do mal, exposta nos Princípios da filosofia de Descartes, de 1663. Blijenbergh, inconformado com a afirmação espinosana de que o mal não tem positividade alguma, entende que tal noção leva à impossibilidade de se avaliar se uma conduta é boa ou má (ou melhor, recompensável ou punível), de maneira que também conduziria à impossibilidade de se condenar o pecado, o que além de absurdo só poderia ser uma heresia por parte do filósofo: por entender e interpretar Espinosa dessa maneira, Blijenbergh é já o primeiro a julgá-lo como ateu em função de sua obra, anos antes de se iniciar o ataque maciço (que a partir de 1670 estabelece de vez a primeira imagem — ateísta - do espinosismo) ao autor do Tratado teológico-político. Não necessariamente, porém, essa expressão representa uma concepção negativa da obra de Espinosa; numa perspectiva que a considere um modelo a ser adotado como forma de pensamento, é certo que já nos desprendemos do próprio filósofo, mas nem por isso perdemos a presença das suas idéias.

${ }^{25}$ Meses após a publicação do Tratado teológico-politico, os Estados da Holanda proíbem não só sua leitura como sua posse. Apesar dessa proibição, na década seguinte à publicação do Tratado surgem por toda a Europa dezenas de refutações - o que mostra que, apesar de todas as ameaças infligidas a quem cometesse o crime da sua leitura, ele foi lido e muito lido.
} 
ções ateístas de Espinosa, de maneira que este, ao tratar nos últimos capítulos de temas como a relação entre direito natural e direito civil, condições para a liberdade política e consideração de um sistema político adequado à paz e à segurança, estaria apenas apresentando mais argumentos para a fundamentação de uma idéia que percorreria todo o livro: a irrelevância da religião para a vida política e a inexistência do Deus pregado nas cerimônias religiosas; o ateísmo, enfim, argumentado também do ponto de vista do discurso político. Ou seja, segundo toda essa crítica inicial ao Teológico-político, a função das concepções estritamente políticas, no pensamento espinosano, seria corroborar as suas concepções anti-teológicas: mais do que apresentar uma teoria válida do Estado, sua finalidade seria conceber uma forma de poder sem conteúdo religioso, de maneira a enfraquecer ainda mais os princípios clássicos do direito divino e da autoridade política da Igreja.

Num ponto, apenas, esta crítica está certa: a breve teoria do Estado apresentada nos capítulos finais do Teológico-político é, de fato, parte imprescindível de toda a teoria espinosana da religião e do poder teológico-político. O próprio Espinosa, no prefácio à obra, anuncia que o seu objeto de estudo se divide em duas partes — uma sobre teologia e outra sobre política —, e que nesta segunda parte, que se inicia com o capítulo XVI, estuda no campo da política a mesma liberdade de pensamento e manifestação do pensamento que nos capítulos anteriores demonstra como compatível diante da religião e da fé. ${ }^{26} \mathrm{O}$ que marca desde logo a relação direta da análise política com a análise da teologia é a extensão, na política, das mesmas conclusões alcançadas na teologia. Porém, por que não o sentido inverso — a análise da política antes da análise da religião (como faz Hobbes, por exemplo, em suas obras)? Entre outras razões porque, no campo da teologia, muito do que se pode dizer a respeito da política não tem relevância: a explicação do direito natural, mas especialmente a explicação da necessidade dos direitos, tem seu lugar apenas no campo da política e não teria como ser concluída nem compreendida na perspectiva da religião - e é a demonstração plena da liberdade de pensamento e expressão desse pensamento, essa liberdade fundamental que contém todas as outras, que a obra almejar construir.

Mais do que isso, tendo diante de si um leitor cristão, a análise de um campo não pode ser pensada sem a análise do outro: também a análise do Estado e da sociedade exige considerações acerca dessas instituições que são a teologia e a Igreja. Em si mesma, essa consideração simultânea da religião e do Estado não tem nada de anormal, sendo mesmo um temário comum das teorias políticas do período e, o que vale mais segundo os interesses dos teólogos, é uma forma de teoria política fundada tradicionalmente no próprio pensamento religioso, forma

26 Tratado teológico-político, cap. XVI: “[...] Após evidenciar a liberdade que a lei divina revelada concede a cada um, passo a outro aspecto da questão, o qual consiste em mostrar que essa mesma liberdade pode e deve ser concedida, sem que isso lese a paz da república e o direito das potestades soberanas [...]" 
da qual este sempre se aproveita para defender a influência das instituições religiosas nas instituições civis. Entretanto, o que incomoda aos teólogos no caso de Espinosa é, evidentemente, uma questão de conteúdo teórico e não uma questão de forma argumentativa ou de escolha das matérias: ao apresentar uma teoria do poder político que conclui pela necessidade de separação entre o poder do Estado e as instituições da religião, ou seja, pela necessidade de não existir nenhum tipo de influência da Igreja e das Escrituras Sagradas sobre a organização política do Estado, Espinosa está negando a validade de um privilégio exigido desde a Baixa Idade Média pelas instituições eclesiásticas, qual seja, ser a fonte de legitimidade de todas as instituições humanas — religiosas, morais, políticas, jurídicas, militares. Por tudo isso, a concepção espinosana do Estado é tão herética quanto a sua interpretação da Bíblia, primeiro, porque exige que a Igreja não tenha autoridade sobre o Estado e, segundo, porque permite que a legitimidade e as finalidades da sociedade política sejam determinadas independente dos conteúdos da religião. Embora, para Espinosa, tanto a religião quanto o Estado se realizem como instituições humanas, seus campos de operação devem ser completamente separados, de maneira que ser fiel e ser cidadão não podem significar a mesma coisa, mas expressões distintas da condição individual. Ora, não basta aos leitores teólogos do Tratado teológico-político a consideração espinosana de que a religião em geral deve, portanto, ser respeitada, e que a atividade religiosa pode ser compatível com a atividade civil, já que o direito à prática religiosa é garantido por Espinosa: aos teólogos, importa que a prática civil seja subordinada de certa maneira à prática religiosa, o que se torna impossível num sistema em que religião e Estado, na qualidade de instituições, devem manter-se separados.

Esse é um detalhe muito importante, porque a maneira como a crítica ideológica às teses do Tratado teológico-político se estabelece ${ }^{27}$ mostra que, apesar de todo o choque causado já pelas concepções de Deus e dos fundamentos da religião — profecia, milagre, fé, autenticidade dos textos sagrados, etc. —, o que causa maior indignação aos teólogos é justamente essa tese que separa o poder político da autoridade religiosa. As teses espinosanas sobre os artigos da fé, ainda que chocantes para os teólogos e de certa forma suficientes para a acusação do ateísmo, não tomam exclusivamente a crítica a Espinosa; ao contrário, o filósofo é em geral acusado pelos primeiros críticos do Teológico-político de ter negado a própria autoridade e o poder de Deus sobre as coisas humanas. Já que o Deus das Escrituras Sagradas é exposto por Espinosa como uma entidade que não mais entra em contato diretamente com os fiéis, já que - demonstra o

${ }^{27}$ Como mostra a análise de Lambert van Velthuysen do TTP (Carta 62, de Velthuysen a ao amigo de Espinosa, Jacob Osten). Nela, Velthuysen não apenas comenta e refuta a análise espinosana dos artigos da fé, mas ao considerar que o que o tratado prega é o puro ateísmo, o jurista-teólogo Velthuysen está julgando, já, a própria crítica de Espinosa ao poder teológico-político. 
Tratado teológico-político — os profetas não falam por si próprios e nada mais são que intérpretes de Deus, já que os apóstolos não são intérpretes de Deus mas doutores que escreveram acerca de questões de fé e, como os profetas, pertencem a um período que há muito se encerrou, e já que, finalmente, os próprios sacerdotes e demais oficiantes da Igreja não são intérpretes privilegiados da Bíblia (pois as verdades expressas na Bíblia são todas acessíveis à luz natural de cada um), resta que, segundo Espinosa, do próprio Deus até os sacerdotes não haveria nenhuma figura religiosa que constituísse uma autoridade sobre os fiéis, e por isso mesmo nenhuma intermediação entre cada fiel e Deus seria necessária. Ao analisar as Escrituras, o que Espinosa teria por finalidade seria, na verdade, impossibilitar a imposição da religião na forma de autoridade sobre os homens, ao mesmo tempo que a própria Igreja ou a própria religião não deveriam ser tomadas como uma instituição secular, mas apenas uma inspiração para as obras da fé. Ou seja: o Deus de Espinosa, dizem seus críticos reiteradamente, é absurdamente uma entidade sem poder algum. ${ }^{28}$

Ora, a negação da autoridade divina no campo da política é uma evidência no Tratado teológico-político e simplesmente uma das várias teses espinosanas contrárias às opiniões dos teólogos. $\mathrm{Na}$ perspectiva da teologia, a concepção de um Deus sem autoridade é uma heresia inaceitável porque, desde santo Agostinho na Cidade de Deus, Deus é sempre exposto como uma entidade poderosa, tanto diante da Natureza, quanto sobre a história humana e suas instituições, ${ }^{29}$ e os próprios textos sagrados por diversas vezes se referem ao Altíssimo cuidando de elogiar os seus atributos de monarca do universo, ao passo que Espinosa considera que as qualidades atribuídas nos textos sagrados a Deus são formas distintas de expressar o próprio nome de Deus, e não exatamente suas qualidades, até porque também se trata de atributos antropomórficos, mais adequados à linguagem e à imaginação humana do que à própria natureza divina, que por ser infinita não pode reconhecer limitações em nenhum atributo humano, por mais venerável que este pareça ser. Seja como for, o tema do poder de Deus é objeto constante de vários dos primeiros ataques sofridos por Espinosa, e é opinião comum dos seus críticos a acusação da heresia espinosista também por conta dessa concepção de um Deus sem autoridade, e de uma autoridade religiosa que não tem poder sobre o Estado, mas unicamente sobre a fé, também identificada heretica-

${ }^{28}$ Marilena Chaú apresenta várias críticas feitas a Espinosa por seu empenho em negar um poder antropológico em Deus: por exemplo, para Velthuysen (cf. M. Chauí, $A$ nervura do real, vol. 1, p. 42n, n. 173), assim como para Boyle (op. cit., p. 183), Deus precisa ser autoridade, majestade, e ambos repudiam o Deus espinosano também em função dessa sua falta de imperium. Segundo Limborch, o "poder de Deus" em Espinosa "são meras palavras" (op. cit., p. 173) e, para Bayle, o Deus de Espinosa "é um pobrediabo", sem jus, potestas, personalitas (op. cit., p. 289). Retornaremos a este assunto, para uma análise dessas críticas, no capítulo 2.III ("Jus sive potentia: lex sive potestas").

29 "O poder de dar o império e o reino não o atribuamos senão ao verdadeiro Deus, que dá a felicidade no reino dos céus somente aos piedosos, e o reino terrestre a piedosos e ímpios, como lhe apraz a Ele, a quem nada apraz injustamente" (Agostinho, A Cidade de Deus, livro V, cap. XXI, p. 222). 
mente por Espinosa às obras (como escreveu o Tiago, "a fé sem obras é morta") e não à vontade do fiel. ${ }^{30}$ Assim, o Espinosa herético é desde sempre um autor, também, de política. Ao falar de Deus e da religião, Espinosa tratara também de todas as delicadíssimas questões sobre a lei divina e a relação entre Estado e Igreja.

É verdade que ao demonstrar a necessidade de separação entre Igreja e Estado, Espinosa não está sendo pioneiro: essa discussão tem, já, séculos de existência e aprofundamento. Mas a especificidade da tese espinosana está em demonstrar que essa separação exige, apesar da preservação da própria religião natural, a aniquilação da teologia, ou seja, a supressão da instituição religiosa sempre que a religião pretende ser uma forma de poder. A instituição da teologia, em si mesma, pretende-se interpretação verdadeira da religião quando as verdades da fé não carecem da intermediação de doutores, pois são todas acessíveis à luz natural de cada um. Mais do que isso, diante do tema do poder e autoridade de Deus e da Igreja, a teologia pretende ser o único discurso autorizado a demonstrar a relação entre religião e Estado, e a única a ter autoridade para fundamentar a doutrina em favor do direito divino dos reis. Ora, mostra Espinosa, ${ }^{31}$ a teologia está por sua natureza separada da filosofia (pois a teologia só exige a obediência do fiel, enquanto só à filosofia cabe produzir conhecimento), e por isso as questões da política não podem ser compreendidas a partir da teologia — que, a propósito, tem por base somente os textos sagrados (que nada dizem a respeito do poder político secular, e que a teologia ainda por cima interpreta equivocadamente) e as opiniões dos seus próprios doutores da Igreja (cuja autoridade está circunscrita a uma entidade que em si mesma não é política, e que sob a perspectiva da razão não é superior às necessidades da própria política).

Assim, é porque as teses de Espinosa sobre a religião são teses contra a teologia política e contra o poder teológico-político, que as críticas a Espinosa desde já o século XVII serão centradas, muitas vezes, numa defesa da autoridade das instituições religiosas e numa reiteração

30 Tratado teológico-político, cap. XIV: “[...] a fé não exige tanto a verdade quanto a piedade e só é piedosa e pode salvar em função da obediência, pelo que ninguém é fiel a não ser em função da sua obediência. Não é, portanto, quem apresenta os melhores argumentos que necessariamente demonstra a maior fé, mas sim quem apresenta as melhores obras de justiça e caridade".

31 Tratado teológico-político, cap. XV: “[...] e demos por incontestável que nem a teologia tem de subordinarse à razão, nem a razão à teologia, visto cada uma delas possuir o seu próprio domínio: a razão, como já dissemos, o domínio da verdade e do saber; a teologia, o domínio da piedade e da obediência. [...] A teologia, porém, não diz senão isso nem prescreve senão a obediência, além de que não pretende nem pode nada contra a razão: determina os dogmas da fé, como mostramos no capítulo anterior, mas só na medida em que eles são indispensáveis com vista à obediência, deixando à razão a tarefa de determinar como é que eles devem ser entendidos com rigor e em função da verdade, razão que é autêntica luz da mente, sem a qual esta não vê senão sonhos e ilusões. E por teologia entendo aqui precisamente a revelação, na medida em que esta indica o objetivo para o qual dissemos apontar a Escritura (isto é, a razão por que e o modo como devemos obedecer, ou melhor, os dogmas da verdadeira piedade e da fé), quer dizer, aquilo a que se chama com propriedade a palavra de Deus e que não consiste num determinado número de livros $[\ldots . . . "$ 
das teses mais radicais da teologia política do período, evidenciando entre outras coisas que a validade de muitas teses antiteológicas desenvolvidas então tanto pelos jusnaturalistas quanto pelo realismo teórico dos autores políticos não era sequer cogitada pelos teólogos. Mais do que maus condutores da fé e elementos perniciosos à segurança pública, os teólogos, mostram as teses de Espinosa e as críticas teológicas a essas teses, são defensores de uma forma irracional de autoridade política, e desde então combater o ateísmo e panteísmo espinosistas pressupõe empreender uma defesa da autoridade soberana de Deus e da Igreja sobre as autoridades seculares e as liberdades individuais; porém, diante já do Tratado teológico-político, os dogmas da teologia política clássica não podem mais ficar de pé; é preciso não apenas refutar Espinosa, mas refutar toda essa nova forma de fazer teoria acerca da política, que recusa tomar a teologia como mestra para a análise do Estado e, muito pior, recusa que os textos sagrados tenham relevância para a constituição do pensamento político. Não à toa, os autores políticos (como Montesquieu) que a partir daí desenvolverem a tese de que a Igreja não pode ter influência sobre a política terão muito trabalho para se safar da acusação de espinosismo, ${ }^{32}$ ainda que pudessem ser acusados de continuadores de outros autores que, a exemplo de Marsílio de Pádua já no século XIV, empreenderam uma crítica severa à interferência das instituições religiosas nas coisas do Estado.

\footnotetext{
32 Logo após a publicação de Do espirito das leis, em 1747, Montesquieu recebe a acusação de espinosismo... Em edição posterior da obra, incluiu um apêndice ("Defesa do Espirito das leis") onde responde a essa acusação e a outras objeções: "Ainda que o Espirito das leis seja uma obra de pura política e de pura jurisprudência, o autor teve muitas vezes a oportunidade de falar da religião cristã: fê-lo de forma a mostra toda a sua grandeza, e, se não teve como objetivo trabalhar para que nela acreditem, procurou fazer com que fosse amada. No entanto, em duas folhas periódicas que foram publicadas uma após a outra, lhe foram feitas as mais terríveis imputações. Não se trata nada menos do que saber se ele é espinosista e deísta; e, ainda que essas duas acusações sejam por si mesmas contraditórias, ele é levado incessantemente de uma à outra. Sendo ambas incompatíveis, não podem torná-lo mais culpado do que uma só, mas ambas podem torná-lo mais odioso. Então ele é positivista, ele que, desde o primeiro parágrafo de seu livro, distinguiu o mundo material das inteligências espirituais. Então ele é espinosista, ele que, no segundo parágrafo, atacou o ateísmo: 'Aqueles que disseram que uma fatalidade cega produziu todos os efeitos que vemos no mundo disseram um grande absurdo, pois que absurdo maior do que uma fatalidade cega que produziu seres inteligentes?' Então ele é espinosista, ele que prosseguiu com estas palavras: 'Deus se relaciona com o universo como criador e como conservador; as leis segundo as quais ele criou são aquelas segundo as quais ele conserva; ele age segundo essas regras, porque as conhece; conhece-as porque as fez, e as fez porque se relacionam com a sua sabedoria e com o seu poder.' Então ele é espinosista, ele que acrescentou: 'Como vemos que o mundo, formado pelo movimento da matéria e privado de inteligência, ainda subsiste, etc.' Então ele é espinosista, ele que demonstrou contra Hobbes e Espinosa 'que as relações de justiça e de eqüidade eram anteriores a todas as leis positivas'. Então ele é espinosista, ele que disse no início do segundo capítulo: 'Esta lei que imprimindo em nós mesmos a idéia de um criador nos leva em sua direção é a primeira das leis naturais por sua importância.' Então ele é espinosista, ele que combateu com todas as suas forças o paradoxo de Bayle, segundo o qual é melhor ser ateu do que idólatra, paradoxo do qual os ateus tirariam as conseqüências mais perigosas?" (da tradução de Cristina Murachco citada na bibliografia, Do espirito das leis, pp. 711-712).
} 
A essa acusação primordial de impiedade e ateísmo manifestada na análise da teologia e da política, houve desde cedo uma leitura que procurou de certa maneira dissociar os dois campos em Espinosa não para livrá-lo, como filósofo político, dos problemas da relação entre a concepção da política e o conteúdo dos textos sagrados, mas, ao contrário, para amplificar essa imagem negativa, acusando nele uma impiedade política muito maior do que a impiedade derivada de suas concepções sobre teologia e religião: a acusação de hobbesianismo em Espinosa. De fato, quando Espinosa escreve, é a filosofia de Hobbes, ainda muito recente, ${ }^{33}$ que causa ainda as maiores repercussões na intelectualidade política holandesa, e tão logo é publicado o Tratado teológico-político, percebem-se em ambos os filósofos teses muito parecidas. Em lugar, porém, dessa comparação significar um reconhecimento da validade teórica de Espinosa, ela é desde logo colocada como crítica à sua invalidade, numa dupla via que, aí iniciada, também persistirá até hoje ao lado da crítica ao Espinosa obscuro e metafísico: os inimigos teóricos de Hobbes, de um lado, consideram Espinosa sem dúvida um autor político, tanto como o seu suposto mestre inspirador (afinal, tanto como ele Espinosa elabora uma teoria do Estado ao lado de uma análise da religião, uma teoria política ao lado de teorias da natureza humana, da física, do conhecimento) mas autor, como o filósofo inglês, de uma teoria em favor do poder absolutista (pois se Espinosa parece não se colocar diretamente em favor da monarquia absolutista como Hobbes, em lugar disso estaria definindo o poder como devendo ser absoluto em qualquer regime que seja, e não seria outro o motivo do seu elogio da democracia), 34 e partidário, principalmente, de uma nefasta concepção de que a justiça só é determinada pela lei, esse comando do soberano, assim como fora da vida civil os homens teriam todo o direito de serem violentos entre si, como se a razão humana não fosse capaz de garantir uma ordenação moral ali onde não há a presença nem de leis, nem de castigos; numa via oposta, também ela iniciada já no século XVII pelos discípulos de Hobbes e também ela defendida até hoje (por alguns autores que consideram Hobbes um precursor do positivismo jurídico), Espinosa é certamente filósofo da política, já que trata do direito e do Estado, mas está muito longe de ter chegado à

\footnotetext{
${ }^{33}$ Essa relação entre as teorias de Espinosa e Hobbes, e principalmente os prejuízos causados pelo exagero dessa comparação entre ambos, será abordada em detalhes nos capítulos 3.I ("A imagem da reductio ad Hobbesium") e 3.II ("Espinosa, para além de Hobbes e contra Hobbes").

34 Tratado político, cap. XI, \1: "Passo agora ao terceiro Estado, que é inteiramente absoluto e a que chamamos democrático. A diferença entre esse Estado e o aristocrático consiste, principalmente, já o dissemos, em que, neste último, depende unicamente da vontade e da livre escolha da assembléia suprema que este ou aquele se torne patrício; ninguém tem, portanto, hereditariamente, o direito de sufrágio e o de aceder às funções públicas. Ninguém pode reivindicar os seus direitos, como é o caso numa democracia. Todos aqueles, com efeito, que nasceram de pais no gozo dos seus direitos cívicos, ou no território nacional, ou que souberam merecer a República, ou que, por outras causas ainda, possuem legalmente o direito de cidadania, todos, repito, têm direito de sufrágio e acesso às funções públicas; podem reclamar os seus direitos e não se lhos pode negar senão por se terem tornado culpados de um crime, ou marcados de infâmia."
} 
grandiosidade de Hobbes ou, simplesmente, de ter dito algo de acertado como ele ou de original frente a ele; de maneira que, se é o caso de considerá-lo filósofo da política, isso significa acusá-lo de plagiador dos verdadeiros criadores da teoria política, para além de todas as reprimendas que sua teoria inconsistente e aporética merece receber.

Diante desse primeiro esboço, não deixa porém de ser curiosa a afirmação do jovem Leo Strauss, a respeito de uma recepção positiva do pensamento político espinosano já no século XVIII. Strauss, que ao menos nunca teve dúvidas quanto às diferenças entre Espinosa e Hobbes (que ele chega a considerar opostos em tudo), vê nas décadas anteriores à Revolução Francesa - e, portanto, anteriores às primeiras experiências contemporâneas do republicanismo e da democracia — o sepultamento definitivo do pensamento absolutista hobbesiano, ao mesmo tempo que as idéias de Espinosa em favor da democracia finalmente teriam alcançado as bênçãos dos teóricos e partidários desse novo projeto de prática política. Se todavia considerarmos, unicamente diante dessa perspectiva, as análises de Paul Vernière na sua aprofundada análise da recepção do pensamento espinosano às portas da Revolução Francesa, ${ }^{35}$ perceberemos que a imagem bayleana do Espinosa "ateu de sistema" continua bem presente no jargão da política, e que sua leitura continua uma atividade clandestina. Mesmo no caso de autores cuja proximidade teórica com Espinosa é, aqui sim, irrecusável, como Rousseau, a manifestação direta a respeito de Espinosa é pejorativa ou negativa, como numa crítica que endereça igualmente a Hobbes e Espinosa numa passagem do Discurso sobre as ciências e as artes. ${ }^{36}$ Assim, se é verdade que uma idéia de democracia é acolhida na passagem para a contemporaneidade na história do Ocidente, e se é também verdade que a Espinosa se concede o reconhecimento de ter elogiado de uma forma ou de outra a democracia e a vida republicana, essa idéia de democracia que funda a contemporaneidade não é, de forma alguma, a idéia espinosana de democracia. ${ }^{37}$ Às portas da Revolução, Espinosa continua ateu e pernicioso, por mais que tivesse chegado perto do conhecimento do melhor regime político.

A propósito, é justamente aí, diante da experiência revolucionária que leva à prática republicana como símbolo contra os regimes absolutistas e despóticos, que se desenvolverá com toda a intensidade a imagem do Espinosa utópico. O que marcará o pensamento político contemporâneo, da filosofia às ciências humanas, desde as suas bases será a identificação entre democracia e Estado de direito, ou entre democracia e regime de governo representativo; não mais, certamente, a idéia grega de governo de todos os cidadãos ou a idéia moderna de participação de

35 Cf. P. Vernière, Spinoża et la pensée française avant la Révolution, pp. 612-702.

36 P. Vernière, Spinoza et la pensée française avant la Révolution, pp. 478-479. A propósito de toda a influência das teses de Espinosa sobre Rousseau a despeito de nenhum registro comprovando a leitura direta daquele, cf. pp. 481-494.

37 Voltarei a este ponto no capítulo 4.II ("Democracia, uma necessidade da política e do direito”). 
todos os cidadãos no poder. Assim, se a história contemporânea do pensamento político se inicia tendo como grandes paradigmas as experiências republicanas norte-americana e francesa, a democracia passa a ser defendida a partir finalmente de um critério completamente empírico, o da eficácia administrativa e jurídica de um Estado de direito popular porque seus órgãos de governo oficialmente representam todos os seus cidadãos. Surgirá, daí por diante, uma multiplicidade não de teorias políticas a favor da democracia, mas de formas de teoria acerca da política, do Estado, do direito, da sociedade, cuja convicção comum por entre a infinidade de metodologias e conceitos será a idéia de representação política como única maneira de concretizar a vida democrática.

Ao mesmo tempo que essa idéia, surgirão, não à toa, campos de pensamento político cujas premissas são não mais concepções ou idéias de política (como teriam sido nas filosofias políticas de antes, nas "metafísicas" da política e do direito, e acima de tudo nas utopias de jusnaturalistas, de renascentistas e de escolásticos), mas a própria prática política, entendida esta não como experiência política, mas como instituição vigente do poder e do Estado: estudar a política e o poder, desde as bases do pensamento contemporâneo, torna-se estudar a estrutura do Estado e de suas instituições, assim como os fenômenos que estão à volta da concretização histórica desse poder, seja na sociedade, seja nas próprias instituições. É aí, nesse campo teórico contemporâneo onde o estudo da política é operado como conhecimento da estrutura do Estado, que se desenvolve a idéia de que a metafísica não tem mais autoridade sobre as verdades da filosofia e da ciência, que o conhecimento científico tem mais objetividade que o conhecimento filosófico e é, portanto, mais verdadeiro que este e por isso suficiente em si mesmo, assim como finalmente o conhecimento técnico dessa estrutura estatal tem validade científica apesar de ser desde suas bases um conhecimento técnico: por tudo isso, surge entre outros tantos campos de pensamento político o projeto de uma ciência do direito (Rechtwissenschaft, na acepção de Savigny, seu primeiro grande formulador já na história do pensamento jurídico contemporâneo "liberto" da metafísica e da filosofia) ${ }^{38}$ cujo escopo será, apenas, permitir o conhecimento verdadeiro da estrutura institucional do Estado e da sociedade (daí sua cientificidade) e oferecer instrumentos para a resolução de conflitos (daí sua aplicabilidade).

\footnotetext{
38 “[...] vem Savigny a distinguir a teoria filosófica do Direito em si mesma, ou o Direito natural, do elemento filosófico ou sistemático da ciência (positiva) do Direito: a última pode ser estudada 'tanto com o Direito natural como sem ele'. Para o jurista, a 'filosofia não é necessária, mesmo como simples conhecimento prévio'. No elemento 'filosófico' da ciência do Direito não deve, pois, subentender-se a aceitação de quaisquer princípios jusnaturalistas, mas apenas a orientação, característica da própria ciência do Direito, no sentido de uma unidade imanente pressuposta por est última, orientação que, segundo Savigny, é comum à ciência do Direito e à filosofia" (K. Larenz, Metodologia da ciência do Direito, p. 10).
} 
No interior dessa concepção técnica do próprio conhecimento político, toda concepção tida como não histórica ou não prática do Estado tende a ser considerada "metafísica", e será basicamente dessa forma que as críticas da filosofia contemporânea do direito serão feitas à própria filosofia e principalmente às concepções clássicas da sociedade e do Estado. Se, portanto, a insatisfação que Espinosa parece expressar no início do Tratado político diante das utopias e sátiras dos autores políticos antigos, assim como sua convicção de que só os práticos da política sabem do que estão falando quando tratam do Estado, ${ }^{39}$ parece provocar no leitor contemporâneo uma certa identidade com o filósofo, essa parece ser insuficiente diante de tudo o que Espinosa dirá depois a propósito do Estado em geral e dos diferentes regimes políticos, pois sua exposição, por algum motivo, aparece aos leitores contemporâneos (e em especial aos leitores jurídicos) uma exposição sem bases na realidade concreta, por mais referências faça à experiência e por mais elogios faça aos historiadores e ao realismo teórico de Maquiavel. Espinosa, como aliás o comum dos demais jusnaturalistas, estaria simplesmente apresentando uma concepção racionalista, idealista, do Estado e da política, e não apresentando sua descrição empírica e histórica, não apresentando uma análise das instituições da política tais como elas realmente são, e sim imaginando como elas deveriam ser, coisa que afinal o equipararia, na prática, aos mesmos autores utopistas que ele parecia atacar no início do seu inacabado tratado sobre os regimes políticos. Não à toa surgirá, no correr do século XIX, a imagem de um Espinosa autor dessa teoria de uma perigosa democracia — o "espírito democrático", no dizer de um dos críticos dessa época, Baxter, que vêm em Espinosa um entusiasta e um libertino ao mesmo tempo, por causa da defesa de democracia baseada no direito natural ${ }^{40}$ — pregada por uma ideologia republicana filosófica cujo perigo reside, em primeiro lugar, na sua ausência de realismo prático, mas também no poder que essa concepção alucinada de democracia - como governo da razão, governo mais natural, governo em que todos governam e ninguém é governado - tem de desviar a atenção da teoria política do verdadeiro sentido para o qual deve ser conduzida a prá-

39 Tratado politico, cap. I, \1: "A maioria dos filósofos concebe os afetos que em nós travam combate como vícios em que os homens caem por sua culpa; por isso habituaram-se a rir deles, lamentá-los, maltratá-los e (quando querem parecer mais santos do que todos) detestá-los. Acreditam, assim, fazer coisas divinas e elevarem-se ao cume da sabedoria, prodigalizando toda espécie de louvores a uma natureza humana que não existe em parte nenhuma e ferindo com seus discursos aquela que realmente existe. Concebem os homens não tais como são, mas como gostariam que fossem. Eis por que, quase todos, em vez de uma ética, escreveram sátiras, e não tiveram sobre a política idéias que pudessem ser postas em uso, concebendo-a como quimera ou utopia, àquela idade de ouro dos poetas, isto é, a um tempo no qual nenhuma instituição era necessária. Por esse motivo, acredita-se que, de todas as ciências que têm um uso, é na política que a teoria passa por mais discrepar da prática, não havendo homens que se estimem menos idôneos para dirigir a República do que os teóricos, isto é, os filósofos".

${ }^{40}$ Cf. Marilena Chauí, A nervura do real, vol. 1, p. 231: "O entusiasmo, afirma Baxter, é o 'espírito democrático', a desnaturação da família, pelo direito natural individual, do Estado, pela ausência de referência a Deus e à família, e a redução do direito natural ao hedonismo epicurista, próprio da imoralidade libertina. Eis os signos evidentes do ateísmo espinosista e, portanto, de traição e crime contra o Estado". 
tica do Estado: a organização da sociedade através das instituições de que a sociedade já dispõe. Não à toa, para a teoria político-jurídica trilhada desde inícios do século XIX, a única democracia possível e de fato já conquistada na prática é o Estado de direito constitucional representativo; a forma monárquica ou a forma republicana sequer importam tanto quanto a existência ou não de uma prática política baseada num sistema político-jurídico sólido, onde o justo e o legítimo estão claramente publicados no ordenamento jurídico e nos pareceres dos juristas e dos políticos profissionais. Assim, por todo o século XIX, se graças mesmo à instalação definitiva da concepção laica da legitimidade e do direito no Estado, o "ateísmo" espinosano não tem mais relevância na consideração do pensamento político clássico, o que agora assume uma relevância ainda maior é a sua concepção "panteísta" de que a natureza da política e do direitos seriam determinadas pela natureza humana e pela ordem da natureza: uma metafísica, enfim, da política, como quer Simone Goyard-Fabre nas suas primeiras menções ao pensamento jusnaturalista e, dentro dele, o pensamento de Espinosa.

Leo Strauss, é claro, não deixaria de notar em sua análise da leitura contemporânea de clássicos antigos e modernos o fundamento antimetafísico dessa crítica, e quando considera que Espinosa, com relação a Hobbes, foi "reabilitado" na história do pensamento político antes do filósofo inglês, ${ }^{41}$ mas parece não notar que um conhecimento adequado da teoria espinosana da democracia pelos leitores dessa passagem da modernidade à contemporaneidade não tinham a devida noção do tipo de filósofo político que Espinosa verdadeiramente é. Strauss, decididamente, considera Espinosa um filósofo político, ${ }^{42}$ mas não no sentido apenas de um autor que

\footnotetext{
${ }^{41}$ Parece-me que essa idéia é válida apenas no que diz respeito ao desenvolvimento da história do pensamento democrático, por conta do reconhecimento de Espinosa como primeiro autor a desenvolver na modernidade uma teoria explicitamente a favor da democracia (nem Pierre de la Court, que na Balanca política, I, 7, considera a democracia "a forma primitiva e a mais legítima de governo", chega a considerar que a liberdade política só existe completamente — ou se existe realmente - na democracia, como faz Espinosa pela primeira vez). No que diz respeito a uma mais justa consideração da estrutura interna do próprio pensamento político de cada um deles, o reconhecimento (literalmente falando) de Hobbes começou primeiro.

${ }^{42}$ Leo Strauss, Qu'est-ce que la philosophie politique?, pp. 18-19: "Pela expressão de teoria política, alguns por vezes ouvem atualmente reflexões gerais sobre a situação política chegando à sugestão de uma política de espírito liberal. Tais reflexões fazem, em última instância, apelo a princípios aceitos pela opinião pública ou por uma parte considerável da opinião pública; isso equivale a dizer que elas supõem dogmaticamente princípios que muito bem mereceriam ser interrogados. A Auto-émancipation [Autoemancipação] de Pinsker e L'Etat juif [O Estado judaico] de Herzl são obras de teoria política nesse sentido. A Auto-émancipation de Pinsker traz como divisa: 'Se eu não me bas por mim mesmo, quem o fará? E se não for agora, quando?' Ela omite as seguintes palavras: 'E se eu me bas unicamente por mim mesmo, o que sou?' A recusa silenciosa do pensamento é, da parte de Pinsker, uma premissa crucial da argumentação desenvolvida em seu opúsculo. Pinsker não justifica essa recusa. Para encontrar-lhe uma justificação, seria preciso remeter ao décimo-terceiro e ao décimo-sexto capítulos do Tratado teológicopolítico de Espinosa, uma obra de um filósofo político. Somos obrigados a distinguir a filosofia política da teologia política. Entendemos, por teologia política, os ensinamentos políticos fundados sobre a revelação divina. A filosofia política se limita ao que é acessível ao espírito humano deixado a si mesmo. No
} 
também tratou da política dentro de seu imenso sistema, mas um filósofo essencialmente político, que ao tratar do Estado e de outros assuntos tem seu espírito político sempre presente. É esse tipo de pensador da politica, cujo tratamento da política não é adicional e sim fundamental, cujas convicções políticas não são utópicas mas deduridas necessariamente de uma concepção consistente do real, que Strauss é um dos primeiros a apontar pertinentemente, quando entra num debate em torno das questões típicas do pensamento político-jurídico da primeira metade do século Xx: onde o papel da história na determinação das finalidades da sociedade e do Estado, agora que a concepção positivista do direito e a prática burocrática da administração pública são tomadas quase como axiomas do próprio poder político?

Quando Strauss coloca a questão sobre "o que é a filosofia política?", sua análise contrária à idéia de um pensamento político separado das considerações éticas e morais e contrária a uma teoria política separada da realidade histórica (seja porque é fundada numa metafísica racionalista como muitas vezes no pensamento moderno, seja porque é fundada numa concepção tecnicista do Estado como quase sempre no pensamento contemporâneo) decorre de uma concepção da filosofia política como militância política no mundo da prática: fazer filosofia política deve ser pensar as condições políticas das sociedades históricas, mas pensá-las de forma a garantir a permanência do que elas têm de positivo e provocar a mudança do que elas têm de problemático, e o critério para a definição do que é adequado ou não em termos políticos para uma sociedade - o que é justo ou injusto, enfim, para recuperarmos uma noção dos antigos que segundo Strauss jamais deveria ter sido perdida — não pode ser apresentado por uma autoridade política, mas sim pela própria sociedade. A filosofia política, enfim, não deve ser mera descrição da estrutura do poder: ela deve ser — e se assim for, ela já é uma prática política uma reflexão acerca de como deve ser a estrutura do poder e a vida política das sociedades humanas. Essa postura ao mesmo tempo teórica e prática na reflexão política, Strauss vê muito bem presente em Espinosa, seja pela maneira como Espinosa (apesar de sua crítica à noção moral ou prudencial de justiça, que o separa de antigos e medievais) observa a prática histórica da política e concebe as estruturas dos sistemas políticos que classifica, seja porque também sua história pessoal, como filósofo e como pessoa, é uma história de revolta contra o autoritarismo e militância em favor da liberdade.

É aí que reside a chave adequada de leitura da qualidade política da filosofia de Espinosa: a obra deve ser lida por aquilo que ela mesma diz, não apenas pelas teses que apresenta - essas

que respeita à filosofia social, ela tem a mesma matéria da filosofia política, mas ela a considera de um ponto de vista diferente. A filosofia política repousa sobre a premissa segundo a qual aquela associação política de seu país ou de sua nação é a associação mais abrangente ou a que tem mais autoridade, ao passo que a filosofia social se representa a associação política como uma parte de um todo mais amplo, o qual ela designa pelo nome de 'sociedade'." 
teses que desde sua época afrontam as convicções de teólogos, juristas e políticos -, mas pelas considerações espinosanas a respeito do próprio pensamento político. Qualquer leitura do pensamento político de Espinosa, se feita de fora do próprio percurso espinosano e, por isso mesmo, a partir de concepções exteriores do seu próprio vocabulário teórico e ordem argumentativa, desde o início tem seu acesso prejudicado às idéias do filósofo, e corre o risco tantas vezes confirmado na prática de produzir leituras profundamente equivocadas, estéreis tanto como esclarecimento quanto ao pensamento político espinosano, quanto como objeções às teses desse mesmo pensamento. Ainda que às vezes até sejam empenhadas em desviar-se da tradicional visão superficial do pensamento espinosano, as críticas a ele feitas a partir de leituras anacrônicas (porque apuram a consistência dos termos espinosanos pelo sentido fundado em outros períodos ou elaborado por outras obras) ou analógicas (porque buscam estabelecer uma compreensão do seu pensamento a partir da comparação com outras formas de pensar) têm como resultado mais a revelação das próprias convicções do objetor a respeito da política e da teoria política, do que uma análise válida do próprio Espinosa. Se, com efeito, o que leva os críticos do ateísmo espinosista a recusar sua filosofia política é a recusa, por Espinosa, da legitimidade do poder de Deus e da religião sobre as sociedades humanas, sua objeção não terá eficácia enquanto não reconhecer a necessidade racional da separação operada pela filosofia espinosana entre teologia e política; se o que leva os críticos do panteísmo espinosista a menosprezar sua filosofia política é a identificação, por Espinosa, do poder do direito com a necessidade da natureza, sua objeção não terá eficácia enquanto não reconhecer a necessidade racional do direito enquanto potência do Estado e dos indivíduos simultaneamente; se o que leva os críticos do absolutismo espinosista a atacar sua filosofia política é a radicalização, por Espinosa, das concepções hobbesianas do poder absoluto do Estado, sua objeção não terá eficácia enquanto não reconhecer a necessidade racional da origem do poder e do direito em todo os elementos do corpo político independente da forma do Estado; se o que leva os críticos do utopismo espinosista a ridicularizar sua filosofia política é a concepção, por Espinosa, de um Estado resultante da razão, sua objeção não terá eficácia enquanto não reconhecer a necessidade racional de uma prática política que permita realizar o que a razão mostra sem a necessidade da natureza humana em sociedade; se o que, enfim, leva os críticos da metafísica espinosista a ignorar sua filosofia política é a fundamentação, por Espinosa, de suas teses sobre a política e o Estado na ontologia, sua objeção não terá eficácia enquanto não reconhecer a necessidade racional do princípio de autoconservação que impulsiona todas as coisas segundo sua própria natureza.

De fato, essa leitura interna do pensamento político-jurídico espinosano é, ainda, uma tarefa fundamental também para as poucas interpretações em seu favor, antes que estas corram o ris- 
co de constituir com suas glosas e comentários, uma espécie de doutrina político-jurídica espinosista. Pois a historiografia do pensamento político espinosano não passou sem sofrer os prejuízos também causados pela defesa do pensamento espinosano diante das urgências da prática política democrática ou das questões teóricas fundadas pelas várias correntes de pensamento político contemporâneo - mais do que se propor, principalmente, um conbecimento do pensamento político espinosano nele mesmo, para com isto analisar através dele a experiência política presente. Se pensarmos na "reabilitação" do pensamento espinosano a que se refere Leo Strauss, veremos que nela Espinosa aparece como teórico da democracia e da liberdade; certamente não um teórico da mesma democracia tal como projetada pelos seus reabilitadores nos inícios da contemporaneidade - para estes, fundadores da prática representativa do poder democrático, a idéia espinosana de democracia era utópica e inaplicável na prática, apesar de uma bela idéia -, mas certamente um defensor das liberdades individuais na vida política, não importa sob que forma política ou diante de quais autoridades. Espinosa, para os fundadores da idéia contemporânea de democracia, é já um grande teórico da política liberal, e para os formadores do pensamento liberalista contemporâneo (já no século XIX, mas especialmente no século $\mathrm{xx}$ ), ele é um dos precursores do pensamento liberalista, tendo-se mesmo antecipado em poucos anos ao liberalismo político de John Locke. Porém, sem entrar ainda no mérito dessa leitura, ${ }^{43}$ cabe notar que ela é a tentativa de localização, em Espinosa, de uma idéia de pensamento político fundada não na própria idéia espinosana de liberdade enquanto autodeterminação no real, e sim na idéia liberalista de liberdade enquanto domínio de direitos e de bens; não por acaso, a extensa corrente que procura ver em Espinosa um liberalista - e que provavelmente é a que mais conseguiu adeptos entre seus defensores, nas últimas décadas - é autora, também, de uma leitura externa, que em lugar de revelar sua validade para a prática política e econômica liberalista, acaba por investir no enfraquecimento da sua concepção autêntica de liberdade enquanto autodeterminação individual segundo a própria natureza do indivíduo.

Todas as leituras do espinosismo, pró ou contra Espinosa, consideram pois a relevância de seu pensamento político dentro do sistema, ainda que sob condições que raramente parecem concordar com o que seria uma leitura interna de Espinosa. Não que essa leitura nunca tenha sido feita. Ao contrário, existe uma considerável tradição de comentadores voltados diretamen-

${ }^{43}$ Defendida, por exemplo, por L.S. Feuer (Spinoza and the rise of liberalism. Boston, Beacon Press, 1958), A. Matheron (Individu et communauté chez Spinoza. Paris, $1^{a}$ ed., 1969) e S.B. Smith (Spinoza, liberalism, and the question of Jewish identity. New Haven \& London, Yale University Press, 1997). A idéia de uma existência, em Espinosa, de um modelo de Estado liberal, exige em primeiro lugar a consideração da sua teoria política como teoria do Estado, o que nem sempre é o caso. 
te para o seu pensamento político, impulsionados pela tarefa de decifrar as teses espinosanas segundo a estrutura mesma dos seus textos. Desde cedo, essa tradição centenária teve como questão primordial decifrar o papel da política dentro de todo a filosofia de Espinosa. Algo já foi dito, acima, a respeito da impressão de incompatibilidade ou de complementaridade que os textos ou os capítulos da obra espinosana trazem. De fato, todos os textos de Espinosa voltados à política parecem estar na parte final do seu pensamento ou, pior, num acréscimo que talvez seja dispensável diante da exposição, por exemplo, do método para o conhecimento adequado, no Tratado da emenda, e a exposição geométrica da totalidade do real, na Ética; nestas duas obras, a política parece estar ausente da argumentação principal: no Tratado da emenda o vocabulário precisamente político-jurídico não aparece, e na Ética só aparece dentro de comentários com forma de anotação (prefácios, escólios, apêndices e capítulos ${ }^{44}$ ) adicional às análises centrais da obra. Assim, se não há dúvidas quanto à existência de pensamento estritamente político em Espinosa, sempre houve certa discussão a respeito de quais são esses textos políticos.

Há entre os comentadores da obra política, especialmente até as últimas décadas, a convicção de que não há como se considerar as breves considerações sobre a justiça e a injustiça, o bem e o mal, e mesmo toda a extensa análise da servidão e liberdade, presentes na Ética, como parte dos textos políticos de Espinosa, ainda que certamente haja, lá, conceitos fundamentais para a construção de uma teoria da sociedade: é na Ética, certamente, que se encontra o conceito nuclear de todos os textos espinosanos, inclusive dos textos políticos - o conceito de conatus -, e é principalmente ali que se acha uma teoria da relação entre as coisas singulares e as comunidades de indivíduos, o que, no campo da sociedade e do Estado, constituem a base da definição dos indivíduos políticos e do corpo político; todavia, esses conceitos fundamentais não constituem, sozinhos, uma teoria política.

Essa opinião, resultante ainda da necessidade de se definir qual a estrutura geral do corpus spinozanum, está presente em autores como Harry Austryn Wolfson e Victor Goldschmidt. Wolfson, na década de 1930, considera que a política em Espinosa é certamente um tema de relevância direta para as preocupações do filósofo, dada a sua formação filosófica dever tanto, segundo Wolfson insistentemente afirma, a uma tradição de pensamento filosófico e teológico que bebe tanto da filosofia ocidental como da árabe e do pensamento político e religioso judaico-cristão. Mais do que isso, a própria condição pessoal de Espinosa, como integrante da comunidade judaica de Amsterdã em sua juventude e a partir de 1656 excomungado por conta de suas idéias sobre a religião — o que lhe traz a condição de herege entre os judeus, ateu entre os

\footnotetext{
${ }^{44} \mathrm{Na}$ Ética, capítulos são as 32 anotações que compõem o apêndice da Parte IV (é o único dos dois apêndices contidos na Ética — o outro é o apêndice da Parte I — dividido em capítulos).
} 
holandeses e subversivo diante dos orangistas: na prática, um ex-cidadão desligado de suas origens e estrangeiro em sua própria pátria —, dá-lhe uma perspectiva política que se manifesta por meio de seus textos. Porém, Wolfson considera que o interesse de Espinosa pelo pensamento político é decorrente mais dessa reação pessoal contra seus adversários políticos e ideológicos, motivada sempre por casos circunstanciais, do que o resultado de um projeto filosófico consistente: a filosofia política de Espinosa seria unicamente a manifestação política de um grande filósofo. Para Wolfson, o que marca em Espinosa ainda uma condição aporética nos textos políticos de Espinosa sequer é a sua condição de incompletude, mas um seu deslocamento mesmo diante da articulação principal do corpus, a Ética, que para Wolfson contém toda a filosofia de Espinosa (os demais textos confluiriam para essa obra principal, ou seriam adições, pelo seu autor, a propósito de temas circunstanciais). ${ }^{45}$

Goldschmidt, seguindo Wolfson meio século depois, considera que a Ética comporta uma filosofia da sociedade mas não uma teoria do Estado, o que só haveria nos dois tratados políticos; ${ }^{46}$ para Goldschmidt, de fato, o lugar da filosofia política na filosofia espinosana é - como acabará por dizer a maioria dos autores que se dirigem a Espinosa em busca das suas teses sobre política e direito, sociedade e Estado - a que ele deixou exclusivamente no Tratado teológicopolitico e no Tratado politico, considerando, porém, a teoria política enquanto teoria do Estado. Somente nestas obras seria possível encontrar os conceitos autênticos das idéias de Espinosa sobre a política: só ali, com efeito, estão suas definições dos regimes políticos e das instituições civis em cada regime, só ali está desenvolvida a sua crítica ao poder teológico-político e ao autoritarismo das autocracias, etc. Goldschmidt, porém, cuida de lembrar que à Ética resta uma posição fundamental diante dos dois tratados — ou sequer haveria sentido na remissão de Espinosa à Ética, no início do capítulo II do Tratado político - , qual seja, a de premissa tanto para colocar, para todo o sistema de sua filosofia, a idéia de subjetividade, ${ }^{47}$ quanto para colocar as premissas ontológicas para a teoria da sociedade; mas não é o caso de tratar na Ética dessa teoria da sociedade porque ali a reflexão é, segundo Goldschmidt, ontológica e não baseada na experiência. O que une Wolfson e Goldschmidt nessa mesma observação não é um desinteresse diante da Ética - característica, na verdade, comum dos autores de pensamento político ou jurídico que buscam interpretar Espinosa a partir de seus instrumentos não filosóficos —, mas, muito pelo

\footnotetext{
${ }^{45}$ H.A. Wolfson, The philosophy of Spinoza, II, p. 241: "O estudo da sociedade é um objeto apropriado para ser incluído na Ética. O estudo do Estado, entretanto, enquanto um tipo especial de sociedade humana é tratado por ele, assim como é em Aristóteles, em duas obras separadas, nos últimos cinco capítulos do Tratado teológico-politico e no Tratado político."

46 V. Goldschmidt, "La place de la théorie politique dans la philosophie de Spinoza", Écrits II, p. 25.

$47 \mathrm{O}$ tema da subjetividade na teoria político-jurídico de Espinosa, e especialmente a noção a esse tema relacionada de direito subjetivo, será abordado com mais detalhe nos capítulos 5.I ("Espinosa e o sujeito de direitos") e 5.II ("Direitos naturais sem jusnaturalismo?").
} 
contrário, uma consideração dos temas filosóficos em Espinosa demasiadamente influenciada pelo peso da filosofia não política moderna e clássica: um autor que baseia sua explicação geométrica do real certamente coloca como imprescindível o conceito de subjetividade (como numa repercussão do cogito cartesiano, embora no pensamento espinosano não exista o cogito) assim como as idéias de essência e existência como conceitos fundamentais para a concepção do mundo (como numa repercussão - aqui sugerida especialmente por Wolfson - do pensamento grego, embora Espinosa não conhecesse grego e, provavelmente, tenha estudado dentre os filósofos antigos somente os de língua latina, em especial o pensamento estóico).

As obras evidentemente políticas do corpus spinozanum - o Tratado teológico-político e o Tratado político - , entretanto, não ficaram totalmente imunes à dúvida sobre o reconhecimento e condição dos textos políticos de Espinosa. O Tratado teológico-político, no qual Espinosa apresenta uma crítica ao poder teológico-político baseada na análise de dois campos distintos - a teologia, cuja análise ocupa formalmente os capítulos I a XV, e a política, que corresponde aos capítulos XVI a XX —, de início sofreu, como já se mencionou acima, uma leitura centrada principalmente na sua extensa parte sobre a teologia, tomada por uma teoria detalhada a respeito da religião e da fé, da autenticidade e autoridade dos textos sagrados assim como de sua correta interpretação, da separação entre fé e razão assim como entre filosofia, teologia e poder, da lei divina e das instituições religiosas e cerimoniais, do significado das profecias e dos profetas, do papel dos apóstolos como doutores em matéria religiosa, da natureza perfeitamente compreensível dos milagres e outros pretensos mistérios da fé, etc. A análise que Espinosa empreende nesses capítulos é, em suma, uma negação da existência de mistérios e poderes sobrenaturais, um reconhecimento da verdade das certezas morais elementares da religião natural e, principalmente, um projeto de aniquilação da teologia, essa vituperação institucional tanto da religião quanto da paz civil. Passados os tempos de defesa da influência direta da Igreja e da teologia sobre as instituições civis, veio a partir do século XVIII, como também se viu, uma leitura voltada menos para o caráter do ateísmo espinosista e mais para suas concepções elaboradas nos últimos capítulos do TTP, na parte que corresponde, segundo o próprio Espinosa em seu prefácio à obra, à política. Aí, porém, se não temos uma leitura entusiasmada das suas teses sobre a necessidade de se instaurar a liberdade de pensamento para garantir a paz pública, temos principalmente uma crítica crescente às concepções ditas jusnaturalistas de Espinosa, assim como a consideração da irrelevância de suas teses a respeito da relação entre Estado e religião, na medida em que a Igreja não é mais, no Estado contemporâneo europeu, uma instituição tão influente sobre as instituições do poder político-jurídico. Ao mesmo tempo, há por essa mesma leitura centrada nos capítulos finais do Teológico-politico uma recuperação das teses do Tratado político, este sim voltado inteira- 
mente à análise do Estado e das instituições civis. Entretanto, essa leitura do Tratado político, tomando-o como uma elaboração mais técnica dos elementos da política desenvolvidos já no tratado anterior, e principalmente como a exposição de um projeto de prática política — na medida em que desde cedo o Tratado politico pareceu, à leitura contemporânea, uma teoria dos modelos de regimes políticos, cuja tese central é a contraditória defesa tanto de um direito natural idêntico à potência dos indivíduos e do Estado, quanto de um direito positivo cujo poder deve ser absoluto —, foi não apenas levada a considerar que essa obra final do corpus é mais relevante para a teoria político-jurídica, já que desta vez o seu tema é estritamente a teoria do Estado, como também iniciou uma longa lamentação pela incompletude do seu texto, especialmente porque, além disso implicar uma mera inconclusividade de uma obra na qual Espinosa enfim teria encontrado um método mais preciso para escrever a respeito da política — a exposição das instituições que devem fazer parte do Estado e do poder político —, o texto é interrompido bruscamente bem ali na parte em que Espinosa inicia a sua exposição do tema mais relevante para a teoria contemporânea do Estado: a exposição da democracia, tida pelos leitores contemporâneos, também como uma exposição, infelizmente somente iniciada, de um modelo de instituições para a democracia.

Por isso, incômoda condição traz para os leitores contemporâneos o encontro com os textos de Espinosa: de um lado, o Tratado teológico-politico precisa passar por um trabalho de garimpagem para que se encontre ali as teses que realmente digam respeito à política, para isso devendo elas ser separadas tanto da parte a respeito da teologia quando da própria análise política do poder teocrático, naquilo em que este poder já não mais tem relevância para a teoria contemporânea do Estado. De outro lado, o Tratado político oferece como principais dificuldades: a brevidade e laconismo de suas teses; a curiosa contradição entre a crítica, no início da obra, às utopias e idealizações filosóficas da política e o desenvolvimento, em praticamente todo o resto do texto, de uma concepção aparentemente idealizada das instituições políticas; a excêntrica teoria do direito natural apresentada no capítulo II que vem confirmar as concepções já expostas no capítulo XVI do Tratado teológico-politico; e, finalmente — desafio maior —, a incompletude dos capítulos sobre a democracia, que exigem que o leitor ou ignore a existência de um modelo espinosista para esse regime, ou que busque no Tratado teológico-politico bases para a construção, por analogia, de um regime adequado à democracia, por analogia com a exposição da monarquia e da aristocracia (os dois outros tipos de regimes políticos; sem contar com a teocracia, que embora seja um regime político não deve, graças à separação entre religião e poder político, 
valer para a vida política soberana); ${ }^{48}$ não bastasse isso, finalmente, a carta a um amigo ${ }^{49}$ que foi incluída pelos editores como prefácio anuncia que o Tratado político deveria concluir-se com um capítulo sobre as leis positivas: portanto, outra dificuldade que se anuncia ao leitor da política espinosana é a necessidade (concebida mas não concretizada) de uma teoria das instituições jurídicas. Em suma: os textos políticos de Espinosa que chegaram a nós são, para a leitura contemporânea muitas vezes, um pensamento político incompleto, cuja compreensão depende ora de uma comparação ou analogia com outros textos e modelos teóricos, ora da desconsideração de certas idiossincrasias conceituais de Espinosa. Sem o trabalho do leitor a completar o que Espinosa deixou inacabado ou a ordenar o que ele expôs com obscuridade, a sempre instigante teoria política espinosista não consegue dizer nada de razoável.

Muito pode ser dito a respeito dessa leitura contemporânea que discute o prejuízo causado pela inconclusividade do Tratado politico, à qual corresponde, de uma certa maneira, uma inconclusividade de toda a obra: para essa mesma leitura, o Tratado político se apresenta como o fecho de um ciclo teórico, onde a análise metafísica e empedernidamente racionalista do real pela Ética, assim como a crítica à teologia e à religião juntamente com a apresentação detalhada da teoria sobre o direito natural no Tratado teológico-político, já se completaram e permitem ao filósofo retomar no Tratado político aquelas mesmas teses — tal como ele mesmo diz no início do capítulo II: "Dissemos em nosso Tratado teológico-político do direito natural e do direito civil, e na nossa Ética explicamos o que é o pecado, o mérito, a justiça, a injustiça e, finalmente, a liberdade humana. Para não obrigar, todavia, os leitores do presente tratado a procurar noutros trabalhos os princípios que são mais necessários neste, resolvi dar novamente estas explicações e acrescentar uma demonstração apodítica" 50 — e apresentar, enfim, modelos de organização política. A apresentação desses modelos, assim, seria a grande finalidade do pensamento político espinosista: de-

${ }^{48}$ É o que faz, de certa forma, Alexandre Matheron em Individu et communauté chez Spinoza (cf., a propósito, especialmente Parte III, capítulos IX e X). Matheron não apenas considera que Espinosa apresenta modelos de instituição política nos seus dois tratados políticos, como elabora um quadro explicativo da estrutura desses modelos, incluindo nesse quadro tanto a democracia quanto (em determinado momento em que considera válida a análise analógica) a teocracia.

49 Trata-se da Carta 84: "Caro amigo. Tua alentada carta acaba de ter-me sido entregue. Agradeço sinceramente pelo interesse tão esmerado que demonstras por mim. Não deixaria passar esta ocasião etc., de não estar ocupado em certo assunto, que considero mais útil, e que, segundo creio, agradará mais a ti, a saber, em elaborar o Tratado político que, por tua sugestão, comecei faz algum tempo. Deste tratado já estão completados seis capítulos. O primeiro contém espécie de introdução à obra; o segundo trata do direito natural; o terceiro, do direito das autoridades soberanas; o quarto, determina que assuntos políticos dependem do governo das autoridades soberanas; o quinto, qual é o fim que a sociedade pode considerar como último e supremo, e o sexto, de que forma deve ser organizado o Estado monárquico para que não se caia em tirania. Atualmente, dedico-me ao sétimo capítulo, em que demonstro de forma metódica todos os membros do precedente capítulo sexto, relativo à ordem de uma monarquia bem organizada. Depois passarei ao Estado aristocrático e ao popular e, por fim, às leis e outras questões particulares concernentes à política. E sem mais, que estejas bem, etc.”

${ }^{50}$ TP, cap. II, $\ 1$; grifos meus. 
pois que a crítica ao poder teológico-político se achasse consumada e não mais fosse necessário discutir a relação entre religião e política (uma discussão que o Tratado político definitivamente já pode deixar de lado; mas por quê?), bastaria produzir de vez a explicação da política por ela mesma: a forma para isso é uma teoria das instituições e dos regimes políticos, instrumento teórico fundamental (na leitura contemporânea, sem dúvida) para a orientação da prática política. E a convicção pela democracia, já implantada no Teológico-político, retorna em momentos do Político, mas sofre abruptamente, no capítulo XI (sobre a democracia), o impacto da contradição entre a definição da democracia como Estado absoluto onde todos os cidadãos têm direito a voto nas assembléias e a afirmação empírica de que as mulheres devem ser excluídas desse conjunto de cidadãos que participam das decisões públicas e do governo, agravada pelo silêncio representado pelo próprio término do capítulo, logo após a sentença de que "não pode acontecer, sem grande prejuízo para a paz, que os homens e as mulheres governem juntos".

A expressão reliqua desiderantur, aposta pelos editores da obra póstuma ao final deste intrigante início de capítulo, adiciona à questão sobre o lugar da política no pensamento de Espinosa a dúvida quanto a qual é o restante que falta, a partir daí. Apesar de apenas conjecturas poderem ser feitas a respeito do que haveria daí por diante, o peso dessa pergunta não tem como ser ignorado por quem quer que vá trabalhar a política segundo Espinosa. Por trás dela, há muitas indagações (e todas desafiam a responder, novamente à questão do lugar da política no pensamento de Espinosa): Como seriam as instituições da democracia, tivesse Espinosa concluído seus capítulos sobre esse regime? Haveria realmente uma equivalência prática entre o regime democrático e os não democráticos, ou Espinosa concluiria sua exposição sobre a democracia demonstrando que ela, enfim, é o único sistema cujas instituições são plenamente apropriadas para a concretização do Estado absoluto? O que seria trazido pelo capítulo final do Tratado político, anunciado por Espinosa na Carta 84 como um estudo sobre as leis? Esse estudo — pela primeira vez posterior, no corpus, à análise dos regimes políticos — seria a exposição da elaboração das leis em qualquer regime, ou unicamente do regime democrático, depois que se tivesse feito uma escolha voltada especificamente para ele? Mais do que tudo isso: a conclusão desse breve tratado sobre a política manteria a consistência do sistema espinosano, contrariando mesmo a hipótese de que sua inconclusividade talvez se devesse à chegada numa aporia intransponível?

A incompletude do Tratado político significa a presença de pelo menos todas essas questões. Impossível, evidentemente, projetar uma "reconstituição" do texto. Mas isso mesmo, antes de mais nada, não é necessário: o Tratado político, independente do motivo que levou à sua interrupção, avançou o suficiente para mostrar a maneira como Espinosa analisa a política e o direi- 
to sem ter de passar pelos desvios da discussão teológica. O TP mostra (utilizando-se agora de uma forma expositiva que se endereça não mais às convicções religiosas dos seus leitores, mas sim à sua experiência política e à sua razão) o caminho, no campo das instituições e do poder, para a construção da paz e segurança tão apontadas outrora no Tratado teológico-político. Principalmente, o TP mostra o que é esse centro da política apontado por Maquiavel, o poder, e por quais princípios ele é o motor dos diferentes regimes políticos. Ao mesmo tempo, o TP deixa no campo do estado civil, mas também no campo da filosofia política, o tema do direito natural, sob uma curiosa disposição, certamente diferente daquela elaborada pelos seus contemporâneos. Apesar do inacabamento da obra, os temas que ela teve tempo de abordar se imbricam completamente.

Daí, também, a necessidade de se considerar o que é, até o fim, a concepção espinosana da democracia e do ordenamento jurídico. Esses seriam os temas finais do Tratado político, e ainda que estejam já em outras partes do corpus, só ali, ao que tudo indica, receberiam a análise que Espinosa considerava desde o início apropriada. Diferentemente das leituras que consideram que o Tratado político não foi completado porque Espinosa deparou-se com uma imensa aporia (no caso, a suposta impossibilidade de definir as instituições da democracia, ou de manter a defesa da democracia - feita já no Teológico-político — diante da força institucional dos regimes monárquico e aristocrático, de cuja análise ele acaba de chegar), a estrutura do texto como um todo mostra, primeiro, que as concepções ali presentes acerca tanto do direito natural e sua relação com o estado civil, como dos diferentes regimes políticos cuja descrição pôde ser elaborada, é equivalente à apresentada, sob outra forma expositiva e analítica, no Teológico-político, o que permite não necessariamente uma concepção analógica da democracia, mas demonstra que o Tratado político é a exposição geométrica de uma concepção integral da política, já apresentada numa oportunidade anterior. Ainda, a lapidação do texto acompanha, como sabemos, o desenvolvimento também da tuberculose que matou Espinosa, que, talvez sentindo a morte por perto, tratou de antes dela destruir uma série de papéis: nada que nos foi deixado dele é um esboço nem um parágrafo sem ponto final; ao mesmo tempo, a leitura de suas cartas mostra que, conforme chegamos às últimas, constatamos bruscamente um homem abatido fisicamente, enfraquecido já pela doença que em seguida o silencia. Enfim, e talvez em termos teóricos seja este o dado mais decisivo, a concepção da democracia e da elaboração das leis, cuja exposição e análise fora projetada para os capítulos finais da obra, está na verdade exposta de várias maneiras desde o início da obra: conforme avança o Tratado político, Espinosa nos mostra, através de sua análise dos diferentes regimes políticos, que o poder que move a política não é diferente em cada um desses regimes — o poder político é essencialmente o mesmo em qualquer estado civil 
—, mas que os diferentes regimes são formas diferentes de imaginá-lo; o que é o poder, mostrará Espinosa? A potestas, essa capacidade de determinar a condição de outrem, é dominação do outro e apropriação privada de necessidades públicas; o imperium, esse poder de comandar e estabelecer leis, é necessidade de estabelecimento de paz e segurança; a summa potestas, essa autoridade soberana dentro do Estado, é um conjunto de funções cujo destino oscila entre a imposição como autoridade (authoritas, ou ainda a simples potestas) ou entre a instrumentalização do Estado para fins públicos (porque o imperium tem uma função: a paz e a segurança; sem instrumento para isto são as instituições; a imagem das instituições, a summa potestas). Em todas as suas formas, o poder é uma potência do corpo político, ou do Estado, ou da autoridade política; em nenhuma dessas formas, o poder é legítimo se não for absoluto: em nenhuma dessas formas, o poder tem o direito de ser contrário à necessidade do conjunto de cidadãos; em todas essas formas, o poder não é constante ou não é legítimo se não for poder popular. Esse poder, pois, que tem uma forma no regime monárquico, outra no regime aristocrático, outra no puro despotismo, outra ainda na ausência mesma de regime que é a anarquia (e ainda outra na teocracia, lembrando-nos das figuras analisadas já no Tratado teológico-político), enquanto não assume a forma democrática, não se completa, não é absoluto, não cumpre a sua função original de estabelecer a paz e a segurança - porque, em todas os outros regimes políticos, o poder é dominação no campo político — potestas —, mas ainda não garantia de segurança; é comando — imperium —, mas ainda não expressão da vontade pública ou popular; é instituição e autoridade civil — summa potestas —, mas ainda não instrumento racional para a prática da liberdade. $\mathrm{Na}$ democracia, o poder é o quê? Ele é o conatus da comunidade política constituída - conforme a definição de democracia - por todos os cidadãos sem exceção; esse poder não pode, por isso, ser um impulso pelo enfraquecimento dos seus próprios indivíduos constituintes: necessariamente, é uma potência da qual nenhum indivíduo no corpo político, nenhum cidadão, deve ser concebido como separado: o poder tem autoridade sobre a vida coletiva sem ser autoridade contra a necessidade de cada um; o poder, na democracia, não é nem potestas nem potestatis, mas apenas imperium; não é, portanto, uma força cogente que obriga a todos pelo medo, mas uma força racional que apazigua a todos pela segurança, e na qual todos os cidadãos se sentem tomando parte. Ora, o Tratado político mostra, como já mostrara o Tratado teológico-político, que o poder, sempre que é concebido como separado dos cidadãos, é contrário à natureza destes; sendo contrário à natureza destes, é incompatível com a necessidade do corpo político; sendo incompatível, não pode ser legítimo, porque a política é o campo das necessidades públicas e não das finalidades privadas. O poder, mostra Espinosa a todo momento, só é legítimo enquanto poder 
democrático, isto é, enquanto poder cuja legitimidade é válida não por sua origem numa autoridade, mas por sua racionalidade e necessidade.

Qual é o restante que falta ao Tratado político - e à filosofia política de Espinosa? Falta-lhe de fato um resto de texto, mas definitivamente não um resto de filosofia. A democracia está explicada nos textos espinosanos desde já a Ética. Não apenas o Tratado político nos traz a definição da democracia, como nos mostra o caminho pelo qual ela é vulgarmente conhecida (TP XI, $\iint{ }_{\text {S }} 3$ e 4), nos mostra o caminho pelo qual ela não pode ser concebida (os "modelos" da monarquia e da democracia), nos mostra já a formulação do poder enquanto necessidade quando mantém o direito natural no estado civil, invertendo por completo com isto não apenas a concepção jusnaturalista da relação entre direito natural e direito civil como também recusando a validade das teorias políticas cujo centro é o poder enquanto legitimidade fundada na autoridade. É a autoridade que se funda na legitimidade, mostra Espinosa; e é por isso, também, que apesar de não nos ter chegado o capítulo do Tratado político sobre a elaboração das leis, que sabemos tanto o papel dado por Espinosa às leis e às instituições político-jurídicas, como sua relação imbricada com a concepção racional de democracia: legitimidade e democracia são duas necessidades racionais da vida política. No Tratado teológico-político, muito bem visto por E. Balibar como uma defesa da democracia, ${ }^{51}$ o poder nos vários regimes políticos é mostrado como não sendo legítimo em função da autoridade de um monarca ou de grupos aristocráticos; mesmo na teocracia, esse governo divino sobre os homens, a lei de Deus é "soberana" justamente porque não há nenhum homem no poder, mas o poder está naquele cuja vontade certamente almeja o bem de todos: ultrapassando a capa retórica do discurso voltado para os teólogos e trazendo ao argumento os termos da Ética, a vida política na qual as leis de Deus são seguidas é a vida na qual são seguidas as leis necessárias à autopreservação de todos os homens — porque todos são parte de Deus e tomam parte nele: como já diz a epígrafe bíblica do Tratado teológico-político, "conhecemos que permanecemos em Deus e Deus permanece em nós"; 52 o que permite a Espinosa dizer, ainda, que o regime político que mais se aproxima da democracia é a teocracia, porque ali o poder é um lugar vazio. Entretanto, é toda a parte do Tratado teológico-político dedicada à questão da política — os capítulos XVI a XX — que contêm, expressamente e para além dessa concepção fundamental sobre o poder e a potência na política, o elogio da democracia: "Na demo-

\footnotetext{
${ }^{51}$ Cf. E. Balibar, Spinoza et la politique, pp. 42-48.

521 João, 4: 3. A epígrafe é escolhida a dedo para o leitor cristão e traz o tema da imanência divina nas coisas humanas (inclusive na política), e das coisas humanas em Deus — o que não só é diferente como é o contrário de apontar uma imanência da religião ou da teologia na política.
} 
cracia ninguém transfere seu direito natural para outro homem, em proveito do qual, a partir de então, aceitaria não mais ser consultado. Cada um transfere seu direito natural para toda a sociedade de que faz parte e assim todos permanecem iguais como o eram outrora em estado de natureza. Detive-me no exame desse regime porque ilustra melhor do que todos os outros minha demonstração, a saber, a importância da liberdade em uma comunidade politicamente organizada". 53 O que o TTP mostra, além da separação entre teologia e política, é a necessidade popular - democrática — da política. Para além, finalmente, dos dois tratados políticos - e contrariando a opinião de Wolfson e Goldschmidt —, a Ética, sem usar o vocabulário da política, mostra que a liberdade na vida em sociedade não apenas é uma necessidade racional como só se realiza como concórdia de todos os seus integrantes; numa perspectiva política, a liberdade política só se realiza plenamente — absolutamente — na democracia, onde todos tomam parte na determinação da potência da coletividade. ${ }^{54}$ A Ética, a propósito, ainda que aborde essas teses sobre política ou sobre a sociedade (ainda que não sobre o Estado; não é, ainda o lugar - reservado desde logo ao Tratado teológico-político e ao Tratado político $)^{55}$ em trechos de dimensão retórica ou que se voltam para a experiência do leitor, não contraria o conjunto das teses - sobre ontologia, teoria do conhecimento, teoria dos afetos, física, na medida em que é válida essa classificação — dispostas na estrutura geométrica nuclear da obra, mas ao invés disso estende o seu alcance para o mundo da experiência política e moral, no qual residem, exclusivamente as concepções do justo e do injusto, do bom e do mau, do pecado e do mérito... ${ }^{56}$

53 Tratado teológico-político, cap. XVI; conforme tradução de Marilena Chaú, "Direito natural e direito civil em Hobbes e Espinosa", in Ética sem culpa, politica com liberdade, no prelo.

${ }^{54}$ Sobre a teoria da democracia e a razão democrática em Espinosa, conferir especialmente o capítulo 4.II ("Democracia, uma necessidade da política e do direito").

${ }^{55}$ Uma objeção talvez seja feita a esta idéia de que o Tratado político já estaria nas intenções de Espinosa desde os tempos da composição da Ética e do Tratado teológico-politico: a própria afirmação de Espinosa, na Carta 84 (aquela que serviria de prefácio ao TP), de que ele havia iniciado aquela obra sob sugestão do amigo anônimo a quem a carta é endereçada. Ora, em primeiro lugar, Espinosa afirma que iniciou a escrita do tratado sob a sugestão do amigo, e não que o concebera já sob a sugestão alheia. Mas, mais importante que isso, é o fato de que o Tratado político é a exposição, na teoria político-jurídica, de teses já anunciadas na Ética e no Tratado teológico-politico. O conjunto das três obras forma um projeto político consistente, ainda que em cada uma haja uma análise completa da política sob determinado aspecto e para determinado público.

${ }^{56}$ Cf. Ética I, Apêndice: “Todos os prejuízos que me cumpre indicar dependem de um só, a saber: os homens supõem comumente que todas as coisas da Natureza agem, como eles mesmos, em consideração de um fim, e até chegam a ter por certo que o próprio Deus dirige todas as coisas para determinado fim, pois dizem que Deus fez todas as coisas em consideração do homem, e que criou o homem para que este lhe prestasse culto. É isto que antes de mais passarei a examinar, indagando em primeiro lugar, a causa por que quase toda a gente dá aquiescência a tal preconceito e é propensa naturalmente a abraçálo; a seguir, mostrarei a falsidade dele e finalmente direi como daí nesceram prejuízos acerca do bem e do mal, do mérito e do pecado, do louvor e do vitupério, da ordem e da confusão, da beleza e da fealdade, e outros do mesmo gênero. Não é este, decerto, o lugar adequado para deduzir tudo isto da natureza da mente humana, bastando agora que eu tome por fundamento o que por ninguém é posto em dúvida, a saber, que 
Não faltam, pois, à filosofia política espinosana as conclusões a que ele aponta ou se dirige desde o começo: sem perder de vista a verdade contida no texto, a falta dos parágrafos e capítulos finais nos permite ver a força das próprias bases dos textos políticos de Espinosa. Esse olhar para as bases, para os fundamentos dos textos políticos, enfim, nos permite lançar nova luz sobre a filosofia política não apenas contida nos textos, mas na obra vivida de seu autor, na sua própria experiência política, esse manancial que não serve apenas de objeto ao pensamento político, mas é o campo próprio desse pensamento. “O que é a filosofia política?” Não é apenas descrição do que se observa na vida dos Estados e das sociedades: é reflexão sobre a experiência política e a partir dela. O que é a filosofia política espinosana? É reflexão, na experiência política, sobre esta experiência e a partir dela. Se é verdade que os textos políticos se baseiam em princípios contidos na geometria e ontologia da Ética, cada um desses textos tem como horizonte um horizonte político, onde liberdade se mostra acessível ao ser humano em todas as suas expressões; essa filosofia espinosana, expressão necessária de uma verdade eterna individual, é toda ela uma obra política: sem o horizonte da liberdade visível desde o início, nenhuma reflexão seria necessária; o horizonte e a atualidade da liberdade são, necessariamente, desejo de cada um de nós e de todos nós. Com que legitimidade podemos, pois, sequer a incompletude dos textos políticos de Espinosa, se tanto sua vida como sua obra se fundamentam na experiência política? Assim como os textos espinosanos têm de uma maneira ou de outra a política no horizonte, da mesma forma a obra espinosana tem como fundamento a ação política: seu primeiro texto, escrito já quando praticava a crítica ao poder teológico-político por meio da insubmissão aos dogmas teológicos da comunidade judaica de Amsterdã, sua defesa perante a Sinagoga (escrita em sua língua materna e língua comum daquela comunidade, o português) durante o processo de sua excomunhão e que infelizmente jamais chegou até nós, é já um texto político e uma obra política: é um texto político, porque escrito enquanto defesa perante a Sinagoga, e não como retratação, foi desde logo concebido pelo jovem Espinosa como expressão pública de uma recusa da vontade irracional da autoridade teológica; inútil, portanto, enquanto defesa de um réu, mas eterno enquanto defesa de uma idéia; ${ }^{57}$ além disso, é uma obra política porque, enquanto defesa de uma idéia e contra a submissão à autoridade dos dogmas teológicos da comunidade, apresenta publicamente uma via para a resolução dos problemas políticos que ele próprio, com sua defesa,

toda gente nasce ignorante das causas das coisas e que todos desejam alcançar o que lhes é útil e de que são cônscios".

${ }^{57} \mathrm{O}$ fato do texto dessa defesa ter sido perdido enquanto foram preservadas outras partes do processo (como o texto original do herem, ou seja, excomunbão on expulsão da comunidade) é um indicativo de duas coisas: primeiro, que na qualidade de defesa contra o processo de excomunhão, sequer pode ter sido aceito ou registrado; segundo, que, por não constituir retratação e por constituir crítica às acusações, não deveria ser preservado em nenhum instrumento público. 
denuncia; se, como quer Strauss, a filosofia política vem para apresentar vias de ação política, a obra política - como texto e como participação direta — de Espinosa começa aí, nesse exercício desse direito que ele sempre definirá, em seus tratados, como o mais pleno de todos e base necessária de toda sociedade livre: a liberdade de pensamento e de manifestação do pensamento.

\section{II LUGAR DA FILOSOFLA DO DIREITO NO PENSAMENTO ESPINOSANO}

Considerando que há uma filosofia política espinosana constituída não apenas por sua teoria do Estado e da política (contidas nos capítulos XVI a XX do Tratado teológico-político e em todo o Tratado político), mas pela perspectiva política que a obra espinosana toda possui, é o caso de considerar quais são os seus limites. O reconhecimento de textos políticos em Espinosa nunca foi problema, como vimos: o Tratado teológico-político desde logo permitiu a atribuição ao seu autor de uma imagem associada de alguma forma, ainda que nefasta, à política; o reconhecimento, enfim, de uma perspectiva política em sua filosofia e em sua vida pessoal também nunca foi problema entre seus críticos e seus defensores: a vida pessoal do filósofo oferece uma série surpreendente de experiências que deixam bem às claras o impacto dos distúrbios políticos e religiosos à sua volta, assim como indicam um certo impacto, também, das questões disputadas por determinados grupos e dos problemas políticos que percorrem a Holanda. Entretanto, a maneira como esse pensamento político espinosano foi interpretado ou criticado recebeu, na maioria das vezes, influência de uma leitura comprometida ideologicamente ou metodologicamente com outras formas de conceber a política e o Estado desde seus fundamentos: levando em consideração unicamente interpretações do seu pensamento político que estabelecem essa leitura pejorativa até hoje, é justamente uma concepção da democracia republicana como regime representativo que vê em Espinosa uma teoria utópica da democracia; é uma concepção teocrática ou teológica da sociedade e do Estado que vê em Espinosa uma teoria da vida social sem regras morais nem regras de justiça; é, enfim, uma visão liberalista do Estado que vê nele ora o autor de uma teoria absolutista de inspiração hobbesiana, ora o precursor da própria teoria do Estado liberal.

Ora, a leitura contemporânea da política de Espinosa produziu, como também já vimos, a concepção de que se trata de uma metafísica da política e do direito. Esta interpretação, tipicamente contemporânea e pós-kantiana, é produzida no interior não mais de uma filosofia política voltada para si mesma, mas de fora da própria filosofia política, porque resultante de uma cisão i- 
naugurada na passagem para a contemporaneidade entre as diferentes formas de se pensar o Estado. Assim como a filosofia kantiana inspira o pensamento contemporâneo a afastar a metafísica clássica de seu próprio campo, e assim como a filosofia hegeliana inspira essa mesma contemporaneidade a identificar realidade, racionalidade e história, a formação do pensamento político-jurídico desde inícios do século XIX é equivalente à negação da validade teórica de padrões conceituais que, segundo a leitura contemporânea, seriam típicos do pensamento político-jurídico moderno, tais como "esse ideal comum a todos os jusnaturalistas, o de uma ciência demonstrativa do direito". 58

De fato, é uma criação dos comentadores jurídicos contemporâneos a idéia de que há, especialmente nos séculos XVII e XVIII, uma corrente de autores que se caracterizam por uma concepção do direito e uma metodologia teórica que estaria agora em desuso, a dita doutrina do direito natural, ou doutrina jusnaturalista. ${ }^{59}$ Independente da discussão sobre a existência ou não de uma tal doutrina antes dos autores modernos, ou da idéia anedótica de que, ainda no período contemporâneo, o tema do direito natural é ressuscitado ou reexumado de tempos em tempos, importante é a idéia, contemporânea, de que a maneira como os modernos pensavam o direito está ultrapassada ou é anacrônica. É regra geral, entre autores das três grandes áreas de pensamento jurídico nos últimos dois séculos — dogmática jurídica, ciência política e filosofia jurídica - considerar que aquela teoria pré-contemporânea dos filósofos modernos, ao tentar conciliar concepções metafísicas e conhecimento empírico, idealização racionalista e análise do poder, produziu um pensamento a respeito da sociedade e do Estado que, ainda que às vezes lance luzes interessantes sobre os elementos da política, de forma alguma dá conta de explicar o que é o Estado contemporâneo, muito menos seu conjunto nuclear de instituições, o direito contemporâneo. Assim, quando a historiografia da filosofia do direito ou simplesmente a teoria jurídica contemporânea (não importa a área — dogmática jurídica, ciência política ou filosofia jurídica - pela qual é elaborada) observa a teoria jurídica moderna, a primeira coisa que vê é uma insuperável diferença de forma e conteúdo, interpretada normalmente a partir da maneira como a teoria jurídica contemporânea já concebe o direito e o Estado, assim como o próprio pensamento acerca do direito e do Estado.

No que respeita à maneira como essa teoria jurídica contemporânea se refere a Espinosa, essa diferença que ela estabelecera com o pensamento jurídico moderno entendido como jusnaturalismo será mesmo radicalizada: se os jusnaturalistas modernos elaboraram uma teoria idealista do Estado, explicando-o segundo uma fundação no contrato social, na supressão do estado de

\footnotetext{
${ }^{58}$ N. Bobbio, Sociedade e Estado na filosofia politica moderna, p. 37.

59 Trataremos dela (mas especialmente da visão pejorativa que os contemporâneos têm dela) nos tópicos do capítulo 2 .
} 
natureza a partir da passagem ao estado civil, e na relação sempre tensa entre direito natural e direito civil ou positivo, em Espinosa nós teríamos uma radicalizacão desse idealismo jusnaturalista, já que na teoria espinosista do Estado temos, por exemplo, a idéia de que o direito natural, concebido correntemente pelos jusnaturalistas como um direito válido no estado de natureza, é mantido no estado civil, onde o único direito válido deveria ser o direito civil; mais do que isso, contraditoriamente a essa concepção Espinosa conceberia a lei positiva como comando de um Estado soberano ao qual todos os seus súditos devem obedecer ainda que lhes pareça um absurdo, o que é claramente a imposição de um direito civil no estado civil e, ao que tudo indica, uma afronta ao direito natural de cada súdito, apesar de se encontrar já no estado civil; finalmente, a teoria espinosista do Estado afirma princípios valiosos como liberdade de pensamento e expressão do pensamento, participação política dos indivíduos e preservação da segurança individual na vida em comum, mas tanto nos textos em que isso estaria sendo explicado — capítulos XVI a XX do Tratado teológico-político, e principalmente capítulos VI a XI do Tratado político seu autor só oferece modelos completamente idealizados de Estado e, quanto mais se aproxima do regime pelo qual ele manifesta claramente sua predileção — a democracia —, mais utópicas parecem suas propostas.

Ou seja, há na leitura contemporânea da teoria espinosana da democracia a idéia de que temos aí uma concepção mais idealista do que concretizável, mas essa mesma leitura, se recusa aplicabilidade ao modelo espinosano de regime democrático (em que todos os cidadãos têm direito a voto e, ao mesmo tempo, têm direito a ocupar os cargos públicos), ${ }^{60}$ ao menos se compraz com a idéia espinosana de que a democracia deve "é, em sua natureza fundamental, o "poder absoluto' de uma comunidade de homens livres", o que assegura a Espinosa o papel de precursor do pensamento rousseauniano e dos que de alguma forma se filiam a este: "ainda que ele não fosse compreendido e não se visse nele senão um pensador maldito, Espinosa teve, na história da filosofia política, a estatura de um pioneiro que preparava na surdina uma demolição pelas bases". ${ }^{61}$ Sua concepção de democracia, para o pensamento jurídico contemporâneo - que costuma ver em Rousseau a formulação mais profunda, na modernidade, de uma teoria democrática, e que vê a si mesmo como o formulador mais coerente de uma democracia prática —, é válida especialmente como prenúncio, e não como realidade.

Muito pelo contrário, para essa leitura jurídica a democracia espinosista é, em si mesma, irrealizável justamente por causa das suas bases metafísicas: apesar da nobre concepção de que "o regime democrático [...] se apresenta como a forma pura e eminente do governo do Estado cuja

\footnotetext{
60 Tratado político, cap. XI, $\int 3$.

${ }^{61}$ Simone Goyard-Fabre, Qu'est-ce que la démocratie?, p. 102.
} 
ação tende inteiramente para a liberdade", o mesmo valor que levara a essa idéia, "o valor fundamental da razão que se exprime na democracia" faz também com que ela "participe da ordem metafísica da grande Natureza e, assim, traga em si uma força política ontologicamente fundada". ${ }^{62}$ Ainda que Espinosa seja defensor desse regime que será, mais de um século depois dos seus escritos, deflagrado por toda a Europa sob formas certamente muito diversas daquela projetada por ele, seu projeto já era desde sempre irrealizável, porque idealização racionalista do Estado e fundamentação ontológica ou metafísica da política. É essa imagem do Estado espinosano (democrático ou não: em Espinosa haveria, além do modelo da democracia, os modelos da monarquia e da aristocracia e até mesmo da teologia, todos concretizáveis; embora o Tratado teológico-político explicite a preferência pela democracia) como um Estado utópico que se instala no pensamento jurídico contemporâneo. Se Leo Strauss considera uma reabilitação do pensamento político de Espinosa junto com a passagem para a contemporaneidade, essa reabilitação é real enquanto reconhecimento do papel de Espinosa como precursor do pensamento democrático, e nada mais. Ao contrário, quando se coloca a proposta de adentrar na teoria espinosana do Estado ou da democracia para considerar o que pode torná-la aplicável — ou seja: quando se propõe que a teoria espinosana do direito e do Estado não é utópica, mas é voltada para sua própria realização concreta e merece portanto ser testada na prática —, o que essa proposta causa é uma outra reabilitação, negativa agora, de Espinosa na contemporaneidade jurídica: a retomada e exploração da clássica opinião de Pufendorf em seu tratado Do direito da natureza e das gentes, de que o conceito espinosano de direito - jus sive potentia - não tem realidade nenhuma e, por isso, não serve de base para uma teoria das instituições do Estado:

Por direito e instituição da natureza, Espinosa não entende outra coisa que as regras da natureza de cada indivíduo, em virtude das quais concebemos cada um desses indivíduos como naturalmente determinado a existir e a produzir suas operações, de uma certa maneira. Por exemplo, a natureza determina os peixes em geral a nadar, e os peixes grandes a comer os pequenos. Sobre o que é preciso notar que, pelo termo Direito, esse autor não entende a Lei pela qual devemos nos orientar, e o que cada um pode fazer sem que um outro sofra dano, mas somente a faculdade natural de agir. Ora, sobre essa base, não se pode inferir em boa lógica que cada um deva fazer necessariamente tudo o que tem direito de fazer. Além disso, como é falar muito impropriamente chamar Lei Natural a essa qualidade física pela qual cada coisa produz suas operações de uma maneira fixa e determinada, é também dar um sentido bem impróprio ao termo Direito fazê-lo significar o poder e a maneira de agir que se acha nas criaturas destituídas de razão: pois, para falar justamente, o direito de agir convém somente aos seres inteligentes. ${ }^{63}$

\footnotetext{
${ }^{62}$ Simone Goyard-Fabre, op. cit, p. 101.

${ }^{63} \mathrm{~S}$. Pufendorf, Do direito de natureza e das gentes, Livro II, cap. II, \2. Conforme tradução de Barbeyrac na bibliografia, 1740, pp. 188-189. Sobre essa crítica de Pufendorf a Espinosa, Alfred Dufour aponta essa diferença entre os autores como resultante de um espírito teórico conciliador em Pufendorf, que se manifesta tanto no plano filosófico como no plano metodológico: Dufour explica (por meio inclusive de termos anacrônicos, de carga hegeliana), sobre Pufendorf, que este tem, como Suarez, "o esforço de síntese e a arte de conciliar posições diametralmente opostas", buscando pois "conciliar em matéria de filosofia prática as teses extremas de Guilherme de Ockham e de Gabriel de Vasquez, em particular a res-
} 
Atento às argumentações de Espinosa, Pufendorf não apenas apresenta essa crítica ao seu conceito de direito (publicado pela primeira vez em 1672, dois anos após o Tratado teológico-político), como no capítulo seguinte se aproxima da concepção espinosana de sociedade. ${ }^{64}$ Para Pufendorf, assim, não há problema na concepção espinosana da segurança mútua como finalidade da associação entre os homens, e sim na concepção de que cada indivíduo pode fazer aquilo que quiser segundo sua potência individual. O que a crítica de Pufendorf quer aí mostrar é que o conceito espinosano de jus não tem realidade não apenas porque seja um conceito ontológico (em termos jusnaturalistas: baseado na determinação natural de cada ser), mas principalmente porque nesta concepção ontológica não cabe nenhum conteúdo moral (que, em Pufendorf, determina a natureza mesma de cada indivíduo, como ente moral: já que o direito natural de cada um é equivalente à sua potência física e não à sua tendência moral, nenhum valor de justiça pode ser atribuído seja aos direitos, seja às ações humanas: só pela potência necessária de cada um não se pode conceber a idéia de dever, assim como o devido não encontra seus limites ali onde a liberdade individual passa a causar dano a outrem — o que é absurdo e entra em contradição com a própria finalidade de estabelecimento, em sociedade, da paz e segurança civis.

Causa espanto ao jurista-filósofo Pufendorf, porém (e será daí por diante um espanto comum da parte de todos os juristas diante de Espinosa) essa idéia tão imprópria de um direito que, no campo da política e do Estado, parece não ter realidade nenhuma e propor mesmo a negação da idéia de direito, que em sua concepção jurídica, certamente, não pode ser separada

peito da moralidade intrínseca dos atos e do fundamento da força obrigatória da Lei natural". A grande marca da diferença com relação a Espinosa viria, porém, da postura com o método: "o mesmo espírito de conciliação e a mesma arte do balanceamento das teses opostas [operado por Pufendorf e por Suarez no plano filosófico] são igualmente sensíveis sobre o plano metodológico, onde para emancipar as ciências humanas (jurisprudência, ciência política e história) da tutela da teologia, Pufendorf não lhes impõe, para isso, a das ciências da natureza. É que, diferentemente de Hobbes, que resulta no materialismo mecanicista, e diferentemente de Espinosa, que versa numa forma de sociologia naturalista, Pufendorf se recusa a aplicar tal como nas ciências humanas o método galilaico-cartesiano sem dar conta da especificidade das realidades sócio-morais." Parece um espírito conciliador que será reanimado por Leibniz, também tanto no plano teórico como no metodológico. Cf. A. Dufour, Droits de l'homme, droit naturel et histoire, p. 74 , n. 31 .

${ }_{64}$ Cf. N. Bobbio, Sociedade e Estado na filosofia politica moderna, p. 54, reconhecendo a semelhança, nesse aspecto, entre Pufendorf e Espinosa: "Desde Platão, a razão fundamental foi sempre a necessidade da divisão do trabalho. O tema fora reexumado também por Espinosa no Tratado teológico-politico (1670), publicado dois anos antes do tratado de Pufendorf: '[...] Se os homens não se prestassem socorro mútuo, faltariam tanto o tempo quanto a capacidade de fazerem o que lhes é possível em vista do próprio sustento e da própria conservação. Com efeito, nem todos são igualmente hábeis em tudo; nem cada um seria por si só capaz de obter aquilo de que individualmente tem mais necessidade' [TTP, cap. v]. Pufendorf retoma essa idéia quase com as mesmas palavras: '[...] para ter uma vida cômoda, há sempre necessidade de recorrer à ajuda de coisas e de homens, já que cada um não dispõe de energia e de tempo para produzir, sem a colaboração alheia, o que é mais útil e sumamente necessário' [DJNG, Livro II, cap. III, \9]." Da tradução de Carlos Nelson Coutinho do texto de Bobbio. 
da moral nem do dever, ainda que possa, sim, corresponder a uma certa idéia de necessidade. De forma alguma, porém, pode Pufendorf aceitar a idéia de um direito idêntico à força física, tal como explicitava o próprio exemplo de Espinosa no Tratado teológico-político, de que "os peixes maiores têm direito natural de comer os peixes menores" em função de terem uma potência maior, tese endossada pela afirmação de que acontece exatamente da mesma forma com os seres humanos ${ }^{65}$ (Rousseau, leitor entusiasmado de Pufendorf, refletirá essa crítica numa das anotações em que menciona Espinosa $\left.{ }^{66}\right)$. Se a medida do direito é essa potência natural, essa força física maior ou menor que a dos outros seres naturais, e se isso é enfim — suprema iniqüidade jurídica - mantido por Espinosa no estado civil, de que valem as instituições jurídicas e civis? Certamente não valem de nada, assim como os princípios da moral já no estado de natureza: onde eles estão quando Espinosa considera que, por direito natural no estado de natureza, tudo pode ser feito conforme a potência?

Essa crítica pufendorfiana, que na verdade apresenta à teoria jurídica de Espinosa uma série imensa de questões típicas das teorias do direito natural (das antigas às modernas), ${ }^{67}$ quando recolocada a partir de uma perspectiva contemporânea — não mais jusnaturalista, portanto —, joga na irrelevância a questão dessa condição dos direitos no estado de natureza (que historicamente não mais existe, ou mesmo nunca existiu enquanto já vieram à existência as primeiras sociedades) e centraliza sua recusa diretamente na idéia espinosana de que o direito natural se mantém no estado civil. ${ }^{68}$ De fato, para o jurista contemporâneo a questão da existência ou não de direitos naturais no estado de natureza é irrelevante porque é sabido, desde Hegel, que o estado de natureza é uma concepção idealista e sem realidade concreta diante do Estado, que é sempre estado civil; como a sociedade organizada, na perspectiva hegeliana, é já uma sociedade fundada em regras e num aparelho de coerção, a organização social só tem forma jurídica na forma de Estado, e não teria realidade alguma caso se desse, historicamente, o dito estado natu-

65 Tratado teológico-politico, início do cap. XVI.

${ }^{66}$ Cf. Vernière, Spinoz̧a et la pensée française avant la Révolution, p. 482: “Ora, [a concepção realista do direito natural por Hobbes no De cive], fundada numa psicologia do desejo, fora já integralmente aceita por Espinosa tanto no Tratado político como no Teológico-político: o homem, sumetido às leis do 'apetite' e se esforçando como tudo na natureza em perseverar no ser, tem da própria natureza 'tanto direito quanta potência de existir e agir'. Rousseau certamente se recusa a ver nesse direito do mais forte outra coisa que uma tautologia [Contrato social, I, 3] e por aí confirma as críticas de Pufendorf contra Espinosa; mas por trás dessa querela das palavras deve-se reconhecer que Rousseau se afasta, no sentido mesmo de Espinosa, de toda concepção teológica ou metafísica do direito”.

${ }^{67}$ Esses problemas serão retomados, aqui, no capítulo 2.

68 Carta 50, de Espinosa a Jelles: "No que respeita à política, perguntas qual a diferença entre mim e Hobbes. Consiste nisso: conservo o direito natural sempre bem resguardado e considero que em qualquer Cidade o magistrado supremo só tem direito sobre os súditos na medida exata em que sua potestade sobre eles supere o deles, como sempre ocorre no estado natural", tradução (ligeiramente modificada) de Marilena Chauí em "Direito natural e direito civil em Hobbes e Espinosa", in Ética sem culpa, politica com liberdade, no prelo. 
ral. De modo que, diante dessa idéia hegeliana de irracionalidade (porque sem existência histórica) das concepções jusnaturalistas, todo conceito jusnaturalista dos direitos devidos ou possíveis num estado de natureza são inválidos, incluindo o conceito espinosano de direito natural (certamente mais um jusnaturalista, para a historiografia contemporânea). Porém, a partir do momento em que Espinosa sustenta esse conceito absurdo, que nenhum outro jusnaturalista sequer cogitara, de que há no estado civil o mesmo direito natural que há no estado de natureza, isso parece querer dizer que o fundamento do direito no estado civil — isto é, em termos contemporâneos: o princípio de legitimidade do direito positivo e do próprio Estado - é o direito natural. A idéia, é claro, é inadmissível, e nessa perspectiva a crítica pufendorfiana original (não há realidade no conceito espinosano de direito) é retomada com referência ao próprio Estado: o direito, tal como concebido por Espinosa, não existe historicamente, nem no estado de natureza (porque não existe ou não mais existe o estado de natureza), muito menos no estado civil (porque nele só existe o direito positivo).

A idéia espinosana de jus sive potentia tem sua cidadania filosófica recusada no pensamento jurídico dos últimos dois séculos, e é a base para o ataque maciço ao Espinosa "metafísico" e, justamente por isso, "antijurídico": se concebemos que o direito é medido pela potência no estado civil ou na vida política, concebemos que a instituição do direito não tem, em si mesma, racionalidade ou validade, e com isso o poder do Estado ou a legitimidade do direito positivo não pode ser reconhecida como contendo um conjunto de princípios ou valores válidos e obrigatórios para a sociedade civil; se a sociedade civil, ou se cada indivíduo e particular, decidir por si mesmo que não deve obediência ao Estado porque concebe que pode escapar da sanção contra essa desobediência civil, o poder das instituições se esfacela, independente de se considerar se é legítimo ou não, se é justo ou não. A idéia espinosana de jus sive potentia, enfim, da mesma forma como mostra que em estado de natureza não têm eficácia os valores e noções morais, mostra que eles também não têm eficácia em estado civil; mais do que isso, a desobediência civil do indivíduo, se fisicamente possível a partir de institucionalmente ilegítima, é outra barreira ao poder do Estado e do direito positivo sobre a ação humana. Se o direito é potência, pois, impossível para o pensamento contemporâneo manter intacta a sua idéia de legitimidade do poder político-jurídico.

A crítica contemporânea a Espinosa, assim, mescla a idéia de metafísica jurídica com antijuridismo porque considera que os conceitos espinosanos tendem a negar a validade do direito positivo. Entretanto, há de início três coisas a serem consideradas desde logo, diante desse incômodo que Espinosa causa prontamente ao leitor jurista contemporâneo: em que condições é legítimo considerar que Espinosa elabora uma "metafísica do direito"; em que condições faz 
sentido considerar que ele elabora uma teoria do direito "antijurídica"; e em que condições cabe dizer que ele nega a validade do direito positivo. Essas críticas, geralmente, têm como base textos e conceitos de Espinosa, mas não a sua obra; em geral, tomam como ponto de partida afirmações localizadas que, além de não consideradas realmente como "uma parte num todo", recebem uma leitura anacrônica ou analógica que desde o início afasta o jurista contemporâneo da concepção absoluta de direito elaborada por Espinosa - na qual o direito não é uma instituição separada da política, mas se identifica com esta assim como ambos têm seu sentido racional determinado por uma certa natureza. Observados estes aspectos, poderemos compreender que, além da questão sobre qual o lugar da política na obra espinosana, tínhamos desde o início, já presente no interior daquela, a questão de saber qual o lugar do direito na filosofia espinosana: Espinosa, esse dito "metafísico do direito" e "teórico antijurídico", é ou não filósofo do direito. Em geral, os juristas consideram que não, em função exatamente dessa imagem que une a figura do metafísico com a figura do antijurista ou, se quisermos, anarquista. Mas por algum motivo não é a posição de certa parte dos comentadores de Espinosa que se acercam de sua teoria do Estado; para alguns destes comentadores, essa mesma teoria do Estado que afirma o jus sive potentia é, consistentemente, um elogio do poder político-jurídico.

Simone Goyard-Fabre está correta ao afirmar que "a filosofia do direito de Espinosa não é senão uma parte de um todo, e, como tal, é evidente que ela participa do espírito metafísico": é o próprio Espinosa que afirma que sua teoria do Estado tem bases na ontologia. É realmente na estrutura ontológica do real que se encontra o fundamento para a firmação de que o conatus do corpo político exige a participação direta de todos os seus constituintes, que o poder político deve, pois, ser democrático. A crítica ao poder teológico-político no Tratado teológico-político e a exposição geométrica do poder político-jurídico no Tratado político só o confirmam. De fato, ao Espinosa explicitar no início do capítulo II do TP a existência, nas obras anteriores (Ética e TTP, no caso) de conceitos necessários ao próprio TP: "o direito natural e o direito civil, [...] o pecado, o mérito, a justiça, a injustiça e, enfim, a liberdade humana". Com isto, para todos os leitores fica clara a relação entre este texto evidentemente político e suas bases seja no tratado anterior sobre a política, seja nas ditas bases metafísicas de sua filosofia, instituídas na Ética:

Dissemos em nosso Tratado teológico-político do direito natural e do direito civil, e na nossa Ética explicamos o que é o pecado, o mérito, a justiça, a injustiça e, finalmente, a liberdade humana. 
Para que os que lêem este tratado não tenham de buscar em outros o que é imprescindível para sua compreensão, decidi explicar aqui esses conceitos de novo e demonstrá-los apoditicamente. ${ }^{69}$

Embora diga que vá demonstrar o assunto de forma adequada ao TP, a remissão à Ética e ao TTP não é sem motivos. Ambas estão escritas, mas só o Teologico-politico foi publicado; a Ética, cuja composição fora iniciada antes do TTP e concluída cinco anos após a publicação daquele, permanece inédita enquanto Espinosa compõe o Tratado político, de maneira que é evidente que sua publicação seria um requisito para a publicação do próprio TP. ${ }^{70}$ Não houvesse essa necessidade dos conceitos contidos na Ética, seria desnecessária a remissão àquelas obras e bastaria apresentaria a apresentação feita no TP de forma necessariamente demonstrativa — apodictitè demonstrare - dos mesmos conceitos. Como veremos, a demonstração apodítica feita desses conceitos no Tratado político não poderia ter sido realizada nos textos anteriores; assim como a remissão aos textos anteriores implica uma conexão a outros temas e outros conceitos que não estarão no Tratado político, como se aparentemente não dissessem respeito à política ou ao direito. Como estão dispostos, pois, os temas jurídicos em Espinosa?

Considerando que temas e conceitos jurídicos são aqueles que dizem respeito ao Estado (porque se trata, tanto segundo a concepção dos juristas modernos, quanto dos juristas contemporâneos, de uma teoria a respeito das instituições jurídico-políticas e dos direitos e deveres instituídos por essas instituições ou com a elas relacionados), eles estão no Tratado teológico-político e no Tratado político. Entretanto, considerando que essa teoria do Estado, mesmo quando considerada uma teoria das instituições e dos direitos, deve dar conta de uma concepção dos fundamentos históricos e sociais do próprio Estado e da sociedade que a ele se refere, assim como dos valores ou finalidades atribuídas a ele, uma teoria jurídica não pode ser apenas uma teoria do Estado, mas também uma teoria sobre as relações entre Estado e sociedade (deve, portanto, apresentar uma compreensão histórica, política, social do Estado) e uma análise dos princípios e legitimidades de acordo com o Estado (ou seja, deve também compreender uma concepção dos valores que são operados pela prática jurídica, pelas instituições político-jurídicas, ou que são levantados como fundamentos éticos, morais, legítimos do Estado). Numa palavra, é insuficiente a uma teoria jurídica ser apenas uma teoria do Estado ou das instituições porque não

69 Tratado politico, cap. II, $\mathbb{\int}$ 1: In nostro Tractatu Theologico-politico de Jure Naturali, et Civili egimus, et in nostrâ Ethicâ explicuimus, quid peccatum, quid meritum, quid justitia, quid injustitia, et quid denique bumana libertas est. Sed ne ii, qui bunc tractatum legunt, opus habeant ea, quae ad bunc ipsum tractatum maximè spectant, in aliis quaerere, ae bic iterum explicare, et apodicticè demonstrare constitui.

${ }^{70}$ Ambos, em função da morte de Espinosa em fevereiro de 1677, só seriam publicados postumamente em Amsterdã por J. Rieuwertsz em dezembro do mesmo ano, numa edição preparada pelos seus amigos Lodewijk Meijer e Jarig Jelles, tanto em latim (B. de S. Opera Posthuma, Quorum series post Praefationem exbibetur) como numa tradução holandesa (De Nagelate Schriften van B. d. S. Als Zedekunst, Staatkunde, Verbetering van 't Verstant, Brieven en Antwoorden. Uit verscheide Talen in de Nederlandsche gebragt). 
estaria incluída a explicação da sua própria legitimidade; quando muito, uma teoria descritiva das instituições ou uma exposição de modelos de Estado ou de regimes políticos apenas serviria para conceber a existência do poder ou analisar sua estrutura formal e operativa, restando inexplicada a ponte entre o poder e a legitimidade. Numa filosofia política como a de Espinosa, em que a própria filosofia é concebida e praticada como liberdade política e o Estado é descrito como devendo ser um instrumento para a realização da paz e da segurança, o Estado é, desde sua primeira aparição, uma instituição literalmente política: ele é uma summa potestate criada para garantir paz e segurança e constituída pela união das potências daqueles que são seus cidadãos. Sem a operação simultânea dessa finalidade e sem essa origem (que, no entanto, são simultâneas e atuais à existência do Estado), o Estado é uma forma sem conteúdo legítimo diante da necessidade natural da própria política.

Por tudo isso, da mesma forma como a filosofia política espinosana não se restringe à sua teoria do Estado (contida nos dois tratados) e, entendida estritamente como teoria a respeito da política, estende-se também aos elementos dessa teoria contidos na Ética e em outros textos, a sua filosofia jurídica acompanha exatamente o mesmo movimento. Diferentemente de uma concepção segundo a qual filosofia jurídica seria uma análise filosófica das instituições jurídicas, a de Espinosa não apenas trata destas instituições (o Estado, as leis, as funções públicas, os direitos, a propriedade e assim por diante) como só é levado a tratar delas por causa da maneira como concebe o direito: este, quando concebido como direito natural, não apenas tem um sentido determinado pela natureza, como essa natureza é a potência ou necessidade natural de quem tem esse direito; quando concebido como direito civil, tem um sentido determinado por uma natureza que é a potência ou necessidade política de quem o opera ou a quem ele é atribuído. Ao falar do direito, Espinosa constrói certamente uma teoria do Estado também nos moldes estritamente formais do pensamento jurídico do seu tempo - é no Tratado político, especialmente, que ele o faz - , mas essa teoria do Estado é o ponto final de uma extensa articulação filosófica entre vários textos, sob diferentes métodos de análise e de exposição, cujo conjunto, considerado o caráter necessário de cada texto em particular, mantém uma consistência impressionante e impensável por qualquer autor do seu tempo: apesar da existência, em outros autores, de uma articulação entre seus escritos sobre política e direito e seus escritos sobre metafísica e física (Hobbes, Wolff...), dando mesmo a entender - como querem os comentadores do período contemporâneo - que é uma característica marcante dos jusnaturalistas, nenhum deles tem a política, tal como será mostrada no momento oportuno, tão claramente fundada desde as bases ontológicas de todo o sistema, e nenhum outro tem, nas conclusões e considerandos da sua reflexão política, uma confirmação tão necessária do que a ontologia já apresentara sobre esse 
princípio do conhecimento (seja o político, seja o não político) que é a experiência política, ou, numa expressão mais adequada a todo o sistema espinosano - e que o revela como uma reflexão constante e consistente sobre ou a partir dessa experiência —, a experiência da liberdade.

Assim como a filosofia política espinosana é toda ela uma defesa da democracia, ${ }^{71}$ a filosofia espinosana como um todo, numa perspectiva política, é uma filosofia da liberdade - da qual a filosofia política ou a filosofia do direito é uma das expressões. Não há, em Espinosa, uma separação da teoria política ou da teoria jurídica com relação à idéia de liberdade, porque esta é seu princípio formador e seu horizonte constante: a teoria do Estado mostra que o Estado deve ser instituído para causar a paz e a segurança, e mostra que sem as liberdades necessárias a cada cidadão, o Estado não tem um poder legítimo; pelos mesmos textos e conceitos, a teoria do direito mostra que a paz e a segurança são uma realidade simultânea à existência da garantia e exercícios das liberdades, de modo que a mesma filosofia que explica o que é o direito explica o que é o Estado e vice-versa. Assim como o Estado não tem realidade nenhuma como idéia pura, o direito também não; Estado e direito, num certo sentido, serão idênticos; assim como, identicamente, têm realidade enquanto são exercidos segundo a sua necessidade própria. Assim como o Estado, o direito ser fundado na potência da sociedade política ou do indivíduo político; e assim como o direito, o Estado precisa ser exercido para ter realidade e não ser uma ficção.

Qual é, pois, a filosofia jurídica espinosana? Não é, somente, a sua teoria do Estado ou das instituições políticas, ou político-jurídicas. Muito menos, não é uma parte (uma teoria das instituições jurídicas do Estado) de uma sua filosofia política (uma teoria do Estado), exatamente porque, em Espinosa, política e direito, seja como campos de experiência, seja como campos de conhecimento, se identificam: exercer a vida política é exercer a vida jurídica, e vice-versa; refletir sobre a política é refletir sobre o direito e vice-versa. Não há poder nenhum numa política que não se reconhece também enquanto campo de criação da liberdade jurídica e não há legitimidade nenhuma num direito que não se reconhece também como instrumento da liberdade política. Por tudo isso, a filosofia político-jurídica de Espinosa não se restringe, em definitivo, a uma teoria dos tipos de lei em geral, da relação entre estado de natureza e estado civil, da soberania do Estado, dos diferentes regimes políticos, da paz e segurança na vida política... Formalmente, são esses os temas correntes de uma teoria seiscentista do Estado. Entretanto, em Espinosa essa teoria político-jurídica tem basicamente duas peculiaridades que jamais podem ser desconsideradas pelo seu leitor:

\footnotetext{
${ }^{71}$ Veremos, daqui até o final do capítulo 4.II, tudo o que está contido nessa expressão.
} 
Primeiro, seus dois tratados políticos utilizam para a análise do Estado tanto a exposição geométrica (no TTP, apenas no cap. XVI; no TP, por toda a obra) quanto a exposição retórica (por todo o TTP e, numa menor intensidade, por todo o TP). É uma opinião corrente entre os comentadores de Espinosa considerar que a grande diferença metodológica entre o TTP e o TP é o fato do primeiro deles, dirigido para um público de leitores cristãos (e por isso o livro tem como epígrafe uma citação de João Evangelista, passa de ponta a ponta por referências não só ao Antigo mas também ao Novo Testamento, localiza nos apóstolos os únicos doutores em toda a Bíblia, elogia várias vezes a idéia cristã de justiça e caridade assim como já no prefácio manifesta seu espanto pelos cristãos serem mais conhecidos pelos seus atos violentos do que pela prática dos valores que pregam, etc.) solicitar desse mesmo leitor uma postura racional, atenta à consistência das suas análises e conclusões (no final do Prefácio, Espinosa se dirige ao seu leitor chamando-o de "leitor filósofo", submetendo-lhe a obra à apreciação, "na esperança de não ser mal acolhido, tendo em conta a importância e a utilidade do tema, quer da obra, quer até de cada um dos capítulos”). Apesar desse protesto de esperança — não de segurança — diante do leitor, o TTP é cuidadosamente recoberto, especialmente em seus capítulos dedicados à análise da teologia e da religião, por uma articulação retórica muito precisa, presente já pelo uso do vocabulário religioso e teológico, como no freqüente uso das referências aos escritores judaicos e especialmente à Bíblia, não como base para argumentação ou como conclusão de suas análises, mas como confirmação do que a sua análise produz por si mesma, o que é a demonstração em ato de uma das teses do próprio Tratado, de que a Bíblia nada diz que seja contrário à luz natural e a luz natural não é incompatível com a leitura da Bíblia. Quando Espinosa escreve o Tratado político, não tem mais diante de si um leitor teólogo (seu livro não trata mais de teologia), mas agora se trata de um leitor jurista: a estrutura do TP não é mais, como fora o tratado anterior, estudo hermenêutico e teoria de leitura hermenêutica, mas agora se trata de uma exposição geométrica - tal como na Ética e tal como no capítulo XVI do TTP — desse objeto que pode, enfim, ser conhecido diretamente pela análise racional da experiência política e não carece mais de estratégias retóricas que apazigúem o ânimo do leitor religioso. É necessária, agora, uma outra estratégia retórica, muito mais discreta, que apazigúe o ânimo desse leitor jurista que toma o TP para conhecer uma demonstração espinosana da natureza do direito e da política, sem qualquer referência à teologia e com base apenas nas argumentações da filosofia: no TP, a exposição geométrica é necessária porque o objeto analisado permite um conhecimento verdadeiro, mas especialmente porque a verdade desse conhecimento pode ser mostrada unicamente pela demonstração racional, sem necessidade de amparo nos dogmas das instituições: conhecer a natureza da política ou do poder, por ser conhecer verdadeiramente, pede apenas o uso da razão e 
nenhuma relação tem mais com a Bíblia (que, como o TTP mostra, não pede o conhecimento do fiel, mas sua obediência). Entretanto, como se trata de falar do mundo da prática política, nesse pensamento político que é ação política e é voltado para a ação política, é preciso apelar por vezes ao amparo de uma outra autoridade retórica: a crítica ao idealismo dos filósofos (na verdade, são os teólogos), o elogio ao conhecimento político dos políticos (na verdade, os filósofos políticos), o recurso aos historiadores clássicos (Tácito, Quinto Cúrcio, Salusto...) que são lidos pelos ideólogos republicanos da época e citados ostensivamente nas obras dos juristas e filósofos do tempo (e que, no TP, servem na verdade como símbolo, para os leitores eruditos, de que as teses demonstrativas do tratado são compatíveis com o que os autores clássicos mostraram sobre a prática histórica — sem serem, porém, premissas imprescindíveis para a argumentação espinosana, que se mantém perfeitamente de pé se são retiradas as citações dos historiadores, assim como se mantêm de pé as teses do TTP se retiramos as citações bíblicas que lá servem unicamente de ilustração, e não objeto de análise).

Segundo, é preciso ler os textos de Espinosa tanto de acordo com a leitura que ele sugere pela aparência da obra - no que nos convidamos a ser conduzidos por uma demonstração apodítica que se dirige à nossa intenção de leitura racional, ou a ser conduzidos por uma conversa com nossas crenças que visa nos apaziguar o ânimo... e ambos os efeitos se produzem sem que nos demos conta disso até que já passamos por todo o percurso uma primeira vez: o leitor piedoso que se sente intrigado com as teses do ttp, ao final percebe em si a consciência de uma idéia consistente da relação entre política e direito, e que teme retornar à crítica da teologia enquanto não admite que a liberdade elogiada por Espinosa ao final da obra na verdade não será a mesma que ele havia de início de indicado como inofensiva à vida religiosa tal como ele próprio guarda ainda em sua piedade; o leitor jurista que segue atento as deduções e reflexões do tp, e diante daquele final prematuro já se percebe intrigado com o significado não tão consistente das suas próprias fontes teóricas, o que o obriga a retornar ao início para uma nova trilha conforme o sentido conceitual que verdadeiramente é operado por Espinosa - , quanto por aquela que só se revela depois que percebemos que todos os seus textos formam expressões distintas de um só pensamento, o que só se revela necessariamente depois que já se passou uma primeira vez por eles. A leitura de Espinosa, é certo, jamais deixa o leitor no mesmo estado em que chegara da primeira vez: o que é imperceptível do lado de fora por aquele que ainda não a atravessou, revela depois do percurso que o leitor tem muitas passagens a empreender por sua própria experiência política, depois que percebe através dos textos de Espinosa que ele mesmo, como indivíduo, é parte da vida política, da idéia jurídica, da necessidade do real. Pensar a política torna-se, agora, desejo de concretizar a liberdade política: descobrir no pensamento político- 
jurídico de Espinosa a crítica ao poder teológico-político e ao irracionalismo jurídico torna-se conscientização da própria tristeza em meio à servidão.

Retornando, pois à questão: qual é a filosofia jurídica espinosana? Como teoria do Estado, é aquela se encontra nos dois tratados políticos, como teoria realista (baseada na consideração da natureza dos homens e das sociedades) que apresenta geometricamente os fundamentos do Estado e da soberania, da liberdade e dos direitos na vida política. Como teoria das instituições, é aquela que na argumentação geométrica dos tratados políticos mostra como as instituições são adequadas a cada situação política e como toda prática política depende da força das suas instituições, assim como é aquela que, na crítica retórica e na interpretação hermenêutica, demonstra que a autoridade só é legítima na vida política quando se mantém fundada na natureza da própria política, e que quando não diz respeito à política ou representa uma violação dessa natureza, não merece legitimidade alguma. Como teoria da sociedade, ela tem seus fundamentos já na Ética, e mostra que toda associação (inclusive a política, inclusive a jurídica) só é válida enquanto decorre também da necessidade de concórdia entre os elementos de qualquer comunidade; é essa necessidade de concórdia que fundamenta a vida política e constitui sua única finalidade pública irrecusável, o único conteúdo verdadeiro da expressão paz e segurança pública. E finalmente, assim como a filosofia toda de Espinosa é uma crítica a todas as formas de superstição, sua filosofia jurídica é, como teoria jurídica, uma demonstração geométrica de que o direito só é válido quando exercido e necessário, e que uma lei só é eficaz quando é seguida segundo sua necessidade: não é a autoridade que dá poder ao direito e à lei, é a necessidade da lei que torna racional sua autoridade e é a necessidade do direito que exige das leis defendê-lo e revela ser despotismo a indiferença das instituições. Numa palavra, a filosofia jurídica espinosana é toda a filosofia espinosana quando voltada para o tema da liberdade, em qualquer dos seus aspectos: a liberdade e o direito, no sentido espinosano dos termos, são a mesma coisa, e quando são concebidos como outra coisa que o necessário são, na verdade, ausência de liberdade e ausência de direito. Porque a política, conhecida segundo a necessidade de sua natureza, se revela dessa forma, é natural que Espinosa, por onde quer que passe na sua abordagem da sociedade e da política, conclui pela democracia ou apresenta uma política cuja racionalidade é idêntica à sua necessidade democrática. Considerada como um todo, a filosofia espinosana, quando voltada para a perspectiva da política, é uma defesa da democracia. Tanto pelo que afirma expressamente, quando pelas bases "metafísicas" a que acopla sua teoria da política, como inclusive pelo que não diz: que outra filosofia, afinal, conseguiria provar que as bases da democracia estão na própria necessidade ontológica do real? ${ }^{72}$

\footnotetext{
${ }^{72}$ É o que procuro demonstrar no capítulo 4.II.
} 
Simone Goyard-Fabre está, assim, certamente correta ao afirmar que "a filosofia do direito de Espinosa não é senão uma parte de um todo, e, como tal, é evidente que ela participa do espírito metafísico". É realmente na estrutura ontológica do real que se encontra o fundamento para a firmação de que o conatus do corpo político exige a participação direta de todos os seus constituintes, que o poder político deve, pois, ser democrático. A crítica ao poder teológico-político no Tratado teológico-politico e a exposição geométrica do poder político-jurídico no Tratado político só o confirmam. Todavia, há razão em dizer que Espinosa se fixa em metafísicas "hipóteses e ideais, bem mais que se fixa na realidade objetiva do jurídico para descrevê-la e elucidá-la"? E que, por essa razão mesma, "essa metafísica do direito não pode nos ajudar a conhecer a realidade mesma do jurídico"? Se a causa da inaplicabilidade da teoria jurídica espinosana para o conhecimento do poder político-jurídico é a sua base metafísica, então sequer as constatações de Espinosa a partir da experiência e da história fariam sentido, pois em Espinosa o uso da história nos textos políticos é menos uma constatação de dados da experiência empírica do que o acréscimo de sentenças cuja autoridade confirme, de acordo com o público que lê seus tratados, as teses geométricas já dispostas no texto.

Para o leitor contemporâneo, a concepção de Espinosa como filósofo jurídico não incomoda se ele é amoldado, já nessa classificação, como um "metafísico", juntamente com todos os problemas que essa designação pode trazer contemporaneamente a um filósofo. Entretanto, dizer que Espinosa é um filósofo do direito torna-se uma ousadia a partir do momento em se propõe que ele de fato tanto define o que é o direito quanto, principalmente, aponta uma prática para o direito. Afinal, apesar da metafísica, há ou não essa direção em Espinosa? Há, e ela é válida no sentido contemporâneo do termo, justamente graças à fundamentação metafísica. Como compreender esse paradoxo, que parece negar toda a idéia que o pensamento jurídico contemporâneo tem acerca do que é jurídico e do que é a prática jurídica? E antes ainda da questão jurídica, há em Espinosa uma direção para a prática politica ou não? Usualmente, quem nega Espinosa enquanto um autor jurídico também nega que o seu pensamento político seja algo útil para a prática, ou sequer voltado para ela, como um certo historiador do capitalismo:

O primeiro grande filósofo [Espinosa, no caso] que deu um lugar de honra à idéia de que as paixões só podem ser combatidas com sucesso através de outras paixões, nem por isso tinha qualquer intenção de traduzir essa idéia para o reino da moral prática ou da engenharia política, embora tivesse um vivo apreço por tais possibilidades. De fato, essa reflexão não se repete nas obras 
políticas de Espinosa, que carecem, em outros aspectos, de sugestões práticas sobre como fazer as peculiaridades da natureza humana funcionarem para proveito da sociedade. ${ }^{73}$

É apavorante a densidade pejorativa desse parágrafo, que certamente foi imaginado pelo seu autor como maximamente claro e preciso acerca do seu objeto: a inexistência de intenções práticas por parte de Espinosa, cujas "boas intenções" são uma metafísica inútil para o horizonte ético ou político (ou jurídico). É este mesmo o ponto central de toda a desconfiança da leitura jurídica diante de Espinosa, como não poderia deixar de ser. Ao tomá-lo como metafísico, a leitura jurídica contemporânea considera por antecipação que a sua leitura nada diz sobre a realidade concreta, assim como não teria partido de nenhuma realidade concreta. Na metafísica jurídica espinosana, não haveria nem conceito apropriado de direito (como já dissera Pufendorf), nem conceito possível de dever (como dissera já Blijenbergh), nem prudência teórica (como já revelara Hobbes, ao ler Espinosa: “É mais ousado que eu!”). De nada adianta considerar que há uma necessidade teórica no uso, por Espinosa, das bases metafísicas ou ontológicas. Ao dizer que Espinosa elabora uma metafísica jurídica, a leitura contemporânea não entende com isso que ele faz uma teoria política compatível com a ontologia, mas que ele faz sua teoria do Estado e do direito de dentro da ontologia. A forma dos tratados - essas obras que, pelo que designa o próprio nome, devem apresentar e analisar um objeto a partir da experiência — seria, na verdade, só um engodo; a verdade das teses ali não viria da experiência empírica nem da prática jurídica, mas apenas de um projeto idealista, racionalista, metafísico. A leitura contemporânea toma nas mãos os tratados políticos de Espinosa e vê modelos de regimes políticos na sua teoria do Estado, concepções amorais na sua concepção de direito e de direitos, formulação metafísica da idéia de lei desde a teoria sobre a teologia, desde já a Ética... e principalmente, o que a leitura jurídica vê nessa metafísica jurídica espinosana, é a falta de praticidade na democracia que é concluída como a forma mais natural de governo: como praticá-la? Impossível: jamais, na prática, um regime político democrático poderia ter a participação de todos os cidadãos nos cargos públicos, como expressamente diz o capítulo XI do Tratado político, quando define que a democracia é aquele regime no qual todos os cidadãos têm direito de voto e de tomar parte nos cargos públicos. Uma idéia utópica porque impraticável, metafísica porque deduzida de um nominalismo entre qualidade de governo e quantidade de pessoas no poder, e prejudicada ainda por cima pela ausência (já que a redação do Tratado político foi interrompida bem ai) do modelo prático que Espinosa teria em mente.

73 A.O. Hirschman, The passions and the interests. Political arguments for capitalism before its triumph, Princeton, 1997 , p. 24. 
Neste ponto, as considerações de Antonio Negri — ali onde propõe a idéia de uma dupla fundação da filosofia espinosana, expressando-se especialmente em sua filosofia política ${ }^{74}$ — sobre a relação entre os textos políticos e o resto da obra revelam impressionante proximidade com os leitores jurídicos de Espinosa (que normalmente não se deixam aproximar do seu conteúdo, muito menos se dispõem a enfrentar a consistência de cada texto por ele mesmo). Analisando essa relação entre os textos de acordo com a seqüência temporal em que foram escritos e desenvolvidos por Espinosa, Negri considera que o filósofo interrompera a escrita da Ética, em 1675, não em função das turbulências políticas da época e em defesa da liberdade da religião (afinal, de fato, essas turbulências nunca cessaram, muito menos a intolerância religiosa e intelectual), mas porque teria sentido, conforme concluía as duas primeiras partes da obra, que a Ética não dava conta da prática histórica, e que isso seria tarefa para um tratado sobre a política donde a dedicação, nos anos seguintes, ao Tratado teológico-político. Mais do que isso, segundo Negri o próprio Tratado teológico-político, apesar de todo o êxito teórico em termos de análise da Bíblia e da teologia, e também análise dos fundamentos da política, teria ao seu final (justamente na questão metafísica do direito, a explicação acerca do direito natural) deparado com uma carência, para toda a argumentação daquele tratado, de fundamento ontológico — donde o retorno, depois da publicação do Tratado teológico-político, à composição da Ética. Assim, o que haveria em Espinosa seria, de fato, uma necessidade mútua de perspectiva política para a ontologia e de fundamentação ontológica da política, mas as obras em si mesmas guardariam um descompasso teórico que exigiria, portanto, uma leitura segundo duas fundações distintas, uma na construção geométrica da ontologia, outra na crítica histórica da política; juntas, elas formariam uma totalidade desarmônica, ainda que não inconsistente.

Ora, o alegado "retorno à Ética" depois da escrita do Teológico-politico não é uma tentativa de recuperar a ontologia. Embora seja verdade que a política remeta necessariamente à ontologia ${ }^{75}$ (o próprio Espinosa faz questão de afirmá-lo no início do Tratado político) e embora a ontologia espinosana sempre exija, no plano da sociedade, a ação concreta ${ }^{76}$ (pois é da natureza das comunidades que seus indivíduos constituintes se unam para preservar a existência todo: conatus das comunidades, da sociedade, do Estado), os dois livros, Ética e Tratado teológico-político, tratam de assuntos diferentes para públicos diferentes, mas são obra de uma mesma experiência singular. Da mesma forma, o Tratado político: ele não é escrito porque tenha faltado algo ao Tratado teológico-político e à Ética, mas sim porque faltou um público a atingir: o dos juristas. Mais do que isso: porque, dentre os críticos do TTP, os teólogos se manifestaram, claramente, de uma manei-

\footnotetext{
${ }^{74}$ Cf. A. Negri, $A$ anomalia selvagem, especialmente capítulos III e VII.

${ }^{75}$ Como reconhece Negri no final do capítulo V de $A$ anomalia selvagem.

${ }^{76} \mathrm{E}$ a tese do materialismo. Voltaremos a ela no capítulo 4.II.
} 
ra para a qual não adianta resposta; mas, dentre essas críticas, há algumas que merecem, sim, resposta, porque não são feitas no campo da teologia, e sim no campo da filosofia: a crítica dos juristas. É contra os juristas que lêem o TTP (Velthuysen; talvez já Pufendorf), mas também para expor, finalmente, uma teoria política longe da leitura cristã (tanto que se permite uma exposição geométrica, assim como já faz uma análise do direito e da política sem tratar da lei divina), que Espinosa escreve o Tratado político. Se não completou essa e outras obras (como o Tratado da emenda do intelecto) ou se não tratou de outros assuntos (como uma revisão da sua física; na verdade, uma reescrita da sua física), é exclusivamente porque a morte lhe chegou, e não porque ele ache que sua obra carecesse de emendas. Quando um autor assina a versão final da sua obra, é porque a considera perfeita, acabada: o Breve tratado, os Princípios da filosofia de Descartes (com os Pensamentos metafísicos como apêndice), o Tratado teológico-politico, a Ética, são obras plenamente perfeitas para Espinosa: tiveram sua autorização final..$^{77} \mathrm{E}$ quanto às demais obras? Todas elas não foram escritas até o fim: o Tratado da emenda do intelecto, o Compêndio de Gramática hebraica, o Tratado político... porém, e isso é muito importante, não foram queimados por Espinosa antes de sua morte, e juntamente com a sua correspondência, foram deixados aos seus amigos para publicação na obra póstuma. De maneira que, ali, faltam apenas os capítulos ou parágrafos finais, mas não a autoria de Espinosa, não a verdade das suas próprias idéias: diante do reliqua desiderantur acrescentado pelos editores ao Tratado da emenda e ao Tratado político, falta só um resto de texto, não um resto de filosofia; à teoria da democracia apenas iniciada no capítulo XI do Tratado político, faltam apenas o término da crítica espinosana às concepções vulgares da democracia (iniciada nos $\int \mathbb{S} 3$ e 4) e toda a reversão que Espinosa faria, para o leitor jurista, demonstrando as razões da maior utilidade da democracia; e, principalmente, falta a exposição para os juristas da teoria espinosana do direito positivo. Isso — esse texto — realmente falta; mas a intuição e os fundamentos de todo ele está, já, na parte publicada ou escrita da obra espinosana.

O Tratado político é um texto que Espinosa sabia, desde sempre, que deveria ser alcançado; mas, primeiro, era preciso completar (na Ética) a exposição geométrica da liberdade, assim como (no Tratado teológico-político) a exposição antiteológica da liberdade; depois, faltaria ainda uma exposição da política e do direito dentro da experiência histórica da política (o que não era o caso na Ética, onde cabia apenas a experiência racional da política) e fora do discurso imaginativo dos teólogos e da instituição religiosa (o que era necessário no Tratado teológico-político, mas já abria

\footnotetext{
77 Sendo que só os três primeiros foram apresentados por Espinosa em vida (o Breve tratado, como um curso; os Princípios e o Teológico-político, efetivamente publicados); quanto à Ética, Espinosa em vida a completou e chegou a preparar sua publicação em Amsterdã, não a tendo levado adiante exclusivamente por conta da celeuma causada pelo TTP.
} 
caminho para uma exposição racional e histórica da política e do direito, o que é feito de forma completa, tendo ali um público de leitores cristãos, no Teológico-político); iniciado, o Tratado político é um texto no qual Espinosa afirma, enfim, a procedência a partir da Ética e do Tratado teológicopolítico: o que se dissera ali é base para o que se dirá no Político, mas, principalmente, fora uma outra forma de dizer as mesmas coisas. ${ }^{78}$ A escrita do Tratado político, enfim, é lenta, minuciosa, como a dos outros textos, ${ }^{79}$ e em certo momento no meio do trabalho, Espinosa certamente sabe que pode não chegar mais ao fim do trabalho; talvez por isto, e talvez por saber que é preciso divulgar o lugar aonde o Tratado político deve levar, Espinosa escreve a carta a um amigo (a Carta 84, também publicada na edição do TP na obra póstuma) em que expõe o assunto do Tratado político, assim como menciona o que já foi tratado nos capítulos já escritos e o que deverá ser tratado dali por diante; sobre nenhum outro dos seus trabalhos, Espinosa faz isso (expor o que deverá ser abordado nos textos ainda a escrever); seja como for, ele assina, com esta carta, o projeto de uma exposição geométrica da política cuja conclusão é uma teoria das instituições jurídicas do Estado - certamente, àquela altura do texto, um Estado democrático, tal como o Estado democrático com que se conclui, na verdade, o Tratado teológico-político. Pelo que Espinosa nos deixa, seja em textos escritos, seja em textos por escrever, o direito presente no Estado deduzido tanto na sua fundamentação ontológica quanto na sua articulação retórica quanto na sua exposição geométrica, é um direito democrático.

Longe, portanto, de ser um filósofo político antijurídico, Espinosa é um democrata racionalista que pensa a política e o direito como um instrumento único da liberdade na história; sem a instituição jurídica, a organização política não tem estabilidade; sem a consciência política, o direito não tem legitimidade alguma: tanto a instituição jurídica quanto a consciência política produzem respectivamente essa estabilidade e essa legitimidade de forma ética (ou seja, de forma a cumprir a necessidade política e jurídica do conjunto de cidadãos, verdadeiro princípio da vida política) enquanto sejam democráticas. Quando a leitura jurídica contemporânea a Espinosa e posterior a ele o acusa de irrealismo jurídico por causa já do seu conceito de direito, ela revela, em primeiro lugar, que não compreendeu o que Espinosa expressamente afirma como direito. Não é à toa que Espinosa afirma que o direito é a potência. Ele só faz sentido, racionalmente (da ontologia à prática histórica, a prática política), enquanto potência. E se direito é potência (e direito é potência), aquele direito que não o for não poderá "propriamente", ser chamado de direito; mas Espinosa não se preocupa com o nome dos direitos, e sim com a sua prática — a sua

\footnotetext{
78 Conforme expressão do próprio Espinosa no início do capítulo II do Tratado político.

79 "Cada filósofo tem o seu método de trabalho", diz Raymond Polin no início dos seus comentários à edição Klibansky da Carta sobre a tolerância, de Locke (Paris, PUF, 1999, p. XXXV). É verdade. O método de trabalho de Espinosa, na filosofia, é o mesmo do seu trabalho como polidor de lentes: a peça não está pronta enquanto não termina o seu lento e minucioso polimento.
} 
potência. Desde que existam enquanto direitos, desde que esses direitos sejam na prática exercidos de fato e com efeito, pode-se dar a eles o nome que se quiser; enquanto potência, são uma realidade irrecusável e além das designações. Entretanto, quando sua existência enquanto direitos ou seu exercício é impedido porque, justamente, não se reconhece sua necessidade (sua potência), não adianta chamá-los de direitos. O direito, essa necessidade da vida política e da vida democrática, é algo que não pode depender do arbítrio de uma autoridade; é algo que deve valer unicamente em função da sua necessidade, porque só a necessidade põe a natureza da liberdade, a natureza da cidadania, a natureza do poder como deve ser numa sociedade política livre. Ali onde torna-se questão de honra, especialmente por parte das instituições — teológicas, políticas, científicas - negar que o direito tenha seu sentido determinado pela potência, talvez estejamos, já, no culto do despotismo, onde o sono da razão produz monstros. Para compreender a lei em Espinosa, é preciso lê-la tal como sua crítica e sua análise e sua defesa são realizadas pelo texto espinosano - e não comparar suas concepções com as de outros autores ou outros tempos. O mesmo valerá para a leitura dos conceitos espinosanos de direito, de direito natural, de direito civil, autoridade, poder, potestade, potência. Para compreender a teoria espinosana do direito positivo, a teoria espinosana do direito natural, dos direitos subjetivos, das instituições, do Estado, da justiça na vida política, da paz espinosana que só realiza na forma de democracia, é preciso compreender a articulação dos seus conceitos dentro da teoria e o sentido que ele está apresentando e também retirando de cada um desses termos. Quando tentamos ler a democracia espinosana como regime representativo, não apenas não compreendemos o que ele afirma ser a democracia como não percebemos qual é o lugar em que ele coloca essa idéia de regime representativo; quando tentamos ler seu conceito de lei como vontade de um soberano ou instrumento de coação, não apenas não compreendemos o que ele demonstra serem as leis em cada campo, como não percebemos a relação necessária que ele mostra entre obediência e concórdia na democracia, e entre obediência e servidão nos despotismos. E assim por diante. Porque Espinosa conhece que o direito é uma realidade política, e porque conhece que sua prática institucional não é efeito racional do poder das autoridades, mas é uma necessidade da própria liberdade política, elabora uma filosofia jurídica cuja missão é dizer a necessidade do direito e denunciar a violação despótica desse mesmo direito; diferente do que considera Paul Vernière, Espinosa não faz só uma "laicização do direito": ele mostra que o direito enquanto entidade política, por sua só necessidade, já é: laico, ou, o que significa o mesmo, político. ${ }^{80}$ A filosofia jurídica espinosana, fosse apenas descrição da prática política e jurídica de seu

${ }^{80} \mathrm{P}$. Vernière, Spinoza et la pensée francaise avant la Révolution, p. 459. É o mote pelo qual Vernière considera a maior identidade entre as teorias jurídicas de Espinosa e Montesquieu, que Vernière decididamente 
tempo, teria certamente uma forma muito diferente. Mas, mantendo a coerência que marca a produção, a forma e o conteúdo de todos os textos espinosanos, sua filosofia jurídica é escrita enquanto instrumento político de reflexão a respeito do direito, cujas bases devem estar muito bem assentadas. Por isso, embora sua primeira manifestação pública em defesa da liberdade de pensamento e contra a superstição das autoridades religiosas marque o início da sua vida intelectual, a sua filosofia sobre a experiência do poder político-jurídico aguarda pacientemente o momento oportuno para ser escrita, depois que as bases ontológicas para o conhecimento da natureza dos indivíduos e das comunidades já foram colocadas pela Ética, depois que o Tratado teológico-político já demonstrara que a teologia e qualquer instituição cuja natureza não é política ou cuja autoridade não legítima não determina a verdadeira justiça, depois que o Tratado da emenda do intelecto já definira as condições que permitem ao homem conhecer e usufruir do que lhe é um bem, depois que os Princípios da filosofia de Descartes já recusara há muito a realidade da negação, depois que a própria correspondência de Espinosa, por contraposição aos seus tratados e à Ética, mostram o quanto o modo espinosano de produção dos seus textos é tão paciente e detalhista como seu ofício de polidor de lentes... O Tratado político, principalmente, é esse momento oportuno em que Espinosa, enfim e apesar de todo o horror que necessariamente causara aos teólogos e aos religiosos sua ousadia de enfrentar os tabus do pensamento sobre as autoridades religiosas, enfrenta agora os tabus das autoridades jurídicas, nas quais reina uma superstição tão intensa quanto aquelas que na teologia e na religião também produzem medo e ignorância de si. A filosofia jurídica espinosana, presente em toda a sua obra mas aprofundada apenas nos dois últimos tratados, é uma exigência política de Espinosa enquanto filósofo da liberdade e cidadão da razão.

Por tudo isso, não apenas pode-se falar de um pensamento jurídico espinosano - porque de fato ele existe enquanto tal: há em Espinosa uma teoria das leis, uma teoria dos direitos, uma teoria das instituições e da justiça — , como é preciso notar a sua relação ou a sua simultaneidade diante do pensamento político. Em certa medida, essas concepções e teses jurídicas e políticas se confundem, na medida em que política e direito são uma coisa só, enquanto campo do poder público ou da liberdade pública; esse duplo caráter político e jurídico dos conceitos deve ser ressaltado como inclusivo de ambos os aspectos. Por outro lado, é preciso também reconhecer a dupla perspectiva que essa teoria da sociedade e do Estado promove: de um lado, essa teoria é uma teoria da política enquanto prática da democracia; de outro (residiria aqui, já segundo os comentadores, uma teoria especificamente jurídica), ela é uma teoria das instituições jurídicas na vida política, preferencialmente na vida política democrática. Embora tenham sido 
poucos os autores dedicados a delinear uma teoria jurídica no interior do pensamento político de Espinosa, em geral todos consideram que essa teoria é uma teoria das instituições jurídicas, ou das instituições do Estado (por exemplo, uma teoria das leis, dos direitos, da obediência, das relações internacionais etc). Ainda que essa seja uma leitura válida quando se busca em Espinosa uma teoria do Estado, ela é realmente empobrecedora quando se busca nele uma teoria jurídica ou uma filosofia jurídica, já que de antemão uma visão parcial da maneira como Espinosa trata do justo e do jurídico em seus textos. De fato, há nele uma teoria das instituições (ele definitivamente era um conhecedor das instituições do direito romano — possuía em sua biblioteca os Institutos de Justiniano, seus amigos juristas, como Koerbagh, eram autores em teoria do direito —, assim como da maneira como estas eram interpretadas pelo jusnaturalismo moderno; sem mencionar as instituições dos Estados europeus e as considerações do pensamento político desde o Renascimento com respeito às instituições e instrumentos do Estado), mas não por acaso esta é uma crítica das instituições segundo a forma como eram tradicionalmente concebidas: em Espinosa, a teoria das instituições é também uma elaboração simultânea dos conceitos jurídicos e políticos (porque é um fundamento da sua teoria da democracia - entendendo esta como uma teoria que explica todas as formas políticas para concluir pela democracia, e não uma teoria que analisa apenas a democracia). Certamente, como resultado dessa teoria das instituições dentro da teoria da democracia, é possível conceber uma teoria especificamente jurídica do Estado, ainda que isso não seja de maneira alguma prioritário em relação à definição mesma da democracia.

Conhecida, ao final, a filosofia espinosana em todos os aspectos em que trata do direito e do Estado, compreendemos a presença dos problemas jurídicos em todos os momentos do sistema, e a sua filosofia como um todo se revela filosofia jurídica e teoria do direito: o que constitui a autêntica teoria jurídica de Espinosa é não uma simples teoria das instituições, mas antes uma ética jurídica, no sentido de que bá dentro da teoria política uma concepscão do que deve ser o direito e, também, uma demonstração do que deve ser, com base na natureza da politica e do direito, o pensamento acerca do direito e a prática do que deve ser a política. Assim, qual o lugar da teoria jurídica dentro do pensamento espinosano? Ela é, primeiro, uma crítica às concepções da tradição — seja às concepções do direito romano e do direito eclesiástico, seja às concepções do jusnaturalismo —, mas a partir disso ela se exprime como uma análise do direito que, embora acompanhe a análise da política e em muitos sentidos se confunda com ela, para além disso é uma teoria da necessidade da justiça e da necessidade dos direitos - cuja estrutura própria, inclusive, pode prescindir dos recursos da retórica, ao menos numa medida em que as considerações gerais acerca da política e da religião não poderiam. É necessário, pois, reconhecer dentro do pensamento espinosano uma teoria jurídica: não sob a forma de 
uma mera teoria das instituições, e sim na qualidade de uma ética do jurídico que explique o papel do direito e dos direitos no campo da perspectiva política e da consistência ontológica. Reconhecida essa potência própria da filosofia de Espinosa, abre-se-nos também toda a amplitude da Ética como demonstração geométrica de uma liberdade que é efeito, na história de cada indivíduo, de uma experiência de desejo; percebemos que, ainda que não fossem jamais escritos os dois tratados políticos, a Ética já é uma defesa da democracia, porque é demonstração geométrica da necessidade da liberdade que, no plano da política, só se completa, só é perfeita, como liberdade democrática; pois, como diz F. Haddad-Chamack:

A politica, enquanto ciência da organização da sociedade e ciência e prática do governo, não é somente um substituto da ética, um quebra-galho à mão dos homens que vivem sob um regime de submissão às paixões, incapazes de aceder por si mesmos à vida de Razão; a politica é também uma propedêutica necessária à ética, como menciona o Tratado da emenda do intelecto. ${ }^{81}$

${ }^{81}$ F. Haddad-Chamad, "Liberté individuelle et paix civile d'après le Traité théologico-politique de Spinoza", p. 50. 


\section{CAPÍTULO 2 \\ ESPINOSA, JUSNATURALISTA?}

Quando Espinosa diz: "Cada um existe por supremo direito natural e faz o que decorre de sua natureza" (Ética IV, P37, schol.), está apenas retornando à concepção dos estóicos, segundo a qual o direito natural nada mais é que a necessidade de todo ser de adequar-se à ordem racional do todo.

N. Abbagnano, Dicionário de filosofia, verbete "Direito", p. 283.

\section{I A IMAGEM DO ESPINOSA JUSNATURALISTA}

É praticamente uma unanimidade entre os historiadores da filosofia do direito considerar Espinosa um jusnaturalista. ${ }^{82}$ Isso se deve, talvez, menos por uma concepção justificável do próprio termo jusnaturalismo do que pelo simples fato de Espinosa ser um autor do século XVII, da mesma forma como é um autor em cujos textos (Ética, TTP, TP) está presente o conceito de direito natural. Essa classificação, é claro, exige dos seus adeptos o reconhecimento de Espinosa como filósofo do direito, mas é marcada menos pelo reconhecimento do valor da sua teoria do que pela sua desvalorização - já que essa classificação de um autor como jusnaturalista é feita, normalmente e sob sentido pejorativo, pelos inimigos teóricos do jusnaturalismo. Assim, há dentro da historiografia da filosofia do direito uma tradição contemporânea desenvolvida já desde o século XIX que, ao considerar a existência de uma filosofia do direito em Espinosa (marcada, para essa corrente, acima de tudo pela teoria do direito natural), considerará que sua validade se restringe evidentemente ao jusnaturalismo moderno, sem qualquer aplicabilidade no direito contemporâneo e nem mesmo na teoria jurídica; em contrapartida, haverá uma outra corrente, extremamente diversificada, que, também reconhecendo Espinosa como jusnaturalista e, nestes termos, filósofo do direito, inspira ao pensamento contemporâneo uma série de questões éticas e políticas que poderiam ser aproveitadas pela teoria jurídica atual. Finalmente,

${ }^{82}$ É o que por exemplo faz, com toda a serenidade, Norberto Bobbio: “[...] uma das teses comuns a todos os jusnaturalistas é a tese de que é preciso sair do estado de natureza e por que é útil (Hobbes e Locke) ou necessário (Espinosa) ou algo imposto pelo dever (Kant) instituir o estado civil [...]" (Sociedade e Estado na filosofia politica moderna, p. 53). 
há uma outra corrente (esta mais ligada à história da filosofia do que à filosofia do direito ou à teoria jurídica) que vê em Espinosa um autor que, dentro do seu pleno debate com seus contemporâneos, elabora uma teoria do direito natural adversa às teorias contratualistas do seu tempo, o que o coloca na peculiar condição de um jusnaturalista anticontratualista. O que há em comum entre todos esses autores, porém, é a idéia de que Espinosa é um jusnaturalista, não importa o sentido que se pretenda dar a esta classificação.

Um dos principais historiadores da filosofia do direito na segunda metade do século $\mathrm{XX}$, Guido Fassò (um dos primeiros a ver em Espinosa um valor equivalente ao de Hobbes, Grotius, Pufendorf, Locke em termos de filosofia jurídica) é um dos únicos na historiografia da filosofia do direito a não desviar-se do estudo interno da filosofia jurídica espinosana e, nestes termos, o capítulo sobre Espinosa em sua grandiosa História da filosofia do direito é de uma importância única. Todavia, tanto porque Fassò se dedica à investigação das fontes teóricas do pensamento dos autores mas também tende em igual medida a classificá-los por comparação, quanto porque tende a interpretar as teorias jurídicas como doutrinas que recuperam teses clássicas e as deixam intactas e, principalmente, porque sua leitura interna e direta dos textos espinosanos não é ainda suficiente para perceber as verdadeiras explicações que Espinosa está oferecendo para além do jogo retórico (essa estratégia espinosana para afastar aquele que não é "leitor filósofo"), sua leitura da teoria jurídica espinosana não o deixa imune a alguns equívocos que por sinal marcam os "leitores juristas" de Espinosa até hoje:

A doutrina espinosana é rigorosamente panteísta: Deus é a única substância, que, Unidade total, identifica-se com a natureza, cuja ordem tem por isto o caráter de absoluta necessidade; e na natureza está compreendido o homem, cuja razão e paixões, com tudo o que da razão e da paixão humanas se origina, entram na ordem da necessidade natural. Também a vida política, e sua organização na forma de Direito, se incluem nesta ordem necessária, manifestação da suprema realidade, Deus sive natura, na qual as leis são - como o haviam sido para os estóicos - expressão, ao mesmo tempo, do dever-ser e do ser. Este determinismo pelo qual tudo procede por uma intrínseca necessidade, é interpretado por alguns de modo finalista, como expressão da vontade racional de Deus, e por outros como puro mecanicismo no qual a premissa teológica vem a estar praticamente anulada. Esta última interpretação é própria da crítica marxista, que vê na doutrina de Espinosa um materialismo total. ${ }^{83}$

O que marcará essa leitura de Fassò (que costuma ser bem conhecida dos estudiosos de filosofia jurídica das últimas décadas) é outra vez uma imagem pejorativa do filósofo, a de panteísta, que segundo Fassò se mantém segura diante das diferentes interpretações que os vários comentadores do seu pensamento político produzem, levando os alcances da "doutrina espinosana" do finalismo e voluntarismo ao mecanicismo e materialismo. No seu esforço de realismo historiográfico, Fassò considera necessário não apenas apresentar os elementos da teoria espinosana

${ }^{83}$ G. Fassò, História de la filosofía del derecho, vol. 2, pp. 115-116. 
do direito e da lei, do Estado e da democracia, como é preciso manter de ponta a ponta o caráter panteísta que segundo ele fundamenta o significado que para Espinosa o direito possui em todas as suas expressões. Como muitos outros comentadores antes e depois dele, Fassò nota uma seqüência impressionante de semelhanças teóricas com relação a Hobbes (ainda que haja, é claro, diferenças quanto a alguns pontos), ${ }^{84}$ sendo a maior dentre elas - esta interpretação não será sem conseqüências para a história recente da bistoriografia da filosofia jurídica - a filiação de Espinosa ao contratualismo, nos mesmos termos de Hobbes:

Semelhante ao teorizado por Hobbes é também o meio pelo qual, segundo Espinosa, os homens dão remédio aos inconvenientes causados pelo ilimitado Direito natural, identificado pelo poder de cada indivíduo. Tal instrumento é o habitual por todo o pensamento jurídico-político do século XVII, o do contrato social. Mas o recurso a este na doutrina de Espinosa (que é a razão pela qual é possível juntá-lo aos jusnaturalistas da "Escola do Direito natural") é, na realidade, explícito e claro unicamente no Tractatus theologico-politicus, ao passo que nas obras posteriores, a Ética e o Tractatus politicus, não existem referências precisas. ${ }^{85}$

Alfred Dufour, um dos poucos comentadores a também reconhecer a importância de Espinosa como autor de uma teoria do direito, é também um dos que alimentam aquela visão panteísta do filósofo:

Ora, determinar como base e como método para a filosofia em geral ou para a do Direito e do Estado em particular os dados e as maneiras de proceder das ciências físicas e matemáticas "na abstração das verdades reveladas" leva a consagrar a ascensão de um pensamento livre frente a um pensamento dogmático, de um pensamento que ganha apoio na experiência do sujeito mais que sobre a autoridade de uma Revelação. É precisamente esse pensamento livre com seus novos paradigmas mecanicistas e sistemáticos que tomará forma em toda uma corrente da filosofia do Direito natural do século XVII. Trata-se da corrente racionalista do Direito natural moderno que estabelece como fundamento para o Direito natural a natureza humana tal como resulta dos dados apenas da razão e da experiência. É a corrente que ilustram os protagonistas da utilização da metodologia das ciências físicas e matemáticas na ordem político-jurídica, a saber Hobbes em uma perspectiva mecanicista de tipo materialista, Espinosa em uma perspectiva sistemática de tipo naturalista-panteísta, assim como Pufendorf e Thomasius numa perspectiva empíricosistemática de tipo espiritualista. ${ }^{86}$

Cabe notar que não apenas é enfática a classificação de Espinosa como jusnaturalista moderno, como ele também é, nessa catalogação, equiparado em importância às figuras soberanas de Hobbes e Pufendorf. Mas há aqui algo mais: além dessa equiparação (determinada pelo uso de um mesmo método de análise do direito "tal como resulta dos dados apenas da razão e da experiência"), Espinosa é singularizado dentro dessa suposta corrente jusnaturalista como o autor de uma perspectiva "sistemática de tipo panteísta-naturalista". Ou seja: segundo Fassò e Dufour, a condição jusnaturalista revelaria o tipo de filósofo do direito que Espinosa é; e sua pers-

84 Voltaremos a este assunto no capítulo 3.I.

85 G. Fassò, História de la filosofía del derecho, vol. 2, p. 117.

86 A. Dufour, Droits de l'homme, droit naturel et histoire, p. 54. 
pectiva panteísta do real especificaria o tipo de jusnaturalista que só ele é. Mais do que isso, ele deteria certos aspectos teóricos que o filiariam a Grotius e ao tacitismo no que respeita às suas convicções políticas e seu interesse pelos historiadores clássicos, ${ }^{87}$ mas sua filosofia jurídica seria marcada certamente pelo exemplo metodológico de Euclides e Descartes e pelas bases da teoria política de Hobbes.

Entre os juristas, fará fortuna essa idéia de que Espinosa é um típico teórico do contrato social, como já fora em especial Hobbes (a quem será sempre comparado, e tido como "seguidor" na concepção do direito natural e na teoria do contrato social), e como ainda viria a ser o próprio Rousseau (que compararão a Espinosa, seu "precursor" na teoria da democracia) quase um século depois. Aplicada a Espinosa, essa idéia significará, entre os leitores juristas, uma intensificação da crítica que nessa leitura por vezes é feita à filosofia hobbesiana e, por diferentes razões, à rousseauniana: às vezes porque em Espinosa teríamos a intensificação da falta de realismo de um e de outro, às vezes porque, simplesmente, Espinosa não seria tão original diante de Hobbes nem tão inspirador quanto Rousseau. Seja como for, essa concepção da filosofia espinosana como sendo, também, uma teoria do direito natural revela-se, até mesmo para além da leitura jurídica e já no meio da interpretação feita pelos ditos especialistas, uma constante. A princípio, temos absolutamente todos os motivos para considerar em Espinosa um jusnaturalista: ele trata da relação entre estado de natureza e estado civil (para alguns, é por isso um contratualista), conceitua tanto o direito natural (que ele identifica à potência, que está presente em toda a sua obra) quanto a lei natural (que ele identifica à necessidade, que também percorre toda a sua obra), analisa o direito civil com base na análise do direito natural (o que faz todo jusnaturalista moderno), e ainda por cima afirma que, diferentemente de Hobbes, mantém no estado civil o direito natural (o que seria a radicalização do jusnaturalismo, não tentada por nenhum outro). Mesmo a leitura estrita e atenta do filósofo não se cansa de deparar com o conceito de direito natural, como se Espinosa estivesse demonstrando que, apesar de todas as mudanças por que podem passar as instituições humanas e apesar de todas as vicissitudes da vida dos indivíduos, há, como dizem os jusnaturalistas de qualquer tempo, um direito natural que pode ser reconhecido como imutável, legítimo necessariamente, inegável e proporcional à potência de cada um, porque é natural a cada sujeito de direitos independente de seu reconhecimento pelo Estado; quanto à lei natural, parece que a própria idéia absoluta de lei, válida esta para a análise do justo e do legítimo tanto no campo da política quanto no campo da teologia, torna-se lei eficaz somente enquanto decorre da lei natural, definida pelo próprio Espinosa como a que determina alguma ação em função da sua necessidade natural de ação, como se toda

\footnotetext{
${ }^{87}$ Sobre a relação entre Espinosa e a ideologia republicana tacitista do século XVII, ver capítulo 4.II.
} 
legitimidade fosse válida em função da natureza em certa medida. As leituras dos conceitos espinosanos de direito natural e lei natural são várias, mas encontram-se nessa convicção de que Espinosa é um teórico do direito natural, e que sua teoria do direito é fundada a todo momento na idéia de direito natural - restando ao leitor de Espinosa, apenas, decifrar as origens do sentido de que Espinosa estaria fazendo uso, para que possa enfim compreender a qual contratualismo se filia, se antecipa de fato algum outro contratualismo, ou ainda se seu jusnaturalismo é mesmo tipicamente moderno ou se contará mais a inspiração no jusnaturalismo estóico, que a maioria dos comentadores de Espinosa considera como indubitável. ${ }^{88}$ Não importa qual o resultado da interpretação que se dê a esse intrincado jogo de conceitos tirados diretamente de Espinosa ou trazidos a ele pela garimpagem historiográfica: independente das suas conclusões, essa concepção generosa que parece unificar as opiniões de todas as correntes interpretativas já estabelece, como por outras vias e razões se estabelecem outras imagens da "formação do espinosismo", 89 a imagem também pejorativa do jusnaturalista.

O próprio termo jusnaturalismo, criado pelos críticos teóricos do pensamento político moderno e difundido no pensamento jurídico contemporâneo como o avesso do historicismo, do positivismo e do realismo jurídicos, designa menos o caráter teórico de cada um dos autores que a esse movimento costumam ser associados do que já a manifestação, pelos seus pósteros, da recusa da sua validade teórica. Ao mesmo tempo, independentemente da validade dessa pecha para a compreensão do pensamento político-jurídico moderno (se é ou não o caso de considerar uma corrente ou uma escola de direito natural nos séculos XVII e XVIII, assim como também a existência de teorias de caráter assemelhado, elaboradas muito antes ou tentadas ainda depois), a própria idéia de classificação de um jusnaturalismo pelos críticos dessa suposta corrente indica uma certa maneira de ver a forma como o pensamento jurídico seria feito de fora: não apenas de fora da atualidade contemporânea, mas principalmente de fora do pensamento jurídico, que muitas vezes a contemporaneidade considera não envolver o pensamento filosófi-

\footnotetext{
88 Guido Fassò, para quem essa doutrina teria influenciado Espinosa além da filiação deste ao contratualismo, considera o seguinte (História da le filosofía del derecho, vol. 2, p. 78): "A doutrina panteísta da racionalidade imanente do Ser, princípio e essência do universo, permite aos estóicos dar sólido fundamento à idéia, tantas vezes esboçada, de forma mais ou menos diversa, no pensamento grego, de um 'justo por natureza'; e, com efeito, é no estoicismo que a doutrina do Direito natural encontra sua primeira formulação precisa. Os estóicos, quando desenvolvem a tese, aludida por Platão nas Leis e repetida em sua escola no Mênon, da existência de uma lei ditada pela reta razão (lógos alethés, lógos orthós), podendo identificar esta com uma natureza que é a Realidade mesma, Deus, dão ao Direito natural um fundamento metafísico, que justifica seu valor absoluto".

${ }^{89}$ Que mencionamos, no que respeita à política, nos capítulos 1.I e 1.II as idéias de Espinosa ateu, absolutista, panteísta, utópico, individualista, liberalista, metafísico jurídico e, finalmente, antijurídico.
} 
co - donde mais um motivo para a invalidade daquelas teorias elaboradas no período moderno por filósofos ou juristas-filósofos ${ }^{90}$ aos quais, apesar da inegável destreza teórica e genialidade demonstrativa, não seriam juristas no sentido preciso do termo (ao menos no sentido contemporâneo - que cria a idéia de jusnaturalismo): eles não realizam, ou não se contentam em realizar, uma descrição e análise da estrutura jurídica do Estado ou da prática jurídica, como faziam certamente os juristas clássicos do período romano. Embora, ainda, se atribua também a esses autores a fundação de uma teoria política moderna (para alguns, uma ciência política moderna), o caráter jusnaturalista dessa corrente representaria mesmo um distanciamento das análises rigorosas e realistas do mundo político vindas no século XVI especialmente de Maquiavel e, com algumas ressalvas, Bodin. E, quando for o caso de a historiografia contemporânea considerar que algum desses autores do jusnaturalismo merece ser reconhecido como precursor do pensamento jurídico realista que nos últimos dois séculos ela julga ter sido produzido (especialmente pelo positivismo jurídico), será preciso considerar uma diferença com relação aos outros jusnaturalistas que os aproxime do pensamento posterior, ou talvez mesmo buscar uma nova leitura do seu pensamento que permita deixar de lado as teses sobre o direito natural, como se elas não fossem parte necessária do sistema; é o que tem acontecido, por exemplo, nesse esforço de alguns autores pela recuperação da reputação teórica da teoria jurídica hobbesiana dentro do universo positivista e historicista do direito: ${ }^{91}$ Hobbes, esse que foi certamente um gigante em todas as áreas da política por que tenha passado, merece enfim ser reconhecido como um dos precursores do positivismo jurídico graças à maneira como localiza a legitimidade política exclusivamente na lei e, antecipando em três séculos a divisa kelseniana, deixa de fora

\footnotetext{
90 'Sob a velha etiqueta de 'escola do direito natural', escondem-se autores e correntes muito diversos: grandes filósofos como Hobbes, Leibniz, Locke, Kant, que se ocuparam também, mas não precipuamente, de problemas jurídicos e políticos, pertencentes a orientações diversas e por vezes opostas de pensamento, como Locke e Leibniz, como Hobbes e Kant; juristas-filósofos, como Pufendorf, Thomasius e Wolff (Wolff, para darmos apenas um exemplo, é considerado como o antiPufendorf); professores universitários, autores de tratados escolásticos que, depois de seus discípulos, talvez ninguém mais tenha lido; e finalmente, um dos maiores escritores políticos de todos os tempos, o autor de $O$ contrato social' (N. Bobbio, Sociedade e Estado na filosofia política moderna, p. 14).

${ }^{91}$ O próprio Bobbio é tão entusiasta dessa idéia que, ao mesmo tempo que questiona se Hobbes tem realmente de ser incluído, "juntamente com Grotius, Espinosa e Pufendorf, entre os quatro grandes jusnaturalistas do século XVII", chega a exigir o reconhecimento de Hobbes dentro da história do positivismo jurídico: "Thomas Hobbes pertence, de fato, à história do direito natural: não existe nenhum tratamento da história do pensamento jurídico e político que não mencione e examine sua filosofia como uma das expressões mais típicas da corrente jusnaturalista. Por outro lado, Hobbes pertence, de direito, à história do positivismo jurídico: sua concepção da lei e do Estado é uma antecipação, verdadeiramente surpreendente, das teorias positivistas do século XIX, nas quais culmina a tendência antijusnaturalista iniciada no historicismo romântico. Quando se fala, por exemplo, de Austin, costuma-se recordar que ele teve um precursor (isolado) em Hobbes. Jusnaturalismo e positivismo são duas correntes antitéticas, em perene polêmica: uma representa a negação da outra. Como é possível que Hobbes pertença, ao mesmo tempo, às duas?" (N. Bobbio, Thomas Hobbes, p. 101).
} 
do universo jurídico a ilusão da justiça. Feita essa recuperação, é mesmo possível ao leitor jurista contemporâneo ver no filósofo de Malmesbury, mais que um jusnaturalista ou coisa pior, um dos grandes clássicos da ciência política cujo realismo teórico ainda hoje se confirma como explicação dos fundamentos da política e da relação operativa muito precisa entre direitos e obrigações.

Ao mesmo tempo, é necessário a essa historiografia contemporânea produzir o efeito contrário: para confirmar ainda mais o seu próprio caráter realista, deve argumentar pela invalidade teórica daqueles autores nos quais concebe uma diferença irrecusável. Assim, se com relação a alguns autores modernos é o caso de promover uma "reabilitação" (como dissera Strauss) graças à sua imagem precursora, com relação a outros é preciso radicalizar a diferença que naturalmente já os separa, por conta de seu idealismo teórico, do realismo do pensamento jurídico que desde inícios do século XIX se considera emancipado dos dogmas jusnaturalistas. Desde que Hegel, em seu Das maneiras de se tratar cientificamente do direito natural (ato solene oficial de sepultamento do jusnaturalismo), demonstra que os conceitos do direito natural, ainda que fruto de projeto racionalista, são inadequados para a compreensão da realidade histórica do direito e do Estado em função do seu caráter excessivamente abstrato e, portanto, não mais devem estar contidos numa teoria política ou jurídica, o pensamento jurídico contemporâneo considera-se fundado por uma emancipação teórica dos conceitos ditos jusnaturalistas e fortalecido constantemente pela tarefa de rebatê-lo em cada uma das suas manifestações, estejam estas em suas formas originais (da parte de jusnaturalistas modernos, ou de autores antigos ou medievais de outras formas de teorias do direito natural), estejam anacronicamente traduzidas já para a solução de problemas jurídicos atuais (das parte daqueles que, conforme a famosa frase de Batiffol, ${ }^{92}$ desenterram esse cadáver que não cansa de ressuscitar). ${ }^{93}$

O que é o jusnaturalismo? Antes de mais, o jusnaturalismo é uma invenção contemporânea. Não apenas é um conceito criado especialmente pelos críticos contemporâneos do pensamento jurídico

\footnotetext{
92 "A escola do direito natural [...] ressurge. Nos esforçamos em condená-la, e ela renasce das suas cinzas. É um 'cadáver de não se cansa de ressuscitar' (H. Batiffol). Teríamos razão em incluí-la, embora suas origens sejam antigas, nas doutrinas contemporâneas" (Michel Villey, Pbilosophie du droit, II. Les moyens du droit, p. 91).

93 "[...] como notamos muitas vezes, parece com efeito que é contra o jusnaturalismo que o hábito se impôs, no início do século XIX, de chamar 'filosofia do direito' uma reflexão que não mais se limitaria a especular sobre o ideal abstrato do 'justo', mas abordaria os problemas ligados à realidade histórica, 'positiva', fenômenos jurídicos, sob a condição todavia de não se confundir nesse aspecto com a simples jurisprudência ou ciência do direito positivo. Existe hoje alguma coisa de espantoso nessa identidade antijusnaturalista do contexto em favor do qual a expressão foi imposta. Pois se investigarmos os empregos do termo além do século XIX, é preciso registrar um certo recuo e, em todo caso, uma clara inversão de tendência" (A. Renaut \& L. Sosoë, Pbilosophie du droit, p. 14).
} 
clássico (seja o moderno, seja o escolástico ou o greco-romano), ${ }^{94}$ como é um termo não utilizado pelos próprios autores a que a contemporaneidade atribui o título de jusnaturalistas. $\mathrm{O}$ que os historiadores do pensamento jurídico pré-hegeliano em geral consideram é que, a propósito, com respeito ao pensamento jurídico dos séculos XVII e XVIII é possível ver aí uma corrente de autores que, apesar de todas as diferenças teóricas entre si, partilham quase sempre pressupostos idênticos e, não por acaso, constituem uma única tradição jurídica contratualista, ou seja, que na sua teoria jusnaturalista explica a fundação do direito e do Estado por meio do argumento do contrato social ou, o que é praticamente o mesmo, pelo argumento da passagem do estado de natureza para o estado civil, senão por uma análise empírica do estado civil a partir da sua oposição com um idealizado estado de natureza. Mais do que isso, esses autores modernos representam a radicalização, por sua vez, do próprio conceito de direito natural, existente desde o pensamento grego mas nunca antes articulado de forma a servir de elemento comum de uma tradição de teorias políticas.

Apesar de ser muito claro para toda a historiografia do direito que a diferença entre direito natural e direito civil pertence ao pensamento político e à doutrina jurídica desde os antigos (ou seja, que há já nos antigos uma “doutrina do direito natural”), e também que os autores jurídicos modernos (a "Escola do direito natural", 95 como diz Michel Villey, e como repetiria como já vimos - Guido Fassò), ao fazer uso naturalmente desse vocabulário, deram-lhe um significado muito mais complexo, há uma certa polêmica com relação à denominação ou classificação dos diferentes períodos dessa suposta doutrina ou escola, isto é, há uma polêmica a respeito de se definir todas essas teorias (das antigas às seiscentistas) como jusnaturalistas ou, ao contrário, se o termo jusnaturalismo cabe exclusivamente ao dito jusnaturalismo contratualista.

De acordo com a idéia de que só no período moderno existe uma "Escola do direito natural", mas contra a idéia de que essa escola é o único jusnaturalismo - isto é, a única fonte de doutrinas do direito natural —, diz Michel Villey:

É certo que a doutrina do direito natural é renúncia a fundar as soluções do direito. Mesmo a "fundar" o direito, já que o direito nos parece ser uma ciência autônoma, que tem seus princípios próprios e não precisa se abrigar hipocritamente atrás da moral, da antropologia etc. E reconhecer o caráter dialético das soluções, não é separar o direito do fato? Nós só podemos justificar um procedimento, e ainda de maneira muito vaga. Assim, o direito natural clássico é o testemunho de

\footnotetext{
${ }^{94}$ N. Bobbio: Sociedade e Estado na filosofia politica moderna, p. 13: "Embora a idéia do direito natural remonte à época clássica, e não tenha cessado de viver durante a Idade Média, a verdade é que quando se fala de 'doutrina' ou de 'escola' do direito natural, sem outra qualificação, ou, mais brevemente, com um termo mais recente e não ainda acolbido em todas as línguas européias, de 'jusnaturalismo', a intenção é referir-se à revivescência, ao desenvolvimento e à difusão que a antiga e recorrente idéia de direito natural teve durante a idade moderna, no período que intercorre entre o início do século XVII e o fim do XVIII" (grifos meus).

${ }^{95}$ M. Villey, Pbilosopbie du droit, vol. 2, p. 88.
} 
um grave ceticismo, tão grave, tão carregado de modéstia que compreendemos por comparação os esforços do direito natural moderno, e do idealismo alemão, para fundar o direito, mas eles fracassam — resta então o positivismo, esse nada de filosofia. ${ }^{96}$

Também considerando o jusnaturalismo um conjunto de doutrinas do direito natural, e contra a idéia de um jusnaturalismo restrito aos autores modernos, diz Guido Fassò,

uma doutrina segundo a qual existe e pode ser conhecido um 'direito natural' (jus naturale), ou seja, um sistema de normas de conduta intersubjetiva diverso do sistema constituído pelas normas fixadas pelo Estado (direito positivo). Este direito natural tem validade em si, é anterior e superior ao direito positivo e, em caso de conflito, é ele que deve prevalecer. O Jusnaturalismo é, por isso, uma doutrina antitética à do 'positivismo jurídico', segundo a qual só há um direito, o estabelecido pelo Estado, cuja validade independe de qualquer referência a valores éticos. Às vezes o termo é reservado, por antonomásia, a doutrinas que possuem algumas características específicas comuns, de que se falará a seguir, e que defenderam as mesmas teses nos séculos XVII e XVIII: tanto que se gerou a opinião errônea de que a doutrina do direito natural teve origem apenas nesse período. ${ }^{97}$

Finalmente, e no ainda mesmo sentido, Alfred Dufour apresenta já uma classificação histórica do que considera doutrinas:

É preciso reconhecer [...] que somente algumas das doutrinas do direito natural, elaboradas em função das diferentes acepções que identificamos das noções de direito e de natureza exerceram uma real influência sobre a história do direito e do pensamento jurídico ocidental.

Se os pareceres aqui divergem quanto ao seu número, seus critérios de distinção e sua denominação, parece-nos legítimo reduzi-los a três:

1. A doutrina clássica antiga do direito natural pagão dos filósofos gregos e dos jurisconsultos romanos: o jusnaturalismo antigo.

2. A doutrina escolástica medieval do direito natural cristão: o jusnaturalismo escolástico.

3. A doutrina sistemática moderna do direito natural racionalista: o jusnaturalismo moderno.98

Ora, qual a importância dessa diferenciação entre a identificação entre jusnaturalismo e pensamento seiscentista, e entre jusnaturalismo e simples doutrina do direito natural? No primeiro caso (jusnaturalismo é o contratualismo moderno), considera-se que o termo jusnaturalismo só faz sentido se fizer sentido, também, a opinião de que todos aqueles autores que nos séculos XVII e XVIII elaboram suas "doutrinas do direito natural” fazem uso de uma tese nuclear — a concepção contratualista da sociedade e do Estado -, o que permitiria dizer que, em conjunto, representam todos o desenvolvimento de uma mesma idéia sobre os fundamentos da política e do direito, e por isso uma única "escola". No segundo caso (jusnaturalismo é qualquer doutrina ou teoria do direito natural), a idéia, menos historiográfica do que positivista ou antijusnaturalista, quer ao mesmo tempo marcar uma identidade entre diferentes formas de se pensar o di-

\footnotetext{
96 M. Villey, Les carnets, XVI-4, p. 334.

97 Guido Fassò, "Jusnaturalismo", p. 655.

98 A. Dufour, "Droit naturel/droit positif', p. 67.
} 
reito utilizando o conceito de direito natural, e também marcar uma diferença irrecusável entre essas formas e aquela que as classifica, assim, como jusnaturalistas. Não há, da parte de uma teoria classificada como jusnaturalista, a recusa de outra doutrina ou teoria do direito natural pelo fato de ser "jusnaturalista"; o termo e a idéia de jusnaturalismo, assim como a idéia de invalidade do seu juízo em função do seu projeto jusnaturalista, é um privilégio do pensamento contemporâneo, e especialmente dos juristas contemporâneos. Mais do que revelar o que são os jusnaturalistas, a classificação de uma doutrina ou uma teoria como jusnaturalismo revela o antijusnaturalismo do classificador.

A classificação do jusnaturalismo, assim, em termos de história da filosofia é marcada por uma incorreção interpretativa. Jusnaturalismo é sempre um termo pejorativo, criado não para esclarecer o conteúdo de uma corrente teórica, mas sim para considerar a existência de uma corrente teórica equivocada, em contraposição a uma corrente teórica ou concepção jurídica atual — em geral, o positivismo jurídico. Esse caráter pejorativo é evidenciado em definitivo pela maneira mesma como o jusnaturalismo (não importa como este seja concebido) é explicado pelos comentadores e historiadores de filosofia do direito. Especialmente quando essa classificação é dada por uma leitura jurídica — bem entendido: quando é feita por um jurista —, o seu tom é de distanciamento e de reprovação; quando, ainda, é feita por historiador da filosofia — ou seja, quando é resultado de uma análise da filosofia de um autor —, ela por vezes se compromete com o costume da interpretação por meio da classificação por doutrinas. Nos dois casos, é muito comum chegar, por intermédio já de um pré-julgamento da validade do conceito, a um conhecimento parcial do conceito de direito natural proposto pelo autor.

Diante, de qualquer modo, dessa polêmica da classificação dos jusnaturalismos, parece-me que ela tem uma solução precisa, se considerado o seu sentido pejorativo sempre presente. Se, pela classificação de um pensamento como jusnaturalismo, busca-se seja sua filiação a uma doutrina ou corrente, seja a sua concepção mesma enquanto doutrina ou corrente, o único momento em que as teorias que fazem uso do conceito de direito natural têm de fato uma semelhança de pressuposto é o pensamento seiscentista contratualista, que recebeu, não por acaso nesse costume antijusnaturalista, a designação de "Escola do direito natural". O simples uso do conceito de direito natural não é suficiente para transformar o pensamento que o utiliza uma teoria do direito natural (porque talvez não exista aí uma explicação do conceito ou, mais do que isto, talvez essa explicação não seja o centro da teoria), e a elaboração de uma teoria do direito natural não é suficiente para constituir uma doutrina (porque essa explicação do direito centralizada no conceito do direito natural talvez não seja resultante nem adequada a um cos- 
tume ou tradição dogmática). ${ }^{99}$ Mas a operação, nas teorias do Estado elaboradas nos séculos XVII e XVIII, de um pressuposto teórico (compreensão racional dos fundamentos do estado civil com relação ao estado de natureza) que é assumido igualmente por fundamento por diferentes teorias do Estado, isso constitui uma certa semelhança metodológica (no caso, análise matemática ou geométrica do direito, ainda que isso represente uma certa "flutuação metodológica", como quer Dufour) ${ }^{100}$ além da semelhança conceitual (uso dos mesmos conceitos), ainda que não a elaboração de uma doutrina (já que não há propriamente identidade teórica entre os autores). Nos termos, pois, dessa semelhança metodológica, há o investimento comum numa explicação do direito e do Estado que toma como fundamento uma certa interpretação da relação ou distinção entre direito natural e direito civil — no caso, a passagem ou tensão entre estado de natureza e estado civil, que são respectivamente os campos a que se referem o direito natural e o direito civil — e a mantém como princípio de compreensão e análise do direito e da política, o que permite propor, exclusivamente sob o projeto de uma classificação pejorativa, a idéia de uma "Escola do direito natural", independente da responsabilidade de seus próprios autores, porque a idéia de escola traz, no caso, a idéia de uma transmissão dogmática, e não o costume de uma reflexão crítica (que permita, se for o caso, demolir as feições externas da escola); ao mesmo tempo, essa mesma idéia já pejorativa de escola não dá ao seu crítico o direito de considerar que as teorias dos autores a ela associados são, por si mesmas, teorias do direito natural, porque se consideradas em si mesmas, essas teorias seiscentistas aparecem como teorias também do direito civil e, o que é mais importante, revelam singularidades que marcam mais suas diferenças com respeito às outras teorias do que suas semelhanças: ou seja, se a idéia de escola é vista a partir de cada uma das teorias, ela é completamente demolida; se ela é vista de fora, da aparência causada pelo uso de mesmos procedimentos metodológicos, ela só é sustentável enquanto não se pre-

\footnotetext{
${ }^{99}$ Ou seja, não há, propriamente, teoria do direito natural. A idéia em si, é já pejorativa. Há teorias do direito, que se utilizam ou não da idéia de direito natural. Essa idéia está presente, de uma forma positiva ou negativa, em todas as formas de pensamento jurídico, até nas positivistas (que consideram importante conceituar o direito natural para mostrar o que o direito não é).

100 "Que a noção de método esteja longe de designar sempre a mesma realidade, é o que deixa entender já à primeira vista a flutuação da terminologia que a qualifica com o passar do século. Essa terminologia a faz aparecer, com efeito, ora como o método dos geômetras ou método geométrico - assim Descartes, em suas Respostas às Segundas Objeções às suas Meditacões metafísicas (1641), assim igualmente a Lógica de Port-Royal (1662), para não falar em Espinosa, a quem já voltaremos - ora como o método dos matemáticos ou método matemático - assim, Grotius em seu De Jure Praedae (1604-1605) como em seu De Jure Belli ac Pacis (1625), assim Galileu em seu Saggiatore (1623) como em seu Diálogo sobre os dois maiores sistemas do mundo (1632) e seus Discursos e demonstracõoes matemáticas acerca de duas novas ciências (1638), assim Hobbes, enfim, em seus Elements of Law. Particularmente característica dessa flutuação terminológica no século xvii parece muito curiosamente a linguagem de Espinosa. Apresentando os Princípios da filosofia de Descartes demonstrados more geometrico a exemplo da Ética, Espinosa, com efeito, fala indiferentemente do método dos matemáticos e do método geométrico [nos Princípios da filosofia de Descartes]" (A. Dufour, Droits de l'bomme, droit naturel et histoire, p. 96).
} 
tenda ir a fundo em cada teoria em particular. A idéia de jusnaturalismo enquanto a "Escola do direito natural" dos séculos XVII e XVIII, quando assume seu caráter pejorativo, depende de não ir a fundo na análise dos seus autores — ou verá que há muita "contemporaneidade" neles.

Talvez se pretenda, apesar disso, investir na idéia de que qualquer explicação do direito que faça uso do conceito de direito natural é um jusnaturalismo (de fato, essa postura é a mais comum, ainda que por diferentes motivos). Ainda aí, porém, será preciso assumir desde a base o caráter pejorativo da classificação, o que em verdade é muito mais natural dessa idéia de jusnaturalismo - pois aqui, a classificação de algo como jusnaturalista não se baseia na idéia de período histórico, mas na diferença de conteúdo ou de concepção da própria idéia de direito, de maneira que a classificação de uma concepção de direito natural valeria para uma concepção de direito a qualquer tempo, inclusive como concepção contemporânea. ${ }^{101}$ É nesse sentido que vai a crítica positivista ao que ela mesma chama de jusnaturalismo, ou a crítica filosófica ao que ela mesma chama de antijuridismo: veríamos, hoje, que esse direito natural não tem nenhuma realidade concreta ou jurídica; uma concepção de um direito natural seria, necessariamente, a concepção de um direito inexistente, e para que a idéia que lhe deu origem pudesse ter algum sentido válido no discurso contemporâneo (como "direitos humanos", "direitos subjetivos" etc), seria preciso reformular a forma da concepção, ainda que não necessariamente sua intenção. Essa idéia de jusnaturalismo porque concepção de direito natural, elaborada numa leitura antijusnaturalista, pode significar afirmação de um conceito realista de direito, mas não a compreensão adequada do realismo (ou da falta de realismo) da concepção criticada; quando, porém, essa mesma idéia de jusnaturalismo é sustentada em favor da concepção filosófica do direito (o que é muito mais raro), sua eficácia teórica também se restringe mais à apresentação de uma concepção crítica da concepção antijusnaturalista, do que recuperar para a contemporaneidade uma concepção clássica de direito, naquilo em que ela mantém sua atualidade. Numa ou noutra concepção do que seja o jusnaturalismo, essa classificação é uma armadilha para a completa compreensão tanto do conteúdo da obra dita jusnaturalista, quanto da sua atualidade racional ou prática.

$\mathrm{Na}$ medida, ainda, em que seja válida a elaboração de uma história do jusnaturalismo, não importa qual seja a concepção adotada, não se pode negar a rigidez metodológica das teorias ju-

101 "A essência do direito, a delimitação da sua província, as condições da sua validade, eram problemas há muito conhecidos do estudioso antes da invenção da jurisprudência positiva e da ciência política. Eles sobrevivem, mutato nomine, nos manuais de ensino acadêmico. Os juristas e advogados de hoje podem desdenhar seus incautos antepassados. Podem declarar que não têm nada a fazer com o direito natural nem com os ideais que ele representara. Mas eles não têm tido sucesso em eliminar os problemas que o direito natural tentava resolver. Eles não deixam de se confrontar com aqueles problemas no momento em que começam a refletir acerca dos resultados de seus esforços e da firmeza do solo em que caminham" (Alexander Passerin d'Entrèves, Natural law. An introduction to Legal Philosophy, p. 19). 
rídicas que levantam a idéia do direito natural dentro da perspectiva racionalista: é só no pensamento moderno que, de fato, as diferentes teorias parecem falar uma língua comum ou, mais decididamente, que o argumento do direito natural é percebido como um conceito típico (assim como tantos outros) da teoria política ou teoria do poder - em geral separado, na verdade, da natureza e, em certa medida, de Deus. O que leva os modernos a conceber suas "teorias do direito natural" da maneira como fazem (dentro da análise do Estado) é o fato de considerarem que o argumento do direito natural, quando voltado para a explicação da política, tem uma finalidade diferente do argumento do direito natural quando voltado (nos gregos) para a explicação da justiça e do cosmos, ou quando voltado (nos medievais) para a defesa da religião. É só nos modernos que o argumento do direito natural se torna, verdadeiramente, um argumento, a ponto de constituir a base de uma forma de teoria jurídica ou, sob um olhar de fora, uma corrente teórica.

Mas mesmo o reconhecimento dessa peculiaridade das teorias jurídicas seiscentistas não significa o caminho preciso para a resolução de todos os problemas referentes à classificação ou historiografia do jusnaturalismo. Este, seja qual for a maneira pela qual é concebido, merece uma historiografia que o livre tanto dos prejuízos causados por essa mesma classificação, quanto apresente seu verdadeiro caráter e sua necessidade atual, apesar daquela classificação; ${ }^{102}$ além do esclarecimento das diferenças necessárias entre concepções jusnaturalistas, não jusnaturalistas ou já antijusnaturalistas, essa outra história do jusnaturalismo deve dar conta de mostrar que se trata, na verdade, de história do pensamento jurídico e nada mais; enquanto não se assume na historiografia e na teoria jurídica essa identidade jurídica entre as inconciliáveis metodologias teóricas utilizadas desde sempre para se pensar o direito, o ressuscitamento do jusnaturalismo continuará incomodando antijusnaturalistas e a acusação de antijuridismo continuará causando perplexidade naqueles que o positivismo jurídico chama de jusnaturalistas.

Nesse panorama, enfim, Espinosa recebe a pecha de jusnaturalista, não apenas em função de sua suposta filiação ao contratualismo, mas já em função das duas formas de se conceber o jusnaturalismo: Espinosa seria jusnaturalista seja porque está no meio daqueles autores seiscen-

102 É por esse motivo, a propósito, que não incluo aqui uma história, ainda que breve, do jusnaturalismo. Em função da sua extensão, seria quase o mesmo que apresentar uma história do pensamento jurídico; em função da análise do desenvolvimento de uma idéia, seria uma leitura externa do pensamento jurídico dos autores a que se atribui a condição de jusnaturalistas, mesmo quando são jusnaturalistas (naquilo em que essa classificação $f a z$ sentido). Mais adequado no caso dos jusnaturalistas, parece-me, seria realizar uma compreensão do seu pensamento jurídico a partir da sua estrutura particular e não segundo modelos comparativos; e no que respeita a Espinosa, mais adequado aqui é trazer os conceitos de direito natural ou as concepções jusnaturalistas (ou de jusnaturalismo) conforme são pertinentes à leitura de Espinosa. 
tistas da "Escola do direito natural", seja porque sua teoria político-jurídica faz uso expresso e constante do conceito de direito natural. Ou seja: se por jusnaturalismo se entender qualquer concepção ou doutrina do direito natural, Espinosa pode por essa via ser classificado de jusnaturalista.

O conceito de direito natural está, afinal, demonstrado em todas os textos políticos de Espinosa, colocado bem ali como argumento prioritário para a explicação do Estado, tanto nos seus dois tratados políticos, quanto na Ética. O capítulo XVI do Tratado teológico-político, provavelmente escrito antes dos trechos da Ética que se referem ao direito natural e ao poder de Deus, constitui a sua exposição fundamental e mais completa do conceito de direito natural, ${ }^{103}$ que por só ser analisado nesse capítulo é decididamente considerado por Espinosa um conceito político, sem relação com a teologia. Ali, Espinosa define o direito e instituição de natureza "as regras da natureza de cada indivíduo, regras segundo as quais concebemos qualquer ser como naturalmente determinado a existir e a operar de uma certa maneira", definição que reaparecerá no Tratado político, cap. II, 4, em outros termos: "as próprias leis ou regras da natureza segundo as quais tudo se faz, isto é, a própria potência da natureza". Essa definição de direito natural, em princípio idêntica nas três obras, é apresentada de diferentes maneiras: no TTP, é definição inicial para o desenvolvimento da argumentação sobre a necessidade da liberdade natural; no TP, é corolário do desenvolvimento (que se beneficia da remissão ao TTP) desse mesmo argumento; na Ética, onde o tema também é incluído, não é apresentado exatamente um conceito de direito natural (por um motivo simples: ele só é concebível no plano da imaginação), mas a sua concepção é analisada e criticada (porque algo referente a essa idéia imaginativa que é o direito natural, é posta verdadeiramente no real e por isto cabe na argumentação geométrica da Ética). Ou seja: na Ética, Espinosa mostrará que o direito natural é uma designação imaginativa para uma realidade (a liberdade necessária de todo agente — de Deus, de cada um — segundo sua natureza) que o vulgar só compreende parcialmente. No TTP, o direito natural é posto como um conceito elementar da teoria política para que se estabeleça, no plano da experiência política, o conhecimento da liberdade necessária de todo agente; o conhecimento da maneira como se constitui essa necessidade, porém, levará à constatação da necessidade de se abandonar o conceito de direito natural por um outro conceito, que não permite mais um conhecimento parcial dessa liberdade necessária. No TP, finalmente, a condição do conceito de direito natural é idêntica à do TTP, mas aí ele demonstra a irracionalidade da noção vulgar de direito natural

${ }^{103}$ Lembremos que Guido Fassò, talvez desconsiderando as menções ao direito natural na Ética e no Tratado político, diz que só no TTP há uma exposição explícita do direito natural, no que não deixa de estar certo; porém, pelas remissões que são feitas graças ao início do TP, a exposição feita no capítulo XVI do TTP pode ser considerada integralmente presente nas premissas do TP, assim como não guarda incompatibilidade alguma com a Ética. 
não pela definição primeira desse direito e a análise da experiência a ele correspondente, mas em primeiro lugar pela compreensão, geométrica já, dessa experiência (o que permite, já, o conhecimento da necessidade da liberdade), de que a própria experiência da atividade mostra que o conceito vulgar de direito natural não pode contrariar essa necessidade, sendo inútil manter o conceito de direito natural da forma como é concebida pelos jusnaturalistas de qualquer tempo ou doutrina.

Em todos os momentos em que a expressão direito natural ou direito de natureza aparece nos textos de Espinosa (salvo quando é claramente a menção da noção vulgar de direito natural), ela pede ser substituída por um conceito que ponha o significado verdadeiro daquilo a que ela quer se referir sozinha. Esse esvaziamento do conceito de direito natural por Espinosa é tão importante para a constituição do pensamento político, que exige estar presente em todas os textos políticos; e conforme o caráter de cada texto, o esvaziamento será feito de uma maneira que lhe seja adequada. Os dois tratados, ali onde analisam racionalmente a experiência política, têm uma estrutura geométrica, como a Ética; mesmo havendo, nas três obras, o uso da demonstração geométrica (que no texto do TTP aparece recoberta por uma aparência semelhante à dos capítulos sobre a teologia), isso vem da compreensão geométrica do seu objeto: assim como a política pode ser conhecida verdadeiramente pela razão, a própria irracionalidade da noção vulgar também o pode; não à toa, não é somente nos dois tratados que se achará essa crítica e essa desconstrução da noção vulgar de direito natural: porque ela é determinada pelo conhecimento racional da ação e da liberdade tanto de Deus como de cada um, a base dessa crítica e análise está totalmente na Ética; diferente, pois, das opiniões já mencionadas de Wolfson e Goldschmidt, ${ }^{104}$ de que a Ética não é um texto político, já está lá, por completo, a demonstração da irracionalidade do jusnaturalismo, seja como contratualismo, seja como teoria do direito natural; os dois tratados apenas dialogarão com os públicos (de leitores cristãos no TTP; de leitores juristas no TP) que usualmente defendem essas idéias de jusnaturalismo.

Assim, no escólio 2 da proposição IV, P37 da Ética, Espinosa inicia uma explicação do estado natural e do estado civil (statu hominis naturali, et civili) dizendo que

\footnotetext{
Cada um existe em virtude do direito supremo da Natureza (summo naturae jure) e, conseqüentemente, é em virtude do supremo direito da Natureza (summo naturae jure) que cada um faz o que segue da necessidade da sua natureza; e, por conseguinte, é em virtude do supremo direito da Natureza (summo naturae jure) que cada um julga o que lhe é bom e o que lhe é mau e atende à sua utilidade, conforme sua índole (ex suo ingenio), e se vinga, e se esforça (conatur) por conservar o que ama e destruir aquilo a que tem ódio.
}

104 Capítulo 1.I, supra. 
Como sabemos, a Ética não faz nenhuma remissão ao TTP nem ao TP, apesar de seu conteúdo ser totalmente compatível com o que é dito nos dois tratados e, por tudo o que consideramos no capítulo anterior, suas perspectivas serem simultaneamente complementares entre si. Entretanto, o que leva Espinosa a mencionar o direito natural na Ética é a apresentação, nesse escólio (ou seja, num texto no qual cabe a referência à experiência e onde entra, em certa medida, o texto retórico nas demonstrações da Ética), de uma confirmação, pela experiência, de que toda ação humana é efeito de uma necessidade segundo a natureza do agente. Em termos da Ética, a atividade de Deus só produz coisas necessárias segundo a natureza de Deus, isto é, tudo o que existe, é efeito necessário da natureza de Deus, ou nada tem causa contingente ou é sem relação com a natureza necessária de Deus; se a ação de Deus, pois, produz sempre efeitos necessários segundo sua natureza, e se a necessidade da ação segundo a natureza de Deus se expressa nos modos finitos dos atributos de Deus, essa mesma necessidade da ação segundo a natureza do agente está presente nos seres humanos, que são modos finitos dos atributos de Deus. A vida política, evidentemente, é um dos campos da experiência humana e nela o ser humano não perde sua natureza nem é privado de sua índole; ${ }^{105}$ portanto, como na vida política o ser humano continua sendo um ser natural ainda que não esteja nisso que o vocabulário jurídico chama de "estado de natureza", também nessa vida política (no "estado civil") cada um tem sua necessidade determinada pela própria natureza, e só age (na acepção espinosana do termo) se sua ação é fundada nessa necessidade da própria natureza. Assim, o que diz a Ética, até chegar nesse ponto de sua demonstração à maneira dos geômetras? Que a ação humana, seja a ação de um só homem (um indivíduo singular), seja a de um grupo unido de homens (um indivíduo coletivo: um grupo de indivíduos que ao se unirem operam como um único indivíduo), ${ }^{106}$ não é livre (não é determinada pelo próprio agente) quando é contrária à necessidade sua própria natureza

\footnotetext{
${ }^{105}$ Nenhum ser humano (aliás, nenhum ser) perde sua natureza; no máximo, ela pode ser violentada ou violada, situação à qual se dá o nome de violência. Ser violento significa agir contra a necessidade da natureza de algo (de modo a produzir seu enfraquecimento ou inércia); sofrer violência, significa parecer uma ação contrária à necessidade da sua própria natureza (de modo que se padece enfraquecimento ou inércia). A violência, por isso, sempre será ação contra um conatus, sempre será ação contra a necessidade, ficando desde logo a questão de saber se nunca um ser pode ser violento com outro, ainda que essa diminuição de conatus no outro tenha como finalidade o aumento do próprio conatus. Seja como for, um ser humano é violento com outro sempre que o trata como uma coisa, da mesma forma como um ser qualquer é violento com outro (seu semelhante ou não), quando o coisifica, no sentido de que o utiliza contra a natureza daquele. A utilidade que é índice, em Espinosa, da ação racional, fica aquém do limite dessa coisificação desde que haja semelhança. Concebida e verdadeira a diferença, a coisificação do outro só é válida ao agente quando também for necessária à sua própria natureza (como no caso, citado explicitamente por Espinosa no escólio da proposição IV, P37 da Ética, do uso que os homens podem fazer dos animais).

106 Ética II, def. 7: "Por coisas singulares [isto é, indivíduos], entendo coisas que são finitas e têm existência determinada. Se uma pluralidade de indivíduos concorre para uma mesma ação, de maneira que todos juntos sejam a causa de um só efeito, consideramos então todos juntos uma mesma coisa singular."
} 
e, ao contrário, só é livre (determinada pelo agente) quando é necessária segundo sua natureza. Se estado de natureza e estado civil são concebidos pelos jusnaturalistas do período como diferentes situações em que se encontra o homem (estado civil: situação em que um poder está estabelecido; estado de natureza: situação em que não poder estabelecido), a Ética de Espinosa mostra que a necessidade natural de cada um, sendo determinada internamente - o conatus (impulso para a perseveração na existência) do indivíduo, sua essência atual —, mantém-se a mesma independente das influências externas (embora estas causem efeitos sobre a intensidade do conatus do indivíduo, ainda que jamais faça com que o conatus deixe de ser sua essência atual); assim, independente de estar no estado civil ou no estado de natureza, o indivíduo sempre tem sua necessidade determinada por sua natureza, e enquanto agente sua ação só é livre (isto é, determinada pelo próprio agente) se é determinada necessariamente segundo sua natureza. Jamais, diante da questão da liberdade, o indivíduo está destituído da sua necessidade natural de ação, isto é, de sua necessidade de ação segundo a sua natureza.

Esse o argumento fundado na ontologia. Considerada essa realidade no plano da experiência política, é o caso de explicá-la com os termos do seu vocabulário próprio, que recobre com um sentido retórico e analógico aquilo que no plano do conhecimento racional não precisa desse recurso. O estado de natureza e o estado civil são conceitos que aparecem em escólios da Ética, e não em suas definições, axiomas, proposições... Ou seja, os conceitos de estado de natureza e estado civil, ainda que racionais porque dotados de sentido, só fazem sentido ali no plano dos escólios, e antes que se chegue a esses escólios está dada toda a fundamentação ontológica da realidade a que essas noções se referem, mas não o campo da experiência política do qual vem o significado analógico e corrente original dos próprios termos estado de natureza e estado civil. Estes são designações produzidas no campo da experiência política e cujo sentido só se torna apreensível se também estamos diante desse campo; se estamos somente no campo da ontologia do necessário, as suas designações em questão não nos aparecem, ainda que apareçam já todos os elementos que constituem a sua fundamentação ontológica; finalmente, quando estamos diante desse campo em que são produzidas as denominações estado de natureza e estado civil, a fundamentação ontológica do seu sentido não se revela impossível, mas, pelo contrário, o fato de haver algum sentido consistente nas expressões estado de natureza e estado civil mostra que, ali onde essa consistência se mantém, a ontologia se confirma como fundamento necessário até mesmo dessas noções criadas no plano da experiência política. $\mathrm{Na}$ Ética, pois, os escólios nos concedem conhecer, no plano da experiência, o sentido consistente dos termos aí produzidos mas que só se mantêm consistentes enquanto se mantêm no plano da experiência; quando saímos de lá, algo falta a essas noções: sua atualidade enquanto experiência. 
Resumindo de certa forma essa explicação: estado civil e estado de natureza são noções a respeito da prática política (ou da ausência desta) que só fazem sentido pleno quando estamos no plano da prática política. É possível explicar o que se passa no plano da política com um vocabulário adequado exclusivamente à estrutura geométrica da Ética, mas essa explicação não alcançaria a imaginação do vulgar, que por sua própria índole necessita de imagens para que se sinta compreendendo algo (ainda que seja, sempre, uma compreensão somente parcial do seu objeto). Entretanto, ainda que seja uso de vocabulário adequado à imaginação, sua articulação dentro da argumentação no escólio não seria efetiva se seu verdadeiro sentido não fosse dado fundamentalmente pelos conceitos e conteúdos concebidos no solo ontológico da Ética. O que quer dizer Espinosa, pois, quando diz: "Cada um existe em virtude do direito supremo da Natureza"? O conceito apela já para a experiência do leitor ou há um precedente no argumento da Ética? De fato, num outro escólio, o escólio da proposição II, P3, Espinosa já fizera uma crítica direta à concepção de que Deus tem um poder e um direito antropomórficos: “O vulgar entende por potência de Deus a livre vontade de Deus e o seu direito sobre todas as coisas que são, as quais, por isso, são comumente consideradas como contingentes. Com efeito, dizem que Deus tem o poder de tudo destruir e de tudo reduzir ao nada. Vão mais longe, e comparam muitas vezes a potência de Deus à dos reis." Isso já havia sido, diz Espinosa, refutado nos corolários 1 ("Deus não efetua coisa alguma por liberdade da vontade.") e 2 ("A vontade e o intelecto estão para a natureza de Deus na mesma relação que o movimento e o repouso, e, de maneira geral, todas as coisas naturais que devem ser determinadas por Deus a existir e a agir de certo modo.”) da proposição I, P32. O que Espinosa afirma na Ética, assim, é que a ação de Deus não é uma ação livre porque voluntária ou contingente, mas unicamente porque necessária, no sentido de que decorre da necessidade da sua natureza. Não é o caso de considerar que Deus, tendo uma liberdade infinita decorrente necessariamente da sua infinitude de potência, possa exercer essa potência também como um comandante secular da Natureza ou do homem. Ele não é, como imagina o vulgar, imperium in imperio. Ora, ao dizer que há um "direito supremo da Natureza", Espinosa não se refere a um direito antropomórfico nem de Deus, nem da Natureza. Seguindo a crítica que fizera já no escólio da proposição II, P3, Espinosa trata aqui de um jus que é potentia: um jus em virtude do qual cada um "existe", "faz o que segue da necessidade da sua natureza" e "julga o que lhe é bom e o que lhe é mau e atende à sua utilidade, conforme sua índole, e se vinga, e se esforça por conservar o que ama e destruir aquilo a que tem ódio". Esse jus, portanto, primeiramente põe a existência de cada um, que põe a atividade de cada um, que põe o juízo do bom e do mau, o cálculo do útil, a ação impulsionada pelos afetos: esse jus é a potentia, ou o conatus, de cada ser, não na Natureza (como se fora dela ele a perdesse), mas se- 
gundo sua natureza (a existência é impulsionada pelo conatus; a atividade pela autodeterminação, ou seja, pelo conatus; o juízo do bom, do mau, do útil, por ser determinado segundo sua índole, é determinado, também, pelo conatus e pelo desejo). Tanto no escólio da proposição II, P3, quanto nesse escólio 2 da proposição IV, P37, Espinosa afirma que a existência, a ação e a liberdade de qualquer ente é determinada pelo seu conatus. Assim, se o direito e o Estado, ou melhor, se o estado civil dependem de um esclarecimento do que é o estado natural, este se revela diverso daquilo que é na boca dos jusnaturalistas modernos e, com algumas diferenças, na dos jusnaturalistas estóicos: se nos jusnaturalistas estóicos o estado natural é aquela condição em que a Natureza é comandada por Deus, em Espinosa o estado em que há esse summo naturae jure não é o de ações comandadas por um Deus rector naturae; e se nos jusnaturalistas modernos o estado natural é aquele em que não há ainda ou não há mais nem direito civil nem poder político estabelecidos, a soberania do summo naturae jure espinosano não é uma potência que se possa perder ou se separar da existência. Em qualquer situação que seja, toda existência é marcada pela atividade determinada necessariamente pela própria natureza. Concebendo-se na Natureza ou concebendo-se no Estado, o indivíduo sempre é expressão de uma potência natural, à qual o vulgar, se desejar, pode dar o nome que bem entender; não é um nome que muda a realidade dessa potência que, em qualquer situação, é a única determinante da ação livre. Isto, apenas, é suficiente para mostrar o que todos os comentadores em geral negariam: que Espinosa não é um continuador do jusnaturalismo estóico; pois a natureza que em Espinosa determina a necessidade da ação não é a Natureza de que o homem, ou Deus, pode conceber-se senhor (porque seu criador, porque seu legislador, ou porque seu artífice). Porém, na seqüência desse escólio 2 da proposição IV, P37, aparece uma afirmação que parece contradizer tudo isso e fundar, na Ética, a filiação de Espinosa ao jusnaturalismo por meio de outra "doutrina", a tese do contratualismo moderno:

\footnotetext{
Se os homens vivessem sob a direção da Razão, cada um usufruiria deste direito sem dano algum para outrem. Mas, como eles estão sujeitos aos afetos, que ultrapassam de longe a potência, ou seja, a virtude humana, e por isso são muitas vezes arrastados em sentidos contrários e se contrariam uns aos outros, quando têm necessidade de mútuo auxílio. Portanto, para que os homens possam viver de acordo e ajudar-se uns aos outros, é necessário que renunciem ao seu direito natural e assegurem uns aos outros que nada farão que possa redundar em dano de outrem.
}

São quase as palavras de Hobbes no Do cidadão e no Leviatã, quando o filósofo inglês explica o contrato social como esse ato pelo qual abandona-se o estado de natureza (essa condição sem poder político; na verdade uma situação sem segurança para a preservação da própria vida) pela fundação do estado civil (essa condição de poder estabelecido, essa troca entre a obediência dos súditos e a proteção pelo soberano): no Do cidadão, que Espinosa possuía em sua biblioteca, 
Hobbes assim explica que "a primeira lei especial de natureza é que não devemos conservar nosso direito a todas as coisas":

[...] os homens não devem conservar o direito que têm, todos, a todas as coisas, e alguns desses direitos devem ser transferidos, ou renunciados. Pois, se cada um conservasse seu direito a todas as coisas, necessariamente se seguiria que alguns teriam direito de invadir, e outros, pelo mesmo direito, se defenderiam daqueles (pois todo homem, por necessidade natural, empenha-se por defender seu corpo e as coisas que julga necessárias para protegê-lo). E disso se seguiria a guerra. Age pois contra a razão da paz, isto é, contra a lei de natureza, todo aquele que não abre mão de seu direito a todas as coisas. ${ }^{107}$

Como é uma necessidade racional, segundo Hobbes, a renúncia a esses direitos naturais no estado civil, é o caso de explicar o que significa transferir esses direitos, pelo que se funda o estado civil:

Diz-se que abre mão de seu direito quem a ele renuncia de forma absoluta, ou o transfere a outrem. Renuncia absolutamente a seu direito quem, por sinal suficiente ou símbolos adequados, manifesta a vontade de que deixe de ser lícito ele fazer aquilo a que antes tinha direito. E transfere seu direito aquele que, por sinal suficiente ou símbolos adequados, declara a outro que é sua vontade que se torne ilícito ele resistir-lhe, naquilo em que antes poderia resistir. A transferência de direito consiste meramente na não-resistência — isso porque, já antes de ocorrer a transferência, seu beneficiário detinha, também ele, direito a tudo, de modo que a ele não se poderia conferir nenhum direito novo. Apenas o direito de resistência, que aquele que transferiu o direito antes possuía, e que impedia o outro de livremente desfrutar de seus próprios direitos, agora é completamente abolido. Portanto, quem quer que adquira algum direito no estado natural dos homens, tudo o que faz é conseguir segurança para si, e ficar livre de qualquer justo entrave no desfrutar seu direito primitivo - como, por exemplo, quando alguém vende ou dá uma terra: a pessoa assim se priva definitivamente de todo direito que tinha a essa terra, mas nem por isso priva outros de um eventual direito a ela. ${ }^{108}$

No Leviatã, que não é listado no inventário da biblioteca particular de Espinosa mas pode muito bem ter sido lido por ele, ${ }^{109}$ Hobbes diz:

Desta lei fundamental da natureza [Todo homem deve esforçar-se pela paz, na medida em que tenha esperanca de consegui-la, e caso não a consiga pode procurar e usar todas as ajudas e vantagens da guerra.], mediante a qual se ordena a todos os homens que procurem a paz, deriva esta segunda lei: Que um homem concorde, quando outros também o façam, e na medida em que tal considere necessário para a paz. e para a defesa de si mesmo, em renunciar a seu direito a todas as coisas, contentando-se, em relação aos outros homens, com a mesma liberdade que aos outros homens permite em relação a si mesmo. Porque enquanto cada homem detiver seu direito de fazer tudo quanto queira todos os homens se encontrarão numa condição de guerra. Mas se os outros homens não renunciarem a seu direito, assim como ele próprio, nesse caso não há razão para que alguém se prive do seu, pois isso equivaleria a oferecer-se como presa (coisa a que ninguém é obrigado), e não a dispor-se para a paz. É esta a lei do Evangelho: Faz aos outros o que queres que te façam a ti. E esta é a lei de todos os homens: Quod tibi fieri non vis, alteri ne faceris. Renunciar ao direito a alguma coisa é o mesmo que privar-se da liberdade de negar ao outro o benefício

${ }^{107}$ Hobbes, Do cidadão, Livro I, cap. II, \3. Tradução de Renato Janine Ribeiro, p. 39.

108 Hobbes, op. cit. Livro I, cap. II, \4. pp. 39-40.

109 O Leviatã, publicado originalmente em inglês em 1651, recebeu sua tradução holandesa em 1667, um ano antes da primeira edição da tradução latina. Cf. Catherine Secretan, "La réception de Hobbes aux Pays-Bas au XVII' siècle", p. 28. 
do seu próprio direito à mesma coisa. Pois quem abandona ou renuncia a seu direito não dá a qualquer outro homem um direito que este já não tivesse antes, porque não há nada a que um homem não tenha direito por natureza; mas apenas se afasta do caminho do outro, para que ele possa gozar de seu direito original, sem que haja obstáculos da sua parte, mas não sem que haja obstáculos da parte dos outros. De modo que a conseqüência que redunda para um homem da desistência de outro a seu direito é simplesmente uma diminuição equivalente dos impedimentos ao uso de seu próprio direito original. Abandona-se um direito simplesmente renunciando a ele, ou transferindo-o para outrem. Simplesmente renunciando, quando não importa em favor de quem irá redundar o respectivo benefício. Transferindo-o, quando com isso se pretende beneficiar uma determinada pessoa. Quando de qualquer destas maneiras alguém abandonou ou adjudicou seu direito, diz-se que fora obrigado ou forçado a não impedir àqueles a quem esse direito foi abandonado ou adjudicado o respectivo benefício, e que deve, e é seu dever, não tornar nulo esse seu próprio ato voluntário; e que tal impedimento é injustiça e injúria, dado que é sine jure, pois se transferiu ou se renunciou ao direito. ${ }^{110}$

Ou seja, para Hobbes, há uma separação inegável entre estado civil e estado de natureza em todos os sentidos, tanto no tempo em que cada um é operado como no seu conteúdo. O homem, ser natural no estado de natureza, tem sua natureza — seus desejos, impulsos, vontades egoístas - controlada no estado civil: é por isso que, se o estado de natureza é um estado de liberdade natural, o estado civil é um estado de domínio, de alienação de direito ao soberano por cada homem, de fundação para o cidadão de uma condição alterius juris (ser cidadão na visão hobbesiana, enfim, é estar alterius juris), assim como é manter sui juris somente o soberano. Quando todos os homens são, no estado de natureza, sui juris, ninguém está verdadeiramente seguro em sua vida; e como a reta razão hobbesiana mostra que a primeira lei de natureza, a primeira necessidade humana determinada pela natureza do homem, é a busca da paz, a conseqüência, desta lei, quando unida à constatação de que em estado de liberdade natural os homens não conquistam essa paz, é tomar uma providência que acabe com o estado de insegurança. Ora, o estado de insegurança é o estado natural em que todos os homens correm o risco de ter sua vida tirada pelos demais, e por isso é preciso instituir — estabelecer uma instituição a ilegitimidade da liberdade natural, através da criação de uma idéia de liberdade válida na vida coletiva: a liberdade controlada, ou ausência de liberdade, tal como determinar o poder soberano (que recebe essa prerrogativa desde que mantenha com seu poder aquilo que em estado de natureza todos perceberam ser impossível conquistar, a segurança de cada um). Assim, na visão contratualista e especialmente hobbesiana, a vida política é necessariamente uma vida na qual não cabe a liberdade natural, e onde a liberdade — concebida aí por Hobbes segundo o sentido clássico de "ausência de impedimentos externos, impedimentos que muitas vezes tiram parte do poder que cada um tem de fazer o que quer, mas não podem obstar a que use o poder que lhe resta, conforme o que seu julgamento e razão lhe ditarem"111 — ou seja, faculdade de agir, é

110 Hobbes, Leviatã, cap. XIV, p. 79.

111 Hobbes, op. cit., p. 78. 
determinada não mais pela força ou potência de cada um, mas por aquele a quem todos aceitam estar submetidos e que de fato os comanda; se um indivíduo, ao contrário, decide não mais obedecer ao seu soberano a quem havia transferido seus direitos naturais, retorna com isto ao estado de natureza.

O Tratado teológico-político de Espinosa, de fato, diz coisa parecida no seu capítulo XVI:

\begin{abstract}
Se tivermos, além disso, em conta que os homens, quando não se entreajudam, vivem miseravelmente e que, quando não cultivam a razão, vivem escravos da necessidade, ver-se-á com toda a clareza que, para viver em segurança e o melhor possível, eles tiveram forçosamente de unir-se e fazer assim com que o direito natural que cada um tinha sobre todas as coisas (jus, quod unusquisque ex natura ad omnia babebat) se exercesse coletivamente e fosse determinado, já não pela força e o apetite de cada um (ex vi et appetitu uniuscujusque), mas pela potência e a vontade de todos em conjunto (ex omnium simul potentia, et voluntate). [...] Por isso, tiveram de estatuir firmemente e acordar entre si que tudo seria regido apenas pelos ditames da razão, [...] que refreariam o instinto sempre que ele sugerisse algo que redundasse em prejuízo de outrem, que não fariam a ninguém o que não quisessem que se lhes fizesse, e que defenderiam, enfim, o direito do próximo como se se tratasse do seu. ${ }^{112}$
\end{abstract}

Ou seja, segundo uma leitura tipicamente hobbesiana, o próprio Espinosa estaria aqui, tal como no texto do escólio 2 da proposição IV, P37, afirmando expressamente que é prejudicial, na vida comum, viver segundo os próprios impulsos passionais que marcam o homem em sua condição natural, e que a própria razão mostra que mais útil que aquilo é renunciar aos direitos naturais - o que, hobbesianamente, significa tornar-se alterius juris. Da mesma forma, ainda, como Hobbes considera que o estado de natureza é um estado de liberdade natural e que o estado civil é um estado de domínio - o que significa que a liberdade natural é uma liberdade inútil, já que não garante a preservação da própria vida —, em Espinosa a liberdade necessária por natureza não é suficiente, tal como ensinaria também a razão, para conquistar a paz que é finalidade da vida política.

Assim, Espinosa estaria repetindo Hobbes, para além de continuá-lo ou estendê-lo à sua filosofia, pois que fundaria a exposição do Estado e do direito na mesma fundação utilizada por Hobbes, o contratualismo. Entretanto, contra a validade racional dessa imagem retórica do contrato mencionada tanto na Ética quanto no TTP, o sentido autêntico do texto espinosano, lido não por uma ótica hobbesiana mas segundo o próprio texto de Espinosa, mostra que este entende a transferência de direitos de uma forma completamente diferente da de Hobbes. No texto do escólio, Espinosa, como Hobbes, considera que o homem é racional mas também passional, e que embora pudesse manter numa vida pacífica se sempre se guiasse pela razão, deixa-se constantemente levar-se por suas paixões e apetites, o que coloca os mesmos homens

112 Conforme tradução de Diogo Pires Aurélio, ligeiramente modificada. Segundo Guido Fassò (História de la filosofía del derecho, vol. 2, p. 117), esse trecho prova que, em Espinosa, é especialmente no TTP que "a teoria do contrato social se formula conforme o esquema do jusnaturalismo do século XVII". 
constantemente em situações de disputas pelas mesmas coisas. A vida guiada só pelas paixões e não pela razão, mostram os dois autores, é uma vida de guerra pelas mesmas coisas. A hipótese, originalmente hobbesiana, é assumida por Espinosa como válida; mas, diferentemente de Hobbes, Espinosa não concebe uma vida humana que possa ser conduzida só pela razão: a essência do homem, diz Espinosa, ${ }^{113}$ é o desejo (cupiditas), e por sua natureza o homem jamais deixa de ser impulsionado pelos seus apetites; sua razão, apenas, é o cálculo pelo qual cada um determina suas ações em função desse desejo, que por sua vez é a consciência do próprio conatus, ou seja, da necessidade da sua preservação da existência. Como, porém, o argumento dessa renúncia de direitos naturais quer dizer uma recuperação da determinação da ação segundo a razão e não segundo o vaivém dos afetos, a diferença entre Hobbes e Espinosa está em que, para Hobbes, a vida civil é racional porque é não depende mais do autocontrole, enquanto para Espinosa ela só é racional porque aí há pleno autocontrole. $\mathrm{O}$ argumento espinosano não fala em transferir os direitos naturais em benefício de um só (como diz Hobbes), mas sim em deixar de lado aquilo — o "direito natural" — que, sendo mais forte que a razão, impede a paz e a concórdia.

Ou seja, o que é o direito natural em Hobbes? A liberdade natural de cada um, que cada um tende a exercer em prejuízo de outrem e por isso colocando em perigo a própria vida. O que é esse "direito natural" a que se deve renunciar pela paz, em Espinosa? É a servidão da vida passional, em que o indivíduo é arrastado pelas paixões contrárias porque não consegue, ainda, guiar-se autonomamente pela sua razão. Tanto em Hobbes como em Espinosa, transferir os direitos naturais é fundar o estado civil; na acepção hobbesiana, significa todos se tornarem alterius juris e aceitarem a vida na servidão; em Espinosa, ao contrário, significa todos continuarem sui juris no campo da vida política. Se em Hobbes o estado civil, resultado do contrato social, é uma anulação do estado de natureza, em Espinosa não há essa anulação do estado natural porque este não é, como pensam os jusnaturalistas contratualistas, ausência de poder político, mas a própria potência necessária de cada um segundo sua natureza. Rigorosamente falando, a oposição entre estado de natureza e estado civil não existe, e assim como o estado de natureza é aquela condição em que a ação é determinada pela potência, o estado civil é exatamente a mesma coisa, mudando-se apenas o tipo de potência, porque mudou a disposição dos corpos com a criação do corpo político, cuja necessidade (simultânea tanto para a Cidade quanto para os cidadãos) é a lei:

De que maneira possa isto suceder, quer dizer, que os homens, que estão necessariamente sujeitos aos afetos (pelo corolário da proposição 4 desta parte) e são inconstantes e mutáveis (pela proposição 33 desta parte), possam dar uns aos outros esta segurança mútua e ter confiança mútua, vê-se pela propo-

113 Ética III, def. af. 1: "O desejo é a própria essência do homem, enquanto esta é concebida como determinada a fazer algo por um afeto qualquer nele verificado." 
sição 7 desta parte e pela proposição 39 da Parte III, isto é, pelo fato de nenhum afeto poder ser entravado, a não ser por um afeto mais forte e contrário ao afeto a entravar, e pelo fato de cada um se abster de causar dano pelo temor de um dano maior. Portanto, é sobre esta lei que a sociedade poderá fundar-se, com a condição de ela reivindicar para si o direito que cada um tem de se vingar e de julgar do bem e do mal. Conseqüentemente, ela deverá ter o poder de prescrever uma regra comum de vida, de fazer leis e de as apoiar não na Razão, que não pode entravar os afetos (pelo escólio da proposição 17 desta parte), mas em ameaças. Tal sociedade, firmada em leis e no poder de se conservar a si mesma, chama-se Cidade, e os que são defendidos pelo direito dela, cidadãos.

No próprio estado civil, mostram Hobbes e Espinosa, não é a razão que mantém a todos em respeito nem é ela que faz com que todos obedeçam; mas, enquanto em Hobbes é o afeto do medo da outra parte do contrato (súditos ou soberano) é o que mantém constante o cumprimento do pacto, em Espinosa o que constitui constantemente a vida política (o Estado, a Cidade) é simultaneamente o amor de cada um por si mesmo (consciência do desejo de autopreservação) e também pelo outro (consciência da autopreservação fortalecida pela preservação do outro); se é verdade que o conhecimento dessa utilidade não vem do ensinamento moral ou racional, mas vem do instrumento institucional da ameaça e da coação, a experiência dessa utilidade mostra que o sentido da cidadania (proteção pela Cidade e liberdade nela) não é uma ficção criada pelo intelecto, mas é uma sensação efetivamente percebida pelo ânimo. Assim, em Espinosa, o estado civil é um estado em que se vive não controlando a própria natureza, mas conhecendo a utilidade que a vida em concórdia traz para a própria potência: na vida em concórdia, não é preciso ter medo de viver arrastado pelos afetos. Não bastasse isso, a expressão espinosana "é necessário que renunciem ao seu direito natural" revela, outra vez, o mesmo uso retórico adotado no início do escólio com relação à expressão summo naturae jure: assim como esta expressão, a afirmação "é necessário que renunciem ao seu direito natural” se utiliza de uma tese ainda não dedutível somente pela argumentação geométrica da Ética (embora suas molduras o sejam), e também volta-se para a imaginação do leitor, este um leitor acostumado ao vulgar do contratualismo, que afinal, entre as teses seiscentistas sobre a origem da Cidade, contém o que o vocabulário das outras teorias ou doutrinas não suportam: a concepção hobbesiana (com esta Espinosa concorda) de que os valores políticos — justiça, etc. — só começam na vida política. ${ }^{114}$ Ou seja: apesar dessa outra aparente aproximação entre Espinosa e Hobbes por conta do argumento da "renúncia" dos direitos naturais, essa renúncia, que em Hobbes é de fato renúncia e fundação do poder, em Espinosa nada mais é do que renúncia de um cálculo determinado: o cálculo individualista do uso da própria potência; no plano da vida política, ou no dito estado civil (que o vulgar imagina como recuperação da razão e a razão conhece como ne-

114 Nem aí, porém, Espinosa será um seguidor de Hobbes: na filosofia espinosana, a justiça e seus pares, revelados como obra da vida política, terá em Espinosa a companhia da concórdia, pelo que será efeito da razão; em Hobbes, a paz a que se refere essa mesma concórdia no horizonte da política não é, nem pode ser, efeito da razão, mas apenas cultivo do medo. 
cessidade de concórdia), a mesma potência e a mesma natureza necessárias, o mesmo indivíduo conhece a liberdade do cálculo do bem comum. $\mathrm{Na}$ perspectiva espinosana, pois, o estado civil hobbesiano, e o estado civil do contratualismo, não é outra coisa senão imaginação de impotência e fundação da servidão no campo político.

Ainda sobre essa idéia de que Espinosa é um jusnaturalista porque seria contratualista, não é à toa que ele fora questionado pelo seu amigo Jarig Jelles ${ }^{115}$ a respeito da sua semelhança com Hobbes: é base, afinal, da teoria política deste a idéia de que o estado civil é constituído pelo contrato social, ou seja, pelo ato no qual todos transferem seus direitos naturais, menos um (o direito à vida, ou o direito a preservar a própria vida), a um soberano, ao qual todos passam a dever obediência daí em diante. Com efeito, quando Espinosa diz que na sociedade política "cada indivíduo deve transferir para a sociedade toda a sua própria potência", isso não seria uma retomada da transferência de direitos hobbesiana? Não — por toda a necessidade de preservação de potência e de conatus que a ontologia já determina, e que a experiência também pode mostrar —, mas a razão disto não ser percebido por Jelles (mais impressionado com o argumento da transferência de potência do que atento à condição da potência transferida) é o fato de não compreender a relação necessária entre preservação da potência individual (um princípio afinal também presente em Hobbes) e preservação da potência de cada um na comunidade política, cuja chave no plano da vida política é explicitada em seguida por Espinosa, numa afirmação que não apenas mostra de qual transferência se trata e marcará, sobre esse aspecto, a maior das diferenças entre ele e o filósofo inglês:

Em democracia, com efeito, ninguém transfere o seu direito natural para outrem a ponto de este nunca mais precisar de o consultar; transfere-o, sim, para a maioria do todo social, de que ele próprio faz parte e, nessa medida, todos continuam iguais, tal como acontecia anteriormente no estado de natureza. ${ }^{116}$

Ou seja, a transferência de direito natural em Espinosa não é, como em Hobbes, alienação de direito natural, mas extensão de potência individual, porque sua expressão dentro de uma sociedade política. Se em Hobbes transferir os direitos naturais significar atribuir a uma autoridade um poder exclusivo de lidar com esses direitos e essa liberdade como quiser (independente da vontade do indivíduo subjugado - do súdito), em Espinosa a transferência de direito natural significa expressão, numa escala política (na sociedade política), dessa potência idêntica à natu-

115 Em carta (perdida) que seria respondida, por Espinosa, na sua célebre Carta 50 (Ed. Gebhardt, vol. IV, pp. 238-239); cf. início do cap. III (“Espinosa, hobbesiano?”).

116 Tratado teológico-político, cap. XVI. 
reza de cada um e que, por ser natural, não se separa do próprio indivíduo em nenhum momento, inclusive aquele em que ele está em sociedade; em Espinosa, transferir o direito, isto é, transferir a potência, significa fazer com que a própria potência individual seja somada à potência individual de outros integrantes da mesma sociedade, de maneira que a potência da sociedade como um todo não é poder arbitrário de um soberano sobre seus súditos, mas um poder político idêntico às potências individuais que se somam igualmente para constituir um corpo político. Em suma: na transferência de direitos espinosana, não há perda de direitos, mas soma de direitos. Transferir o próprio direito natural ou a própria potência natural a outrem significa permitir que a própria potência seja útil também a outrem. E, num estado civil de caráter democrático (que é o preferido por Espinosa), ninguém permite que sua potência seja útil a um outro de forma que essa utilização resulte em anulação da potência para si: "ninguém transfere o seu direito natural para outrem a ponto de este nunca mais precisar de o consultar", ou seja, a transferência de potência não significa permissão para que seu uso seja determinado exclusivamente por outro, além de significar muitas outras coisas. Numa palavra: em Espinosa não há contratualismo porque o estado civil não é fundado numa perda de direitos naturais, mas sim na sua expressão no plano da política. O estado civil espinosano é a articulação política das potências naturais individuais em conjunto: como o desejo natural de toda potência individual é a sua própria preservação e isso vale igualmente para a política, o estado civil mais desejável é aquele em que as potências individuais estejam todas preservadas e em atividade; por definição, democracia, deduzida de uma compreensão racionalista da política e do direito que não considera racional a imagem do poder soberano porque autoridade soberana que não deve consultar seus próprios súditos.

Essa descrição do direito natural no estado civil democrático contém pelo menos duas inovações por parte de Espinosa. Com ela, Espinosa considera que mesmo no estado civil há a realidade (exercício? prática?) do direito natural, assim como, por esse fato mesmo, há uma igualdade entre a condição que determina o estado de natureza e a determina o estado civil: em ambos, a liberdade natural de cada um não é transferida a um outro (um soberano diferente de cada um, no caso). Assim, embora seja compreensível a diferença entre Espinosa e os contratualistas (não há em Espinosa contrato social, isto é, anulação dos direitos naturais em função da obediência a um soberano), mantém a idéia mesma de direito natural e leva a considerar que Espinosa, se não é jusnaturalista em função de uma teoria do contrato social (já que ela não existe), o seria em função de uma concepção de estado de natureza onde reina um certo direito natural, ou mesmo em função dessa sua concepção de estado civil no qual o direito natural é, como ele diria na Carta 50 a Jarig Jelles, preservado. Entretanto, a presença dessa concepção de direito 
natural (no estado de natureza ou no estado civil) também não é suficiente para constituir Espinosa como um jusnaturalista; e é aí, em especial, que aparece a diferença central entre o pensamento jurídico espinosano e todo jusnaturalismo (e não apenas o jusnaturalismo contratualista): Espinosa, ao elaborar uma teoria jurídica que faz uso dos termos jusnaturalistas, não elabora uma teoria do direito natural, mas sim uma teoria que mostra que não faz sentido um tal conceito, de modo que este merece, mesmo, ser abandonado. Ou seja: o que Espinosa elabora é uma antiteoria do direito natural, cujo resultado é não apenas a recusa de racionalidade da concepção vulgar de direito natural, como a afirmação da sua inadequação para o próprio pensamento jurídico. Espinosanamente, se é o caso de elaborar uma teoria verdadeira e realista sobre o direito, ela não pode manter intacto o conceito irracional de direito natural, assim como deve fundar, para o mesmo vocabulário jurídico dos juristas e políticos, um sentido que identifique adequadamente direito civil e liberdade necessária.

\section{II O DIREITO NATURAL EM ESPINOSA: UM ANTICONCEITO}

O leitor do Tratado teológico-político de 1670 não conhece a Ética (ainda a ser finalizada e publicada). Entretanto, sem que possa imaginar, tem diante de si não apenas uma análise do Deus das escrituras sagradas como por vezes a apresentação, camuflada, daquele que será o Deus da Ética. Tomadas em si mesmas, são duas concepções de Deus completamente incompatíveis: o Deus do Teológico-político, anunciado por toda a obra como o Deus da Bíblia, é essa entidade religiosa a que a interlocução com um leitor cristão (especialmente protestante) obriga apresentar como o Deus dos cristãos; a religião defendida na obra é não uma religião em particular, mas a "religião verdadeira", cujo conteúdo foi ditado por Deus na forma de verdades muito simples e que exige de nós unicamente a obediência a Deus... mas é por citações dos textos da Bíblia cristã (Antigo e Novo Testamentos) que Espinosa mostra a confirmação das teses que argumenta. Ou seja, esse Deus do Teológico-político, se tomado como um Deus da religião, ainda que não seja afirmado por Espinosa como exclusivamente o Deus cristão - pelo que só os cristãos teriam acesso a ele - é apresentado tendo-se em mente o Deus dos cristãos e o cerimonial religioso cristão; o fato de a maior parte das citações e dos casos bíblicos analisados por Espinosa dizer respeito à história e religião dos judeus tem suas razões, dentro dessa consciência de que o leitor é, principalmente, cristão: se o Novo Testamento estabelece a religião cristã, a religião verdadeira já tem suas bases no Antigo Testamento, pois é lá que Deus cria o mundo, o seu povo, as instituições da religião e, principalmente, é lá que ele fala com os homens e estabelece suas 
leis. As verdades da religião estão, já, no Antigo Testamento, e os judeus a conheciam; o que os textos dos evangelistas e dos apóstolos vêm acrescentar é a afirmação de Cristo como expressão da sabedoria divina pela natureza humana e caminho para a salvação. ${ }^{117}$

A Ética, ao contrário, é um texto que se volta diretamente para a razão de qualquer ser humano, independente da sua crença. Justamente porque ela diz o verdadeiro utilizando-se de uma forma demonstrativa (a demonstração geométrica) necessariamente adequada à exposição racional e à leitura racional, ela é diretamente acessível e compreensível por qualquer pessoa (porque não há quem não seja dotado de razão); o Tratado teológico-político, ao contrário, voltado para um público de leitores cristãos, só se torna compreensível para esse público se volta-se, também, para as suas crenças; assim, enquanto texto filosófico o TTP mantém a tarefa de dizer, a cada linha, o verdadeiro; mas, como aí não cabe a exposição geométrica (porque o assunto a-

117 Tratado teológico-politico, cap. I ("Da profecia"): "Tirando estes, não encontro na Sagrada Escritura quaisquer outros meios pelos quais Deus tenha comunicado com os homens e, por conseguinte, como atrás demonstramos, mais nenhum é de admitir ou supor. E embora se compreenda que Deus pode, sem dúvida, comunicar imediatamente com os homens, pois comunica a sua essência à nossa mente sem precisar de qualquer meio corporal, todavia, para que um homem percebesse só pela mente certas coisas que não estão contidas nos primeiros princípios do nosso conhecimento, nem deles se podem deduzir, a sua mente teria de ser por força superior e, de longe, mais perfeita que a mente humana. Assim sendo, não creio que alguém tenha atingido tanta perfeição, a não ser Cristo, a quem os preceitos divinos que conduzem os homens à salvação foram revelados imediatamente, sem palavras nem visões: Deus manifestou-se, portanto, aos apóstolos através da mente de Cristo como outrora a Moisés por meio de uma voz que vinha do ar. E assim, à voz de Cristo, tal como àquela que Moisés ouvia, pode chamar-se a Voz de Deus. Neste sentido, podemos afirmar que a Sabedoria divina, isto é, a Sabedoria que é superior à do homem, assumiu em Cristo a natureza humana e Cristo foi o caminho da salvação." Diferente do que consideram Alexandre Mathéron e Diogo Pires Aurélio (cf. trad. Pires Aurélio do TTP, p. 380, n. 9), não penso ser verdade que a figura de Cristo não tenha função alguma no sistema espinosano. Cristo é apresentado sempre como um homem que tem acesso direto à mente ou às idéias de Deus, o que, segundo o texto bíblico, é por algum motivo vetado aos outros homens, que no máximo têm acesso à sabedoria divina por meio de visões ou outras imagens, como no caso dos profetas. Ou seja: já que a Bíblia faz uma separação entre os homens (seres dotados de incontáveis imperfeições) e Cristo (homem que atinge a perfeição apesar de ser homem), Espinosa opera com a idéia de que Cristo é um homem tão perfeito que tem acesso à mente divina, algo a que os demais não têm por causa daquilo que os textos sagrados chamam de imperfeição. Espinosanamente, Cristo é um homem perfeito que com sua própria mente compreende a mente de Deus, e por isso ele é caminho para a salvação: para que um homem se salve, deve tomar Cristo por seu caminho, ou seja, deve fazer com que sua natureza humana também expresse a mente de Deus, o que se faz compreendendo as idéias de Deus (tal como Cristo faz) e não interpretando sua aparência (tal como faziam os profetas e como não farão os apóstolos). Assim, com sua discrição característica, Espinosa afirma, por palavras que podem ser lidas em conformidade com a fé do leitor cristão - Cristo é o caminho para a salvação - o que ele já desenvolvera no Tratado da emenda do intelecto e também mostrará na demonstração geométrica da Ética: beatitude humana e conhecimento verdadeiro são a mesma coisa. Assim, qual a função de Cristo no Tratado teológico-politico? Não é servir de prova de que a religião cristã é a única verdadeira (Espinosa defende a religião verdadeira, nunca uma religião em particular), ou de que todos devemos ser cristãos (tanto que afirma que qualquer gentio, dotado da luz natural e piedade natural, pode ser salvo sem que tenha tido acesso à autêntica palavra de Deus), e sim ilustrar a necessidade da relação entre conhecimento verdadeiro (que sempre é conhecimento daquilo que Deus sabe ser verdadeiro) e salvação humana (que nunca é definida por Espinosa como vida eterna depois desta vida, mas sim como beatitude). De fato, sem a figura de Cristo significando essa relação entre conhecimento verdadeiro e beatitude humana, como mostrar aos leitores cristãos que esse é um ideal cultuado em sua própria religião? 
bordado é considerado, pelo leitor cristão, verdadeiro segundo os dogmas da religião e da teologia, e por isso sem necessidade sequer de ser analisado pela filosofia, assim como de forma alguma pode ter as teses da teologia negadas pela análise filosófica), é preciso manter o conteúdo verdadeiro tanto por uma argumentação dedutiva e às vezes geométrica do seu tema quanto, a todo momento, por uma camuflagem retórica dessa análise, que se volta para a crença do leitor ao mostrar como verdadeiras teses religiosas que na mente do leitor são verdadeiras enquanto dogmas da religião, e no texto de Espinosa são verdadeiras em função exclusivamente da argumentação desenvolvida no texto. Quando Espinosa, no Tratado teológico-político, faz citações dos textos bíblicos, está tomando objetos para a sua análise gramatical, filológica e hermenêutica da Bíblia, ou está simplesmente apontando, na Bíblia, trechos que confirmam o que ele acaba de argumentar e deduzir por si só; que leitor cristão terá coragem de negar que concorda com Espinosa? ${ }^{118} \mathrm{Na}$ Ética, porém, não aparecem citações da Bíblia, nem de qualquer outra autoridade dogmática equivalente; no máximo, Espinosa apresenta citações de outros filósofos ou de poetas nos escólios, prefácios, apêndices, de forma, ainda, a ilustrar apenas o que a argumentação em volta por si só mostra e demonstra. Porque a Ética se volta somente para a razão do leitor, o seu texto tem um sentido que depende inteiramente do que ele mesmo define e afirma; e que pode ser seguido completamente pelo leitor, desde que disposto pelo "tão difícil quanto raro" ânimo racional, que o permite ter acesso ao verdadeiro sem ter medo de se desprender das suas superstições e tabus; porque o Tratado teológico-político se volta também para a razão do leitor, o seu conteúdo necessariamente é verdadeiro de ponta a ponta, e a exposição retórica dos seus argumentos jamais é operada como inserção de teses falsas entre as teses verdadeiras, o que certamente arruinaria a necessária consistência do texto (necessária não só aí como em qualquer texto de Espinosa); no Tratado político, enfim, como o texto também se volta para a razão do lei-

118 Como sabemos, praticamente todos os leitores religiosos que lêem Espinosa. O choque causado pela filosofia espinosana à leitura religiosa não se deve pela incompreensão da relação entre a análise e dedução apresentada a cada momento pelo filósofo, e sim pela perplexidade em considerar que, de premissas dogmaticamente inaceitáveis é possível deduzir verdades bíblicas. A apresentação de textos bíblicos que confirmam o que Espinosa considera a respeito da religião só acirram o ânimo do leitor religioso. Ingenuidade de Espinosa, pois, em achar que apresentando suas demonstrações dessa forma conseguiria converter o leitor cristão à filosofia? Não: ao pedir, no prefácio, que seu leitor seja um "leitor filósofo", Espinosa aponta a única perspectiva pela qual é possível compreender a argumentação do texto: a leitura racional. As citações bíblicas colocadas como endosso ou confirmação das análises no correr do texto estão, na verdade, fora da análise, que pode ser perfeitamente compreendida sem elas (o mesmo acontece, a propósito, no caso da citação dos historiadores antigos, no TTP como no TP; ver cap. 4.II); a recusa, pelo leitor cristão, da validade do Teológico-político mostra, historicamente, que a leitura não foi racional, mas religiosa, o que confirma a tese espinosana, apresentada no próprio Teológico-politico, de que a teologia não tem acesso à razão (por isso é impossível, por uma leitura teológica, compreender um argumento racional), mas só a razão tem acesso à razão (de modo que à leitura racional é necessário compreender qualquer objeto), tanto que pela luz natural (pela razão) é possível conhecer as verdades muito simples da religião verdadeira ou religião natural (que Espinosa, utilizando-se ainda do debate teológico da sua época, ilustra através dos preceitos noaquitas). 
tor, mas ainda precisa do recobrimento retórico (já que o leitor jurista do TP tem formação jusnaturalista e, ou, antidemocrática), nenhuma tese ali pode ser falta dentro da argumentação em que é desenvolvida.

Para compreender as teses e os conceitos espinosanos, é preciso compreender a maneira como estão dispostos no texto em que estão dispostos. Sempre que é preciso dirigir-se em certa medida à experiência, às crenças, aos preconceitos do leitor, Espinosa precisa apresentar o verdadeiro sob uma forma que, considerada isoladamente, pode mesmo significar o avesso do que é efetivamente dito por Espinosa. Por exemplo, quando no Tratado politico é dito que "a experiência parece ensinar que, no interesse da paz e da concórdia, é conveniente que todo o poder pertença a um só", ${ }^{119}$ nada compreendemos desse texto se, primeiro, não reconhecemos que é parte de um argumento (que em seguida apresenta a contradita: nesse poder de um só, a paz e a concórdia só existem enquanto servidão, e por isso não podem ser aceitas como paz e concórdia) e, também, se não notamos a peculiaridade com que Espinosa lustra o seu texto: é a experiência a fonte dessa idéia que a reflexão revela ser inválida, e essa experiência também nada demonstra (só a razão demonstra), mas apenas "parece ensinar" (docere videtur), e ainda por cima o que ela aí ensina é falso. No Tratado teológico-político, esse momento único onde a política é analisada por Espinosa dentro do desafio extremamente árduo de demonstrar para o religioso que a teologia nada demonstra de verdadeiro, o Deus que é analisado no texto necessita aparecer como o Deus da religião e conduzir a uma compreensão verdadeira de Deus (que não é o Deus de uma qualquer religião particular), equivalente, na perspectiva do TTP, ao Deus da Ética. No TTP ainda, a análise do direito e do Estado - voltada para esse mesmo leitor que critica a ímpia concepção hobbesiana de que não existe justiça antes das convenções humanas e que considera necessário conciliar a idéia de poder secular com a autoridade da religião e o poder de Deus - precisa também aproveitar a imagem de um Deus da religião cristã para mostrar que a autoridade de Deus na religião não necessita tornar-se autoridade política ou autoridade na política, o que é equivalente às teses, apresentadas na Ética, de que é incorreto conceber Deus como princeps (governante) da natureza e que a infinitude de Deus é uma infinitude de potentia (potência), e não de potestas (poder).

Assim, quando nos deparamos com os conceitos do Tratado teológico-politico e os comparamos com os da Ética e os do Tratado político, é inevitável um estranhamento. Como compreender que um mesmo autor, que uma mesma filosofia, demonstre ora a partir da Bíblia, ora a partir da razão, ora a partir da experiência empírica? Para compreendê-lo, é preciso ler cada texto de Espinosa por aquilo que ele diz e segundo a forma como diz. A constatação, que impressiona o lei-

119 Tratado politico, cap. VI, \4. 
tor filósofo e deixa perplexo o leitor antifilósofo, é de que essa leitura direta do texto espinosano revela em cada texto e em cada argumento um texto completamente racional e válido em função da sua consistência, ainda que aproveitando a capa do discurso retórico. Não é verdade que Espinosa demonstre às vezes a partir da Bíblia; ele utiliza a Bíblia como desafio ao leitor teólogo de achar, nela, o que contradiga o que ele demonstra racionalmente. Espinosa também não afirma nada que valha somente em função da experiência empírica; ele aponta para a experiência de forma a desafiar o leitor cético a encontrar nela o que a demonstração racional organiza. Apelo aos textos sagrados, aos textos históricos, às autoridades dogmáticas sobre cada tipo de leitor, eis o que move a utilização precisa de cada citação. Sem esse apelo retórico às autoridades dogmáticas segundo a índole de cada leitor, a potência para manter sua atenção se perde, e antes de chegar às conclusões do livro o leitor estaria tentado a fechá-lo. Na Ética, o que segura o leitor é a impressionante engenharia geométrica que o intriga de tal modo que não consegue abandonar o sistema espinosano sem conseguir compreender a maneira pela qual Espinosa realiza a proeza de demonstrar aquelas teses que, de fato, tanto sentido fazem ao próprio leitor, mas que de forma alguma uma concepção vulgar poderia supor demonstráveis a partir da ontologia; no Tratado teológico-politico, o que segura o leitor até o fim é o impacto dessa demonstração de teses antiteológicas a partir de uma análise dos próprios textos sagrados e de tantos artigos de fé que compõem as crenças do próprio leitor; no Tratado político, sem a necessária dedução explícita a partir da ontologia (como na Ética) e sem a necessária análise da Bíblia (como no Teológico-político), esse tratado que versa sobre a experiência política revela a consistência da reflexão sobre o direito e o Estado e pode, assim, envolver o leitor numa demonstração também geométrica da passagem da natureza da política à natureza das instituições... porque é um texto onde o leitor claramente não é concebido como cristão, a exposição retórica (muito mais tênue) é calculada de acordo com as crenças politicas do leitor, mas outra vez sem dizer em momento algum o falso, o absurdo.

Assim, o leitor cristão que se depara com as autoridades religiosas no Tratado teológico-político, por não se permitir a leitura racional, vê no tratado uma dedução herética a partir de dogmas que são, eles sim e em si mesmos, verdadeiros. O mesmo leitor do Teológico-político, diante da análise do direito e do Estado, vê-se diante de outra heresia, em termos agora de teoria política: a defesa da democracia. Por que uma heresia? Porque Espinosa ousa basear essa definição nas considerações que faz a respeito da natureza das sociedades e do homem nos resultados da sua análise da teologia e da religião: a definição do melhor regime político, e a consideração mesma de qualquer questão estritamente política, só pode ser feita de fora da teologia. O que torna herética, também, a afirmação de que a democracia é o mais natural dos regimes políticos, é a tese 
de que essa dedução não vem da teologia política, apesar de toda a análise que Espinosa fizera, nos capítulos do TTP sobre a teologia, da teocracia dos judeus, e apesar das considerações que fará, ao final da obra, a respeito do Estado hebraico, em vista do que a análise racional da política já permitiu mostrar. Ora, esse leitor que se recusa a ser "leitor filósofo", que recusa permitir-se à leitura racional, exige ao mesmo tempo que os seus dogmas sejam respeitados, da autoridade da teologia sobre a interpretação das Escrituras à influência da religião e da moral nos usos do poder e na criação ou limitação de direitos.

Assim como o Tratado teológico-político, apesar de permitir uma leitura racional e apesar de continuar de pé diante das críticas dos teólogos, necessariamente causaria críticas da parte da teologia: como demonstra Espinosa, a razão não está a serviço da teologia, e por isso a teologia, por sua natureza própria, é incapaz de compreender a filosofia e necessariamente volta-se contra ela. A história da leitura do Teológico-político é uma confirmação, também, das suas teses. Ao mesmo tempo, a parte do Teológico-político sobre a política necessariamente traria as acusações de hobbesianismo, absolutismo, panteísmo, antijuridismo: a teoria política aí desenvolvida mostra, por uma argumentação racional que também joga retoricamente com o vocabulário jurídico do tempo, que a razão não está a serviço das instituições político-jurídicas, que a razão não se dobra ao poder nem pode ser limitada por ele. Assim como a crítica teológica à obra, embora venha denunciar um ateísmo espinosista, seja em verdade motivada pela subversão espinosana dos termos teológicos para denunciar a irracionalidade da própria teologia, a crítica jurídica ao TTP, embora centrada especialmente na acusação de antijuridismo (especialmente por conta do seu conceito de jus sive potentia, direito ou potência), é deflagrada pela demonstração espinosana de que a autoridade político-jurídica, em si mesma, é vazia e não tem legitimidade enquanto não é operada enquanto democracia. É a tese da democracia que apavora, ao mesmo tempo, teólogos e juristas; mas não é contra ela que eles estabelecem suas acusações — porque isso os obrigaria a enfrentar o sistema espinosano segundo argumentos filosóficos, e não segundo dogmas religiosos ou jurídicos —, e sim contra a elaboração espinosana de conceitos também presentes em seus domínios: especialmente Deus e fé, no caso da teologia, e direito e lei, no caso do direito. Espinosa significa, para as instituições da teologia e do direito, a revelação da ilegitimidade política de qualquer instituição religiosa e da legitimidade somente na democracia das instituições jurídicas; incendiário nos dois campos, portanto.

Se à teologia resta o desafio de refutar Espinosa segundo a prova de que seu Deus é uma concepção ateísta, ao direito resta o desafio de refutá-lo segundo a prova de que seu conceito de direito não tem realidade alguma. É a tradição tipicamente jurídica da imagem espinosista do Espinosa antijurídico, inaugurada por Samuel Pufendorf numa revisão do seu tratado Do direito 
de natureza e das gentes, ${ }^{120}$ e que até hoje está na boca de todo mundo entre os juristas que não compreendem o que significa o cálculo ontológico-político que leva a concluir que a democracia é o mais natural dos regimes políticos.

Se o Tratado teológico-politico de Espinosa é inteiramente uma obra-prima em termos de construção retórica (porque consegue dizer o verdadeiro através da aparência do seu contrário, para depois de conquistada a serenidade de ânimo no leitor mostrar, enfim, o verdadeiro segundo os seus termos racionais adequados), o seu Prefácio, porta de entrada para esse texto que acabará por negar praticamente tudo em que o seu leitor cristão acredita, é uma peça textual com uma responsabilidade retórica ainda maior. Ali, Espinosa não apenas ambienta o leitor para o assunto do livro, como já faz uma defesa da liberdade de pensamento e de religião e antecipa, de forma resumida, o que será tratado em cada um dos capítulos. Depois de dizer, no prefácio, que o que leva a escrever o Tratado teológico-político, diante da contradição entre o que pregam as Escrituras e as atrocidades praticadas pelos que se dizem cristãos e fiéis, foi a decisão de "empreender um novo e inteiramente livre exame da Escritura, recusando-me a afirmar ou admitir como sua doutrina tudo o que dela não ressalte com toda a clareza”; só com tal método seria capaz de descobrir as razões pelas quais

[...] a luz natural é, não só desprezada, mas até condenada por muitos como fonte de impiedade; que as invenções humanas passam por documentos divinos e a crendice por fé; que as controvérsias dos filósofos desencadeiam na Igreja e no Estado as mais vivas paixões, originando os ódios e discórdias mais violentas, que facilmente arrastam os homens para sublevações e tantas outras coisas que seria longo descrever aqui $[\ldots .]$.

Esclarecido isto, Espinosa anuncia todos os temas que trabalhará com respeito à religião uma exposição de certa forma extensa, em função não apenas de se referir à parte sobre a teologia, que toma a maioria dos capítulos do tratado, mas também por ser, simplesmente, sobre teologia: mesmo aí, no anúncio do que será abordado depois, Espinosa precisa ser minimamente detalhado na justificação dos temas. Ao final dessa listagem dos temas teológicos ele revela que toda a análise da Bíblia segundo o método inventado por ele permite ver adequadamente que a liberdade de pensamento e expressão do pensamento não impede a prática da religião e da fé, especialmente porque a teologia não está subordinada à filosofia (o conhecimento natural), nem a filosofia está subordinada à teologia:

${ }^{120}$ Confirme vimos no início do capítulo 1.II.
${ }^{121}$ Conforme tradução de Diogo Pires Aurélio. 
[...] apresentados os fundamentos da fé, concluo, finalmente, que o conhecimento revelado não tem outra finalidade senão a obediência e que, tanto pela finalidade como pelos fundamentos e pelo método, ele é completamente diferente do conhecimento natural, não tendo nada em comum com este, pois cada ocupa a sua área sem que o outro se insurja e sem que nenhum tenha de considerar subordinado. Como, além, disso, os homens são por índole bastante diferentes, e como uns preferem esta, outros aquela opinião, inspirando a uns sentimentos religiosos o que a outros só provoca escárnio, concluo ser necessário deixar a cada um a liberdade de julgar e a possibilidade de interpretar os fundamentos da fé segundo a sua maneira de ser, e não se ajuizar de ninguém, a não ser pelas suas ações, conforme piedosas ou ímpias. Só assim poderão todos obedecer a Deus de livre e inteira vontade e dar valor apenas à justiça e a caridade. ${ }^{122}$

A conclusão desse anúncio da análise da teologia já constitui uma atitude política do filósofo. Embora teologia e filosofia sejam campos por sua própria natureza separados, a experiência mostra que pode haver uma interferência indevida não apenas entre ambos os campos, como entre algum deles e a política. Por que Espinosa considera necessário mostrar que a teologia não deve interferir na filosofia? Porque essa interferência significa não uma forma de fazer filosofia ou de fazer teologia, mas uma forma de impedir que se faça teologia: a interferência da teologia na filosofia significa a exigência de que a filosofia não interprete a Escritura senão por aceitação expressa dos dogmas da própria teologia; e filosofia, mostra Espinosa, não precisa da teologia para interpretar a Escritura, mas sua própria interpretação da Escritura mostra que esta não é um texto demonstrativo ou descritivo e, por isso, não pede uma interpretação argumentativa, mas apenas uma leitura textual, o que é suficiente para a compreensão das suas verdades e que, por isso mesmo, é algo inaceitável para a teologia, especialmente a teologia antireformista e a teologia católica. Ora, Espinosa exige a liberdade de pensamento porque esta é uma necessidade natural de cada um; mas não diz isso no prefácio, reservando a demonstração dessa idéia para o interior do livro; aí, ele apenas aponta para a experiência, que mostra que, como cada um tem uma sentença diferente a respeito de todas as coisas, se não for permitida a liberdade de discussão e pensamento, isso certamente provocará, como a experiência mostra que provoca, sedições, o que por sua vez é prejudicial à conquista da grande finalidade da vida cristã: justiça e caridade.

Essa expressão, justitia et charitas, aparece freqüentemente nos capítulos sobre teologia e vem lembrar ao leitor que a religião cristã ao menos nos textos sagrados empenha uma finalidade nobre; se a fé do cristão é, como toda fé, obediência, e se essa fé se manifesta em obras, estas obras são a prática da justiça e da caridade que pregam os textos bíblicos. Obedecer a Deus, assim, exige praticar a justiça e a caridade. Entretanto, essa obediência a Deus tem sua necessidade própria (que é a necessidade da lei divina), e só é uma obediência válida na medida em que essa necessidade é vista pelo fiel, e não na medida em que ele obedece com medo de ser casti-

${ }^{122}$ Conforme tradução de Diogo Pires Aurélio, ligeiramente modificada. 
gado por não obedecer; a obediência externa, sem o conhecimento verdadeiro da necessidade da justiça e da caridade (e do que são elas), não vale de nada; por isso, se a obediência sem justiça e caridade não é obediência, a prática da justiça e da caridade já são obediência. O justo e caridoso, eis o fiel cristão. Não à toa, Espinosa se mostra chocado, já no texto do prefácio, por "ver homens que se orgulham por professar a religião cristã, ou seja, o amor a alegria, a paz, a continência e a lealdade para com todos, combaterem-se com tal ferocidade e manifestarem cotidianamente uns para com os outros um ódio tão exacerbado que se torna mais fácil reconhecer a sua fé por estes do que por aqueles sentimentos". Que a verdadeira prática da religião cristã, assim, seja reconhecida como prática da justitia et charitas, e não de qualquer violência contra o que quer que seja, especialmente a natureza de cada um, que exige a liberdade para pensar o que quiser e dizer aquilo que pensa. Sem liberdade de pensamento, não há fé verdadeira, e isto pelo que ensina o próprio texto das Escrituras. Dito isso — que a teologia não tem autoridade política sobre a liberdade de pensamento e que a própria Bíblia nada diz contra essa liberdade de pensamento, assim como mostra que a fé não se dá por proibição do pensar ou do dizer, mas sim por prática da justiça e caridade —, ele anuncia o que tratará na outra parte, sobre a política; o texto original de Espinosa, que trabalha com praticamente todos os conceitos principais do discurso político-jurídico da época (imperium, republica, jus, jure, potestas, potestatis, potentia, libertatis...) e que já antecipa muito da análise crítica e conceitual que Espinosa faz simultaneamente da prática jurídica e do pensamento jurídico, é o seguinte:

\begin{abstract}
Postquam his libertatem, quam lex divina revelata uniquique concedit, ostendi, ad alteram quaestionis partem pergo; nempe hanc eandem libertatem salvâ reipublicar pace, et summarum potestatum jure posse, et etiam concedi debere, nec posse adimi, absque magno pacis periculo, magnoque totius Reipublicae detrimento: ad haec autem demonstrandum a jure naturali uniuscujusque incipio; quod scilicet eo usque se extendit, quo uniuscujusque cupiditas et potentia se extendit, et quod nemo jure naturae ex alterius ingenio vivere tenetur, sed suae unusquisque libertatis vindex est. Praeterea ostendo hoc jure neminem revera cedere, nisi qui potestatem se defendendi in alium transfert, atque eum necessario hoc jus naturale absolute retinere, in quem unusquisque jus suum ex proprio suo ingenio vivendi, simul cum potestate sese defendendi transtulit; atque hinc ostendo, eos, qui summum imperium tenent, jus ad omnia, quae possunt, habere, solosque vindices juris, et libertatis esse, reliquos autem ex solo eorum decreto omnia agere debere. Verum quoniam nemo potestate suâ se defendendi ita se privare potest, ut homo esse desinat, binc concludo, neminem jure suo naturali absolute privari posse, sed subditos quaedam quasi naturae jure retinere, quae iis adimi non possunt sine magno imperii periculo, quaeque adeo ipsis vel tacite conceduntur, vel ipse expresse cum iis, qui imperium tenent, stipulantur. His consideratis ad Rempublicam Hebraeorum transeo, quam, ut ostendam, quâ ratione, et quorum decreto Religio vim juris habere incepit, et obiter etiam alia, quae scitu digna videbantur, satis prolixe describo. Post haec ostendo, eos, qui summum imperium tenent, non tantum juris civilis, aed etiam sacri vindices, et interpretes esse, eosque solos jus habere discernendi, quid justum, quid injustum, quid pium, et quid impium sit: et tandem concludo, eosdem hoc jus optime retinere, et imperium tuto conservare posse, si modo unicuique et sentire, quae velit, et, quae sentiat, dicere concedatur. ${ }^{123}$
\end{abstract}

Esse breve parágrafo do prefácio, sabe Espinosa, não é o seu primeiro texto político nem a sua primeira manifestação política — este papel cabe à defesa perante a Sinagoga judaica de Amsterdã, de catorze anos antes —, mas é a primeira aparição pública da sua teoria da política

${ }^{123}$ Ed. Gebhardt, vol. III, pp. 11, 8-12, 2. 
e direito, e é, também, a primeira aparição, já, da sua defesa da democracia. A leitura de viés do texto do prefácio não permite notá-lo, tanto por causa dos recursos retóricos já utilizados aí por Espinosa, quanto pelas interpretações empreendidas, para os leitores de hoje, pelos tradutores do TTP. ${ }^{124}$ Entretanto, dentro mesmo da construção do prefácio, esse breve e lacônico trecho que anuncia os capítulos finais do tratado mostra não apenas o domínio preciso do latim por Espinosa, ${ }^{125}$ quando mostra, especialmente, o seu conhecimento a respeito das teorias políticas seiscentistas e do vocabulário jurídico do direito romano. Não bastasse isso, mostra a que vêm os textos da teoria política espinosana: mostrar que é necessário fazer teoria política verdadeira, sem estabelecimento de sentidos imprecisos e muito menos sem elogio ao que é necessariamente absurdo diante da natureza da política:

Após evidenciar a liberdade que a lei divina revelada (lex divina revelata) ${ }^{126}$ concede a cada um [...]

O início do parágrafo se refere ao que acaba de ser mencionado, a parte do Teológico-político sobre a teologia; uma das conclusões que ali são trabalhadas, pois, é "a liberdade que a lei divi-

\footnotetext{
${ }^{124}$ Seria interessante empreender uma análise comparativa dessas traduções dos textos políticos de Espinosa. Se é verdade que as traduções dos textos espinosanos produzem, graças a leituras anacrônicas e dificuldades de compreensão do próprio conceito original, recriações de texto que passam a dizer o inverso do que Espinosa escreveu, essa distorção é ampliada na tradução dos textos políticos: aí, como poderemos ver a partir deste ponto, a leitura dos textos de Espinosa é dificultada por uma adaptação teórica que diferentes tradutores produzem, respectivamente à sua formação hobbesiana, teológica, jurídica, contemporânea. Raramente, se é que alguma vez, um texto político de Espinosa foi completamente traduzido com a plena preservação do sentido colocado por Espinosa ali em cada conceito e em cada lugar. O comum é as traduções não perceberem, primeiro, que o vocabulário é essencialmente um vocabulário jurídico seiscentista e, segundo, que a escolha de cada termo por Espinosa é calculada minuciosamente. Absolutamente nenhum conceito político colocado por Espinosa em seus textos pode ser substituído por outro. Quando Espinosa utilizar potestas, esse termo não poderá ser substituído por potestatis, potentia, authoritas, imperium, nem ser interpretado como se fosse um deles. O sentido de cada conceito político espinosano é dado tanto pela escolha do conceito quanto pelo cálculo da utilidade dessa escolha para a crítica ou definição que está sendo elaborada; traduzido o conceito de forma equivocada, perdemos não só o seu sentido espinosano, mas ocasionamos o ocultamento da crítica. O que me leva a pensar que essa opção pela adaptação dos termos em lugar de sua tradução filosófica é muitas vezes uma tentativa de criar uma imagem pejorativa do pensamento político de Espinosa. O grande desafio não só da tradução, mas simplesmente da compreensão da política espinosana, exige esse uso dos conceitos tal como Espinosa os utiliza; só assim a consistência da sua filosofia aparece - e revela toda a sua crítica. 125 Contrariando, portanto, a idéia de que ele teria um latim extremamente pobre (daí também o laconismo de seus textos), já que aprendido relativamente tarde. Se Espinosa é lacônico, é porque exige a precisão conceitual. Se ele utiliza os conceitos correntes de uma maneira diferente daquela já vulgarizada, é porque exige recuperar o seu sentido preciso, seja o dado pela filologia, seja o dado por ele mesmo quando esclarece que está, por si mesmo, dando sentido novo a cada definição.

${ }^{126}$ Como instrumento para a leitura do prefácio, nos utilizamos basicamente da tradução de Diogo Pires Aurélio, estabelecendo ligeiras modificações conforme são apontadas por esta mesma análise desse trecho do prefácio. Com respeito aqui à expressão lex divina revelata, ela recebe as seguintes traduções: Elwes: revealed law of God; Madeleine Francès: Loi divine révélée; Atilano Domínguez: ley divina revelada; Pires Aurélio: lei divina revelada; Shirley: Divine Law; Alessandro Dini: legge divina rivelata; Pierre-François Moreau: loi divine.
} 
na revelada concede a cada um". Ora, antes mesmo de conhecer o que é introduzido no livro através dos capítulos sobre a política, é necessário perceber aqui duas coisas:

Primeiro, a forma como a expressão lex divina revelata é traduzida; alguns tradutores, como Shirley e Moreau, omitem o termo "revelada", como se considerassem que lex divina e lex divina revelata são a mesma coisa. Essa omissão é desde logo problemática porque a lei divina não é, necessariamente, lei revelada, ainda que no horizonte da teologia seja este o seu significado (tanto que é o termo escolhido aqui para o prefácio). Espinosa, aqui, não propõe nada à lex divina, mas sim à lex divina revelata, o que não é sem razões nem sem conseqüências. No capítulo IV do TTP, em que Espinosa trata "Da lei divina", mas também no capítulo V, que trata das cerimônias religiosas, e no capítulo XII, "Do verdadeiro texto da lei divina etc.", a lex divina é definida e analisada em todas as suas acepções espinosanamente pensáveis: lex divina, lex divina universalis, lex divina revelata, lex divina naturalis, lex Dei. Embora, à primeira vista, pareça haver uma sinonímia entre algumas destas expressões, nem sempre essa impressão se confirma no texto de Espinosa; no caso específico da lex divina revelata, a análise espinosana no capítulo IV mostrará que se trata de uma forma equivocada de conceber a lex divina, ainda que seja a forma pela qual esta é vulgarmente concebida (a saber: um comando de Deus para a ação humana na terra, pelo que Deus é uma autoridade sobre as ações humanas, nos mesmos termos em que um governante político seria). Por enquanto, o que interessa diante do leitor do prefácio é anunciar que essa lex divina, tal como concebida por ele mesmo, não é incompatível com a liberdade de pensamento e expressão, que é já constatada por Espinosa como uma necessidade natural no homem. Antes de empreender qualquer análise da teologia e especificamente do conceito de lex divina, Espinosa já antecipa a questão política a ser trabalhada no campo da teologia: a necessidade de não haver nenhum impedimento, por parte das instituições religiosas, à liberdade de pensamento. A princípio, não há nenhuma heresia aí, ainda que a tese já seja por todos os motivos preocupante para uma autoridade eclesiástica; o aspecto subversivo e herético, porém, aparecerá plenamente quando Espinosa definir a lex divina e analisar a lex divina revelata, no capítulo IV. 127

Segundo, o prefácio já mostra que lex é um termo válido para o vocabulário teológico, mas jus não. Nos parágrafos do prefácio em que anuncia o que será trabalhado na parte sobre a teologia, e nos próprios capítulos dedicados àquela, não aparece a definição muito menos a análise do jus. Por algum motivo - que aparece quando compreendemos o sentido do termo jus e, principalmente, o sentido verdadeiro da expressão lex divina — Espinosa não fala aí de jus divinum: esta é outra expressão carregada pelo pior da concepção vulgar da lex divina, que vem não

127 Voltaremos a isto no próximo tópico, 2.III (“Jus sive potentia: lex sive potestas"). 
apenas da teologia judaico-cristã, mas principalmente da teologia política cristã, segundo a qual o jus divinum é a lex divina revelata, ou seja, o direito divino é uma autoridade de Deus no mundo secular e político. Com respeito à expressão jus divinum, Espinosa também elaborará uma crítica que lhe acusa sua irracionalidade, ${ }^{128} \mathrm{e}$, com respeito ao termo jus em geral, nessa parte sobre a teologia ele no máximo dedica menções esporádicas a direitos que, aí, não têm tanta relevância dentro das análises efetivamente desenvolvidas. Essa análise do jus só aparecerá quando chegar o capítulo XVI, ou seja, quando estivermos já dentro da análise da política. Com respeito à lex, que, como o termo jus, pode também dizer respeito à política, especificamente quando concebida como lex humana, ${ }^{129}$ não há por toda a parte sobre a teologia uma exposição da sua aplicação no plano do Estado e da política (embora o capítulo IV já deixe pelo caminho a definição da lex bumana, que repercutirá de outra forma nos capítulos finais); entretanto, como aí se trata já de analisar a lex divina, é evidente a necessidade de definir a lex em geral. Ora, a maneira como Espinosa define a lex humana no capítulo IV não coloca ainda a sua necessidade política (que terá a forma da democracia, quando chegarmos aos capítulos finais), assim como a compreensão do que é uma lex divina não exige aí a concepção do que é uma lex humana (embora a compreensão do que é uma lex divina, assim do que é uma lex humana, exijam respectivamente a idéia de $\left.l e x^{130}\right)$. Estabelecido isto — que há uma lex concebível no plano da teologia e da religião que não é lex no sentido político, ao mesmo tempo que há uma necessidade política imposta à teologia (permitir a necessária liberdade de pensamento e expressão) —, Espinosa anuncia enfim a parte sobre a política:

[...] passo a outro aspecto da questão, o qual consiste em mostrar que essa mesma liberdade pode e deve ser concedida, sem que isso lese a paz pública (reipublicae pace) $)^{131}$ e o direito das potestades soberanas (summarum potestatum jure) ${ }^{132}[\ldots]$

\footnotetext{
128 O que também veremos no próximo tópico.

${ }^{129}$ Isso já é anunciado no início do capítulo IV, quando Espinosa considera que isso a que se dá o nome de lei humana (lex bumana) mereceria mais propriamente ser chamado de jus (direito). O que, como ainda veremos, é também uma crítica tanto à idéia de lex bumana quanto à idéia de jus.

130 A propósito, será no que têm de pior que lex humana e lex divina poderão se aproximar: ambas serão um instrumento voltado para a imaginação daquele que não tem potência racional suficiente para compreender a necessidade da ação na vida comunitária, seja na comunidade religiosa ou nacional, seja na comunidade política ou civil. Como diz Diogo Pires Aurélio, num artigo em que investe no conceito espinosano de nação como um resultado das leis e dos costumes, "a lei [...] é o rosto com que o conjunto das potências individuais aparece na imaginação de cada um. Como figura imaginária, como processo cuja fundação assenta no plano passional e não no plano racional, a lei apresenta-se sempre, no domínio político, como lei particular, delimitada por fronteiras - territoriais ou espirituais - sem poder ser pensada e vivida como universal. Uma vez escrita, incorporada numa língua e remetida para uma narrativa mítica, a lei traça um corte entre aqueles que se lhe submeterem e os que lhe são traidores ou obedecem a outra lei. A lei, em resumo, consagra institucionalmente e torna vinculante o que, hisoricamente, não foi senão fruto das circunstâncias" ("Natureza e nação segundo Espinosa", pp. 297-298).

131 Tradução Elwes: safety to the state; Francès: paix intérieure; Atilano: paz del Estado; Pires Aurélio: paz social; Shirley: public peace; Dini: pace dello Stato; Moreau: paix de la république.
} 
Em que medida é válida, desde logo, essa separação entre a análise da teologia e a análise da política? Pelo que mostrarão os capítulos do TTP e pelo que já anuncia discretamente o prefácio, é o fato dos dois campos serem necessariamente distintos: teologia e política utilizam vocabulários que, numa perspectiva racional, não podem ser o mesmo vocabulário. Os conceitos da teologia ou para o pensamento teológico e os conceitos válidos para o pensamento políticojurídico são necessariamente distintos por causa da sua diferença de natureza; quando se imagina não só a prática política como associada à teologia, mas também quando se imagina e se elabora o pensamento político com o vocabulário da teologia, é impossivel a formação de um pensamento verdadeiro acerca da política. No que diz respeito aos termos jurídicos em questão, eles mesmos servem para mostrar a distância que o objeto da análise da política guarda em relação ao objeto da análise da teologia e da religião: só a lex divina revelata seria objeto de análise exclusivamente da teologia, ao passo que na análise da política entrará uma série de termos autenticamente político-jurídicos: jus, imperium, potestas...

A mesma liberdade de pensamento que não impede a prática da religião, é então apontada por Espinosa como inofensiva, no campo da política, à reipublicae pace e ao summarum potestarum jure. Como compreender estes termos, decididamente político-jurídicos? A expressão reipublicae pace representa aquilo que Espinosa já coloca, no início do prefácio, como finalidade do Estado:

E já que nos coube em sorte esta rara felicidade de viver numa República (Republica), onde se concede a cada um inteira liberdade de pensar e de honrar a Deus como lhe aprouver e onde não há nada mais estimado nem mais agradável do que a liberdade, pareceu-me que não seria tarefa ingrata ou inútil mostrar que esta liberdade não só é compatível com a liberdade e paz pública (hanc libertatem non tantum salva pietate, et Reipublicae pace concedi), como inclusivamente, não pode ser abolida, sem se abolir, ao mesmo tempo, a paz pública e a piedade (Pace Reipublicae, ac pietate). ${ }^{133}$

O que é essa paz? Espinosa nunca a define, em nenhuma das suas obras. Mas o uso que faz do termo é sempre voltado para a experiência do leitor e, principalmente, a pax sempre é a-

132 Tradução Elwes: magisterial authority; Francès: souveraine Puissance; Atilano: poderes supremos; Pires Aurélio: autoridades soberanas; Shirley: civil authoritates; Dini: supreme potestà; Moreau: Souverain. Diferentemente de poder soberano, aqui se trata daqueles que detêm o poder soberano: as autoridades soberanas. No pensamento jurídico seiscentista, ser uma autoridade soberana implica ter o imperium, isto é, o jus ou potentia de legislar ou de determinar o legítimo (coisa que mais adiante Espinosa considera perfeitamente assegurável, desde que cumprida uma condição específica: a liberdade de pensamento e expressão do pensamento). A propósito dessa idéia de soberania enquanto direito de legislar, cf. Dennis Lloyd, $A$ idéía de lei, p. 211: “[...] a idéia moderna de soberania está mais associada ao poder supremo de legislar do que à suprema autoridade executiva ou judicial para entrar em guerra, impor sentenças de morte, administrar o país em seus negócios cotidianos e atuar como tribunal final para resolver disputas entre súditos. O soberano no uso presente é, portanto, aquela pessoa ou órgão que age como legislador supremo numa dada comunidade. É em conseqüência do seu poder para mudar a lei que tal legislador é considerado o detentor da autoridade legal suprema no Estado, a que outras autoridades, legislativas, executivas ou judiciárias se subordinam, pelo menos teoricamente".

133 Conforme tradução de Diogo Pires Aurélio. 
companhada de um outro termo que funciona como reforço do seu sentido: caridade, concórdia, liberdade, tranqüilidade, piedade, sossego. No trecho acima, em que Espinosa anuncia ainda o que motiva à sua reflexão, ele indica duas esferas de pax que estão no horizonte seja da religião (Pace Reipublicae e pietas), seja da política (Pace Reipublicae e libertas). Ora, a pietas é a exigência essencial da vida religiosa e Espinosa sempre elogiará a piedade e tomará o cuidado de apontar o caminho que permita preservá-la (é nisto que consiste a fé) sem perigo de produzir as práticas incorretas da religião; e, no caso da política, a libertas é o horizonte constante da vida humana já enquanto indivíduo, ampliada e multiplicada quando se reconhece na vida coletiva ou política: tão importante quanto a piedade na vida religiosa, é a liberdade na vida política ou melhor, na vida humana. Horizontes unanimemente reconhecidos como válidos para os agentes de cada campo, pietas e libertas revelam-se, respectivamente na religião e na política, finalidades a perseguir necessariamente, e nenhum teólogo assim como nenhum jurista poderá negar o valor de um ou outro desses fins. Em Espinosa, cuja filosofia abole a idéia de finalismo governando as ações e o mundo, pietas e libertas não são válidos, verdadeiramente, porque sejam concebidos como finalidades, mas sim porque são necessidade atual de cada um, enquanto ser religioso e enquanto ser político. A pietas na vida religiosa, e a libertas na vida política, são duas formas de se conceber a mesma atividade individual que é cultivo da própria potência: assim como a libertas é autodeterminação da ação (seja na ética, seja na política), a pietas é a expressão, na religião, da libertas. É por isso que é possível a Espinosa, apesar de separar os campos da teologia e da política, conceber verdadeiramente em um e outro uma atividade necessária segundo a natureza do agente, e estabelecer, por meio de uma idéia de pax, uma identidade entre ambas as ações, sem as quais, tanto num campo quanto no outro, o indivíduo é servo. Entretanto, no ato dessa identidade entre pietas e libertas, Espinosa retira do elo entre ambas ( $\operatorname{cax}$ ) o sentido exclusivamente moral ou físico do termo (serenitas, tranqüilitas) e indica um sentido político: Reipublicae Pace. Como entender essa expressão? Que ela é política, não há dúvida, porque o uso do termo reipublicae pace exige a concepção de uma entidade coletiva ou de uma comunidade; não exige, porém, a concepção de um Estado separado dos súditos ou cidadãos, nem a condição de um arbitrarismo no uso do poder: a expressão reipublicae pace não pode ser traduzida por nada que permita conceber esse tipo de situação. O prefácio (assim como depois, nos capítulos sobre a política) não parte da separação entre os regimes políticos da república e do principado, ${ }^{134}$ embora o trecho acima citado localize a Holanda em que Espinosa escreve e cuja liberdade ironicamente elogia como sendo uma Republica: como mostrará a teoria espinosana do Estado, os

${ }^{134}$ De que parte O príncipe de Maquiavel: "Todos os estados, todos os domínios que tiveram e têm poder sobre os homens foram e são ou repúblicas ou principados". Tradução de Maria Júlia Goldwasser, cap. I, p. 3. 
regimes políticos formalmente são monarquia, aristocracia ou democracia. A Republica da expressão reipublicae pace não é, certamente, o regime político republicano que se diferencia do principatus: ela é a própria comunidade política. A expressão reipublicae pace, portanto, não significa uma pax impossível de ser pensada ou instituída nos ditos principados, assim como não significa que só pode ser conquistada num regime político republicano por se tratar de uma regime político. A reipublicae pace é uma pax referente à vida coletiva independente do regime político, de modo que diz respeito à coisa pública que envolve tanto quem tem poder quanto quem está sob esse poder. A "paz do Estado”? Espinosa por vezes utiliza um termo específico para significar a organização social, ou a organização da sociedade política: Civitas. Se ele quisesse significar uma pax das autoridades que detêm o poder e que por este poder organizam a sociedade, teria falado de Civitas e não de Reipublica. A opção por Reipublicae pace mostra que Espinosa considera que essa pax não é efetiva apenas sobre um poder, sobre uma autoridade, sobre uma Cidade em particular, mas sim sobre a coisa pública que a vida política necessariamente é. Reipublicae pace, por isso, é a paz pública que, ao ser perturbada, é perturbação já de tudo o que envolve a vida política: governantes e governados, Estado e sociedade, cidadãos e autoridades... Entretanto, para que fique claro que a pax que se perde, se não é uma paz exclusiva da autoridade política concebida como separada dos súditos ou cidadãos, também não é uma paz exclusiva dos súditos e irrelevante para o Estado ou a Cidade, essa Reipublicae pace também não é paz do povo, somente. Ao escolher a expressão Reipublicae pace, Espinosa mostra que, quando não há liberdade de pensamento, atormenta-se por isto não apenas a pietas no plano da religião e a libertas no plano da política, como toda a vida humana, e para cada um, torna-se turbulenta. É a paz pública que é necessidade de qualquer indivíduo ou autoridade definidos pela vida política; quando essa paz não existe ou é perturbada, simultaneamente não são preservadas nem a piedade, nem a liberdade. Conclusão: se a paz pública é finalidade da vida política, da prática política e mesmo do poder do Estado, que tanto seja baseada na liberdade de pensamento como no cultivo da piedade e da liberdade, porque estas, em seus campos distintos, são a forma individualizada em cada campo da própria paz pública.

Se assim é, o que significa a inclusão, no anúncio do que será analisado na parte sobre a política, do direito das potestades soberanas (ou seja, as autoridades soberanas, as autoridades políticas, os soberanos) graças à expressão hanc eandem libertatem salvâ reipublicae pace, et summarum potestatum jure posse, et etiam concedi debere ("essa mesma liberdade pode e deve ser concedida, sem que isso lese a paz pública e o direito das potestades soberanas")? Quando Espinosa trata exclusivamente da política (cinco capítulos finais do TTP e totalidade do TP), ele sabe ter diante de si um leitor cuja leitura é principalmente jurídico-política. Finalizado o percurso dos capítulos 
anteriores do TTP, esta parte chama mais a atenção desse tipo de leitor e, talvez, perca interesse da parte do leitor teólogo; ainda que parte de um tratado que versa sobre a teologia, essa parte se permite uma conceituação mais precisa em termos políticos. Aí, justamente, aquela libertas que acompanhava a reipublicae pace na primeira aparição desta expressão agora deve ser mostrada como de interesse daquele que deve permitir, na vida política, a liberdade de pensamento e expressão, ou seja, aquele ou aqueles que detêm a summa potestatis, a potestade suprema, ou os postos soberanos do governo, acima dos quais, numa disposição hierárquica (tal como os juristas da época - assim como os contemporâneos — concebem a organização das várias autoridades político-jurídicas particulares dentro do Estado), não há autoridade política alguma e sob os quais só pode haver súditos. O que torna, justamente, aquela libertas uma finalidade dessa autoridade soberana, é concebê-la como o jus que lhe é próprio. Mas que direito é esse que cabe à autoridade política e que não será perturbado se se permitirem as liberdades necessárias dos súditos? Trata-se de um jus que só cabe à autoridade suprema: o imperium, ou poder de comandar. E nada mais. Seja como for esse imperium, seja como for essa reipublicae pace, a liberdade de pensamento não pode ser incompatível com ela. Mas há mais: a liberdade de pensamento é a condição para a preservação tanto da reipublicae pace quanto do summarum potestatum jure:

[...] e que, pelo contrário, não pode ser suprimida sem graves riscos para a paz e em detrimento de toda a república (Reipublicae).

Essa afirmação constitui a primeira crítica direta feita por Espinosa ao absolutismo e ao autoritarismo, ou simplesmente à concepção de que a autoridade pode ser legítima pelo simples fato de ser autoridade. Ao considerar que há, de um lado, súditos a quem deve ser concedida a liberdade de pensamento e expressão e, de outro, uma autoridade política a quem cabe concedê-la, e ao também afirmar que a própria autoridade política não se sustenta se não concede tal liberdade, Espinosa afirma que a base do poder e do direito das autoridades políticas depende diretamente da liberdade dos súditos ou cidadãos: sem liberdade pública, o Estado é condenado ao detrimento, à destruição. Esse princípio conduzirá toda a concepção espinosana do Estado e do direito, assim como dependerá de um argumento fundamental, a fundação no anticonceito espinosano de direito natural, que agora aparece pela primeira vez:

Para demonstrar esse ponto, começo, porém, pelo direito natural de cada um (jure naturali uniuscujusque), ${ }^{135}$ que vai até onde for o seu desejo e a sua potência (uniuscujusque cupiditas et potentia), ${ }^{136}$ sem que

\footnotetext{
135 Tradução Elwes: natural rights of the individual; Francès: droit de nature en lindividu; Atilano: derecho natural de cada individuo; Pires Aurélio: direito natural do individuo; Shirley: natural right of the individual; Dini: firitto naturale di ciascuno; Moreau: droit naturel de chacun.
} 
alguém esteja, com base no direito de natureza (jure naturae), ${ }^{137}$ obrigado a viver segundo a índole de outrem (ex alterius ingenio) ${ }^{138}$ e sendo, em vez disso, cada um o defensor da sua própria liberdade (unusquisque libertatis vindex est). ${ }^{139}$

A análise da política se inicia a partir da análise do direito natural e do direito de natureza, nos primeiros parágrafos do capítulo XVI do TTP. A idéia de que a liberdade deve estar no horizonte da política porque isso não só não é incompatível com a paz pública e o direito das autoridades soberanas como também é sua condição, é um pressuposto da análise da política que vem demonstrado, já, pelas considerações a respeito da teologia; a análise da teologia, a seu modo, mostra que a natureza humana exige liberdade de pensamento e que a supressão desta causa turbulência na vida humana, individual ou coletiva. Por ser uma questão de natureza humana, cabe em qualquer circunstância, inclusive na política; daí, ser pressuposto necessário antes que se inicie, e por ser verdadeiro deverá ser confirmado pelas teses sobre a política. Se a necessidade da liberdade não fosse já pressuposta, esta análise da política não seria iniciada por Espinosa a partir do argumento do direito natural: é a concepção prévia de que nenhuma concepção ideal ou prática da política pode ser adversa à realidade natural do homem, que indica que o ponto de partida para qualquer concepção realista sobre a política deva partir de uma análise da natureza da política. Ora, porque a política é o campo da vida humana coletiva, porque aí o ser humano não perde a sua própria natureza, e porque esta natureza é a própria essência humana, é preciso conhecê-la. É preciso iniciar qualquer consideração sobre a política e o direito a partir do reconhecimento prévio de que a natureza jamais pode ser desconsiderada; e para que esse princípio se verifique já nas bases da análise, é da constatação da natureza humana que se deve partir. Essa constatação da natureza humana é, nas bases da teoria política espinosana, a exploração do argumento clássico do jusnaturalismo sobre o direito natural, porque o jusnaturalismo da época concebe em termos de direito natural, estado de natureza e de contratualismo a análise da natureza humana como fundamento naturalista para a reflexão so-

\footnotetext{
136 Tradução Elwes: his desires and power; Francès: le désir et la puissance de chacun; Atilano: el deseo y el poder de cada uno; Pires Aurélio: o seu desejo e a sua potência; Shirley: individual's desire and power; Dini: il desiderio e la potenza di ciascuno; Moreau: son désir et sa puissance.

137 Tradução Elwes: [omitido]; Francès: droit de nature; Atilano: derecho de naturaleza; Pires Aurélio: em tal direito; Shirley: natural right; Dini: diritto di natura; Moreau: le droit de nature.

138 Tradução Elwes: as another pleases; Francès: comme il plait à un autre; Atilano: segundo el criterio de otro; Pires Aurélio: segundo o mando de outrem; Shirley: as anoher pleases; Dini: al modo di un altro; Moreau: selon la complexion d'un autre.

139 Tradução Elwes: is teh guardian of his own liberty; Francès: chacun assure, en personne, la garantie de sa liberté; Atilano: cada um es el garante de su propria libertad; Pires Aurélio: sendo cada um o responsável da sua própria liberdade (o que seria um enfraquecimento do termo: vindex rigorosamente significa aquele que reclama ou reivindica alguma coisa em juízo, ou reclamante; aquele que defende algo contra outrem; que pune, vinga; "responsável", em português, sugere responsabilidade moral, inclusive pelo conteúdo que tradicionalmente o direito atribui a esse termo); Shirley: each man being the guardian of his own freedom; Moreau: chacun est le défenseur de sa propre liberté.
} 
bre a política. No caso de Espinosa, o que ocorre? Ele reconhece, em primeiro lugar, que a análise da política deve sempre manter um necessário realismo: "Aplicando-me à política não quis aprovar fosse o que fosse de novo ou desconhecido, mas somente demonstrar por razões certas e indubitáveis aquilo que melhor concorda com a práxis"; 140 mas esse realismo consiste em expor na natureza de cada coisa tal como ela é e não tal como se imagina que devesse ser... quando os jusnaturalistas concebem a vida civil como fuga de um estado de natureza, é claramente uma concepção imaginativa para Espinosa, pois ela nem mostra o que é a realidade da natureza, nem qual é a natureza da vida política.

Antes de compreender o que é o estado civil, pois, será preciso compreender fundamentalmente o que é o estado de natureza, ou essa condição na qual a liberdade é necessariamente liberdade natural. Todavia, em lugar de partir de uma definição do estado de natureza, ou da separação entre estado de natureza e estado civil (que é, aliás, o que faria um jusnaturalista), a definição que ele apresenta primeiramente no argumento que abre a teoria política do TTP é a definição de direito natural, no início do capítulo XVI do TTP chamado de jus et institutum naturae, direito e instituição de natureza:

Por direito e instituição de natureza entendo unicamente as regras da natureza de cada indivíduo, regras segundo as quais concebemos qualquer ser como naturalmente determinado a existir e a operar de uma certa maneira. ${ }^{141}$

E, no Tratado político:

Por direito natural, portanto, entendo as próprias leis ou regras da Natureza segundo as quais tudo se faz, isto é, a própria potência da Natureza. ${ }^{142}$

É interessante notar desde logo que essa definição do direito natural mantém a forma utilizada por Espinosa nas definições da Ética: per... intelligo... (“por... entendo..."). É uma definição apropriada a uma exposição geométrica (e o cap. XVI é o principal momento geométrico do TTP), válida porque põe um sentido que é sustentado pelas proposições a respeito da experiência e não porque seja baseada diretamente numa constatação empírica: em vez de constatar um jus et institutum naturae e descrevê-lo, ele apresenta uma definição que deverá dar conta do que se verifica na experiência e do que a razão compreende da realidade; sendo incompatível o que a razão perceba a partir de certo ponto sobre a realidade, a definição torna-se insustentável; não havendo essa incompatibilidade, ela se mantém como definição verdadeira. Significa que sua verdade ou validade não vem de sua correspondência com uma realidade empírica observada,

\footnotetext{
140 Tratado politico, cap. I, $\int 4$.

141 Tradução de Diogo Pires Aurélio.

142 Tratado político, cap. II, $\int 4$; tradução de Manuel de Castro.
} 
mas da consistência do próprio sistema argumentativo aberto pela definição. A definição não é, assim, constatação primeira do objeto que se pretende analisar, mas é elemento conceitual fundamental para a construção de uma compreensão das proposições que podem ser apresentadas a respeito da coisa definida. O direito natural que Espinosa aqui define não é, desde logo, um direito natural que a experiência empírica mostra e que a razão reconhece; é um conceito que, numa compreensão racional da experiência da necessidade da liberdade, permite articular sua compreensão de uma maneira consistente e, por isso, verdadeira; por isso, também, Espinosa pode nomear essa entidade da maneira que quiser, desde que evidencie o significado atribuído ao que recebe a denominação. ${ }^{143}$ Todavia não é, por causa disso, uma concepção idealista, na medida em que sua formulação é resultado de uma compreensão racional, já, da experiência da necessidade da liberdade; a definição tem como função, apenas, apresentar uma compreensão precisa do que a razão já conhece, assim como sua concepção não tem contradição com a ex-

143 Como nota Marilena Chauí (A nervura do real, vol. 1, p. 36), "no que tange aos conceitos fundamentais de sua filosofia, diferentemente de seu amigo Koerbagh, Espinosa não julga necessário criar neologismos, bastando-lhe as definições 'per... intelligo' ('por... entendo').” Adriaan Koerbagh, médico e jurista, "publica um Corpus Juris cujas idéias estão próximas das de Hobbes e do naturalismo político que começa a surgir na Holanda. Inconformado com as disputas teológicas calvinistas e com a intolerância do clero gomarista, publica, em 1668, um dicionário, Een bloemhof van allerley lieflijkheid sonder verdriet, geplant door $V$ reederijk Waarmond, ondersoeker der waarheyd, tot nut en dienst van al die geen, die der nut en dienst uyt trekken, wil (Um jardim florido composto de todas as coisas amáveis, plantadas por Pacífico Boca Sincera, buscador da verdade, para uso e proveito de todo homem que queira usá-lo e aproveitá-lo), no qual os verbetes oferecem o sentido das palavras em sua língua de origem, o sentido adquirido em latim ou grego, se a palavra fosse de origem hebraica, a pseudo-romanização e helenização de termos holandeses e a confusão do sentido atual sob os efeitos das seitas religiosas, das disputas teológicas e das lutas políticas, propondo um uso correto e transparente, em holandês. Koerbagh estava convencido de que a maior parte das lutas teológico-políticas provinha de qüiproquós de linguagem e acreditava contribuir para a paz da República e a liberdade de pensamento com uma purificação da linguagem. Há, nessa primeira obra, ainda, para o caso de idéias novas que se perderiam se transcritas para uma das línguas existentes, a proposta de neologismos, como por exemplo, ipsantie, para substituir substantia. Define ipsantie: 'Entidade independente, existente em si, que não necessita de nada mais para existir, entidade única, a saber, Deus, ou o Ser sem começo. Existem inumeráveis dependentes que dependem dessa única entidade independente'. Reconhecemos aí uma primeira versão da substantia espinosana. No mesmo ano da publicação de Een bloemhof, Koerbagh decide publicar um novo dicionário, mais sistemático do que o primeiro, o Een ligt schijnende in duyistere plaasten, om te verligten de voornaamste saaken der Gods ondersoeker der Waarheid (Uma lez brilhante em lugares escuros para iluminar os pontos essenciais da teologia e da religião); essa luz havia sido acesa também por Pacífico Boca Sincera, buscador da verdade, mas o editor interrompeu a edição por considerar a obra ímpia porque, à maneira de Hobbes no Leviatã, Koerbagh redefine palavras do vocabulário religioso, jurídico e político em termos históricos, mas num tom irônico e irreverente que não encontramos no filósofo inglês. Koerbagh é chamado a depor perante o Consistório, é torturado e condenado à prisão. Suas obras são proibidas. Morre na prisão, em 1669, vítima dos maus-tratos físicos e psíquicos” (M. Chauí, op. cit., pp. 14n-15n, n. 71). Espinosa, que decide a partir de 1665 escrever seu Tratado teológico-político contra "os preconceitos dos teólogos", ainda terminará a obra sob o impacto da morte do amigo e contra essa prática intolerante de perseguição civil e religiosa; de forma alguma, pois, cabe considerar que Espinosa tinha orgulho de ser holandês (como considera Atilano Domínguez, na sua tradução do TTP, p. 73, nota 15); na ironia do seu elogio à liberdade de pensamento existente na república holandesa (final do prefácio do TTP), Espinosa na verdade denuncia o absurdo da intolerância intelectual que só será confirmada a partir da publicação do Tratado. 
periência a que se refere, o que pode ser comprovado, a propósito, pela demonstração do que se afirma pela articulação do que já está definido.

Nos capítulos anteriores do TTP, o direito natural só havia aparecido uma vez, no início do capítulo IV (sobre a lei divina), e como consideração a respeito da experiência:

[...] que um homem, quando se lembra de uma coisa, imediatamente se lembre de outra que lhe é parecida ou de que se tinha apercebido em simultâneo com a primeira, é ainda uma lei que segue necessariamente da natureza humana (lex est, quae ex naturâ bumanâ necessario sequitur). Que, pelo contrário, os homens cedam ou sejam obrigados a ceder uma parte do seu direito, que por natureza têm (de suo jure, quod ex natura babent), e assumam viver segundo uma certa regra, isso depende de uma decisão sua.

Ora, aí não aparece efetivamente nenhuma definição do direito natural. O que aí está sendo definido, aliás, é um conceito posto como certamente distinto da idéia de direito natural, a "lei que segue necessariamente da natureza humana", que é mesmo retomada na seqüência do argumento. O capítulo IV, que estabelece as diferenças entre as leis humanas, as leis divinas e as leis naturais, mostrará a necessidade de todas elas e recusará sentido a qualquer lei que é seguida não por sua necessidade, mas por temor de conseqüências funestas ou esperança de recompensa. Essa consideração sobre a necessidade, aqui, cabe exclusivamente à lex, e não ao jus. Sobre o jus naturae, há apenas essa menção que sem dúvida é uma crítica a Hobbes, mas não aproveita o mote para mostrar, aqui, que necessidade há no direito (jus); isso, por algum motivo, só ocorre no capítulo XVI, quando Espinosa passa para a análise da política: é porque o jus é um termo que só tem algum sentido racional no horizonte da política; mesmo no horizonte da teologia, o jus não pode ser concebido como um conceito racional, pois no campo da teologia, assim como no campo da religião natural, a política, campo do poder, não tem nem pode ter lugar, ao mesmo tempo que a lex divina, destituída dos sentidos supersticiosos ou irracionais que pode receber, não mantém nenhum sentido de dominação, mas, ao contrário, mostra-se também proporcional à potência, porque consciência da necessidade do direito, que é a potência. ${ }^{144}$

Entretanto, está sendo aproveitada nessa definição de direito natural dada no capítulo XVI a definição de uma coisa analisada já naquele capítulo IV (portanto, que é válida já fora do horizonte da política, mas que também será válida nele), a lei de natureza: ao definir, nesse início do capítulo XVI, o direito natural na forma extensa direito e instituição de natureza, temos aí incorporada a idéia de lei natural, graças à presença do termo instituição. O que é confirmado pelo definiens: "as regras da natureza de cada indivíduo, regras segundo as quais concebemos qualquer ser como naturalmente determinado a existir e a operar de uma certa maneira". O capítulo IV começa de-

\footnotetext{
144 Assunto a que voltaremos no tópico III deste capítulo ("Ius sive potentia: lex sive potestas") e no capítulo
} 4.I (“O direito positivo, um instrumento para a razão"). 
finindo o que é a lei em sentido absoluto: "significa aquilo que faz um indivíduo, ou todos, ou alguns de uma mesma espécie, agir sempre de uma certa e determinada maneira", e da qual há duas formas: a "lei que depende da necessidade natural", isto é, a lei natural ou lei necessária ("é aquela que deriva necessariamente da própria natureza, ou seja, da definição de uma coisa") e a "lei que depende da decisão humana", isto é, a lei humana, que aliás "se chamaria com mais propriedade direito" ("é aquela que os homens, para tornar a vida mais segura e mais cômoda, ou por outro motivo qualquer, prescrevem a si e aos outros"). A princípio estamos diante de uma distinção tipicamente tomista ou (em outro sentido) aristotélica, ${ }^{145}$ mas ao explicar que a lei humana, na verdade, "deriva, necessariamente embora, da humana potência", Espinosa mostra que, em sentido, absoluto, toda lei é necessária, isto é, toda lei é natural, no sentido de que determina à ação não porque é um modelo de ação, mas porque é a própria necessidade de ação do agente a que se refere enquanto lei. Numa palavra, uma ação é adequada quando o agente age por necessidade da sua natureza; se cabe considerar um guia ou índice para a ação a lei —, esta deve ser expressão da necessidade da ação, que em si mesma é determinada, já, pela potência do agente: a potência é necessariamente anterior à lei que a concebe como direito. Por isso, mesmo quando consideramos uma lei tipicamente humana, civil, positiva, trata-se de uma convenção cujo fundamento e racionalidade também depende, "necessariamente embora", da necessidade natural: a racionalidade da instituição civil depende da necessidade da instituição de natureza, presente, enfim, na definição do direito natural ao início do capítulo XVI. Já há na natureza, portanto, uma instituição; mas não no estado de naturez̧a (essa situação de ausência de estado civil, segundo Hobbes e demais jusnaturalistas), e sim na natureza da liberdade humana (que é, espinosanamente, autodeterminação segundo a própria potência necessária: aqui nada que seja incompatível com a índole — ingenio — do agente pode ter validade racional ou, no plano da vida política, legitimidade).

Que é, pois, falar do estado de natureza? Não é descrever ou supor uma situação sem poder político, mas é mostrar a necessidade natural que é a base até mesmo do poder político e do es-

\footnotetext{
145 Aristóteles, Ética a Nicômaco, v, 7: "Da justiça política, uma parte é natural e outra parte legal: natural, aquela que tem a mesma força onde quer que seja e não existe em razão de pensarem os homens deste ou daquele modo; legal, a que de início é indiferente, mas deixa de sê-lo depois que foi estabelecida: por exemplo, que o resgate de um prisioneiro seja de uma mina, ou que deve ser sacrificado um bode e não duas ovelhas, e também todas as leis promulgadas para casos particulares, como a que mandava oferecer sacrifícios em honra de Brásidas, e as prescrições dos decretos. [...] As coisas que são justas em virtude da convenção e da conveniência assemelham-se a medidas, pois que as medidas para o vinho e para o trigo não são iguais em toda parte, porém maiores nos mercados por atacado e menores nos retalhistas. Da mesma forma, as coisas que são justas não por natureza, mas por decisão humana, não são as mesmas em toda parte. E as próprias constituições não são as mesmas, conquanto só haja uma que é, por natureza, a melhor em toda parte". Cf., a propósito, P. Aubenque, "La loi selon Aristote", p. 148, e E.C.B. Bittar, A justiça em Aristóteles, p. 98.
} 
tado civil. Se este não se sustenta na sua própria necessidade natural, provoca seu detrimento, como anunciara já o prefácio do TTP: "essa liberdade [...] não pode ser suprimida sem graves riscos para a paz e em detrimento de toda a república". A liberdade de pensamento e expressão não é uma dádiva da autoridade: é condição da sua própria legitimidade e preservação. Definir o direito natural, assim, significa expor a natureza da necessidade política, e não a diferença da vida política ou a ausência da vida política. Para que o leitor do TTP, esse leitor cristão acostumado com os tratados de teologia política vindos tanto do direito canônico quanto dos tratados protestantes e ainda do próprio direito romano, possa compreender o que é essa necessidade natural da política ou porque essa necessidade política é natural, a expressão jus naturae cai como uma luva, e certamente se aplica aos seres humanos na medida em que são, também, seres naturais. Mas a expressão jus naturae, com relação a este ser natural que é o homem, e que continua natural ainda que em estado civil (porque é da natureza humana reconhecer a utilidade da vida política para o exercício mais livre da sua potência), não significa, de forma alguma, uma ordem da natureza que deve ser seguida pelos homens nas suas ações e na sua liberdade (que é o que diriam os estóicos e o que lêem, em Espinosa, os leitores dos estóicos), mas sim “aquilo que faz um homem, ou todos, ou alguns [...], agir sempre de uma certa e determinada maneira [...] para tornar a vida mais segura e mais cômoda, ou por outro motivo qualquer, prescrevem a si e aos outros"; porque o jus naturae é institutio naturae nesse sentido, conceber uma lei natural é conceber a necessidade da potência, e conceber um direito natural é conceber a eternidade dessa necessidade: se a lei é consciência da necessidade de um direito, o direito, sendo a própria potência, pede sua eternidade, isto é, seu exercício, já por necessidade natural. Nessa perspectiva, quem vem primeiro, a lei natural ou o direito natural? Ambos são simultâneos, porque imanentes um ao outro, e ambos redutíveis à potência, ainda que a lei tenha, com relação ao direito, a adicional condição de índice exterior da ação. A validade dessa exterioridade institucional na lei e a eternidade dessa potência necessária no direito, porém, só se produzem em simultâneo. Traduzindo o sentido: um direito só existe quando é exercido em função da sua necessidade, assim como uma lei só é eficaz quando obedecida em função da sua necessidade.

Dada a definição de direito natural (que envolve, pois, a definição de lei natural), Espinosa mostra, por um exemplo, que esse direito se observa já sem qualquer referência à política. Assim, para explicar a definição, ele parte de um exemplo que vale para os seres naturais, e por isso utiliza o exemplo dos peixes, antes de apresentar um exemplo que envolva os homens que, apesar de também serem seres naturais, são dotados de razão e vontade, que na tradição argumentativa em volta do direito natural são o que leva o ser humano a realizar uma ação não por direito natural, mas por outra regra; embora, em Espinosa, a razão mantenha toda a sua na- 
turalidade e não signifique em momento algum qualquer anulação ou controle da potência natural do indivíduo, é preciso aqui, na primeira explicação da definição do direito natural, mostrar que a realidade deste independe da vontade e da razão, mas é idêntica à potência.

No texto do capítulo XVI do TTP, Espinosa fala já diretamente de potência quando se refere à maneira como essa liberdade se encontra já nos seres naturais, como os peixes que, por terem maior potência que os menores, têm direito natural a devorar estes (ou seja, podem devorá-los exclusivamente em função da potência; nenhum outro motivo é mencionado ou tem relevância, aqui):

Os peixes, por exemplo, são por determinação da natureza feitos para nadar e os maiores dentre eles para comerem os mais pequenos, pelo que os peixes são, de pleno direito natural (summo naturali jure), donos da água, da mesma forma e com o mesmo direito com que os grandes comem os pequenos. É, com efeito, evidente que a natureza, considerada em absoluto, tem direito a tudo quanto está em sua potência (jus summum babere ad omnia, quae potest), isto é, o direito de natureza (jus naturae) estende-se até onde se estende sua potência, pois a potência da Natureza (naturae potentia) é a própria potência de Deus (potentia Dei), o qual tem pleno direito a tudo.

Tal como, também, no Tratado politico:

Conseqüentemente, o direito natural da Natureza inteira e, por conseguinte, de cada indivíduo estende-se até onde for sua potência e, portanto, tudo o que um faz, seguindo as leis de sua própria natureza, fá-lo em virtude de um direito natural soberano, e tem sobre a Natureza tanto direito quanta potência. ${ }^{146}$

No prefácio ao TTP, Espinosa mencionara o direito natural de cada um como aquele direito que vai até onde vai o seu desejo e a sua potência, já se referindo pois a um vocabulário que considera o direito natural como direito natural do ser humano na natureza ou com base em sua natureza. A argumentação da explicação do direito natural, no capítulo XVI do TTP, antes de mencionar o desejo que, junto com a potência, determina o direito natural do homem, precisa primeiro evidenciar qual desses conceitos deve ser prioritariamente reconhecido: potentia. Se, como diz Espinosa por algum motivo, para explicar o que é o direito civil é preciso antes explicar o que é o direito natural já que (de alguma maneira) o direito natural é base do direito civil, é preciso, antes de explicar o direito natural no homem, explicá-lo na natureza. O que significa, pois, o exemplo dos peixes? Ele aponta para um fato que nem a experiência nem a razão podem negar, que é a dominação exercida pelos seres naturais mais fortes (maiores) sobre os mais fracos (menores), em função dessa força que os seres com maior potência têm, mas os de menor potência não. O que é o estado de natureza? Uma situação na qual se percebe uma diferença entre as potências dos diversos indivíduos, de maneira que indivíduos mais potentes dominam

146 Tratado político, cap. II, \4; tradução de Manuel de Castro. 
os não tão potentes; essa dominação do outro por se ter uma potência maior que a do outro, aí no estado de natureza não tem nada de absurdo: é uma situação completamente natural, por necessidade natural tanto de quem domina o outro (tem necessidade de autopreservação, sente que para se conservar precisa dominar o outro, consegue a dominação porque é maior - mais forte - que o outro) quanto de quem é dominado pelo outro (tem necessidade de autopreservação, sente que para se conservar precisa não ser dominado pelo outro, não consegue impedir a dominação porque é menor - mais fraco - que o outro). A natureza, se a observarmos, é assim: as ações aí produzidas são determinadas pela constituição natural de todos os seres; isso, diz Espinosa, "é evidente” (negá-lo não faz sentido). E da observação desse fato — os seres naturalmente mais fortes dominam por determinação natural os naturalmente mais fracos —, percebe-se o que vale para todos os seres naturais ou para a natureza inteira: todos os seres naturais, enquanto seres naturais, agem determinados por sua potência, que é natural. Nas palavras de Espinosa: a natureza tem direito a tudo o que está na sua potência. ${ }^{147}$ Eis o que é, no estado de natureza, o dito direito natural: a potência de cada ser para agir segundo a sua necessidade natural, e não segundo qualquer outra coisa. Ora, da forma como Espinosa sempre define o direito natural ou o direito ou a liberdade que operam nessa condição natural, não se trata da constatação de uma ordem jurídica presente na natureza, de um conjunto de regras morais que a razão descobre sozinha ou que são reveladas ao homem, de um conjunto de princípios de ação que valem universalmente e merecem ser formalizados na forma de um conjunto de leis. Trata-se, simplesmente, de algo que é eterno em cada ser (isto é, confunde-se com sua essência e sua existência): sua potência atual, no caso (pelo que mostra a parte III da Ética) seu impulso natural pela autoconservação, seu conatus.

O conatus (impulso pela perseveração na existência) é a essência atual de cada ser, por sua necessidade natural. Quando observamos rigorosamente a natureza em absoluto, constatamos com evidência a atualidade desse impulso em cada ser natural; pelo que Espinosa pode retirar de seres naturais em particular exemplos da comparação entre potências contrárias entre si (para os peixes maiores, o conatus pede devorar os menores; para os menores, o conatus pede não serem devorados, mas como são menores — mais fracos —, são dominados, são destruídos), e com respeito à própria natureza, Espinosa pode dizer que nela toda ação é determinada (operada atualmente, portanto: a ação não produz efeitos enquanto não é concretizada) pela potência do agente. Ou seja: por natureza, cada ser age determinado pelo seu conatus. Não há verdadei-

147 Alguns traduzem o potest da expressão jus summum habere ad omnia, quae potest por poder, o que me parece uma imprecisão diante do que Espinosa está já aí demonstrando. Os seres naturais, enquanto seres naturais, têm como fazer plenamente o que podem segundo sua natureza ou determinação natural, ou seja, segundo sua potência. Não é um poder ou uma dominação que lhes permite aplicar sua potência; é a própria potência que já se dá, nos seres naturais, como dominação. 
ramente outra causa para a determinação da ação, embora seja possível imaginar quaisquer outras causas (falsas, porém). Esse princípio da ação, por ser natural, jamais deixa de operar. Toda ação de um ser qualquer (humano ou não) depende da sua estrutura ou potência natural e é determinada por ela; por isso, a medida da ação é a potência, e somente ela, em qualquer situação. Para essa potência que é medida da ação, pode-se dar o nome que quiser, só não é racional negar sua realidade. Porque é uma realidade evidente, Espinosa afirma expressamente sua evidência; mas para que o leitor do seu texto político compreenda o que está dizendo, dá a isso um nome que está na boca de todo mundo, jus naturale. Significa que poderia ter dado outro nome? Sim, desde que mantivesse o principal: o sentido (autodeterminação da ação segundo a potência, ou liberdade segundo a potência). Mas há um motivo para a escolha do termo jus naturale ou jus naturae, apesar da possibilidade de apelar a um outro termo do vocabulário político, como libertas, potestas, potestatis, ou mesmo vis. O motivo para apelar à expressão jus naturale é estar escrevendo não apenas para demonstrar que a medida da ação é a potência, mas para negar a validade das teorias jusnaturalistas, que consideram que na natureza (seja na natureza inteira, seja na natureza bumana) já há um direito (conjunto de leis, ou conjunto de faculdades, ou bierarquia das ações). Ora, essa ordem política ou hierárquica presente já na natureza segundo todos os jusnaturalistas, Espinosa nega em absoluto:

Visto, porém, que a potência universal de toda a Natureza não é mais do que a potência de todos os indivíduos em conjunto, segue-se que cada indivíduo tem pleno direito a tudo quanto esteja em sua potência, ou seja, o direito de cada um estende-se até onde estender-se a sua exata potência. E, uma vez que é lei suprema da natureza que cada coisa se esforce, tanto quanto esteja em si, por perseverar no seu estado, sem ter em conta qualquer outra coisa a não ser ela mesma, resulta que cada indivíduo tem pleno direito a fazê-lo, ou seja (conforme já disse), a existir e agir conforme está naturalmente determinado.

Em Espinosa, a natureza não é uma ordem separada do ser humano, que ele pode dominar ou à qual pode adequar-se ou não; a natureza é a comunidade dos seres naturais, ou a comunidade dos seres considerados segundo sua natureza individual. Se é o caso de se falar numa potência da natureza, ela só pode ser potência de todos os seres naturais em conjunto. ${ }^{148}$ Por isso mesmo, não fará sentido conceber um estado de natureza como uma ordem separada da necessidade de cada ser individual, e no que diz respeito à condição do homem no estado de natureza, não fará sentido considerar que ali o homem não se vê em sociedade. Não à toa, ele dirá adiante:

\footnotetext{
148 Virá daí a concepção da democracia como o mais natural dos regimes políticos: é o único regime político absoluto, ou seja, é a única situação política onde se concebe e se pratica a vida coletiva como integração de todos os seus indivíduos constituintes, sem a exclusão de nenhum deles. Ver capítulo 4.II.
} 
[...] sempre que algo na natureza nos parece ridículo, absurdo ou mau, é porque só conhecemos as coisas em parte e ignoramos em grande medida a ordem e a coerência de toda a natureza, além de que pretendemos que tudo esteja orientado segundo as normas da nossa razão, quando o que a razão considera ser mau não o é do ponto de vista da ordem e das leis de toda a natureza, mas apenas do ponto de vista das leis da nossa própria natureza.

O jus naturae dos jusnaturalistas, sabe Espinosa, é outra formulação do imperio in imperio: é a concepção jusnaturalista de que, se não há perspectiva política, já há uma tendência para ela, já há uma potencialidade dela, já há uma possibilidade natural de realizá-la a partir de certo momento sob a forma de estado civil. Ora, mostra Espinosa, o homem está em estado civil e é um ser natural, como todo ser; se está em estado civil, não é porque tenha realizado essa tendência para a vida política, mas porque sua natureza já é operada numa situação política. Em Espinosa, nem o estado civil é a saída do estado de natureza (porque na vida política o ser humano continua agindo por determinação da sua necessidade, e só está na vida política em função de ter sua ação determinada pela natureza), nem o estado de natureza é a ausência de estado civil (porque o estado de natureza, em vez de ser um período cronologicamente anterior à fundação do Estado, é nada mais que a condição de qualquer ser na perspectiva natural; no caso do homem, é a sua condição numa perspectiva natural, ao mesmo tempo que o estado civil é a condição humana numa perspectiva política). Como, em Espinosa, a própria idéia fundamental de que toda ação de cada ser é determinada por sua potência é uma negação de uma ordem jurídica ou moral que precisa ser atualizada para que surta efeitos (a potência atual já é produção de efeitos), não cabe conceber o jus naturae como uma faculdade para a ação, nem o estado de natureza como uma situação em que a ação não segue ainda uma regra adequada. Tal como são mostrados por Espinosa, o jus naturae e o estado de natureza são, do ponto de vista jusnaturalista, incompatíveis e principalmente inaceitáveis. O estado de natureza não é, como dissera Hobbes, um estado de guerra de todos contra todos; é apenas a condição natural da necessidade de todos os seres, independente de qualquer avaliação moral ou racional que aí se imagine poder fazer. Dizer que, no caso dos peixes, é por determinação da natureza que os maiores devoram os menores (e a dominação das águas consiste nesta destruição dos mais fracos), significa dizer que é contra sua natureza — sua estrutura natural, sua necessidade natural — que não aconteça dessa forma. Essa situação de destruição de um ser natural por outro só não aconteceria se não houvesse essa diferença de forças. É com esta idéia em mente que se deve olhar para a vida humana e, principalmente, para a vida coletiva humana, onde cada violência será uma tentativa de dominação do outro por meio de sua aniquilação e em função da sua fraqueza. Se não temos isso em mente, toda concepşão da politica e do que é devido ou adequado na vida política deixa a violência sem barreiras. 


\section{III JUS SIVE POTENTIA: LEX SIVE POTESTAS}

A interrupção prematura do capítulo XI do Tratado politico, além de todos os problemas trazidos a essa argumentação que não teve o devido tempo para ser devidamente concluída (incompletude da teoria da democracia, suposta ausência no TP de uma escolha entre os diferentes regimes políticos, o que fora feito no TTP mas parece ter se perdido de vista em função de toda a atenção dada agora à monarquia e à aristocracia, etc.), deixa o texto espinosano numa situação incômoda também pela tese nefasta que apresenta a respeito das mulheres, nos $\iint 3$ e 4 , provavelmente as últimas linhas que Espinosa escreveu:

\3. Pelo que precede, é patente que podemos conceber diversos gêneros de Estado democrático; o meu desígnio não é falar de cada um, mas de me cingir ao regime em que todos são governados unicamente pelas leis da pátria (solis legibus patris tenentur) e, além disso, são autônomos (sui juris sunt) e vivem honrosamente (bonesteque vivunt), possuem o direito de sufrágio na assembléia suprema e têm acesso aos cargos públicos (muneraque imperii subeundi). Digo expressamente que são regidos unicamente pelas leis do país (solis legibus patris tenentur) para excluir os estrangeiros (peregrinos), súditos de outro Estado. Além disso, acrescentei que, além de estarem submetidos às leis do Estado, sejam ainda autônomos (in reliquis sui juris sint), para excluir as mulheres e os servos, que estão sob o poder dos maridos e dos senhores (ur muileres, et servos secluderem, qui in potestate virotum, et dominorum esse), as crianças e os pupilos, que estão sob o poder dos pais e dos tutores (ac etiam liberos et pupillos, quamdiu sub potestate parentum, et tutorum sunt). Disse, enfim, vivem honestamente, para excluir os marcados pela infâmia por causa de um crime, ou de um gênero de vida infamante.

\4. Perguntarão, talvez, se as mulheres estão por natureza, ou por instituição, sob o poder dos homens? (Sed forsan rogabit aliquis, num foeminae ex naturâ, an ex instituto sub potestate virorum sint?) Se é por instituição, nenhuma razão nos obrigaria a excluir as mulheres do governo (regimine secludere). Se, todavia, apelamos para a experiência, veremos que isto provém da sua fraqueza. Em nenhuma parte da terra homens e mulheres reinaram conjuntamente, mas em toda parte, onde se encontram homens e mulheres, vemos que os homens reinam e que as mulheres são governadas, e que, desta maneira, os dois sexos vivem em boa harmonia; pelo contrário, as amazonas que, segundo uma tradição, outrora reinaram, não admitiam que os homens permanecessem no seu território, não alimentavam senão os indivíduos do sexo feminino e matavam os machos que tinham gerado. Se as mulheres fossem, por natureza, iguais aos homens, se tivessem no mesmo grau a fortaleza de ânimo e índole (animi fortitudine, et ingenio) que consistem, na espécie humana, os elementos da potência (potentia) e, conseqüentemente, do direito, certamente, entre tantas nações diferentes, não se poderia deixar de encontrar umas em que os dois sexos reinassem igualmente, e outras em que os homens seriam governados pelas mulheres e receberiam uma educação própria para restringir as qualidades do seu caráter (ut ingenio minùs possent). Mas isto nunca se viu em parte alguma, e pode-se afirmar, por conseqüência, que a mulher não é, por natureza, igual ao homem e também que é impossível que os dois sexos reinem igualmente e, ainda menos, que os homens sejam regidos pelas mulheres. Se, além disso, considerarmos as paixões humanas, se reconhecermos que quase sempre o amor dos homens pelas mulheres não tem outra origem senão o desejo sensual, de tal modo que não apreciam nelas seu caráter e sabedoria, mas as da beleza que têm, que não admitem que as mulheres amadas tenham preferência por outros que não eles, ver-se-á, sem esforço, que não se poderia instituir o reinado igual dos homens e das mulheres sem grande prejuízo para a paz. Mas é bastante sobre este ponto. ${ }^{149}$

149 Ed. Gebhardt, vol. III, pp. 359, 19-360, 23: \III. Ex dictis in in praeced. Art. patet, nos posse imperii Democratici diversa genera concipere, sed meum institutum non est de unoquoque, sed de eo solummodò agere, in quo omnes absolutè, qui sollis legibus patriis tenentur, et praeterea sui juris sunt, honesteque vivunt, jus suffragii in supremo Concilio ba- 
Ora, o que leva uma tal filosofia, que concebe a justiça e a caridade como finalidade da vida religiosa, a paz e a segurança como finalidade da vida política, e a liberdade e a concórdia como finalidade da vida ética, a aparentemente considerar que em certa medida não cabe aí a igualdade? De fato, o capítulo XI parte, como haviam feito as seções anteriores sobre a monarquia e a aristocracia, de uma definição específica para o regime em análise. Aí, a democracia aparece como o único regime no qual todos os cidadãos são definidos por uma situação jurídica que não existe para nenhum deles na monarquia e que é privilégio de alguns na aristocracia: cada cidadão, na democracia, é sui juris, ou seja, age segundo seu próprio direito, não depende da autoridade ou autorização de quem quer que seja para escolher suas ações e lidar com seus negócios, desde que o faça, é claro, dentro dos limites estipulados pelas leis civis e pelos costumes (não pode ser criminoso nem ter uma conduta infamante, pois isto seria, já, viver contra o bem comum). Ora, se essa seqüência de capítulos sobre os regimes políticos é uma teoria das formas de governo, o que Espinosa mostra nelas é que, em todas, existe uma autoridade soberana que determina os direitos de seus súditos, mas nem em todas os súditos recebem na mesma medida a qualidade de cidadãos; ou seja, se em toda vida política os súditos são definidos por sua sujeição jurídica ao estado ou à autoridade soberana, o que determina as diferenças entre os vários regimes políticos é o grau de participação desses súditos na própria autoridade soberana, uma participação que, seguindo aparentemente o modelo das tipologias clássicas, vem da nulidade na monarquia à totalidade na democracia. Ora, pela maneira como Espinosa define primeiramente cada um dos três regimes que identifica, sua compreensão dessa participação ou exclusão do poder político parece ser a mesma dos autores clássicos: na monarquia, nenhum súdito

\footnotetext{
bent, muneraque imperii subeundi. Dico expressè, qui solis legibus patriis tenentur, ut peregrinos secludam, qui sud alterius imperio esse censentur. Addidi praeterea, auò, praeterquam quòd legibus imperii teneantur, in reliquis sui juris sint, ut mulieres, et sevos secluderem, qui in potestate virorum, et dominorum, ac etiam liberos et pupillos, quamdiu sub potestate parentum, et tutorum sunt. Dixi denique, bonesteque vivunt, ut ii apprimè secluderentur, qui ob crimen, aut aliquod turpe vitae genus infames sunt. $\int I V$. Sed forsan rogabit aliquis, num foeminae ex naturâ, an ex instituto sub potestate virorum sint? Nam, ni ex solo instituto id factum est, nulla ergo ratio nos coëgit foeminas a regimine secludere. Sed si ipsam experientiam consulamus, id ex earum imbecillitate oriri videbimus. Nam nullibi factum est, ut viri, et foeminae simul regnarent, sed ubicunque terrarum viri, et foeminae reperuntur, ibi viros regnare, et foeminas regi videmus, et hâc ratione utrumque sexum concorditer vivere. Sed contrà Amazonae, quas olim regnasse famâ proditum est, viros in patrio solo morari non patiebantur, sed foeminas tantummodò alebant, mares autem, quos pepererant, necabant. Quòd si ex naturâ foeminae viris aequales essent, et animi fortitudine, et ingenio, in quo maximè bumana potentia, et consequenter jus consistit, aequè pollerent, sanè inter tot, tamque diversas nationes quaedam reperirentur, ubi uterque sexus pariter regeret, et aliae ubi a foeminis viri regerentur, atque ità educarentur, ut ingenio minùs possent: quod cum nullibi factum sit, affirmare omnibò licet, foeminas ex naturâ non aequale cum viris habere jus, sed eas viris necessariò cedere, atque adè̀ fieri non posse, ut uterque sexus pariter regat, et multò minus, ut viri a foeminus regantur. Quòd si praeterea bumanos affectûs consideremus, quòd scilicet viri plerumque ex solo libidinis affectu foeminas ament, et earum ingenium, et sapientiam tanti aestiment, quantìm ipsae pulcbritudine pollent, et praeterea quòd viri aegerrimè ferant, ut foeminae, quis amant, aliis aliquo modo faveant, et id genus alia, levi negotio videbimus, non posse absque magno pacis detrimento fieri, ut viri, et foeminae pariter regant. Sed de his satis. Reliqua desiderantur.
} 
participa das decisões da autoridade soberana porque, nela, nenhum súdito é sui juris, ou seja, nenhum súdito tem liberdade para agir de forma autônoma, muito menos para determinar o que é devido ou não para si mesmo na vida civil; na aristocracia, concebida como regime político no qual a autoridade soberana é constituída por um colegiado formado por pessoas autônomas na vida comercial, patrimonial, legislativa ou militar, a sociedade é fundada já numa idéia de condição sui juris de certos indivíduos, cuja vontade coletiva, submetida constantemente a deliberações e debates, é posta como medida do bem comum, sem que jamais se considere todavia a viabilidade de estender essa condição sui juris a todas as pessoas sob esse regime; na democracia, diferentemente, a condição sui juris é absoluta entre os patrícios, pois que se considera, aí, que independentemente de outras qualificações da vida social (habilitação econômica, patrimonial, militar e assim por diante), o que determina a condição sui juris de uma pessoa na vida política é sua condição de patrício (ou seja, natural da pátria ou nela naturalizado) capaz de direitos (ou seja, capaz, segundo o direito civil, de direitos e obrigações). Ser sui juris, pois, significa não apenas ser súdito de determinada soberania, mas ser livre, sob essa mesma soberania, para agir e negociar na vida política; ser alterius juris, bem ao contrário, significa depender juridicamente de um outro, necessariamente uma alteridade sobre si, para poder agir ou negociar na vida civil; em vez de uma incapacidade determinada pela natureza, como aquela que segundo o direito romano torna por natureza incapazes de direito tanto os animais quanto os dementes (uma tal incapacidade é aqui irrelevante), essa é uma incapacidade determinada pela vontade da própria autoridade política, que por conta do seu poder estabelece ou retira direitos para si ou para quem estiver sob seu poder. Ora, não cabe, por uma questão de realismo político (exigido pelo Tratado político desde seu início), conceber uma forma política que a experiência mostra ser sempre fundada na presença de súditos alterius juris sob uma forma ideal em que todos possam passar à condição sui juris; por isso, a exposição sobre a monarquia necessariamente é uma análise de uma experiência política em que a condição sui juris jamais é cogitada para cada súdito (já que, na monarquia, a autoridade política é fundada na autoridade de um só), e a exposição sobre a aristocracia é por sua vez uma análise da experiência política em que a condição sui juris é determinada por uma situação socialmente privilegiada conforme os costumes da pátria, não podendo esse privilégio ser dividido com outras castas ou classe, muito menos ser concebido na forma de um direito comum; se, porém, existe uma experiência política específica na qual a autoridade política considera que aqueles que tenham de fato condições práticas de dirigir suas próprias ações e negócios (assim como seu caráter e sua liberdade) mereçam o reconhecimento dessa condição como um direito, está estabelecida a idéia de que a sociedade política (a civitas) é fundada na liberdade coletiva e na razão política que existe em todos os homens, de maneira 
que ser súdito equivale a ser cidadão sui juris, porque cada um é súdito de uma autoridade política da qual toma parte diretamente... uma tal experiência política é rara mas existe (ou não entraria nessa tipologia que é toda baseada na experiência), e recebe o nome de democracia.

Ora, essa idéia de democracia, apresentada no Tratado político, é fundada na idéia de que todos os cidadãos são sui juris, apesar de ser possível a instauração de uma autoridade soberana ou de um regime político fundado na exclusão ou na alienação de direitos. Não que essa alienação de direitos (ou seja, essa determinação dos direitos por uma autoridade soberana, sem participação dos súditos ou cidadãos), vulgarmente concebida como presente nas formas políticas não democráticas (na monarquia é o monarca, que limita os direitos de seus súditos; na aristocracia é a elite que limita os direitos da plebe) tenha racionalidade, seja útil segundo o bem comum ou seja necessidade de cada um; isso não está em cogitação na constatação dos regimes políticos; mas no reconhecimento de cada regime político, ela é marca daqueles que são tidos como diversos desse outro, denominado democracia, em que se concebe que aqueles que têm de fato capacidade de ação e juízo também têm de direito essa capacidade. Ou seja, no plano da teoria dos regimes políticos, o que marca a definição da democracia é a idéia de que trata-se do único regime político que todos os que têm de fato condições para a cidadania, são de direito cidadãos, uma condição política que na prática se traduz por outros direitos políticos, a começar (como define o $\int 3$ do cap. XI do TP) pelo direito de sufrágio e pelo acesso às funções públicas.

Se a concepção corrente é essa, e da qual Espinosa se aproveita para uma definição inicial da democracia que permita reconhecer o terreno conceitual e desenvolver uma análise desse regime tal como a experiência o apresenta e segundo o que a razão considera (análise ao final da qual seria possível apresentar uma definição mais apurada de democracia, pois), a experiência da teoria política parece mostrar que, em lugar de se conceber a forma de Estado mais apropriada para uma sociedade segundo as condições de fato para seus súditos serem, de direito, cidadãos sui juris, é na verdade a condição jurídica de cada súdito (sui juris ou alterius juris) que é determinada pelo poder da autoridade soberana estabelecida. Em vez de ser considerada a extensão da autonomia jurídica de cada súdito segundo a sua capacidade de fato, a idéia de condição jurídica parece ser determinada pelo tipo de Estado que já está implementado, independente de se considerar não apenas a necessidade natural de cada súdito quanto à sua própria liberdade, mas já em função da criação de um conceito de capacidade jurídica diante do qual a idéia de capacidade de fato é irrelevante ou, pior, um conceito de capacidade jurídica baseado numa concepção de capacidade de fato separada da necessidade natural da pessoa. Assim, o motivo que leva, numa monarquia (tal como ela é concebida na perspectiva de uma tipologia das formas de governo), a não conceder aos súditos a condição sui juris, não é partir da constatação de 
uma necessidade natural de todos serem governados ou determinados por um só (Espinosa considera isso mesmo impossível), mas reconhecer que essa dependência jurídica só pode ser defendida, na experiência monárquica, como necessidade da própria sociedade política ou da autoridade política, mas jamais necessidade de cada um (pode até ser imaginada como tal; jamais todavia essa imagem corresponderá à necessidade natural, em cada um, de autodeterminação); mais do que isso, o motivo que leva, na aristocracia, a considerar que só aqueles que detêm propriedades, poderio militar, influência institucional, reputação ilibada podem ser considerados suficientemente autônomos e prudentes para determinar por si sós sua vida na sociedade e também a vida da própria sociedade, não é a constatação de uma impossibilidade de se alçar as pessoas de fato excluídas dessa elite ao direito de realizar as mesmas ações que ela, mas na verdade é o medo de que a prática permitida por esse direito se transforme num fato: só isso transformaria os privilégios da elite num direito público, e porque os privilégios naturalmente operados numa aristocracia são exatamente baseados num sistema de exclusão de outras classes sociais ou civis, a eliminação dessa separação entre cidadãos de excelência e cidadãos de indigência exigiria a criação de uma outra idéia de sociedade, na qual um direito não poderia, jamais, ser um privilégio. Ora, o que a experiência parece mostrar como sendo essa situação em que toda capacidade jurídica é acessível a quem parece merecer, por sua natureza, capacidade jurídica? Que o único lugar onde isso acontece é esse regime, a democracia, no qual nenhum cidadão está excluído do poder, pois que não é um estrangeiro, não é um criminoso, não é um infame e, também, não é alterius juris. O que é marca, na democracia, para a condição de cidadão é, basicamente, a condição sui juris; depois dela, não havendo outros impedimentos (condição de estrangeiro; situação civilmente irregular diante do poder público ou dos costumes), cada um está pronto para a prática da autonomia política e da igualdade entre todos os cidadãos que só a liberdade absoluta da democracia permite conceber e praticar.

Por isso mesmo, o que está em questão é o que determina, numa pessoa, a condição sui juris. Porque sabe muito bem desse problema, é disso que Espinosa começa a tratar em sua primeira abordagem ( $\iint 3$ e 4) do que a experiência a uma primeira vista diz sobre essa concepção de vida política: se na democracia, todos os cidadãos são cidadãos porque, em primeiro lugar, são sui juris, quem são, mesmo na democracia (ou em qualquer sociedade humana), aqueles que não podem sê-lo? O $\$ 3$ os menciona, como aqueles que estão sempre "sob o poder" (in potestatis) de alguém: as mulheres (que estão in potestate dos maridos ou, simplesmente, dos homens), os servos (que estão in potestate dos senhores), os filhos (que estão in potestate dos pais), os pupilos (que estão in potestate dos tutores); uma classificação determinada definitivamente pelo uso vulgar (já que presente nos costumes e na sociedade holandesa e recebida por todas as fontes clás- 
sicas do direito romano-holandês), e à qual poderíamos acrescentar segundo as mesmas razões os idosos (cuja senilidade ou perda de agilidade de fato os incapacita até para as funções legislativas ou conciliares), os devedores (cuja situação os coloca sob a dependência jurídica dos credores), os animais (cuja condição irracional, enfim, os coloca como bens de uso), etc. Ora, o que a tipologia das formas de governo não concebe de forma alguma? A existência de uma forma política na qual todas as pessoas sejam cidadãs, ou seja, uma forma política em que todas as pessoas sejam sui juris. Mesmo a democracia, apresentada por uma teoria das formas de governo, parece ser assim. Nela, todos os cidadãos votam e ocupam cargos públicos; mas por uma questão de fato, o direito à cidadania parece não pode ser estendido a todos.

Donde o estranhamento causado pela leitura especialmente do $₫ 4$ do capítulo XI. Bem ali, onde chegamos, no plano de uma teoria do Estado, ao máximo de liberdade pública ou de partilha da liberdade que se poderia conceber num regime político, a consideração da democracia partir de uma constatação da incapacidade de fato, determinada por natureza, de alguns para o mérito da capacidade jurídica, ou da condição sui juris. O caso das mulheres, considerado no $\S 4$, é o primeiro de uma série apresentada no $\ 3$ e isso permite crer que Espinosa continuaria o capítulo pela confirmação das outras formas de incapacidade jurídica, nos mesmos termos da análise do caso das mulheres. Ora, por mais que conheçamos a condição histórica e política das mulheres na Holanda, o que leva Espinosa a concluir, naquele parágrafo, que é por uma questão de natureza que elas não podem, como os homens, ter a condição sui juris reconhecida ou concedida pela autoridade política? "É pela sua fraqueza", parece mostrar a experiência: a experiência mostra que elas estão sob a potestas dos homens porque estes, de fato, interessam-se pelas mulheres incitados pelo "prazer sensual" e não lidam com elas em função "da sua fortaleza de ânimo ou da sua índole", mas unicamente "em função da beleza que têm"; de arremate, as mulheres, in potestate dos homens, são por eles concebidas como sua propriedade, já que "não admitem que as mulheres amadas tenham preferência por outros que não eles". Como demonstração do fato dessa dependência jurídica das mulheres em relação aos homens e da maneira como os homens de fato consideram as mulheres e lidam com elas, "é o bastante". A análise desses parágrafos que estão ao final do Tratado politico mereceria atenção especial para se considerar a condição da mulher na filosofia espinosana; ${ }^{150}$ mas definitivamente não é só da condição das mulheres (de fato ou de direito) que Espinosa trata aí; sem que o leitor vulgar esse leitor que se entrega de todo à crença na aparência e nisso que a experiência mostra, pois

\footnotetext{
150 Não farei isso aqui; a condição das mulheres na filosofia de Espinosa é uma das questões abertas para uma exposição detalhada da filosofia política de Espinosa, o que está além das pretensões deste trabalho, mas que depende da validade do que se propõe, aqui, como outra forma de empreender esse estudo amplo da filosofia política espinosana.
} 
“contra fatos não há argumentos" - perceba, Espinosa camufla nesses parágrafos não apenas uma defesa sem igual da igualdade das mulheres em relação aos homens na vida civil, mas deixa os elementos fundamentais do que seria certamente o conceito definitivo da democracia: uma vida politica na qual todos são cidadãos, além de todos os cidadãos serem sui juris.

Por mais lastimável que seja a experiência que Espinosa descreve nesses parágrafos, o seu sentido filosófico aparece desde que nos atenhamos ao texto em si mesmo. "Perguntarão, talvez, se as mulheres estão por natureza, ou por instituição, sob o poder dos homens? Se é por instituição, nenhuma razão nos obrigaria a excluir as mulheres do governo." Em primeiro lugar, é um fato que as mulheres estão sob o poder dos homens e que estão, por isso, excluídas do governo (ou seja, não governam junto com os homens, ou não governam os homens). Porque é um fato, não é necessário sequer partir de uma dúvida a respeito da sua prática, da mesma maneira como é o caso de tomar essa prática como uma experiência que todos os leitores do tratado (todos homens, certamente: o tratado é voltado para leitores juristas: leitores que têm acesso à atuação institucional; o próprio texto indica que não é voltado para leitoras) conhecem, como princípio empírico e como elemento retórico. O texto não questiona se é justa essa condição alterius juris das mulheres, mas unicamente a que ela é devida. Duas hipóteses: por convenção e por natureza. São as duas formas clássicas de leis clássicas para a determinação dos direitos: lei civil e lei natural. Ora, toda a tradição jurídica considera, em linhas gerais, que a lei civil não pode contrariar a lei natural; ao contrário, é desejável que a lei civil seja conseqüência da lei natural, ou sua expressão. Nesse panorama, na hipótese de uma lei civil ser contrária à lei natural, estamos claramente diante de uma imposição institucional contrária seja à vontade de Deus, seja à necessidade humana, seja à ordem da natureza ou do mundo: uma convenção contrária à necessidade natural ou à ordem natural não pode ser positiva, pois é uma quebra na harmonia da natureza, ou na ordenação natural das coisas; ao contrário, se uma lei civil é a expressão dessa lei natural ou mesmo se não apresenta com ela incompatibilidade, essa convenção é por isso concebida como a perfeição humana que se equivale à perfeição da natureza. Daí a necessidade de, diante de uma prática convencional — que pode não ser realizada: as amazonas, afinal, não estabeleciam essa convenção —, considerar se ela é decorrente apenas da instituição, ou se tem algum fundamento natural. Caso o fundamento seja apenas institucional, não há legitimidade nessa imposição, porque não há, nela, racionalidade: "nenhuma raz̃ão nos obrigaria a excluir as mulheres do governo". Ou seja: a primeira necessidade racional da convenção é basear-se na natureza. O que dirá, pois, essa natureza? "Se [...] apelamos para a experiência, veremos que isto provém da sua fraqueza." A experiência mostra que a condição alienis juris é uma conseqüência da fraqueza das mulheres. A afirmação, em si mesma, nada prova, mas é conclu- 
são antecipada de uma descrição, justamente, de uma experiência específica (veremos, ao final, de que experiência se trata), da qual se tiram as premissas para a justificação, nos termos dessa experiência, dessa determinação das mulheres como alterius juris. Em primeiro lugar, a experiência mostra que "Em nenhuma parte da terra homens e mulheres reinaram conjuntamente, mas em toda parte, onde se encontram homens e mulheres, vemos que os homens reinam e que as mulheres são governadas, e que, desta maneira, os dois sexos vivem em boa harmonia": a experiência não mostra, porém, por que nunca houve essa partilha do poder por homens e mulheres, nem em que sentido pode ser considerada essa boa harmonia; não diz, também, que é impossivel que homens e mulheres reinem juntos, mas diz que, porque os homens reinam sobre as mulheres, é produzida a boa harmonia. A experiência, ainda, mostra o mesmo a partir da hipótese contrária: "pelo contrário, as amazonas que, segundo uma tradição, outrora reinaram, não admitiam que os homens permanecessem no seu território, não alimentavam senão os indivíduos do sexo feminino e matavam os machos que tinham gerado". O que diz esse fragmento? Não uma constatação com pretensão histórica (se tivesse esse peso, colocaria uma contradição quanto ao que fora afirmado antes: “em toda parte... vemos os homens reinarem..."), mas a apresentação de uma lenda (“...segundo uma tradição...”), fundada justamente na relação entre governo das mulheres (“...as amazonas que outrora reinaram...”) e exclusão dos homens pela violência (“...matavam os machos...”) e que, por ser a prova em contrário do trecho anterior, mostra o que essa mesma experiência a que apela o argumento considera como "harmonia": preservação da vida, mas não, ainda, divisão do governo. A experiência, ainda, impossibilita a prova em contrário do que já vem de mostrar em primeiro lugar: "Se as mulheres fossem, por natureza, iguais aos homens, se tivessem no mesmo grau a fortaleza de ânimo e índole que consistem, na espécie humana, os elementos da potência e, conseqüentemente, do direito, certamente, entre tantas nações diferentes, não se poderia deixar de encontrar umas em que os dois sexos reinassem igualmente, e outras em que os homens seriam governados pelas mulheres e receberiam uma educação própria para restringir as qualidades do seu caráter." A experiência sabe que não há matriarcados no mundo ("isto nunca se viu em parte alguma”); porque sabe isso, e porque concebe ainda que a história já deu tempo suficiente para que a humanidade experimentasse todas as formas de poder que pudesse, a inexistência dos matriarcados sugere a conclusão da sua impossibilidade: "pode-se afirmar, por conseqüência, que a mulher não é, por natureza, igual ao homem e também que é impossível que os dois sexos reinem igualmente e, ainda menos, que os homens sejam regidos pelas mulheres." Isso no que diz respeito ao que as mulheres parecem, segundo a experiência, não fazer (matriarcados, dominação dos homens, governo harmônico ou não violento); além disso, a experiência mostra o mesmo a partir da 
condição dos homens, mais especificamente a partir do que os homens fazem, com respeito às mulheres; Espinosa, aí, aponta três formas de ação dos homens com respeito às mulheres: "se, além disso, considerarmos as paixões humanas, se reconhecermos que quase sempre o amor dos homens pelas mulheres não tem outra origem senão o desejo sensual...”, ou seja (a tese é forte), as mulheres são concebidas pelos homens como bens de uso sexual; “...de tal modo que não apreciam nelas seu caráter e sabedoria, mas as da beleza que têm...”: os homens não concebem, nas mulheres, qualidades intelectuais por que devam ser notadas, mas unicamente qualidades físicas que indicam que podem ser usadas; “...que não admitem que as mulheres amadas tenham preferência por outros que não eles...”: por conseqüência, o ciúme masculino é a síntese da convicção de que as mulheres, válidas segundo o seu uso, são também de uso exclusivo; essa idéia é fundamental, porque mostra que a mulher é considerada pelo homem como sua propriedade, e é por isso que é concebida como bem de uso e, concebida dessa forma, é alterius juris porque o homem, sendo seu dono, é dono da sua vontade, dos seus direitos, do seu corpo: literalmente, "dono da alma" das mulheres que domina, tal como toda entidade que está alterius juris, segundo o cap. II, \9: "Segue-se, do que precede, que cada qual está na dependência de um outro na medida em que está no poder (alterius esse juris) desse outro, e que pode repudiar qualquer violência, castigar como julgar bem o dano que lhe é causado e, de uma maneira geral, viver segundo a sua própria índole". Ora, porque a experiência mostra que é assim, caso essa prática seja interrompida, como conseqüência haverá "grande prejuízo para a paz" (paz que, como a pax romana, significa instauração da harmonia - aquela harmonia mencionada anteriormente - por meio da dominação do outro).

Infelizmente, nenhuma das afirmações de Espinosa aqui é falsa. De fato, se harmonia é dominação das mulheres pelos homens, a paz será perturbada se essa dominação acabar. Isso porque, como o leitor concebe em sua própria experiência (é para essa experiência que apela o texto de Espinosa) pois que já formado nessa prática, que as mulheres já estão dominadas pelos homens (irrelevante se é possível que não sejam, apesar da lenda das amazonas); elas já são castigadas quando recusam ser propriedade (donde a imagem da naturalidade do ciúme masculino); o ânimo delas já é desqualificado como sem fortaleza (porque é imaginado como um ânimo por natureza sem os atributos da imagem do ânimo masculino), e a índole delas já é desqualificada como sem prudência (porque é imaginada como uma índole por natureza sem o grau de luz natural inventado pelo imaginário masculino); e assim por diante. Em suma: a experiência vê tudo isso porque a prática masculina da exclusão, opressão, dominação, coisificação, violação das mulheres já é um costume dos homens; vendo essa realidade com os olhos já de que as domina (impossível conceber as mulheres como pessoas livres quando já são violadas como bens de uso; 
impossível conceber as mulheres como pessoas sui juris quando já são ridicularizadas como seres sem racionalidade e de ânimo minoritário), imaginamos que é "segundo a natureza". Espinosa, justamente, apela aí para uma experiência específica - a experiência que concebe essa dominação como harmonia: a experiência masculina ou, em termos atuais, machista - que interpreta o real a partir de uma imagem machista de harmonia (que permite justificar a dominação segundo os interesses de quem domina), e não a partir de uma idéia racional de concórdia (que exige justificar a dominação segundo a natureza do domínio - e que, por ser idéia racional, exige que a fraqueza ou fortaleza da natureza das mulheres seja considerada segundo ela mesma e não segundo uma interpretação externa e, por ser idéia de concórdia, revela que no campo da vida política a dominação não institui harmonia alguma, mas ao invés disso é causa mesma de impossibilidade da paz).

O que é, pois, essa "fraqueza" da qual advém o fato de as mulheres serem dominadas pelos homens? Não da sua natureza própria (seria da sua natureza se essa constatação adviesse da análise racional da natureza feminina; ao invés disso, a tese é tirada do pólo multiplamente oposto, o imaginário do machismo opressor), mas unicamente de uma fantasia dessa natureza (que busca localizar na natureza da mulher as causas de uma impotência que só existe na vida social e, não à toa, é causada por algo exterior à mulher, e por isso mesmo não pode constituir sua natureza). De fato, em nenhum momento Espinosa considera que essa "harmonia", concebida pela experiência nesse parágrafo, é a concórdia que a vida racional exige e que vem sendo trabalhada desde a Ética e o Tratado teológico-político. O termo harmonia, que na filosofia de Espinosa é acusado como uma idéia imaginativa, é estratégico: aponta para uma idéia de organização de diversos elementos que não é determinada pela natureza mesma desses elementos, mas por um modelo vindo de fora: nesse caso, o estado de harmonia que a experiência machista quer fazer valer é uma organização de forças que exige que, na vida coletiva, a classe dos homens domine a classe das mulheres, ao mesmo tempo que as mulheres sejam bens de uso (e de uso exclusivo) dos seus proprietários. É isso que a experiência mostra como o costumeiro, é isso que a experiência machista considera segundo um vocabulário e um olhar que não traz, dentro dele, o ponto de vista daquela que é aí concebida como sem sabedoria nem prudência (ao mesmo tempo que é concebida como violenta: é essa a função da lenda machista das amazonas). Não à toa, essa dominação, que o texto espinosano vem indicar como concebível na experiência de quem a pratica como poder sobre o corpo e poder sobre a honra, é denunciada muito sutilmente pelo uso de um conceito - potestas - que, na filosofia de Espinosa, significa sempre isso: uma dominação contra a necessidade natural do dominado. As mulheres, afirma Espinosa, estão sob a potestas dos homens (o que a história mostra a homens e mulheres: eles sentem o praz̧er sádico - 
e também o prazer sensual, quando prazer por dominação, é prazer sádico — da dominação e elas, a dor da dominação - que, enquanto aceita e não replicada, é sadomasoquismo) porque dependem deles (como imagina o homem na sua experiência de dominador, e a mulher na sua experiência sadomasoquista de dominada), já que elas são alterius juris (o que a experiência mostra, mas qual rąãa demonstra?).

O último parágrafo deixado pelo jusfilósofo Espinosa é uma denúncia. Não apenas à irracionalidade histórica da opressão sobre as mulheres (para a qual só a ideologia da opressão imagina uma razão), mas à irracionalidade teórica da concepção da política a partir de uma ideologia de opressão (segundo a qual as finalidades do poder político são de interesse privado e determinadas pela lógica do individualismo possessivo: as mulheres, no exemplo dado, são alterius juris porque são propriedade privada dos homens), e não a partir de uma idéia racional de política (segundo a qual as finalidades do poder político são de interesse público e determinadas pela natureza da comunidade política: as mulheres não podem ser propriedade privada dos homens porque, como mostra a Ética, isso é contrário ao conatus tanto delas - que de fato têm sua potência contida pela impotência externa — quanto dos homens - que concebem sua autopreservação somente em função da posse do outro). Ora, se à leitora e ao leitor atual a irracionalidade histórica do exemplo mostrado por Espinosa salta aos olhos, ainda não salta aos olhos a irracionalidade da expressão "estar sob a potestas de alguém” para indicar uma causa de poder político. O texto de Espinosa afirma: as mulheres estão sob a potestas dos homens (é um fato), mas descreve essa potestas como uma determinação da ação das mulheres segundo algo que, se a uma primeira vista vem da sua natureza, na verdade vem de fora delas e só funciona enquanto negação da sua natureza, por isso mesmo não pode ser uma prática política legítima. Estar sob a potestas de alguém, aí, é ter a própria potência (a própria necessidade, o próprio "direito natural": a própria necessidade de direitos) negligenciada e a capacidade de ação na vida civil determinada por quem não consulta a vontade daquela que é dominada: a própria natureza da dominação da mulher pelo homem é, de ponta a ponta, despotismo, e por isso não tem cidadania racional na prática política nem no pensamento político. Mais do que uma denúncia de uma prática despótica (que certamente apareceria com mais evidência ao final do capítulo ou no capítulo seguinte, depois de um percurso crítico, nessa análise da democracia, tal como aquele por que passaram a monarquia e a aristocracia, inicialmente definidas também como regimes políticos e ao final reveladas como uma outra coisa: práticas oligárquicas de dominação), ${ }^{151}$ esse pa-

${ }^{151}$ É o caso de considerar, a propósito deste assunto, que Espinosa apresentaria, num eventual elenco de instituições para a democracia, um sistema institucional onde essa opressão das mulheres fosse abolida; numa palavra, Espinosa provavelmente colocaria aí, como dedução racional a partir da própria experiência política, a equivalência de direitos de homens e mulheres nas instituições da política, inclusive as já 
rágrafo inicia, no plano da "teoria da democracia", uma denúncia do conceito de potestas, ou poder político válido porque operado por uma autoridade, independente da necessidade daquele que está sob o poder. A potestas, um dos inúmeros conceitos político-jurídicos da época e que percorrem os textos políticos de Espinosa, é negada por ele como um conceito político racional, da mesma maneira que o jus naturale é negado como um conceito racional para o direito. Por que Espinosa, nesse $\ 4$, não diz que as mulheres estão sob o imperium dos homens? ou sob seu dominium? ou sob sua vis? ou sob sua potentia? A meu ver, as explicações são as seguintes: As mulheres não estão sob o imperium dos homens porque os homens não as têm sob seu poder porque as comandam como autoridade soberana, mas as comandam porque as dominam pela

mencionadas no exemplo empírico dos $\iint 3$ e 4 . Mas além desse argumento a favor de uma consideração, por Espinosa, da racionalidade da equivalência de direitos entre homens e mulheres nas instituições do regime democrático, deve ser considerado que todos os momentos em que Espinosa trata pejorativamente das mulheres são momentos de abordagem retórica da experiência: a "pieguice de mulher" que, como a parcialidade e a superstição, não é um bom princípio (como a Razão o é) para a prática da benevolência, no escólio da proposição II, P49 da Ética; os supersticiosos implorando pelo auxílio divino com "promessas e lágrimas de mulher" no Prefácio do Tratado teológico-politico, as "prostitutas" como um perigo para a reputação do monarca lascivo no Tratado político; o dom profético até "numa mulherzinha, Agar", provando no início do capítulo II do Tratado teológico-político que o profeta não precisa ter um intelecto forte, etc... todas essas teses com tom de anedota só aparecem em momentos de total apelo retórico. Ao mesmo tempo, em Espinosa, jamais a mulher é tida como inferior ao homem na argumentação geométrica. Por exemplo, na Ética II, cap. Xx, sobre a instituição do matrimônio, Espinosa estabelece igual potência (ou igual direito) tanto para a mulher quanto para o homem, ao afirmar que a "beleza física" e a "liberdade da mente" são causa do amor não só do homem, mas "de ambos, isto é, do homem e da mulher" (ou seja, a razão mostra que o casamento não pode ser uma instituição de dominação de alguém sobre outrem); embora, aí, se estabeleça uma função para o matrimônio (procriação, educação dos filhos), não há nada de irracional nisso, na medida em que Espinosa tematiza uma instituição definida na época por esses termos mesmos, e não a própria união sexual em si (cujo lugar não é na teoria do Estado e sim na teoria dos afetos: Ética III, def. af. 48). Em suma: ali onde Espinosa sabe que seu leitor só se convence por um vocabulário institucional, aproveita no meio das suas demonstrações o anedotário masculino da época (mas nunca se permite ofender diretamente a mulher); todavia, ali onde é seguro falar para a só razão do leitor, sua argumentação se dirige justamente para aquilo que na natureza de todos os humanos está presente. A propósito, ainda, da condição da mulher na filosofia de Espinosa, cf. A. Matheron, "Femmes et serviteurs dans la démocratie spinoziste", in Anthropologie et politique, Paris, Vrin, 1986; Myriam Revault d'Allonnes, "Puissance et utopie au péril de la différence sexuelle", in M.R. d'Allones \& H. Rizk (eds.) Spinoza: puissance et ontologie, pp. 127-138, Paris, Kimé, 1994; nesta comunicação, a propósito, antes de entre outras coisas criticar (à p. 132) o fato de Espinosa definir uma função para o matrimônio, d'Allones coloca (p. 131) uma questão contra a dominação masculina sobre as mulheres, a questão (que corrobora a tese de que a vida política racional deve ser democrática) "das transformações, das inversões possíveis e pensáveis. Nos textos de Espinosa, como na análise que deles faz A. Matheron, uma coisa é clara. Se a relação mestre/escravo é suscetível de inversão ou de desaparição (sob preço mesmo do 'desagrado em pensá-lo' - A. Matheron), o mesmo não vale para a relação homens/mulheres. Não é preciso que elas reinem. O fantasma das Amazonas ilustra um perigo maior: 'Se a submissão das mulheres só resultasse de uma ilustração, nenhum motivo mais nos obrigaria a excluir as mulheres do governo.' Para esse medo de uma transformação, impossível esta de se pensar, há um remédio, que não se reduz ao caminho ascético. E esse remédio, eletivo e seletivo, designa o ponto paradoxal: na medida em que Espinosa critica Hobbes, ou Bodin, é para afirmar a preeminência da potentia sobre a potestas, é para criticar a perpetuidade da soberania, contestar o direito da potestas sobre a potentia. Ou, na medida em que se trata de mulheres, a potestas retoma seus direitos." Porque a potestas em Espinosa é um termo vazio, no domínio da razão nenhuma exclusão é reservada às ou pelas mulheres. 
força e pela dependência; se Espinosa dissesse que as mulheres estão sob o imperium dos homens, estaria dizendo, com isso, que essa dominação é necessária pela natureza da autoridade política, o que não teria sentido algum e por isso não é o caso. As mulheres não estão sob o dominium dos homens porque os homens não justificam juridicamente essa dominação por uma tese de propriedade material das mulheres, mas pele tese da dependência racional e anímica das mulheres em relação aos homens; se Espinosa dissesse que as mulheres estão sob o dominium dos homens, estaria dizendo, com isso, que essa dominação é fundada na aquisição contingente das mulheres pelos homens, quando ai ela tem de passar como uma necessidade segundo a natureza das próprias mulheres (como na idéia aristotélica da tendência de algumas pessoas a serem escravas: devem ser adquiridas e utilizadas por pessoas mais capazes, para a proteção tanto de uma parte quanto da outra). As mulheres não estão sob a vis dos homens porque os homens se consideram em disputa com as mulheres, mas, ao contrário, se consideram seus protetores; se Espinosa dissesse que elas estão sob a vis dos homens, estaria negando, com isso, que essa dominação é fundada numa necessidade natural das próprias mulheres em relação aos homens, assim como estaria permitindo a hipótese de autonomia das mulheres caso elas se rebelassem contra a força masculina a partir de sua própria força conjunta, exatamente como acontece no estado de natureza. Finalmente, as mulheres não estão sob a potentia dos homens porque elas têm, por sua própria natureza e necessidade (eis o que constatamos quando analisamos a natureza das mulheres segundo a sua necessidade), por determinação do seu conatus, elas necessitam uma liberdade seguida da sua própria potência, assim como necessitam que sua liberdade não seja jamais tolhida ou determinada por uma potência externa; se Espinosa dissesse que as mulheres estão sob a potentia dos homens, levaria a discussão para o vocabulário da ontologia e perderia a oportunidade de denunciar a irracionalidade da noção de potestas ali mesmo na raiz de onde é operada: na experiência de quem exerce o poder enquanto dominação contra a necessidade natural do dominado, em lugar de exercê-lo como poder público, poder includente da potência de cada um segundo a natureza e necessidade de cada um, e não segundo modelos ou imagens de impotência articulados para possibilitar a manutenção de um poder estabelecido. Ou seja (e tomando de novo a exposição do $\ 4$ do capítulo XI), se contra a ideologia machista é preciso denunciar tanto a sua irracionalidade histórica quanto a sua irracionalidade teórica, essas linhas finais do Tratado político também se revelam, na sua articulação com toda a — sempre política - obra espinosana, uma defesa da igualdade entre homens e mulheres como necessidade para uma concepção racional de democracia, como prática política pacífica porque prática de concórdia e igualdade, e não porque prática de dominação e coisificação. 
Toda a filosofia política espinosana é uma crítica à idéia de potestas, tal como esta é concebida pelo pensamento jurídico. Se a sua concepção de fundação do estado civil nega o contratualismo (o que impede de considerá-lo um jusnaturalista contratualista), e se o seu uso do vocabulário jusnaturalista revela o esvaziamento da própria idéia de direito natural e exige que a fundação dos direitos seja feita a partir da ontologia (o que impede de considerá-lo jusnaturalista de qualquer tipo, impede de considerar nele uma "teoria do direito natural" — é, na verdade, uma antiteoria - e, finalmente, impede que a partir de Espinosa se proponha um novo jusnaturalismo), a sua exposição do estado civil não é, exatamente, uma teoria do Estado no sentido convencional, mas uma reflexão sobre a política que nega legitimidade ao poder despótico ou autocrático, seja porque elabora essa análise a partir da Ética e do Tratado teológico-político, seja porque a concepção racional da vida política sempre trabalha com conceitos válidos para a estrutura geométrica dos textos políticos (imperium, summa potestas — diferente de potestas —, civitas, etc.), mas inválidos para a representação imaginativa dos usos privados do poder político.

Mais do que uma teoria das formas políticas, o pensamento espinosano começa como crítica do irracionalismo político tanto na sua prática institucional quanto na sua concepção teórica. Esta, quando operada como justificação de uma autoridade específica ou de uma prática violenta de dominação, é falsa desde a base. Uma teoria verdadeira da política, ao contrário, deve expor a necessidade da sociedade política segundo sua natureza e a necessidade de cada indivíduo na vida política também segundo sua natureza. Essa natureza, porém, não pode ser tomada como aquela que é idealizada segundo os interesses privados do uso do poder (tal como ocorrera naquele exemplo das mulheres), mas deve ser tomada segundo a necessidade e definição da própria coisa: a vida política, instituída para a instituição da paz e segurança, tem como finalidades — uma finalidade pública — a concórdia e a liberdade; cada indivíduo, cuja essência atual é o conatus e cuja natureza necessita não ser violada ou violentada, é tanto mais livre quanto mais em concórdia com os seus semelhantes.

Curiosamente, a lex, que merece um dos primeiros capítulos do Teológico-político, não apresenta a mesma relevância que o conceito de jus nos capítulos finais da obra; muito pelo contrário, a sua aplicabilidade no campo da política, tal como definida a lex no capitulo IV, praticamente desaparece. Quanto ao conceito de jus, que na parte sobre a teologia nunca entra diretamente nos temas analisados, aparecerá várias vezes e assumirá o centro de toda a discussão sobre a política, seja na forma velada de jus naturae ou jus naturale, seja na forma precisa e rigorosa de jus sive poten- 
tia. Ao mesmo tempo, ainda na parte sobre a política, os termos potestas e potestatis perderão sua força diante de conceitos que realmente dizem respeito à compreensão racional da política e do poder, como imperium e summa potestas. Cabe uma questão, pois: Há, no TTP, algum motivo para essa relativa circunscrição do termo lex à parte sobre a teologia e dos termos potestas, jus, imperium à parte sobre a política (assim como ao uso restrito de potestas em relação a imperium)? Temos desde logo algo que se opõe à visão da teologia pelos teólogos e do direito pelos juristas: de um lado, os teólogos têm por premissa a idéia (que Espinosa de fato rebaterá de várias formas em várias obras) de que Deus é um imperium in imperio, ou seja, Ele é governante não só da natureza e do universo como dos destinos do homem e das coisas seculares, aí incluída a vida humana em sociedade; de outro lado, os juristas consideram que o poder e o direito não podem ter eficácia sem a simbologia da lex, que é erigida por todos como forma da vontade soberana e marca do legítimo, contra a qual nenhum outro princípio pode atentar (e de fato, Espinosa reconhecerá um papel racional para a lei, seja como instrumento, seja como fundamento, mas negará que a lex esteja acima do jus e, diferentemente, da justitia). Já no prefácio ao Teológicopolitico Espinosa anunciara que há um momento teórico para o tratamento de "uma questão", a da teologia e da religião, e um outro, distinto, para o tratamento da "outra questão", sobre a política; a grande razão para essa divisão se deve justamente à natureza dos objetos da análise: a parte sobre a religião e a teologia exige não só a abordagem de certos temas como também uma exposição retórica da argumentação; a parte sobre a política e o Estado exige não só a abordagem de outros temas, como possibilita enfim uma abordagem geométrica (no capítulo XVI) dos seus conceitos e problemas fundamentais, ainda que não dispense em muitos momentos a cobertura retórica. Lá, no correr de cada um dos capítulos (seja os referentes à teologia, seja os referentes à política), todos os conceitos desse parágrafo do prefácio estão presentes de alguma forma (ou seja, lex aparece nos capítulos sobre política; jus, imperium, potestas, já aparecera nos capítulos sobre a teologia), a despeito de o anúncio no prefácio permitir a pressuposição em contrário; mas a maneira como os "termos políticos" jus, imperium, potestas são tratados na parte sobre a teologia só se justifica graças à função retórica que têm ali, assim como lex aparecerá na parte sobre a política numa função inversamente retórica, por receber ali um tratamento geométrico que já não mais depende do sentido originário da lex no discurso teológico e, ao mesmo tempo, poder ser entendida exclusivamente no ambiente dos conceitos políticos do jus, do imperium e da potestas, dos quais, respectivamente, a lex é complemento, instrumento e imagem.

O capítulo IV do TTP, "Da lei divina”, guarda uma importância fundamental não apenas por 
apresentar a definição de lex divina mas também por apresentar a definição genérica de lex - e a lex divina é, evidentemente, uma das formas de lex -, estabelece para a própria lex divina uma definição ("uma regra [de vida que o homem prescreve a si mesmo ou aos outros em função de um determinado fim] que diz respeito apenas ao soberano bem, isto é, ao verdadeiro conhecimento e amor de Deus") que recusa as definições clássicas da escolástica, como a de são Tomás de Aquino (para quem a lei divina, instaurada por Deus — já que é a lei eterna, tal como percebida pelo homem —, proíbe o pecado, regula tanto as ações quanto a alma, é certa, verdadeira e reta, e ordena o homem a um fim sobrenatural e divino) ${ }^{152}$ e, muito diferentemente, as de autores seus contemporâneos, a exemplo de Hobbes (para quem a lei divina, seja como reta razão criada por Deus, seja como conjunto de preceitos dispostos na Bíblia, é imposta ao homem como guia para a sua ação). ${ }^{153}$

Ora, a visão tradicional da lex divina é de que ela é sempre revelada, no sentido de que cada homem depende de submeter-se à mente divina para ter acesso a essa lei que é nada mais que vontade de Deus; não é possível ao homem, na visão judaico-cristã (o que é endossado pela fi-

152 Suma de teologia, Questão XCI, solução do artigo IV, p. 1741: "Além da lei natural e da humana, é necessário, para a direção da vida humana, haver uma lei divina. E isto por quatro razões. Primeiro, porque pela lei o homem dirige os seus atos em ordem ao fim último. Ora, se ele se ordenasse só para um fim que lhe não excedesse a capacidade das faculdades naturais, não teria necessidade de nenhuma regra racional, superior à lei natural e à humana desta derivada. Mas como o homem se ordena ao fim da beatitude eterna, excedente à capacidade natural das suas faculdades, como já estabelecemos, é necessário que, além da lei natural e da humana, seja também dirigido ao seu fim por uma lei imposta por Deus. Segundo, da incerteza do juízo humano, sobretudo no atinente às coisas contingentes e particulares, originam-se juízos diversos sobre atos humanos diversos; donde, por sua vez, procedem leis diversas e contrárias. Portanto, para poder o homem, sem nenhuma dúvida, saber o que deve fazer e o que deve evitar, é necessário dirija os seus atos próprios pela lei estabelecida por Deus, que sabe não poder errar. Terceiro, porque o homem só pode legislar sobre o que pode julgar. Ora, não pode julgar dos atos internos, que são ocultos, mas só dos externos, que aparecem. E contudo, a perfeição da virtude exige que ele proceda retamente em relação a uns e a outros. Portanto, a lei humana, não podendo coibir e ordenar suficientemente os atos internos, é necessário que, para tal, sobrevenha a lei divina. Quarto, porque, como diz Agostinho, a lei humana não pode punir ou proibir todas as malfeitorias. Pois, se quisesse eliminar todos os males, haveria conseqüentemente de impedir muitos bens, impedindo assim a utilidade do bem comum, necessário ao comércio humano. Por onde, a fim de nenhum mal ficar sem ser proibido e permanecer impune, é necessário sobrevir a lei divina, que proíbe todos os pecados. E essas quatro causas estão resumidas no salmo, que diz o seguinte: $A$ lei do Senhor que é imaculada, isto é, que não permite a torpeza de nenhum pecado; converte as almas, porque regula, não só os atos externos, mas também os internos; o testemunho do Senhor é fiel, por causa da certeza da verdade e da retidão; e dá sabedoria aos pequeninos, ordenando o homem a um fim sobrenatural e divino". Há quem não concorde que as concepções de Espinosa e de Tomás sejam incompatíveis, como G. Courtois ("La loi chez Spinoza et saint Thomas d'Aquin", Archives de philosophie du droit, $\mathrm{n}^{\circ} 25,1980$, pp. 159-189), que considera a existência em ambos de um anti-normativismo na concepção da lei divina.

153 "A mesma lei que é natural e moral também é merecidamente chamada divina: tanto porque a razão, que é a lei de natureza, foi outorgada por Deus e cada homem como regra de suas ações, quanto porque os preceitos de vida que dela derivamos coincidem com aqueles que foram promulgados pela Majestade Divina como leis de seu reino terreno, por intermédio de Nosso Senhor Jesus Cristo e de seus santos profetas e apóstolos [...]" (Thomas Hobbes, Do cidadão, Parte I, capítulo IV, \1 “A lei natural e moral é divina"; trad. de Renato Janine Ribeiro, p. 75). 
losofia católica), ter acesso sozinho às leis ou princípios verdadeiros que regem a natureza, o destino humano, a justiça divina: para que conheça esses princípios que indicam o que é ou não justo ou devido a cada ente, é preciso conhecer o juízo determinado já por aquele que criou todas as coisas e é regente do universo; esse conhecimento, segundo são Tomás, produz-se somente como conhecimento revelado ao homem de verdades cuja origem e causa são divinas. A concepção de são Tomás, em verdade, coloca uma novidade para a própria concepção clássica do pensamento cristão a respeito da lei divina, ao considerá-la não só idêntica à lei eterna, como a idéia que o homem tem dessa lei eterna: ou seja, a lei divina é, sempre, uma concepção humana de uma lei que, porém, é realmente divina, porque eterna; mas a sua definição — na Suma de teologia inclusive - só é possível desde que o ser humano esteja presente como ente subordinado a essa lei e ente que a concebe como um ordenamento de Deus sobre ele. $\mathrm{Na}$ concepção de são Tomás, em termos lógicos a lex aeterna é anterior à concepção da lex divina porque, em si mesma, a lex aeterna é a lex tal como ditada pela divina providência a todas as coisas; somente na medida em que o homem está presente nesse universo como entidade que percebe não só a existência dessa lei mas também a concebe como regente dele mesmo, concebe assim que essa lex aeterna, enquanto guia da sua ação, é válida porque vem da autoridade divina, merecendo nestes termos também a designação de lex divina - uma lei que tem autoridade sobre ele da mesma forma como as leis humanas de que o homem é autor. Ora, como o homem está subordinado à lei divina mas não é seu autor (não tendo, portanto, nenhuma interferência no seu processo de criação e validação), resta-lhe, por estar subordinado a ela, recebê-la como revelada. O caráter da revelação da lex divina é o que marca a autoridade irrecusável dessa lei sobre o homem, ainda que este seja racional e em certa medida capaz de calcular os seus próprios atos; porque são Tomás considera o homem subordinado também e principalmente à lex divina (nem a lex humana nem as ações humanas podem ser contrárias à lex divina), está mantido, aí, o princípio agostiniano de que a justiça humana é insuficiente para o estabelecimento da paz neste mundo. Ao homem resta, pois, encontrar-se com a verdadeira lex divina tal como revelata pelos meios determinado pelo próprio criador; já em são Tomás, estes meios são as Escrituras Sagradas e, agora, a instituição da Igreja, com suas autoridades religiosas e seculares como intermediadoras entre Deus e os homens. À razão humana, ainda que faculdade que permita aos homens elaborar suas próprias leis e também intentar sua própria interpretação das Escrituras, a maior autoridade da lex divina revelata sobre todos os atos humanos impede qualquer insubordinação às instituições de Deus na terra.

No caso de Hobbes, a divisão clássica, recebida especialmente a partir da classificação escolástica, concentra-se menos na separação entre as leis (todas, segundo Hobbes, redutíveis de al- 
guma forma à reta raz̃ão, ou conhecimento racional do útil) do que na distinção entre lei civil e direitos civis (para mostrar, também, que se trata de dois pontos de vista distintos a respeito de uma mesma realidade jurídica: a lei é um ordenamento que estabelece uma liberdade, e o direito a liberdade estabelecida por essa ordem). Assim, Hobbes tem o mérito de inaugurar, no plano dessa divisão das leis que identifica, ainda, lei natural e lei divina (também em Hobbes, a lei divina é a percepção pelo homem da lei natural), uma concepção de lei civil que se pretende baseada nas leis naturais, porque fundamentadas, ainda, na reta razão, que exige que toda lei civil, no estado civil, seja vontade do soberano (já que no estado civil hobbesiano, estamos todos alterius juris). O que torna válida uma lei como regra de ação, segundo Hobbes, é sua validade diante da reta razão (essa luz natural que reconhece a utilidade ou necessidade de uma ação ou de um direito), e por lei natural deve-se entender nada mais do que um princípio para a ação segundo a razão reta. Porém, como as próprias leis naturais mais primitivas reveladas por essa reta razão mostram, já, que ninguém pode ser juiz nem defensor de si próprio no estado civil, as primeiras leis naturais já concluem pela necessidade de estabelecimento de uma ordem jurídica na qual nem a reta razão nem a potência individual de cada um determinam algo como direito e como liberdade: é uma dedução da lei natural hobbesiana ser emudecida no estado civil, e substituída cada reta razão que revelava a cada um sua regra de ação, por uma razão soberana de Estado, personificada na vontade do soberano, a quem todos devem obediência e que por sua potestas determina, agora, o que é necessidade de cada um. Ou seja, em Hobbes, a concepção da relação entre lei humana e lei natural por via da reta razão tem, como finalidade, justificar como universalmente racional o comando do soberano, pelo simples fato de sua potestas absoluta definida, já, como privilégio particular do qual os súditos não têm nenhuma condição de participar. ${ }^{154}$

Ora, o que faz Espinosa? Para ele, a lex divina tem necessariamente o aspecto da revelação — dado o uso da expressão lex divina revelata —, justamente para marcar ao leitor cristão que o conceito a ser analisado é o conceito clássico cristão que considera que Deus é uma autoridade na terra. Tomada como vontade divina ou providência divina, essa lei é logicamente uma lei revelada, pois o homem não tem como participar do seu processo de criação nem tem poder sobre o seu significado - seja (como em são Tomás) uma lei que constitui uma justiça divina sobre todas as coisas, seja (como em Hobbes) uma lei que é apreensível pela razão reta: num caso e

\footnotetext{
${ }^{154}$ Leo Strauss, em Droit naturel et histoire, mostra bem o quanto Hobbes estabelece uma identidade entre potentia e potestas (p. 175), ainda que mantenha a idéia de potestas como poder válido em função da necessidade da potência do seu detentor e não da daquele que está sob esse poder. É uma concepção da qual Espinosa se afastará por completo, não somente em função dessa negação do valor da autoridade política por si mesma, mas também por conta de sua concepção própria da potentia, que é uma atualidade de ação, e não atualização de uma potencialidade para a ação (tal como em Aristóteles e, sob ligeiras diferenças, Hobbes).
} 
no outro, a lex divina revelata é algo que se impõe à natureza humana, e não algo que seja determinado por ela. Todavia, na análise efetivamente empreendida no capítulo IV e em outros trechos do tratado, Espinosa não se restringirá à idéia de lei revelada para a caracterização da lei divina; ao contrário, ele aí estabelece, também, uma identidade expressa entre lex divina e outras expressões, como lex Dei (lei de Deus); assim como uma identidade entre a lex divina naturalis (lei divina natural) e a própria religio (religião). Ao mesmo tempo, o tratamento da lex divina revelata no capítulo IV inverte completamente o valor que aparentemente ser-lhe-ia reconhecido em função de como Espinosa anunciara, no prefácio, o tratamento do tema: se no prefácio a lex divina revelata é a lex divina com relação à qual é o caso de provar a inexistência de qualquer incompatibilidade com a liberdade de pensamento e expressão, no capítulo IV ela é definida como uma visão humana da lex divina (até aqui, exatamente como em são Tomás e em conformidade com o que o leitor cristão entenderia da leitura do prefácio) concebida pelo homem como uma autoridade institucional sobre ele (também como em são Tomás; e também como em Hobbes), o que, porém (a partir daqui, o conceito espinosano de lex divina revelata), é uma concepsão limitada e equivocada, porque não mostra que a lex divina é válida, como no caso de qualquer lex, em função de determinar uma ação necessária em função da natureza ou definição do agente. Uma primeira leitura das explicações de Espinosa sobre essa lex divina que parece se manifestar por tantas expressões distintas parece dizer que se trata exatamente da mesma coisa em campos diferentes, como a lex divina naturalis na natureza, a lex divina universalis na religião e a lex Dei na vida moral e na vida política humana; de fato, não apenas se trata de diferentes expressões da lex divina, adequadas a cada campo, como estas parecem retomar e preservar uma concepção múltipla da lei divina derivada seja do pensamento helenista, seja principalmente do pensamento judaico-cristão; mais do isso, parece estabelecer a análise da lei divina nos termos criados pelo vocabulário latino cristão (afinal, os leitores do TTP são, em geral, cristãos).

De fato, o vocabulário espinosano a respeito da lei divina é aquele em uso pela teologia cristã do seu tempo; também, as definições parecem a uma primeira visa ser as mesmas, mas uma leitura mais atenta mostra que o sentido não é mais o mesmo: Espinosa apresenta definições e explicações que produzem argumentos totalmente adversos às conclusões da teologia. Se Espinosa concluirá teses sobre a lei divina muito diferentes daquelas professadas desde os primórdios da teologia política cristã (ou seja: em termos doutrinários, desde santo Agostinho), isso se deve, primeiro, à força da sua análise acerca da lei divina em todas as suas acepções; mas trata-se de uma crítica à teologia que, além de se manifestar no correr das suas análises, encontra-se, já, na forma como Espinosa define a lex divina e as suas expressões próprias. Para toda a tradição teológica, a lex divina é revelada, seja diretamente por Deus, seja pelos seus intérpretes (os profetas, 
os apóstolos), seja pelos seus representantes (os sacerdotes, os juízes, os reis, os apóstolos) ou pelos representantes de seus intérpretes (o clero); não importa a forma pela qual a lei divina chega aos homens, segundo os teólogos ela tem sempre uma origem revelada, porque ela é a própria vontade e verbo de Deus, e este é sempre revelado aos homens, nunca deduzido por eles sozinhos. O que faz Espinosa? Mostra que a lei divina revelata, tal como é concebida, é de fato de origem divina e palavra de Deus, de modo que sua origem é o próprio Deus; portanto, jamais temos acesso à lei divina revelata se não for por uma forma deixada pelo próprio Deus; como Ele não mais se comunica conosco, e como não há mais verdadeiros profetas, resta a expressão mais direta deixada por Deus, a Bíblia; de modo que, se é o caso de conhecer a lei divina revelata, ela está na Bíblia, que segundo Espinosa é compreensível por qualquer pessoa graças à sua própria luz natural, isto é, à sua razão; para o conhecimento da lei divina revelata, não é necessário depender da intermediação de nenhuma autoridade religiosa, dos sacerdotes aos teólogos (só esta idéia já é sacrílega para os teólogos de qualquer tempo; não por negar a validade da palavra de Deus - ao contrário, aponta e defende sua validade e origem enquanto lei divina revelata - , mas por negar a validade do poder dos teólogos sobre o acesso e o conhecimento dessa lei divina). Basta ter em conta ao menos os conteúdos teóricos da teologia judaico-cristã e também do direito canônico para perceber o gigantismo filosófico dessa concepção da lei divina revelata; mas, não bastasse isso, essa concepção está ali no meio de uma análise da lex que não permitirá ler como revelata a lex divina que não estiver registrada ali nas escrituras sagradas. É em função somente da lex divina revelata que se estabelecem os cultos externos da religião, pois a fé individual só é válida enquanto manifestação exterior da crença e não somente enquanto crença - como disse o evangelista, "a fé sem obras é morta" —, de modo que nenhuma instituição ou autoridade religiosa vale para outro campo que não seja estritamente o da lei divina revelata. A outra lei divina, aquela que se refere ao outro livro de Deus, o "Livro da Natureza”, também será acessível à luz natural, mas para ela não será necessário nenhum culto exterior.

Tanto a idéia de lex divina revelada é uma concepção inválida da lex divina necessária, que Espinosa, ao analisá-la, considera que é somente uma compreensão parcial da lex divina motivada por falta de conhecimento da necessidade, tirando dos textos bíblicos uma série de exemplos que mostram que é por fraqueza de intelecto que se concebe que as leis determinadas por Deus são reveladas a partir de certo momento e na forma de decretos, e não princípios necessários que se acham, já, na natureza de cada homem ou cada agente. A lex divina, sendo lex, determina ações; entretanto, como a ação determinada por uma lei diz respeito apenas à ação segundo a natureza ou definição de uma coisa, por lei divina é o caso, somente, de compreender aquilo que 
determina a ação de Deus, e não de algo que esteja fora de Deus. A identificação da lex divina com outras formas que não a lex divina revelata mostra-o perfeitamente: a lex divina não é uma autoridade sobre os homens, mas sim a própria necessidade de ação de Deus segundo sua natureza e definição. ${ }^{155}$ A única condição para se conceber que a lex divina determina a ação do homem seria a participação do homem em Deus ou sua identidade com ele; ora, Espinosa, no TTP, nega que o homem seja idêntico a Deus, mas afirma de várias formas a imanência recíproca entre cada homem e Deus: enquanto participa da natureza divina, o homem tem sua ação determinada pela mesma necessidade que determina a ação de Deus; ao contrário, enquanto é considerado um ente subordinado a Deus, ou uma natureza hierarquicamente inferior à natureza de Deus, não faz sentido, em termos espinosanos, conceber qualquer determinação da ação humana segundo uma lex divina. Que é a lex divina com relação ao homem, pois? Na medida em que o homem participa da natureza divina (o que, no TTP, significa ser fiel, obedecer a Deus mas já não no sentido teológico, e sim num sentido ontológico, compatível a propósito com a participação do homem em Deus tal como definida na Ética), ela é a necessidade da ação humana tal como determinada por sua condição natural: Deus não é um princeps sobre os homens e o universo, mas apenas a necessidade absoluta da ação de cada homem e de todas as coisas... por uma recusa de racionalidade à concepção parcial e judaico-cristã da lex divina como lex divina revelata, Espinosa destrói qualquer idéia de autoridade das instituições religiosas sobre as ações humanas e exige que a necessidade da lex divina seja reconhecida como necessidade da natureza e definição do homem. Por isso, em termos espinosanos, sempre que se concebe a lex divina revelata, é o caso de denunciar a sua irracionalidade e parcialidade; e se voltamos ao prefácio, a afirmação de que a liberdade de pensamento e expressão é algo que a lex divina revelata concede agora nos mostra o seu pleno significado: a concepção imaginativa de que Deus é uma autoridade sobre os homens não modifica em nada a necessidade natural de cada um pensar e dizer o que pensa, da mesma forma como uma tal incompatibilidade só poderia mesmo ser imaginada com relação a uma concepção irracional da lex divina... Se conhecemos a lex divina tal como

155 A maior parte dos juristas do tempo de Espinosa considera que é uma autoridade sobre os homens. Grotius o afirma expressamente nos Prolegômenos, \XI, ao seu Do direito de guerra e paz (p. 12), reconhecendo que as leis do Criador são fonte de direito porque ele é, de fato, uma autoridade sobre a ordem do universo e a natureza humana: "[...] não poderia ser concedido sem ser grande crime, o acordássemos que não existe Deus ou que os assuntos humanos não objeto das preocupações Dele. Tendo o contrário sido em nós inculcado em parte por nossa razão, em parte por uma tradição perpétua, e sendo-nos confirmado por provas numerosas e milagres atestados por todos os séculos, segue que devemos obedecer sem exceção a Deus, como o Criador e aquele a quem somos devedores do que somos e de tudo o que possuímos; na mesma medida Ele tem se mostrado por muitas maneiras generoso e todo-poderoso: donde devemos concluir que Ele pode conceder àqueles que $\mathrm{O}$ obedecem grandiosas recompensas, recompesas mesmo eternas, sendo eterno Ele mesmo, e que Ele deve ter desejado que assim acreditemos, sobretudo se Ele o prometeu em termos expressos: no que cremos nós, cristãos, convencidos que fomos pela fé indubitável dos testemunhos". 
ela é verdadeiramente, vemos não mais a figura de uma autoridade sobre nós, mas a necessidade da liberdade humana em todos os seus aspectos.

O que direito e teologia, concebidos como instituições, têm em comum? Ambos são a personificação da idéia de potestas, ou seja, da idéia de que uma regra de ação é válida ou obrigatória porque é acompanhada de uma sanção. É por medo de castigos ou esperança de bens que o religioso obedece a Deus, e não segundo a sua luz natural, que lhe mostraria a necessidade da lei divina; enquanto não busca compreender a necessidade dessa lei divina, o homem mantém uma obediência sem conhecimento das próprias causas, e por isso mesmo uma falsa obediência, uma falsa fé. Na vida política, ocorre o mesmo. Embora a criação das leis, como mostram os $\iint 4$ e 5 do capítulo III do Tratado político, seja privilégio da autoridade soberana e especialmente sua interpretação não caiba a cada um — enquanto é concebido como alterius juris nesse assunto — mas novamente à summa potestatis, essa elaboração legislativa e essa interpretação das leis não pode ser contrária ao que é bem comum, necessidade da comunidade política, finalidade pública: o privilégio dessa potestatis para legislar e interpretar as leis é válido unicamente para cumprir uma função do Estado na vida política, e não para estabelecer um domínio sobre a vontade e necessidade dos cidadãos:

\4. Além disso, não podemos conceber que seja permitido a cada um interpretar os decretos da Cidade, isto é, as suas leis. Se houvesse tal permissão, ser-se-ia, com efeito, seu próprio juiz; não haveria atos cometidos por si que não pudessem tornar-se desculpáveis ou louváveis com uma aparência de direito, e, conseqüentemente, regular-se-ia a vida segundo o próprio arbítrio, o que é absurdo.

\5. Vemos, portanto, que cada cidadão depende não de si mesmo, mas da Cidade, às injunções da qual é obrigado a obedecer, e que ninguém tem o direito de decidir o que é justo, o que é injusto, o que é moral ou imoral, mas, pelo contrário, visto que o corpo do Estado deve ser conduzido de certo modo por um pensamento único e que, conseqüentemente, a vontade da Cidade deve ser tida como a vontade de todos, é o que a Cidade decreta ser justo e bom o que cada um deve aceitar como tal. Portanto, mesmo se o súdito julga iníquos os decretos da Cidade, é contudo obrigado a submeter-selhes. ${ }^{156}$

Como mostrara o capítulo IV do Teológico-político, a lei é consciência da necessidade da ação, deve ser válida unicamente por sua necessidade e não pelo poder atribuído à autoridade que a estabelece. A lei, segundo Espinosa, é vista como uma instituição — ou seja, unicamente como um comando de autoridade, e não como expressão de necessidade — apenas quando não é conhecida racionalmente, situação em que sua necessidade apareceria necessariamente. O mesmo capítulo IV do TTP exemplifica com Adão, dizendo que por sua falta de conhecimento, não

${ }^{156}$ Conforme a tradução de Manuel de Castro. 
compreendia a necessidade das leis dadas por Deus, e por isso as concebia como instituição, e Deus como a um príncipe:

Como, porém, a Escritura narra que Deus proibiu Adão e que, mesmo assim, ele comeu, temos forçosamente de admitir que Deus só revelou a Adão o mal que necessariamente lhe aconteceria se ele comesse e não a necessidade com que esse mal viria a seguir. Por isso é que Adão entendeu essa revelação, não como uma verdade eterna e necessária, mas como uma lei, isto é, como algo instituído a que se seguiria um prêmio ou um castigo, não pela necessidade e pela natureza da ação perpetrada, mas unicamente pelo capricho e pela autoridade absoluta de um príncipe. Assim, só na perspectiva de Adão e em virtude da sua falta de conhecimento é que essa revelação foi uma lei e Deus surgiu como legislador ou príncipe. ${ }^{157}$

No capítulo XII, o povo hebraico, também, só precisava desde o seu início de leis escritas porque era tal como uma criança, incapaz de sem elas saber qual a sua necessidade:

Aos primitivos judeus, a religião foi dada por escrito e sob a forma de lei, porque nesse tempo eles eram quase como crianças. Mais tarde, porém, Moisés e Jeremias pregaram-lhes que viria o tempo em que Deus inscreveria a lei nos seus corações. Nessa medida, só aos judeus, e especialmente aos saduceus, competia outrora pugnar pela lei escrita nas tábuas, não àquelas que a têm inscrita nas suas mentes. ${ }^{158}$

Da mesma forma como, na religião, a obediência em função do medo é marca de ausência de conhecimento e abertura para o despotismo da teologia, na vida política a mesma obediência unicamente por causa do medo é marcada pela ignorância da necessidade da lei civil segundo a necessidade de cada um. Isso não é, talvez, sem motivos. Já que, como mostra a Ética, a consciência é consciência do próprio corpo, o desconhecimento da necessidade de uma lei talvez seja causado pela separação entre o corpo do cidadão e o corpo do Estado. Ora, como o Estado é, segundo o que mostra a razão, criado para realizar uma finalidade que é pública — paz, segurança, concórdia -, essa finalidade, por ser pública, deve ser idêntica à necessidade de cada um dos seus cidadãos, de maneira que uma prática política adequada deve ser aquela que por sua própria definição exige a ilegitimidade da obediência unicamente pelo medo: democracia. Ainda que seja certo que são raros os homens que fazem uso da razão e, portanto, raros aqueles que dêem ao trabalho de conhecer por sua luz natural a necessidade das leis civis e sua identidade com elas, o desconhecimento da necessidade da lei, quando causado não pela indisposição do

157 Ed. Gebhardt, III, p. 63, 16-25:Verum quoniam Scriptura tamen narrat, Deum id Adamo praescepisse, et nibilominius Adamum de eadem comedisse, necessario dicendum est, Deum Adamo malum tantum revelavisse, quod eum necessario sequeretur, si de illa arbore comederet, at non necessitatem consecutionis illius mali: Unde factum est, ut Adamus illam revelationem non ut aeternam et necessariuam veritatem perceperit, sed ut legem, hoc est, ut institutum, quod lucrum aut damnum sequitur, non ex necessitate et natura actionis patratae, sed ex solo libitu et absoluto imperio alicujus Principis.

158 Ed. Gebhardt, III, p. 158, 33-p. 159, 7: Primis Judaeis Religio tanquam lex scripto tradita est, nimirum quia tum temporis veluti infantes habebantur. Verum imposterum Moses (Deut. cap. 30. vers. 6.) et Jeremias (cap. 31. vers. 33.) tempus futurum ipsis praedicant, quo Deus suam legem eorum cordibus inscribet. Adeoque solis Judaeis, et praecipue Zaducaeis competebat olim pro lege in tabulis scripta pugnare, at iis minime, qui ipsam mentibus inscriptam habent. 
indivíduo à compreensão racional mas pela inexistência real dessa necessidade, deixa para o legislador e para a autoridade política uma brecha para recusar o critério de validade das leis civis em função da sua necessidade para a vida política, assim como para retornar à concepção hobbesiana da validade da lei civil em função apenas de sua origem soberana: despotismo.

Aceitar que o jus naturae seja autodeterminação da ação segundo a potência é negar a validade de qualquer princípio moral para ação, acusa Pufendorf tendo em mãos o Tratado teológicopolítico. Aceitar que o estado de natureza continue no estado civil é negar que a vida política possa conquistar paz e segurança, dizem os hobbesianos e os positivistas. Aceitar, finalmente, que o direito - qualquer direito, como mostrará agora Espinosa — seja idêntico à potência, isso é negar a realidade mesma do direito, segundo Fichte. Por que tanto incômodo no mundo dos juristas que lêem Espinosa? Porque toda a concepção espinosana do jus e da lex é válida para o estado civil, e exige que a racionalidade deste seja compativel com a ontologia do necessário. De fato, depois de ter demonstrado, no capítulo XVI do Teológico-político, o que é o estado natural segundo exemplos referentes aos seres naturais, Espinosa mostra que o mesmo vale para os seres humanos, pois também eles são, nessa perspectiva, seres naturais:

\begin{abstract}
Nem vemos que haja aqui qualquer diferença entre os homens e os outros seres da natureza, ou entre os homens dotados de razão e os outros que ignoram a verdadeira razão, ou ainda entre os imbecis e dementes e as pessoas sensatas. Tudo o que uma coisa faz segundo as leis da sua natureza fá-lo com todo o direito, pois age conforme determinado pela natureza e não pode sequer agir de outra forma. É por isso que, no respeitante aos homens, enquanto considerados como vivendo sob o império unicamente da natureza, tanto está no seu pleno direito aquele que ainda não conheceu a razão ou que ainda não contraiu o hábito da virtude e vive simplesmente pelas leis do instinto, como aquele que rege a sua vida pelas leis da razão. Por outras palavras, tal como o sábio tem todo o direito de fazer tudo o que a razão manda, ou seja, a viver segundo as leis da razão, também o ignorante e o pusilânime têm todo o direito de fazer tudo o que o instinto lhes inspire, isto é, de viver segundo as leis do instinto. É, de resto, o que ensina Paulo, que não reconhece pecado algum antes da lei, quer dizer, enquanto se consideram os homens como vivendo sob o império da natureza.
\end{abstract}

Com essa consideração, Espinosa abole a idéia clássica do direito romano de que certas pessoas são incapazes, por natureza, de direito. ${ }^{159} \mathrm{Na}$ concepção espinosana, sendo o direito idêntico à potência, não há quem não tenha direitos ou, mais precisamente, não há quem não tenha potência. O que pode ocorrer, porém, conforme o exemplo de que já partira Espinosa, é a dominação de certos indivíduos por outros em função da potência ou, nestes termos, em função de uma maior força: o que permite a dominação de uns por outros não é sua necessidade de ser dominados (porque ser dominado significa ter a potência diminuída, o que é contrário ao cona-

${ }^{159}$ E que servirá de base, a propósito, também para considerar a condição alterius juris das mulheres. 
tus individual), mas a ineficiência da sua resistência (esta sim, necessária) diante daquele que efetivamente é mais potente ou mais forte. A dominação, por ser operação contrária à potência daquele que é dominado, é sempre violência contra ele; mas ela ocorre de fato quando o dominado é, como os "peixes menores", pouco potente. Quando se considera que alguém não tem direitos ou não merece tais direitos por uma debilidade natural, isso só faz sentido enquanto determinação externa do direito (absurda, pois), e não enquanto determinação segundo a necessidade natural: por necessidade natural, cada indivíduo deseja preservação e não limitação da sua potência; dentro da necessidade dessa potência, nenhuma concessão além dela é necessária e toda proibição contra a sua necessidade é violenta. Por isso, se é o caso de considerar uma medida para o direito de um indivíduo, este só pode ser preciso enquanto idêntico à sua própria potência.

O problema que resulta daí, evidentemente, é a operação dessa potência individual em comunidade. Ora, o que significa Espinosa dizer que "a potência universal de toda a Natureza não é mais do que a potência de todos os indivíduos em conjunto"? Significa que a potência da comunidade de indivíduos não é contrária à potência de cada um destes, mas, ao contrário, é produto da sua união atual. A vida coletiva humana, tendo sua potência determinada por todos os indivíduos em conjunto, nunca é incompatível com a potência de qualquer indivíduo que participe dessa comunidade. Da mesma forma que a natureza inteira é o conjunto dos seres naturais, toda comunidade (e isso valerá para a comunidade política) é nada mais que o conjunto dos indivíduos que a constituem, conforme a definição mesma da coisa singular, isto é, do indivíduo (que também mostra o que é uma comunidade):

Por coisas singulares, entendo coisas que são finitas e têm existência determinada. Se uma pluralidade de indivíduos concorrem para uma mesma ação, de maneira que todos juntos sejam a causa de um só efeito, consideramos então todos juntos uma mesma coisa singular. ${ }^{160}$

Ora, o que significa agir contrariamente à necessidade de uma comunidade? Significa não ter a mesma necessidade que ela, não conceber qualquer identidade com ela, estar fora dela. Apenas naquilo em que diferentes indivíduos têm alguma identidade, mostra a Ética, é possível causar uma influência negativa (da mesma forma que uma influência positiva). Para que a influência de uma comunidade sobre um indivíduo (ou vice versa) seja negativa, é preciso que ela se dê naquilo em que há identidade entre ambos. Ora, em termos espinosanos, essa relação é fundamentalmente uma relação ontológica: a potência de uma comunidade ou de um indivíduo com que uma pessoa não reconheça nenhuma identidade, não tem nenhuma autoridade racional sobre ela porque sobre sua potência não causa efeito nenhum. Isso deixa os leitores juristas de

${ }^{160}$ Ética, II, def. 7. 
Espinosa aterrorizados, já que o Estado, essa instituição que é concebida pelos juristas como soberana sobre os súditos ou cidadãos, impõe concretamente sua autoridade e seu poder independente da vontade ou da necessidade de cada particular que toma por súdito ou por cidadão. Em termos da teoria jurídica daquele e de qualquer tempo, a autoridade do Estado deve ser sempre imposta e sempre tem caráter universal sobre seus cidadãos, cabendo a eles a obediência ao Estado e às regras outorgadas por este. Para os juristas, o Estado é autoridade política porque tem poder de obrigar pela coação: os cidadãos aceitam obedecer ao Estado porque têm medo de punição caso não obedeçam, ou porque esperam por benefícios desde que demonstrem obediência. Essa forma de obediência, mostra Espinosa, não é motivada pela razão (que vê a necessidade da lei quando esta é de fato necessária), mas pelo medo, ali num campo (o campo político) onde o medo não deve ser a paixão predominante, mas sim o desejo de união coletiva e de concórdia (o inverso do medo, portanto). Um conjunto de cidadãos ou súditos que têm sobre si uma autoridade estatal a que só obedecem por medo não é, de forma alguma, uma comunidade política, mas um conjunto de servos; é essa servidão que Espinosa acusa quando diz que a paz se torna o que há de mais triste quando só pode ser concebida como servidão e solidão, em vez de liberdade e concórdia. É na necessidade da natureza de cada ser e de cada homem que se encontra essa necessidade da vida coletiva e política, como sociedade de homens livres e desejosos de "paz e concórdia" entre si.

Quando o jurista jusnaturalista concebe o fundamento do direito, funda-o no direito natural de uma ou de outra forma (inumeráveis estas formas, tanto quanto as formulações de direito natural por cada autor). Ora, o que vêem os leitores juristas de Espinosa, quando acusam o seu conceito de direito (que tem a aparência de um conceito de direito natural: jus naturae, jus naturale, jus sive potentia) de ser irreal, irracional, imoral? De maneira alguma essa acusação de irracionalidade vem da sua formulação sob a forma de direito natural, porque é essa mesma a forma que todos os seus primeiros leitores normalmente utilizam (em especial Pufendorf, certamente o maior jusnaturalista do século XVII). Também não é, simplesmente, a derivação do direito a partir da ontologia: nos Seiscentos, todos os autores jurídicos (e muito especialmente os jusnaturalistas), ao elaborar teoria jurídica ou teoria do Estado, fundamentam sua análise do Estado e da política em algo que está fora ou é anterior ao próprio campo da política: a metafísica, a física, a psicologia, a moral, a teologia, a linguagem... O conceito espinosano de direito, tal como Espinosa o define, o explica, o utiliza, é em todas as suas formas um conceito que pode ser reduzido à potentia, o que, para os leitores juristas, significa que é um conceito cuja realidade e racionalidade pode ser concebida completamente fora das instituições do Estado e do poder. Como o direito sempre é idêntico à potência, e como a lei é sempre necessidade, o conceito de 
jus sive potentia abole qualquer medida universal ou transcendental de moral, justiça, legitimidade e mesmo autoridade. Como instituir o poder político, se o direito daquele que deveria obedecer à autoridade política não pode ser determinado pela própria autoridade política separada do cidadão?

Seria o caso, simplesmente, de negar a validade real da potentia, mas isso os leitores juristas de Espinosa não fazem (ao contrário, não têm como negar a realidade da potentia). O que eles fazem é negar a realidade jurídica ou a validade moral dessa potentia. Por quê? Porque todos os jusnaturalistas, apesar de suas notórias diferenças teóricas ou doutrinárias, concebem que o poder, no estado civil, está separado do súdito ou cidadão. O que constitui a soberania, para esses autores (e seus antecessores na teoria renascentista da república e da soberania), é a ausência de autoridade político-jurídica sobre uma entidade estatal (o Estado) e a definição dessa entidade como poder sobre uma sociedade política (o povo, a sociedade); à frente desse Estado, uma autoridade político-jurídica (governante, legislador, magistrado, ou uma mescla de todas essas funções) cujo número e forma pode variar. Entretanto, não importa quantos estejam no poder, qual seja o regime político adotado no Estado ou sobre a sociedade política, qual seja a constituição política e jurídica dessa comunidade política, sempre há uma autoridade política soberana que se identifica com a soberania do Estado e sobre as quais nenhuma outra soberania existe; ao contrário, essa soberania do Estado e de quem é nele autoridade política soberana são concebidas como tendo poder sobre todos os indivíduos considerados súditos ou cidadãos desse Estado. Para os juristas do jusnaturalismo, também, o Estado é uma entidade política soberana que deve direitos e obrigações aos seus súditos, assim como os súditos lhe devem obediência e reivindicação de suas liberdades, mas a autoridade política é sempre concebida pelos jusnaturalistas do século XVII como uma entidade separada dos súditos, já que todos esses jusnaturalistas são contratualistas: o fundamento do estado civil é a alienação de direitos naturais ao soberano, numa ou noutra medida. Ora, os leitores juristas de Espinosa sabem, prontamente, que ele nega o contratualismo e, além disso, apresenta uma concepção de estado civil na qual, não havendo alienação de direitos naturais, não há fundação do poder político numa vontade ou num arbítrio separados da necessidade de cada cidadão ou súdito; na concepção de Espinosa, ninguém, em estado civil, deixa de desejar tomar parte no poder, porque ninguém presta obediência ao Estado a ponto de nunca desejar determinar a validade do imperium do Estado, e especialmente porque o poder político do Estado, isto é, da comunidade política, é nada mais que a denominação política da potência de todos os cidadãos em conjunto. O poder, em Espinosa, está baseado exclusivamente na potência dos súditos, de maneira que por soberania não se deve entender, espinosanamente, uma autoridade do Estado sobre seus súditos, mas a auto- 
nomia política de todos os integrantes de uma comunidade política. Ou seja: na concepção espinosana de direito, já está contida a concepção de necessidade coletiva e pública do poder político; já está contida, portanto, a necessidade democrática da vida política — o que, em termos espinosanos, significa a necessidade do poder político ser determinado por um soberano que é o próprio conjunto de cidadãos, e que não teria legitimidade alguma se assim não o fosse. É isso, definitivamente, que os juristas não suportam e não podem aceitar nessa leitura imediata do Tratado teológico-político e do Tratado político. Os juristas, que se batem por demonstrar que o Estado só é possível enquanto uma autoridade sobre seus cidadãos e definir uma forma ou um modelo para a prática político-jurídica dessa autoridade, não suportam a concepção maximamente subversiva dada por Espinosa de que "a democracia é o mais natural dos regimes políticos": ao dizê-lo — sabem os juristas —, Espinosa exige que o poder político não seja mais privilégio de ninguém no Estado, mas que o Estado seja, necessariamente, a realização concreta da liberdade necessária a cada um na vida política, sem exclusão de quem quer que seja.

Assim, o que leva o jusnaturalista contemporâneo de Espinosa a recusar seu conceito de jus sive potentia é, já, a concepção inserida ali de que o poder deve ser democrático. Fosse apenas a identidade entre o direito e a potência, esta talvez pudesse ser suportada se considerássemos, como pretende fazer Norberto Bobbio quando tem Espinosa nas mãos, que ele pode ser reduzido à filosofia hobbesiana: se substituíssemos o termo potentia pelo termo potestas, talvez a filosofia espinosana fizesse, hobbesianamente, melhor sentido; afinal, talvez fosse mesmo o conceito espinosano de potentia um desvio motivado pelo seu aprendizado tardio do latim, por que não? Não, porque, diferentemente não só de Hobbes como de qualquer outro jusnaturalista (coisa que Hobbes definitivamente é), Espinosa recusa que surja, na vida política, uma potentia política que não se concebe ontologicamente e em cada um, independente da forma do Estado.

Espinosa, ao analisar a política e o direito, acaba por esvaziar a realidade racional e ontológica tanto dos conceitos ligados às teorias do direito natural (porque baseados especialmente na idéia de contratualismo), quanto da maior parte dos conceitos ligados às teorias do direito positivo (porque fundados ainda na identidade entre finalidades privadas e poder do Estado). O tratamento que dá ao direito natural tem como resultado, primeiro, a identificação entre direito natural e potência, o que significa nada mais que a negação da racionalidade do próprio direito natural e sua substituição pela própria estrutura da natureza, concebida ora como força, ora como necessidade. Essa substituição implica, no caso da força, a irracionalidade da noção de capacidade jurídica natural (já que a capacidade jurídica de alguém não é derivada de um direito 
natural ou do seu direito natural, mas sim de sua capacidade física: no que é inútil ter direito a algo se não há capacidade física de realizar esse direito, assim como é inútil não ter direito a algo se há capacidade física para obter o objeto a que esse direito negado se refere); no caso da necessidade, a substituição implica a irracionalidade da própria noção de direito subjetivo natural (já que o direito subjetivo natural de alguém não existe como causa para a produção da sua capacidade física e, na perspectiva do direito positivo, o direito subjetivo indicado pelo direito positivo não produz efeito enquanto direito natural, mas unicamente enquanto direito positivo).

Diante disso, o que mais permite afirmar Espinosa como jurista além de filósofo do direito é o tratamento que dá à sua própria teoria do direito positivo, ao delinear, a partir dela, um projeto jurídico (entenda-se: um projeto de direito positivo, desenvolvido retoricamente no Tratado teológico-político e diretamente no Tratado político). Este projeto, por sua vez, revela-se conseqüência necessária da teoria espinosana do direito natural, pois só é realizável a partir da desconstrução do direito natural, na medida em que ele mesmo opera uma desconstrução da concepção clássica de direito positivo exatamente naquilo em que este era concebido como conseqüência do direito natural. Em outras palavras: Espinosa reconhece, primeiro, apenas o direito positivo como uma entidade jurídica real (produzida de fato na vida política) e racional (dotada, ou dotável, de sentido consistente); mas, em segundo lugar, mostra que só parte do direito positivo pode ser considerada real e racional: justamente, o direito positivo cujos conceitos e cuja estrutura sejam concretos, reais no sentido de que produzem efeitos na vida política e naturais no sentido de que são apreendidos pela experiência.

O resultado dessa concepção do direito positivo é compatível com a identificação entre jus e potentia, porque envolve (graças à identificação entre potentia e potestas) a identificação entre lex e potestas: assim como o direito, concebido seja como direito natural, seja direito subjetivo, só existe enquanto força ou necessidade (e, por isso, se torna dispensável e substituível por termos da física, da política e da história), o direito concebido como lei ou direito positivo, ou como poder político ou jurídico, também só existe enquanto força ou necessidade - no caso, força enquanto domínio (capacidade concreta, no plano da política, de determinação da capacidade de ação de outrem, assim como de si) e necessidade enquanto desejo desse domínio (porque a imposição de uma lei a si é efeito do desejo de autopreservação, ao passo que a imposição de uma lei a outrem é desejo de preservação desse conjunto — se incluído nele quem impõe a norma — ou preservação contra esse conjunto — se excluído dele quem a impõe).

Essa reviravolta na validade dos termos do direito positivo significa que as leis jurídicas não têm força porque sejam justas ou perfeitas, mas é justamente o inverso: as leis só são obedeci- 
das ou eficazes porque a instituição que representam já tem força e domínio sobre os súditos (ou seja: não é a lei que produz a instituição jurídica, mas é a instituição jurídica que produz a si mesma). Como resultado, abala-se a concepção clássica da racionalidade jurídica: a norma jurídica perde racionalidade enquanto idéia (porque não é válida em função de sua verdade, já que nem é produzida enquanto uma idéia verdadeira, nem é avaliada ou operada como tal) e enquanto valor moral (já que religião e política estão separados, assim como moral e política ainda que religião e moral não o estejam nunca —, e já que a moralidade ou imoralidade de uma norma jurídica não é prioritária para a sua utilidade enquanto instrumento de dominação, ainda que essa influência tenha a sua relevância). Resta à norma jurídica, porém, a condição de instrumento racional para a própria atividade política e social, desde que ela seja concebida e operada enquanto um instrumento de manifestação do que é útil para o corpo político, cuja influência só é legítima diante da constatação da racionalidade desse seu significado (no que a lei “injusta”, isto é, inútil ou contrária às necessidades da comunidade ou do indivíduo, não tem legitimidade e é nula pelas leis da própria razão, ou seja, seu caráter absurdo é evidente para o próprio intelecto).

Produzida também essa desmistificação do direito positivo (que o revela apenas um instrumento, de maneira que a sua validade deve ser dada de fora do próprio direito), não há nenhuma ponte a ser estabelecida entre isso e um estado anárquico, porque a vida política se revela, de um ponto de vista racional, sempre necessária por natureza. O que é preciso, porém, é realizar com o direito positivo um procedimento diferente daquele que deve ser operado sobre o direito natural: se este deve ser simplesmente apagado enquanto idéia e enquanto valor, o direito positivo, por ser concebido enquanto uma entidade política, não está concebido fora do seu ambiente racional, devendo apenas ser adequado por completo a ele. Em outros termos, se o direito natural não tem sentido nenhum no campo da política, o direito positivo o tem, mas deve ser destituído de toda carga imaginativa, para que valha enquanto conceito e enquanto interpretação. Da mesma forma, o direito positivo não deve ser causa de nenhum tipo de violência, para que o domínio que ele significa, ou melhor, que ele é, não seja concebido e operado já enquanto violência - que destrói tanto o agente quanto a vítima do ato violento —, mas unicamente na forma de autopreservação — do dominado e do dominante.

Essa necessidade de preservação idêntica entre dominado e dominante é o que coloca, na perspectiva do direito, a necessidade da democracia na política, ao mesmo tempo que pede uma nova desconstrução conceitual, a do conceito de dominium: todo domínio que não é domínio de si, por ser domínio de outrem, é, na verdade, violência, na medida em que o dominado não participa, por definição, da própria dominação e, portanto, é nesse processo transformado numa 
coisa, por desconsideração de sua sensibilidade e do seu desejo. Dominar o outro é determinar a capacidade de ação do outro, o que significa que a ação do dominado não é jamais determinada por ele mesmo; o domínio, por definição, é ausência e recusa de liberdade, porque a ação do dominado nada mais é do que um movimento causado por uma determinação exterior; o domínio, assim concebido, é impotência, e é incompatível com o direito democrático. Por outro lado, a ação comandada pelo dominante ao dominado, quando idêntica à ação que o próprio dominado ordena a si mesmo em sua liberdade, produz um efeito determinado, na prática, pelo "dominado" e não pelo "dominante", no que a ação realizada não é causada sob uma condição de submissão a uma causa exterior, e de domínio se transforma em igualdade na associação política; ou seja, na liberdade, o domínio é irracional (porque violento e substituível por outra forma de ação política) e inútil (porque a ação não se produz livremente, mas contra a liberdade e na direção do ódio e da autodestruição de dominado e dominante).

A conceitografia política e jurídica de todas as tradições acaba por se revelar mistificada e irracional, e o vazio deixado pelo desaparecimento de cada conceito é preenchido a todo momento pelo conatus. Daí, democracia como única forma de governo, e racionalidade como única fonte de sentido verdadeiro para a própria política. Infelizmente, o cumprimento dessa necessidade de aliar democracia e racionalidade está nas mãos de um indivíduo em constante indecisão (o corpo político), e sua mente não pode nunca deixar de ser coletiva: a democracia deve por natureza ser não representativa, mas ao mesmo tempo tem necessidade de ser pacífica, ou seja, não destruidora do seu próprio corpo. A vida política deve ser a realização de uma atividade pacífica, no sentido de que deve ser uma atividade realizadora de sua própria preservação. Maquiavel repercute aqui, muito mais do que qualquer outro autor: o corpo político existe enquanto preserva a si mesmo e é realização da liberdade; uma equação que todavia, em Espinosa, resulta necessariamente em democracia pacífica. 
SEÇÃO 2

UM JURISTA VOLTADO PARA A DEMOCRACIA 


\section{CAPÍTULO 3 \\ ESPINOSA, HOBBESIANO?}

A derivação da construção espinosana a partir da hobbesiana é evidente e não é de modo algum atenuável (como tentam fazer os que consideram dever evitar, para o autor que apreciam, a vergonha da reductio ad Hobbesium).

N. Bobbio, Sociedade e Estado na filosofia política moderna, "O Estado segundo a razão", pp. 85-86.

\section{I A IMAGEM DA REDUCTIO AD HobBesium}

Não deixa de ser curioso que o "texto político" de Espinosa mais citado pela fortuna críti$\mathrm{ca}^{161}$ seja um fragmento retirado de fora das suas obras políticas, ainda que ele diga respeito justamente a estas: o célebre início da Carta 50, a Jarig Jelles, em que Espinosa explica ao amigo a diferença fundamental entre a sua filosofia e a de Hobbes:

No que respeita à política, perguntas qual a diferença entre mim e Hobbes. Consiste nisso: conservo o direito natural sempre bem resguardado e considero que em qualquer Cidade o magistrado supremo só tem direito sobre os súditos na medida exata em que seu poder sobre eles supere o deles, como sempre ocorre no estado natural. ${ }^{162}$

${ }^{161}$ P. Vernière, Spinoza et la pensée française avant la Révoluiton, p. 457; G. Fassò, História de la filosofía del derecho, vol. 2, p. 119, n. 13; G. Belaief, Spinoza's philosophy of law, p. 51; H.G. Hubbeling, Spinoza, p. 106; M.J. Petry, "Hobbes and the Early Dutch Spinozists", p. 151; M.S. Chaú, "Direito natural e direito civil em Hobbes e Espinosa", in Ética sem culpa, política com liberdade; S. Goyard-Fabre, "Hobbes et Spinoza ou La différence des concepts", p. 229; D.P. Aurélio, "Natureza e nação segundo Espinosa", p. 284; etc.

${ }_{162}$ Ed. Gebhardt, vol. IV, pp. 238-239: Quantum ad Politicam spectat, discrimen inter me, \& Hobbesium, de quo interrogas, in hoc consistit, quòd ego naturale Jus semper sartum tectum conservo, quòdque Supremo Magistratui in quâlibet Urbe non plus in subditos juris, quàm juxta mensuram potestatis, quâ subditum superat, competere statuo, quod in statu Naturali semper locum babet. Na mesma página, a versão holandesa do texto: Wat de Staatkunde aangaat, het verschil tusschen Hobbes en my, daar gy naar vraagt, bestaat hier in, dat ik. bet naturelijk recht altijt in zijn geheel laat, en dat d'Oppermacht in een Stat niet meer recht over cen onderzaat heeft, dan naar mate van de macht, daar in sy een onderzaat overtreft; 't welk in de naturelijke stant altijt plaats beeft. Sigo aqui a tradução de Marilena Chauí em "Direito natural e direito civil em Hobbes e Espinosa", in Ética sem culpa, política com liberdade, no prelo. Diogo Pires Aurélio (em "Natureza e nação segundo Espinosa", já citado) traduz: "[...] essa diferença consiste em eu manter inalterado o direito natural e não atribuir, em qualquer sociedade, nenhum direito ao supremo magistrado sobre os súbditos a não ser na medida em que ele, pela potência, é superior a cada um deles, como acontece sempre no estado de natureza"; ou seja, Pires Aurélio traduz Urbe como sociedade e potestatis como potência, quando se trata, respectivamente, da Cidade (organização institucional 
Ainda que um curioso detalhe, ele serve para indicar como é marcante não apenas a relação (ou a diferença) entre as duas filosofias, mas antes o quanto essa referência a Hobbes é em geral tida como imprescindível para a consideração do próprio Espinosa enquanto autor político. ${ }^{163}$ Ela é, como já vimos, uma referência apontada desde a publicação dos seus textos, e uma das responsáveis pela formulação de algumas das suas imagens como autor equivocado de filosofia política: nunca a referência a Hobbes é tomada por seus leitores ou críticos como positiva; ao contrário, a função dessa referência reside unicamente na disposição de refutar a validade da obra. Curiosamente, se tomamos tanto o que Espinosa afirma a respeito dessa sua suposta aproximação com o filósofo inglês, notaremos uma diferença substancial com relação a praticamente tudo o que a tradição de comentadores políticos tem dito sobre ambos. Embora, na sua correspondência, Espinosa tenha o hábito de escrever de forma ligeiramente mais detalhada do que em suas obras (que passam por um processo de constante revisão e lapidação; daí demorarem tanto para vir à luz, a despeito de não serem textos tão longos), a passagem a respeito de Hobbes ocupa poucas linhas e exige de Jelles e de quem quer que leia sua explicação o mesmo esforço de reflexão conceitual que necessariamente permita ao leitor (especialmente o que tende a não ver diferenças entre ambos) descobrir não apenas a inviabilidade do projeto jusnaturalista de Hobbes como a irracionalidade da idéia hobbesiana de potestas. São estas as duas diferenças principais entre os dois filósofos políticos, se insistirmos numa comparação entre ambos (naquilo em que isso faz algum sentido: sem permitir, ainda, a compreensão de um e de outro). O leitor da época (como Jelles) que honestamente se dispõe a ler os textos de Espinosa sobre política e tem a rara disposição de questioná-lo sobre estes trechos e não sobre a crítica à teologia, é um leitor formado no conhecimento dos textos de Hobbes, Grotius, Selden e certamente conhece os institutos do direito romano (ainda que pela via torta do sistema jurídico vigente na Holanda da época); para esse leitor, a semelhança conceitual com Hobbes é notável e não pode

da sociedade, e não simplesmente a sociedade) e do poder (dominação dos súditos ou dos cidadãos pela autoridade — no caso, o "magistrado supremo" —, e não, simplesmente, potência).

163 Para alguns, a repercussão de Espinosa para o pensamento político não pode ser pensada sem sua localização como continuador ou precursor de outras filosofias; Atilano Domínguez, que reconhece toda a filosofia política espinosana como defesa da democracia (ainda que não a considere muito diferente da aristocracia liberal), considera que a atualidade do pensamento espinosano é devida a uma suposta posição intermediária entre o absolutismo hobbesiano e o liberalismo de Locke e Rousseau: "A 'anomalia' ou o enigma de Espinosa está em que, partindo de uma metafísica panteísta e determinista, deduz, com toda lógica, uma política humanista, pluralista e liberal, e que, inspirando-se num filósofo materialista e absolutista, defende, acima de tudo, a liberdade de pensamento e quer conciliar o poder da multidão com a segurança do Estado. Essa anomalia, ou melhor, esse enigma histórico e teórico é o que suscita paixão por seu pensamento e o que faz dele um elo entre o pai do absolutismo, Hobbes, e os pais da democracia liberal, Locke e Rousseau. Por isso sua obra tem plena atualidade" (A. Domínguez, Introdução à tradução do Tratado teológico-político, p. 56). 
passar despercebida: em ambos há a idéia de que a justiça é invenção do estado civil, que a potentia determina a ação dos homens, que a razão mostra que é mais prudente alienar os direitos naturais a um soberano para que se consiga dele proteção à vida, etc. Apesar de chegarem a diferentes conclusões (a uma primeira vista: Hobbes pela monarquia absolutista; Espinosa pela democracia no TTP, e, quanto ao TP, talvez pela aristocracia liberal ${ }^{164}$ ), a maneira como Espinosa concebe a política e mesmo teoriza sobre ela (exposição geométrica da política, como no De cive; fundação da teoria política em conceitos que vêm da filosofia natural e da teoria das paixões, referências aos textos bíblicos para confirmar a análise política, exploração retórica dos próprios argumentos, crítica ao poder teológico e teoria da secularização do poder) parece ter sido aprendida de Hobbes. Ora, o que essa leitura que só vê semelhanças ou chega mesmo a exigir a identidade entre os autores não percebe é que nenhuma dessas teses sobre a derivação de uma filosofia pela outra é sustentável diante de duas concepções (apontadas por Espinosa aí na Carta 50) exclusivamente espinosanas que não são conseqüência da sua filosofia política, mas base para ela: a idéia de não há verdadeiramente alienação de direitos naturais no estado civil (é o que significa a expressão "conservo o direito natural sempre bem resguardado”), e a crítica ao poder do soberano como dominação dos seus súditos (é a que se refere a expressão "considero que em qualquer Cidade o magistrado supremo só tem direito sobre os súditos na medida exata em que seu poder sobre eles supere o deles, como sempre ocorre no estado natural"). Se o leitor de Espinosa lê os textos espinosanos segundo uma leitura hobbesiana, isto se torna invisível; se ele chega aos textos políticos de Espinosa segundo o percurso que o próprio Espinosa elabora, isso revela uma evidência absoluta. Mas é preciso, sabe Espinosa, que o leitor busque perquirir na compreensão dos seus textos políticos através do sentido que é construído exclusi-

${ }^{164}$ É uma hipótese de que sempre se aproxima A. Matheron, apesar de sua intensa análise do conceito espinosano do regime politico da democracia em Espinosa. Para ele, a forma como nos chega o Tratado político nos apresenta uma demonstração da viabilidade da aristocracia federativa liberal, desde que não descambe em oligarquia: "A Aristocracia federal, contrariamente aos dois regimes precedentes [monarquia e aristocracia local], está então em equilíbrio dinâmico: ao final de um determinado tempo, ela deve, logicamente, transformar-se em democracia. Sem dúvida, juridicamente falando, não se tratará de uma democracia no sentido espinosista do termo: regime segundo o qual todos os habitantes que satisfazem a certas condições fixadas pela lei pertencem de direito ao corpo soberano. Na medida em que este tenha sido recrutado por cooptação, continuaremos em Aristocracia, mesmo se todo mundo está cooptado. Mas a diferença é praticamente insignificante: já que os cidadãos de cada cidade desejam sempre ser também tão numerosos quanto possível, a admissão de candidatos reduziu-se, de fato, a uma simples formalidade. Em seu funcionamento efetivo, uma aristocracia aberta a todos não se distinguiria de uma democracia aberta a todos, assim como as aristocracias oligárquicas não se distinguiriam das democracias oligárquicas" (Matheron, Individu et communauté chez Spinoza, p. 497). Parece-me uma visão prejudicada duplamente: primeiro, por considerar que Espinosa está, realmente, falando de regimes políticos (quando o Tratado político, na verdade, está propondo não uma tipologia das formas de governo - que seriam três: monarquia, aristocracia e democracia —, mas sim uma teoria das práticas políticas - que são duas: oligarquias e democracia); e, segundo, a idéia fixa de Matheron quanto a Espinosa conceber um Estado fundado no individualismo possessivo. 
vamente por estes textos; se a leitura for jusnaturalista, ou legalista, ou teológica, nunca poderá ser aceita como verdadeira, porque sempre se revelará contrária às crenças do leitor, apesar de intrigá-lo com o rigor das suas próprias demonstrações.

Ora, essa leitura que insiste na aproximação entre Hobbes e Espinosa se baseia, em certa medida, na constatação de teses aparentemente hobbesianas nos textos de Espinosa, mas é sempre resultado de uma leitura externa ou de uma leitura comparativa. Os textos político-jurídicos de Espinosa, voltados para um leitor jurista mas também exigentes de uma postura de "leitor filósofo" (tal como fora a exigência aos leitores teólogos no prefácio do TTP), são construídos de uma maneira tal que o texto se torna incompreensível se não aceitamos os conceitos espinosanos desde sua base. Sem que compreendamos que o conceito espinosano de jus é um conceito jurídico ou jusnaturalista numa condição necessariamente muito estranha (que de início parece dizer o inverso do que diria um conceito do tipo, e ao final se revela de fato a negação do que se diz no mesmo campo), não perceberemos que a política e o direito exigem, sabe Espinosa, uma reformulação racional desde suas bases, para que os conceitos político-jurídicos possam ser enfim produzidos por uma filosofia verdadeira sem sofrer o peso de um comprometimento com alguma ideologia institucional. No que respeita a essa suposta aproximação entre Hobbes e Espinosa, o que ela revela? Mais do que uma leitura equivocada da relação teórica entre ambos — que é outra, é completamente outra — , revela uma maneira típica do jurista ler a própria história do pensamento político: por filiação de um pensamento particular a uma corrente ou a uma doutrina, a partir unicamente da presença de certos termos ou conceitos; no caso de Espinosa e Hobbes, a leitura é motivada especialmente pela idéia de que Hobbes é autor de um modelo que Espinosa teria adotado, e por isso Espinosa, apesar de algumas conclusões distintas das do filósofo inglês (e, talvez até por isso mesmo, inaceitáveis, mal formuladas, não realistas ou simplesmente antijurídicas), pode ser plenamente redutível ao seu antecessor. Assim, mais do que apresentar os prejuízos causados por uma aproximação entre dois autores em função daquilo que parece estar presente em ambos como conceito e como convicção teórica, o caso da tentativa de aproximação de Espinosa a Hobbes revela (o que é na verdade a única questão relevante em termos de filosofia) os prejuízos causados pela leitura externa ou comparativa de qualquer autor. Não é apenas a Hobbes que Espinosa foi comparado: sua teoria política, por uma ou outra afirmação, foi comparada já a Maquiavel, a são Tomás de Aquino, a Grotius, a de la Court, a Locke, a Leibniz e outros. Todas leituras comparativas, que, se trazem à tona sugestões muito interessantes de contato entre duas filosofias distintas, têm como função, na verdade, fazer a filosofia espinosana ter seu sentido derivado de outra fonte que não ela própria, como se em si mesma ela não tivesse consistência ou não fosse verdadeira. Na medida em que se 
concentra a finalidade dessa leitura comparativa na tentativa de negar a originalidade do filósofo da Ética, o que a leitura pede ao leitor é que comungue das mesmas convicções teóricas que estão sendo uma a uma demolidas por Espinosa na crítica que move seus textos sobre política e direito. Por que demonstrar que Espinosa, como são Tomás, nega a normatividade do direito? ${ }^{165}$ Para provar, primeiro, que em ambos o verdadeiro fundamento da lei não é a sua validade positiva, mas a sua necessidade racional, o que demonstra tanto a originalidade de são Tomás na concepção da lei como fundamento racional de qualquer ação (o que é uma defesa da filosofia tomista para a justificação da orientação religiosa e moral da vida humana) quanto o anacronismo de Espinosa num universo jurídico marcado pelo positivismo jurídico e pela convicção de que a lei só produz eficácia a partir da sua positivação e coercitividade (o que é uma recusa da sua racionalidade num universo jurídico contemporâneo). Por que demonstrar que Espinosa, como Grotius, é um defensor da liberdade de expressão na república? Para mostrar que, como o grande jurista holandês, precisa explicar o direito e a política a partir da história clássica, especialmente porque, tanto como Grotius, Espinosa defenderia um modelo republicano cujas fontes estão num passado romano, e não nas tentativas políticas do presente. E assim por diante. E assim por diante.

Sempre que se busca o esclarecimento do pensamento político de Espinosa por meio de uma análise da relação deste com outros autores, o tom da leitura, que vai da defesa da aplicação do pensamento espinosano ali no campo onde outro autor reina soberano à recusa de sua viabilidade porque só outro autor fundou-se devidamente nas bases realistas da política, uma idéia é sempre a mesma: o pensamento espinosano, se tomado em si mesmo, parece incompreensível ou inválido como pensamento jurídico; não que seja impossível lê-lo por si mesmo e buscar-lhe uma sistematização que o torne decifrável (como se ele fosse um hieroglifo) ao leitor que vem de fora e se choca com o estranhamento do seu sistema filosófico; mas mesmo essa decodificação dos textos espinosanos deixa, ao final, uma codificação espinosista da qual se perdeu toda a construção original dos termos espinosanos. Isso vale não apenas para a leitura externa e comparativa de Espinosa, mas vale mesmo para qualquer leitura externa e comparativa de uma filosofia. No caso de Espinosa, porém, há mais do que o estranhamento dos textos espinosanos como justificativa para essa tentativa de compreendê-lo por meio de sua comparação com Hobbes (já que a leitura de Espinosa por ele mesmo parece insustentável para o leitor jurista): é a necessidade, agora, de uma tomada de posição do leitor em termos de convicção política, tanto prática como teórica. Ler Espinosa a partir de Hobbes revelará, sempre, não apenas a recusa de um sentido consistente no filósofo como a dificuldade de compreendê-lo em si mesmo, mas

165 G. Courtois, “La loi chez Spinoza et saint Thomas d'Aquin”, p. 159. 
também a necessidade de utilizar essa comparação como instrumento para a defesa de uma determinada concepção política ou teórica, para a qual a figura de Hobbes, principalmente, servirá de referência central.

Isso é especialmente visível se percebermos que a idéia da identidade ou extrema semelhança entre as filosofias de Espinosa e Hobbes não é autenticamente contemporânea a Espinosa, e sim uma opinião desenvolvida com fervor no último século e meio. O que se dá já ao tempo de Espinosa - e que certamente o motiva a indicar com uma nota numa das primeiras edições do Tratado teológico-politico sua diferença teórica com respeito a Hobbes ${ }^{166}$ (a única menção a Hobbes, além da Carta 50) —, é uma tendência a reconhecer em ambos teses muito parecidas, embora a tendência desses primeiros leitores seja estabelecer a comparação por meio também da indicação de suas diferenças. De fato, fosse para os leitores da época uma filosofia idêntica à de Hobbes, não causaria certas dúvidas; é um distanciamento com respeito a Hobbes na escolha do regime político ou na concepção da relação entre estado de natureza e estado civil que deixa intrigados os leitores.

Um ano depois da publicação do Tratado teológico-político, no calor das críticas ao ateísmo espinosano e em meio às primeiras refutações teológicas da obra, Graevius, numa carta a Leibniz, menciona o TTP, refere-se à semelhança teórica de Espinosa com Hobbes, mas nota um distanciamento na concep̧cão do direito natural (que é justamente o que o próprio Espinosa apontará a Jelles três anos depois, na Carta 50):

No ano passado apareceu por aqui um livro pestilentíssimo, cujo título é Discursus [sic] teologicopoliticus. $\mathrm{O}$ autor seguiu a via de Hobbes, mas dele se afasta bastante, estabelecendo um direito natural inteiramente iníquo, e, após haver abalado a autoridade das Sagradas Escrituras, abriu largamente as portas do ateísmo. Diz-se que o autor é um judeu chamado Espinosa, expulso de há muito da Sinagoga por suas opiniões monstruosas. ${ }^{167}$

Qual é a "via de Hobbes"? É, para o leitor da época, demonstrar a política a partir da natureza humana mas principalmente contra a influência da religião sobre o Estado. Isso não é tão problemático quanto retirar da vida política algo que Hobbes certamente não retira: a autoridade moral da autoridade política que, sendo autoridade política soberana a quem todos alienaram seu direito natural, decide sozinha o que é justo ou injusto (pois, como diz Hobbes antes de Espinosa, a justiça só se concebe no estado civil). Ora, apesar de todas as críticas que os pró-

\footnotetext{
166 "Seja qual for o regime político em que viver, o homem pode sempre ser livre, na medida em que ser livre é deixar-se guiar pela razão. Todavia (Hobbes é de opinião diferente), a razão, em todas as circunstâncias, aconselha a paz, e a paz só pode conseguir-se se o direito público do Estado se mantiver inviolado. Assim, quanto mais um homem se conduzir pela razão, isto é, quanto mais livre for, mais inabalavelmente observará as leis do Estado e executará aquilo que ordena o poder supremo do qual é súdito" (TTP, cap. XVI, nota XXXIII); conforme tradução de Diogo Pires Aurélio.

167 Apud Marilena Chauí, A nervura do real, vol. 1, p. 125.
} 
prios teólogos também fazem, à época, a Hobbes, o conceito hobbesiano de direito natural não parece tão iníquo quanto o de Espinosa, porque, em Hobbes, o direito natural é algo que não existe no estado civil: juristas e teólogos podem tranqüilamente compor os elementos do poder político e do poder eclesiástico (que Hobbes, aliás, aponta como o Reino das Trevas na terra) sem ter de se preocupar com qualquer instância de legitimidade que não decorra de uma autoridade. Isso, em Espinosa, é impossível desde as primeiras linhas sobre a política (é por isso que, em todos os textos sobre política, Espinosa parte do direito natural ou do estado de natureza). O que há de iníquo no conceito espinosano de direito natural, mesmo se comparado ao de Hobbes? É sua continuidade no estado civil, sua necessidade na vida política mesmo depois que esta foi instituída e a autoridade reconhecida; esse direito natural espinosista, do qual "só por malícia alguém prometerá renunciar", é o que se escondia já por trás da negação da autoridade secular da Igreja e que vem abalar qualquer idéia de autoridade na terra. Sem determinação dos direitos pela autoridade — qualquer que seja ela —, abrem-se pois "as portas do ateísmo": nem Deus é autoridade sobre os homens, já que o direito natural em Espinosa não é (como é nos autores da escolástica ou nos juristas cristãos), a vontade do Criador, nem a autoridade moral dos soberanos políticos neste mundo lhe ocupa o lugar. A iniqüidade do direito natural espinosista está, justamente, em sua ausência de moralidade cristã, em sua ausência de moralidade social, em seu imoralismo individualista fundado exclusivamente na animalidade e na concupiscência de cada um. Aos primeiros leitores de Espinosa, não será questão a idéia (tão excêntrica que mal é comentada) de democracia, nem o projeto (tão sem realismo que nem é computado como teoria jurídica) político-jurídico visível nos dois tratados, mas principalmente o impacto ateísta e imoralista da sua teoria política. De que vale, também no caso da política, a constante referência aos textos religiosos e os eventuais elogios aos princípios da religião cristã, se a base dessa filosofia política é um vazio moral na fonte de todo direito e de toda liberdade? Não à toa, os juristas que lêem os textos de Espinosa e também têm, para si mesmos, a incumbência de empreender a mesma teoria político-jurídica, não a deixam ser o suporte da teologia e da concepção de um direito natural fundado numa reta razão criada por Deus ou fundada na moral; Pufendorf, que não vê realismo algum no conceito espinosano de jus, concebe que o direito sem fundamento moral não tem sentido algum, nem pode uma lei ser tida como guia da ação sem que seja tida, também, como regra do justo. E, quando for o caso de um jurista como Montesquieu defender-se da acusação de espinosismo, essa será uma defesa da acusação de ateísmo, para a qual valerá redirecionar o ataque àqueles - Espinosa e Hobbes — a quem residiria uma verdadeira concepção ateísta da justiça e da moral: na célebre Defesa do Espírito das leis, em verdade uma defesa contra à acusação que sofreu de "espinosismo", Montesquieu reconhe- 
ce expressamente uma identidade entre Hobbes e Espinosa justamente no ateísmo e imoralismo, ao mesmo tempo que recusa ser ele próprio identificado — reduzido? - a Espinosa ou ao espinosismo: "Então ele é espinosista, ele que demonstrou contra Hobbes e Espinosa 'que as relações de justiça e de eqüidade eram anteriores a todas as leis positivas'."168 O jurista e magistrado Montesquieu, entretanto, não dirá, de Espinosa, que este é antijurídico.

O que leva um comentador contemporâneo da filosofia política espinosana ao extremo de considerar que a filosofia de ambos não é apenas semelhante, mas é idêntica? É a posição, muito repercutida no pensamento anglo-saxão, de Robert McShea, ${ }^{169}$ típica também de um movimento que empreende, no século Xx, a "reabilitação" do pensamento hobbesiano, para aproveitar a expressão de Leo Strauss. Este, curiosamente, sustenta a posição diametralmente oposta, defendida anos antes de McShea: entre Espinosa e Hobbes só há oposição. ${ }^{170}$ Como explicar essa variação interpretativa nesse século que, se por algum motivo vem recuperar o pensamento dos modernos apesar da convicção de que o Estado contemporâneo não é fundado nos princípios políticos apresentados por aqueles pensadores, tende a produzir interpretações sempre comparativas?

É curiosa a historiografia do pensamento político elaborada no século xx; ela confere para si a tarefa de garimpar os precursores do pensamento contemporâneo, como se o próprio pensamento contemporâneo sentisse falta, por vezes, de uma fundação em si mesmo. Norberto Bobbio, no seu projeto de defesa do positivismo jurídico (e reformulação deste a ponto de não deixar de lado o horizonte da política, tal como exigia a formulação kelseniana), empreende uma historiografia do pensamento jurídico moderno que aponta, para os leitores juristas de hoje, quem são os fundadores e precursores do pensamento jurídico contemporâneo; nesse projeto, Hobbes é elogiado por Bobbio como um grande precursor do positivismo jurídico, e talvez mesmo seu primeiro formulador. O realismo jurídico de Hobbes, segundo Bobbio, é sem igual entre os jusnaturalistas do tempo, a ponto de ser o caso de considerar sua saída do círculo dos jusnaturalistas; de qualquer forma, mais do que determinar a importância de Hobbes dentro da história do jusnaturalismo, é o caso de reconhecer nele uma filosofia que em pleno século jusnaturalista descobre sozinha a fundação da racionalidade jurídica exclusivamente na vontade do

168 O espirito das leis, "Defesa do Espirito das Leis", tradução de Cristina Murachco, São Paulo, 1996, p. 712.

${ }_{169}$ R. McShea, The political philosophy of Spinoza, New York, Columbia University Press, 1968, pp. 137-138; cf. a propósito, os comentários de Steven B. Smith, Spinoza, Liberalism, and the question of Jewish identity, p. 238, n. 5 .

${ }^{170}$ L. Strauss, Spinoza's critique of religion, p. 229. 
soberano. Em Hobbes, a lei civil é um comando, ela é a formulação institucional do imperium do soberano, sem a qual nenhum súdito saberia de onde provêm a autoridade e a justiça. Ora, ao ter Hobbes dito que a justiça é criação exclusivamente da lei civil, e ao ter exigido que o imperium seja privilégio de um soberano que domina seu próprio povo, ele teria mostrado qual o único fundamento racional para a prática do poder político: a organização política e social fundada a todo momento no reconhecimento público de que as vontades individuais não valem mais, nem tanto, quanto a vontade do soberano. Se todos os homens desejam paz e segurança e concebem que estas só se alcançam em função da submissão a um soberano, para Hobbes isso se dá graças ao medo que leva os homens à obediência e os mantém nela; a troca entre Estado e súditos (ou cidadãos), explica Hobbes, é sempre a troca entre obediência e segurança estabelecidas por um medo recíproco: o de ser destruído ou traído pela outra parte. Contra a traição ou desobediência dos súditos, a autoridade soberana tem seus instrumentos de Estado para exigi-la a todo momento e castigar a desobediência; ao súdito, quando sente que é por sua vez traído pelo soberano e dele não recebe mais proteção, resta unicamente sair do estado civil e deixar de ser cidadão: no estado civil, segundo Hobbes, a autoridade, a soberania, a legitimidade nunca vêm dos súditos, mas unicamente de quem tem o imperium na vida política, imperium que em Hobbes não é apenas poder de comando, legislação e punição, mas que por ser arbítrio do soberano é o único fundamento racional para o poder político. Ou seja: em Hobbes, nenhuma fundação natural ou moral define o conteúdo do justo na vida civil; este é definido exclusivamente pelos instrumentos do Estado, exclusivamente por aquilo que comanda a ação dos súditos e pode puni-los na desobediência, restando a eles como única alternativa a condição de não cidadãos. Tanto em Hobbes quanto no positivismo jurídico, não tem cabimento ser contra a vontade do soberano, a menos que se aceite não ser mais cidadão ou aliado. Os valores da coisa pública, mostra-nos a história, é sempre propriedade privada de quem detém o poder.

Quando Bobbio e outros, pois, empenham-se em reabilitar Hobbes para a história do positivismo jurídico (do qual Hobbes está separado pelo menos em duzentos anos), a intenção é não apenas mostrar o valor de um pensador moderno para o pensamento contemporâneo, mas mostrar o que diferencia um pensador moderno da própria modernidade, concebida, nessa leitura pseudoarqueológica, ainda como inconsistência e desvario. Ora, quando os historiadores da política e do direito no século xx têm a tarefa mais delicada de considerar, agora, a relação entre Espinosa e Hobbes, esse espírito de recuperação do hobbesianismo parece já ter se instalado plenamente: a afirmação da identidade entre Hobbes e Espinosa é sempre elaborada no interior de uma defesa da originalidade ou pioneirismo de Hobbes em relação ao pensamento 
contemporâneo (mas a negação dessa redução de Espinosa a Hobbes é sempre elaborada no interior de uma interpretação do pensamento espinosano por ele mesmo, quando não numa leitura de ambos os autores em si mesmos, sem qualquer necessidade de comparação com o pensamento contemporâneo, especialmente nos moldes do positivismo jurídico). Mais do que isso, aquela leitura que vê identidades entre os dois filósofos costuma ser igualmente enfática com respeito à falta de originalidade de Espinosa nas concepções basilares da política, como se ele partisse do pensamento hobbesiano para elaborar o seu próprio pensamento, e não como se ele chegasse a Hobbes a partir de sua própria ontologia.

A literatura dessa comparação entre ambos é extensa e por vezes de uma beligerância impressionante. Parece-me, no caso específico de considerar a sua relevância e significado, menos produtivo avaliar a validade das interpretações por meio dessa comparação do que considerar o que move a própria comparação (duvido, mesmo, do resultado dessa comparação entre ambos para a compreensão de qualquer um deles). De início, e no que diz respeito especialmente à leitura que conclui pela reductio ad Hobbesium, essa interpretação parece ser motivada por uma incompreensão ou dificuldade de leitura da filosofia espinosana. ${ }^{171}$ Porém, há mais do que isso, na medida em que essa leitura é produzida por uma concepção contemporânea da política e do pensamento político: é preciso, para esse comentador contemporâneo, provar que a filosofia espinosana, naquilo em que não é hobbesiana, não nos alcança; e, naquilo em que nos alcança, é redutível a Hobbes ou a outro autor (a Rousseau, por exemplo, no caso da teoria da democracia).

Em que termos se considera que Espinosa se aproxima de Hobbes? A questão do ateísmo perde toda a sua relevância na leitura contemporânea, mas a justificação do poder político é o centro da teoria do Estado dos últimos dois séculos. Ora, o que leva, justamente, aos defensores dessa leitura comparativa serem aliados, também, de uma concepção contemporânea do Estado? É o fato de o Estado contemporâneo, reconhecidos pelos autores contemporâneos como devendo voltar-se para a democracia, constituir uma prática política cujos princípios são mais

${ }^{171}$ Seria interessante, por exemplo, analisar dois trajetos interpretativos igualmente partidários do positivismo jurídico mas desenvolvidos em vias diversas: o de Norberto Bobbio, que em seus primeiros textos históricos sobre o pensamento político moderno não apresenta análise de Espinosa mas o classifica entre os jusnaturalistas assim como o compara incessantemente a outros autores, para em seus textos das últimas décadas, mais comprometidos ainda com o projeto de defesa do positivismo jurídico diante das distorções trazidas pelo "ressuscitamento" do jusnaturalismo, continuar sem analisar a filosofia de Espinosa e empenhar-se na defesa de Hobbes e correspondente desqualificação de Espinosa como pensador original ou simplesmente como pensador jurídico; também, o caso de Simone Goyard-Fabre, cujos primeiros textos são impulsionados por uma convicção legalista e positivista dentro da qual o jusnaturalismo aparece como metafísica jurídica e Espinosa como um jusnaturalista hobbesiano, para em seus textos dos últimos anos, mais empenhados na historiografia da filosofia moderna sem tanta influência da filosofia jurídica contemporânea, reconhecer em Espinosa não só um autor jurídico como um autor diferenciado de Hobbes. 
adequados à concepção hobbesiana da fundação do poder político-jurídico no arbítrio da autoridade soberana do que à concepção espinosana de democracia como participação de todos na determinação do poder. O Estado contemporâneo é o inverso, em termos práticos, da concepção moderna (especialmente a concepção espinosana) de democracia, que a propósito não se trata de um modelo de sistema político. Quando as teorias jurídicas contemporâneas têm consigo mesmas a tarefa de elaborar um guia para a organização política e principalmente apresentar uma justificação plausível para a correspondência ou não do poder do Estado com o desejo dos seus cidadãos, toda concepção que não parta de uma identificação da racionalidade jurídica com a vontade de quem é autoridade jurídica mostra-se sem fundamento nem realismo. Quando essa perspectiva - que no campo do pensamento jurídico marca o positivismo jurídico em todas as suas formulações - volta-se para o pensamento moderno, tudo o que ali concebe o fundamento do Estado como não sendo a vontade de uma autoridade soberana perde, também, relevância para a teoria política contemporânea. No caso de Espinosa, a figura da autoridade soberana aparece constantemente e em todos os momentos de seus textos políticos; entretanto, como sua concepção de soberania envolve a presença constante da noção do jus sive potentia assim como da democracia como forma mais natural de governo, nenhum poder que vá contra essa concepção espinosana de necessidade natural da vida política pode caber na teoria política de Espinosa. Por isso mesmo, quando o leitor contemporâneo concebe que o Estado é fundado necessariamente num poder do qual o cidadão está separado de forma irreversível (restando-lhe, no máximo, escolher seus representantes e manifestar publicamente — mas sem influência na lógica do Estado — suas opiniões), é impossível conceber qualquer racionalidade na idéia espinosana de democracia, por mais bela que seja, em si mesma, a definição apresentada por Espinosa. O que o leitor jurista contemporâneo do conceito espinosano de democracia vê aí é nada mais do que um belo princípio sem aplicabilidade prática, pelo que a democracia, enquanto idéia apenas da necessidade da política, não parece constituir base suficiente para um modelo de Estado ou para uma prática política efetiva.

Ora, diante de Hobbes, o que vê esse mesmo leitor jurista contemporâneo? Por considerar mesmo que o costume teórico dos filósofos políticos modernos de elaborar modelos ideais de Estado é sem aplicabilidade, resta também condenar o dito modelo hobbesiano de Estado (também, no caso, por apontar para uma monarquia absolutista), e deixar à vista unicamente os princípios com que Hobbes apresenta os fundamentos da política. Ora, como fundamento do estado civil, Hobbes aponta justamente o poder absoluto do Estado sobre aqueles que lhe devem obediência, e considera que a cidadania — a condição civil de um homem — nada mais é do que esse estado de obediência; quando sai dele, o homem deixa de ser cidadão. Mais do que 
isso, quando define a lei, Hobbes mostra que ela, enquanto lei natural, nada mais é do que a razão reta que mostra ao homem o que é mais útil em cada situação; no estado civil, onde um poder soberano está já constituído, essa mesma razão demonstra ao cidadão que sua preservação tão desejada a todo momento só é possível desde que reconhecimento constante da fonte da justiça num outro (o Estado) e não nele mesmo; nesse panorama, a lei civil nada mais é do que comando do soberano e, como diz Hobbes no De cive, ordem e manifestação da vontade do legislador, que deve ser promulgada para que exista sobre todos como lei.172

Não é à toa que Hobbes brilha nos olhos dos positivistas. Mas não é à toa, também, que não basta aos adeptos do positivismo apenas imaginar Hobbes como seu precursor. É preciso, principalmente, desqualificar Espinosa - mas por quê? De todos os autores jurídicos que escrevem logo após a publicação dos primeiros textos de Hobbes, há uma série de hobbesianos que se espalha pela Europa e que, também, se encontram em plena militância intelectual na Holanda. Os hobbesianos holandeses, que também lêem Espinosa e em certos casos também cuidam ainda de refutá-lo (Velthuysen é o caso mais célebre), são tão adeptos das concepções de seu mestre inglês que passam despercebidos pelos leitores do século XX como autores originais. ${ }^{173}$ Espinosa, por não ter sido um hobbesiano declarado mas paradoxalmente por parecer a todo momento hobbesiano de ponta a ponta, precisa ser denunciado como impostor diante de Hobbes, pois teria tentado (segundo a leitura jurídica contemporânea) defender um modelo republicano democrático - tal como, talvez, aquele dirigido na Holanda pelos seus amigos, os irmãos De Witt — apropriando-se indevidamente dos conceitos políticos de Hobbes. Qual a estratégia utilizada por Espinosa para esse embuste? Justamente o conceito realmente metafísico de jus sive potentia. Hobbes, apesar de também "participar do espírito metafísico", como diria Simone Goyard-Fabre, manifesta-o apenas na sua opção metodológica pela demonstração racionalista do seu pensamento, mas este, em si mesmo, é de um realismo inegável, e de uma fortuna argumentativa em favor do positivismo que nenhum leitor jurídico poderia negar. Salvo aqueles que lêem Hobbes por ele mesmo e sabem, com ele, que o poder absoluto tem de ser monárquico; e salvo aqueles que lêem Espinosa por ele mesmo e sabem, com ele, que a liberdade absoluta tem de ser democrática: confrontadas (e não comparadas) estas duas idéias, elas não apresentam nenhuma incompatibilidade.

172 "Já conhecer as leis depende do legislador, que deve publicá-las, porque a não ser assim não serão leis. A lei é a ordem do legislador, e essa ordem é manifestação de sua vontade: não há portanto lei, a menos que se manifeste a vontade do legislador, o que ele faz promulgando-a. Na promulgação duas coisas devem estar presentes, das quais a primeira é que quem publique a lei deve ter o direito de legislar, ou pelo menos ter para tanto uma concessão de quem o possui; a segundo é o significado mesmo da lei" (Do cidadão, Livro II, \13, p. 225; tradução de Renato Janine Ribeiro).

173 De fato, a historiografia dos hobbesianos holandeses é recente e visa a compreensão de suas teorias político-jurídicas também segundo as diferenças que podem manter com Hobbes. 
A insistência da comparação entre Hobbes e Espinosa pela leitura jurídica contemporânea mostra, a meu ver, uma profunda desconfiança em relação à filosofia, mais do que uma defesa da filosofia hobbesiana em si mesma. O pano de fundo dessa comparação em detrimento de Espinosa, não à toa, é um panorama jurídico positivista, no qual a racionalidade dos conceitos jurídicos é devida ao uso que lhes é dado pela própria prática do poder. Para o pensamento jurídico contemporâneo, em linhas gerais não há fundamento em buscar, nas bases da metafísica ou numa leitura ontológica da natureza, o fundamento para a explicação do direito e da justiça. Ao contrário, a grande tarefa empreendida por essa teoria segundo ela mesma é a construção de conceitos jurídicos cujo significado venha já da prática jurídica e cuja validade se dê apenas enquanto eficácia institucional. Todo valor retirado de fora para a análise ou validação do direito e do Estado parece, à maior parte do pensamento contemporâneo, um princípio sem sentido algum (exatamente como qualquer concepção aí classificada como metafísica). O pensamento espinosano, apesar de estabelecer uma quebra entre necessidade por natureza e juízo moral, e apesar de afirmar (como Hobbes) que a justiça só existe no estado civil (por ser justamente um juízo da autoridade política), representa enquanto "metafísica jurídica", a apresentação de uma ausência ainda maior de fundamento, a concepção de entidades metafísicas sem realidade histórica segundo a leitura contemporânea. Os conceitos que abrem a Ética e que definem os elementos fundamentais da teoria espinosana do Estado, como o próprio conceito de jus (potentia) e ainda o de lex (isso que determina uma ação segundo a natureza e definição do agente), não fazem sentido dentro de um horizonte contemporâneo.

Nem poderiam, porque essa concepção contemporânea do Estado e do direito é realmente inversa à de Espinosa, havendo dos dois lados motivos plausíveis para a elaboração de concepções que entre si são opostas: a contemporaneidade é marcada pela novidade do desenvolvimento de doutrinas jurídicas que descrevem a operatividade das instituições do Estado e concebem que a soberania significa poder de coerção e estabelecimento de obrigações e faculdades para os cidadãos, ao passo que para Espinosa, assim como o jus, conceito fundamental para o pensamento político, é potentia, a lex em sentido absoluto também tem seu sentido derivado na ontologia e, quando for o caso de concebê-la no campo das instituições (como direito positivo, portanto), ela não poderá deixar de lado o aspecto absoluto da lei nem ser contrária à necessidade, também, do direito; e, no que disser respeito à projeção da política, à concepção da democracia e à teorização do Estado, de forma alguma será racional substituir a racionalidade da necessidade natural da liberdade pelo irracionalismo da justificação do poder pela força. O impe- 
rium da lei, quando concebido como força física sobre os cidadãos ou como unidade moral de uma coletividade, pressupõe a negligência das necessidades individuais e, por isso, deixa novamente aberto o caminho à violência. Esta, no estado de natureza, é concebida comumente como uma conseqüência da ausência das regras morais, jurídicas, racionais; se, em pleno estado civil ou em pleno Estado, a exclusão se torna ela mesma a regra — como se sente a teoria jurídica contemporânea quando confrontada com o conceito espinosano de democracia - , temos para resolver uma questão ontológica da política que a prática jurídica contemporânea, por não saber resolvê-la com base apenas na dogmática jurídica, prefere ignorar ou deixar em aberto. Daí, justamente, ser tão necessária para a defesa da dogmática jurídica (e da correspondente ideologia contemporânea do poder do Estado) a negação de validade da filosofia do direito.

O que é, nessa altura, a filosofia do direito? Para o pensamento contemporâneo, que é esse único pensamento que convive com o Estado contemporâneo (essa entidade soberana representativa, cujo poder está necessariamente separado da vontade dos cidadãos, ainda que o Estado contemporâneo se defina exatamente pela representação política), a filosofia do direito não pode ser mais uma explicação ou concepção do direito vinda de fora do direito, ou melhor, da prática jurídica. Tudo o que se quiser conceber como jurídico, deve necessariamente, para o contemporâneo, ser fundado na história concreta dessas instituições que constituem o Estado; tudo o que estiver fora, deve ser tomado como irracional ou descabido em termos contemporâneos. É dessa forma que a filosofia contemporânea é interpretada, quando é comparada à filosofia hobbesiana em prol desta e em detrimento daquela. Falta à filosofia espinosana, vêem os leitores contemporâneos, algo que lhe dê racionalidade ou realidade prática: nessa perspectiva hobbesiana e positivista, o que parece faltar a Espinosa é uma concepção do poder que descreva a prática política como ela é. Na verdade, essa observação da prática não está ausente dos textos de Espinosa; ela só não determina o próprio conceito espinosano da summa potestatis. Este, fundado ontologicamente mas tendo diante de si a experiência política, pede justamente que seja colocado à prova diante da realidade concreta da política e do poder. Essa análise da validade do conceito espinosano de soberania diante de qualquer prática jurídica contemporânea é que é evitada constantemente pelos leitores juristas. Por quê? Porque isso que a filosofia jurídica moderna não diz sobre o Estado contemporâneo (já que não o observa), a desavisada tentativa de comparar Espinosa a Hobbes acabará revelando, da concepção ontológica do poder e da democracia presentes em Espinosa e completamente impensáveis em Hobbes, os elementos para a visualização da concepção de poder que, no pensamento contemporâneo, é a norma fundamental do Estado operado como um Estado patrocinador da violência e da exclusão. 
Se insistirmos, verdadeiramente, na comparação entre Espinosa e Hobbes, veremos, primeiro, que dessa comparação pouco aprendemos sobre cada um deles em si mesmos, mas que tanto um quanto o outro exige ser conhecido completamente; segundo, que o sentido dessa comparação nunca é o de defender a filosofia de Hobbes contra a filosofia de Espinosa, mas sim defender a existência de um conceito positivista de Estado contra qualquer conceito não positivista de Estado ou (no caso específico que leva a escolher Espinosa) democracia; terceiro, e principalmente, quando revelada essa necessidade de sair do conhecimento superficial, que nada analisa da filosofia espinosana (a exemplo daquela leitura que é feita por absolutamente todos os autores que consideram que Espinosa é um continuador dissimulado de Hobbes), para uma compreensão dos motivos que levam esse autor a compor essa idéia tão excêntrica de democracia, aparece ao pensamento contemporâneo o desafio de justificar, para manter sua acusação contra Espinosa, a prática contemporânea da legitimação estatal da violência e da corrupção. $O$ que a filosofia espinosana mostra ao leitor jurista contemporâneo é, a todo momento, uma concepção de vida política na qual o poder político não pode ser exercício da violência nem destruição dos seus cidadãos; o que pega a leitura contemporânea de surpresa é a constatação de que existe uma filosofia que não apenas concebe como demonstra que, por uma necessidade ontológica que ninguém pode negar - o conatus do Estado, que é o conatus de todos os cidadãos unidos entre si —, a democracia não pode permitir exclusão nenhuma. Onde isso se encontra em Hobbes? Nenhum defensor da identidade ou proximidade entre ambos sequer toca no assunto.

Qual o limite dessa relação entre Hobbes e Espinosa? Os praticantes dessa comparação, partidários sob a bandeira do positivismo do "modelo hobbesiano", não vão a fundo nela, quando se acham às portas da comparação do que ambos concebem como o que dá validade, em si mesmo, ao poder político. A própria filosofia jurídica contemporânea, diante desse problema, silencia quando aparece o conceito de conatus ou um conceito assemelhado. É que estamos, a todo momento, diante de um problema que nunca deixa de ser de filosofia política: a fundação da política na liberdade, e não no poder. Como já mostrara, segundo Espinosa, não Hobbes, mas Maquiavel.

Por que, a propósito, essa mesma historiografia comparativa de inspiração positivista não se dedica também a uma análise dos motivos pelos quais Maquiavel, cujo realismo político ninguém contesta, mostra sempre um desprezo tão grande pelas leis jurídicas, em sua concepção do stato como fundação das liberdades na vida política? 


\section{II ESPINOSA, PARA ALÉM DE HOBBES E CONTR A HOBBES}

A leitura atenta da filosofia jurídica espinosana enquanto uma filosofia do direito mostra, enfim, a radicalidade das diferenças em relação a Hobbes: não apenas Espinosa não é um continuador de Hobbes, como é na verdade um anti-hobbesiano. Ora, na medida em que a leitura hobbesiana de Espinosa (na verdade, uma leitura positivista) pede que Espinosa seja considerado inaproveitável para a o pensamento contemporâneo, é o caso de considerar o que a crítica que Espinosa efetivamente faz a Hobbes (que é o que conhece todo leitor que vai até o fim na dita comparação entre ambos) reserva, como arcabouço filosófico, ao próprio pensamento contemporâneo. Só aí compreenderemos, justamente, por que Espinosa é tão omitido da análise jurídica do Estado, quando esta se inspira nos clássicos do pensamento político.

Embora uma leitura da superfície (que é o comum das classificações por comparação) do pensamento político de Hobbes e Espinosa sempre aponte para muitas semelhanças - em ambos, por exemplo, a lei civil é comando, assim como há diferenças equivalentes entre lei natural, civil e divina; e em ambos a capacidade de ação se mede pela potentia, ainda que só em Espinosa o direito se identifique com ela e o conceito de potentia em ambos seja diferente, porque baseado em físicas diferentes —, são de fato duas filosofias que concebem de forma diferente tanto a política quanto a liberdade. No caso de Espinosa, o que temos é uma concepção de todos os elementos da política e do direito a partir da idéia de que a liberdade política só se realiza totalmente na democracia; embora sejam concretizáveis diversas formas políticas, em todas, com exceção da democracia — na medida em que pode ser concebida como uma forma de governo —, o cidadão ou súdito está em maior ou menor medida separado do poder, e por isso qualquer prática não democrática implicará despotismo e, portanto, ilegitimidade política e jurídica. Isso não apenas é uma colocação diversa do pensamento hobbesiano, como é uma concepção da estrutura da vida política que se exige enquanto filosofia - elaboração, ainda, da idéia de política, ainda que não uma metafísica (uma "utopia", nos termos do TP) da política - e não enquanto ciência da política, à maneira do De cive. Espinosa escreve sobre política e sociedade - nos dois tratados políticos como também desde a parte IV da Ética - sempre de forma a defendê-las como democráticas, da mesma forma que recusa validade às defesas das outras formas ou, principalmente, de outras qualidades da própria política que não sua fundamentação na multitudo, ou conjunto de todos os cidadãos.

A chave para essa distância que Espinosa marca entre si mesmo e Hobbes está na maneira como concebe, desde o início, o poder político. Porque em Espinosa o poder político não pode ser privilégio de alguma autoridade: quando o poder é separado da finalidade pública, ele impe- 
de a continuidade de uma concepção de Estado fundada justamente nesse privilégio. Toda a teoria espinosana do Estado baseia-se na concepção de que a potência de cada um é preservada no estado civil (exatamente o que Espinosa ressalta a Jelles na Carta 50); tanto no Tratado teológico-político como no Tratado politico, Espinosa mostra claramente que sempre que o poder político é exercido contra a necessidade pública, estamos num estado de despotismo e não num estado de liberdade política. Ora, como Espinosa manifesta isso, em primeiro lugar, pelo que diz na anotação XXXIII ao TTP? Lá, a crítica é ao conceito jusnaturalista hobbesiano de reta razão como guia para o conhecimento da lei natural, ainda que, numa leitura superficial, pareça não haver uma diferença sensível com o que Hobbes considera a reta razão. De fato, a anotação começa dizendo que "Seja qual for o regime político em que viver, o homem pode sempre ser livre, na medida em que ser livre é deixar-se guiar pela razão". Ou seja, em primeiro lugar, qualquer regime político é concretizável (como também afirmara Hobbes), mas a liberdade individual em qualquer situação política é constituída não pela concessão do soberano, mas por uma atividade de cada cidadão — quem determina a liberdade do cidadão é o próprio cidadão, apesar das leis civis mas também considerando-as —, qual seja, guiar-se pela razão. Ora, o que a reta razão diz no caso de Hobbes? A necessidade de autopreservação calculada por medo dos outros homens; ${ }^{174} \mathrm{o}$ estado civil é inaugurado para que se saia de um estado de medo recíproco (a guerra de todos contra todos que é o estado de natureza) em troca de um outro estado de medo recíproco (entre soberano e cidadãos, e dos cidadãos entre si), menos angustiante e mais seguro para a preservação da vida (graças à presença, agora, das instituições do Estado). O que a reta razão diz em Espinosa? A necessidade de autopreservação através, também, da preservação do outro: o estado civil não é a saída de um estado de natureza, mas a prática coletiva de uma autoconservação coletiva. Se Hobbes também diz que a busca da paz é natural, para Espi-

174 “[...] a verdadeira razão é uma lei certa, que (já que faz parte da natureza humana, tanto quanto qualquer outra faculdade ou afecção da mente) também é denominada natural. Por conseguinte, assim defino a lei de natureza: é o ditame da reta razão no tocante àquelas coisas que, na medida de nossas capacidades, devemos fazer, ou omitir, a fim de assegurar a conservação da vida e das partes do nosso corpo" (De cive, livro I, cap. II, $\$ 1$, p. 38); "Por reta razão no estado da natureza humana, não entendo (como querem muitos) uma faculdade infalível, porém o ato de raciocinar — isto é, o raciocínio peculiar e verdadeiro de cada homem acerca daquelas suas ações que possam resultar em detrimento ou benefício de seus próximos. Falo em 'peculiar' porque, embora num governo político a razão do soberano, ou seja, a lei civil, deva ser acolhida por todo súdito individual como constituindo o direito, contudo, fora de tal governo (condição em que nenhum homem poderá distinguir a razão reta da falsa, exceto comparando-a com sua própria), a razão própria de cada homem deve ser considerada não apenas como sendo a regra de suas próprias ações, que ele comete por sua conta e risco, mas ainda como fornecendo a medida da razão alheia, em todas as coisas que a ele disserem respeito. Digo além disso que esse raciocínio é 'verdadeiro', se ele o infere a partir de princípios verdadeiros e corretamente constituídos - porque toda infração às leis de natureza consiste no falso raciocínio ou, melhor dizendo, na loucura daqueles homens que não enxergam aqueles deveres que, necessariamente, devem cumprir em relação ao próximo, tendo em vista a sua própria conservação" (nota de Hobbes referente ao trecho anteriormente citado, De cive, pp. 361-362, nota 3). 
nosa a paz, certamente uma necessidade natural da vida política, é uma situação diferente da concebida por Hobbes. Quando Hobbes diz que a paz é naturalmente desejada pelo ser humano, está com isto querendo dizer que todo ser humano sabe que precisa sair do estado de guerra que é o estado de natureza para se autopreservar; a solução para isso é a transferência dos direitos naturais ao soberano, que decide sozinho do justo e do injusto. Em Espinosa, a razão também aconselha a paz, mas aí a paz "só pode conseguir-se se o direito público do Estado se mantiver inviolado". Ora, diz Espinosa, "Hobbes é de opinião diferente". Por quê? Porque em Hobbes, o direito público do Estado, isto é, o conjunto de direitos e obrigações válidos para a vida civil, é determinação da autoridade soberana; em Espinosa, ele é a potência de toda a multitudo, de maneira que nada que a autoridade soberana determine contrariamente a essa união das potências particulares pode valer como direito público (afinal, seu interesse e benefício não é público, e sim particular). "Assim, quanto mais um homem se conduzir pela razão, isto é, quanto mais livre for, mais inabalavelmente observará as leis do Estado e executará aquilo que ordena o poder supremo do qual é súdito", ou seja: a razão permite ao cidadão ver, nas leis do Estado, a sua própria necessidade e, conforme mostra o capítulo III do Tratado político, é por reconhecer na obediência às leis civis um instrumento útil para a sua própria preservação que o cidadão percebe a necessidade das leis e a sua necessidade no conteúdo das leis; não reconhecendo essa utilidade, o que ele reconhece é a ilegitimidade da lei civil como necessidade da sua própria potência, e portanto a ilegitimidade do direito positivo, naquele momento, como necessidade ou índice do seu direito.

Ser cidadão, para Espinosa, significa gozar das vantagens da vida em sociedade em razão do direito civil; diferentemente, ser súdito significa estar obrigado a obedecer às leis civis. ${ }^{175} \mathrm{~A}$ liberdade política não significa capacidade de fazer alguma coisa segundo o que permite o Estado (a liberdade política não significa direito do súdito), mas sim atividade do indivíduo na vida coletiva segundo o que continua necessário por sua natureza, apesar do direito civil ou graças a ele (a liberdade é necessidade do cidadão); não à toa, a democracia, forma mais natural de governo, é atividade conjunta e simultânea de todos os cidadãos e não instauração de liberdades civis sobre súditos, apenas. O cidadão sabe que é súdito das leis civis; mas sabe que é cidadão porque, apesar de ser súdito, é beneficiado por obedecer ao Estado; enquanto isto é o princípio da obediência, a cidadania não é idêntica à submissão, mas é autodeterminação da vida política: é atividade na vida política segundo os próprios interesses (presentes nos interesses do Estado), e não segundo os interesses de um outro, que sejam distintos ou contrários às próprias necessidades. Ora, numa monarquia ou numa aristocracia, é exatamente isso o que ocorre: alguma

175 Tratado político, cap. III, $\$ 1$. 
parcela da multitudo, senão toda a multitudo, é separada do governo; tanto num caso como no outro, mostra o Tratado político de Espinosa, o estado civil não é um estado de serenidade, mas um estado de medo: na monarquia, todos os cidadãos devem permanecer armados, e na aristocracia os patrícios disputam o poder entre si e mantêm fora dessa disputa a plebe.

Espinosa, ao escrever o Tratado teológico-político, atribui como missão para si uma crítica a todas as concepções de poder despótico. No caso da sua escrita dirigida aos juristas, ele escreve num momento em que os círculos jurídicos da Holanda repercutem com intensidade a obra hobbesiana, a favor ou contra as idéias de Hobbes. De qualquer maneira, o que os textos de Hobbes trazem para essa discussão jurídica européia é certamente uma maneira nova de projetar o pensamento político, como explicação da experiência política segundo uma forma racionalista mas em nada idealista: a obra jurídica tem como função definir os elementos do direito e da política a partir do que é a natureza humana, e não a partir de um modelo institucional já instituído ou carregado por interesses partidários. Por isso mesmo, Hobbes representa, para o início da segunda metade do século XVII, não exatamente um modelo de instituição política, mas um modelo de pensamento político que traz, graças à potência da demonstração geométrica e da análise da natureza humana, a certeza e universalidade das ciências naturais e matemáticas.

Hobbes, para os seus admiradores já em sua vida, é a prova viva de que o pensamento político pode atingir a precisão demonstrativa alcançada por Euclides na geometria e Galileu na física. Por mais que suas idéias merecessem de seus inimigos as críticas mais severas, e por mais que sua filosofia assistisse prontamente a uma crescente reprovação, o racionalismo hobbesiano instala-se no pensamento político holandês como um modelo filosófico que supera já os rigores metodológicos de Grotius e exigirá, de seus adversários, o mesmo poder demonstrativo. Espinosa, sabendo que seus próprios leitores de política têm Hobbes como paradigma de metodologia filosófica, aproxima a disposição dos seus textos (especialmente do Tratado político, em razão de ser um texto voltado só para juristas) da forma hobbesiana, a "via" que Graevius e todos os leitores do tempo notaram na forma das análises espinosanas da política. No entanto, essa forma que parece preencher com teses espinosistas um percurso fundado por Hobbes natureza, natureza humana, vida civil, formas de governo - na verdade, é uma demonstração de que a fundamentação da argumentação em certas falácias - por exemplo, a de que o estado de natureza é um estado de guerra de todos contra todos — produz toda uma demonstração geométrica de uma grande aberração política, o absolutismo político. A teoria política hobbesi- 
ana, sabe Espinosa, é fundada na idéia de que o indivíduo vê na companhia do seu semelhante um grande desprazer e, por isso, na sua destruição uma certa utilidade; mais do que isso, a teoria hobbesiana parte da idéia de que a paixão mais presente na vida política é, ainda, o medo: fundado o estado civil, o súdito se mantém em respeito com os demais homens porque teme ser castigado; o súdito concebe, ele mesmo, que sua conduta na vida civil é determinada por uma potência que está fora dele, e sobre a qual seu cálculo não tem mais relevância alguma, sendo-lhe reservado apenas seu direito natural à autopreservação - que equivale a nenhum cálculo pela reta razão, já que esse único direito natural preservado na vida civil não é deduzido pelo súdito graças à sua luz natural, mas é idêntico aos seus impulsos passionais.

Ora, por que Espinosa coloca, como direito fundamental a ser preservado para todos os cidadãos dentro de qualquer associação (religiosa ou política), o direito ao livre pensamento e livre manifestação desse pensamento? Porque esse direito, sabe Espinosa, envolve e exprime necessariamente todos os direitos concebíveis ao homem em função da sua própria potência, esteja ele em que estado estiver. Somente o direito à vida não constitui concessão alguma pelo Estado, e a prova disso, mostra Espinosa e querem ignorar Hobbes, hobbesianos e positivistas jurídicos, é a recusa por parte de qualquer ser humano em ter suas necessidades determinadas por uma autoridade sobre ele. A filosofia hobbesiana, sabe Espinosa, é a expressão definitiva entre os juristas de sua época de uma demonstração da necessidade do despotismo e do autoritarismo, ou - em termos mais precisos — da concepção da vida política como realização das finalidades de interesses particulares. Ora, se a filosofia hobbesiana defende essa concepção (que sob diferentes formas está presente nas convicções tanto de teólogos quanto de juristas, assim como de hobbesianos e anti-hobbesianos) com a aparência de demonstração necessária de uma verdade científica, Espinosa precisa realizar a tarefa da teoria político-jurídica verdadeira nos mesmos termos, mas sob bases que não sejam afetadas pela concepção declaradamente oligárquica (mais do que meramente absolutista) da vida coletiva como propriedade de particulares que estão no poder, quando deveriam ser instrumento de realização unicamente de finalidades públicas. Ora, em termos espinosanos, a demonstração geométrica é adotada para a análise e exposição da política não apenas porque seja verdadeira e consistente, mas porque se dirige a um público que identifica, agora, demonstração geométrica da política e defesa do absolutismo.

É contra essa concepção de que o absolutismo é um axioma da vida coletiva e pode, por isso, passar por concepção política válida que Espinosa também produz, para a demonstração da política, uma exposição geométrica com a tarefa não apenas de escrever uma explicação realista e verdadeira, mas de não seguir a tradição teórica que costuma conceber a política por utopias 
ou por sátiras. É utópica a idéia de uma sociedade política na qual todos os cidadãos alienaram seus direitos naturais, menos o direito à autopreservação, ao soberano; e é satírica a concepção hobbesiana de que numa sociedade democrática não existe nenhuma obrigação. ${ }^{176}$ Como conceber, pois, uma explicação geométrica da política que tem de dar conta, diante de leitores hobbesianos, de uma concepção da teoria do Estado ainda como tipologia das formas de governo, cuja disposição ainda segue a idéia de uma corrupção das formas de governo significada, no "modelo hobbesiano", por uma necessidade da monarquia em razão do fracasso da aristocracia em manter-se constante, depois que a aristocracia resultara do fracasso da democracia em também manter-se constante? A solução consiste em elaborar uma teoria do Estado que, apesar da forma de tipologia das formas de governo, faça o percurso inverso - da monarquia à democracia —, iniciando com a tarefa corrente entre os juristas de definir as características institucionais de cada sistema político para, ao final reconhecer graças a essa mesma análise que a questão da melhor vida política não é nem nunca foi uma questão de revelar qual a melhor forma de governo. Desde o início da sua concepção de sociedade e de vida política, Espinosa concebe uma liberdade democrática — na qual a preservação da coletividade significa união de todos os cidadãos e atividades contrárias à exclusão de quem quer que seja —, mas precisa eliminar do horizonte a tradição teórica que vem desde os gregos e sob outra forma é consumada pela filosofia hobbesiana, de que a teoria política deve constituir uma escolha entre diferentes formas políticas, ainda que se saiba que todas elas podem ser praticadas. Não é, sabe Espinosa, a forma do Estado que determina a sua legitimidade ou a sua boa fortuna; é a índole da vida política e das ações na vida política que constitui essa legitimidade e toda liberdade concebível na perspectiva da política, coisa que Maquiavel foi o primeiro a notar, e que os juristas são os últimos a reconhecer.

É preciso, portanto, elaborar uma explicação da política que, utilizando o vocabulário político corrente (e já vimos 177 em que termos Espinosa trabalha esse vocabulário; mantendo o que faz sentido e esvaziando o sentido do que não cabe na política), aproveita não apenas a força da demonstração geométrica, mas exige que o objeto da política, fundado na ontologia mas não idêntico a ela, seja constituído pelo campo da experiência política; e o que essa experiência mostra é que, em qualquer situação, ninguém é destituído de sua própria natureza; na perspectiva da política, essa potência recebe do vocabulário político-jurídico o nome de jus, e como a potência de cada indivíduo não pode deixar de ser determinada também por sua própria natureza, o único fundamento eterno do direito de todo súdito ou todo cidadão é o seu próprio co-

${ }^{176}$ De cive, livro II, cap. VII, $\int 7$, p. 124.

177 No capítulo anterior, especialmente tópicos 2.II (“O direito natural em Espinosa: um anticonceito") e 2.III ("Jus sive potentia: lex sive potestas"). 
natus. Este conatus, que a filosofia hobbesiana concebe como tendência ou potencialidade, e no plano da política interpreta como facultas, a filosofia espinosana concebe como essência atual de cada ser e demonstra, no plano da política, como atividade livre e desejo constante de mais liberdade; não fosse assim na experiência política, essa demonstração seria impossível, e o poder político poderia ser considerado legítimo ali onde também deixa margem para a exclusão ou mesmo se baseia nela. Porque Espinosa concebe desde sempre a vida livre como autodeterminação no real, porque concebe a vida política como busca coletiva e integrada de concórdia e segurança, ele não pode deixar de escrever contra as idéias de Hobbes. Mais do que mover-se à escrita política para refutar um filósofo em particular (não faltaram autores a quem dedicar refutações, mas isso, segundo Espinosa, seria exercício de medo e especialmente perda de tempo para a vida racional, que em vez de afrontas exige apenas conhecimento), Espinosa dedica-se à escrita política para demonstrar a necessidade da política e, por sua própria experiência filosófica política, mostrar o que é uma filosofia política verdadeira. Com efeito, o que permite a um indivíduo deduzir racionalmente os princípios da vida política e conceber uma teoria da prática política, do Estado, do direito, dos direitos e das leis? Conhecer-se, fundamentalmente, como ser político, ou seja, como indivíduo consciente do próprio desejo de liberdade e simultânea potência de liberdade política; é conhecer-se como indivíduo já na experiência política, que é conhecimento simultâneo da necessidade de liberdade individual e necessidade de multiplicação dessa liberdade pela união com os demais indivíduos conscientes da mesma necessidade natural na vida coletiva. O que leva Espinosa a conceber que a natureza humana, na vida coletiva, pede uma sociedade de homens livres, é conhecer, já, a liberdade como consciência racional da atividade humana em coletividade. Longe de ser uma concepção utópica ou satírica, é conhecimento reflexivo, já, da experiência política que se dá tanto como experiência histórica como compreensão racional dessa experiência.

Não é, pois, a defesa da democracia simplesmente o que permite conceber Espinosa como anti-hobbesiano. A defesa espinosana da democracia é uma expressão da concepção espinosana da própria política e da própria liberdade. O que permite reconhecer Espinosa como antihobbesiano é algo muito mais pesado para o fardo dos juristas de seu tempo: uma necessidade crítica dessa concepção racionalista e democrata da política de negar racionalidade às concepcôees excludentes do poder político. Ora, o campo mais marcado por essa concepção é o da própria prática político-jurídica. O que significa Espinosa afirmar, no início do Tratado político, que os filósofos são os menos qualificados para falar de política (já que não têm a experiência política como base 
das suas considerações, mas unicamente concepções ideais, das quais só podem ser produzidas utopias e sátiras), e que os políticos, em contrapartida, são os mais qualificados (já que eles vivem na experiência política)? Significa que a verdade da política está na experiência política, e que uma explicação desse objeto exige a recusa de qualquer concepção que não seja necessariamente concreta; ora, a experiência política que se mantém presente em qualquer momento da vida humana e da explicação da política é o desejo de liberdade e a necessidade de direitos. Nenhuma prática política histórica pode apagar isso da natureza humana, ainda que seja possível imaginar a sua alienabilidade a uma instituição política. A observação racional espinosana da experiência política mostra, de ponta a ponta, as conseqüências da necessidade natural de liberdade em cada ser humano. Elaborar uma teoria que negue essa necessidade ou, pior, que negue a relevância dessa necessidade depois que se instituiu uma autoridade política, isso é exigir do ser humano que, no contato com a teoria política, seja alienado da sua própria razão assim como se pretende exigir dele, na vida política, que se aliene do seu próprio desejo natural de liberdade. Se a teoria jurídica tem por costume a justificação da potestas por meio da negligência do conatus, não é à toa que o resultado histórico e ontológico disso é a violência, e a forma institucional dessa dominação injustificável é o despotismo. Se é o caso, pois, de elaborar uma filosofia verdadeira da política, ela deve ser, a todo momento, exposição verdadeira da política e, historicamente, defesa da democracia e denúncia do despotismo. Em quê o positivismo jurídico pode considerar que essa convicção política e essa necessidade teórica, que marcam a filosofia política espinosana em cada linha, é derivada do "modelo hobbesiano"? 


\section{CAPÍtulo 4 \\ ESPINOSA, JURISTA?}

Ao mostrar que individualidade e multidão são indissociáveis, Espinosa antes mostra, também, o absurdo das teorias do "totalitarismo", que vêem no movimento de massas apenas a figura de um mal histórico radical, e não sabem senão contrariar sua fé no eterno recomeço da "consciência humana" e em sua capacidade de instituir o reino dos "direitos do Homem". Bem longe de ser ele mesmo um "democrata" no sentido que poderíamos dar a esse termo, Espinosa dessa maneira talvez se ache fornecendo, à nossa atualidade, indicações e meios de pensamento contra a servidão mais duradouros do que se ele tivesse "conseguido" descrever as instituições da democracia.

E Balibar, "Spinoza: la crainte des masses", p. 320.

\section{I O DIREITO POSITIVO, UM INSTRUMENTO PARA A RAZÃO}

O Tratado político é o verdadeiro tratado jurídico de Espinosa. Penso ser necessário reconhecê-lo, basicamente por dois motivos. Primeiro, a forma da obra, que por não ter agora de se preocupar com uma leitura teológica, não precisa mais utilizar uma estrutura retórica especialmente pensada para leitores cristãos; mais do que isso, o Tratado político, ao declarar como uma de suas bases teóricas o Tratado teológico-político, aproveita-se de uma das conclusões ali instituídas: não é preciso basear-se na teologia ou nas Escrituras Sagradas para tratar da política; ao contrário, a política, como objeto racional de conhecimento, só pede ser explicada por uma observação objetiva e uma análise realista, tarefa para a qual os preconceitos dos teólogos em nada contribuem e com a qual as verdades da religião não guardam relação alguma; terminada a crítica ao poder teológico-político, o trabalho espinosano de crítica à autoridade pode, enfim, concentrar-se nas formas estritamente político-jurídicas de despotismo. Também, quando se dedica ao Tratado político, Espinosa já tem concluída a Ética, da qual acaba de compor especialmente as partes finais (que tratam da servidão e da liberdade, e constituem, junto com outras passagens das partes anteriores, a fundação ontológica da sua teoria da sociedade e da comuni- 
dade $\left.{ }^{178}\right)$. Sua teoria política, enfim, já está esboçada como fundada numa concepção ontológica de comunidade humana governada pela compreensão racional da necessidade de concórdia (graças à Ética) e pela crítica ao jusnaturalismo e à teologia política como bases racionais para compreender os fundamentos do Estado e a necessidade da própria política (graças ao Tratado teológico-político). Ora, que novidade conceitual vem trazer o Tratado político, ou que trajeto teórico ele vem completar dentro da filosofia espinosana? Esse breve tratado sobre o direito e as instituições é a primeira oportunidade que Espinosa efetivamente tem de se dedicar a uma demonstração da sua filosofia da democracia contra outro tipo de superstição teórica, aquela que cabe exclusivamente aos juristas de seu tempo. A apresentação dos fundamentos do Estado já fora de certa forma completada no Tratado teológico-politico, ainda que sob uma forma demonstrativa muito diversa e especialmente fora de um projeto de análise das instituições pertinentes a cada regime político (em vez de empreender uma tal análise, o Teológico-político é uma defesa direta da democracia); entretanto, a mesma teoria política só poderia ser completada dentro de uma perspectiva exclusivamente política, cujos pressupostos dizem respeito à concepção prática da política, como instituição do Estado. É nestes termos que concebem os juristas a teoria política e que Espinosa se propõe elaborar sua nova análise, acrescendo-a de uma autêntica teoria das instituições. Aí, no Tratado político, Espinosa retoma as teses da Ética e principalmente as do Teológico-político, e como no tratado anterior vai da análise do Estado a partir de sua antiteoria do direito natural a uma defesa da democracia elaborada agora sob outras condições teóricas, e especialmente para outro público (que, como já pudemos considerar, é essencialmente marcado pela formação grotiana ou pelo debate hobbesiano). Como se trata, conforme indica o primeiro capítulo do Tratado político, de falar de política com o realismo daqueles que fazem a política a partir da experiência política, portanto —, Espinosa se propõe por isso a explicar para os próprios juristas por que a vida política e o Estado que lhe serve de estrutura institucional devem ser democráticos. Ou seja: por que, em primeiro lugar, é o caso de considerar que esse tratado é autenticamente jurídico? Porque ele se volta para um público que concebe e argumenta a política enquanto teoria das instituições do Estado e teoria das formas de Estado, e porque desta vez tanto o seu vocabulário como o seu cálculo retórico (também aqui presente; mas já numa escala menos intensa) são tipicamente jurídicos, senão jusnaturalistas. Todavia, o conteúdo dessa teoria, como não poderia deixar de ser, leva a concepções que jamais se pensaria, na época, que aquele mesmo vocabulário permitiria. A subversão conceitual que Espinosa opera, porém,

\footnotetext{
178 Não uma "segunda fundação", como quer Negri, mas a finalização de um projeto intelectual, a Ética, concebido desde o início como teoria da liberdade e interrompido por alguns anos para a escrita do Tratado teológico-politico.
} 
com os termos do jusnaturalismo e da teologia política, como já vimos, ${ }^{179}$ permite agora compreender os termos nos quais Espinosa consegue empreender uma teoria do Estado que afirma com o vocabulário da época aquilo que os juristas da época negam constantemente, da irracionalidade do contratualismo à concepção democrática do poder político. Temos aqui um texto que, dentro do projeto espinosano de crítica ao despotismo e simultânea defesa de democracia, tem a forma necessária para um público de leitores juristas, e se apresenta como teoria do Estado porque sua pretensão é valer, justamente, como teoria jurídica — ainda que sua peculiaridade teórica significa, também, a proposta de uma nova forma de teoria jurídica, que ao mesmo tempo que é proposta é, já, consumada por este texto, malgrado seu notório estado de inconclusividade.

Em segundo lugar (e a meu ver o principal motivo), o Tratado político merece o reconhecimento como tratado jurídico porque a estrutura argumentativa concebida por Espinosa é uma defesa da racionalidade do direito positivo. O que permite dizer isso?

Espinosa concebe o capítulo final de todas as suas obras como o ápice de tudo o que foi efetivamente demonstrado até ali; não importa a fora argumentativa ou o objeto da obra, o que é dito no final de seus textos não poderia, por questões de estrutura demonstrativa, ter sido demonstrado antes. O amor intellectualis Dei não poderia, na Ética, ter sido nem ponto de partida nem momento intermediário da obra, porque sua concepção de idéia maximamente positiva que uma mente livre pode ter é conseqüência do desenvolvimento de toda a argumentação geométrica que funda os elementos da liberdade na ontologia, na física, na teoria dos afetos, até que seja possível ao leitor compreender plenamente o estado de liberdade máxima representado pela idéia do amor intelectual de Deus: a grande tese da Ética é a necessidade da liberdade humana, cuja formulação só aparece ao final e traz em si mesma a concatenação conceitual de toda a Ética. No Tratado teológico-político, a plenitude da idéia de liberdade de pensamento e expressão do pensamento, anunciada já no prefácio da obra, tomada como evidência que a experiência mostra a qualquer um, e mencionada constantes vezes no correr do tratado, só se revela quando já passamos pela demonstração de que essa e quaisquer liberdades são determinadas pela necessidade da natureza, e que sua realização plena se dá não apenas no plano da política, mas num ambiente necessariamente democrático: a tese mestra do Teologico-político é a necessidade democrática da liberdade de pensamento, e quando chegamos à sua formulação no final do texto, sua compreensão plena traz também todo o percurso empreendido desde o início do texto. Nessa filosofia onde o final do texto tem uma responsabilidade teórica tão séria — con-

${ }^{179}$ Capítulos 2.II (“O direito natural em Espinosa: um anticonceito”) e 2.III (“Jus sive potentia: lex sive potestas"). 
densar, numa concepção que resulta de todo o percurso da obra, a obra inteira —, o que nos diz, todavia, o final sem conclusão do Tratado político? Não temos esse final da obra, por mais que Espinosa tenha chegado perto dela. Uma das angústias que a expressão reliqua desiderantur apensada ao último parágrafo deixado pelo filósofo traz ao seu leitor, além da inconclusividade textual da sua teoria da democracia, é a ausência dessa alentada conclusão que, para o projeto político de Espinosa, mostraria o que é na sua "filosofia verdadeira" a condição integral da vida política absolutamente livre. Se o Tratado político dá-se por tarefa a produção de uma teoria do Estado que explique sem utopias nem sátiras o que é a vida política efetivamente realizadora da "paz e segurança" que são finalidade de todo poder político, a ausência da conclusão deixa-nos num vazio tão incômodo quanto aquele deixado pela inconclusa teoria da democracia. E, assim como essa inconclusividade da teoria da democracia incentiva a dúvida dos céticos, a mesma dúvida poderia ser colocada quanto à viabilidade, nessa obra que se quer baseada diretamente na prática política, da elaboração de uma concepção que traga em si mesma o sentido de todo o percurso da obra - ou se, pelo contrário, a inconclusividade do Tratado político não seria devida tanto à impossibilidade de concluir a análise da democracia, como pela dificuldade (conseqüente talvez dessa dificuldade de concluir o texto sobre a democracia?) de conceber um fecho para todo o tratado, cujo percurso tortuoso, a propósito, parece ser incompatível com a consistência apresentada nas obras anteriores? Essa concepção conclusiva, se construída, seria qual? Não podemos saber. O final do Tratado político, enfim, não chegou até nós, e conjecturar o seu conteúdo não produz nenhum substituto a esse final inexistente. Entretanto, sabemos, graças ao próprio Espinosa, qual seria o tema desse final do tratado. $\mathrm{Na}$ Carta 84, publicada como prefácio à obra, Espinosa explica ao amigo que está atualmente trabalhando nos capítulos sobre a monarquia e, depois desse assunto, passará ao "Estado aristocrático e ao popular [democrático] e, por fim, às leis e a outras questões particulares concernentes à politica" (grifos meus). Ou seja, o que Espinosa planejara para o capítulo final do seu tratado voltado para os juristas era, justamente, um capítulo sobre as leis civis.

Esse capítulo, assim como a seqüência de capítulos voltados à análise das instituições típicas de cada regime político, seria algo inteiramente novo nos seus textos. Nem mesmo no Tratado teológico-político, onde temos, de um lado, um capítulo sobre a lei divina (que é, como também já vimos, um capítulo sobre a lei em geral e a diferença entre lei divina, lei natural e lei humana mas não, ainda, um capítulo sobre a lei civil), e, de outro, uma parte sobre a política na qual as leis aparecem apenas raramente, sob a forma muito peculiar de "leis da Pátria". No Teológicopolítico, Espinosa tem a tarefa de criticar o poder teológico-político e demonstrar a necessidade de teorização da política sem as lentes da teologia; não é, todavia, ainda o momento de comple- 
tar o percurso dessa mesma teoria política, já que aí a conclusão a que se quer chegar com toda a propriedade é a da liberdade de expressão; sobre como conceber um Estado ou uma vida política já pelas bases unicamente da concepção política de Estado (e não mais pela concepção influenciada pela teologia), isso é tarefa para um trabalho posterior, o Tratado político.

Não à toa, não há, na verdade, teoria do direito positivo (das leis civis) no Teológico-político, a despeito de haver, ali, uma muito breve teoria das leis humanas. Com efeito, o tema da diferenciação das leis é obrigatório a Espinosa, já que ele precisa lidar com um conjunto de leitores formado tanto por teólogos quanto por juristas de formação jusnaturalista: tanto da parte de teólogos quanto da parte dos juristas, a tradição teórica a respeito das leis determina que se considere uma tipologia clássica (lei natural, lei eterna, lei humana, lei divina, lei civil), além da idéia da operação da razão ou da reta razão no reconhecimento das leis (em especial as leis naturais, ou as leis divinas nas leis naturais). Ora, no Teológico-politico, o capítulo IV é uma análise rigorosa de toda essa tradição, assim como a negação da sua validade para o mundo jurídico. Já no início do capítulo, Espinosa nega a identidade entre lex e jus, considerando que, entre os tipos de lex que são classificados normalmente por essa tradição, apenas um - lex bumana mereceria receber o nome de jus. É a única observação a respeito; a idéia de jus não será abordada diretamente enquanto não chegar o capítulo XVI, estabelecendo para o jus a idéia não de uma faculdade, mas de uma potência de cada ser. Essa observação no início da análise da lei, porém, serve para notar que esse tema não coloca a análise, ainda, na teoria do Estado ou no campo da política: porque a lei divina não é lei humana (a única que mereceria com mais propriedade o nome de direito), ela não diz respeito à vida política. Qual a função, pois, do capítulo sobre a "lei divina", nos inícios ainda do Tratado teológico-político? Mostrar que aquilo que se concebe como palavra de Deus ou lei de Deus, especialmente em vista da experiência histórica do povo hebraico (cuja história é marcada por profetas e profetismos, o ponto de partida da análise de Espinosa nos primeiros capítulos do tratado), tem um significado válido ou para o mundo natural, ou para a vida religiosa, mas não para a vida política. Mais do que isso, o capítulo IV do TTP vem mostrar que há uma quebra entre a concepção vulgar de lei (comando de uma autoridade) e a concepção racional da lei (isso que determina a ação em função da necessidade ou definição de uma coisa), presente em toda concepção particular das leis (lei divina, lei humana, lei natural, lei civil etc). Sem o conhecimento desses dois princípios da teoria espinosana da lei, não podemos perceber, que ele exige que a lei religiosa e a lei divina não tenham relação com a vida política, ao mesmo tempo que exige que a lei seja tomada como um sentido diverso do direito nessa perspectiva de análise. Quando chegamos ao capítulo XVI, em que se elabora uma teoria específica sobre os direitos e sobre a relação entre direito natural e direito civil, temos 
ainda outra quebra, entre o conceito vulgar de direito (faculdade, capacidade de ação) e o conceito racional (potência). Se, na concepção vulgar, não só a definição da lei e a do direito ou dos direitos é extremamente distante da concepção racional, esse distanciamento é ampliado quando estamos, ainda, no campo da teologia e na imaginação de que os princípios da teologia têm força de lei e de direito. Mais do que isso: no que diz respeito especificamente à religião, se imaginamos essa figura antropomórfica de um Deus governante do universo, tal como um príncipe político, desconhecemos mesmo o significado da lei divina, que nada mais é, mostra Espinosa, que a lei natural. Assim, partindo de um vocabulário e de uma tradição argumentativa que vem desde os escolásticos e é pouco modificada pelos jusnaturalistas, Espinosa precisa mostrar, contra os teólogos, que a lei divina não é comando e que a lei humana não está subordinada a um mandamento divino, mas que por lei se entende exclusivamente a necessidade da natureza de algo; quanto aos jusnaturalistas, que já negam por sua vez que a lei divina seja um comando sobre as leis civis, Espinosa mostra todavia que a própria lei humana não é uma lei natural, e que a lei moral não é lei racional; a verdadeira lei humana, aponta Espinosa já aí para algo que só desenvolverá no capítulo XVI, é uma necessidade de ação que não é determinada nem por um imperium, nem por uma potestas, mas por uma potentia. A atividade necessária a um indivíduo não é aquela que simplesmente lhe é comandada ou ordenada; é aquela determinada pela sua potentia necessária, é aquela sem a qual o indivíduo não pode ser o que é.

Não é, pois, no capítulo sobre a lei divina que se encontra a teoria espinosana das leis civis. Mas encontra-se, ali, um princípio fundamental para que se compreenda a maneira adequada de conceber as leis civis e lidar com elas. Se é o caso de considerar que a lei é uma regra de ação (que é a concepção tradicional tanto dos teólogos quanto dos jusnaturalistas), essa regra deve ser determinada pela necessidade natural do agente e não por algo que esteja fora dele. É por isso que, para a definição de lex, Espinosa concebe que se trata de uma determinação colocada pela necessidade da própria coisa, do próprio agente. O princípio de validade de qualquer lei é a necessidade da ação a que essa lei se refere. Sempre que esse princípio for quebrado, a lei não merece legitimidade, e sua obrigatoriedade é uma forma de violência (no campo político, uma forma de dominium), porque opera contra a necessidade natural do agente. Assim, quando se concebe que um comando é uma lei (como os preceitos de Deus ao povo hebraico, como os comandos de um príncipe aos seus súditos, como as determinações de um magistrado aos cidadãos), concebe-se, aí, que a legitimidade da lei decorre de um imperium (em termos jurídicos seiscentistas, um comando, um poder de comandar a ação alheia), portanto de uma necessidade exterior à do agente, e 
não necessariamente idêntica ou adequada à dele. Essa identidade, porém, é irrelevante em termos racionais; a ação livre, concebida por Espinosa na Ética e no Tratado teológico-político como a ação determinada pela necessidade do próprio agente, não pode ser produzida por servidão a uma necessidade externa, mas unicamente por atividade de uma necessidade interna do próprio agente. Em qualquer campo, como considerar que uma lei é legítima? Não quando ela decorra de uma autoridade, mas unicamente quando ela é expressão da necessidade do agente para agir. A lei, na verdade, é idêntica à necessidade e em termos racionais deveria ter sua denominação substituída pelo próprio termo necessidade, para evitar a constante confusão fundada por analogia entre a idéia jurídica de lei (comando, de fato) e a entidade racional da necessidade da ação livre (que pode ser operada em qualquer tipo de ação, no campo da ética, da sociedade, das instituições, da religião, da natureza e assim por diante).

Ora, se é incorreto chamar a lei divina e a lei natural de lei porque o uso do termo, aí, é determinado por uma analogia com algo que essas leis não são — comando, ou seja, leis civis, ou seja, direito (que ainda será, posteriormente, reduzido à idéia de potência) —, por que o uso, por Espinosa, da classificação das leis aproveitando essas denominações clássicas? Porque elas são, em cada campo, concebidas como determinantes da ação, ainda que não se perceba, por efeito da imaginação mais do que da razão, que essa determinação é por necessidade da natureza do agente e não por deliberação e vontade de uma força superior ou externa ao agente. Em primeiro lugar, qual a diferença racional entre lei divina e lei natural? A primeira distinção que Espinosa faz com respeito às leis se dá entre a lei natural e as leis humanas, para marcar que ambas são, na verdade, incomensuráveis: só a lei humana, sendo lei "que depende de uma decisão humana", é um comando (ainda que nunca destituído da idéia de necessidade da ação) e por ser concebida portanto como lei civil, e neste sentido unicamente o seu campo é a política (de maneira que deixa para ser estudada, mais adiante, como a instituição do jus e dos jura); no caso da lei natural, ela não depende da decisão de ninguém, mas unicamente a lei que "deriva necessariamente da própria natureza, ou seja, da definição de uma coisa". A lei natural, mostra Espinosa, é a lei enquanto princípio para a atividade livre e necessária, e poderia mesmo ser tomada como a idéia geral de lei. Espinosa só não faz isso porque lida com uma tradição que concebe, primeiro, que há uma distinção entre leis naturais, leis divinas e leis humanas e, segundo, que a lei humana é válida porque decorre de uma autoridade. A tarefa de Espinosa que conhece que a liberdade consiste não na atualização de uma faculdade de ação, mas na autodeterminação da ação segundo a própria necessidade natural — consiste em mostrar que, se a lei deve ser concebida como "regra para a ação" ou "regra de ação", então a única medida — a única regra — racional para essa ação não é dada por uma reta razão ou por uma prudência que deci- 
de por livre-arbítrio o que é melhor ou não, mas sim por uma razão que conhece evidentemente a necessidade própria do agente para agir. Ora, essa necessidade evidente da própria ação, não pode ser determinada por nada que lhe seja externo; a única medida dessa necessidade é o seu desejo, a consciência da sua necessidade de ação e autopreservação, consciência do próprio conatus.

Para que essa idéia — a verdadeira razão da ação livre é o conatus — possa ser apresentada já aí nessa crítica às concepções tradicionais de lei, Espinosa precisa mostrar que, ainda que se conceba a lei como uma regra de ação, ela é sempre uma lei natural. Assim, o que faz o capítulo IV do TTP é mostrar que não só a lei divina é uma expressão da lei natural, como principalmente que a idéia racional de lei só faz sentido enquanto necessidade natural de ação. Mesmo no caso da lei humana, quando ela reaparece como regra para a ação (na medida em que é concebida como comando e é imposta dessa forma), essa definição de lei precisará ser considerada, ou não poderá ser reconhecida, para o comando político na vida civil, legitimidade racional além da autoridade institucional.

Ora, como conceber, nestes termos, a idéia de direito positivo - o centro da teoria jurídica dos juristas que consideram o conceito espinosano de jus um conceito sem sentido - , sendo que o próprio Espinosa, ao exigir que racionalmente o termo lex signifique necessidade da ação segundo a natureza ou definição da coisa, parece impedir que haja qualquer relação entre instituição jurídica (coisa que o direito positivo não pode deixar de ser) e necessidade natural de cada indivíduo?

A concepção tradicional do direito positivo, assim como do próprio direito, é a idéia de que lex e jus são idênticos entre si: a lex é expressão pública da obrigação ou da liberdade de uma pessoa, e o jus é essa mesma obrigação ou liberdade determinada pelo imperium da lex. Todavia, isso não significa necessariamente, aí, a existência de algum direito subjetivo (especialmente no caso do direito romano), ${ }^{180}$ mas significa sempre a idéia de um imperium que é fonte constante de todos os direitos e valores civis. Conforme o humanismo jurídico se desenvolve pelo Renascimento, desenvolve-se também a idéia de um jus presente na natureza humana que exige reco-

\footnotetext{
180 Michel Villey dedicou-se intensamente a demonstrar que no direito romano não existe a idéia de direito subjetivo; entretanto, as análises de Alexandre Passerin d'Entrèves mostram que, apesar da concepção de que as liberdades individuais não decorrem, no direito romano, de uma necessidade individual ou moral e sim de um comando externo por parte dos magistrados e legisladores, concebe-se aí mesmo no direito romano a idéia de facultas agendi, faculdade de agir, que na vida civil opera como direito a uma liberdade que a autoridade política não pode violar, desde que concedida pela Cidade. Cf. d'Entrèves, $\mathrm{Na}$ tural law, an introduction to Legal Philosophy, p. 61.
} 
nhecimento pela lex, assim como pretende ter força de instituição. Em Hobbes, a concepção escolástico-romano que mescla jus e lexé separada pela definição da lei como comando e do direito exclusivamente como faculdade: ao direito, em termos hobbesianos, não cabe considerar a idéia de instituição; de maneira que ao jurista caberia realizar, de um lado, uma teoria da law (das instituições jurídicas) e, de outro, uma teoria dos rights (dos direitos, sejam civis sejam, principalmente - porque podem ser concebidos sem a existência das instituições civis —, naturais).

Ora, Espinosa tem uma concepção extremamente crítica da idéia clássica de direito positivo no TTP e, embora ameniza essa crítica no TP, ele lá a mantém sob outro sentido. A crítica ao direito tomado como instituição — ou seja, da lei humana — por todo o Tratado teológico-político diz respeito à concepção de que a lei não é considerada válida em função da sua necessidade, mas em função da sua imposição por uma autoridade que exige pela força a obediência. Espinosa critica, no próprio capítulo IV, a obediência à lei divina motivada pelo medo de castigos e não pelo conhecimento da necessidade dessa lei, e explica que o que leva o fiel a conceber sua obediência à lei dessa forma é o fato de conceber a própria lei como comando de um soberano político, ao mesmo tempo que está cego para a compreensão da sua necessidade natural e racional. Ora, dada a definição de lei, ela ou é valida em função exclusivamente da necessidade do agente ou não tem validade alguma (já que, do contrário, constitui uma violência contra sua natureza). É essa idéia de racionalidade da lei que está presente em Espinosa, quando ele tem diante de si o fenômeno concreto da obediência em razão do medo (a mesma que, no "modelo hobbesiano", mantém a todos em respeito no estado civil) e não em razão do reconhecimento de uma necessidade da própria ação. Ora, diante da lei natural, quando essa necessidade é reconhecida, percebe-se que a lei divina nada mais é do que a necessidade da própria natureza; quando a suposta ordem da natureza é observada, percebe-se que suas ações não decorrem de uma justiça natural que repõe em seus lugares naturais todas as coisas, mas é a própria necessidade natural de cada ser segundo a sua natureza interna; finalmente, quando se considera a lei humana, percebe-se que ela também trata de uma necessidade natural do homem que é operada seja como liberdade ética, seja como liberdade política: como liberdade ética, enquanto autodeterminação individual da ação; como liberdade política, enquanto autodeterminação individual da ação na vida coletiva. Em vez de ser racional porque comando de um soberano, a lei civil só tem sentido racional enquanto necessidade da ação individual de acordo com a necessidade em determinada situação social. Ao direito positivo resta essa dificuldade, e à filosofia espinosana o desafio de demonstrar qual racionalidade pode ser considerada para ela em vista da concepção 
da lex como necessidade da ação segundo a natureza do agente (e não como comando) e do jus como potência natural de ação (e não como instituição).

Ora, da mesma forma que Espinosa lança um olhar crítico à idéia teológica e supersticiosa de autoridade da lei fundada na autoridade de quem tem o imperium ou a potestas, Espinosa reconhece, em certa espécie de instituições civis, o princípio de todo valor civil e necessidade pública: justamente, as leis civis. Essa consideração do valor das leis civis e da sua necessidade como fonte pública de justiça e de direito na vida política manifesta-se intensamente no Tratado político e parece, a princípio, contradizer a crítica elaborada às concepções teológico-políticas da autoridade das instituições. Por exemplo, Espinosa critica não só a obediência a uma lei por medo de castigos como também a idéia de que as leis divinas só podem ser interpretadas por pretensos especialistas; ora, Espinosa faz questão de ressaltar de várias maneiras o caráter racional e natural das leis divinas, o que significa nada menos que elas estão acessíveis à luz natural de cada um e sua compreensão não carece de intermediação; por isso mesmo, é possível compreender sua necessidade e praticar a fé (que nada mais é que obediência) sem o recurso aos castigos e às recompensas. No caso das instituições civis, essa mesma necessidade das leis existe mas, como os homens pouco se deixam conduzir pela razão (isto é: como eles pouco se permitem conhecer racionalmente a racionalidade da sua própria ação), normalmente agem de forma contrária a sua necessidade ou à necessidade de todos na vida política. Daí, o recurso tão freqüente, na vida civil, à concepção de que as leis civis devem ser impostas juntamente com ameaças ao seu descumprimento; mais do que isso, Espinosa considera que, na vida civil, há uma necessidade de manter a interpretação das leis nas mãos de especialistas, ou do contrário, se cada um tivesse o poder de julgar por si só o que é justo ou não na vida política, não haveria mais nenhuma medida universal de justiça civil:

Se a Cidade dá a alguém o direito e, portanto, a potestade de viver segundo suas próprias disposições, ela se despoja de seu próprio direito e o transfere àquele a quem deu tal poder. Se ela dá esse poder a duas ou a várias pessoas, divide a Cidade e cada um daqueles que tem o poder vive segundo suas próprias disposições. Se, enfim, ela dá tal poder a cada um dos cidadãos, ela se autodestrói, deixa de existir e regressamos ao estado de Natureza. Tudo isto é bastante manifesto e conseqüentemente não se pode de modo algum conceber que a instituição da Cidade permita a cada cidadão viver segundo sua disposição: o direito natural pelo qual cada um é juiz de si mesmo desaparece necessariamente no estado civil. Digo expressamente: a instituição da Cidade, pois o direito natural não cessa de existir no estado civil. Tanto no estado de Natureza quanto no estado civil o homem age segundo as leis da Natureza e cuida de seus interesses, pois em cada um desses dois estados é a esperança e o medo que levam a fazer ou não fazer isto ou aquilo, e a principal diferença entre os dois estados está em que no estado civil todos têm os mesmos medos e esperanças e a segurança tem as mesmas causas para todos, e a regra de vida é comum, o que não suprime, mas pelo contrário conserva, a faculdade de julgar de cada um. Com efeito, quem decidiu obedecer a todas as injunções da Cidade, seja porque teme sua potência, seja porque ama a tranqüilidade, cuida da segurança dela e de seus interesses pessoais segundo sua própria disposição. Além disso, não podemos conceber que seja permitido a cada um interpretar os decretos da Cidade, isto é, as suas leis. Se houvesse tal permissão, ser-se-ia, com efeito, seu próprio juiz; não ha- 
veria atos cometidos por si que não pudessem tornar-se desculpáveis ou louváveis com uma aparência de direito, e, conseqüentemente, regular-se-ia a vida segundo o próprio arbítrio, o que é absurdo. ${ }^{181}$

Não existe, então, alguma contradição entre o Tratado teologico-político e o Tratado politico? Não, graças aos termos em que Espinosa exige a prática desse privilégio da interpretação das leis ou, em termos gerais, da sua imposição e da determinação do que é o justo ou o legítimo para a vida civil: nenhum particular pode julgar as leis civis (as regras de ação dos cidadãos segundo sua necessidades e definição de cidadãos, isto é, segundo sua necessidade pública) segundo seu arbítrio particular. Graças ao texto de Espinosa, isso vale não apenas para cada súdito, mas vale também para o próprio magistrado ou o próprio governante: as leis civis são válidas não porque sejam vontade de um soberano ou imposição de um poder mais forte do que o dos súditos, mas porque são necessidade de toda a vida coletiva. Reside neste princípio a idéia de racionalidade do direito positivo.

Ora, nenhum dos textos de Espinosa em que é desenvolvida a crítica à idéia autoritária das instituições civis nega, em primeiro lugar, que na vida civil as leis civis sejam expressão da necessidade pública — pelo contrário, é isso mesmo que é afirmado por ele —, mas também não nos resta, dos seus textos, um projeto jurídico ou um elenco das leis fundamentais de uma república livre ou de um Estado soberano, tal como era comum nos tratados dos juristas de seu tempo e que, naturalmente, seria de se esperar num tratado que tem a forma de um tratado jurídico. Ora, o Tratado político projetou essa função para si: o término do tratado trataria justamente das leis civis e, vindo depois da análise dos regimes políticos - especialmente depois da escolha pelo regime político da democracia ou, mais precisamente, pela definição da liberdade política absoluta como liberdade democrática —, essa teoria das leis civis ou do direito seria necessariamente uma teoria da validade das leis civis numa perspectiva democrática. Não parece excessivo considerá-lo, diante da maneira como Espinosa concebe as leis geral e, também, as leis humanas não apenas desde os primeiros capítulos do Tratado político (em que as leis civis são marca da justiça e da legitimidade em determinada Cidade) como desde já o Tratado teológicopolítico (em que a lei é definida como regra para a ação segundo a necessidade do agente). Ora, combinadas essas duas concepções, temos a idéia de que a lei civil só faz sentido como expressão, na estrutura do Estado, da necessidade pública dos seus cidadãos. Ainda que não tenhamos, de Espinosa, uma teoria da legislação civil que nos ofereça um modelo de legislação ou, o que certamente estaria ali, uma consideração sobre como elaborar as leis civis, esse modelo não é tão importante quanto a idéia, mesma, de lei civil destituída das suas significações vulgares

181 Tratado político, cap. III, \S 3-4. 
(comandos que devem ser seguidos em função, apenas, do imperium da autoridade política). A lei civil, regra da ação civil, é expressão de uma necessidade do cidadão porque, nessa ação, o indivíduo conquista efetivamente sua preservação e seu fortalecimento na vida coletiva; quando isso não ocorre, a lei civil não tem mais nenhuma relação com ele. Espinosanamente, pois, uma teoria do direito positivo deve ser, primeiro de tudo, uma demonstração da racionalidade do direito positivo unicamente como expressão dessa necessidade individual no plano da vida política: se cabe às leis civis determinar finalidades para a ação civil, essas finalidades não podem ser particulares, mas devem ser sempre públicas.

Mais do que isso, não me parece sem motivo a colocação dessa teoria das leis no final da obra, e não no começo (como faz, de certa maneira, Hobbes; ${ }^{182}$ como fazem, com freqüência, juristas como Bodin e - este sim, referência direta para Espinosa - Grotius). No início da obra, ou seja, antes de empreender a análise das instituições de cada forma de Estado (monárquico, aristocrático, democrático), Espinosa precisa apresentar os fundamentos de todo Estado: aí, aparece a idéia de lei civil como expressão da necessidade pública, coisa que nenhuma soberania pode negar aos seus cidadãos. Passada a análise dos Estados, o que ocorre? Não uma descrição das instituições mais apropriadas em cada tipo de regime político, mas uma consideração de como são concebidas as instituições em cada regime político. ${ }^{183}$ Ora, essa análise mostra que a monarquia e a aristocracia, ainda que práticas políticas existentes na experiência política, são fundadas em princípios institucionais opostos a esse que acaba de ser apresentado no capítulo III da obra: tanto numa quanto na outra, a finalidade da ação política ou do poder é concebida não a partir de uma necessidade da multidão ou do povo - a única necessidade pública no campo da vida política - , mas segundo finalidades particulares, que só podem ser operadas enquanto exclusão de direitos e dominação ou violação da natureza dos súditos. Por esse motivo - identidade autoritária e violenta entre legitimidade política e finalidades particulares —, tanto a monarquia quanto a aristocracia são, na verdade, oligarquias. O único regime político que

${ }_{182}$ Embora Hobbes elabore, antes de sua análise dos Estado, um elenco das leis naturais (perceptíveis pela razão reta e não impostas pela autoridade), estas são concebidas como tendo autoridade sobre o homem em qualquer condição civil e são, nestes termos, leis civis. Na concepção hobbesiana, nenhum ordenamento jurídico pode ser contrário às leis naturais (que não são leis válidas no estado de natureza, mas leis válidas em qualquer situação civil porque necessárias por natureza ao homem).

183 Ou seja: os capítulos sobre os diferentes regimes políticos no Tratado político não são modelos de instituições políticas sugeridas por Espinosa dependendo do caso (incluindo-se aí, portanto, as instituições do direito positivo). Diferentemente, diversos comentadores do pensamento político de Espinosa consideram que ele de fato oferece aí modelos políticos ou ao menos institucionais, em vista da constatação de que há, na prática histórica dos Estados, o uso de diversos tipos de regime político. A meu ver, essa concepção não tem cabimento, porque em nenhuma dessas supostas descrições (da monarquia e da aristocracia, no caso; que foram as que nos chegaram completas) Espinosa considera que esteja sendo cumprido o critério da necessidade pública das instituições do Estado. 
cumpre, por sua própria necessidade e definição, a identidade entre legitimidade política e finalidade pública só pode ser a democracia.

Ora, o leitor do Tratado político já estaria sabendo disso quando chegasse ao capítulo sobre a elaboração das leis. Por isso mesmo, aí a teoria da legislação seria, necessariamente, uma teoria da legislação na democracia, porque a análise dos regimes políticos viria de mostrar que a aristocracia e a monarquia não eram suficientes para cumprir as necessidades públicas das instituições jurídicas tal como definidas no capítulo III. Assim, ainda que não tenhamos esse capítulo escrito, nós temos, pela estrutura dos textos de Espinosa e já por tudo o que afirma a respeito das leis civis, a constatação e demonstração crescente de que as instituições civis só valem como índice do direito e da potência da vida política desde que se mantenham como expressão das necessidades públicas. Fazer teoria jurídica, portanto, não consiste para Espinosa em conceber a teoria do Estado como fundada numa teoria do direito natural (mesmo sendo a sua uma antiteoria), mas sim em concebê-la como conduzindo a uma elaboração racional da legislação e da própria idéia de legislação. O motivo que torna jurídico o Tratado político de Espinosa é, desde seu esboço inicial, a tarefa de chegar a uma teoria da legislação a partir da demonstração de que a democracia é a única prática válida do poder político. Mas para que essa idéia de teoria jurídica seja apreensível, é igualmente necessário superar as concepções clássicas de democracia e mesmo de teoria das formas de governo e reconhecer os motivos pelos quais Espinosa vê na política a necessidade da democracia e na democracia a necessidade da política; a simultaneidade entre essas duas concepções, presente de ponta a ponta nos textos espinosanos como na experiência política do seu autor, mostra que a razão que concebe a vida política como tendo uma necessidade democrática é uma razão democrática, e a atitude filosófica adequada para a compreensão do direito como necessidade de liberdade é um racionalismo democrático.

\section{II DEMOCR ACLA, UMA NECESSIDADE DA POLÍTICA E DO DIREITO}

Uma filosofia jurídica verdadeira - uma teoria do direito e do Estado que mostre verdadeiramente o que é o jurídico — não pode se permitir apresentar uma concepção idealista de direito. É a concepção de que partilham todos os juristas de qualquer tempo e a crítica que os juristas que lêem Espinosa lhe endereçam, quando se deparam com seu conceito de jus sive potentia. Ora, por que essa centralização da crítica no conceito de direito, quando o jurídico, para Espinosa, não é um valor arbitrado por uma autoridade, mas uma realidade de fato? Ao colocar o conceito de jus como idêntico à potentia, Espinosa nega qualquer realidade a outra concepção de di- 
reito que não seja, como esta, expressão atual da necessidade de ação. Ainda que uma concepção fundada na ontologia, é uma realidade verificada em qualquer experiência política, e só é porque, não à toa, é fundada na ontologia: assim como a concepção dos juristas clássicos concebe a liberdade como ausência de constrangimentos para a ação ou omissão graças às concessões do soberano, e por isso concebe o direito como essa faculdade para a ação conforme justamente o arbítrio do soberano, Espinosa, ao conceber a liberdade como autodeterminação da ação, exige que o direito seja expressão atual dessa autodeterminação, e para isso só o conceito de potentia faz sentido. Ora, essa concepção espinosana do direito e do poder, como mostra Alexandre Matheron numa perspectiva individualista, ${ }^{184}$ é completamente baseada na idéia de conatus, e não se manteria de pé se a esse conceito fosse negada qualquer realidade. Toda a concepção espinosana que parte de uma idéia de liberdade como autodeterminação individual (como mostra a Ética), e liberdade coletiva como autodeterminação de uma comunidade e de cada um dentro da comunidade (como mostram a Ética e o Tratado teológico-político), e que por uma necessidade racional deverá considerar como única concepção racional de direito o conceito de potência, é fundada na idéia de que todo ser esforça-se pela sua autoconservação, e de que esse esforço se multiplica quando, na vida coletiva, o indivíduo livremente age em conjunto com os seus semelhantes.

A teoria do conatus, tal como desenvolvida na Ética, contém já a necessidade da concepção da democracia. Se o conatus é a essência atual de cada indivíduo, a mesma essência atual opera na preservação do indivíduo coletivo que é a sociedade, assim como de cada um dentro dela. E, da mesma forma como esse esforço pela autopreservação não "depende de uma decisão humana" mas é uma "determinação segundo a necessidade e definição" de cada ser, o conatus é uma lei natural de todo e qualquer ser em qualquer situação. Não é por decisão do livre-arbítrio, mostra Espinosa, que o ser humano é levado a julgar o caminho mais útil ou mais benéfico para sua vida ou sua autopreservação; porque cada ser tem uma única estrutura e necessidade natural, só há uma única atitude, sempre, a ser tomada diante para a preservação dessa necessida-

\footnotetext{
184 A. Matheron, Individu et communauté chez. Spinoza, p. 23: "Esse conatus funda o Direito Natural: transposição, na duração, do direito eterno das essências a existir. O que há de espantoso nisto? A fonte de todo valor, para Espinosa como para não importa qual de seus contemporâneos, é Deus. A causa única de todas as coisas, por definição, tem todos os direitos. Mas Deus, segundo Espinosa, se confunde com a auto-produtividade interna de cada realidade individual, com o aspecto naturante do Todo e das totalidades parciais que o compõem. E isto, não simplesmente porque não existem normas transcendentais (o que só nos traria um niilismo moral), mas porque, positivamente, a norma é imanente. Cada ser tem tanto direito quanta potência tem para perseverar no seu ser, pois esta potência mede muito exatamente seu grau de participação no divino. Direito absoluto para o Indivíduo infinito, direito relativo e limitado para os indivíduos finitos; não somente para o homem, mas para todos os seres naturais sem exceção: os peixes grandes devorando os pequenos, e isso normal. Deus quatenus: o panteísmo justifica o individualismo ético".
} 
de, que não cabe ser determinada pelo agente, mas é quem determina a ação do próprio agente: essa necessidade da ação, ao agente só cabe conhecê-la; ser livre, em primeiro lugar, é conhecer a própria necessidade de ação determinada pelo próprio conatus. Ora, se essa concepção parece bem explicar a racionalidade ética da ação individual — já que a medida da ação ética, nestes termos, é a necessidade segundo o conatus individual —, como considerá-la no plano da vida coletiva? A explicação, oferecida por Espinosa também na Ética, mostra que da mesma maneira como conhecimento racional e vida afetiva operam na liberdade individual, ambos também determinam essa liberdade no plano da sociedade (e, por isso, da política). É dessa forma, justamente, que a Ética, sem ser obra sobre a política, é já uma obra política: não apenas o seu tema constante é a liberdade, como sua explicação da liberdade humana e do conatus individual visualiza, também, a necessidade coletiva dessa mesma liberdade: porque a liberdade é o estado atual do indivíduo cuja atividade é determinada pela sua necessidade, a liberdade é efeito direto da operação do conatus individual; a liberdade coletiva, como conseqüência, será a operação de um conatus coletivo, a operação simultânea das necessidades de vários indivíduos em conjunto.

Não é à toa que Espinosa, nos textos políticos, considera que a "democracia é o mais natural dos regimes políticos", já que somente nela o poder é absoluto. O que significa isso é, justamente, a idéia de que só na democracia o poder político (da comunidade política) é idêntico à união ou operação simultânea das potências de todos os indivíduos que constituem essa comunidade política. Dizer que o poder na democracia é absoluto significa dizer não que seja absolutista ou despótico, mas que a necessidade do Estado é idêntica à necessidade de todo o conjunto de cidadãos, ou de toda a multitudo. Ora, qual a fundação ontológica dessa idéia na Ética? Ela se acha, já, presente no escólio da proposição IV, P18 da Ética, que demonstra que a vida coletiva é efeito da vida racional:

[...] Uma vez que a Razão não pede nada que seja contra a Natureza, ela pede, por conseguinte, que cada um se ame a si mesmo; procure o que lhe útil, mas o que lhe é útil de verdade; deseje tudo o que conduz, de fato, o homem a uma maior perfeição; e, de uma maneira geral, que cada um se esforce por conservar o seu ser, tanto quanto lhe é possível. [...] Depois, visto que a virtude não é outra coisa senão agir segundo as leis da sua própria natureza, e que ninguém se esforça por conservar o seu ser, a não ser segundo as leis da sua própria natureza, segue daí:

Primeiro, que o fundamento da virtude é o próprio esforço por conservar o próprio ser, e que a felicidade consiste em o homem poder conservar o seu ser.

Em segundo lugar, segue que virtude deve ser desejada por si mesma, e que não existe nada de preferível a ela ou que nos seja mais útil, por causa do qual ela deveria ser desejada.

Segue, finalmente, em terceiro lugar, que aqueles que se suicidam são impotentes de espírito e completamente subjugados por causas externas, em oposição à sua natureza.

Além disso [...] há fora de nós muitas coisas que nos são úteis e que, por isso, devem ser desejadas. Entre elas não podemos conceber nenhumas preferíveis às que estão inteiramente de acordo com a nossa natureza. Com efeito, se, por exemplo, dois indivíduos, absolutamente da mesma natureza, se unem um a outro, formam um indivíduo duas vezes mais poderoso que cada um deles separadamente. Portanto, nada mais útil ao homem que o homem. Os homens — digo — não podem desejar nada mais vantajoso para conservar o seu ser do que estarem todos de tal maneira 
de acordo em tudo que as mentes e os corpos de todos formem como que uma só alma e um só corpo, e que todos, em conjunto, na medida das suas possibilidades, se esforcem por conservar o seu ser; e que todos, em conjunto, procurem a utilidade comum de todos. Daqui se segue que os homens, que se governam pela Razão, isto é, os homens que procuram o que lhes é útil sob a direção da Razão, não desejam nada para si que não desejem para os outros homens, e, por conseguinte, eles são justos, fiéis e honestos. [...]

Faz sentido perceber, aí, a base de uma concepção espinosana da política como democracia?

O que o escólio mostra é que a ação virtuosa (a ação positiva na vida ética) é simplesmente aquela que realiza o necessário segundo a natureza do agente, da mesma forma como todo homem calcula a positividade de uma ação segundo a sua utilidade para sua própria preservação. O que, porém, é concluído especificamente nesse escólio é a utilidade da ação humana em conjunto. Como explicá-la? Cada indivíduo conhece a necessidade de sua ação em função do conatus, pois o conatus é a essência mesma de cada um. Da mesma forma, cada homem conhece que sua preservação depende de afastar causas exteriores (ou mesmo interiores, como a própria tristeza) que tenham como efeito a sua destruição ou enfraquecimento. Mais do que isso, cada um conhece que essa preservação depende de se possuir um corpo forte para resistir à ação contrária de outros corpos e uma mente forte para resistir à ação contrária de outras idéias. Ora, a experiência mostra que a ação conjunta com outros indivíduos constitui uma potência mais forte do que a potência solitária de um único indivíduo; em conseqüência, quanto mais um indivíduo faz sua potência individual operar em conjunto com a potência de outros indivíduos segundo a mesma necessidade, mais forte é a sua ação e mais potente é ele mesmo. Ora, o que possibilita essa ação conjunta, em primeiro lugar, é a identidade entre os diferentes indivíduos, que por possuírem e conceberem potências comuns concebem, simultaneamente, uma extensão de sua própria potência individual na união desta com as potências dos demais. Por isso, na necessidade de constituir uma potência que a potência individual não teria condição de constituir sozinha, a razão mostra a utilidade da ação conjunta com os demais que tenham a mesma necessidade e, com isso, concebam todos em conjunto uma finalidade comum. Ora, é preciso que haja, entre os indivíduos que se concebem entre si uma ação e necessidade conjuntas, necessidades comuns; afinal, como a própria Ética afirma em outro lugar, coisas que nada têm em comum entre si não podem produzir efeitos umas nas outras; ao contrário, é só naquilo em que há propriedades comuns que as coisas podem produzir efeitos simultâneos e constituir, também, uma potência comum, que forma a partir de potências individuais distintas mas semelhantes uma potência coletiva. E é evidente que cada homem concebe como maximamente idêntico ou semelhante a si mesmo outros homens, e no reconhecimento dessa comunidade de propriedades reconhece, também, a utilidade dos outros homens para a extensão da sua própria 
potência. É por isso que Espinosa afirma, aí, que nada é mais útil para o homem do que o próprio homem.

Assim, é a razão, por reconhecer a lógica dessa extensão da potência individual através da operação da potência daqueles indivíduos que apresentam propriedades comuns, que sugere a necessidade da própria união das ações e das potências. Essa união, ainda, só é possível se todos os indivíduos operam de maneira a formar uma potência coletiva e unificada por uma mesma necessidade e finalidade, e não quando operam de maneira a destruir-se a si mesmos por meio de disputas ou discórdia. Ou seja: o que forma uma comunidade de indivíduos que, por uma necessidade comum, constituem por ela um indivíduo coletivo, não é só o reconhecimento de propriedades e necessidades em comum, mas é a operação atual dessa potência comum de maneira unificada (tal como a própria definição de coisa singular, na Parte II da Ética, já colocara). Um corpo coletivo não é, assim, uma aglomerado de indivíduos, mas uma atividade coletiva operada simultaneamente e pela mesma necessidade por um conjunto de indivíduos que conhecem, todos, a sua necessidade comum.

Essa integração e concórdia na ação das partes constituintes de um corpo coletivo é o que determina, também, a preservação de um corpo político. Que é o corpo político, tal como Espinosa o define no Tratado político? É, conforme o $\ 1$ do capítulo III, a civitas (comunidade, e não Cidade; a menos que por Cidade se entenda uma comunidade de cidadãos), conjunto de cidadãos que constitui o corpo inteiro do estado civil. Essa comunidade, cuja organização pode variar infinitamente, é sempre uma comunidade de cidadãos, ou seja, é sempre uma comunidade de indivíduos que, na vida civil, concebem a si mesmos como necessitando de direitos e de liberdade, assim como concebem o Estado como um instrumento para a produção e operação dessa liberdade e desses direitos. Ora, a civitas é efetivamente uma comunidade política desde que seja definida por uma necessidade comum de todos os cidadãos enquanto cidadãos: a civitas deve ser operação conjunta de uma mesma potência civil, deve ser a união de potências individuais para a formação de uma potência coletiva. Quando a civitas não tem como necessidade comum a atividade conjunta de todos os seus cidadãos, ela não é mais uma comunidade política. Por isso mesmo, há uma diferença, estabelecida aí no início do capítulo III do Tratado político, entre civitas e status civilis (estado civil, o estado constituído por qualquer imperium): se qualquer imperium já constitui um estado civil, nem toda coletividade constitui uma civitas. Assim como a realidade do poder político já é constituída por um comando (imperium), a comunidade política (civitas) só pode existir efetivamente se for a expressão conjunta de todos os cidadãos. O que a razão diz a respeito disso é que, se o poder é uma realidade humana, que a vida coletiva tenha a forma da 
civitas: que seja efetivamente uma comunidade de cidadãos (aqueles que retiram utilidade da vida civil).

Nenhuma civitas é possível se não é resultado da ação conjunta dos cidadãos que a devem constituir. Por isso mesmo, a política não deve ser concebida, pelo jurista, como domínio exercido por um governante sobre seus súditos. Estes não são propriedade do governante ou de qualquer autoridade política, mas um corpo de indivíduos que deseja tomar parte na vida política, na medida em que deseja constituir as finalidades dessa vida política. A mesma lógica que explica a preservação de um corpo individual graças à atividade de suas partes constituintes e extensão da potência individual através das potências dos outros indivíduos, exige que a vida política seja, no estado civil, realização da mesma atividade conjunta de todos os cidadãos, sem exclusão de nenhum deles nem separação entre o imperium e a multitudo. Na prática, uma idéia com aparência de projeto republicano, tal como o defendido pelos ideólogos do republicanismo e do tacitismo que tomam conta da oposição à Casa de Orange, na Holanda; aparentemente, também, uma concepção de política e de Estado que se aproxima da política dos irmãos De Witt, mas que não sobreviveu à violência da própria população conduzida pelos inimigos do poder republicano. Entretanto, independente dessa consideração de uma aproximação entre a concepção espinosana da necessidade pública do poder político e a prática política de seu próprio tempo, a ontologia de Espinosa mostra que a vida política não pode, se quiser ser autopreservação do poder político e da sociedade política, prática de exclusão. Ainda que um cidadão ou uma comunidade política (ou um estado, enfim) possa ter inimigos, essa condição é classificada pela atividade contrária à própria comunidade, ao próprio Estado, e significa unicamente que alguém não está dentro dele — mas não significa, de forma alguma, que o Estado ou a comunidade política deve ser concebida como um conjunto de inimigos entre si. Ao contrário, só há civitas, só há comunidade política e só há Estado livre e soberano, se for a atividade atual de um conjunto de cidadãos livremente constituídos e racionalmente determinados a permanecer na vida política. O que move todo indivíduo à vida política e à busca da aliança com os demais não é simplesmente a razão, mas fundamentalmente o conatus, o desejo pela autoconservação; a razão vem mostrar, por seu cálculo das utilidades, quais são os instrumentos mais adequados para a concretização dessa preservação na vida civil.

Ora, qual a definição de democracia, dada pelos dois tratados políticos de Espinosa?

No Tratado teológico-politico, a democracia é a forma mais natural de regime político porque é aquela que realiza plenamente a necessidade de participação de todos os cidadãos no poder, e 
na qual não há de fato nenhuma alienação dos direitos naturais a um soberano, mas a soberania é constituída pela atividade, no estado civil, de todos os cidadãos igualmente. No Tratado político, para além daquela definição vulgar (clássica nas teorias políticas anteriores a Espinosa) da democracia, segundo a qual esta é uma forma de governo na qual muitos ou todos detêm o poder, o célebre e inacabado capítulo XI do tratado apresenta uma definição segundo a qual, na democracia, todos os cidadãos têm direito de voto e de tomar parte nas funções públicas, desde que sejam cidadãos. Nestas duas funções, está a marca da identidade entre necessidade de cada particular e finalidade pública: porque todo cidadão tem direito de deliberar, a finalidade da comunidade política sempre é determinada também por ele; porque todo cidadão tem oportunidade de tomar parte nas funções públicas, a concretização das decisões democráticas também passa por sua atividade direta. Numa palavra, na democracia, nenhum cidadão está separado do poder, mas sempre tem oportunidade de participar dele e de definir as suas finalidades a partir também das suas próprias necessidades, que nessas condições se encontram unidas às necessidades dos demais cidadãos.

Ora, a democracia enquanto participação direta de todos os cidadãos na determinação da liberdade política não é uma concepção idealista de Espinosa, mas a consideração racional de que só nestas condições é possível eliminar a violência e a exclusão da prática do Estado e garantir que cada cidadão se sinta como deve se sentir um cidadão dentro da civitas. ${ }^{185}$ Quando alguém se sente separado do poder, no sentido de que se sente sem direitos necessários reconhecidos e sem a garantia de sua liberdade necessária, não se sente mais um cidadão (porque não sente mais o benefício da vida civil), mas sente-se apenas um súdito (unicamente obrigado, agora, pela força do aparelho estatal, com o qual não vê, agora, nenhuma identidade). Qualquer prática política em que o poder não é a atividade coletiva do conjunto de cidadãos, implica em enfraquecimento de uma de suas partes constituintes e, por isso mesmo, em esfacelamento da unidade civil. Para que esta seja produzida, é preciso que a comunidade política seja a atividade integrada de todos os seus cidadãos, e não uma disputa entre o Estado e seus súditos. Ora, essa concepção da atividade do corpo político como atividade conjunta de todos os cidadãos sem a exclusão de nenhum deles, ela só se concebe enquanto democracia. Quanto às demais formas, elas são, por sua própria necessidade e definição, inaptas a garantir a liberdade absoluta, porque não conseguem estabelecer a organização política sem a operação sistemática de uma certa exclusão. Como, portanto, um dos elementos constituintes dos despotismos que na prática são a monarquia e a aristocracia é a própria exclusão e dominação (por meio unicamente da força, e

185 Como diz Lucien Mugnier-Pollet, a democracia é a "Cidade verdadeira": não se trata de um modelo político, forma que não é forma de Estado, mas apenas a prática coletiva da liberdade. 
jamais da necessidade) da coisa pública pelo interesse privado, nem a monarquia nem a aristocracia podem deixar de ser reconhecidas, pela razão, como ausência de comunidade política, como ausência, mesmo, de corpo político. Em vez de se mostrar instrumento de organização social, o Estado não democrático, fundado necessariamente na exclusão, é causa necessária de servidão, e contra essa prática a única solução é a aniquilação completa do Estado autoritário em favor da instauração de um Estado racionalmente (mas também afetivamente) adequado à civitas que aí quer se formar. ${ }^{186}$

A democracia, justamente, não é em Espinosa o resultado de um nominalismo teórico, continuador de uma tipologia das formas de governo que vem propor uma forma política que a experiência parece mostrar ser impossível; é essa mesma experiência que mostra que a política, essa necessidade da vida coletiva humana, exige uma forma democrática, porque a lógica da vida coletiva é também determinada pelo conatus. A vida política livre como vida democrática, da mesma forma como o direito concebido como potência, são uma necessidade determinada pelo conatus de cada indivíduo singular ou coletivo, e é a razão humana, e não a experiência errante, que conclui pela necessidade natural tanto da democracia na política quanto da potência na liberdade. Conceber a democracia como forma impraticável de política, é o mesmo que conceber que o direito não pode ser uma potência de todos os cidadãos e que a política só pode ser uma prática de exclusão. Não há nada na natureza humana ou na natureza das comunidades políticas consideradas segundo a razão que permita concluir a necessidade da exclusão ou a necessidade da violência. Pelo contrário, exclusão e violência significam, no plano da vida política e no plano da vida individual, violação da natureza necessária de um ser, o que, definitivamente, não é útil para ninguém, não é desejado por ninguém, e nenhum conatus preserva. Por ser dominação e destruição do outro, a exclusão ou a violência jamais é dirigida pela razão nem é racional; ao contrário, sua motivação é unicamente o ódio contra aquele em quem se reconheceu efetivamente alguma identidade e a respeito de quem não se consegue ver nenhuma concórdia,

186 Não é verdade que Espinosa não vá além da afirmação de que a democracia é o regime mais natural de todos e não demarque uma preferência pela própria democracia. Essa é a interpretação de Vernière, para quem Espinosa precede Montesquieu na consideração de que qualquer regime político é válido desde que funcione bem: "Para ambos, pouco importa o regime; uma constituição não é boa em si, mas pelo seu funcionamento. Usbek já disse: 'Esforcei-me muito para saber qual governo se conforma melhor à razão. O mais perfeito, pareceu-me destes estudos, é o que realiza seus objetivos a menor custo: ou seja, o mais perfeito é aquele que conduz os homens da maneira mais adequada a seu pendor e a sua inclinação' [Cartas persas, Carta 80; tradução de Renato Janine Ribeiro, São Paulo, 1991]. Essa tendência sendo a paz e a segurança da vida, Montesquieu se une a Espinosa, que vira o melhor governo naquele que assegurasse a estabilidade das leis e a concórdia dos cidadãos. O essencial não está numa doutrina ideal, mas num mecanismo sólido que permita o movimento das engrenagens sem depender do prestígio de um santo ou da intervenção benfeitora de um herói. Os dois têm um mesmo ódio pelo despotismo, mas hesitam ambos entre uma democracia que satisfaça ao mesmo tempo as exigências racionais de Espinosa e as exigências morais de Montesquieu e uma monarquia temperada pelos poderes intermediários, que lhes parece em geral melhor adaptada à mediocridade humana". 
porque o ânimo do dominum está aí tão dominado pelo ódio e pelo medo que nenhuma paixão alegre nem nenhuma idéia racional pode ser tão ou mais forte que a imaginação odiosa de que a autopreservação só se conquista pela destruição do outro.

Nessa definição espinosana da democracia, qual o papel reservado à história? Assim como o conceito espinosano de jus é acusado de irrealismo, sua concepção de democracia recebe, mesmo segundo aqueles que o consideram jusnaturalista, a acusação de uma idéia pura de democracia. Ora, a concepção espinosana é, por uma necessidade racional, uma idéia de vida política; mas sua consistência decorre, justamente, de ser uma concepção racional da mesma necessidade de liberdade absoluta que se pode observar em qualquer prática concreta da experiência política. Nestes termos, qual a viabilidade de considerar, no conceito espinosano de democracia, uma concepção afetada, também, pela idéias republicanas correntes no jusnaturalismo de seu tempo? De fato, se o pensamento espinosano é uma crítica às teorias do direito natural, em que sentido deve algo às teorias jusnaturalistas do século XVII, especialmente no que diz respeito ao método de concepção da melhor vida política?

A compreensão da democracia espinosana pede, justamente, que se reconheça sua relação com a forma demonstrativa dos juristas do seu tempo, da mesma forma como é uma análise racionalista da experiência política mais do que uma descrição e explicação da experiência histórica da república; essa compreensão exigirá, também, reconhecer na concepção espinosana de democracia uma idéia consistente em si mesma, apesar das constantes referências aos historiadores antigos que são aproveitados, em seu tempo, pela ideologia do tacitismo: a democracia apresentada por Espinosa não é comensurável à república simbolizada pelos elogios de Tácito ao passado histórico romano.

Sobre o tema da história no pensamento jurídico da época de Espinosa, um artigo de Alfred Dufour de 1984, "Grotius et le Droit naturel do XVII" siècle" mostra o que é o lugar da história numa concepção jusnaturalista moderna que não deixará de ter os seus continuadores. Este artigo, na verdade, é o desenvolvimento de um artigo escrito quatro anos antes e que tratara da questão do método da escrita político-jurídica não apenas em Grotius, como também de Hobbes e Pufendorf, "L’influence de la méthodologie des sciences physiques et mathématiques sur les Fondateurs de l'Ecole do Droit naturel moderne (Grotius, Hobbes, Pufendorf)", onde Dufour busca estabelecer uma diferenciação metodológica razoável entre os vários autores do jusnaturalismo moderno, assim como mostra que há entre eles a divisão em basicamente duas correntes: uma adepta da apresentação demonstrativa do direito e da política, e outra, minoritá- 
ria, adepta de uma apresentação teológica do mesmo objeto. Os autores que desenvolvem a metodologia demonstrativa se dividem numa análise e demonstração matemática ou geométrica da política, que a princípio pareceria representar uma postura adversa diante da experiência política. Na verdade, em todos a via analítica ou a via sintética de demonstração da política trabalha com conteúdos que são dados pela experiência, mesmo aqueles que são argumentados como de validade universal, em especial as leis de natureza. Entretanto, o que parece marcar o jusnaturalismo moderno é o esboço de um projeto imutável de princípios para a ação política, que constituem exatamente o que o racionalismo jurídico moderno chama de direito natural. No artigo de 1984, Dufour se concentra mais em Grotius justamente para mostrar a peculiaridade da sua metodologia diante do jusnaturalismo que atravessará os séculos XVII e XVIII: embora ele seja um autor voltado para a prática política, embora elabore uma explicação do direito e das instituições políticas segundo uma via demonstrativa quase equivalente à desenvolvida por Descartes nas ciências matemáticas e físicas, e embora, enfim, aposte na racionalidade do direito natural (porque reconhecido pela razão humana, mais do que determinado por uma natureza sobre a qual o ser humano nada pode fazer), Grotius pratica um método demonstrativo cujo procedimento pode ser dito, segundo Dufour, historiográfico. Grotius, na sua exposição da política e do direito (e isso em todos os seus textos, e não apenas no De jure belli ac pacis, de 1625), ilustra suas definições e explicações com exemplos históricos, e especialmente autores clássicos. Mais do que isso, Grotius é um dos primeiros autores holandeses que recebe a influência da publicação das obras de Tácito, por Justus Lipsius, em 1574, e é, portanto, um dos autores ligados à corrente tacitista de pensamento político que se desenvolve nos Países Baixos nos inícios do século XVII, sendo o principal autor jurídico que pode ser ligado de certa forma a essa corrente.

Sob essa influência do tacitismo, que consiste numa concepção especialmente ideológica da excelência da república antiga, ainda não praticada no presente e da qual as tiranias da modernidade são o seu contrário, Grotius conceberá não uma teoria da república, mas uma teoria da legitimidade baseada em princípios que estejam fora do arbítrio de qualquer tirano, porque baseadas em princípios racionais do direito e da política. Isso, porém, não vem ao caso aqui, mas sim o papel que Grotius atribui à história. Numa diferença tênue diante da ideologia tacitista, Grotius fundamenta a sua teoria do direito e da política numa exposição minimamente geométrica, e faz das citações históricas um elemento ilustrativo que reforça mas não substitui o peso da demonstração argumentativa. Entretanto, Grotius não concebe a possibilidade de se elaborar uma tal teoria da política sem tais exemplos históricos: nele, a experiência política é experiência histórica, e essa experiência é igualmente formada pela história testemunhada ou determi- 
nada pelas pessoas na política, quanto pelo relato dessas histórias pelas suas testemunhas autorizadas. Grotius elabora uma teoria do direito natural, sustenta a existência de direitos válidos universalmente ou reconhecíveis pela razão humana, mas não concebe a realidades desses direitos sem uma realidade da consciência histórica. O que o leva a empreender uma teoria demonstrativa do direito natural é exatamente uma convicção de que o olhar histórico sobre a vida do direito e da política é um instrumento acessível à razão, e o que o leva a valorizar a confirmação dos testemunhos históricos e o consentimento popular diante dos atos das instituições é justamente a concepção de que o justo e o legítimo se realizam na história. Como diz Dufour:

Nota-se em Grotius o papel expressamente atribuído tanto à História ao centro dos Prolegômenos do Tratado de 1625, quanto à importância reconhecida à argumentação a posteriori pelo consentimento geral no estabelecimento disso que é de Direito natural no interior do Livro I do mesmo Tratado.

Então, na seqüência, Dufour enfim acrescenta:

Mas notamo-lo também em Espinosa, nos "princípios políticos deduzidos das instituições hebraicas e da sua história" segundo o título mesmo do capítulo XVIII do Tractatus theologico-politicus de 1670. Tanto em um como no outro, o método histórico vem assim completar o método geométrico; segundo a feliz fórmula de René Voeltzel: "Ali onde a razão se cala, a história toma a palavra". ${ }^{187}$

O que há, aqui, é um outro dado típico da recente historiografia do jusnaturalismo, quando se refere a Espinosa: ele, além de ser um autor jusnaturalista excêntrico, seguidor de Hobbes principalmente, se diferenciaria do racionalismo jurídico demonstrativo nos momentos em que faz uma teoria do direito e da lei baseada na observação da história, seja a história bíblica, seja a história dos clássicos, seja a história vivida do seu tempo. Mas, nem aí haveria qualquer originalidade. Espinosa seria mais um autor influenciado pelo tacitismo: seriam prova disso as várias citações de Tácito, principalmente no TTP mas também no TP; e, além disso, no que diz respeito a considerá-lo um teórico do direito natural ou jusnaturalista, estaria simplesmente seguindo o exemplo do maior jurista holandês do século.

Especialmente a frase de Voeltzel mencionada por Dufour a respeito igualmente de Grotius e Espinosa — "Ali onde a razão se cala, a história toma a palavra"188 — é reveladora do que se entende por essa suposta tradição de Grotius a Espinosa em termos de teoria do direito natural e história. O apelo ao uso dos argumentos históricos, ao lado ou no interior de uma exposição geométrica dos fundamentos do direito e da política, seriam imprescindíveis para a validade das suas definições, especialmente num ambiente marcado pelo tacitismo, onde a idéia de positividade da república (no caso a república antiga) é tão evidente e os males da monarquia ou do

\footnotetext{
187 A. Dufour, Droits de l'homme, droit naturel et histoire, pp. 52-53.

188 R. Voeltzel, "La méthode théologique de Hugo Grotius", Revne d'Histoire et de Philosophie religieuse, $\mathrm{n}^{\circ} 32,1952$, p. 131.
} 
despotismo (inclusive os do presente) são tão indiscutíveis, que a conclusão da necessidade da vida republicana dependeria menos de uma intrincada exposição racionalista do que de uma simples constatação dos fatos da história; na corrente tacitista, principalmente, os fatos da história são os fatos a favor da república.

Por isso, para o tacitismo, em vez de a história precisar ser contrária à natureza ou ao direito natural, ele teria, na prática republicana, uma conciliação perfeita entre as finalidades naturais e as finalidades políticas do homem. A história trabalha a favor da natureza e do direito natural quando se realiza como história da república. Por tudo isso, falar da república ou defendê-la exige razoavelmente o uso dos exemplos históricos.

Há problemas em considerar Espinosa nesse registro tacitista ou grociano. Em primeiro lugar, as referências que Espinosa faz a Tácito se diferenciam daquelas adotadas pela corrente tacitista e inclusive por Grotius porque, primeiro, Tácito não é usado por Espinosa como exemplo das vantagens da república, mas sim como exemplo da força da tirania quando não tem sua causa destruída. Mas em Espinosa, principalmente, Tácito não é um autor utilizado para substituir a argumentação racional, mas antes uma referência da época escolhida especialmente para reforçar o que ele mesmo considera sobre os fundamentos da política. Como Tácito, Espinosa escreve contra o despotismo e, é verdade, a favor de uma prática política livre, ou mesmo uma república livre. Mas, diferente do tacitismo, para Espinosa os textos de Tácito, mesmo sendo narrativas verdadeiras — diferentes das narrativas ficcionais adequadas à história religiosa —, não prescindem da concepção racional da vida política fundada também na ontologia além de fundada na experiência política, e valem como reforço argumentativo para essa concepção exatamente porque os leitores dos tratados políticos de Espinosa conhecem a ideologia tacitista.

O papel da história em Espinosa é, pois, diferente do papel atribuído por Grotius. Se em Grotius a razão conhece a natureza mas é a história que confirma essa razão e essa natureza, em Espinosa a história é não meramente um objeto da observação política, mas é o campo da própria prática política. Ao definir a política e o direito no campo da necessidade, como qualquer outro campo do real, Espinosa faz com que a realidade da política e do direito existam enquanto exercício: não há vida política apenas concebida pela razão (daí sua crítica, no $T P$, aos modelos elaborados pelos “filósofos"), nem direito natural ou civil válido enquanto não seja, já, concretizado - porque o direito, segundo Espinosa, não pode ser definido arbitrariamente por um poder ou autoridade separado do cidadão; por isso, na prática, em Espinosa o direito só existe enquanto liberdade concretizada já pelo seu portador.

Se nos antigos há a contraposição entre relativismo histórico e atemporalidade do direito natural, se no seiscentista há uma ideologia da história republicana como história positiva, e se em 
Grotius há uma necessidade de endosso do racionalismo jurídico pela ação ou pelo testemunho histórico, em Espinosa a necessidade da república (ou, mais propriamente, da democracia) e a necessidade da própria justiça (entendida não como valor, mas como um estado concreto de ausência de exclusão política) são princípios racionais que só causam seus efeitos no plano da história. A história não é um modelo para a concepção da política e do direito, nem um substituto ou um adendo à razão: ela é o plano concreto da causalidade entre as necessidades naturais dos homens na vida política e as finalidades comuns que eles estabelecem para cada ação política, segundo essa necessidade.

Como em Espinosa, na verdade, não há racionalidade nos conceitos clássicos de direito natural, e como o direito é concebido como exercício, a realidade do próprio direito, mesmo que reconhecida pela razão, é a realidade de uma experiência histórica, porque uma experiência política. A política, por ser concebida por Espinosa como uma prática coletiva e não como uma abstração imaginativa, não tem realidade alguma fora desse plano histórico. A história, se pode ser tida como apresentação do verdadeiro ou como confirmadora de suposições da razão a partir da experiência política ou da necessidade da natureza, não pode, todavia, ser tida como superior à natureza, no sentido de que não pode servir de modelo ou ideologia para a transformação das necessidades do homem. É com base nestes princípios que a idéia espinosana e antijusnaturalista de história conclui algo sobre os direitos subjetivos.

Espinosa, ao tratar do direito e da lei, mostra, entre outras coisas, que em termos de direitos o sentido racional que pode ser atribuído a essa idéia é o de necessidades individuais atuais, determinadas pela natureza e disposição de cada indivíduo, e que sempre que desrespeitadas, constituem uma violência contra ele. Assim, em termos espinosanos, o direito que cada pessoa merece ter é aquele que já é a sua necessidade atual. Qualquer direito fora dessa necessidade é inútil ainda que exercível, e qualquer proibição fora dessa necessidade é uma violência, ainda que possa ser desobedecida. Há em Espinosa, pois, uma concepção de direito que, sem ser direito natural, exige uma identidade natural com as necessidades de cada indivíduo; e há, na sua concepção de realidade política enquanto prática da política, a idéia de que mesmo as necessidades humanas não podem ser determinadas por uma idéia ou por uma concepção separada da realidade, mas a própria prática política e jurídica deve ser um reconhecimento concreto, institucional, da validade das necessidades enquanto necessidades atuais, e não enquanto dádivas da autoridade política ao portador do direito.

O uso que Espinosa faz da história não apenas quer dizer que o verdadeiro em termos de teoria política exige equivaler à realidade da prática política, mas que mesmo o uso dos exemplos tirados dos historiadores clássicos exige que a prática da historiografia seja uma forma de teoria da 
política e do direito, especialmente porque ela tem como modo de operação exatamente o que a razão necessita quando se volta para a política: a constatação de fatos, mesmo que estes fatos sejam unicamente concepções de política ou, o que é mais constante, concepções de direitos e de legitimidades. $\mathrm{O}$ olhar sobre a experiência política, seja ele descritivo ou analítico, não pode jamais negar a existência da necessidade que exprime cada indivíduo na vida política; sempre que essa necessidade individual, realçada por Espinosa em todos os seus textos, é deixada de lado por força do arbítrio de quem domina, a vida política se transforma, de novo, em vida despótica. Por isso, não apenas os argumentos do direito natural são deixados de lado por Espinosa, mas junto com eles a consideração de que a história é uma entidade separada da razão ou mesmo na natureza; não à toa, a sua teoria política não é apenas uma defesa dessa prática de uma política livre e justa, mas é ela mesma, enquanto observação dessa prática, uma outra forma de prática política: a prática do pensamento político que vê a prática histórica tal como ela é, mas por causa do reconhecimento racional da inutilidade da violência e da utilidade universal da concórdia, defende a prática da política enquanto realização concreta de necessidades atuais. Por essa necessidade ao mesmo tempo histórica, racional e ética, essa forma só tem realidade enquanto democracia.

Especialmente em sua forma contemporânea, a filosofia talvez esteja mais ausente do que presente na teoria da democracia: se é verdade que vem originalmente da filosofia todo o manancial conceitual e teórico sobre a política, esta se torna nos últimos séculos um fenômeno para o qual se concebe cada vez mais que a prática precede a teoria, onde o pensamento sobre a política é uma análise da prática daquela e não tanto uma concepção da política a ser praticada. A própria maneira pela qual se dá essa cisão é dupla: primeiro, enquanto a cisão (decisiva para a histórica da filosofia política) entre toda a filosofia pré-renascentista e o pensamento político formado a partir da modernidade; mas depois, e a meu ver de forma muito mais radical, a cisão (montada exclusivamente nos últimos dois séculos) entre a concepção da política pela filosofia e a análise da sua prática pelas formas de pensamento político que se pretendem científicas, da ciência política à dogmática jurídica, da sociologia à economia. Pensar a política e o direito, como não poderia deixar de ser, depende sempre de uma definição do que se entende por pensá-la; sem a definição clara dessa intenção, o próprio significado do pensamento político perde sua força, e aparentemente essa própria multiplicidade de formas para pensar a política (o que talvez não aconteça com respeito a nenhum outro tema, do pensamento sobre a arte àquele acerca das religiões) estabeleceria de forma irreversível essa fragilidade da teoria política. 
Ao que me parece, se é possível reconhecer uma impotência da teoria política, esta só tem sentido segundo duas vias distintas: enquanto fragilidade de um projeto de ação impraticável (se a ação que está no horizonte da sua teoria é a ação política prática), e enquanto fragilidade de uma argumentação política falsa (se a ação que está nesse mesmo horizonte é a apresentação do verdadeiro). De forma alguma, porém, trata-se de uma fragilidade definida já na estrutura mesma da teoria política, seja enquanto pensamento voltado para a prática, seja enquanto pensamento voltado para o verdadeiro. Nem um nem outro são irrealizáveis de qualquer forma que seja: os projetos de ação política e as explicações consistentes do político são um fato (apesar, respectivamente, dos protestos do racionalismo moderno e do irracionalismo pósmoderno), embora a idéia de fragilidade da teoria política venha, justamente, da concepção de que ambas as práticas não se encontrariam ali onde pretenderiam: a filosofia política não encontraria na prática política a concretização das suas concepções e a eficácia da prática política não seria válida por não ser baseada no racional. Por exemplo, a prova da fragilidade da teoria da democracia seria a constatação da impossibilidade prática da transparência nas instituições políticas e jurídicas, assim como a prova para a irracionalidade da prática política seria a impossibilidade de guiá-la a partir de princípios democráticos, ou de transformar tais princípios nas suas próprias instituições. Em suma: a democracia seria forte em si mesma enquanto idéia e enquanto desejo, mas fraca enquanto horizonte dessa mesma idéia (que pede a teoria) ou desse mesmo desejo (que pede a prática).

Há todo o sentido em constatar essa distância entre teoria e prática no que diz respeito à democracia (a propósito, no que diz respeito a qualquer forma ou qualidade da política), porque não por acaso a prática contemporânea da democracia sempre pareceu adversa às concepções clássicas da democracia e da política, assim como antes realizadora do que determinante do pensamento contemporâneo acerca desse mesmo objeto: como se, por necessidade histórica, não houvesse relação entre a razão que fundamenta a teoria política e a razão que busca justificar a ação das instituições políticas. Entretanto, ainda que a discussão atual sobre os problemas da democracia seja marcada pelo olhar da ciência política ou do senso comum — de qualquer maneira, por um modo de ver fundamentalmente contemporâneo, quando não declaradamente pós-moderno - , parece-me sempre problemático partir por vezes do pressuposto de que a democracia não pode ser tida, por exemplo, como uma idéia concebida fora da contemporaneidade ou do pós-moderno. É claro que são vários os conceitos de democracia e há bibliotecas exclusivamente dedicadas a essa obviedade; mas já há, também (e infelizmente), bibliotecas dedicadas a negar a validade de concepções não contemporâneas da democracia, não importa de quais clássicos ou quais velharias venham elas. 
Sem aprofundar também essa questão, quero tomar esse conjunto de fatos e valores como o grande ponto de partida desta reflexão sobre a filosofia política e a violência, que, na verdade, é uma forma de refletir sobre o velho tema da democracia: a própria reflexão sobre a democracia depende de um posicionamento diante da separação entre pensamento contemporâneo e pensamento pré-contemporâneo, entre filosofia política e ciência política, entre pensamento político e pensamento jurídico. Diante de todas essas dicotomias, a minha tendência é propor, desde logo (e conforme anunciado já nas primeiras linhas deste texto), uma reflexão sobre a prática atual da política a partir de uma concepção moderna (espinosana, a propósito) da política. A justificativa dessa opção não é evidente mas não precisa alongar-se tanto: o "problema atual" ao qual me volto, aqui, é o problema da violência, e especificamente uma forma muito precisa de violência, não apenas relacionada com o pensamento político, mas produzida por ele mesmo. Que violência seria essa, porém, que em vez de ser o tema do pensamento político torna-se o seu próprio produto? Em que sentido é válido considerar que uma forma de pensamento pode de fato causar, como seu efeito direto, uma ação, e ainda por cima uma ação violenta? A meu ver, não há essa relação direta entre pensamento político e ação política, mas antes uma determinação intermeada pelas convicções do agente, e nas quais e das quais operam todas as suas idéias e paixões. Quanto ao pensamento político em si mesmo, o seu efeito direto só pode ser uma concepção política, de modo que se é o caso falar em alguma forma de violência diretamente causada pelo pensamento político, essa violência não é uma ação política, mas unicamente uma idéia. Essa composição nominalista, entretanto, ainda nada diz. A tal idéia violenta dentro do próprio pensamento político ainda é vazia. Qual pode ser o seu conteúdo?

Por extravagante que seja essa concepção de uma idéia violenta dentro do próprio pensamento político, não tenho bem agora em mente o efeito de uma dedução metafísica, mas teço, na verdade, uma compreensão de um dado eminentemente empírico: a concep̧̧ão de que a exclusão pode ser compativel com a democracia. Essa noção, de significado variado e entretanto muito corrente no pensamento contemporâneo e em especial no pensamento pós-moderno, parece-me uma verdadeira aberração teórica, e não apenas por consistir em certa medida numa contradição (na medida em que democracia se concebe enquanto uma certa vida política fundada na inexistência de exclusão), mas em especial por consistir num barbarismo prático do próprio intelectual que concebe uma tal idéia. Se é verdade que não faz sentido proibir o pensamento (e simplesmente porque é inútil legislar a consciência, independente do fato de ser da essência do ser humano desejar a liberdade de consciência), também é verdade que o pensamento não prescinde da consistência para estabelecer os seus juízos ou partir dos seus postulados; nisto, se é o caso de se falar de democracia, e se é também verdadeiro que conceitos e práticas de democracia 
há vários, todavia não é verdade que alguma dessas formas pode impunemente pretender aliar a violência ao legítimo, ou, utilizando do exemplo a que me referia, pretender aliar a banalização da exclusão aos valores ou princípios da democracia. Ainda que se queira conceber a democracia enquanto uma forma política na qual a exclusão é um dos elementos necessários, o primeiro efeito dessa concepção é a atribuição do nome de democracia a uma prática em que jamais a paz pode ser construída ou os direitos garantidos, mas acima de tudo em que jamais a coisa pública deixa de ser utilizada para privilégios particulares.

Parece-me que, se é possível conceber e teorizar a respeito da violência, a construção das conclusões dessa mesma análise não apenas apresenta uma imagem ou uma idéia da violência e das entidades relacionadas a ela, mas, como se trata de pensamento político, produz também uma sugestão de ação diante da própria violência; por exemplo, a concepção da necessidade de eliminá-la, evitá-la, ou recuperar-nos das mazelas causadas por ela. Ou seja: a análise da violência envolve tanto a compreensão do que a violência é quanto a compreensão do que não é nem pode ou nem deve ser identificado a ela, ou do que deve ser concebido como o seu contrário — no que considero que a democracia deve sempre ser incluída. Pois não importa qual seja a modalidade de pensamento político, é improvável que ele venha a considerar a violência um fenômeno positivo ou mesmo justificável, especialmente numa democracia; ainda que o poder e a força sejam elementos necessários ou comuns da vida política, um e outro são concebidos como formas de controle ou determinação que não são violentas, ou melhor, não são violência.

Vendo o problema a partir das concepções modernas ou simplesmente filosóficas da democracia, a incompatibilidade desta com as idéias de exclusão e de violência não apresenta grandes problemas; afinal, por definição (mesmo que aí haja diferenças relevantes entre as diversas concepções), a democracia é uma prática política na qual não apenas a cidadania deve ser estendida a todos os indivíduos na vida política, como todos esses cidadãos não estão separados do poder nem do direito. A exclusão, em contrapartida, por ser a própria separação do cidadão em relação ao poder e a conseqüente aniquilação de seus direitos ou necessidades, exige os recursos institucionais de formas despóticas ou autocráticas de governo, nas quais o silenciamento da necessidade individual seja tido como necessidade pública: como não é possível garantir direitos a todos ou simplesmente mais direitos, que se garantam direitos a alguns ou que se executem os direitos que já existem. ${ }^{189}$ Finalmente, a idéia de violência, mais que a de democracia ou

189 O que faz lembrar, paradoxalmente, a declaração de Bobbio a respeito do atual debate sobre os direitos humanos, pela qual ele considera que, mais importante que discutir quais são ou devem ser os direitos humanos (embora isso seja importante), é reconhecer que eles já existem e, principalmente, pô-los em prática (cf. N. Bobbio, A era dos direitos). Bobbio está correto na sua preocupação pragmática, mas há nessa declaração o perigo de se considerar, irresponsavelmente, que não é necessário termos consciência do significado ou do sentido de tais direitos, no que os direitos humanos passam a ser tratados como 
a de exclusão, é um elemento polêmico, por todas as aproximações que se buscou considerar entre ela e as formas legítimas de poder; até por essa facilidade de manipulação do seu sentido (de forma a negar a oposição necessária entre domínio violento e domínio legítimo), penso ser necessário manter a idéia "naturalista" de violência — ou seja, violência é desnaturação de um ser, é operação sobre algo de modo a contrariar o que lhe é necessário por natureza; e a barbárie, a situação política na qual o Estado ou outra autoridade é causa da violência -, pois ela exige a consideração de que onde há violência, a força não pode ser considerada legítima em nenhum aspecto.

Nenhum teórico político ou jurídico que se preze acharia graça na prática da violência; mas nenhum observador realista dessa mesma político-jurídica poderia negar que ela é um fato em qualquer sociedade humana e em qualquer Estado. Tanto é assim, que essa constatação envolve tanto os filósofos da política (de qualquer tempo) quanto os observadores científicos da vida política. Mas há algo muito peculiar ao tratamento contemporâneo do assunto: aí, especialmente no pensamento pós-moderno, e de forma peculiar na ciência política, embora a idéia "pura" de violência seja axiomaticamente considerada uma coisa incompatível com a vida pacífica ou com as práticas legítimas de poder, haveria certas formas de violência ou, no caso, de desvios ou corrupções do próprio poder, de maneira que, na prática, o exercício do poder e a criação de direitos só seriam possíveis enquanto respectivamente instauração de uma certa impunidade e estabelecimento ou fortalecimento de privilégios. Na prática, seria impossível concretizar os belos ideais clássicos da democracia, da igualdade à liberdade; na prática, ainda que se busque o estabelecimento de direitos e liberdades propostos para uma vida em democracia e legitimidade, nunca seria possível à sociedade ou ao Estado organizar os próprios recursos em benefício do social, isto é, em benefício de toda a coletividade ou de todos os seus integrantes, sem exclusão de nenhum cidadão. Por tudo isso, mais vale, como dizem Norberto Bobbio a respeito dos direitos humanos e Robert A. Dahl a respeito dos direitos políticos e econômicos, ${ }^{190}$ garantir a realização dos direitos possíveis de se garantir, em vez de pretender garantir tais direitos ou a execução de tais direitos a todos. Por razões operacionais, isso é impossível — noção elementar, a propósito, para a concepção da democracia enquanto forma representativa de governo; também por isso, um axioma da política contemporânea.

Sendo certo, pois, para a política contemporânea que sempre há um certo nível de exclusão na prática política, é claro que seria absurdo insistir na realização universal dos direitos. Essa

quaisquer direitos subjetivos protocolares — numa palavra, direitos que estão prescritos e que por isso merecem ser colocados em prática, mas como seus próprios portadores não sabem exatamente porque têm esses direitos, nunca são de fato direitos garantidos, nunca são de fato um poder do cidadão, mas unicamente (como os demais direitos subjetivos) dádivas da autoridade política ou jurídica.

190 Mais precisamente em seu Poliarquia, caps. 1 e 6. 
noção, ainda que pessimista de um realismo considerável, parece-me ser utilizada mais como pretexto para não pensar a política a partir da filosofia do que para dizer algo de verdadeiro a respeito do que deve ser a vida política, no que portanto nem considero a visão do senso comum mas me refiro em especial aos teóricos contemporâneos, que em geral caminham por um ceticismo diante da filosofia e principalmente dos clássicos, seja por discordância teórica, seja por outro tipo de incômodo. ${ }^{191}$ A mim incomoda, porém, essa imagem deixada pela constatação da freqüência da exclusão, tal como tem sido feita: por ser corrente, a exclusão seria banal, natural, essencial pois à vida politica, de maneira que a operatividade de direitos mesmo para alguns depende de não mais se tentar garantir os direitos daqueles a quem se sabe que não seria possível garanti-los. Nessa concepção, a democracia não seria mais a vida política na igualdade de direitos e liberdades, mas a universalização de um regime de restrição de direitos e fortalecimento de privilégios, a começar pelos benefícios da própria autoridade política, que passa a ser concebida não mais como uma instituição cuja legitimidade deve repousar na vontade geral ou nas finalidades públicas, mas unicamente em finalidades específicas de quem é detentor dos cargos políticos de mando. Se a única forma praticável de democracia é a democracia representativa, na qual o povo não apenas não exerce o poder como está separado dele, a própria idéia de legitimidade se perde ao poder ser substituída, na prática, pelas de legalidade e de autoridade. É verdade (traduzindo: é um fato) que sem o aparato da legalidade nenhum direito ou obrigação tem validade prática e que portanto só a idéia de legitimidade é inútil para garantir a execução de um direito, mas a partir do momento em que a execução de um direito passa a ser concebida como efeito exclusivo da legalidade e do arbítrio da autoridade política, perdeu-se outra vez a garantia de realização do direito, porque desapareceu da vida coletiva a concepção da necessidade desse direito, independente da estrutura das instituições ou da vontade particular de quem exerce os ofícios do poder. Se vale insistir na democracia como um projeto para a vida política, não pode ser - porque isso é uma violência à razão, já que uma contradição diante das necessidades físicas de qualquer comunidade política: não há indivíduo que deseje ser excluído, nem comunidade que só possa organizar-se politicamente apenas pela exclusão de determinada par-

${ }^{191}$ É claro que me vêm à mente, aqui, as linhas iniciais de $A$ sociedade contra o social, em que se protesta contra o tom reverente com que são tomados os clássicos do pensamento político quando tentamos esse mesmo pensamento político. Concordo em absoluto com o absurdo da reverência, mas não vejo por quê não tomá-los como referência, especialmente quando o que está nos autores da filosofia política — clássicos ou de botequim - é válido ou verdadeiro; entendo que a crítica pós-moderna, em especial, considera excessivo o tratamento dado aos clássicos por saber que essa ida até eles é uma busca justamente de algo verdadeiro, o que de início tornaria a empreitada inútil sob um ponto de vista pós-moderno, cujo pressuposto é sempre o da inexistência do verdadeiro — que, se inexistiria até em ciência, o que se dirá em ciência desse campo natural do dissenso que é a política. 
cela da sociedade de que decorre - segundo a idéia de que nela devemos tolerar a exclusão, não importa de que forma seja.

Diante desse panorama e retornando a Espinosa como referência para pensá-lo, que relação pode ser considerada entre os afetos e o problema da violência na vida democrática?

Também em Espinosa, está presente a mesma constatação de que a vida coletiva é marcada também pela violência e pelo desrespeito às necessidades individuais: é da natureza humana agir segundo as próprias paixões e reagir passionalmente aos efeitos dos outros indivíduos sobre o próprio ânimo; por isso, na vida coletiva, a última coisa que guia as ações humanas será a razão humana. O fato, porém, de a vida política não ser guiada pela razão não chega a ser trágico, em Espinosa. Como víramos, é da própria natureza da vida humana em coletividade que as relações entre os cidadãos, em todos os seus aspectos, sejam afetadas pelos desejos de cada um, em vez de ser realização simultânea de uma dedução coletivamente produzida — de modo que absurdo seria conceber que a vida política é produto de uma razão coletiva ou de uma concepção racional. Não é, mostra Espinosa, a prática política que é produto da razão, mas sim a concepção racional da política. Ou seja, se não é caso de governar por meio da razão as ações na vida política, é o caso de considerar o que a razão diz a respeito dessa mesma vida política. Em Espinosa, o que a razão diz, ao final, é que a vida política é mais pacífica e mais livre se assume a forma democrática, porque a democracia é a única forma de governo que realiza o desejo humano de governar e não ser governado. Essa idéia de democracia nada tem de imaginativo. Espinosa apresenta a sua definição exclusivamente a partir da consideração dedutiva da experiência política, ainda que segundo diferentes formas (na Ética, no Tratado teológico-político, no Tratado político), já que para diferentes públicos e em diferentes momentos (respectivamente o leitor geômetra, o leitor cristão, o leitor jurista); porque expressões diversas de uma concepção única, o conjunto mantém toda a sua consistência e, nesse sentido, sua verdade teórica.

A concepção espinosana de democracia — prática política em que todos são cidadãos e tomam parte no poder, através da criação de direitos e liberdades e sem exclusão política ou jurídica nem legitimação da violência - é elaborada de forma mais afeita ao discurso do pensamento político nos dois tratados políticos de Espinosa, mas é na Ética que já se encontra a explicação do papel da razão e dos afetos na democracia e vice-versa. Na Ética IV, ao mostrar que os homens, quando guiados pelos diferentes tipos de ódio, são servos das causas externas e não têm domínio sobre si, Espinosa revela que a vida política não pode ser baseada no ódio, na dominação, na destruição. Isso todavia é da natureza humana, assim como quando os homens 
são guiados por diferentes tipos de amor: aí, também, estão os homens à mercê das causas externas, mas não se trata mais de servidão. Por que a diferença, especialmente se considerarmos que a servidão é, em linhas gerais, submissão a uma força externa? A diferença consiste no fato de que, quando tomados por afetos de tristeza, diminuímos a nossa potência, e, quando tomados por afetos de alegria, ela é aumentada; ou seja, ser dominado por causas externas que amamos só dá lucro, ao passo que ser dominado por causas externas que odiamos só dá perdas. Tudo isso porque, na verdade, só a afetação pelas causas externas que odiamos é uma forma de dominação; a afetação pelas causas que amamos não é submissão alguma, porque, como justamente amamos aquilo que concebemos aumentar a nossa potência, desejamos ter nossa potência aumentada pela coisa amada e a própria afetação já é um pedido nosso, não mais uma dádiva da causa externa mas já uma operação interna. Quanto à causa externa que odiamos, ela é odiada por ser concebida enquanto causa da nossa tristeza e impotência; portanto, por ser concebida como contrária à nossa natureza e aos nossos desejos, que são manter potência e ter mais potência. É contra a natureza humana, pois, desejar aumentar a própria tristeza ou impotência, ou mesmo preservá-la, de modo que qualquer atitude individual em favor da preservação da própria impotência não é guiada por um desejo interior, mas pela força das causas externas: aqui, odiar não é uma operação interna positiva, mas unicamente permitir-se operar um desejo que vem de fora; é estar submisso não às paixões, mas às paixões tristes, à tristeza e ao ódio, aumentar a própria impotência sem reagir a ela.

Espinosa explica que o ódio não apenas é um cultivo da impotência como não tem positividade alguma, já que é sempre destrutivo - especialmente sobre quem odeia, independente da destruição de quem é odiado. Porque a natureza humana (de todo ser, aliás) deseja a preservação não da impotência mas da potência, e porque o ser humano tem condição de compreender a negatividade do ódio e da tristeza e a positividade do amor e da alegria desde que conheça o seu modo de produção, é capaz também de compreender que o cultivo do ódio e da tristeza só pode destruí-lo, da mesma forma como só uma reação a essas paixões tristes pode recuperar a sua potência.

Ora, em Espinosa, da mesma forma como a teoria do conatus explica a estrutura do indivíduo, ela explica também o indivíduo coletivo, a comunidade política, a ponto de se poder falar num conatus do Estado. É expondo esse conatus da vida coletiva, justamente, que Espinosa caminha pela Ética IV a ponto de conceber a vida coletiva resultante da autopreservação da própria comunidade política na forma de uma vida democrática. Espinosa mostra que as comunidades humanas, sempre organizadas em busca de utilidades comuns, ganham e mantêm sua própria força conforme a utilidade que buscam concretizar conjuntamente é de fato uma utili- 
dade coletiva, pública, e não uma utilidade de parte apenas do grupo coletivo, ou uma utilidade que exclui sua validade para alguém dentro da multitudo ou diante dela. Apesar da infinidade de formas de organização da vida coletiva, qualquer uma é válida enquanto organização coletiva: qualquer uma pode ser estabelecimento de poderes e direitos, seja monarquia, aristocracia ou democracia. Entretanto, Espinosa mostra nos seus dois tratados políticos que apesar de todas serem aplicáveis ou alcançarem certa eficácia institucional e jurídica, apenas a democracia consegue fazê-lo plenamente, porque só nela a construção da liberdade se completa e a criação de direitos exige sua realização enquanto exercício de fato: não há, na democracia, condição de separar o cidadão do poder ou transformar direitos em privilégios; não há como a democracia ser, portanto, despotismo.

O que a Ética IV diz a respeito da comunidade política de homens esclarecidos pela razão quanto à necessidade de todos serem livres é que essa necessidade consiste na própria natureza de cada indivíduo e de cada grupo: na Ética, Espinosa mostra que a potência individual aumenta quando se reúne com a potência de outros indivíduos, de forma que como parte de uma coletividade a potência individual se multiplica; e, da mesma forma como toda forma de ódio só acarreta a impotência individual, a união de impotências causa uma impotência muito maior, pelo que o que deve ser causa da união de vários indivíduos não pode ser um afeto de ódio ou de tristeza nem um desejo de destruição ou dominação do outro, mas unicamente um desejo de fortalecimento da própria coletividade, o que só se forma enquanto o conjunto de cidadãos concebe sua união segundo uma necessidade que é causa de alegria para todos e por isso para todos positiva e desejável.

O que deve causar a união dos indivíduos é um desejo de aumento da potência concretizável unicamente pela potência coletiva. Essa união de potências individuais, portanto, exige que não se produza a impotência de quaisquer integrantes da multidão de indivíduos constituintes; por isso, se a comunidade política é uma forma de associação de potências individuais, então seus princípios, numa concepção racional, são a criação de direitos e liberdades que não causem perda de direitos e liberdades, seja porque essa perda não é necessária, seja porque a criação de direitos e liberdades sem exclusão seja criação de uma potência jurídica necessária segundo a estrutura de toda a comunidade política. A democracia, assim, é uma forma política que realiza tanto a necessidade jurídica de universalidade de direitos e liberdades, quanto a necessidade ontológica de preservação e aumento da potência do indivíduo coletivo e de cada individuo singular dentro da comunidade política.

Apesar de sua base ontológica ou graças a ela, a concepção espinosana da democracia tem no seu centro a teoria espinosana dos afetos e o conceito de conatus. Não apenas a sua idéia de democracia envolve a participação do conceito de razão (através da qual o indivíduo conhece a 
necessidade - porque a utilidade — da vida democrática), como essa dedução é resultante do fato da estrutura afetiva do ser humano e das comunidades humanas. A vida democrática não é desejável porque é a mais bela ou a mais virtuosa (isso é irrelevante), mas sim porque é a única em que a liberdade coletiva é uma realidade: só na democracia a comunidade política (não os representantes dos cidadãos, e sim todos os cidadãos diretamente, sem exceção) deseja a inclusão de todas as suas partes constituintes (não suas instituições apenas, mas fundamentalmente todos os seus cidadãos) no exercício da alegria. Mais do que exercício de direitos, a vida coletiva é melhor quando é causa de alegria para quem nela vive. A própria vida em comum já é por si mesma uma causa de alegria, na medida em que Espinosa explica que o que é concebido como útil pelo homem é desejado por ele, e "nada mais útil para o homem do que o próprio homem". O ser humano conhece, pela sua razão, o aumento de potência que é causado pela vida em comum, e em qualquer forma de associação com os outros - a associação soberana, a Cidade (o Estado), é a maior de todas. ${ }^{192}$ Conhece também, pela sua razão, a diminuição de potência que é causada pelo cultivo do ódio, inclusive o ódio sob forma de posse exclusiva de algo considerado um bem: deixando de lado a questão oportuna aqui a respeito da propriedade na sociedade liberal, importa notar que a concepção espinosana de vida humana e de vida política exprime a idéia de que toda posse exclusiva de um bem, na medida em que é excludente e não na medida em que é proveito desse bem, é causa de tristeza e impotência tanto em quem possui a coisa quanto principalmente em quem não pode usufruí-la; mas, principalmente, é efeito de tristeza e impotência de quem a concebe como devendo ser um bem de uso exclusivo.

É assim no caso da constituição dos direitos. Quando um direito é considerado um bem de uso exclusivo porque de outro modo não poderia ser acessível ou utilizável, isso só se justifica se, primeiro, for verdadeiro que ele não seria acessível ou utilizável de outro modo e, segundo, se, mesmo não sendo acessível ou utilizável de outro modo, ele não é desejado por quem, segundo as instituições do Estado, não tem acesso a ele ou não tem permissão de utilizá-lo. Em qualquer outro caso, estamos em despotismo, porque está sendo recusado por meio da força física o acesso a um direito que se deseja. Não importa qual o pretexto para a recusa desse direito ao outro: ela é sempre calcada no ódio ao outro, porque se imagina irracionalmente que o fato

\footnotetext{
192 A propósito: isso impede a idéia de um Estado internacional ou de paz perpétua fundada numa comunidade internacional; não há comunidade possível além das soberanias formadas pelas comunidades políticas (sejam estas idênticas ou não a nações). A única comunidade para além das soberanias políticas não poderia mais ser política, e seu sentido seria apenas o de uma comunidade natural (como aquela que Sêneca menciona numa carta à sua mãe: "Olha para a Natureza. Na Natureza somos todos cidadãos.") ou, em termos espinosanos, o de uma comunidade racional, fundada não na decisão racional mas na estrutura do real (e na qual cabe qualquer forma de identidade, independente da presença de convenções, e portanto independente da noção recusada por Espinosa de contrato social, assim como da noção também recusada por Espinosa de Natureza enquanto império).
} 
de o outro ter acesso ao direito implica que se não tenha acesso a esse direito: concebe-se que o outro também fará ou deverá fazer uso exclusivo do direito, ao mesmo tempo em que se concebe que se deve fazer do direito esse uso exclusivo - mas quando o uso exclusivo e excludente de direitos nada mais é que a transformação de uma idéia de direito enquanto uma prática de privilégio para o proprietário exclusivo do direito, e padecimento de uma dor irrecusável por aquele a quem se nega esse mesmo direito.

Não à toa, existe a "identidade pela dor"193: ela é um fato, em qualquer sociedade baseada na idéia de que os direitos, na prática, são privilégios e é bom nos conformarmos com isso. Não é prática de um prazer masoquista, mas uma compaixão pelo outro ao se conhecer que o outro que padece da dor é idêntico a nós por necessitar não padecê-la. Decantar, pois, a desgraça que é ser excluído ou concebido como excluído quando não se deseja sequer ser concebido como tal, isso não é cultivar a dor, mas reagir contra ela, porque também uma maneira de refletir a seu respeito e conhecer as suas causas, e só enquanto conhecidas estas é que se pode buscar curar a tristeza. Afinal, o ato despeitoso de conceber o outro como menos valoroso do que merece é uma forma de ódio; que, manifestada publicamente, deixa de ser só cultivo da própria ignorância e se transforma em ação individual no campo público, e de fato destrutiva porque machuca tanto como qualquer outra arma. Não é por outro motivo que as pechas excludentes são desembainhadas para agredir; assim, se não há masoquismo naquele que se identifica na dor, há sadismo naquele que se diverte com a dor do outro ou de si mesmo.

O pensamento contemporâneo a respeito da democracia é marcado por uma tendência a propor a democracia como prática política mais adequada (ou menos pior), mas principalmente é marcado por uma grande desconfiança quanto às sua concretização. Ainda que a história contemporânea tenha sido o período de construção de formas institucionais de sociedade e poder que dêem à democracia uma prática viável nas sociedades atuais, o pensamento contemporâneo acerca dessa mesma prática contemporânea parece preocupar-se mais com uma compreensão dos mecanismos dessas instituições ou interesses coletivos do que por compreender ou conceber as necessidades do próprio ser humano na vida política. Não há, em qualquer outro período da história do pensamento, uma separação tão profunda entre o exame da prática política e o exame das necessidades na política. A democracia, na teoria ou na prática, não poderia deixar de sofrer as conseqüências — e sofre. Talvez o pior padecimento da vida democrática seja, na

193 Refiro-me, é claro, às concepções de Renato Janine Ribeiro apresentadas em A sociedade contra o social, pp. $40-44$. 
contemporaneidade, cada momento em que a idéia de legitimidade é concebida como idêntica ao arbítrio das autoridades políticas, econômicas, jurídicas, militares, religiosas, pessoais. Assim como na contemporaneidade a justiça tornou-se um tabu para o pensamento jurídico e a prática do direito, na prática política e do pensamento acerca dessa prática a concepção de um necessário racionalmente válido é um projeto temerário, a meu ver porque se considera que qualquer necessidade política concebida como de valor universal se revelará irrealizável de todo: ou seja, o que quer que se defina como a necessidade da vida política em qualquer comunidade humana, lá estará a idéia de que a igualdade e a liberdade não podem ser uma prática universal, mas no máximo um desejo de validade universal.

Ora, conceber que na prática é impossível evitar a exclusão ou outras formas de violência (a corrupção, por exemplo) na vida democrática é dar o nome de democracia a uma prática de despotismo (apropriação da coisa pública segundo fins particulares), porque é considerar que a busca do útil coletivo na vida política, ao envolver a banalização da exclusão (que significa impedir particulares de ter proveito da coisa pública), considera que esta tem a sua própria utilidade no todo da prática política, por não prejudicar a existência de ao menos alguma prática política voltada para fins públicos. Não importa qual seja a concepção de democracia: se esta é concebida como uma prática política na qual a exclusão é banal, não apenas se perde a divisão entre público e privado e entre ética e violência e ainda entre democracia e autocracia, como principalmente se aposta na identidade entre política e autoritarismo. Não é impossível ao homem imaginar que a política pode ser o campo do autoritarismo; o homem não apenas é um ser sempre imaginante, como as suas idéias (de qualquer gênero) são fundamentalmente baseadas na sua estrutura passional. Para conceber a política como campo não do autoritarismo, mas da legitimidade da coletividade e da coisa pública, é preciso não apenas partir dos próprios afetos (lá está o desejo de ter potência e de ter a própria potência aumentada pela união com as demais potências individuais) como também da reflexão racional acerca da experiência coletiva: dela, segue a dedução da vida coletiva como campo público de criação de direitos e liberdades sem a exclusão de quem quer que seja. Ao contrário, a concepção da vida coletiva como devendo ser baseada na exclusão ou enfraquecimento de determinados indivíduos independente da necessidade desses mesmos indivíduos é, necessariamente, elaboração de uma concepção que se recusa pôr à prova, pois não há como justificar de forma alguma a utilidade da violência ou da exclusão. Qualquer tentativa de justificação da violência ou da exclusão depende de ser válida a idéia de que a dor de uns merece ser provocada por outros — normalmente, o ideólogo da exclusão e da violência. 
Todo discurso em favor da exclusão e da violência, mesmo quando articulado de forma a tentar compensar um ganho por outras vias (e normalmente não um ganho para os excluídos ou os violentados), é um exercício e cultivo do ódio. O ódio, necessariamente, é a paixão suprema de toda prática despótica, porque o despotismo se fundamenta a todo momento na aniquilação de quem é dominado ou explorado; jamais há espaço, na mente despótica e na prática despótica, para a recepção ou transformação do dominado num par ou num aliado. Ao contrário, a mente despótica imagina que o outro é sempre tão perigoso que pode causar a destruição do déspota ou do bem desejado pelo déspota. Jamais a mente despótica é capaz de conceber (porque para isso precisaria ir além das idéias imaginativas) a união com o outro para a prática de uma ação coletiva que os igualitarize. Para que isso aconteça, é preciso que a mente despótica deixe de pensar a partir das bases do despotismo; é preciso, simplesmente, que passe ao uso pleno da razão - pois a recusa deste uso envolve a ignorância da própria necessidade de identidade com o outro, ainda que na dor, mas preferencialmente no desejo de autoconservação.

Se a vida despótica é marcada pelas paixões tristes, o que marca a vida democrática (ao menos essa concebida por Espinosa) são as paixões alegres. Se o despotismo é fundado no ódio e no desejo de aniquilação do dominado, a democracia é fundada no desejo de autodeterminação, mas não no de ser dominado nem no de oprimir: ao contrário, a democracia funda-se no desejo de determinar a própria liberdade e conhecer que o outro também pode fazê-lo de forma que todos tenham suas próprias liberdades ampliadas na constituição do campo político. Na Ética IV, quando Espinosa explica a necessidade do indivíduo em refrear os efeitos destrutivos das causas externas e internas a partir primeiramente da compreensão de que a causa fundadora da passividade é o próprio indivíduo, ele coloca como princípio da liberdade a iniciativa individual de determinação da própria potência, em quaisquer das suas formas: a capacidade de agir ou a faculdade para agir, por exemplo, dependem fundamentalmente do estado de ânimo do agente. $\mathrm{Na}$ passividade, a força para agir é inútil ou inexistente, porque o ânimo do agente está inerte: passivo, o indivíduo concebe que a sua situação individual é efeito exclusivamente das causas externas, e não efeito, também e primeiramente, da sua constituição interna; a partir do momento em que conhece essa causalidade primordial, ele é capaz de conceber o seu domínio sobre si mesmo e sobre as causas externas e internas da sua ação; é capaz de conceber, finalmente, a sua natureza enquanto natureza ativa, e a sua atividade enquanto atividade autônoma. A liberdade, portanto, é uma condição inaugurada pela reação à passividade e simultânea à atividade do indivíduo livre. Como a liberdade é um estado de ação fundado na autonomia e na potência do indivíduo, ela é também um estado de alegria. A ação autônoma não é acidental, mas cultivada pela consciência individual da necessidade da própria ação em relação ao próprio a- 
gente: o agente não pode deixar de realizar esta ação (pois é seu desejo realizá-la), que não pode deixar de ser realizada por este agente (que é quem a deseja). Por conhecer essa necessidade da ação, o agente sabe que ela implica aumento de potência e assim por diante: conhecer a necessidade da ação é saber da alegria que a própria liberdade constitui.

Assim, não existe liberdade sem alegria; mas também não existe nem alegria sem liberdade. A alegria não é um valor agregado ao espírito humano, mas é um efeito mental da sua constituição corporal. Para que se produza a alegria, é necessário que se produza o fortalecimento da potência do corpo pois, em Espinosa, a alegria é idéia do aumento da potência do corpo. Não à toa, para que a liberdade seja deduzida na Ética, Espinosa precisa ter demonstrado a estrutura da relação entre as idéias, os afetos (que também são idéias) e o corpo; só um indivíduo (uma coisa singular, tal como definida na Ética II) cuja mente conhece a atividade autônoma do corpo é livre, e só um indivíduo livre age autonomamente de modo a ter consciência da própria ação livre. As partes III e IV da Ética, ao explorarem respectivamente os afetos e a servidão - e tendo como centro o conceito de conatus (Ética III, P6, P7) —, mostram que a liberdade, a alegria e o amor são simultâneos, assim como a servidão, a tristeza e o ódio também o são. Todos são igualmente, também, resultantes da natureza humana: temos uma natureza propícia tanto para a alegria quanto para a tristeza, tanto para o amor quanto para o ódio - depende da estrutura do nosso corpo, da nossa mente e conseqüentemente de tudo aquilo que desejamos. Entretanto, a tristeza em qualquer das suas formas nunca é desejada, apesar de ser natural; já que ela é consciência da diminuição da potência, o que se deseja é o seu contrário. Esse desejo de alegria e de potência não teria nenhuma relação com a vida política, não fosse o fato da potência individual aumentar quando se ajunta às outras potências individuais. Por conhecer que o que há de mais útil ao homem é o próprio homem, cada indivíduo calcula o aumento de potência que deve ser produzido pela vida coletiva dirigida pelo desejo de todos os seus integrantes. E ao conhecer que aquele que impede a alguém o acesso a um bem que deseja está sendo para ele causa de tristeza, que aquele que auxilia a alguém o acesso a um bem que deseja está sendo para ele causa de alegria, que aquele que é tido como causa externa de tristeza é odiado, que aquele que é tido como causa externa de alegria é amado, e que o homem livre deseja para os outros a mesma alegria e a mesma liberdade, a razão lhe faz ver que a vida em comum é mais alegre quando movida por alegrias comuns. A vida política, mostra a razão, pede o cultivo coletivo de uma alegria comum a todos os seus participantes. Todo princípio ou fim da vida coletiva ou política merece ser louvado não por uma virtude em si mesma ou por um valor anterior à sua realização prática, mas unicamente por ser causa de fortalecimento comum de todos os indivíduos organizados autonomamente na igual necessidade de liberdade e preservação da liberdade. 
É por isso que, em Espinosa, vida democrática e liberdade política são a mesma coisa. A única forma política que realiza sem exclusão nem cultivo do ódio a liberdade de todos os seus integrantes é a democracia. Quanto à liberdade, se ela é um estado de movimento do agente determinado pelo interior do próprio agente, torna-se no plano da política liberdade e movimento de todos os indivíduos da vida coletiva; é por isso que, na vida política democrática, todos são cidadãos: na democracia, o legítimo é determinado pelo necessário, e do necessário ninguém está excluído nem destituído. Se a democracia, assim, é o campo da concórdia e do cultivo das paixões alegres na Cidade, a paixão alegre da democracia é, por excelência, o amor intelectual à liberdade concretizada coletivamente por todos os cidadãos. No plano da vida política, não há conquista mais potente do que essa liberdade de todos fundada na eliminação da exclusão e da violência. 


\section{PARTE II}

\section{DO DIREITO NATURAL AO DIREITO JUSTO: O RACIONALISMO JURÍDICO ESPINOSANO}

Civitas, cujus subditi, metu territi, arma non capiunt, potiùs dicenda est, quòd sibe bello sit, quàm quòd pacem habeat. Pax enim non belli privatio, sed virtus est, quae ex animi fortitudine oritur: est namque obsequium constans voluntas id exequendi, quod ex communi Civitatis decreto fieri debet. Illa praetera Civitas, cujus pax a subditorum inertiâ pendet, qui scilicet veluti pecora ducuntur, ut tantùm servire discant, rectiùs solitudo, quàm Civitas dici potest. Cùm ergo dicimus, illud imperium optimum esse, ubi homines concorditer vitam transigunt, vitam humanam intelligo, quae non solâ sanguinis circulatione, \& aliis, quae omnibus animalibus sunt communia, sed quae maximè ratione, verâ Mentis virtude, \& vitâ definitur.

Se numa Cidade os cidadãos não tomam das armas porque estão prisioneiros do terror não se deve dizer que aí reina a paz, mas que nela não há guerra. A paz não é mera ausência de guerra, mas uma virtude que se origina da força do espírito, pois nela a obediência é o desejo constante de seguir o direito comum da Cidade, deve ser feito. Uma cidade, é preciso dizê-lo ainda, em que a paz é efeito da inércia dos súditos conduzidos como um rebanho e formados unicamente na servidão, merece mais o nome de solidão que o de cidade. Quando dizemos que o melhor Estado é aquele em que os homens vivem na concórdia, entendo que vivem uma vida humana, uma vida que não se define pela circulação do sangue e realização das outras funções comuns a todos os animais, mas principalmente pela razão, a virtude da mente e a vida verdadeira. 
SEÇÃO 3

EM QUÊ ESPINOSA É NOSSO CONTEMPORÂNEO? 


\section{CAPÍTULO 5 \\ DO DIREITO NATURAL AOS DIREITOS NATURAIS}

De forma mais geral, que chances "uma filosofia da lei natural" tem hoje de assegurar, melhor que uma filosofia do sujeito, o "destino jurídico dos direitos do homem"? Em particular: pode-se conceber uma "filosofia da lei natural" que seja compatível ao mesmo tempo com as condições de pensabilidade do direito (a esse respeito acabamos, quanto ao exemplo espinosista, de emitir mais que reservas) e as exigências do pensamento contemporâneo? Bl. Barret-Kriegel, para ilustrar uma tal filosofia, evoca, contra Espinosa, Locke.

A. Renaut \& L. Sosoë, Philosophie du droit, p. 77.

\section{I ESPINOSA E O SUJEITO DE DIREITO}

Diante de todo o percurso que leva da destruição do direito natural à definição da democracia pacífica como uma necessidade do próprio direito racional (porque é uma necessidade da política, da qual o direito é uma manifestação), é possível perceber com muita clareza a contemporaneidade de Espinosa enquanto pensador jurídico. Espinosa não apenas escreve contra a tradição teórica do direito positivo (que vem do direito romano no caso do direito político, e da tradição judaico-cristã no caso do direito divino, do direito canônico e dos instrumentos jurídicos cuja autoridade é moral) e contra a tradição teórica do direito natural (em especial a de sua época, que procurava e continuaria procurando construir um sistema científico de pensamento jurídico e prática jurídica), mas, naquilo que a sua crítica trabalha como afirmação de uma teoria jurídica própria, ele produziu a idéia de que a única prática jurídica adequada à natureza humana é a prática democrática, donde não há racionalidade em desvencilhar qualquer projeto político ou jurídico do horizonte da democracia.

É certo que aquela desconstrução conceitual havia operado um esvaziamento das concepções clássicas do direito e da política justamente porque os conceitos tradicionais eram incompatíveis não apenas com a idéia de democracia, mas acima de tudo eram incompatíveis com a própria idéia de liberdade. Como a liberdade pede uma forma de associação política que seja realização dela mesma, e como a liberdade é definida desde a Ética como uma prática da auto- 
determinação da ação, não é possível, por uma necessidade racional, conceber outra forma de governo além da democracia como forma adequada de associação entre indivíduos igualmente livres. E, no horizonte da democracia, mostram-se sob a ótica espinosana inadmissíveis conceitos jurídicos clássicos como jus naturale, jus civile, potestas, dominium, imperium. A redução de todos à potentia obriga uma reformulação do próprio discurso do direito, pois que se percebe agora que o direito tal como concebido classicamente só tem sentido enquanto uma prática institucionalizada da violência, o que de maneira alguma pode ser conciliado com a liberdade e, por isso mesmo, com a democracia. Feita a desconstrução da conceitografia clássica, o projeto jurídico espinosano pede a elaboração de uma conceitografia outra baseada menos em neologismos do que num trabalho de limpeza do discurso jurídico existente. Não há necessidade de criar novos termos para que o pensamento possa conceber certas concepções, desde que essa significação seja alcançada com a superação das irracionalidades presentes nos termos em uso. Essa depuração da linguagem e do pensamento tem como conseqüência o esclarecimento do sentido de determinados termos, de modo que a tentação neologística é superada pelo reconhecimento do sentido verdadeiro dos conceitos já existentes, ou leva à aniquilação completa dos termos cujo sentido não pode deixar de ser irracional; apenas na impossibilidade de uma tal depuração ou aniquilação, há legitimidade (porque há necessidade) de uma terminologia nova. O que Espinosa produz quando lida com os conceitos clássicos da política e do direito é exatamente esse trabalho de depuração conceitual e aniquilação terminológica. Ao falar do direito utilizando os termos da própria tradição, Espinosa não finge, como é o comum do próprio pensamento jurídico, que lida com termos completamente racionais, pois o discurso jurídico, por não ser um discurso racional ou científico, opera um conjunto de significados construídos e articulados vulgarmente sem o suficiente rigor racional, o que causa, mesmo na filosofia política, um prejuízo intelectual insuperável, enquanto não se supera a falta de sentido do próprio discurso jurídico. Ao falar de direito e política utilizando os conceitos do próprio direito, ele a todo momento opera uma subversão do sentido dos conceitos que utiliza, com o que não apenas revela a falta de sentido presente na concepção vulgar, como abre caminho para a construção de uma conceitografia jurídica racional, que venha substituir a anterior e, dessa forma, permita falar com mais verdade acerca do seu próprio objeto.

No caso do conceito de direito natural, o que Espinosa produz é a sua completa aniquilação, porque não há nenhum sentido racional nele. Na realidade, o que se afirma ser direito natural é outra coisa, a potentia, cuja sentido racional não é dado pelo discurso da política, mas sim pelas ciências da natureza. Aquilo que se entendia tradicionalmente por direito natural existe enquanto potentia e, no campo da política, não se transforma em outra coisa; por esse motivo, 
não há motivo para tentar um novo conceito em substituição ao conceito de direito natural, por inutilidade de um conceito diferente do conceito de potentia, e por irracionalidade da proposta de sua adaptação ao campo da política e do direito. No caso do direito positivo, ele é reconhecido como a única realidade jurídica, mas enquanto conjunto conceitual, é também composto por concepções irracionais ou problemáticas, que acabam por prejudicar ou mesmo impossibilitar a relação entre direito e razão, o que equivale a dizer que impedem a conexão entre direito e democracia; assim, no que diz respeito ao próprio conceito de direito positivo e às concepções atreladas a ele, qualquer significação estranha à prática concreta da política não faz sentido (por isso Espinosa começa o Tratado político criticando as filosofias em detrimentos das práticas da política: o que ele faz aí é uma crítica à visão tradicional do pensamento político, que aliava a política aos modelos morais e naturais; ao mesmo tempo que aponta para uma análise objetiva e científica do fenômeno da política, no que mais uma vez se mostra aproximado de Maquiavel) e, além disso, qualquer concepção atrelada à idéias de potestas e de dominium apresenta uma irracionalidade incontornável enquanto não se produz uma depuração conceitual, na medida em que potestas e dominium são concepções clássicas do direito que se revelam incompatíveis com a estrutura natural da democracia; nesta, o conceito de dominação, por significar servidão, não pode ter lugar (devendo ser substituído pela idéia de violência, pois na democracia é isso que o dominium é, devendo ser aniquilado de seu interior) e o conceito de poder político, por significar uma potência cuja força depende da atividade de todo o corpo político e não do arbítrio de quem o representa, não tem realidade em si mesmo (devendo ser substituído, pela idéia de autodeterminação, pois na democracia é isso que a potestas, quando existente em ato, é; como conseqüência, para a perspectiva do direito, essa autodeterminação não deve ser conceituada como poder, mas sim como potestade: a força política é uma atividade atual das instituições políticas - que não são separadas dos súditos ou cidadãos mas os envolvem, pois estes tomam parte na sua atividade —, e não um potencialidade, um privilégio, ou um posto).

Assim, no caso do dominium e da potestas, Espinosa trabalha uma depuração conceitual que leva à substituição dos termos tradicionais por idéias necessárias ao pensamento político racional. Tanto dominium quanto potestas passam por um processo de interdição conceitual: no caso do dominium, por ser inadmissível no campo da democracia (já que a liberdade na política depende de liberdade de ação e associação, sendo desnecessária a servidão para a produção de uma e outra coisa); no caso da potestas, por ser inexistente nesse mesmo campo (já que a potência de quem governa sobre quem é governado nada mais é do que governo de si, autodeterminação: o poder na democracia não existe enquanto uma potencialidade do Estado sobre seus súditos ou cidadãos, mas sim como uma potência dos cidadãos associados entre si; quando ao 
poder em outras formas de governo, não é poder, porque é violência, já que nas outras formas de governo o controle dos governados por quem governa é feito a partir da dominação).

Ora, é interessante que Espinosa escolha sempre esvaziar o significado conceitual dos termos clássicos dentro do próprio discurso da política e do direito. Embora tais conceitos revelem a pretensão de significar idéias cujo sentido é dado por uma perspectiva natural ou ontológica, é preciso analisar o seu sentido dentro do próprio discurso político-jurídico para constatar que aí mesmo ele não apresenta sentido. É por isso que o esvaziamento dos conceitos de direito natural, direito positivo, poder e domínio é feita a partir de uma consideração do estado de natureza e do estado civil, onde Espinosa, contra Hobbes, mostra que também a distinção entre ambos é inadmissível: o chamado estado de natureza nunca deixa de existir, e o estado civil não se diferencia dele; pelo contrário, é o próprio estado de natureza, sob uma perspectiva política. As leis que regem o estado civil são as leis naturais que regem o estado de natureza, sem nenhuma diferença além da elaboração conceitual imaginativa que procura dissociar ou relacionar direito natural e direito positivo, ou que procura localizar na política os princípios da moral, por serem, segundo aquela tradição, princípios válidos ao estado civil por uma questão de relação entre o direito natural (fonte dos valores morais, tais como justiça e injustiça) e o direito positivo ou civil ou das gentes (porque é neste que a política se realiza e os valores morais devem ser aplicados como índice de dominação).

Como não há, pois, essa diferenciação ontológica entre estado natureza e estado civil na perspectiva da política, não faz sentido, também, a concepção clássica de ser humano produzida pela tradição jurídica aliada à distinção entre estado de natureza e estado civil. Essa concepção, que decorre do direito romano e se desenvolve por toda o pensamento medieval, atinge um ponto culminante no pensamento político renascentista e moderno, apesar de todas as rupturas realizadas por este último com relação às perspectivas e métodos analíticos das teorias políticas medievais e, principalmente, antigas. Quando o pensamento político desenvolve sua configuração estritamente moderna, ocorre a produção de um conceito completamente novo no pensamento jurídico, o conceito de sujeito de direito.

Por esse conceito, que aparece pela primeira vez em Suárez, mas recebe um desenvolvimento maior em Grotius e Pufendorf, ${ }^{194}$ entende-se, em linhas gerais, o ser humano enquanto portador de direitos e obrigações. A princípio, portanto, trata-se de uma extensão do conceito de pessoa dado pelo direito romano, que significa a mesma coisa; mas, no tratamento dado pelos autores do século XVII, a relevância dessa figura do portador de direitos e obrigações assume

\footnotetext{
194 A propósito, ver Y.-Ch. Zarka, "Individu, personne et sujet dans les doctrines du droit naturel au
} XVII" siècle", 1995, e "The invention of the subject of law", 1997. 
um relevo nunca sonhado antes na tradição do pensamento jurídico. De fato, malgrado o desenvolvimento do conceito de pessoa em cada sistema jurídico desde o direito romano, ${ }^{195} \mathrm{o}$ seu significado na conceitografia jurídica medieval decorre da preocupação de definir o sujeito civil como súdito do direito positivo.

Toda a tradição jurídica que desenvolve o conceito de pessoa é fundada na distinção entre direito natural e direito positivo, porque concebe o sujeito civil como portador de direitos e obrigações determinados pelo direito positivo e pela autoridade política (secular ou não), mas cuja legitimidade repousa num mérito supostamente atribuído pelo direito natural. Essa distinção entre realidade do direito ou obrigação determinada pelo direito positivo e legitimidade da atribuição segundo o direito natural (no que é possível haver ilegitimidade do direito positivo, caso afronte a lei de natureza) é em sua forma elementar mantida no século XVII, mas havia em sua elaboração medieval um princípio que seria superado a partir da modernidade (ao menos dentro da filosofia política; na prática jurídica a história seria sempre outra): trata-se da concepção clássica de que o significado do direito natural deve ser interpretado pela autoridade que detém a potestas sobre a determinação do que é justo ou injusto, assim como para a resolução dos conflitos. Independente da definição dessa autoridade como secular ou eclesiástica, o que é relevante é a definição de que não apenas o direito positivo é determinado pela autoridade política, mas na prática até mesmo o direito natural o é, na medida em que sua interpretação e a avaliação da adequação entre direito positivo e direito natural é uma questão de poder e não de ciência. Assim, enquanto dura o pensamento jurídico medieval (que reproduz e alicerça esses costumes da prática jurídica), o objeto do conceito de pessoa não é jamais concebido como fonte de direitos e obrigações, mas exclusivamente enquanto seu suporte, segundo uma maquinaria demonstrativa que obviamente se fundamenta na metafísica e na teologia.

Apesar de seguidor estrito de Tomás de Aquino, Suárez é um autor fundamental para o pensamento jurídico renascentista e moderno porque, entre outras coisas, a sua concepção de pessoa aponta esta figura pela primeira vez como portadora não simplesmente dos ditos direitos e deveres, mas antes de tudo portadora da fonte que determina esses direitos e obrigações: o homem, na perspectiva do direito, é um indivíduo cuja essência natural contém os atributos que caracterizam a sua humanidade e exigem da autoridade política considerá-lo como pessoa. Assim, cada indivíduo, na perspectiva do direito, é sujeito de direito porque em sua própria essência contém os elementos suficientes para a designação dos direitos de que necessita na vida

195 A referência é feita a partir do direito porque antes deste o conceito de pessoa não ocorre enquanto conceito jurídico, assim como no vocabulário moderno a referência remonta, no máximo, a essa tradição romana, já que toda a tradição jurídica medieval decorre dela, e não exatamente de outras influências, como por exemplo as instituições jurídicas gregas. 
política, assim como das obrigações que lhe cabem dentro da comunidade em que se encontra. Nessa concepção que mantém as estratégias conceituais da metafísica, a mudança produzida por Suárez consiste nessa consideração do indivíduo como fonte dos seus próprios direitos, o que repercutirá daí por diante nas concepções jurídicas devedores da escolástica tardia e nas teorias do direito natural do início do século XVII (mas que será acrescentada às concepções tomistas do direito natural e integrará os princípios do direito canônico daí por diante); além dessa concepção, há uma inovação no pensamento suareziano que marca, na concepção do sujeito de direito, um distanciamento em relação a Tomás de Aquino e os outros escolásticos, mas o aproxima de Domingo de Soto e Luís de Molina: segundo Suárez, apenas os princípios fundamentais do direito natural são imutáveis, sendo que as leis naturais que decorrem daqueles e dizem respeito a cada pessoa em particular acabam por se adaptar às circunstâncias históricas a que o indivíduo está submetido: neste sentido, o sujeito é fonte não apenas dos seus direitos naturais, mas sua individualidade produz uma alteração no próprio direito natural (Suárez, De legibus ac Deo legislatore, II, 12,14). Em Suárez, porém, embora o indivíduo seja fonte dos seus direitos e obrigações por conta da sua própria essência e ainda seja fonte de alterações no próprio direito natural, ele não é, ainda, o intérprete dessa mesma essência, nem mesmo dessas alterações. A interpretação da capacidade jurídica de cada indivíduo não é, ainda, uma ação sob o seu próprio poder, pela simples razão de que esse poder é uma prerrogativa da autoridade política.

É com Grotius que o conceito de sujeito de direito atinge uma forma legitimamente moderna, não apenas porque ele começa a se desvencilhar da concepção metafísica das entidades políticas (embora mantenha uma concepção teológica do direito natural e dos fundamentos do direito), mas porque como ele o sujeito de direito é concebido como autor da interpretação dos seus próprios direitos e obrigações: em Grotius, o direito natural tem um significado acessível à razão humana, o que torna a sua interpretação acessível a qualquer um; com isto, a definição dos direitos e deveres de cada pessoa passa a ser concebida como uma tarefa mais científica do que técnica.

Não é o caso de apresentar o pensamento de Grotius em suas linhas gerais, mas é preciso, aqui, ressaltar duas coisas. Primeiro, o sujeito de direito é um conceito secundário e difuso no pensamento de Grotius, embora seja uma conseqüência de todo o seu sistema de pensamento jurídico; Grotius não elaborou uma teoria específica do sujeito de direito, tanto que não é um conceito explicitado por ele; mas o seu pensamento jurídico é incompreensível sem a concepção de racionalidade de todos os conceitos aplicados tanto no discurso jurídico quanto na própria prática jurídica, de modo que o portador da razão que conduz essa compreensão (cada indivíduo, e não necessariamente uma autoridade acima dele, porque o direito faz sentido à luz da 
lei de natureza de que decorre) é imprescindível para o reconhecimento da legitimidade de um comando do direito positivo. Grotius, a propósito, dá tanta atenção à derivação da legitimidade das leis positivas a partir do direito natural, que praticamente considera a legitimidade uma realidade presente na natureza e não no terreno das instituições jurídicas; entretanto, essa legitimidade não tem como produzir efeitos na realidade humana enquanto não se faz presente no direito positivo, que é o único instrumento de que as pessoas dispõem para obrigar e capacitar. Segundo, e diferentemente das suposições levantadas por uma recente e considerável tradição interpretativa, a concepção grotiana do indivíduo como determinador dos seus direitos e deveres não é sequer comparável à maneira como Descartes coloca o sujeito como autor do seu próprio conhecimento, como determinador da legitimidade intelectual das suas próprias idéias, porque, ao passo que em Descartes se propõe uma relação entre verdade e razão (no que não há como se considerar a existência de uma idéia verdadeira sem a operação de um intelecto que reconhece a evidência dessa idéia), a relação entre legitimidade e razão não é uma relação intelectual, e sim natural. Além disso, há uma diferença de prioridades com respeito à própria concepção do ser humano. Em Descartes, o primado do sujeito metafísico e epistemológico tem como conseqüência uma análise da ação humana cuja perspectiva é exclusivamente moral, e a influência direta de Descartes sobre os pensadores jurídicos do período teria um grande alcance justamente graças ao impulso que deu a uma concepção do homem como um ser moral e do direito como uma qualidade moral do homem e da própria natureza (basta considerar que a concepção cartesiana do homem como ser moral influenciará a concepção pufendorfiana de pessoa). Em Grotius, o ser humano é observado não a partir de uma perspectiva epistemológica, e sim de uma perspectiva exclusivamente jurídica (nos termos de um jurista adepto da relação entre direito natural e direito positivo): o homem é um ser definido pela sua facultas (ou seja, sua faculdade natural e civil de domínio, sua liberdade de escolha para exercer uma determinada potestas) e pela sua aptitudo (sua disposição natural para a potestas ou diante dela). Essa distinção, que retoma em certa medida as concepções tomistas, é o verdadeiro alicerce da concepção do sujeito de direito na modernidade, porque mostra que a fonte de qualquer capacidade ou necessidade jurídica reside na estrutura natural de cada indivíduo, assim como interpreta sua condição política (como dominante ou dominado, dependendo de sua aptidão) como um fator determinado pela natureza. Defendendo essa distinção entre facultas e aptitudo, Grotius todavia se afasta do tomismo e aponta em definitivo para o jusnaturalismo quando aproxima os conceitos de potestas e libertas: ao passo que o tomismo entendia a liberdade como uma condição de submissão a uma ordem teológica e natural, Grotius a concebe como um atributo natural de cada indivíduo que consiste na preservação do próprio direito natural; como a natureza designa 
o que cada indivíduo e, em especial, o homem são (sua facultas e sua aptitudo), a natureza passa a ser o próprio direito a ser defendido pelo indivíduo, e a liberdade envolve a defesa desse direito. Essa concepção altera também o sentido de jus e lex, pois identifica estes conceitos à vontade humana, porque esta é índice da natureza individual, e separando-os da concepção tradicional que ora os concebia como vontade arbitrária do soberano, ora como princípio imutável presente na natureza; é essa concepção renovada do direito subjetivo (jus) e do direito objetivo (lex) que será observada em Hobbes, ainda que sem grandes alterações em relação à matriz grotiana: o que Hobbes faz é explicar a relevância de uma e outra forma jurídica diante do estado de natureza e do estado civil, sempre com a concepção, porém, de que o jus é determinado pela necessidade que todo indivíduo tem de se preservar, a ponto de ser cortada a legitimidade do domínio do soberano desde que não se verifique a segurança de vida que é sua única obrigação garantir ao súdito que lhe alienou os próprios direitos naturais.

Quando Espinosa escreve seus textos sobre política, ele tem como principais referências na concepção do sujeito de direito, além das instituições de direito romano presentes no próprio direito europeu, o pensamento teológico medieval e a definição estabelecida a partir de Grotius e retomada por Hobbes. Ao mesmo tempo que publica o Tratado teológico-político, completa a redação da Ética (o que inclui a redação integral das partes IV e V) e se prepara para a redação do Tratado político, aparece (em 1672, em Lund, Suécia) o tratado Do direito de natureza e das gentes, principal obra do principal teórico seiscentista do direito natural (e, conseqüentemente, do sujeito de direito), Pufendorf. Embora não se saiba se Espinosa conheceu este ou outros textos de Pufendorf, este (já com acesso aos Opera posthuma e, portanto, ao TP), ao integrar o coro dos detratores do pensamento espinosano, não se limita (como já vimos) a criticar o "ateísmo" e "panteísmo" de Espinosa, mas é o primeiro grande jurista já a recusar que Espinosa possa servir de base à elaboração de um sistema jurídico, pelo fato de sua doutrina ter destruído por completo o direito natural, que Pufendorf considera ser a única fonte imutável e legítima de direito e justiça. Essa crítica contra Espinosa não é motivada apenas pela diferença na concepção do direito natural (Espinosa e Pufendorf praticamente representam as extremidades teóricas a respeito do assunto), mas por uma diferença fundamental entre suas concepções de homem. A concepção pufendorfiana será muito influenciada pela concepção cartesiana, e será mesmo uma transposição da concepção moral do homem para o campo do direito: em Pufendorf, o que move a ação humana é exclusivamente a vontade, determinada pelo jogo de paixões que compõem a sua alma; e a liberdade humana, justamente, consiste na capacidade do indivíduo em lidar com suas próprias paixões na busca daquilo que lhe é útil e justo. A conseqüência dessa concepção para o próprio direito será a definição da prática da justiça como resultado da vontade humana, embora o justo e o injusto se- 
jam atributos metafísicos presentes na própria natureza e na vontade divina. Na sua crítica às concepções jurídicas de Espinosa, o que Pufendorf procura ressaltar é que a redução do direito à potência física significa uma perda teórica irreparável: como Espinosa recusa a legitimidade do justo e do injusto como valores morais, não há sequer as condições mínimas para se produzir a administração jurídica das ações humanas, porque não há como aplicar o princípio de autoridade da moral (que é natural e sempre justa, enquanto significa uma realização de finalidades adequadas) sobre a vontade (que na sua fragilidade diante da força das paixões pode afastar o sujeito da realização das suas finalidades naturais), e isso significa que não há como aplicar as instituições jurídicas na vida humana, no que o próprio homem é violentado em sua essência (estes argumentos serão retomados posteriormente por Leibniz, que completará o ciclo de definição do sujeito de direito como um sujeito metafísico e moral). ${ }^{196}$

O que tanto incomoda Pufendorf e causa entre os juristas do final do século XVII (em especial os hobbesianos holandeses, como Velthuysen) a primeira sensação de irrelevância jurídica do pensamento espinosano (embora este seja relevante — porque pernicioso - enquanto "pensamento teológico") é o fato de, em Espinosa, não existir sujeito de direito. Não que Espinosa não conceba nem apresente elementos para uma concepção de mérito legítimo de direitos e obrigações (ele o faz pela explicação de que esse mérito nada mais é do que uma necessidade de cada indivíduo), mas ocorre que os seus escritos também realizam uma desconstrução do conceito de sujeito de direito, ao retirarem a moral do horizonte do direito e da política e ao conceber o indivíduo como modo finito dos atributos da substância, e não como suporte de atributos que o definem como substância ou que determinam sua subordinação a ela (no caso, tais atributos são justamente os direitos e obrigações, que são concebidos pela tradição jurídica como atributos do súdito, assim como do sujeito de direito). Ora, como não poderia deixar de ser, a definição da condição humana enquanto realização de certos direitos ou deveres civis não poderia ser incompatível com o esvaziamento que Espinosa produziu no próprio conceito de jus: já que este é idêntico à potentia, ele não tem sentido racional enquanto capacidade determinada seja pelo soberano (no que o direito subjetivo tem como fonte não o seu portador, mas uma entidade que está separada dele e o domina), seja pela natureza (no que o direito subjetivo tem o seu portador como fonte, mas essa condição metafísica não garante eficácia na vida civil enquanto não é feita a ponte para o direito positivo). Pelo contrário, como o jus só causa efeitos enquanto potentia, não há por que considerá-lo uma entidade jurídica; a única entidade jurídica cuja existência é real é a lex, mas sua realidade se produz exclusivamente enquanto corpo do direito positivo, e não enquanto interpretação ou prática do direito natural. $\mathrm{O}$ direito, em toda a

${ }^{196}$ Cf. R. Sève, "Leibniz et le droit naturel moderne”, p. 130. 
sua realidade, se inicia e se consuma enquanto direito positivo, o que significa que tanto a distinção entre direito positivo e direito natural é inútil (já que não existe o direito natural), como também o é a distinção correspondente entre direito subjetivo e direito objetivo: apenas o direito objetivo (atribuição, pelo direito positivo, de direito ou obrigação) tem sentido racional, mas não há racionalidade na suposição de que seu efeito é a produção de um direito subjetivo (o atribuído direito ou obrigação, enquanto capacidade civil), porque esta capacidade, embora atribuída pela letra da lei, não manifesta a natureza individual do seu "portador", mas é apenas uma composição imaginária, para o discurso hermético do direito, dessa natureza.

É um problema extremamente constrangedor para todo o jusnaturalismo moderno, pois o que garante a este o projeto de constituição de uma prática jurídica concreta e justa é a idéia de que é possível ao direito positivo a afirmação das necessidades e capacidades de cada indivíduo dentro da vida civil, assim como só essa afirmação segundo uma forma jurídica (ou seja, segundo quem detém a potestas) é legítima e racional. Ora, a partir da perspectiva espinosana, segundo a qual a atribuição de direitos ou obrigações não passa de produção ou interpretação de um texto (e aqui valem toda a sua análise do funcionamento da lei hebraica do TTP) e é completamente inútil se pode ser burlada pelas capacidades naturais do destinatário da norma, assim como é desde sempre irrelevante para a determinação dessa mesma capacidade. O que Espinosa pede é uma concepção diferenciada de destinatário da norma, porque, primeiro, o conceito relevante de capacidade passa a ser outro (a potentia) e, segundo, o destinatário da norma não pode ser separado do modo de produção da norma, ou seja, no horizonte da democracia (único horizonte político racional), não pode haver uma distinção real entre governante e governado, o que significa que o súdito ou cidadão não pode se encontrar separado do direito e da política. Diante dessas inovações que viram do avesso a estrutura positivista do jusnaturalismo moderno, o direito como um todo precisa se adaptar às necessidades da democracia e do ser humano, o que envolve a negação da concepção clássica de sujeito de direito enquanto portador de atributos determinados por quem exerce domínio sobre ele, e que, não por acaso, entende esses mesmos atributos determinados pelo imperium ou pela potestas como propriedades morais do indivíduo (tanto em sentido positivo, onde o direito é um ganho ou um crédito concebido ao súdito, como em sentido negativo, em que a obrigação é um prejuízo ou uma dívida); mais do que isso, no que respeita às propriedades materiais (desde Locke, uma entidade concebida no interior do liberalismo como necessidade primordial na natureza humana, assim como fonte de toda forma de direito subjetivo), elas não podem ser concebidas como instrumento de dominação (destruição ou diminuição de outros indivíduos), nem como fim em si mesmo (destruição ou diminuição de si), mas unicamente como um instrumento para a garantia de uma autopre- 
servação serena, na qual o indivíduo não se perde da sua própria felicidade nem da busca do verdadeiro bem. ${ }^{197}$

Espinosa, ao desconstruir o sujeito de direito, não cria uma inconsistência teórica entre essa desconstrução e a afirmação do sujeito político. Ao contrário, é no sujeito político que se pode ver melhor o que Espinosa entende por um indivíduo no campo da política e do direito, e é essa concepção que orienta o preenchimento da lacuna conceitual deixada pela inexistência do sujeito de direito. Seguindo a definição de indivíduo ou coisa singular deixada na Ética II, def. 7 ("Por coisas singulares, entendo coisas que são finitas e têm existência determinada. Se uma pluralidade de indivíduos concorrem para uma mesma ação, de maneira que todos juntos sejam a causa de um só efeito, consideramos então todos juntos uma mesma coisa singular.”) ${ }^{198}$ e a definição de democracia dada pelo Tratado político já no cap. II, \ 7 (regime no qual a potência da multitudo é operada juridicamente pela própria multitudo em sua totalidade), é possível conceber enquanto um indivíduo no campo da política tanto cada cidadão, como também a multitudo, entendida esta como o conjunto de cidadãos que opera como uma causa única, ${ }^{199}$ o que ocorre apenas na democracia: só aí, há a integração de todos os cidadãos como causa única da ação política, é por isso só nela a multitudo é livre, assim como cada cidadão considerado individualmente é livre, pois aí nenhum cidadão está submetido a uma causa da qual não é também o determinante.

A concepção clássica de sujeito de direito é que é incompatível com essa concepção de sujeito político na democracia, porque o seu pressuposto é a exigência da separação entre governante e governado, assim como (e principalmente) a separação entre o imperium da autoridade político-jurídica e a facultas de cada indivíduo em particular: o súdito não detém a potestas necessária para a designação do que é legítimo ou não dentro do Estado ou da cidade, ainda que essa legitimidade deva ser considerada a partir da natureza de cada cidadão, sem o que o poder político seria abertamente violento e injustificável do ponto de vista da liberdade visada pela associação política. Mas, ao ser produzida essa separação o poder político-jurídico e a vontade de cada súdito (mas não necessariamente a separação entre aquele poder e a vontade do soberano), não há como pretender que a realização do direito seja idêntica à realização da vontade do súdito, muito menos, em termos espinosanos, do que é necessário a cada indivíduo.

197 Conforme o Tratado da emenda do intelecto, \16-17.

198 Cf. o que foi dito a respeito dessa definição na p. 90.

199 Marilena Chauí, A nervura do real, vol. 1, p. 163n [n. 241]: “[...] a realidade do múltiplo aparece na definição do indivíduo, na Parte II, e na definição da multitudo como sujeito político, no Tratado político. Nos dois casos, Espinosa demonstra que passamos da dispersão numérica ou da coleção de componentes à unidade de constituintes, unidade determinada pela causa: quando todos os componentes de um agregado agem como uma única causa, constituem um indivíduo corporal e um indivíduo político.” 
É preciso, pois, substituir o conceito de sujeito de direito pelo de sujeito político (pelo qual pode ser compreendido cada cidadão, mas também uma associação na multitudo), assim como é preciso substituir o conceito correlato de direito subjetivo pelo conceito ontológico e político de necessidade. O que é devido a cada indivíduo segundo a sua natureza é aquilo que lhe é necessário por sua própria natureza, numa determinação imanente ao próprio sujeito, e jamais separada dele. Em vez de se conceber o devido como uma propriedade a que o sujeito tem direito, deve-se conceber a sua potência individual como uma potência do Estado, assim como a sua necessidade individual como uma necessidade da multitudo que o sujeito integra. Isso permite ver que, na democracia, quando uma ação deve ser realizada ou omitida, isso se deve por uma necessidade de preservação ou fortalecimento da própria multitudo, e não por uma designação proveniente do arbítrio de quem se arroga um imperium de dominação.

Essa desconstrução espinosana do conceito de sujeito de direito, por fim, terá ainda uma outra concepção no interior da teoria: a revelação dos motivos pelos quais o pensamento jurídico espinosano é, enquanto filosofia do direito, uma filosofia daquilo que receberia séculos depois o nome de direito justo (no que Espinosa continua a se opor ao seu próprio tempo e se mostra nosso contemporâneo) e, enquanto prática jurídica, um pacifismo (no que, enquanto jurista, ele se manifesta como um democrata racionalista, opondo-se não só a Hobbes e tantos outros, mas de forma particular a Grotius e à então recente tradição beligerante de direito internacional). ${ }^{200}$

\footnotetext{
200 A qualificação da tradição grotiana como "beligerante" parece provocativa, na medida em que Gro-

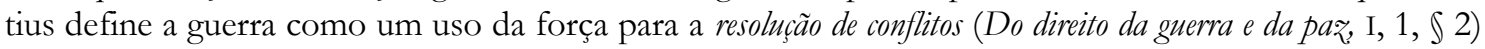
e considera legítima apenas a guerra por motivos justos. Na verdade (como um dos últimos capítulos desta dissertação procurará mostrar), o que Grotius vê na guerra não é inocentemente um instrumento de pacificação, e sim de dominação, na medida em que concebe a guerra como uso de força e faz dela um movimento positivo em si mesmo: a guerra não leva ao fim da destruição, e sim à autopreservação de uma soberania por meio da recuperação do que originalmente era sua propriedade material ou moral - no que a guerra, que deveria ser motivada por razões públicas, é sempre conduzida na verdade por razões particulares; será contra isso que Rousseau, apesar de influenciado por um seguidor de Grotius — Pufendorf —, empenhar-se-á em dizer que a guerra não deve ser conflito entre particulares, e sim entre soberanias, que são entes públicos: "A guerra, pois, de modo algum é uma relação de homem a homem, mas uma relação de Estado a Estado, na qual os particulares só são inimigos acidentalmente, e não como homens nem mesmo como cidadãos" (Do contrato social, I, 4). Em Espinosa, a guerra tal como projetada por Grotius ainda é violência porque, embora Espinosa afirme a racionalidade da declaração de guerra em caso de perigo para a preservação de um Estado soberano, nele a guerra não é motivada pela dominação do outro (já que a recuperação de bens particulares só é real enquanto há essa dominação), mas pela celebração da paz mediante livre acordo dos soberanos envolvidos no confronto (Tratado político, III, 13), o que só ocorre pela concepção de que a paz é a preservação do que nunca deixou de ser bem público, senão mesmo patrimônio público. Assim, em Espinosa, a recuperação de bens particulares são se faz pela guerra e o que era bem público (mesmo a honra do Estado) não pode ser recuperado por razões ou finalidades particulares, devendo guerra e paz ser entendidas de uma forma muito diferente daquela desenvolvida por Grotius e Pufendorf.
} 


\section{II DIREITOS NATURAIS SEM JUSNATURALISMO?}

Se a filosofia jurídica de Espinosa esvazia também a idéia de sujeito de direitos — suporte de direitos ou obrigações - e aponta, em seu lugar, para uma concepção de sujeito político - agente livre na vida coletiva - , como resolver, portanto, a questão da própria definição dos direitos na prática jurídica?

Essa é uma questão importante central não só diante do projeto jusnaturalista, mas diante de qualquer teoria jurídica: qual, de fato, a medida para a definição (racional, inclusive) do mérito, da ação, liberdade ou obrigação devida? Sem esse cálculo, não é possível afirmar se uma condição política ou jurídica é justa ou não, suficiente ou não. E, nesse momento — o século XVII — em que a fundação dos direitos no ditame das leis positivas apenas começa a ser retomada depois de séculos longe da vigência direta do direito romano, a idéia de lei positiva como medida dessa liberdade está longe de formar a opinião jurídica vulgar. Bem ao contrário, o conceito de direito subjetivo, nessas teorias jurídicas dos Seiscentos, torna-se mesmo sua questão central, ainda que não seu ponto de partida (reservado normalmente ao contratualismo ou ao direito natural). O que marca, em linhas gerais, o próprio pensamento jusnaturalista é esse projeto de definição de uma medida para a determinação dos direitos subjetivos, de maneira que, conforme nota Richard Tuck, ${ }^{201}$ o pensamento jusnaturalista é constituído menos propriamente por teorias do direito natural, do que por teorias dos direitos naturais (no sentido de direitos subjetivos fundados no direito natural). Partindo dos ditos modelos contratualistas, os jusnaturalistas têm para si mesmos um projeto jurídico prático a concluir: a elaboração dessa medida e, especialmente, desse elenco de direitos subjetivos, de maneira que por tudo o que a razão esclarece a respeito da necessidade de direitos e obrigações nas sociedades políticas soberanas e organizadas juridicamente, seja possível visualizar qual é o tipo de liberdade que se concede num Estado com determinada caracterização. A colocação de Espinosa nesse panorama é problemática exatamente por conta dessa exigência das teorias jurídicas do período, e não à toa o seu conceito de jus foi acusado de falta de realismo jurídico: também porque não permite a elaboração de um elenco de direitos subjetivos, ao mesmo tempo que sua medida — a potentia — é não institucional. Absolutamente todos os juristas (jusnaturalistas ou não) da época consideram que sem esse elenco não se completa o percurso da filosofia jurídica, ou este não é legítimo enquanto não tenha como referência o reconhecimento das liberdades civis em particular, para além da caracterização geral de liberdade e obrigação na vida civil. Que fazer, pois, quando temos uma filosofia jurídica na qual o sujeito de direitos é uma concepção sem sentido, e que exige que absolutamen-

${ }^{201}$ R. Tuck, Natural rights theories. Their origin and development, pp. 1-4. 
te todos os conceitos jurídicos clássicos sejam substituídos por conceitos racionais?

Ora, da mesma maneira que o jurista Espinosa coloca a irracionalidade da idéia de sujeito de direitos — na medida em que essa determinação do indivíduo não decorre da sua natureza mas, novamente, de uma potestas sobre ele: o conceito de sujeito de direitos não tem efeitos jurídicos enquanto não é reconhecido como conceito institucional; enquanto não é uma definição dada pelo próprio Estado, portanto, independente de "corresponder" à necessidade do indivíduo a que se refere - e exige uma concepção política dessa entidade definida por uma necessidade de liberdade, ele não deixa em branco, na verdade, a definição dos direitos subjetivos. Ao contrários, a sua postura como jusfilósofo e jurista é notável exatamente porque não é fundada no contratualismo nem fundadora de um jusnaturalismo, mas unicamente considera a idéia de direitos em função de uma necessidade ontológica e histórica, um plano no qual, de fato, não cabe o jusnaturalismo moderno. Ora, para compreender a peculiaridade dessa noção espinosana de direitos subjetivos, ou de direitos devidos em razão da natureza — da necessidade — de cada um, tal como se fossem "direito naturais" sem a idéia de jusnaturalismo, é preciso, já que se trata agora de uma concepção jurídica que deve resultar concretamente das reflexões sobre o direito (e que, em Espinosa, vão - como vimos na Parte I deste trabalho — da desconstrução do jusnaturalismo à afirmação da democracia como medida da concórdia política, o que tem todos os reflexos nos conceitos jurídicos conseqüentes), considerar mais de perto a maneira como os próprios jusnaturalistas da época concebem essa definição dos direitos subjetivos. Embora todos tenham igualmente o projeto de definição dos direitos subjetivos e todos (com exceção de Espinosa) trabalhem o paradigma de um sujeito de direitos (é esse paradigma que une as diferentes "teorias dos direitos naturais" do século XVII), há algumas diferenças sutis entre eles que irão, conforme o jusnaturalismo caminha para o século XVIII, estabelecer-se definitivamente no discurso político-jurídico, e passarão finalmente a constituir não um ponto de chegada da teoria jurídica jusnaturalista, mas o seu ponto de partida (o que começa já com Locke, que define um direito subjetivo original, a propriedade, como fonte de razoabilidade do próprio direito natural e, diferentemente, marca da realidade do estado civil). Ao final dessa consideração (que não tem, aqui, como ser extensa), teremos já os elementos para compreender qual a estranheza do conceito espinosano de direitos subjetivos, além da estranheza natural do "espinosismo" dentro do vulgar das teorias jurídicas dos direitos naturais.

No que respeita ao conceito de direitos subjetivos, o significado atribuído tanto pela tradição do direito romano quanto pelo jusnaturalismo diz respeito, numa visão jurídica da expressão, à 
própria idéia de liberdade. Numa palavra, a liberdade de um indivíduo, para a visão do jurista, é determinada pelo seu direito subjetivo: na visão do jurista - de qualquer tempo - a liberdade de alguém consiste simplesmente na capacidade de ação que lhe é permitida seja por lei, seja por sua condição natural.

Em linhas muito gerais, há uma distinção fundamental entre a concepção romana de direito subjetivo e a distinção jusnaturalista do século XVII. Em ambos os casos, a capacidade de ação de um indivíduo é determinada tanto pela sua condição natural (seu direito natural subjetivo) quanto por sua condição civil (seu direito subjetivo determinado pelo direito positivo, ou pelo direito civil). A tradição romana, porém, considerada mesmo enquanto tradição das instituições do direito romano, considera em geral que o direito subjetivo determinado pelo direito civil é mais legítimo do que qualquer outra concepção de direitos da pessoa: já que a ação produzida na vida política é governada pelo direito civil, é o próprio poder soberano das instituições civis que tem, sozinho, autoridade e legitimidade para decidir sobre o que é ou não devido a cada pessoa, seja ela cidadã ou não. Ou seja, na tradição romana, o direito subjetivo que vale na prática é aquele concebido e concedido pelo próprio direito civil; aqui, os direitos de cada pessoa são uma concessão das autoridades a que estão submetidos. Essa ligação, senão mesmo identidade, entre o conteúdo do direito positivo e a liberdade concedida é tão marcante do direito romano que Michel Villey, em seu empreendimento inigualável de recuperação das tradições jurídicas clássicas dentro da historiografia contemporânea do pensamento jurídico, reconheceu a importância de negar a existência de um direito subjetivo — tal como concebido pelos adversários contemporâneos do positivismo jurídico - no direito romano. Para Villey, o direito romano é a melhor prova da concepção de liberdade civil determinada exclusivamente pelas instituições jurídicas, não merecendo nenhuma cogitação o projeto de uma definição metajurídica dos direitos ou liberdades civis. Nuançando essa posição (porque ela leva o eterno "leitor jurista" a considerar que o direito não carece, por conseqüência, sem mesmo de uma concepção conseqüente de direito subjetivo), Passerin d'Entrèves estuda a idéia de facultas agendi no direito romano como elementar para a definição de cada capacidade jurídica dos cidadãos livres em Roma; ou seja: mesmo no direito romano, a idéia de capacidade jurídica não é de todo separada de uma concepção de necessidade política da instituição jurídica, e os desenvolvimentos do próprio direito romano também passam por uma revisão dessa dimensão política do seu próprio corpus. Não houvesse essa concepção, a propósito, a própria concepção do jus gentium, tal como fundada especificamente pelos romanos (um corpus juris específico para os negócios entre estrangeiros ou entre estrangeiros e romanos), não teria sido produzida pela experiência prática jurídica. 
A menção ao direito romano é aqui relevante porque é bem presente, entre os juristas mais que entre os filósofos políticos mais separados da prática institucional, nas concepções jurídicas do século XVII; quando uma teoria jurídica lida, aí, com a definição dos direitos, ela tem como problema de fundo a idéia classicamente romana de instituições jurídicas: não uma formalização de direitos subjetivos concebidos como necessários, mas medida da legitimidade e aplicabilidade de qualquer direito. Se é o caso de questionar o que são os direitos subjetivos e quais são eles, é preciso, primeiro, dar conta desse estatuto da instituição jurídica.

É o que ocorre (de forma relevante para o desenvolvimento das teorias jurídicas holandesas) quando chegamos a Grotius, pois como ele é produzida uma inovação no conceito de direitos da pessoa. Grotius, convicto de que o homem é criatura de Deus e que Deus é autoridade sobre a natureza e a liberdade humana, considera todavia — e nisso reside sua parcela de racionalismo - que é possível à observação racional da política apreender a realidade de certas faculdades humanas de ação que são próprias da natureza humana. Isso significa que, se é mantida a distinção entre um direito da pessoa determinado por lei positiva, e um direito da pessoa concebido a partir das faculdades individuais e naturais do seu portador, estas faculdades devem ser sempre levadas em consideração. Ou seja, se o direito civil concede ou não a prática de determinadas ações a uma pessoa, só há legitimidade nessa concessão (ou nessa proibição) desde que a faculdade natural de agir dessa pessoa não seja violentada. Numa palavra, para Grotius, e para o jusnaturalismo moderno em geral, os direitos de qualquer pessoa são determinados não simplesmente por uma autoridade, mas antes de mais nada são idênticos às faculdades dessa pessoa. Ora, em Grotius nós temos o realce de uma idéia de direitos subjetivos fundada no próprio sujeito de direito e que é movida por um princípio independente tanto da vontade divina (que ao que parece decidiu deixar as coisas como já estão: no plano da história secular, o devido e o indevido segundo a ótica da reta razão humana não terão influência transcendental) quanto das instituições jurídicas (que passam a ser concebidas como resultado do pensamento jurídico que se dedica à reflexão sobre os direitos subjetivos): em Grotius, essa medida imutável diante das instituições é a facultas. Está criado o problema tipicamente jusnaturalista da determinação dos direitos subjetivos: como passar das faculdades naturais e racionais dos homens para as faculdades jurídicas e civis na vida política? Por criação e determinação de direitos subjetivos no século XVII, o problema será basicamente a criação de faculdades de ação segundo faculdades naturais ou racionais.

Para os romanos, faculdade e capacidade para a ação eram a mesma coisa - o que significa que as faculdades humanas para a ação na vida civil eram determinadas, na prática, pela própria Cidade. A partir de Grotius somente (isso nem os escolásticos tardios como Suárez haviam 
consumado, por causa da idéia de faculdade humana determinada pelas instituições de inspiração teológica), essa faculdade enquanto faculdade institucional perde força, e o conceito empreendido por Grotius é o de faculdade natural para a ação, que por ser uma faculdade natural não pode ser desconsiderada também enquanto faculdade civil. Mas quem é aquele que determina expressamente quais são as faculdades naturais? Essa é uma questão teórica que define os juristas dos Seiscentos na qualidade de jusnaturalistas: eles conceberão, normalmente, que existem faculdades universais, presentes na natureza humana e válidas para todos os homens — faculdade para o livre pensamento, por exemplo; ainda que não a faculdade para a livre manifestação desse pensamento —, da mesma maneira como considerarão que uma obrigação qualquer depende também da vontade daquele que é obrigado à ação: sua insubordinação voluntária à autoridade civil soberana equivale a uma declaração de inimizade com relação ao Estado, e perda simultânea da condição jurídica de patrício.

Há, aí, um projeto notável dos jusnaturalistas seiscentistas, ainda não reconhecido na justa medida pela historiografia do jusnaturalismo (até porque esta vem por vezes de uma perspectiva que defende uma concepção rival): o que curiosamente passa a ser projetado pelos jusnaturalistas, nessa teoria que obriga o direito civil a ser expressão das faculdades naturais, é uma ciência jurídica racional que se pretende indicadora de um elenco universal de faculdades humanas, ou seja, de direitos naturais subjetivos, que possa ser reconhecido por qualquer Estado e ser base para qualquer conjunto de leis, da mesma maneira como já vinha sendo trabalhada, desde o século XVI (por Bodin especialmente) como teoria das instituições jurídicas do Estado e da soberania da autoridade política. Na perspectiva corrente dessa ciência jurídica seiscentista, os direitos subjetivos criados pela lei civil não podem ser incompatíveis a nenhuma faculdade natural humana.

Em Hobbes, o único filósofo a rivalizar com Grotius antes da aparição de Pufendorf, há uma radicalização dessa concepção de direitos naturais subjetivos, com relação à concepção grociana. Em Hobbes, mais que simples faculdades (que sempre dependem de um reconhecimento do direito civil para se tornarem, de fato, direitos na vida civil), os direitos naturais são determinados pelos apetites individuais, cujo conteúdo, portanto, é muito mais ligado à índole da cada sujeito de direitos do que na perspectiva de Grotius. Se em Grotius nós temos a idéia, tipicamente jusnaturalista, de que os direitos de cada pessoa, naquilo em que são universais, podem ser reconhecidos pela razão e portanto ser objeto de uma ciência dos direitos naturais, em Hobbes mantém-se a idéia de inteligibilidade dos direitos da pessoa, mas enquanto direitos naturais trata-se não exatamente de direitos universais, mas de direitos individuais de cada pessoa; a grande perversidade da concepção hobbesiana estará, porém, na base da elaboração do seu 
elenco de direitos subjetivos e partirá, como vimos, da alienação dos direitos naturais: na prática, da concepção de que a vida civil é uma vida na qual os apetites emudecem e todos são domínio daquele que tem a faculdade jurídica absoluta sobre a comunidade política, o soberano.

Em Hobbes, o apetite individual é índice da faculdade individual natural; ocorre que esta faculdade natural para a ação, guiada pelo apetite, exige ser substituída pela faculdade civil: ou seja, na visão hobbesiana, os direitos naturais individuais são inválidos no estado civil caso sejam contrários ao direito civil, à vontade do soberano, às regras enfim da vida política institucionalizada. Isso não é de maneira nenhuma, porém, um positivismo jurídico em Hobbes. Unicamente Hobbes sabe que é inútil considerar faculdades naturais enquanto direitos propriamente ditos quando tais faculdades são contrárias à vontade soberana: elas, simplesmente, não podem ser pleiteadas a ninguém na qualidade de direitos. O que Hobbes sabe, porém - e é também uma convicção jusnaturalista —, é que mesmo quando a faculdade natural de um indivíduo pede ou permite algo que não é permitido pela lei civil, melhor seria modificar a lei civil — mas enquanto essa lei tem poder sobre o súdito, a este resta conformar sua própria natureza a ela.

\section{O que faz Espinosa?}

No caso específico dos direitos naturais, Espinosa inicialmente parece concordar com a posição hobbesiana, na concepção célebre — presente em ambos - de que em sua condição natural cada indivíduo pode fazer o que bem entender e tiver forças para realizar. Bem explicando, no estado de natureza não há direitos para agir (no vocabulário jurídico, isso é uma entidade do estado civil), e sim capacidade ou incapacidade física para agir. Tais direitos subjetivos, mostrara Hobbes, aparecem enquanto tais unicamente no estado civil, ou no momento em que os homens estão na sua condição de cidadãos. E tais direitos subjetivos, mostra também Espinosa, aparecem somente na condição civil dos homens, só que, diferentemente de Hobbes, em Espinosa fica claro que a designação dos desejos individuais enquanto direitos subjetivos é apenas nominal: como, em Espinosa, o direito de cada ser é idêntico à sua potência, ou seja, como Espinosa identifica direito e potência, não caberá em Espinosa falar de direitos subjetivos seja à maneira dos romanos, seja à maneira dos jusnaturalistas.

Em primeiro lugar, o caso dos romanos. Se, em Espinosa, o direito de cada ser a agir ou deixar de agir é medido e determinado pela sua potência individual, isso significa evidentemente que é uma violência à natureza de cada cidadão ou súdito permitir que seus direitos sejam determinados por alguma autoridade, que por definição é uma instância exterior e hierarquicamente superior a ele. Ao contrário, é necessário que a instituição civil opere não como autoridade separada 
do cidadão, mas enquanto instrumento da própria potência do cidadão. Se é um fato que a autoridade civil determina leis à vida civil, e se por conseqüência tais leis pretendem determinar os direitos subjetivos de cada cidadão ou súdito, é necessário que o conteúdo do direito subjetivo determinado pela lei seja idêntico à necessidade ou potência que constitui o cidadão. Se a autoridade civil impede uma ação desejada pela necessidade individual de uma pessoa em sua vida civil, o que ocorre é uma contradição inconciliável entre a vontade do Estado e a necessidade do cidadão, contradição esta que só pode ser contornada pelo desrespeito à vontade da autoridade, simplesmente pelo fato de que, por estar essa autoridade separada do próprio cidadão, não poder ela determinar as necessidades desse cidadão. Assim, não cabe espinosanamente considerar que as leis civis determinam os direitos naturais, ou melhor, as faculdades naturais de ação de cada indivíduo. As leis civis determinam as faculdades civis, o que em nada impede a violência das instituições do Estado sobre o cidadão.

Em segundo lugar, o caso de Grotius. Se é verdade que o próprio Grotius já sustenta uma concepção de que a autoridade civil tem sua legitimidade devendo ser determinada por uma razão natural, e seus conteúdos devendo ser compatíveis com o direito natural objetivo e os direitos naturais subjetivos, ainda há, em Grotius, a presença de uma autoridade separada de cada cidadão: o Estado a partir do momento em que se constituiu como Estado legítimo e dedicado à prática institucional da justiça. Em resumo: na visão de Grotius, desde que o Estado tenha garantido uma ordem jurídica e política na qual os direitos dos cidadãos são reconhecidos para a universalidade dos cidadãos e funcionem, na vida política, enquanto seus direitos naturais, está cumprido o papel dos direitos naturais. Estes são faculdades naturais, que só valem enquanto direitos desde que reconhecidos oficialmente como tais. Daí a lição grociana de que as leis civis não podem ser cegas às faculdades naturais. Mas estas são identificadas não pela vontade ou desejo individual de cada um, e sim por uma certa racionalidade jurídica ou ciência racional do direito cuja tarefa é estabelecer o elenco dos direitos naturais e desse mesmo elenco legitimar que o Estado decida sozinho o restante dos seus conteúdos. Por que isso é um problema para a visão espinosana? Porque, também em Grotius, há um momento no qual o súdito é concebido como separado do Estado enquanto produtor de suas próprias leis e estipulador dos direitos subjetivos. Se em Grotius os direitos subjetivos são fundamentalmente faculdades, estas em Grotius tendem a ser concebidas num quadro ideal das faculdades humanas, e não enquanto o efeito da necessidade individual de ação conforme reconhecível pela razão de cada indivíduo. Numa palavra: espinosanamente, qualquer direito subjetivo que não é de fato sentido enquanto necessidade por um indivíduo, não cabe ser dito sequer sua faculdade. Portanto, em Espinosa, é insuficiente considerar o direito enquanto uma faculdade do indivíduo. 
Em terceiro lugar, Hobbes. Aqui a diferença no caso dos direitos naturais diz respeito diretamente à concepção da política legítima enquanto uma democracia. Se em Hobbes cabe considerar que o soberano, separado enquanto autoridade do seu súdito, pode por vontade própria determinar quais são os direitos subjetivos de quem quer que seja, em Espinosa sempre que há essa separação entre soberania e cidadania não há mais vida política, exatamente porque a liberdade necessária de cada indivíduo passa a ser violada pela imposição institucional de uma idéia de capacidade para a ação que nada revela da potência de cada indivíduo, mas em vez disso revela a servidão universal que o soberano despótico quer impor como marca dos seus súditos. Em Espinosa, como a única prática política legítima é a democracia, de forma alguma é tolerável ou útil um sistema de estipulação de direitos no qual o conteúdo dos direitos da pessoa não seja determinado pela sua própria potência. Assim, espinosanamente, não há como construir um direito subjetivo válido seja na monarquia, seja na aristocracia - no despotismo em qualquer grau, em suma.

Considerando Espinosa por ele mesmo.

A própria concepção espinosana da democracia envolve essa subversão dos conceitos clássicos e jusnaturalistas dos direitos naturais, porque a democracia exige, no ato de afirmação dos direitos e das leis, ausência de toda forma de exclusão institucional ou burocrática. A todo momento, o pensamento jurídico de Espinosa nos pede para ver as contradições crônicas dos elementos do próprio direito, de maneira que possamos voltar nossa atenção para a principal tarefa do cidadão enquanto jurista: conceber os seus direitos enquanto liberdades que precisam ser concretizadas. Assim como a democracia é uma prática política na qual cada cidadão toma parte na vida política — o que se faz de infinitas maneiras — , jamais se poderia conceber nela os direitos devidos a cada um como faculdades ou capacidades determinadas exclusiva e excludentemente por alguma autoridade separada do próprio agente-cidadão, seja essa autoridade política, religiosa, científica ou moral.

Portanto, se é um fato que a vida política também depende da existência e força das instituições, estas são instrumento da potência soberana (de todos os cidadãos, portanto), e deixam de ter qualquer legitimidade quando são operadas contrariamente ao que é necessidade pública. Jamais uma instância civil legislativa é legítima quando legisla voltada para interesses particulares ou quando legisla em detrimento do interesse público. A imposição de limites, pois, à ação individual de qualquer cidadão é ilegítima quando se volta para o benefício de particulares com isso, em vez de ser criado um direito, são criadas impotências, de um lado, e reforçados 
privilégios, de outro. O que a democracia pede, enfim, enquanto idéia de direitos subjetivos ou “direitos naturais", numa perspectiva não jusnaturalista, é o reconhecimento jurídico de que as necessidades individuais valem por si mesmas (não cabendo, porém, a nenhuma autoridade e nenhum modelo racional jusnaturalista falar em lugar de cada cidadão). Isso, no que diz respeito à idéia de direitos subjetivos, porque em termos contemporâneos (é sempre o caso de considerá-los quando se trata do conceito espinosano de democracia) é o caso também de considerar o que esse racionalismo jurídico espinosano tem a dizer sobre o tema dos direitos humanos. Não é possível colocar e aprofundar esse problema aqui; cabe, todavia, ao menos sugeri-lo:

Os direitos humanos são, em linhas gerais, a forma contemporânea dos direitos subjetivos naturais universais concebidos pelo jusnaturalismo moderno. É o caso de considerar essa semelhança na medida em que em ambos os casos há a concepção de certos direitos tidos como válidos universalmente para os seres humanos, na qualidade de seres humanos (o que envolve serem pessoas dotadas de vida civil, familiar, profissional, intelectual e assim por diante). Ocorre, porém, uma grande diferença: no horizonte jusnaturalista, tais direitos são não apenas universais como são apreensíveis pela razão humana — no sentido de que seria possível a uma ciência racional da política e do direito estabelecer um elenco dos direitos. No caso dos contemporâneos e é claro que em especial nas últimas décadas, o que se considera direitos humanos não é um conjunto de direitos naturais que todo ser racional pode considerar como válidos, mas sim um certo elenco de direito sugerido por uma instituição como devendo ter validade universal, ao menos ali nas ações em que se considera importante garantir com justeza os direitos sem os quais os cidadãos não podem ser considerados completamente livres.

Nisso, sempre houve da parte dos contemporâneos uma crítica à idéia de uma fundamentação racional dos direitos humanos, por se considerar que uma tal concepção racionalista dos direitos subjetivos universais nada mais seria que um modelo intelectual de cidadania, e que melhor que tentar elaborar o modelo racional universal dos direitos humanos (projeto aliás impossível), deve-se garantir a existência de tais direitos, sejam eles quais forem. E, melhor do que discutir quais devem ser os direitos humanos, melhor é comemorar a existência dos que já foram oficializados e pô-los em prática. ${ }^{202}$ Posição prática acertadíssima, mas a crítica ao modelo racional deixa no caminho um preconceito contra a consciência racional dos fundamentos dos direitos subjetivos e da política.

Em termos espinosanos, é importante deixar a cada comunidade política a criação dos seus próprios direitos, já que seus direitos são expressão da sua potência individual (e por isso não

202 Posição de Norberto Bobbio. Cf. N. Bobbio, A era dos direitos, bem como a Introdução deste trabalho. 
cabe a criação ou aplicação de nenhum modelo exterior). Mas isso não significa de forma alguma que a este elenco de direitos subjetivos basta existir, isto é, basta que ele tenha qualquer conteúdo. Há, em Espinosa, uma exposição clara de que a ação política não pode ser excludente nem deixar de ter uma forma e conteúdos democráticos. O que o pensamento jurídico espinosano faz ver, portanto, no que diz respeito aos direitos humanos, é que há necessidade, sim, de uma fundamentação racional específica para a concepção ou aplicação seja dos direitos humanos, seja de quaisquer direitos — pode-se falar, em Espinosa, de um racionalismo democrático que exige o reconhecimento da legitimidade do Estado enquanto criador de direitos que são sentidos como necessários pelos seus próprios cidadãos, e não que sejam concebidos apenas como válidos para qualquer sociedade ou Estado que se pretendem democráticos. Assim, se é o caso de fazer de alguma forma uma ciência racional do direito, essa só poderá ser, em termos espinosanos, uma ciência da prática individual, social e institucional do direito enquanto direito democrático.

A historiografia do jusnaturalismo considera Espinosa um mau jusnaturalista também em função desse seu desinteresse em cumprir aquilo que, para seus colegas, é uma questão de honra dentro do universo jurídico: a elaboração de um elenco de direitos subjetivos ou de um modelo para a determinação desse elenco. Essa imagem do jurista incompetente é de certa forma endossada pela comparação ostensivamente feita, nestes termos, com as teorias jusnaturalistas de Pufendorf e Locke, que buscam dar conta dessa tarefa doutrinária e, de formas diversas, sustentam a idéia de fundação de um sistema jurídico numa idéia de direito natural subjetivo - a integridade moral em Pufendorf, a propriedade em Locke —, da mesma maneira que conta, já, com as críticas a Espinosa feitas pelos próprios Pufendorf e Locke.

Ora, se os juristas seus contemporâneos consideram que a melhor prova da inaplicabilidade do seu pensamento jurídico é a impossibilidade, determinada pela concepção excêntrica do jus como potentia, de constituição de um elenco de direitos que valesse universalmente (afinal, que outra maneira de estipular publicamente o devido e o indevido, especialmente quando o próprio Espinosa reconhece que isso é um privilégio da autoridade soberana? — de onde, portanto, esse panteísta tira a conexão racional para deduzir seja a identidade entre direito e potência, seja mesmo a constatação - até esta, talvez, merecendo ser recebida com certa desconfiança: será constatação, realmente? - de que é a autoridade soberana quem comanda na civitas?), os juristas nossos contemporâneos, abrigados nos paradigmas já do positivismo jurídico, consideram que sua teoria jurídica sequer serve de inspiração para a elaboração de um pensamento jurídico contemporâneo ou, muito menos, alcança o mérito de resolver, ela mesma, algum problema jurídi- 
co atual. Passado, pois, o tempo do jusnaturalismo e percebido, também, que em Espinosa não há antecipação de nada (nem da teoria contemporânea da democracia, que pelo jeito nada tem a ver com aquela "idealizada" por Espinosa), o jeito é enterrá-lo junto com o jusnaturalismo, não importa quantas vezes isso for necessário, tanto quanto é necessário ao positivismo jurídico reenterrar o jusnaturalismo. Se, portanto, aos juristas do seu tempo valia a pena apresentar uma refutação à concepção espinosana de jus (que era para eles o inverso do que deveria ser, no século do sujeito, um conceito de direito), para a leitura contemporânea o seu anacronismo é superado mesmo pela sua falta de sentido, e Espinosa assume, nestes termos, uma irrelevância sepulcral.

Não poderia ser diferente. O que Espinosa faz com sua filosofia é uma teoria jurídica que exige, do pensamento jurídico assim como da prática jurídica, a concepção democrática do direito. O que é um desafio para o leitor jurista, na medida em que a filosofia jurídica espinosana é voltada, também ela, para um "leitor filósofo". Sempre que os textos espinosanos sobre o direitos são interpretados segundo um padrão externo ao seu sistema, a aplicabilidade e atualidade do seu pensamento se oculta; inversamente, quando aceitamos "a estranheza do pensamento espinosano", 203 percebemos que o que une todos os conceitos e análises construídos pelo seu pensamento político é a idéia de democracia. A concepção racionalista da política e do direito, em Espinosa, não idealiza, mas demonstra a necessidade democrática da vida política (porque nenhuma sociedade política exige a exclusão, nenhum indivíduo político exige ser excluído, e todos desejam tomar parte na determinação da sua própria liberdade), da mesma forma como demonstra a necessidade democrática do "jurídico" (porque a liberdade humana exige reconhecimento público, porque a vida civil exige igualdade de direitos e oportunidades). Porque parte da concepção de que o conatus é a essência atual de cada indivíduo e mantém ininterruptamente essa concepção, Espinosa determina, como princípio racional da vida política e da condição jurídica, a necessidade histórica da vida democrática como criação e exercício de direitos sem exclusão de qualquer pessoa. É esse o conceito de democracia que está no horizonte do pensamento democrático desde a sua fundação e que exige, da prática política e jurídica, ser fundação de uma idéia racional (porque necessária) de direito: a potência de cada cidadão na vida civil, em função da sua necessidade individual (ou seja, aquilo sem o que o indivíduo deixa de ser o que é por sua natureza) e da necessidade coletiva de paz e concórdia. Essa expressão, tomada como ideal tanto por modernos como contemporâneos - que caminham ao lado da idéia de Estado como organizador da vida coletiva, como instaurador da segurança - em Espinosa é determinada como fundação de direitos para todos os integrantes do corpo político que constitui a civitas — da comunidade polí-

${ }^{203}$ Marilena Chauí, $A$ nervura do real, vol. 1, p. 37. 
tica -, ou seja, para todos os integrantes da multitudo, sem exclusão de quem quer que seja. Contra, pois, as concepções jurídicas que consideram que a criação de direitos só é possível desde que esses direitos sejam operados como privilégios, contra a idéia de que um direito já vale apenas por estar descrito num ordenamento jurídico, contra a idéia de que a exclusão é natural da necessidade de uma comunidade política, e a todo momento contra as sátiras e utopias que concebem, entre outras coisas essa desnaturação voluntária de cada um —, Espinosa exige, por uma necessidade racional (sem nenhuma determinação moralista, sem nenhum apego a alguma ideologia jurídica, sem nenhuma apologia da supremacia do Estado sobre o cidadão), que o fundamento do Estado não seja a potestas — que é, por definição, instrumento e estratégia de exclusão - , e sim um a pax. Esta, o que é? Quando notamos a racionalidade completamente politica da teoria jurídica de Espinosa - o inverso absoluto, portanto, da concepção kelseniana, na esteiras da qual correu a maior parte da dogmática jurídica do último século —, notamos que qualquer noção de legitimidade para os conceitos e instituições da vida coletiva só podem ser fundados naquilo que o ser humano tem de mais concreto, sua potência. O maior desafio da prática política de qualquer tempo nunca será a instauração do poder — essa coisa que sempre esteve aí e sempre estará. O maior desafio, e que constitui o grande incômodo trazido por Espinosa a todo leitor jurista, é a concepção de um direito cuja racionalidade não siga do arbítrio de uma autoridade, mas sim da consistência entre necessidade individual e ordem racional. Quais devem ser os direitos subjetivos, num elenco espinosano, esse elenco que tem de fazer, portanto, a economia da idéia de sujeito de direitos — de modelo de suporte de direitos subjetivos? Não é essa a pergunta a ser feita, e sim outra: Quais são as faculdades jurídicas que não podem ser concebidas? Resposta: são todas aquelas obrigações e deveres que são contrários à natureza de cada indivíduo. A verdadeira tarefa de uma teoria jurídica democrática não é, num horizonte espinosano, a definição de um elenco de direitos: isso seria, já, limitar a liberdade ou capacidade para a liberdade nos cidadãos, e em vez de ser fundada a sociedade numa liberdade coletiva e portanto numa concepção comum de potência da multitudo, ela seria antes fundada numa idéia de impotência da multitudo, porque sua liberdade lhe vem sendo apresentada sob a imagem de uma concessão da autoridade soberana, e não como a conseqüência da necessidade atual e maximamente dinâmica de cada indivíduo, essa necessidade que nenhuma codificação pode enclausurar nem mesmo alcançar, e que à autoridade soberana cabe, necessariamente reconhecer e garantir, se não quer revelar o seu próprio despotismo.

Feito, pois, o percurso de reconhecimento da juridicidade do pensamento espinosano sem que partíssemos dos modelos externos de pensamento jurídico, reconhecemos agora tanto as dimensões dessa diferença entre Espinosa e os outros juristas, quanto o peso quase insuportável 
que sua concepção serena de direito traz a todo pensamento jurídico que insiste em conceber o direito como dominação, e não como liberdade: se o pensamento jurídico não reconhece que todo direito só faz sentido racional como exercício de uma necessidade atual, a democracia é impossível, e o perigo das grandes desgraças está sempre em volta das vítimas do Estado: nessa perspectiva, seus próprios cidadãos. Silenciada, pois, diante do positivismo jurídico a voz jusnaturalista dos filósofos idealistas que Espinosa, dois séculos antes, já havia cuidado de refutar e renegar, e constrangido, agora, o pensamento jurídico que ousa fundar-se na ausência de justificação racional (e não se importa em investir na imagem da utilidade da exclusão para esta ou aquela elite) pelo peso da concepção espinosana de direito que se revela necessariamente concepção de direito democrático e concepção jurídica racional de democracia, em que termos a teoria jurídica contemporânea pode lidar com o estranhamento do pensamento espinosano sem aceitar as certezas que sua crítica ao irracionalismo jurídico aponta? Diante da Espinosa, e sem o peso de toda a imagem toscamente elaborada por todos aqueles que não compreenderam a necessidade de um racionalismo jurídico democrático, abre-se enfim o caminho para a exploração racional, ainda que no campo jurídico, do conceito ontológico e político de justiça. Não foi à toa que Espinosa trazia, em seus textos contra o irracionalismo teológico, a bandeira da justiça e caridade: era a apresentação da concepção ontológica e política de concórdia elaborada na Ética, e que no plano da política se camufla na expressão paz, e segurança, exigindo, tanto de um lado como do outro, a autodeterminação de uma potência coletiva que, existente e fortalecida, mostrará o único conceito de justiça que só pode ser concebido numa democracia, e sem o qual uma democracia não pode, ela mesma, ser concebida. 


\section{CAPÍTULO 6 \\ DA JUSTIÇA AO DIREITO JUSTO}

Direção proeminente dentro da teoria do direito natural, usualmente designada como "racionalista", é aquela cujos representantes vêem a natureza do homem na sua razão e, conseqüentemente, procuram deduzir da razão as normas de um direito justo. Eles admitem que estas normas são imanentes à razão ou, o que dá no mesmo, que a razão, como autoridade normativa, como legisladora, prescreve aos homens a conduta reta, isto é, a conduta justa. Este direito natural surge assim como direito racional. $\mathrm{O}$ justo é o natural, porque é o racional.

H. Kelsen, O problema da justiça, p. 85.

\section{I JUSTIÇA DESMISTIFICADA E NECESSIDADE DA JUSTIÇA}

A justiça, esse tabu na filosofia jurídica contemporânea, ${ }^{204}$ é um tema precioso para os juristas do século XVII. Curiosamente, o que motiva essa passagem quase obrigatória pelo tema entre os autores modernos é uma necessidade comum de superação das doutrinas jurídicas cristãs medievais. Se é verdade que o jusnaturalismo moderno é marcado ora por uma base contratualista, ora por uma concepção secular do poder político-jurídico, todos os autores dessas “teorias dos direitos naturais" desenvolvem uma forma de pensamento jurídico separada finalmente da teologia jurídica que domina toda a Idade Média desde santo Agostinho. Essa concepção cristã da justiça, que é retomada e reforçada em especial por são Tomás de Aquino e uma corrente de juristas de inspiração tomista que se dedicam com muita atenção ao assunto pelo final da Idade Média e ainda pelo Renascimento, pressupõe uma distinção entre a justiça humana e a justiça divina, considerando uma necessária subordinação das instituições seculares em relação às religiosas ou teológicas. Nessa hierarquização, que desde santo Agostinho determina que só na Cidade de Deus é possível alcançar a justiça verdadeira (pois só ela é fundada na perfeição da

204 Insisto nessa designação. Embora o tema da justiça sempre reapareça no panorama do pensamento jurídico e, especialmente (como mencionado na Introdução), marque a discussão jurídica anglo-saxã desde o início da década de 1970, sua repercussão e seu aprofundamento dá-se mais fora dos círculos jurídicos — nos círculos de filosofia política ou ciências sociais — do que propriamente neles. 
vontade divina), a justiça humana recebe uma sentença, irrefutável segundo a teologia, de incapacidade de estabelecer a justiça perfeita na terra. Os homens, na vida terrena, têm todos a condição comum da imperfeição e da impossibilidade de se alçarem por si próprios à perfeição, ao mesmo tempo que não podem, por causa da vontade divina, deixar de buscar sua redenção pela religião. Assim, em linhas gerais, o que marca o pensamento jurídico teológico por mais de um milênio até os inícios do Renascimento é uma complexa doutrina teocrática que considera que Deus é uma figura soberana tanto sobre a ordem do universo quanto sobre o destino e as instituições dos homens - a concepção teológica de Deus como princeps, tão criticada por Espinosa no Tratado teológico-político como marca de falta de conhecimento da ordem necessária da natureza - e, nesse horizonte, cada indivíduo está condenado a conviver, antes de completar o árduo caminho por sua redenção após a morte, com duas ordens institucionais terrenas: a instituição da Igreja, que é representante na terra da autoridade divina e imagem da perfeição hierárquica da natureza segundo a vontade de Deus, e as instituições políticas seculares, que apesar do caráter não eclesiástico deixam-se subordinar à ordem teológica e geralmente estão por isso cooptadas com uma concepção teocrática do poder político-jurídico.

Quando são Tomás, já presente a um momento muito posterior ao esfacelamento das instituições originais do direito romano no diversos sistemas jurídicos regionalizados que se espalham pela Europa no final da Idade Média e prenunciam o desafio futuro da uniformização dos regimes jurídicos, dedica-se à sistematização das grandes doutrinas jurídicas do pensamento medieval pela guia da teologia, sua obra acaba por operar o estabelecimento definitivo da hierarquia teocrática da lei e da justiça divinas sobre as instituições humanas. De fato, o que é deixado pelos textos tanto de são Tomás quanto especialmente dos seus seguidores, é uma defesa da concepção teocrática da justiça, como modelo para a prática jurídica de qualquer instituição e conteúdo de validade universal para toda regra de ação e crença. Quando, nos inícios do pensamento moderno, é iniciado todo um projeto de separação entre a Igreja e as instituições políticas fundação marcada em especial pelo pensamento de Marsílio de Pádua —, a construção dessa concepção secular das instituições políticas alcançará adeptos por todo o continente, mas sempre sofrerá com a insistência da concepção teológica da justiça que é tida como a finalidade ou função das instituições jurídicas. Essa idéia teológica ou teocrática de justiça, mais do que a concepção (já contraditada pelas próprias instituições políticas renascentistas) de uma ordem política terrena governada pela Igreja ou fundada numa ordem eclesiástica, ainda é um princípio moral que permanece sem total refutação às portas do século XVII. Não por acaso, se os jusnaturalistas não têm grandes dificuldades em desenvolver uma teoria do Estado separada da idéia de poder político da Igreja (da mesma forma como relegam à Igreja o papel de instituição 
religiosa apenas, quando não de anti-instituição política), têm todavia como tarefa a elaboração de uma idéia outra de justiça, que não permita o acesso enviesado das doutrinas teológicas como fundamento moral do poder político, nem estabeleça para a teoria política uma perda de objetividade que lhe comprometeria sua própria preservação; não por acaso, ainda, essa superação da justiça teológica recebe, dos juristas dos séculos XVI e XVII, uma formulação completamente nova, porque baseada exclusivamente na justiça política, um princípio retomado dos jurisconsultos romanos e defendido como bandeira da objetividade jurídica por uma série de professores de direito romano nas universidades européias, dos quais um dos mais célebres e combativos foi, sem dúvida, Jean Bodin.

Não me parece o caso, porém, de propor aqui uma história dessa notável teoria da justiça que funda essa ciência jurídica moderna. ${ }^{205}$ Ao invés disso, e no que diz respeito já ao lugar de Espinosa nesse horizonte teórico, parece-me que o tema da justiça, tal como chega ao pensamento jurídico moderno, coloca para este um problema teórico que não pode ser resolvido sem o estabelecimento de uma forma metodológica nova para a reflexão sobre o Estado: como conceber um conceito racional de justiça que não dependa necessariamente da validação teológica? É para responder a essa questão, parece-me, que o pensamento jurídico moderno acolbeu uma mudança em seus padrões metodológicos, conduzindo, no campo da teoria jurídica, a uma retomada das doutrinas fundadas na estrutura mesma das instituições jurídicas historicamente dadas (Bartolo de Saxoferrato, Jean Bodin, Guillaume Budé) e, no campo da reflexão jurídica, exigiu uma precisão conceitual fundada em certezas tão irrefutáveis quanto aquelas alcançadas pelas matemáticas (Hugo Grotius, Thomas Hobbes, Samuel Pufendorf, Christian Wolff) ou evidência histórica tão presente quanto as que só a experiência empírica fornece ao observador das instituições humanas (Maquiavel, Francis Bacon, Thomas Hobbes novamente). Nesse panorama, o papel dos juristas romanistas foi fundamental para a estipulação, nos costumes jurídicos, de um vocabulário maximamente secularizado sobre a estipulação da justiça nas instituições humanas; especialmente, foi essa concepção realista, empenhada em estabelecer tanto nas instituições jurídicas quanto no pensamento em volta dessas instituições, que determinou o caráter do pensamento jurídico mais apropriado às recentes teorias da soberania e do Estado. No âmbito da filosofia, é especialmente em Hobbes que essa secularização atinge um ponto sem réstia alguma das concepções clássicas da justiça, quando ele afirma, no De cive, que a injustiça consiste no desrespeito ao que a reta razão mostra como uma lei verdadeira (“[...] já que todos reconhecem que é conforme ao direito aquilo que não viola a razão, devemos considerar injustas apenas as

\footnotetext{
205 Isto, sem dúvida, é um dos tantos temas em volta deste trabalho que merece uma atenção historiográfica exclusiva, e que a propósito ainda não recebeu o devido tratamento da parte dos historiadores do pensamento jurídico moderno.
} 
ações que repugnem à reta razão, ou seja, que contradigam alguma verdade segura, inferida por um correto raciocínio a partir de princípios verdadeiros. E a injustiça que é cometida, dizemos que é cometida contra a lei.” ${ }^{206}$ e, no Leviatã, que a injustiça existe apenas no estado civil, já que só se comete injustiça quando se quebra um pacto firmado com alguém já na vida civil (" $\mathrm{Na}$ terceira lei de natureza: Que os homens cumpram os pactos que celebram.], reside a fonte a a origem da justiça. Porque sem um pacto anterior não há transferência de direito, e todo homem tem direito a todas as coisas, conseqüentemente nenhuma ação pode ser injusta. Mas, depois de celebrado um pacto, rompê-lo é injusto. E a definição da injustiça não é outra senão o não cumprimento de um pacto. E tudo o que não é injusto é justo.") 207. Ou seja, assim como fizera com respeito à paz ("ausência de guerra"), o conceito hobbesiano de justiça é um conceito negativo: ausência de injustiça, que consiste simplesmente na quebra dos pactos, na deslealdade. A noção espinosana de justiça, tal como apresentada na Ética e nos seus textos políticos (mas não na sua crítica à teologia: lá a concepção, como veremos, é diferente - e fundamental), é muito semelhante à de Hobbes e, não por acaso, enche os olhos de quem quer ver em Espinosa um seguidor do filósofo inglês:

Na Ética, o tema da justiça aparece no mesmo escólio 2 da proposição IV, P37 em que Espinosa trata também do estado de natureza e do estado civil; ali, ele apresenta uma definição "do justo e do injusto" a partir da definição prévia da distinção entre estado de natureza e estado civil, assim como a distinção entre o pecado e o mérito, pois sem todas essas noções, a idéia de justiça (seja lá o que ela for) não faz, ainda, sentido:

Cada um existe em virtude do direito supremo da Natureza e, conseqüentemente, é em virtude do supremo direito da Natureza que cada um faz o que segue da necessidade da sua natureza; e, por conseguinte, é em virtude do supremo direito da Natureza que cada um julga o que lhe é bom e o que lhe é mau e atende à sua utilidade, como lhe convém, e se esforça por conservar o que ama e destruir aquilo a que tem ódio. [...] [É sobre a lei da transferência dos direitos naturais à autoridade soberana] que a sociedade poderá fundar-se, com a condição de ela reivindicar para si o direito que cada um tem de se vingar e de julgar do bem e do mal. Conseqüentemente, ela deverá ter o poder de prescrever uma regra comum de vida, de fazer leis e de as apoiar não na Razão, que não pode entravar os afetos, mas em ameaças. Tal sociedade, firmada em leis e no poder de se conservar a si mesma, chama-se Cidade, e os que são defendidos pelo direito dela, cidadãos.

Como premissa, a diferença entre estado de natureza e estado civil: no estado natural, cada um julga segundo seu próprio desejo o que é devido ou não; a idéia de uma regra única que determine universalmente o devido a cada um depende hipoteticamente de uma razão única e soberana, que é a marca do estado civil considerado como um estado no qual todos anulam seus direitos natu-

206 Thomas Hobbes, Do cidadão, livro I, capítulo II, \1, p. 38.

207 Thomas Hobbes, Leviatã, cap. XV, p. 88. 
rais, o que, em termos espinosanos, significa unicamente deixar de seguir o impulso determinado naturalmente pelos afetos ou pelo desejo. A marca da distinção imaginada entre estado de natureza e estado civil - segundo os contratualistas, mostra Espinosa na verdade - é a idéia de que é possível apagar o desejo através da razão; mais do que isso, que é possível, no horizonte de uma comunidade política, refrear os desejos individuais por meio de uma razão soberana, tomada ela mesma como determinante do devido a cada um: ou seja, o que constitui o estado civil é essa condição exclusiva de uma medida universal do devido a cada um estipulada por uma potestas e à qual as condutas individuais devem, por hipótese, adaptar-se. Entretanto, a mesma filosofia espinosana reconhece que essa idéia de refreamento dos afetos é impossível, por causa dos afetos não serem contrários à razão, mas, ao invés disso, constituírem a essência mesma do homem. O que este escólio mostra é que a concepção de estado civil como saída do estado de natureza costuma ser interpretada segundo uma imagem que não corresponde à realidade da civitas (definida aqui nos mesmos termos com que Espinosa a define no Tratado político: uma comunidade política fundada nas leis civis e, por isto mesmo, sui juris, soberana): uma situação concreta na qual as ações são determinadas por um poder transcendente à necessidade individual de cada um. Como não é o momento oportuno para a análise da política, mas apenas para a indicação, no plano da Ética, da base ontológica das teses sobre a política, Espinosa não avança nessa esclarecimento; nem necessita, pois a função do conceito, aqui no escólio, é chamar a atenção do leitor adepto da concepção contratualista. Essa atenção é necessária para que Espinosa explique que, se o estado de natureza é considerado um estado não natural, não cabe ali algo que só caberá ao estado de natureza:

Pelo que precede, facilmente compreendemos que não existe nada no estado natural que seja bom ou mau por consenso de todos; é que qualquer um que se encontre no estado natural atende só à sua utilidade e distingue como lhe convém, e só enquanto tem em conta sua utilidade, o que é bem e o que é mal e não está obrigado por nenhuma lei a obedecer a ninguém, senão a si.

Ou seja: é só no estado de natureza tal como concebido pelos contratualistas que existe essa condição segundo a qual as ações individuais não têm nenhuma medida moral — exatamente o que Pufendorf criticaria em Espinosa, quando lesse sua exposição do estado natural, no capítulo XVI do Tratado teológico-político, como um estado de natureza tipicamente contratualista —, isto é, não há li noção razoável do bom ou do mau, do iníquo ou do equânime. O que o texto espinosano diz exatamente, porém, não é uma afirmação da realidade de um tal estado de natureza como distinto ou adverso ao estado civil, mas unicamente que no estado natural não faz sentido essa medida universal — esse "bom ou mau por consenso de todos" — que é específica da vida civil. Ou seja, se é o caso de considerar uma medida universal e transcendente do justo e 
do injusto, não é na natureza que se achará fundada essa medida, mas unicamente em algo que é concebido como não dizendo respeito ao estado natural. É possível conceber uma tal medida universal do bom e do mau; entretanto, não é possível concebê-la como sendo fundada na natureza: espinosanamente, toda medida universal do bom e do mau não segue da necessidade natural do que quer que seja.

Entretanto, esse cálculo do bom ou do mau é corrente na vida humana, justamente porque natural do homem: movido por seu desejo, o homem é essencialmente um ser que age em função do que sente como útil ou positivo para si, da mesma maneira que considera o útil e o positivo (assim como seus inversos) para os demais homens, de acordo com os afetos por que é tomado por esses outros homens e por si mesmo. Somos, por natureza, calculadores do útil e do melhor para nossos desejos e nossa liberdade, assim como para o que diz respeito aos outros indivíduos. Essa condição natural, porém, enquanto unicamente condição natural, nada determina para a estrutura da vida civil, porque não é dela que decorre o princípio fundador da sociedade (a busca da paz e da segurança):

Por conseguinte, no estado natural não se pode conceber o pecado; mas sim, no estado civil, em que se distingue pelo consenso comum o que é bom e o que mau e cada um é obrigado a obedecer à Cidade. Assim, o pecado não é outra coisa que a desobediência que, por essa razão, é punida só em virtude do direito da Cidade; e, ao contrário, a obediência é contada ao cidadão como mérito, porque, por esta mesma razão, é julgado digno de gozar das vantagens da Cidade.

Aparentemente, Espinosa se aproxima muito de Hobbes, quando este concebe a justiça e a injustiça como cumprimento ou descumprimento dos pactos firmados. Para Hobbes, justamente, a cláusula pacta sunt servanda (os pactos obrigam necessariamente e devem por isso ser cumpridos) é a medida racional da justiça na vida humana, exclusivamente uma vida civil nesse aspecto. Todavia, mais aproximado quanto a este ponto de Maquiavel, Espinosa não vê nos pactos a fundação de uma necessidade imanente a cada indivíduo (e por isso criadora de obrigações para ele), mas unicamente a declaração de uma aliança concebida entre os pactuantes. O que a concepção de estado civil contém em si mesma é, na verdade, a única condição racional a idéia de pecado, ou delito: quebra dessa aliança estabelecida entre a parte submetida a uma autoridade (no plano da civitas, o cidadão) e essa autoridade (no mesmo plano, a lei civil). Ou seja, só é concebível o delito na medida em que a aliança é operada como obediência. O que torna essa obediência racional nos termos do Teológico-político, é a necessidade da aliança, e não o temor do súdito em relação à autoridade coatora. Qual o movimento operado aqui, porém, à maneira de Hobbes (e que consiste subliminarmente uma crítica a Hobbes)? A concepção do devido e do indevido em função não de uma necessidade natural, mas em função de um temor do castigo por causa da prática do pecado ou do delito, que faz conceber a necessidade da ação não em 
função da natureza do agente (o que exige a filosofia espinosana e do que foge a filosofia hobbesiana), mas unicamente como impotência do agente diante de um poder mais forte que ele, porque coator no estado civil (e não porque mais potente segundo sua própria natureza). Ou seja: se é o caso de conceber o pecado, o delito, e em conseqüência a culpa, essa idéia está relacionada diretamente à imagem da incapacidade de se conceber uma medida do bom ou do mau fora da universalidade moral e imanente à necessidade da natureza. Donde as noções do justo e do injusto, na forma de noções vulgares - o devido e o indevido a cada um, segundo o que é determinado pela lei civil (tal como apresentadas, também, no Tratado teológico-político) ${ }^{208}$ —, são apresentadas como conseqüência dessa concepção elementar da ação na vida coletiva como movida pelo medo da coação:

Além disso, no estado natural ninguém é senhor de uma coisa por consentimento comum, nem existe nada na Natureza que possa dizer-se que é deste homem e não daquele, mas tudo é de todos; e, por conseguinte, no estado natural não pode conceber-se nenhuma vontade de dar a cada um aquilo que é seu, ou de tirar do outro que é seu, isto é, no estado natural nada sucede que possa dizer-se justo ou injusto, mas, sim, no estado civil, em que se discerne, por consenso comum, ou que é deste ou que é daquele. Por aqui se vê que justo e injusto, pecado e mérito são noções extrínsecas, não atributos que expliquem a natureza da mente. Mas sobre este assunto já basta.

Por que já basta? Porque é o suficiente para mostrar que a concepção do justo como o devido segundo o decreto de uma autoridade nada diz a respeito da necessidade da ação segundo a necessidade natural. O que este escólio mostra a respeito dessa definição vulgar da justiça, e o que os tratados políticos repetem na mesma medida, é que não é na lei civil que se encontra a chave para compreender em que medida uma ação ou condição é devida em função, pois, da necessidade do próprio agente ou indivíduo. Se é o caso de conceber uma medida de justiça que possa desprender-se dessa dependência do decreto da autoridade civil — o que, ao menos no estado natural, é válido - é preciso não partir do imaginário da potestas, denunciado por toda a obra espinosana como estratégia de justificação do domínio independentemente da necessidade das partes.

Todo o escólio já coloca a pista para a determinação dessa justiça separada da noção de potestas e, por isso, desmistificada: o estado natural. Em termos espinosanos (não contratualistas e não jusnaturalistas, mas elaborados segundo um racionalismo democrático), o estado natural nada mais é do que a necessidade natural de preservação da potência na determinação do devido a

\footnotetext{
208 TTP, cap. XVI: "A justiça é a disponibilidade constante para atribuir a cada um aquilo que, de acordo com o direito civil, lhe é devido; a injustiça, pelo contrário, consiste em tirar a alguém, sob uma falsa aparência de direito, o que lhe pertence segundo a verdadeira interpretação das leis. À justiça e à injustiça também se chama eqüidade e iniqüidade, porquanto os que estão incumbidos de dirimir os litígios não devem entrar em linha de conta com o estatuto social do indivíduo; estão, pelo contrário, obrigados a tomar todos por iguais, a defender igualmente o direito de cada um e a não invejar o rico nem desprezar o pobre."
} 
alguém. O que a razão, pois, mostra (e isso Espinosa ressalta constantemente como sendo o que é evidenciado pela razão) é que o necessário é sempre o útil para a preservação da potência. Só. Se, no estado civil, é preciso elaborar uma denominação que permita a todos tomar conhecimento da validade de uma ação (pois que, como mostra o Tratado teológico-político no capítulo IV, poucos são os que fazem uso da própria razão a ponto de por si sós perceberem a necessidade das próprias ações assim como das leis), e se o imaginário já tem no termo justiça a noção comum mais forte para fazer apreender esse sentido, que se conceba uma noção política de justiça enquanto atribuição de uma necessidade segundo o que é útil para a preservação de potência de cada um. Em termos racionais, não há como negar a validade — e a necessidade — dessa compreensão da idéia de justiça. Entretanto, porque se trata de uma concepção espinosana, damo-nos conta de a justiça assim desmistificada também é, como o conceito de jus, mais uma noção que pode ser reduzida à potentia.

Num outro registro, porém. O jus, identificado diretamente com a potência, exige não ser tomado como faculdade assim como exige ser exercido para ter realidade. A lex, tomada como necessidade, exige valer em função da sua determinação pela potentia imanente, e não em função de sua determinação por uma potestas exterior: a validade da lei obriga em função da necessidade da própria ação, e não em função da força de uma autoridade coatora. O que a crítica espinosana ao poder teológico-político e, simultaneamente, sua crítica ao irracionalismo jurídico exige, é que a prática jurídica seja expressão pública dessa validade simultânea da lex e do jus em função da utilidade de ambos para a vida política. Embora seja absurdo confiar que cada indivíduo conheça completamente, por sua luz natural (que em todos está presente), a necessidade da ação e da liberdade, é preciso que haja a expressão pública de uma justiça racional: em outros termos, é preciso que a civitas — a comunidade política — seja expressão atual de uma prática coletiva da liberdade política. Essa prática coletiva da liberdade, que realiza no plano da experiência política e da história aquilo que a razão mostra ser uma finalidade válida para a prática política — paz e segurança: preservação coletiva da potência coletiva —, recebe no percurso crítico ao poder teológico-político, como símbolo da finalidade pública dentro do vocabulário ainda tomado pelo domínio vulgar da teologia, a designação justiça e caridade. Por todo o Tratado teológico-político, justiça e caridade são repetidos como princípios válidos necessariamente para a vida religiosa - isto é, a vida dedicada à obediência a Deus em função de se conbecer a sua necessidade, e não em função de se temer a vingança divina - : justiça e caridade, justamente, são a expressão, no campo da teologia como também no campo das instituições jurídicas, do que a Ética demonstra ser uma necessidade atual de toda comunidade livre: a concórdia, isto é, atividade livre de todos os integrantes de uma coletividade em favor da sua união e preservação e aumento simultâneo da 
sua potência. Ou, num vocabulário político, a pa\%:

É isto a paz espinosana: uma atividade coletiva, sem exclusão de nenhum dos integrantes da comunidade política, em favor da união das potências de todos para a preservação, pela potência coletiva, da potência de cada um. Toda atividade contrária à preservação dessa potência é uma atividade contrária à própria coletividade - tanto que, no plano da teoria do Estado, aquele que não vê identidade entre si mesmo e as necessidades do Estado, é necessariamente concebido como inimigo do Estado: sua necessidade individual sendo contrária à necessidade do Estado, é devido ao Estado, segundo seu próprio conatus, expulsá-lo de seu interior; ou, se não houver de fato essa falta de identidade entre indivíduo e Estado, o conatus de cada um impulsiona justamente à união, à concórdia, ao aumento simultâneo de potência. Numa perspectiva racional (em termos espinosanos) pois, cabe conceber a justiça? Necessariamente, nestes termos: a justiça é a expressão da concórdia política, fundada exclusivamente no conatus.

\section{II Direito justo em Espinos a?}

Assim como a concepção da identidade entre distintas coisas singulares impulsiona à concórdia entre elas, a concepção da identidade entre distintas teorias filosóficas impulsiona a uma aproximação entre ambas. Entretanto, essa concórdia não implica em confronto, isto é, em comparação das duas, como se se quisesse, por essa medida, compreender o sentido de uma em função da outra. A compreensão de uma coisa singular, por depender necessariamente do conhecimento da sua índole particular - é nesse conhecimento que consiste uma ethica -, exige que seu sentido seja apreendido exclusivamente segundo a estrutura mesma da coisa. Foi nestes termos que Espinosa, leitor e intérprete das Sagradas Escrituras no Tratado teológico-politico, recusa-se a empreender uma interpretação que não consista no conhecimento apropriado da Bíblia segundo sua letra e seu caráter: porque é um texto voltado para a piedade e a obediência, e não para o conhecimento, não é uma interpretação filosófica (demonstrativa) que a Bíblia exige segundo sua própria natureza, mas uma leitura que apreenda o seu sentido alegórico ali onde o texto fala por alegorias, o seu sentido literal ali onde o texto é descritivo, o seu sentido retórico ali onde ele fala para o ânimo do fiel. Ora, e no caso de duas filosofias que, vistas de fora, parecem ter semelhanças impressionantes entre si, senão identidades irrecusáveis? Da relação entre Espinosa e Hobbes, acusou-se à exaustão essa identidade ou essa proximidade; mas o resultado dessa impossível conciliação entre filosofias de naturezas tão opostas (uma fundada no poder democrático, outra no privilégio do poder), gera apenas a incompreensão de uma e de outra. É 
preciso, ao contrário, que a concórdia, que o impulso para a união entre diferentes coisas singulares, também aí surja de dentro de cada uma, no seu contato com a outra. Diferentes filosofias, entretanto, entram em contato entre si por qual meio, se é que isso é possível? Se não está ali, no interior de ambas, a correspondência declarada, o diálogo travado diretamente por ambas, não cabe sequer imaginar o que seria esse diálogo que nunca existiu. Mas, assim como as idéias de cada filosofia operam por si mesmas em outras mentes, é nessa extensão das idéias originais para um campo outro que se cria, por um desejo também outro, uma nova idéia.

Nesse panorama, o conhecimento da estrutura jusfilosófica do pensamento espinosano em razão da sua natureza própria - e longe das insistências comparativas — produz necessariamente o reconhecimento de uma potência talvez desconhecida desse pensamento, no campo da contemporaneidade jurídica: Espinosa, esse anticontratualista, antijusnaturalista, racionalista democrático que exige do direito ser instrumento racional de um desejo público de vida política sem exclusão, é por sua simples presença um impulso irrecusável para a concepção do direito como direito justo - para recuperar, com a devida licença, um termo contemporâneo, de Rudolf Stammler, exposto em Die Lehre von dem Richtigen Rechte [A doutrina do Direito Justo], de 1902, e na sua Theorie der Rechtswissenschaft [Teoria da Ciência do Direito], de 1911.209 Cabe realmente essa aproximação? Se o reconhecimento da potência da filosofia espinosana como explicação racional da necessidade democrática da política é revelador de uma necessidade idêntica à política e ao pensamento político de qualquer tempo, essa é uma aproximação que não decorre de uma comparação — até porque, confrontados, Espinosa e Stammler se revelam incomensuráveis —, mas é válida unicamente enquanto reconhecimento de uma identidade muito específica entre dois desejos filosóficos singulares: a de definição filosófica da necessidade do direito como um

\footnotetext{
209 “Todo o pensamento - e recorde-se que também o Direito é para Stammler um modo de pensamento, na medida em que é um 'querer vinculante' — está sob a exigência última da 'justeza'. Ninguém, observa Stammler, pode 'declarar incorreta' a distinção entre pensar 'justamente' e 'não justamente', 'ou sequer duvidar da sua justeza sem a ter já pressuposto'. Ora, a mesma questão de justeza tem de ser levantada acerca do conteúdo de qualquer querer jurídico. Aqui, porém, a idéia de 'justeza' equivale à de uma 'completa unidade de consciência', ou seja, à de um 'completo acordo entre todos os conteúdos de consciência pensáveis'. Um particular querer jurídico, digamos, uma determinada proposição jurídica, será, portanto, 'justa' sempre que ela se deixa incluir sem contradição no conjunto de todos os geralmente pensáveis quereres jurídicos. Daqui decorre a idéia de 'Direito justo' como 'ideal social'. Significa ela que 'todo o pensável querer social se ordena numa radical harmonia'. O que não deve ser erradamente compreendido como se, na opinião de Stammler, existisse um determinado Direito 'ideal' que fosse o único e só o único 'justo'. Muito ao invés, todo o Direito exige um material empírico e é, por conseguinte, necessariamente 'positivo'. Não existe, pois, nenhum 'Direito justo em si mesmo', mas apenas Direito positivo justo ou injusto (ou em parte justo e em parte injusto). 'Direito justo é o Direito positivo cujo conteúdo de vontade possui a característica da justeza'. A idéia de Direito justo não é assim para Stammler outra coisa senão um padrão para se avaliar cada Direito positivo. Cada Direito positivo aspira, de acordo com o seu "sentido geral", à justeza. Pode, decerto, nas suas particularidades ser reconhecido como injusto, mas, no seu todo, é, precisamente enquanto Direito, sempre 'uma tentativa no sentido de ser justo" " (Karl Larenz, Metodologia da ciência do Direito, pp. 120-121).
} 
direito que, operado concretamente, não produz injustiça — em termos espinosanos, um direito que não produz exclusão política; em termos stammlerianos (mas não apenas stammlerianos), um direito que não produz inadequação entre a norma jurídica positiva e a necessidade individual do cidadão.

Porque esta não é uma tentativa de comparação entre Espinosa e uma determinada filosofia contemporânea - isso seria incompatível com todo o percurso desenvolvido até aqui —, não é o caso sequer de expor a teoria de Stammler (este que é reconhecido por Michel Villey como o "mais significativo" dos contemporâneos que ressuscitam o direito natural), 210 mas sim de expor o que essa teoria significa para o próprio pensamento jurídico e em que sentido ela é uma referência relevante para a consideração da importância peculiar de Espinosa a um problema jurídico que, se não é exclusivamente contemporâneo, é esclarecido necessariamente pela filosofia jurídica de Espinosa, assim entendida como racionalismo democrático e crítica do irracionalismo jurídico.

A concepção contemporânea de direito justo, deflagrada pelos textos de Stammler e que de certa forma se torna tema relevante de todas as teorias críticas do positivismo jurídico — que, por essa condição apenas, muitas vezes recebem a pechas de "doutrinas do direito natural", dando a entender que para um leitor positivista toda análise crítica do próprio positivismo é marca de jusnaturalismo - , pode de certa maneira ser tomada como questão apropriada para as teorias da justiça que nas últimas três décadas têm se dedicado, também, a uma crítica e reformulação do positivismo jurídico em suas bases. Sem entrarmos nessa discussão, o conceito é relevante em função da significação que tem como indicação uma cisão profunda dentro do próprio pensamento contemporâneo: ainda que essas análises críticas do pensamento positivista (assim como da prática jurídica, senão especialmente em função dela) sejam classificadas como "jusnaturalismo contemporâneo", elas são especificamente pensamento contemporâneo. No caso tanto de Stammler (no começo do século) quanto, por exemplo, de John Rawls (décadas de 1960 e 1970), temos dois autores que, pertencentes a períodos muito separados de "mo-

210 “ A primeira [onda] de 'renascimento do direito natural', no começo do século: Stammler, uma parte da escola dos neokantianos, o jesuíta Cathrein, Gény, cuja obra principal tem como subtítulo $O$ irredutivel direito natural, Charmont: $O$ renascimento do direito natural, Rommen: $O$ eterno retorno do direito natural, Del Vecchio na Itália. A doutrina mais notável é a de Stammler. Formado na linha de Kant, mas fazendo uma hábil mescla de sua filosofia política com sua análise das 'formas' da Razão teórica, Stammler só exige da Razão formas, a linguagem, os conceitos da ciência jurídica e 'a Idéia do direito', o ideal que, insuflado no direito, torná-lo-á mais e mais justo (richtiges Recht). Mas seu 'conteúdo' varia através da história com as condições mutáveis da economia. Teoria de um 'direito natural de conteúdo mutável' " (M. Villey, Philosophie du droit, II. Les moyens du droit, p. 92). 
vimento jusnaturalista" (uma pecha rejeitada por ambos), reconhecem para si mesmos uma base teórica comum - a filosofia kantiana — que, curiosamente, é também a base teórica central do pensamento de Hans Kelsen, autor da teoria positivista certamente mais radical de todo o século Xx. É Kelsen, justamente, um dos autores mais empenhados em rebater os argumentos dessa filosofia jurídica que busca uma concepção de direito justo válida tanto para a prática jurídica quanto para o pensamento jurídico. Para Kelsen, que não vê em nenhum conceito de justiça qualquer fundamento racional em termos práticos jurídicos, a questão da justiça é, fundamentalmente, uma questão pertinente à moral religiosa, mas em nada considerável em termos de razão jurídica prática:

De todo o grande contingente daqueles que [...] se ocuparam da questão da justiça, duas cabeças alçam-se muito acima de todas as demais. A primeira, cingida do glorioso esplendor da especulação filosófica; a outra, da coroa de espinhos da crença religiosa. Tanto quanto o divino Salvador, Jesus de Nazaré, apenas o filósofo de Atenas, o "divino" Platão, lutou pela justiça. [...] Se a questão da justiça constitui o problema central de toda teoria e prática social, então o pensamento europeu atual, em uma de suas esferas mais importantes, apresenta-se fundamentalmente marcado pela maneira como o filósofo grego e o profeta judeu colocaram essa questão e a responderam. Se é que nos cabe esperar encontrar uma resposta para ela, para a questão da justiça absoluta, havemos de encontrá-la em um ou no outro - ou, do contrário, tal questão será inteiramente irrespondível. $\mathrm{E}$ isso porque inexiste, e decerto nem pode existir, pensamento mais profundo e quer mais sagrado voltados para a solução do enigma da justiça. ${ }^{211}$

Estas afirmações de Kelsen são interessantes especialmente pela maneira como caracterizam a questão da justiça fora do plano da razão prática: a justiça ou é um tema religioso por excelência (centro de qualquer doutrina religiosa moralmente louvável, como, segundo Kelsen, o cristianismo), ou é um tema místico ou extremamente idealista dentro do próprio pensamento filosófico (tema para qualquer filosofia descompromissada com o realismo teórico, a exemplo da filosofia platônica e do mito formado em torno da figura de Sócrates).

Ora, o caso de Kelsen é emblemático de uma corrente imensa de autores jurídicos que, por todo o século $\mathrm{xx}$, identificam objetividade jurídica a técnica jurídica, considerando nestes termos a inviabilidade mesma de se incluir, como matéria necessariamente jurídica, o pensamento crítico sobre o direito. O positivismo jurídico, especialmente, não importa quão majestoso seja também o alcance da sua descrição da estrutura das instituições jurídicas, em geral toma como um pressuposto para a sua definição de pensamento jurídico (na maioria das vezes, pouco esclarecido) a idéia de que tudo o que diz respeito ao direito, inclusive em termos de teoria sobre o direito, deve advir diretamente da prática jurídica. A justiça, sendo valor moral que impõe à prática jurídica um sentido exterior à estrutura do ordenamento jurídico, e ao seu formalismo um conteúdo arbitrado por uma concepção moral ou subjetiva, não tem, em si mesma, sentido

${ }^{211}$ H. Kelsen, A ilusão da justiça, Introdução, p. 1. 
racional para a dita ciência contemporânea do direito. Como expressão sintética dessa forma de concepção da "ciência jurídica" segundo o projeto positivista ou, mais propriamente, dogmático, talvez a concepção de Theodor Viehweg seja a mais esclarecedora (também porque relativamente recente e contemporânea, ainda, dessa nova crítica ao positivismo jurídico, de suposta inspiração "jusnaturalista”, estabelecida pelas teorias da justiça das últimas três décadas), graças à divisão que estabelece, para a ciência jurídica (aí, conjunto de teorias a respeito do direito), entre pensamento jurídico dogmático (campo de teorias que explicam a estrutura do ordenamento jurídico e os procedimentos pelos quais o direito é aplicado) e pensamento jurídico zetético (campo de teorias que estabelecem uma reflexão crítica a respeito da dogmática jurídica, ou seja, a respeito da prática técnica jurídica), com a peculiaridade de considerar que, para que se atinjam as finalidades práticas do direito (dar solução juridicamente eficaz a casos concretos), é base teórica necessária somente a dogmática jurídica; a zetética jurídica, ainda que possível, não é requisito para a fundamentação da prática jurídica. Isso significa que, segundo Viehweg, a prática jurídica não precisa necessariamente de fundamentação ética para justificar a sua própria operação; basta-lhe, para essa justificação, a sua base processual ou técnica. ${ }^{212}$

\footnotetext{
212 "Ao envolver uma questão de decidibilidade, a Ciência do Direito manifesta-se como pensamento tecnológico. Este possui algumas características do pensamento científico stricto sensu, à medida que parte das mesmas premissas que este. Os seus problemas, porém, têm uma relevância prática (possibilitar decisões: legislativas, judiciárias, administrativas, contratuais, etc.) que exige uma interrupção na possibilidade de indagação das ciências em geral, no sentido de que a tecnologia dogmatiza os seus pontos de partida e problematiza apenas a sua aplicabilidade na solução de conflitos. Para entender isto vamos admitir que em toda investigação jurídica estejamos sempre às voltas com perguntas e respostas, problemas que exigem soluções, soluções referentes a certos problemas. Surgem daí duas possibilidades de proceder à investigação, quer acentuando o aspecto pergunta, quer o aspecto resposta. Se o aspecto pergunta é acentuado, os conceitos-chave, as diomensões que constituem as normas e as próprias normas na sua referibilidade a outras normas, que permitem a organização de um sistema de enunciados, são postos em dúvida. Isto é, aqueles elementos que constituem a base e conferem a estrutura a um sistema patente ou latente dentro do qual um problema se torna inteligível conservam o seu caráter hipotético e problemático, não perdem a sua qualidade de tentativa, permanecendo abertos à crítica. Eles servem, pois, primariamente, para delimitar o horizonte problemático de um campo temático dado, mas ao mesmo tempo ampliam esse horizonte, trazendo esta problematicidade para dentro deles mesmos. No segundo aspecto, ao contrário, determinados elementos são subtraídos à dúvida, predominando o lado resposta. Isto é, postos fora de questionamento, mantidos como respostas não atacáveis, eles são, pelo menos temporariamente, posto de modo absoluto. Eles dominam, assim, as demais 'respostas', de tal modo que estas, mesmo quando postas em dúvida, não os podem pôr em perigo; ao contrário, devem ajeitar-se a eles de maneira aceitável. No primeiro caso, usando uma terminologia proposta por Viehweg, temos uma questão de pesquisa ou questão 'retética', no segundo uma questão 'dogmática'. Entre elas, como dissemos, não há uma separação radical, ao contrário, elas se entremeiam, referem-se mutuamente, às vezes se opõem, outras vezes colocam-se paralelamente, estabelecendo um corpo de possibilidade bastante diversificado. As questões 'dogmáticas' relevam o ato de opinar e ressalvam certas opiniões (dokein). As questões 'zetéticas', ao contrário, desintegram, dissolvem meras opiniões (setein) pondo-as em dúvida, o que pode ocorrer ainda dentro de certos limites (na perspectiva empírica das ciências: Sociologia, Psicologia, Antropologia Jurídica etc.) ou de modo a ultrapassar aqueles limites, por exemplo, na perspectiva da Filosofia do Direito. As questões 'dogmáticas' são tipicamente tecnológicas. Neste sentido, elas têm uma função diretiva explícita. Pois a situação nelas captada é configurada como um dever-ser. Questões deste tipo visam
} 
Nesse panorama elementar, no qual o pensamento jurídico contemporâneo concebe-se seja como uma teoria jurídica voltada para a decidibilidade e a resolução de conflitos, seja como uma reflexão sobre a orientação ética devida a essa mesma prática jurídica, apresenta uma pertinência absoluta a crítica espinosana à potestas, porque ela diz respeito, exatamente, à negação de legitimidade a um poder político-jurídico que se perdeu do compromisso com as finalidades públicas, quando a própria política tem, como necessidade imanente, a exigência da qualidade democrática. Em todos os momentos em que Espinosa trata da autoridade política, e mesmo nos textos em que considera as peculiaridade dessa autoridade de acordo com cada regime político, jamais ele reconhece à autoridade política o direito de suprimir a validade dessa finalidade pública. No Tratado político, capítulo III, $\int 6$, ele reafirma a exclusividade de direito que cabe à autoridade como entidade legisladora, mas nega que esse poder deva suprimir a necessidade pública de preservação da potência coletiva, ou — pela interpretação que propomos - concórdia da vida política:

Não há dúvida que os contratos, ou as leis, pelos quais o conjunto dos cidadãos transfere o seu direito para um conselho, ou para um homem, devem ser violados quando essa violação importa ao interesse comum. Mas a nenhum particular compete julgar, isto é, decidir se é do interese comum violar as leis estabelecidas ou não. Apenas aquele que detém o poder público pode julgar; assim, segundo o direito civil, só aquele que detém o poder público pode interpretar as leis. A isto acresce que nenhum particular tem o direito de agir como defensor das leis; por conseguinte, na realidade as leis não obrigam aquele que detém o poder. Que, todavia, as leis sejam de tal natureza que não possam ser violadas sem que por isso a Cidade seja enfraquecida, isto é, que o temor experimentado em comum pela maioria dos cidadãos se transforme em indignação, por isso mesmo a Cidade é dissolvida e a lei suspensa; já não é, portanto, em concordância com o direito civil, mas em virtude do direito de guerra, que ela se protege. E, assim, o detentor do poder não é obrigado a observar as leis do contrato por nenhuma outra razão que não a que tem o homem no estado natural de impedir tornar-se seu próprio inimigo, isto é, destruir-se.

Esse mesmo parágrafo mostra como Espinosa desconsidera a validade de pactos que pedem a validade para a multitudo. Contra, justamente, a idéia de que uma obrigação é válida porque imposta por uma instituição coatora, esse parágrafo, combinado com o princípio segundo o qual toda ação ou lei é válida em função da sua necessidade racional e natural, reconhece na multitudo a potência de retirar-se de uma aliança com o Estado, quando este mostra-se, já, sepa-

possibilitar uma decisão e orientar a ação. De modo geral, as questões jurídicas são 'dogmáticas', sendo sempre restritivas (finitas) e, neste sentido, 'positivistas' (de positividade). As questões jurídicas não se reduzem, entretanto, às 'dogmáticas', à medida que as opiniões postas fora de dúvida — os dogmas — podem ser submetidas a um processo de questionamento, mediante o qual se exige uma fundamentação e uma justificação delas, procurando-se, através do estabelecimento de novas conexões, facilitar a orientação da ação. O jurista revela-se, assim, não só como o especialista em questões 'dogmáticas', mas também em questões 'zetéticas'” (T.S. Ferraz Jr., A ciência do direito, pp. 45-46). 
rado das finalidades públicas. Ou seja, por mais que os conteúdos das normas jurídicas e a interpretação desses mesmos conteúdos sejam um privilégio da autoridade soberana, jamais essa autoridade determina, por força da sua potestas, a necessidade da multitudo. Nesse sentido, a legitimidade de qualquer vontade de uma autoridade exige, numa democracia — ou seja, numa situação política onde a lógica da necessidade natural da política é operada constantemente que os conteúdos da prática jurídica sejam, tanto na formulação das leis quanto na sua interpretação e aplicação, adequados às necessidades públicas da multitudo. Do contrário, o próprio poder político perde sua legitimidade e se estabelece, como diz o texto, o "direito de guerra", no qual, apesar do estado civil, escolhe-se a prática da violência.

O que é interessante no uso da expressão "direito de guerra", aí, é que se trata de uma conseqüência do desrespeito, pela autoridade soberana, de um princípio dessa aliança pública entre os cidadãos e o Estado: a preservação da própria comunidade política. Ora, o único critério que o parágrafo aponta para que o conjunto de cidadãos deixe de obedecer à autoridade soberana é, novamente, o seu próprio conatus. Nesse sentido, porque o Estado não é um bem particular de quem o governa, a multitudo detém uma potência maior do que a da autoridade soberana, e sua recusa a obedecer a quem faz da coisa pública um bem de uso particular (é isso o que gera, sempre, impotência na civitas) já obriga, em contrapartida, à autoridade soberana a não manter o mesmo estado de impotência e insegurança; se o "estado de guerra" se instala, porém, é porque a autoridade soberana não tem, por sua própria índole, interese particular na fundação adequada do poder público.

Nestes termos, parece-me que cabe, em Espinosa, a concepção de direito justo. Em toda a sua teoria política, o que Espinosa critica é o direito tornado instrumento de uso particular quando, por sua natureza, deveria ser o elemento central do poder público do Estado (já que, também mostra Espinosa, a força de um Estado depende da força das suas instituições).

Ora, ao mesmo tempo, quando insiste na descrição da vida política como uma vida fundada nas instituições (ainda que estas obedeçam a uma necessidade natural — não por um princípio jusnaturalista, mas por uma necessidade ontológica), Espinosa aponta tais instituições como o índice da qualidade da própria vida política. Por isso mesmo, numa sociedade política fundada na liberdade e realizadora da paz e da segurança, as instituições políticas por força da própria liberdade absoluta da comunidade política permitirão a inexistência da exclusão política e jurídica. Não é à toa que a assembléia suprema é a instituição central da democracia: ela é a própria marca da igualdade de todos os cidadãos na sua identidade com o próprio Estado. Pode-se di- 
zer, tomando como base a concepção espinosana de democracia, que ela é a única prática política na qual cada um concebe a si mesmo como uma extensão da civitas.

O que é pois, em termos espinosanos, um direito justo? Não se trata de aplicar, a Espinosa, um conceito ou um registro que lhe são completamente anacrônicos. Mas é o caso de ver, em Espinosa e a partir dele, a articulação de uma realidade política concreta que, por necessidade ontológica, é contrária à natureza da liberdade e por isso mesmo ilegítima, sob uma perspectiva racional, para a vida política. Essa realidade, que move Espinosa para a crítica do poder teológico-político, assim como para a crítica ao irracionalismo jurídico (que entre outras coisas produz, além da idéia de legitimidade da potestas por si mesma, a idéia de que as diferentes práticas políticas são determinadas por formas de Estado, e não conteúdos concretos de prática política), é nada mais do que a exclusão movida por parte de quem deveria ser o maior inimigo da violência no plano da vida política: a autoridade soberana, o Estado, as instituições civis concebidas como entidades separadas da necessidade e presença de cada cidadão. Por tudo o que Espinosa demonstra sobre a natureza humana na vida coletiva, a vida política se mostra uma vida despótica a cada momento em que um ato de violência é praticado por causa do Estado. Se a democracia, compreendida enfim como uma prática política idêntica à criação e preservação de direitos e liberdades, é fundada na inexistência de exclusão político-jurídica, essa exclusão é estabelecida autoritariamente a toda vez que um ato violento é praticado por causa da inoperância do Estado ali onde cabe a ele ser potência dos seus próprios cidadãos, instrumento para a preservação da paz pública e do próprio poder soberano. Se a vida política exige, pela natureza de cada um na vida política, ser uma vida em concórdia e sem exclusão, o Estado não pode se permitir ser instrumento do movimento inverso a essa necessidade. Caso o seja - caso o próprio Estado se torne instrumento ou agente de corrupção, violência, despotismo —, estamos, sem dúvida, numa "estado de guerra": não de todos contra todos nem de uma soberania contra outra, mas sim de uma autoridade despótica contra o conjunto de cidadãos, mesmo quando sua violência - por negligência ou por dolo — se dê contra apenas uma pessoa.

Em termos espinosanos, sempre que o Estado ou uma instituição civil torna-se agente de violência, toda a coisa pública entra em detrimento. Ora, porque jamais a comunidade política ou qualquer cidadão necessitam ser tratados de maneira violenta ou negligente, é necessário, na perspectiva da democracia, conceber uma idéia de direito justo como necessidade do próprio Estado: porque um Estado só se mantém democrático enquanto continua orientado para finalidades públicas, e porque a potentia (e não a potestas) de um Estado depende da qualidade das suas instituições, o direito justo numa democracia só pode ser a prática jurídica como instrumento de eliminação da exclusão. Por isso mesmo, a justeza da prática jurídica, assim concebida, 
assume finalmente a qualidade de uma concepção racional de direito, porque válida e legítima enquanto exercício atual de fortalecimento de toda a comunidade política. 


\section{BIBLIOGRAFIA}

\section{Obras de Espinosa}

\section{Edições de referência}

Spinoza Opera. Im Auftrag der Heidelberger Akademie der Wissenschaften herausgegeben von Carl Gebhardt. Heidelberg, C. Winter, 1925; 2. Auflage 1972, 4 vols.

\section{Traduções consultadas}

Obras completas

Pbilosophy of Benedict de Spinoza. Translated from the Latin by R.H.M. Elwes, with an introduction by F. Sewall. Nova York, Tudor, 1941.

CEuvres de Spinoza. Traduites et annotées par Charles Appuhn. Paris, Garnier, s. d.; reimpressão Paris, Garnier-Flammarion, 1964-66, 4 vols.

Spinoza Euvres complètes. Texte traduit, presenté et annoté par Roland Caillois, Madeleine Francès et Robert Misrahi. Paris, Gallimard, 1954 (Bibliothèque de la Pléiade).

The Collected Works of Spinoza. Edited and translated by Edwin Curley. Princeton, Princeton U. P., vol. I, 1985.

Obras Isoladas

Tratado da Emenda do Intelecto

Tratado da Reforma da Inteligência. Tradução, introdução e notas de Lívio Teixeira. São Paulo, Cia. Edit. Nacional, 1966.

Tratado da Correção do Intelecto. Tradução e notas de Carlos Lopes de Mattos. São Paulo, Abril Cultural, 1a ed. 1972, $2^{a}$ ed. 1979 (Coleção Os Pensadores).

Principios da Filosofia Cartesiana e Pensamentos Metafísicos

Pensamentos Metafísicos. Tradução e notas de Marilena de Souza Chaui. São Paulo, Abril Cultural, $1 \underline{a}$ ed. 1972, 2aed. 1979 (Coleção Os Pensadores).

Tratado Teológico-Politico

Tratado Teológico-Politico. Introducción, traducción, notas y índices de Atilano Domínguez. Madri, Alianza, 1986.

Tratado Teológico-Político. Introdução, tradução e notas de Diogo Pires Aurélio. Lisboa, Imprensa Nacional-Casa da Moeda, 1988.

Ética

Ética. Tradução e notas da Parte I de Joaquim de Carvalho, tradução das Partes II e III de Joaquim Ferreira Gomes, tradução das Partes IV e V de António Simões. São Paulo, Abril Cultural, 1ạ ed. 1972, 2a ed. 1979 (Coleção Os Pensadores).

Éthique. Texte originel et traduction nouvelle par Bernard Pautrat. Paris, Seuil, 1988.

Ethics. Edited and translated by Edwin Curley, with an introduction by Stuart Hampshire, Penguin, 1994. 
Tratado Político

Tratado Político. Tradução de Manuel de Castro. São Paulo, Abril Cultural, 1a ed. 1972, 2a ed. 1979 (Coleção Os Pensadores).

Tratado Político. Traducción, introducción, index analítico y notas de Atilano Domínguez. Madri, Alianza, 1986.

Correspondência

The Letters. Translated by Samuel Shirley, introduction and notes by Steven Barbone, Lee Rice and Jacob Adler. Indianapolis, Hackett, 1995.

Correspondência (Cartas 2, 4, 9, 12, 21, 32, 34 e 50). Tradução e notas de Marilena de Souza Chaui. São Paulo, Abril Cultural, 1a ed. 1972, 2a ed. 1979 (Coleção Os Pensadores).

“Letter from Spinoza to Lodewijk Meijer, 26 July 1663”. Ed. by A. K. Offenberg, in S. HESSING (ed.). Speculum Spinozanum 1677-1977. Londres, Routledge \& Kegan Paul, 1978.

\section{INSTRUMENTOS DE TRABALHO}

\section{Léxicos e Latinidade}

GIANCOTTTI BOSCHERINI, E. Lexicon Spinozanum. Haia, M. Nijhoff, 1970, 2 vols.

\section{Biografias}

COLERUS, J. (Johannes Köhler). La Verité de la Résurrection de Jésus-Christ Défendue Contre B. de Spinoza et ses Sectateurs. Avec la Vie de ce Fameux Philosophe. À la Haye, chez T. Johnson, Marchand Libraire dans le Pooten, 1706.

LUCAS, J. M. La Vie de Feu M. Benoît de Spinoza (1679), in Nouvelles Littéraires, vol. X, Amsterdã, 1719.

MEINSMA, K. O. Spinoza et son cercle. Étude critique et historique sur les hétérodoxes hollandais. Traduit du néerlandais par S. Roosenburg, appendices latins et allemands traduits par J. P. Osier, introduction et notes par H. Méchoulan et P.-F. Moreau. Paris, J. Vrin, 1983.

VAZ DIAS, A. M., Van der TAK, W. G. Spinoza Mercator \& Autodidacticus. Oorkonden en andere authenticke Documenten betreffende des Wijsgeers jeugd en Diens betrekkingen, met dertien facsimile's. s'-Gravenhage, 1933; tradução inglesa "Spinoza Merchant \& Autodidact", Studia Rosenthaliana, vol. XVI, no 2, 1982.

\section{Livros sagrados e obras de referência}

A Bíblia de Jerusalém. Edição em língua portuguesa sob a coordenação de G. S. Gorgulho, I. Storniolo e A. F. Anderson. São Paulo, Paulinas, 1981.

A Bíblia Sagrada, contendo O Velho e o Novo Testamento. Tradução seiscentista de João Ferreira d'Almeida. $36^{a}$ impressão, Rio de Janeiro, Imprensa Bíblica Brasileira, 1977.

Biblia Hebraica Stuttgartensia. Stuttgart, Deutsche Bibelgesellschaft, 4ª ed., 1990.

Biblia Sacra Vulgata. Iuxta Vulgatam Versionem. $3^{\mathrm{a}}$ ed., Stuttgart, Deutsche Bibelgesellschaft, 1983.

AbBagnano, n. Dicionário de filosofia. São Paulo, Martins Fontes, $3^{a}$ ed. Revista e ampliada, 1998. Traduções de Alfredo Bosi, Maurice Cunio, Antonietta Scartabello, Carla Conti, Rodolfo Ilari, Silvia Salvi (desde a $1^{\mathrm{a}}$ ed.) e Ivone Castilho Benedetti (textos incluídos na $3^{\mathrm{a}}$ ed.), do original Dizionario di Filosofia, Turim, UTET, 1971.

BOBbiO, N. et alii. Dicionário de política. Brasília, Edunb, 4a ed., 1992. Tradução de Carmen C. Varrialle, Gaetano lo Mônaco, João Ferreira e Luís Guerreiro Pinto Cacais do original Dizionario di politica. Turim, UTET, 1983.

CHÂTELET, F. et alii. Dicionário das obras políticas. Rio de Janeiro, Civilização Brasileira, 1993; tradução de Glória de C. Lins e Manoel Ferreira Paulino do original Dictionnaire des cuvres politiques. Paris, PUF, 1986, 1991. 


\section{FONTES PRIMÁRIAS}

Agostinho. Confissões. Tradução e notas de J. O. Santos, SJ e A. A. de Pina, SJ. São Paulo, Abril Cultural, 1973 (Coleção Os Pensadores).

Agostinho. A cidade de Deus (contra os pagãos). Tradução de Oscar Paes Leme. $3^{\mathrm{a}}$ ed. Petrópolis, Vozes, 1991, 2 vols.

ARISTÓTELES. Ética a Nicômaco. Tradução de Leonel Vallandro e Gerd Bornheim da versão inglesa de W.D. Ross. São Paulo, Abril Cultural, 1987 (Coleção Os Pensadores).

DesCARTES. Euvres de Descartes. Publiées par Ch. Adam et P. Tannery. Paris, J. Vrin, 1996, 11 vols.

MONTESQUiEU. Cartas persas. Tradução e apresentação de de Renato Janine Ribeiro, São Paulo, Paulicéia, 1991.

MONTESQUIEU. O espirito das leis. Tradução de Cristina Murachco, apresentação de Renato Janine Ribeiro, São Paulo, Martins Fontes, $2^{a}$ ed., 1996.

HEGEL, G.W.F. Premières publications: Différence des systèmes philosophiques de Fichte et de Schelling; Foi et savoir. Traduction, introduction et notes par M. Méry. Paris, Ophrys, 1964.

HOBBES, Th. The Works of Thomas Hobbes of Malmesbury; now first collected and edited by sir W. Molesworth: Opera latina. The English works. Londres, J. Bohn, 1839-45, 16 vols.; reimpressão Aalen, Scientia, 1961-66.

HOBBES, Th. Leviathan. Edited with an introduction by C. B. Macpherson. Harmondsworth, Penguin, 1968.

HOBBES, Th. Leviatã on matéria, forma e poder de um estado eclesiástico e civil. Tradução de J. P. Monteiro e M. B. Nizza da Silva. São Paulo, Abril Cultural, 1974 (Coleção Os Pensadores).

HOBBES, Th. A natureza bumana. Tradução, introdução e notas J. A. Lopes. Lisboa, Imprensa NacionalCasa Moeda, 1983.

LOCKE, J. Morale et loi naturelle. Textes sur la loi de nature, la morale et la religion. Présentation, traduction et notes par Jean-Fabien Spitz. Paris, Vrin, 1990.

LOCKE, J. Lettre sur la tolérance. Texte latine et traduction française. Édition critique et préface par Raymond Klibansky; traduction et introduction par Raymond Polin. Paris, PUF, $2^{\mathrm{a}}$ ed., 1999.

PUFENDORF, S. Le droit de la nature et des gens, ou système général des principes les plus importants de la morale, de la jurisprudence, et de la politique. Tradução de Jean Barbeyrac. Londres, Jean Nours, 1740, 3 vols.

QUINTO CÚRCIO. Quinte-Curce. Histoires. Texte établi et traduit par H. Bardon. Paris, Les Belles-Lettres. Tome I (livres III-VI), 1947, et Tome II (livres VII-X), 1948.

TÁcito. Tacite. Histoires. Texte établi et traduit par H. Goelzer. Paris, Les Belles-Lettres, 1938.

TÁcito. Tacite. Annales. Paris, Les Belles-Lettres. Tome I (livres I-III) et Tome II (livres IV-XII): texte établi et traduit par H. Goelzer, 1953; Tome IV (livres XIII-XVI): texte établi et traduit par P. Wuilleumier, 1978.

TOMÁS DE AQUINO. Suma teológica. $1^{a}$ Parte da $2^{a}$ Parte, Questões 71-114. Tradução de Alexandre Corrêa, Porto Algre, Escola Superior de Teologia São Lourenço de Brindes - Caxias do Sul, Universidade de Caxias do Sul, $2^{\mathrm{a}}$ ed., 1980.

\section{Estudos monográficos e artigos individuais.}

ABensour, M. A democracia contra o Estado. Marx e o momento maquiaveliano, Belo Horizonte, Editora UFMG, 1998.

ABREU, L.M. "Ética e utopia em Spinoza", in BLANCO-ECHAURI, J. Espinosa: ética e política, pp. 51-64.

AKKERMAN, F. 'J.H. Glazemaker, an early translator of Spinoza”, in DE DEUGD, C. (ed.). Spinoza's political and theological thought, 1984.

AMSELEK, P. "Norme et loi", in Archives de philosophie du droit, no 25, Paris, Sirey, 1980, pp. 89-107.

ANGOUlVENT, A.-L. Hobbes ou la crise de l'Etat baroque. Paris, PUF, 1992.

ANTÓN, J.E. "Religión, salvación y autonomía en Spinoza", in BLANCO-ECHAURI, J. Espinosa: ética e politica, pp. 211-219.

AUBENQUE, P. "La loi selon Aristote", in Archives de philosophie du droit, n 25, Paris, Sirey, 1980, pp. 147157.

AURÉLIO, D.P. “A política na correspondência de Espinosa”, in Discurso, no 31, 2000, pp. 229-257.

AURÉLIO, D.P. "Natureza e nação segundo Espinosa", in BLANCO-ECHAURI, J. Espinosa: ética e política, pp. 279-299. 
BADIOU, A. “L'ontologie implicite de Spinoza”, in D’ALLONES, M.R. \& RIZK, H. (orgs.). Spinoza: puissance et ontologie. Paris, Kimé, 1994.

BALIBAR, E. "Jus, pactum, lex. Sur la constitution du sujet dans le Traité theólogico-politique", Studia spinozana, vol. 1, 1985, pp. 105-142.

BALIBAR, E. "Spinoza: la crainte des masses", in GIANCOTTI, E. (ed.) Spinoza nel 350 anniversario della nascità, pp. 293-320. Preprint. Originalmente em in Kibrick, S. (ed.): Homenaje a Baruch Spinoza. Com motivo del tricentenario de su muerte. Buenos Aires, 1976.

BALIBAR, E. Spinoza et la politique. Paris, PUF, 1985.

BARASH, J.A. "Saint-Paul, Spinoza et l'absence de l'éthico-politique chez Heidegger", in D’ALLONES, M.R. \& RIZK, H. (orgs.). Spinoza: puissance et ontologie. Paris, Kimé, 1994.

BARATA-MOURA, J. “¿Es la verdad una categoría política para Spinoza?”, in BLANCO-ECHAURI, J. Espinosa: ética e política, pp. 301-314.

BARBONE, S. "El status metafísico del Estado político", in BLANCO-ECHAURI, J. Espinosa: ética e política, pp. $423-430$.

BARREIRO, X.L.B. "Ilustración y fideísmo. La polémica Jacobi -Lessing e sus repercusiones", in BLANCOECHAURI, J. Espinosa: ética e politica, pp. 175-189.

BARTUSCHAT, W. "The ontological basis of Spinoza's theory of politics”, in DE DEUGD, C. (ed.). Spinoza's political and theological thought.

BASTIT, M. "Loi", in Archives de philosophie du droit, no 35, Paris, Sirey, 1990.

BATIFFOL, H. "La loi et la liberté", in Archives de philosophie du droit, n 25, Paris, Sirey, 1980, pp. 79-87.

BELAIEF, G. Spinoza's philosophy of law. Haia-Paris, Mouton, 1971 [originalmente, dissertação apresentada em 1963].

BERTMAN, M.A. “Hobbes'and Spinoza’s politics”, in GIANCOTTI, E. (ed.) Spinoza nel $350^{\circ}$ anniversario della nascità, pp. 321-331.

BethenCOURT, F. História das Inquisições. Portugal, Espanha e Itália. Séculos XV-XIX. São Paulo, Companhia das Letras, 2000.

BignotTo, N. Maquiavel republicano. São Paulo, Loyola, 1991.

BIGnOtTo, N. O tirano e a cidade. São Paulo, Discurso Editorial, 1998.

BITTAR, E.C.B. A justiça em Aristóteles. São Paulo, Forense Universitáriua, 1999.

BLANCO-ECHAURI, J. Espinosa: ética e política. Encontro Hispano-Portugués de Filosofia, Santiago de Compostela, 5 7 de abril de 1997, Santiago de Compostela, Universidade de Santiago de Compostela, 1999.

BLANCO-ECHAURI, J. "Anacos de espellos que a chuvia nas dunas (a voltas con Espinosa)", in BLANCOECHAURI, J. Espinosa: ética e política, pp. 15-45.

BLANCO-ECHAURI, J. "Un iusnaturalismo irónicamente perverso (Genealogía e historia de una metamorfosis: I. Ius sive facultas)", in BLANCO-ECHAURI, J. Espinosa: ética e política, pp. 315-351.

BLOCH, M. Os reis taumaturgos. São Paulo, Companhia das Letras, 1993. Tradução de Júlia Mainardi do original Lếs róis thaumaturges. Étude sur le caractère surnaturel attribué à la puissance royale, particulièrement en France et en Angleterre. Paris, Gallimard, 1983.

BLOM, H. "Politics, virtue and political science: an interpretation of Spinoza's political philosophy" , Studia spinozana, vol. 1, 1985, pp. 209-230.

Bobbio, N. \& Bovero, M. Sociedade e Estado na Filosofia Política Moderna, 2 a ed., São Paulo, Brasiliense, 1987 (tradução de Carlos Nelson Coutinho a partir do original Societè e stato nella filosofia politica moderna. Modello giusnaturalistico e modello hegelo-marxiano. Milano, Il Saggiatore, 1979).

BOBbio, N. "Hegel e o jusnaturalismo", em Estudos sobre Hegel. Direito, sociedade civil, Estado. São Paulo, Brasiliense-Unesp, $2^{a}$ ed., 1991, pp. 23-55 (tradução de Carlos Nelson Coutinho a partir do original "Hegel e il giusnaturalismo", in Studi hegeliani. Milano, Einaldi, 1981; artigo originalmente publicado na rivista di Filosofia, LVIII, 1966, pp. 379-407).

BOBBIO, N. "Quelques arguments contre le droit naturel", in Annales de philosophie politique, III: Le droit naturel. Paris, PUF, 1959.

BOBBIO, N. As ideologias e o poder em crise. São Paulo, Polis, 1988. Tradução de João Ferreira do original Le ideologie e il potere in crisi, Firenze, Le Monnier, 1982.

BOBbio, N. Direito e Estado no pensamento de Emanuel Kant. São Paulo, Mandarim, $2^{\mathrm{a}}$ ed., 2000. Tradução de Alfreto Fait do original Diritto e stato nel pensiero di Emanuele Kant. Turim, Giappichelli, 1969.

BOBBIO, N. Estado, governo, sociedade. Para uma teoria geral da política. São Paulo, Paz e Terra, $7^{a}$ ed., 1999. Tradução de Marco Aurélio Nogueira do original Stato, governo, società. Per una teoria generale della politica. Turim, Einaudi, 1985. 
BOBBIO, N. Liberalismo e democracia. São Paulo, Brasiliense, $2^{a}$ ed., 1988. Tradução de Marco Aurélio Nogueira do original Liberalismo e democrąia. Milão, Franco Angelo Libri, 1983.

BOBBIO, N. Norberto Bobbio: el filósofo y la política (Antología). México D.F., Fondo de Cultura Econômica, 1996. Compilação de José Fernández Santillán; tradução de José Fernández Santilán e Ariella Aureli.

BOBBIO, N. Os intelectuais e o poder, São Paulo, Editora da Unesp, 1997. Tradução de Marco Aurélio Nogueira do original Il dubbio e la scelta. Intellettali e potere nella società contemporanea. Roma, La Nuova Italia Scientifica, 1993.

BOBBIO, N. Thomas Hobbes, Rio de Janeiro, Campus, 1991 (tradução de Carlos Nelson Coutinho a partir do original Thomas Hobbes. Turim, Einaudi, 1989).

BOSS, G. "Les principes de la philosophie chez Hobbes et chez Spinoza", Studia spinozana, vol. 3, 1987, pp. 87-124.

BOUVERESSE, R. Spinoza et Leibniz. L'idée d'animisme universel. Etude suivie de la traduction inédite d'un texte de Leibniz sur l'Ethique de Spinoza e d'un texte de Louis Meyer. Paris, Vrin, 1992.

BREHIER, E. Chrysippe et l'ancien stö̈cisme, Paris, PUF, 196-.

BRETON, S. Politique, religion, écriture chez Spinoza. Lyon, Profac, 1973.

BRETON, s. Spinoza. Théologie et politique. Lyon, PROFAC, 1973.

BRUNSCHVICG, L. Spinoza et ses contemporains. Paris, Felix Alcan, 1923.

BUCKLE, S. Natural law and the theory of property. Grotius to Hume. New York, Oxford University Press, 1991.

CAMARERO, L.R. "En torno a la actualidad de Spinoza: la crisis del finalismo y del determinismo", in BLANCO-ECHAURI, J. Espinosa: ética e politica, pp. 113-127.

CAMPS, V. "Las dos éticas de Spinoza", in BLANCO-ECHAURI, J. Espinosa: ética e política, pp. 65-71.

CARRIT, E.F. Moral and politics. Theories of their relation from Hobbes ans Spinoza to Marx and Bosanquet. London, Oxford University Press, 1935.

CHANTEUR, J. "L'homme est-il un être pour la guerre?”, in Cabiers de philosophie politique et juridique, no 10 , Caen, Centre de Publications de l’Université de Caen, 1986, pp. 13-35.

CHANTEur, J. "La loi chez Platon", in Archives de philosophie du droit, n 25, Paris, Sirey, 1980, pp. 137-146. CHAUÍ, M.S. Introdução à leitura de Espinosa. São Paulo, FFLCH-USP, 1971. Tese de doutoramento.

CHAUí, M.S. A nervura do real. Espinosa e a questão da liberdade. São Paulo, FFLCH-USP, 1977. Tese de livredocência.

CHAUÍ, M.S. "Linguagem e liberdade. O contradiscurso de Baruch Espinosa", in Da realidade sem mistérios ao mistério do mundo. Espinosa, Voltaire, Merleau-Ponty. São Paulo, Brasiliense, 1981, pp. 10-103.

CHAUí, M.S. Convite à Filosofia. São Paulo, Ática, 1994.

CHAUÍ, M.S. "Fidelidade infiel: Espinosa leitor de Descartes", conferência apresentada no Congresso Internacional Descartes 400 anos, Associação de Estudos Filosóficos do Século XVII _ UFRJ, Rio de Janeiro, 1996.

CHAUÍ, M.S. "Imanência e luz: Espinosa, Vermeer e Rembrandt”, Discurso, n. 26, 1996.

CHAUI, M.S. "La plèbe et le vulgaire dans le Tractatus politicus", in MOREAU, P.-F. et alii (orgs.). Spinoza et la politique. Paris, L’Harmattan, 1997, pp. 95-118.

CHAUÍ, M.S. "Sobre a essência singular em Espinosa", conferência apresentada no II Encontro de Estudos Filosóficos do Século XVII, Departamento de Filosofia, FFLCH/USP, 1997.

CHAUÍ, M.S. "Causa formal e causa eficiente na matemática dos Seiscentos", III Encontro de Estudos do Século XVII, Departamento de Filosofia, FFLCH/USP, maio de 1998.

CHAUí, M.S. A nervura do real. Imanência e liberdade em Espinosa. Vol. 1: Imanência. São Paulo, Companhia das Letras, 1999.

CHAUí, M.S. Ética sem culpa, política com liberdade. São Paulo, Companhia das Letras, 2001, no prelo.

COELHO, A.B. "Espinosa e os sistemas ideológico-práticos de obediência", in BLANCO-ECHAURI, J. Espinosa: ética e política, pp. 353-369.

COMTE-SPONVILLE, A. "La volonté cynique. Vertu et démocratie", in Cahiers de philosophie politique et juridique, no 18, Caen, Centre de Publications de l’Université de Caen, 1990, pp. 189-215.

CONCHE, M. Orientação filosófica. Traducação de Maria José Perillo Isaac. São Paulo, Martins Fontes, 2000.

CORDÓN, J.C. "La idea de soberanía en Spinoza", in BLANCO-ECHAURI, J. Espinosa: ética e política, pp. 441454.

CORLETT, J.A. (Ed.) Equality and liberty. Analyzing Rawls and Nozick. New York, St. Martin’s Press, 1991.

COTTA, s. "Droit subjectif", in Archives de philosophie du droit, no 35, Paris, Sirey, 1990. 
COURTOIS, G. "Innocence et responsabilité selon Spinoza", in Archives de philosophie du droit, n 22, Paris, 1977, pp. 97-111.

COURTOIS, G. "La loi chez Spinoza et Saint Thomas d'Aquin", in Archives de philosophie du droit, no 25, Paris, Sirey, 1980, pp. 159-189.

CRISTOFOLINI, p. "Esse sui juris e scienza politica”, Studia spinozana, vol. 1, 1985, pp. 53-71.

D’ALLONES, M.R. “L'imagination du politique”, in D’ALLONES, M.R. \& RIZK, H. (orgs.). Spinoza: puissance et ontologie. Paris, Kimé, 1994.

D’ENTREVES, A.P. "Le Droit naturel”, in Annales de philosophie politique, III: Le droit naturel. Paris, PUF, 1959.

D’EnTREVES, A.P. Natural law. An introduction to legal philosophy. With a new introduction by Cary J. Nederman.Transaction Publishers, New Brunswick, New Jersey, 1994 [edição original: 1951].

DAHL, R.A. Poliarquia. São Paulo, Edusp, 1997. Tradução de Celso Mauro Paciornik do original Polyarchy: participation and opposition, Yale University, 1972.

DANIELs, N. (Ed.) Reading Rawls. Critical studies on Rawls' A theory of justice. Standford, Standford University Press, 1989.

DAVID, R. Os grandes sistemas do direito contemporâneo. Tradução de Hermínio A. Carvalho. São Paulo, Martins Fontes, $3^{\mathrm{a}}$ ed., 1996.

DE DEUGD, C. (ed.). Spinoza's political and theological thought. International symposium under the auspices of the Royal Netherlands Academy os arts and sciences. Commemorating the 350th anniversary of the birth of Spinoza, Amsterdam 24-27 november 1982. Amsterdam, 1984.

DE JOUVEnEL, B. "L'idée de Droit naturel", in Annales de philosophie politique, III: Le droit naturel. Paris, PUF, 1959.

DE LA CÁMARA, M. et alii. “Comentario de E4P37S2: cinco perspectivas”, in BLANCO-ECHAURI, J. Espinosa: ética e politica, pp. 487-499.

DE LA CÁMARA, M.L. "O Simeón o Jacobo: la función teórica del tiempo”, in BLANCO-ECHAURI, J. Espinosa: ética e política, pp. 191-197.

DE VISSCHER, J. "Y-a-t-il du volontarisme dans la pensée politique de Spinoza?”, in DE DEUGD, C. (ed.). Spinoza's political and theological thought, pp. 226-229.

DELACAMPAGNE, Ch. La philosophie politique aujourd'bui. Paris, Seuil, 2000.

DELEUZE, G. Spinoza. Philosophie pratique. Paris, 1970; ed. ampliada, 1981.

Delumeau, J. História do medo no Ocidente, 1300-1800. São Paulo, Companhia das Letras, 1989. Tradução de Maria Lúcia Machado do original La peur em Occident (XIVe-XVIII siècles): une cite assiégée. Paris, Fayard, 1978.

DEN UYL, D.L. "Sociality and social contract: a Spinozistic perspective", Studia spinozana, vol. 1, 1985, pp. 15-51.

DI VONA, p. "La parte V dell'Ethica", in GIANCOTTI, E. (ed.) Spinoza nel 350 anniversario della nascità, pp. $237-248$.

DOMÍNGUEZ, A. "Sentido ético de la política de Spinoza", in BLANCO-ECHAURI, J. Espinosa: ética e política, pp. 371-391.

DuCOS, M. "La loi civile à Rome. Droit et philosophie du droit à la fin de la République", in Cabiers de philosophie politique et juridique, no 12, Caen, Presses Universitaires de Caen, 1987, pp. 15-30.

DUFOUR, A. Droits de l'homme, droit naturel et histoire. Paris, PUF, 1991.

Dufour, A. "Droit naturel/Droit positif", in Archives de philosophie du droit, no 35, Paris, Sirey, 1990.

DuRoux, F. "Puissance et utopie au péril de la différence sexuelle", in D’ALLONES, M.R. \& RIZK, H. (orgs.). Spinoza: puissance et ontologie. Paris, Kimé, 1994.

ECHEVERRIA, E.J.P. La filosofía política de Espinosa. Valladolid, Universidade de Valladolid, 1989.

ECHEVERRÍA, J.P. "Spinoza, entre la tradición republicana y el Estado moderno", in BLANCOECHAURI, J. Espinosa: ética e política, pp. 465-473.

FARIA, J.E. Poder e legitimidade. São Paulo, Perspectiva, 1978.

FASSÒ, G. Historia de la filosofia del derecho, vol. 1: Antigüedad y Edad Media; vol. 2: A Idade Moderna. Madri, Piramide, 1982 (traduzidos por José F. Lorca Navarrete do original Storia della filosofia del diritto, vol. 1: Antichità e Medioevo, e vol. 2: L'atè moderna, Bologna, Il Mulino, 1966).

FERNÁNDES G, E. "Daminio de los afectos", in BLANCO-ECHAURI, J. Espinosa: ética e política, pp. 73-112. FERrAZ Jr, T.S. A ciência do direito. São Paulo, Atlas, $2^{a}$ ed., 1980.

FERRAZ Jr, T.S. Introdução ao estudo do direito. Técnica, decisão, dominação. São Paulo, Atlas, $2^{a}$ ed., 1994. 
FERREIRA, M.L.R. "Espinosa e Hobbes: implicações de uma divergência”, in BLANCO-ECHAURI, J. Espinosa: ética e política, pp. 455-464.

FERRY, L. Philosophie politique 1 - Le droit: la nouvelle querelle des anciens et des modernes. Paris, PUF, 1984.

FERrY, L. Philosophie politique 2 - Le système des philosophies de l'bistoire. Paris, PUF, 1984.

FERry, L. \& RENAUT, A. Philosophie politique 3-Des droits de l'homme à l'idée républicaine. Paris, PUF, 1985.

FERRY, L. \& SOSOE, L. "L'étique et le droit à l'âge démocratique", in Cabiers de philosophie politique et juridique, no 18, Caen, Centre de Publications de l’Université de Caen, 1990, pp. 11-21.

FERRY, L. "Fichte, Johann Gottlieb, 1762-1814. O fundamento do direito natural, 1796", in CHÂTELET, F., DUHAMEL, O. \& PISIER, E. Dicionário das obras políticas. Rio de Janeiro, Civilização Brasileira, 1993. Tradução de Glória de C. Lins e Manoel Ferreira Paulino.

FEUER, L.S. Spinoza and the rise of liberalism. Boston, Beacon Press, 1958.

FOUCAUlT, M. Vigiar e punir: história da violência nas prisões. Petrópolis, Vozes, $7^{a}$ ed., 1977. Tradução de Ligia M. Ponde Vassallo do original Surveiller et punir. Paris, Gallimard, 1975.

FRANCES, M. Spinoza dans les pays néerlandais de la seconde moitié du XVII siècle. Paris, Félix Alcan, 1937.

FURTADO, J.P. “As gramáticas de Deus. A interpretação das Sagradas Escrituras nos capítulos primeiro ao terceiro da 'Parte II’ do Trabalho de Direito Natural de Tomás Antônio Gonzaga e no sétimo capítulo do Tratado Teológico-Político de Baruch de Espinosa", in Revista do IFAC (4):51-58, dez. 1997.

GAGNEBIN, S. A la recherche d'un ordre naturel. Neuchâtel, La Baconnière, 1971.

GARULLI, E. "La multitudo o 'soggetto collettivo' in Spinoza", in GIANCOTTI, E. (ed.) Spinoza nel $350^{\circ}$ anniversario della nascità, pp. 333-342.

GIANCOTTI-BOSCHERINI, E. "Réalisme et utopie: limites des libertés politiques et perspective de libération dans la philosophie politique de Spinoza”, in DE DEUGD, C. (ed.). Spinoza's political and theological thought, 1984.

GIANCOTTI, E. "La teoria dell'assolutismo in Hobbes e Spinoza", in Studia spinozana, vol. 1, 1985, pp. 231-258.

GIANCOTTI, E. (ed.) Spinoza nel 350 anniversario della nascità. Atti del congresso internazionale Urbino 4-8 ottobre 1982. Napoli, Bibliopolis, 1985.

GIANNINI, H. "Les modes de percepction", in MOREAU, P.-F. et alii (orgs.). Spinoza et la politique. Paris, L'Harmattan, 1997, pp. 15-23.

GOLDSCHMIDT, V. "La place de la théorie politique dans la philosophie de Spinoza" [comunicação apresentada no Colloque Spinoza de Leyde-Amiens, junho-setembro 1977], in Écrits 2. Parus, Vrin, 1984.

GOLDSCHMIDT, V. "Le fondement naturel de droit positif selon Epicure", in Archives de philosophie du droit, $\mathrm{n}^{\mathrm{o}} 21$, Paris, Sirey, 1976, pp. 183-203.

GOLDSCHMIDT, V. La doctrine d'Épicure et le droit. Paris, Vrin, 1977.

GOLDSMith, M.M. "Hobbes on law", in SORELL, T. (ed.). The Cambridge companion to Hobbes, pp. 274-304.

GÓMEZ, Á.Á. "El místico y el rebelde: dos modos de ser racionalista", in BLANCO-ECHAURI, J. Espinosa: ética e política, pp. 137-164.

GÓMEZ, G.S. "Ética y democracia en el pensamiento de Spinoza", in BLANCO-ECHAURI, J. Espinosa: ética e politica, pp. 475-484.

GONZALEZ, H. "La filiation du repentir", in MOREAU, P.-F. et alii (orgs.). Spinoza et la politique. Paris, L'Harmattan, 1997, pp. 119-126.

GOYARD-FABRE, S. "Hobbes et Spinoza ou la différence des concepts", Studia spinozana, vol. 3, 1987.

GOYARD-FABRE, S. La philosophie du droit de Montesquieu. Paris, Klincksieck, 1979.

GOYARD-FABRE, S. Montesquieu : la nature, les lois, la liberté. Paris, PUF, 1993.

GOYARD-FABRE, S. Philosophie politique, XVIe-XXe siècle. Paris, PUF, 1987.

GOYARD-FABRE, S. Pufendorf et le droit naturel. Paris, PUF, 1994.

GOYARD-FABRE, S. "De la signification de quelques problèmes juridiques à l'âge démocratique", in $C a$ hiers de philosophie politique et juridique, $\mathrm{n}^{\circ}$ 18, Caen, Centre de Publications de l'Université de Caen, 1990 , pp. 23-47.

GOYARD-FABRE, S. "Les deux jusnaturalismes ou l'inversion des enjeux politiques", in Cahiers de philosophie politique et juridique, n 11, Caen, Centre de Publications de l’Université de Caen, 1987, pp. 7-42.

GOYARD-FABRE, S. "Qu'est-ce que l'état de guerre?", in Cabiers de philosophie politique et juridique, no 10, Caen, Centre de Publications de l'Université de Caen, 1986, pp. 147-161.

GOYARD-FABRE, S. Essai de critique phénoménologique du droit. Paris, Klincksieck, 1972.

GOYARD-FABre, S. Jean Bodin et le droit de la République. Paris, PUF, 1989. 
GOYARD-FABRE, S. John Locke et la raison raisonnable. Paris, Vrin, 1986.

GOYARD-FABRE, S. La philosophie du droit de Kant. Paris, Vrin, 1996.

GOYARD-FABRE, S. Les fondements de l'ordre juridique. Paris, PUF, 1992.

GOYARD-FABRE, S. Montesquieu adversaire de Hobbes. Paris, Lettres Modernes, 1980.

GOYARD-FABRE, S. Qu'est-ce que la démocratie? Paris, Armand Colin, 1998.

GOYARD-FABRE, S. Qu'est-ce que la politique? Paris, Vrin, 1992.

GUISADO, M.C.C. "Algumas observaciones sobre el método deductivo en Spinoza", in BLANCOECHAURI, J. Espinosa: ética e politica, pp. 199-210.

GUISÁN, E. "Spinoza: el summum bonum y la alegría permanente", in BLANCO-ECHAURI, J. Espinosa: ética e política, pp. 233-240.

HADDAD-CHAMACK, F. "Spinoza et la 'révolution", in Cahiers de philosophie politique et juridique, $\mathrm{n}^{\circ}$ 16, Caen, Centre de Publications de l’Université de Caen, 1989, pp. 45-51.

HADDAD-CHAMAKH, F. "Liberté individuelle et paix civile d'après Traité théologico-politique de Spinoza", in DE DEUGD, C. (ed.). Spinoza's political and theological thought, pp. 44-55.

HAGGENMACHER, p. "Mutations du concept de guerre juste de Grotius à Kant", in Cabiers de philosophie politique et juridique, no 10, Caen, Presses Universitaires de Caen, 1986, pp. 105-125.

HAMMACHER, K. "Ambition and social engagement in Hobbes' and Spinoza's political thought", in DE DEUGD, C. (ed.). Spinoza's political and theological thought, pp. 56-62.

HARPES, J.P. "Normes (éthiques?) avec ou sans sujets ou communnautés communicatives de sujets : entre Foucault et Habermas", in Cahiers de philosophie politique et juridique, n 28, Caen, Presses Universitaires de Caen, 1995, pp. 177-203.

HARRIS, E.E.: "Spinoza's treatment of natural law", in DE DEUGD, C. (ed.). Spinoza's political and theological thought, pp. 63-72.

HART, H.L.A. Direito, liberdade, moralidade. Porto Alegre, Sergio Antonio Fabris Editor, 1987. Tradução de Gérson Pereira dos Santos do original Law, liberty and morality. Oxford University Press, 1968.

HELler, A. Além da justiça. Rio de Janeiro, Civilização Brasileira, 1998 (tradução de Savannah Hartmann a partir do original Beyond justice, 1987).

HUbBELING, H.G. "Today's western spinozism", in DE DEUGD, C. (ed.). Spinoza's political and theological thought, pp. 7-13.

Hubbeling, H.G. Spinoza. Barcelona, Herder, 1981. Tradução de Raúl Gabás do original Spinoza, Freiburg-Munique, Verlag Karl Alber, 1978.

HUTTON, S.: "The prophetic imagination: a comparative study of Spinoza and the Cambridge Platonist, John Smith", in DE DEUGD, C. (ed.). Spinoza's political and theological thought, pp. 73-81.

INGBER, L. "La tradition de Grotius. Les droits de l'homme et le droit naturel à l'époque contemporaine", in Cabiers de philosophie politique et juridique, $\mathrm{n}^{\circ} 11$, Caen, Centre de Publications de l'Université de Caen, 1987, pp. 43-73.

JAEGER, W. Paideia, A Formação do Homem Grego, $2^{\mathrm{a}}$ ed., Brasília, UnB/Martins Fontes, 1989.

KANTOROWICZ, E.H. Os dois corpos do rei. São Paulo, Companhia das Letras, 1998. Tradução de Cid Knipel Moreira do original The King's two bodies. A study in Medieval Polithical Theology. Princeton University Press, 1957.

KAPLAN, Y. "On the relation of Spinoza's contemporaries in the Portuguese-jewish community of Amsterdam to Spanish culture and marrano experience". In DE DEUGD, C. (ed.). Spinoza's political and theological thought, pp. 82-94.

KAPLAN, Y. "Spinoza scholarship in Israel”, in DE DEUGD, C. (ed.). Spinoza's political and theological thought, pp. 19-22.

KAPLAN, Y. "Marrano patterns in Spinoza". In Proceedings of the First Italian International Congress on Spinoza. Napoles, Bibliópolis, 1985.

KElSEN, H. A ilusão da justiça. São Paulo, Martins Fontes, 1995. Tradução de Sérgio Tellaroli do original Die Illusion der Gerechtigkeit. Viena, Manz Verlag, 1985.

KelSEN, H. O problema da justiça. São Paulo, Martins Fontes, 1996. Tradução de João Baptista Machado do original Das Problem der Gerechtigkeit. Viena, Franz Deuticke, 1960.

KELSEN, H. O que é justiça? São Paulo, Martins Fontes, 1997. Tradução de Luíz Carlos Borges do original What is justice? Berkeley e Los Angeles, University of California Press, 1957.

KELSEN, H. Teoria geral do direito e do Estado. São Paulo, Martins Fontes, $2^{a}$ ed., 1992. Tradução de Luís Carlos Borges do original General theory of Law and State. Russell and Russell, 1961. 
KELSEN, H. Teoria pura do direito. São Paulo, Martins Fontes, $2^{\mathrm{a}}$ ed., 1989. Tradução de João Baptista Machado do original Reine Rechtslehre. Viena, Verlag Fraz Deuticke, 1960.

KLEVER, W.N.A. "Power: conditional and unconditional", in DE DEUGD, C. (ed.). Spinoza's political and theological thought, pp. 95-106.

KLINE, G.L. "Absolute and relative senses of liberum and libertas in Spinoza", in GIANCOTTI, E. (ed.) Spinoza nel $350^{\circ}$ anniversario della nascità, pp. 259-280.

LADO, Á.L.R. "La fundamentación ontológica de "lo moral" en Descartes y Spinoza. La ontología proyectiva de Spinoza", in BLANCO-ECHAURI, J. Espinosa: ética e politica, pp. 267-274.

LAGREE, J. "Spinoza et la subversion des normes religieuses", in MOREAU, P.-F. et alii (orgs.). Spinoza et la politique. Paris, L'Harmattan, 1997, pp. 35-53.

LARENZ, K. Metodologia da ciência do direito. Lisboa, Calouste Gulbenkian, 1997. Tradução de José Lamego do original Methodenlehre der Rechtswissenschaft, Berlim-Heidelberg, Springer Verlag, $6^{\mathrm{a}}$ ed., reformulada, 1991.

LARMORE, Ch. "Deus différences prétendues entre sujet de la pensée et sujet de l'action", in Cabiers de philosophie politique et juridique, $\mathrm{n}^{\circ}$ 28, Caen, Presses Universitaires de Caen, 1995, pp. 15-25.

LATOURNERIE, E.A. "Los modos, operarios de la fábrica spinozista", in BLANCO-ECHAURI, J. Espinosa: ética e política, pp. 165-174.

LAUNED, F.C. "Ética y política en Spinoza. Inspiración de hoy y mañana", in BLANCO-ECHAURI, J. Espinosa: ética e politica, pp. 431-439.

LAURENT, p. Pufendorf et la loi naturelle. Paris, Vrin, 1982.

LEVY, Z. "On Spinoza's and Mendelssohn's conceptions of the relationship between religion and state", in DE DEUGD, C. (ed.). Spinoza's political and theological thought, 1984.

LEVY, L. O autômato espiritual. A subjetividade moderna segundo a Ética de Espinosa. Porto Alegre, L\&PM, 1998.

LLOYD, D. A idéia de lei. São Paulo, Martins Fontes, $2^{a}$ ed., 1998 [tradução de Álvaro Cabral a partir do original The idea of law. Middlesex, Penguin Books, 1981].

LUCAS, H.-C. "Die Idee des Friedens in Spinozas Philosophie", in DE DEUGD, C. (ed.). Spinoza's political and theological thought, 1984.

Machado, L.G. O "Tratado de direito natural" de Tomás Antônio Gonzaga. Rio de Janeiro, Ministério da Educação e Saúde, Serviço de Documentação, 1953.

MACHEREY, p. “Spinoza est-il moniste?”, in D’ALLONES, M.R. \& RIZK, H. (orgs.). Spinoza: puissance et ontologie. Paris, Kimé, 1994

MADANES, L. "Les limites de la liberté d'expression selon Spinoza", in MOREAU, P.-F. et alii (orgs.). Spinoza et la politique. Paris, L'Harmattan, 1997, pp. 59-66.

MARTÍNEZ, F.J. "Necesidad y libertad en los Cogitata metaphysica", in BLANCO-ECHAURI, J. Espinosa: ética e política, pp. 241-251.

MATHERON, A. "Etat et moralité selon Spinoza", in GIANCOTTI, E. (ed.) Spinoza nel 350 anniversario della nascità, pp. 343-354.

MATHERON, A. "L'indignation et le conatus de l'État spinoziste", in D'ALLONES, M.R. \& RIZK, H. (orgs.). Spinoza: puissance et ontologie. Paris, Kimé, 1994.

MATHERON, A. "La fonction théorique de la démocratie chez Spinoza et Hobbes", Studia spinozana, vol. 1, 1985, pp. 259-273.

MATHERON, A. "Le moment stoïcien de l'Étique de Spinoza", in Cabiers de philosophie politique et juridique, no 25, Caen, Presses Universitaires de Caen, 1994, pp. 147-161.

MATHERON, A. Individu et communauté chez. Spinoza. Paris, Vrin, $2^{\mathrm{a}}$ ed., 1988 (1ª ed.: 1969).

MAUVE, Ch. "Spinoza-en-France, Spinoza français?", in MOREAU, P.-F. et alii (orgs.). Spinoza et la politique. Paris, L’Harmattan, 1997, pp. 127-138.

McSHEA, R.J. "Spinoza's human nature ethical theory", in GIANCOTTI, E. (ed.) Spinoza nel $350^{\circ}$ anniversario della nascità, pp. 281-290.

McSHEA, R.J. The political philosophy of Spinoza. New York, 1968.

MIGNINI, F. "Theology as the work and instrument of Fortune”, in DE DEUGD, C. (ed.). Spinoza's political and theological thought, 1984.

MIRAS, p. "Réponse", in MOREAU, P.-F. et alii (orgs.). Spinoza et la politique. Paris, L'Harmattan, 1997, pp. 55-58.

MOREAU, P.-F. Spinoza. L'experience et l'éternité. Paris, PUF, 1994.

MOREAU, P-F. "Biographie intellectuelle et règles d'interprétation", in DE DEUGD, C. (ed.). Spinoza's political and theological thought, 1984. 
MOREAU, P-F. "Les principes de la lecture de l'Écriture sainte dans le TTP", in Groupe de Recherches Spinozistes, Travaux et Documents, $\mathrm{n}^{\circ}$ 4: L'Écriture sainte au temps de Spinoza et dans le système spinoziste, Paris, Presses Universitaires de l'Université de Paris Sorbonne, 1992, pp. 119-131; tradução brasileira de Cristiano Novaes de Rezende: "Os princípios de leitura das Sagradas Escrituras no Tratado teológico-político", in Cadernos espinosanos, n IV, São Paulo, Departamento de Filosofia da USP, 1998, pp. 7589.

MOREAU, P.-F. "La notion d'imperium dans le Traité politique", in GIANCOTTI, E. (ed.) Spinoza nel $350^{\circ}$ anniversario della nascità, pp. 354-366.

MOREAU, P.-F. "Spinoza et l'expérience", in MOREAU, P.-F. et alii (orgs.). Spinoza et la politique. Paris, L'Harmattan, 1997, pp. 25-33.

MOREAU, P.-F. "Spinoza et le jus circa sacra", Studia spinozana, vol. 1, 1985, pp. 335-344.

MOREAU, P.-F. "Spinoza. Eléments de biographie", CERPHI-DATA (Documents, Archives de Travail \& Arguments), n 14, École Normale Supérieure, Fontenay-aux-Roses, Saint Claud, décembre 1997, pp. 19 40.

MOREIRA ALVEZ, J.C. Direito romano, $13^{a}$ ed., Rio de Janeiro, Forense, 2000, 2 vols.

MUGNIER-POLLET, L. La philosophie politique de Spinoza. Paris, Vrin, 1976.

MUGNIER-POLLET, L. "Les avatars du pouvoir absolu", in GIANCOTTI, E. (ed.) Spinoza nel $350^{\circ}$ anniversario della nascità, pp. 367-371.

NEGRI, A. "Démocratie et éternité", in D'ALLONES, M.R. \& RIZK, H. (orgs.). Spinoza: puissance et ontologie. Paris, Kimé, 1994.

NEGRI, A. "Reliqua desiderantur: Congettura per una definizione del concetto di democrazia nell'ultimo Spinoza", Studia spinozana, vol. 1, 1985, pp. 143-181.

NEGRI, A. A anomalia selvagem. Poder e potência em Spinoza. Rio de Janeiro, Editora 34, 1993 (tradução de Raquel Ramalhete do original L'anomalia selvaggia. Saggio su potere in Baruch Spinoza. Milano, Giangiacomo Fratelli Editore, 1981).

NIEWÖHNER, F. "Die Religion Noahs bei Uriel da Costa und Baruch de Spinoza. Eine historische Miniatur zur Genese des Deismus", in DE DEUGD, C. (ed.). Spinoza's political and theological thought, 1984.

NIORT, J.-F. \& VANNIER, G. (orgs.). Michel Villey et le droit naturel en question. Paris, L'Harmattan, 1994.

NORMAN, W.J. "Démocratie juste ou justice démocratique ?", in Cabiers de philosophie politique et juridique, $\mathrm{n}^{\circ}$ 18, Caen, Centre de Publications de l'Université de Caen, 1990, pp. 107-124.

OSIER, J.-P. "L’herméneutique de Hobbes et Spinoza", Studia spinozana, nº 3, 1987, pp. ???

PACCHIANI, C. Spinoza tra teologia e politica. Padova, Francisci, 1979.

PÉCORA, A. Teatro do sacramento. São Paulo-Campinas, Edusp-Editora da Unicamp, 1994.

PEÑA, V. "Espinosa: potencia, autoconciencia, Estado", in BLANCO-ECHAURI, J. Espinosa: ética e política, pp. 393-410.

PERELMAN, Ch. Ética e direito. São Paulo, Martins Fontes, 1996. Tradução de Maria Ermantina Galvão G. Pereira do original Éthique et droit. Bruxelas, Éditions de l'Université de Bruxelles, 1990.

Perelman, Ch. Retóricas. São Paulo, Martins Fontes, 1997. Tradução de Maria Ermantina Galvão G. Pereira do original Rhétoriques. Bruxelas, Éditions de l’Université de Bruxelles, 1989.

PÉREZ, Á.C. "Spinoza e Vygotski: o dominio da propia conducta", in BLANCO-ECHAURI, J. Espinosa: ética e política, pp. 259-266.

PETRY, M.J. "Hobbes and the early Dutch Spinozists", in DE DEUGD, C. (ed.). Spinoza's political and theological thought, 1984.

PHILONEnKO, A. La liberté bumaine dans la philosophie de Fichte. Paris, Vrin, 1966.

POLTIER, H. "Du sujet: réflexions autour de Claude Lefort", in Cabiers de pbilosopbie politique et juridique, $\mathrm{n}^{\circ}$ 28, Caen, Presses Universitaires de Caen, 1995, pp. 157-175.

POPKIN, R.H. "Spinoza and the conversion of the Jews", in DE DEUGD, C. (ED.): Spinoza's political and theological thought, 1984.

PREPOSIET, J. "Sagesse et combat idéologique chez Spinoza", in GIANCOTTI, E. (ed.) Spinoza nel $350^{\circ}$ anniversario della nascità, pp. 373-380.

QUILLET, J. "Note sur le concept médiéval de loi", in Cabiers de philosophie politique et juridique, $\mathrm{n}^{\circ}$ 12, Caen, Presses Universitaires de Caen, 1987, pp. 43-52.

QUINTANAR, M.Á.M. "La Ética de Spinoza: selección y diferencia”, in BLANCO-ECHAURI, J. Espinosa: ética e politica, pp. 253-258.

RAMOND, Ch. "Sur l'orientation quantitative du Traité politique de Spinoza", in MOREAU, P.-F. et alii (orgs.). Spinoza et la politique. Paris, L'Harmattan, 1997, pp. 85-94. 
RAWLS, J. Uma teoria da justiça. São Paulo, Martins Fontes, 1997. Tradução de Almiro Pisetta e Lenita M.R. Esteves do original $A$ theory of justice. Harvard University Press, 1971.

REALE, M. Filosofia do direito. São Paulo, Saraiva, $19^{a}$ ed., 1999.

REBOUL, O. Introdução à retórica. São Paulo, Martins Fontes, 1998. Tradução de Ivone Castilho Benedetti do original Introduction à la rhétorique. Théorie et pratique. Paris, PUF, 1991.

RENAut, A. \& SOSOE, L. Philosophie du droit. Paris, PUF, 1991.

RENAUT, A. "État de droit et sujet de droit", in Cabiers de philosophie politique et juridique, no 24, Caen, Presses Universitaires de Caen, 1993, pp. 51-67.

RENAUT, A. "Le droit naturel dans les limites de la simples raison. De Wolff à Fichte", in Cabiers de philosophie politique et juridique, no 11, Caen, Centre de Publications de l'Université de Caen, 1987, pp. 140158.

RENAUT, A. "Le problème de la loi injuste. Remarques sur l'anti-juridisme contemporain", in Cabiers de philosophie politique et juridique, no 12, Caen, Presses Universitaires de Caen, 1987, pp. 167-182.

RENAUT, A. Le système du droit. Philosophie et droit dans la pensée de Fichte, Paris, PUF, 1986.

RIBEIRO, R.J. A sociedade contra o social, São Paulo, Companhia das Letras, 2000.

RIBEIRO, R.J. Ao leitor sem medo, Belo Horizonte, Editora da UFMG, $2^{\mathrm{a}}$ ed., 1999.

RICE, L.C. "Piety and philosophical freedom in Spinoza", in DE DEUGD, C. (ed.). Spinoza's political and theological thought, 1984.

RICOEUR, p. Le juste, Paris, Editions Esprit, 1995.

RIZK, H. "Conatus et ipséité", in D’ALLONES, M.R. \& RIZK, H. (orgs.). Spinoza: puissance et ontologie. Paris, Kimé, 1994.

ROUSSET, B. “Les implications de l'identité spinoziste de l'être et de la puissance”, in D'ALLONES, M.R. \& RIZK, H. (orgs.). Spinoza: puissance et ontologie. Paris, Kimé, 1994.

RUBEL, M. "Marx à l'école de Spinoza", in GIANCOTTI, E. (ed.) Spinoza nel $350^{\circ}$ anniversario della nascità, pp. 381-399.

RYAN, A. "Hobbes's political philosophy", in SORELL, T. (ed.). The Cambridge companion to Hobbes, pp. 208245.

SAADA, J. "Le corps-signe. Ordre des passions et ordre des signes : une économie du corps politique", in MOREAU, P.-F. et alii (orgs.). Spinoza et la politique. Paris, L’Harmattan, 1997, pp. 67-83.

SACKSTEDER, W. "Communal orders in Spinoza", in DE DEUGD, C. (ed.). Spinoza's political and theological thought, 1984.

SAVATER, F. "Ética de la alegría (soliloquio a partir de Spinoza)", in BLANCO-ECHAURI, J. Espinosa: ética e politica, pp. 129-134.

SCALA, A. "Puissance et définition: la proposition XVI du livre I de l'Éthique", in D'ALLONES, M.R. \& RIZK, H. (orgs.). Spinoza: puissance et ontologie. Paris, Kimé, 1994.

SEIDEL, H. "Sozialismus und Spinozismus", in DE DEUGD, C. (ed.). Spinoza's political and theological thought, 1984.

SÉNELLART, M. "Le stoïcisme dans la constitution de la pensée politique. Les Politiques de Juste Lipse (1589)", in Cabiers de philosophie politique et juridique, no 25, Caen, Presses Universitaires de Caen, 1994, pp. 109-130.

SEVE, R. "L'ontologie moderne et la loi", in Archives de philosophie du droit, n 25, Paris, Sirey, 1980, pp. 191-209.

SEVE, R. "La loi civile dans la pensée de saint Augustin", in Cabiers de philosophie politique et juridique, no 12 , Caen, Presses Universitaires de Caen, 1987, pp. 31-42.

SEVE, R. "Leibniz et le droit naturel moderne", in Cabiers de philosophie politique et juridique, $\mathrm{n}^{\circ} 11$, Caen, Centre de Publications de l’Université de Caen, 1987, pp. 127-137.

SIEBRAND, H. "On the early reception of Spinoza's Tractatus Theologico-Politicus in the context of Cartesianism”, in DE DEUGD, C. (ed.). Spinoza's political and theological thought, 1984.

SILVER, V. "Hobbes on rhetoric", in SORELL, T. (ed.). The Cambridge companion to Hobbes, pp. 329-345.

SKINNER, Q. As fundações do pensamento politico moderno. São Paulo, Companhia das Letras, 1996 (1ª reimpressão, 1999). Tradução de Renato Janine Ribeiro e Laura Teixeira Motta do original The foundations of modern political thought. Cambridge University Press, 1978.

SKINNER, Q. Razão e retórica na filosofia de Hobbes, São Paulo, Editora da UNESP, 1999. Tradução de Vera Ribeiro do original Reason and rhetoric in the philosophy of Hobbes. Cambridge University Press, 1996.

SMITH, S.B. Spinoza, liberalism, and the question of Jewish identity. New Haven \& London, Yale University Press, 1997. 
SOROMENHO-MARQUES, V. "Espinosa e a questão do realismo político", in BLANCO-ECHAURI, J. Espinosa: ética e política, pp. 411-420.

SOSOE, L.K. "Christian Thomasius : du primat de l'action sur la pensée", in Cabiers de philosophie politique et juridique, $\mathrm{n}^{\circ}$ 28, Caen, Presses Universitaires de Caen, 1995, pp. 143-155.

SOTO, L.G. "Moralidade e utilidade nos relacionamentos interpessoais", in BLANCO-ECHAURI, J. Espinosa: ética e política, pp. 221-231.

SPITZ, J.-F. "La théorie du double contrat chez Grotius et chez Pufendorf", in Cabiers de philosophie politique et juridique, no 11, Caen, Centre de Publications de l’Université de Caen, 1987, pp. 75-99.

Starobinski, J. Montesquieu. São Paulo, Companhia das Letras, 1990. Tradução de Tomás Rosa Bueno do original Montesquieu. Paris, Seuil, 1953 e 1989.

STRAuSS, L. Droit naturel et histoire. Paris, Flammarion, 1986 [ed. original: Paris, Plon, 1954]. Tradução de Monique Nathan e Éric de Dampierre do original Natural right and history, Chicago, The University of Chicago Pres, 1953.

STRAuSS, L. Qu'est-ce que la philosophie politique? Paris, PUF, 1992. Tradução de Olivier Sedeyn do original What is political philosophy?, New York, Free Press, 1959.

STRAUSS, L. Spinoza's critique of religion. Chicago, University of Chicago Press, 1997 (ed. orig.: New York, Schoken Books, 1965). Tradução de E.M. Sinclair a partir do original alemão Die Religionskeritike Spinozas als Grundlage seiner Bibelwissenschaft Untersuchungen zu Spinozas Theologisch-Politischen Trakat, Berlin, Akademie-Verlag, 1930.

STRAuss, L. Pensées sur Machiavel. trad. de l'anglais par Michel-Pierre Edmond et Thomas Stern. Paris, Payot, 1982.

TERRE, F. \& SEVE, R. "Droit", in Archives de philosophie du droit, n 35, Paris, Sirey, 1990.

TINLAND, F. Droit naturel, loi civile et souveraineté à l'époque classique, Paris, puf, 1988.

TODOROV, T. Symbolisme et interprétation. Paris, Seuil, 1978.

TOSEL, A. "La théorie de la pratique et la function de l'opinion publique dans la philosophie de Spinoza", in Studia spinozana, vol. 1, 1985, pp. 183-208.

TOSEL, A. Du matérialisme de Spinoza. Paris, Kimé, 1994.

TRIGEAUD, J.-M. “Convention", in Archives de philosophie du droit, no 35, Paris, Sirey, 1990.

TRINCIA, F.S. "Differenza tra azione e pensiero. Per una teoria della soggettività", in Cahiers de philosophie politique et juridique, $\mathrm{n}^{\circ}$ 28, Caen, Presses Universitaires de Caen, 1995, pp. 61-74.

TUCK, R. Natural rights theories: their origin and development. Cambridge, Cambridge University Press, 1979.

TUCK, R. "Hobbes's moral philosophy", in SORELL, T. (ed.). The Cambridge companion to Hobbes, pp. 175207.

UENO, O. "Mentis oculi ipsae demonstrationes: jouissance et démonstration dans l'Éthique de Spinoza", in D’ALLONES, M.R. \& RIZK, H. (orgs.). Spinoza: puissance et ontologie. Paris, Kimé, 1994.

UYL, D.D. \& WARNER, S.D. "Liberalism in Hobbes and Spinoza", in Studia spinozana, vol. 3, 1988, pp. 261-318.

VAN DER WAL, G.A. "Spinoza and the idea of reason of State", in Studia spinozana, vol. 1, 1985, pp. 275-304.

VAYSSE, J-M. "Éthique et ontologie fondamentale", in D’ALLONES, M.R. \& RIZK, H. (orgs.). Spinoza: puissance et ontologie. Paris, Kimé, 1994.

VERMEen, p. "Le Spinoza du Jardin des Plantes", in MOREAU, P.-F. et alii (orgs.). Spinoza et la politique. Paris, L'Harmattan, 1997, pp. 139-150.

VERNIERE, p. Spinoza et la pensée française avant la Révolution. Paris, PUF, $2^{\mathrm{a}}$ ed., 1982 (1ª ed.: 1954).

VILLEY, M. Le droit et les droits de l'homme. Paris, PUF, $3^{\text {a }}$ ed., 1998.

VILLEY, M. Philosophie du droit, vol. II: Les moyes du droit. Paris, Dalloz, $12^{\mathrm{a}}$ ed., 1984.

VILLEY, M. Réflexions sur la philosophie et le droit: Les carnets. Paris, PUF, 1995.

VULLIERME, J.-L. "La loi dans le droit, les sciences, la métaphysique", in Archives de philosophie du droit, $\mathrm{n}^{\circ}$ 25, Paris, Sirey, 1980, pp. 47-78.

WALTHER, M. "Die Transformation des Naturrechts in der Rechtsphilosophie Spinozas", in Studia spinozana, vol. 1, 1985, pp. 73-104.

WALTHER, M. "Spinoza und der Rechtspositivismus", in GIANCOTTI, E. (ed.) Spinoza nel 350 anniversario della nascità, pp. 401-418.

WARAT, L.A. A ciência jurídica e seus dois maridos. Santa Cruz do Sul, Faculdades Integradas Santa Cruz do Sul, 1985.

WARAT, L.A. Manifesto do surrealismo jurídico. São Paulo, Acadêmica, 1988.

WARAT, L.A. O direito e sua linguagem. Porto Alegre, Sergio Antonio Fabris Editor, 2a versão, 1984. 
WURTZ, J.P. "L'éthique et le concept de Dieu chez Tschirnaus: l'influence de Spinoza", in DE DEUGD, C. (ed.). Spinoza's political and theological thought, 1984.

YOVEL, Y. "Marrano patterns in Spinoza", in GIANCOTTI, E. (ed.) Spinoza nel 350 anniversario della nascità, pp. 461-485.

YOVEL, Y. "Spinoza: the psychology of the multitude and the uses of language", in Studia spinozana, vol. 1, 1985, pp. 305-333.

ZAKI, M.S. "Équité", in Archives de philosophie du droit, $\mathrm{n}^{\circ}$ 35, Paris, Sirey, 1990.

ZARKA, Y.-Ch. "Hobbes and the method of natural science", in SOREL, T. (ed.) The Cambridge companion to Hobbes, New York, Cambridge University Press, 1996.

ZARKA, Y.-Ch. "La sémiologie de la guerre chez Hobbes", in Cabiers de philosopbie politique et juridique, $\mathrm{n}^{\circ}$ 10, Caen, Centre de Publications de l'Université de Caen, 1986, pp. 127-146.

ZARKA, Y.-Ch. La décision métaphysique de Hobbes, Paris, Vrin, 1997. 